\author{
Universidade de São Paulo \\ Escola de Comunicações e Artes
}

\title{
MUSEUS E COLEÇÕES UNIVERSITÁRIOS: POR QUE MUSEUS DE ARTE NA UNIVERSIDADE DE SÃO PAULO?
}

Adriana Mortara Almeida

Tese apresentada à Escola de Comunicações e Artes da Universidade de São Paulo como exigência parcial para obtenção do grau de Doutor em Ciências da Informação e Documentação

Orientadora: Maria Helena Pires Martins

São Paulo 2001 


\author{
Universidade de São Paulo \\ Escola de Comunicações e Artes
}

\title{
MUSEUS E COLEÇÕES UNIVERSITÁRIOS: POR QUE MUSEUS DE ARTE NA UNIVERSIDADE DE SÃO PAULO?
}

Adriana Mortara Almeida

Tese apresentada à Escola de Comunicações e Artes da Universidade de São Paulo como exigência parcial para obtenção do grau de Doutor em Ciências da Informação e Documentação

Orientadora: Maria Helena Pires Martins

São Paulo 2001 
Comissão Julgadora 
Dedico essa tese ao Rodrigo, que trouxe uma imensa felicidade para minha vida, ao Cláudio, que me alimenta com seu amor e aos meus pais. 


\section{Agradecimentos}

Esta tese não poderia ter sido realizada sem o apoio financeiro da FAPESP e sem o apoio, direto ou indireto, de todos os colegas profissionais, amigos e familiares.

Agradeço a Maria Helena, que sempre acreditou em meu trabalho e me deu força quando precisava, enriquecendo e aperfeiçoando-o. E também ao seu carinho como "avó” do Rodrigo.

Gostaria de agradecer a todos os profissionais de museus que dedicaram seu tempo a responder minhas perguntas, seja por escrito, por telefone, pessoalmente, enfim, a vocês que tornaram possível recolher informações sobre os inúmeros museus universitários do Brasil e de fora do Brasil. Alguns ainda me forneceram fotografias, catálogos e publicações que alimentaram nosso "banco de dados" sobre museus universitários de arte.

Aos colegas do MAC agradeço sua paciência e atenção em fornecer informações, documentos e materiais essências para esse trabalho, especialmente a Meg, a Sara, a Ana, ao Martin, a Isis e a Maria Helena.

Aos funcionários do IEB agradeço sua paciência e atenção em fornecer informações, documentos e materiais essências para esse trabalho, especialmente a Eliane, Ana Paula, Inês, a equipe do Arquivo, a Marta Rossetti e Murillo Marx.

Agradeço às equipes da CPC/USP, por seu empenho em ajudar a encontrar os dados que precisava, especialmente Christina, Luís, Liana e Henrique. A VITAE agradeço pela autorização de consulta à parte de seus cadastros.

Ao Michel e toda equipe do GREM, agradeço por todo apoio dado para minha pesquisa no Canadá; aos profissionais do Reference Center da Smithsonian Institution, por sua paciência e confiança em minha pessoa.

Aos amigos agradeço o apoio dado durante todo esse período estando sempre prontos a dar uma palavra amiga. Agradeço especialmente Teresa e Denise.

Ao Gilson pelo desenho das plantas. A Magda e equipe da Prata da Casa pelo tratamento das imagens.

Aos meus familiares, irmãos, irmãs, cunhados, cunhadas, tios e tias, agradeço todas as ajudas, especialmente ao tio Valério e Laura pelas revisões e traduções, a Bilu pela pesquisa e ao Bruno e Fábio pela edição e impressão.

Aos professores Murillo Marx e Teixeira Coelho pelas sugestões e críticas feitas no exame de qualificação, que auxiliaram muito no desenvolvimento da tese. 


\section{Resumo}

Essa tese trata do perfil dos museus universitários - sua origem, desenvolvimento e perfil atual -, com ênfase para os museus de arte. Procura definir o que seria um museu universitário modelo e busca identificar o quanto desse modelo existe na prática. Descreve a formação e as características dos museus da Universidade de São Paulo e dos museus universitários de arte no Brasil. Analisa a coleção e o museu de arte da Universidade de São Paulo - Coleção de Artes Visuais do Instituto de Estudos Brasileiros e Museu de Arte Contemporânea - diante do modelo proposto para museus universitários. E finalmente, discute a necessidade da Universidade de São Paulo possuir ou não essas coleções de arte.

\section{Abstract}

This thesis addresses the profile of university museums -their origin, development and current profile- with emphasis on art museums. It attempts to define what a model university museum should be and to compare it to the existing situation. It describes the foundation and characteristics of the University of São Paulo museums and of university art museums in Brazil. It analyses the art collection and the University of São Paulo art museum -Visual Arts Collection of the Brazilian Studies Institute and the Contemporary Art Museum- in comparison to the university museum model proposed. And finally it discusses the need for those art collections in the University of São Paulo. 


\section{Sumário}

página

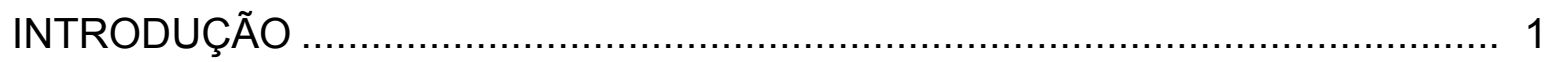

CAPÍTULO 1: Origens e desenvolvimento de museus universitários ................. 9

1. Mas o que seria um museu universitário? .......................................................... 10

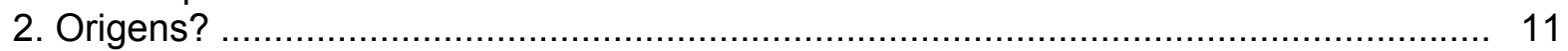

3. A universidade vista como guardiã segura e digna para coleções já formadas ............ 13

3.1. Doações e heranças fundando museus universitários ................................... 13

3.2. Incorporação de coleções e museus na formação da universidade .................. 16

4. O ensino universitário cria necessidade de acesso a objetos e obras para formação dos alunos e para desenvolvimento de pesquisas - a universidade adquire coleções ..... 19

4.1. A pesquisa universitária coleta exemplares e cria coleções - arqueologia, história natural ..................................................................................... 21

4.2. Servir ou não servir para o ensino não universitário? .................................. 23

5. A universidade busca, adquire coleções para fortalecer sua imagem diante da sociedade, como guardiã da "cultura" local, universal... (arte, arqueologia, etc.) ............ 26

6. O museu universitário serve como referência para a região assumindo um papel de museu municipal / estadual / regional .................................................................. 27

6.1. Museu com vocação para ensino público não universitário ............................ 27

7. E hoje, qual o uso dessas coleções das universidades? ...................................... 30

7.1. Museus de História Natural: ensinar, pesquisar, ensinar... ........................... 31

7.2. Grandes museus abertos aos diversos públicos ..................................... 32

7.2.1. O Museu da Universidade da Pennsylvania: pesquisa e educação

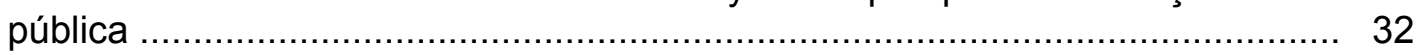

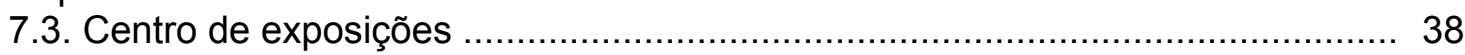

7.4. O museu como centro formador de profissionais ...................................... 39

7.5. Coleções para ensino universitário .......................................................... 41

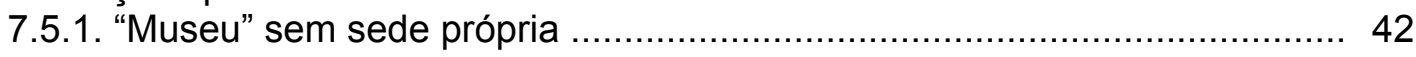

7.5.2. Coleção de ensino e pesquisa ......................................................... 42

7.5.3. Museu de departamento e/ou coleção de ensino e pesquisa em

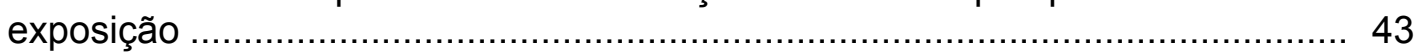

7.5.4. Museu para divulgação da ciência ................................................... 44

7.5.5. Atualização do museu pelas pesquisas ............................................... 45

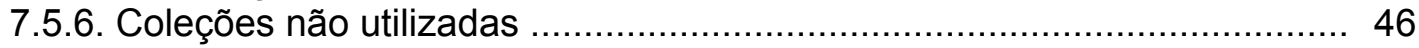

CAPÍTULO 2: Museus da Universidade de São Paulo ................................. 48

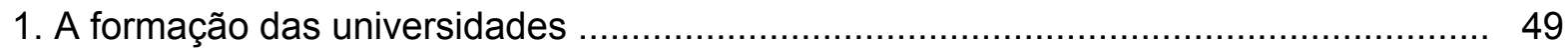

2. Os museus universitários no Brasil .................................................................. 51

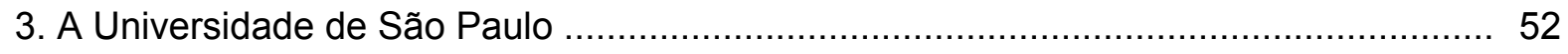

4. Museus da universidade de São Paulo ............................................................... 57

4.1. Museu Paulista/USP e Museu de Zoologia/USP: origem comum, muitos

"donos" e dificuldades ................................................................................ 57

4.2. Museu de Arqueologia e Etnologia: fusão de acervos e pessoal potencializa

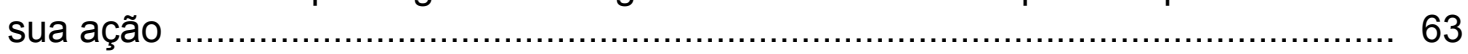

4.3. Museu de Arte Contemporânea: uma rica coleção doada à Universidade ....... 65

5. Museu de arte, de história....como definir a tipologia? ............................................ 66

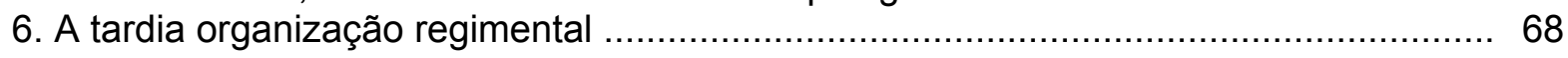


7. Os outros museus e coleções: o que fazer?

7.1. Centro de Ciência e Tecnologia: vulgarização da ciência para o público escolar

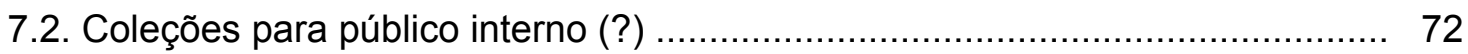

7.3. Coleção para ensino e pesquisa ............................................................. 73

7.4. Museus e coleções voltadas para o público externo ....................................... 74

7.5. Museus e coleções para públicos interno e externo .................................... 75

7.6. Pouco apoio, mas números levados em conta .......................................... 77

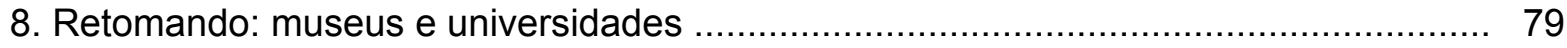

CAPÍTULO 3: Museus de arte universitários: como são? .............................. 82

1. Museus de arte são minoria entre os museus universitários .................................... 83

2. Tipos de museus de arte universitários ............................................................. 84

2.1. Galeria de Arte com acervo voltada para diversos públicos .......................... 84

2.2. Galeria de arte sem acervo para diversos públicos ................................... 85

2.3. Centro de exposições sem acervo próprio ................................................. 86

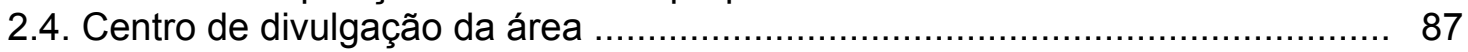

2.5. Coleção para decoração do campus ........................................................ 87

2.6. Coleção para formação em nível superior ................................................. 88

3. EUA: museu universitário sem curso e curso sem museu ...................................... 89

4. Brasil: o ensino utiliza coleções ? ........................................................................ 96

4.1. O ensino da arte no Brasil e sua relação com as coleções de arte .................. 98

4.2. O ensino da arte em museus não-universitários ............................................ 103

5. Coleções de universidades do Brasil: afastadas do ensino universitário? ................... 105

5.1. Museu de Arte Sacra da UFBA ................................................................ 106

5.2. Museu de Arte da UFC - MAUC …......................................................... 109

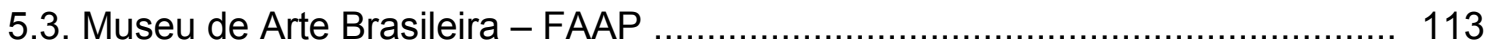

5.4. Galeria Brasiliana - UFMG ................................................................. 116

5.5. Museu de Arte Assis Chateaubriand - MAAC/UEPB .................................. 120

5.6. Museu do Seridó - UFRN ................................................................... 123

5.7. Galeria de Arte Espaço Universitário - UFES ............................................. 125

5.8. Museu de Arte e de Cultura Popular - UFMT ............................................. 128

5.9. Museu da Gravura Brasileira - URCAMP / RS ............................................ 130

5.10. Museu de Arte Popular e Pinacoteca da UFPB ......................................... 132

5.11. Museu D. João VI - UFRJ ..................................................................... 134

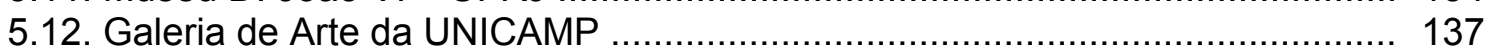

5.13. Museu Regional de Arte - UEFS / Bahia .................................................. 139

5.14. Museu de Arte Leopoldo Gotuzzo - UFPel/RS ........................................... 141

6. Considerações sobre os museus de arte universitários brasileiros ............................ 143

CAPÍTULO 4: Museu e coleção de arte da USP: Coleção de Artes Visuais do Instituto de Estudos Brasileiros e Museu de Arte Contemporânea ..................... 146

1. A Coleção de Artes Visuais do Instituto de Estudos Brasileiros .................................. 149

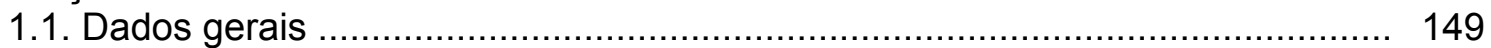

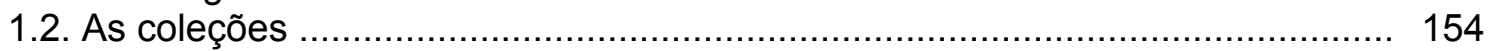

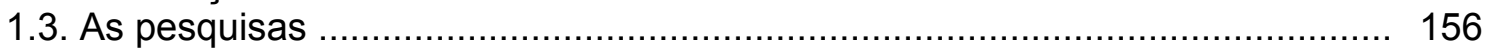

1.4. As atividades de extensão: cursos, exposições e publicações ........................ 163

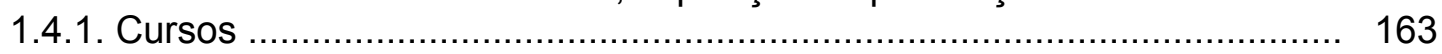

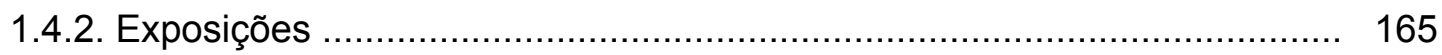

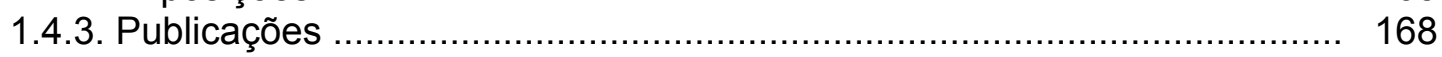

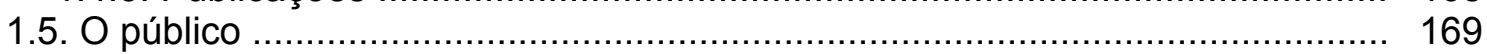

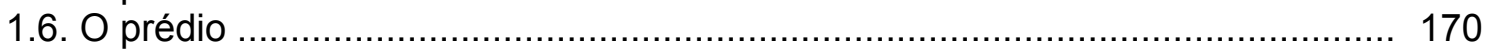

1.7. Uma parte de um instituto: considerações sobre a Coleção de Artes Visuais .. 170

2. O Museu de Arte Contemporânea ....................................................................... 172

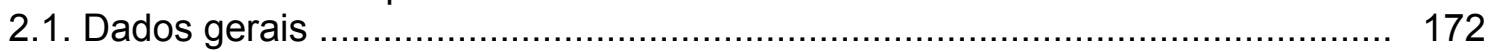

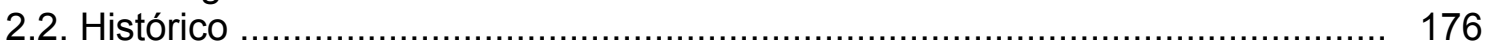

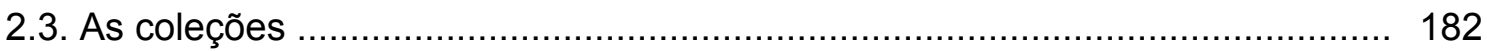


2.4. As pesquisas ................................................................................ 186

2.5. As atividades de extensão: cursos, exposições e publicações ......................... 192

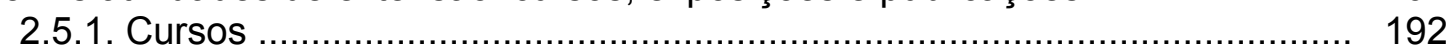

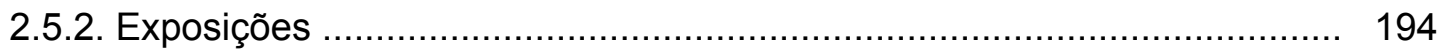

2.5.3. Publicações ....................................................................... 198

2.6. Os prédios: estrutura e localização ....................................................... 200

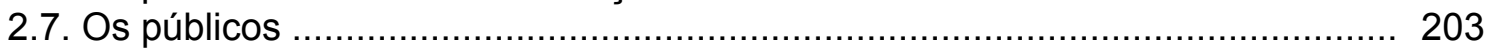

2.8. Considerações sobre o MAC ............................................................. 208

CAPÍTULO 5: MAC/USP: MANTER OU NÃO NA UNIVERSIDADE? ................. 211

1. Cidade no museu ou museu na cidade? ....................................................... 213

2. Desafios para a universidade .................................................................. 215

3. Arte no museu e na universidade: como integrá-las? .................................... 219

4. Os profissionais de um museu de arte universitário ...................................... 221

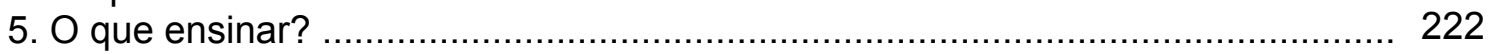

6. Possíveis caminhos para o MAC/USP ................................................. 224

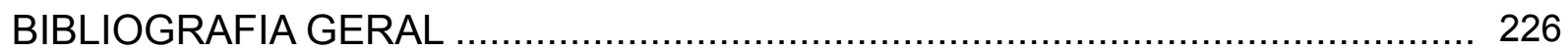

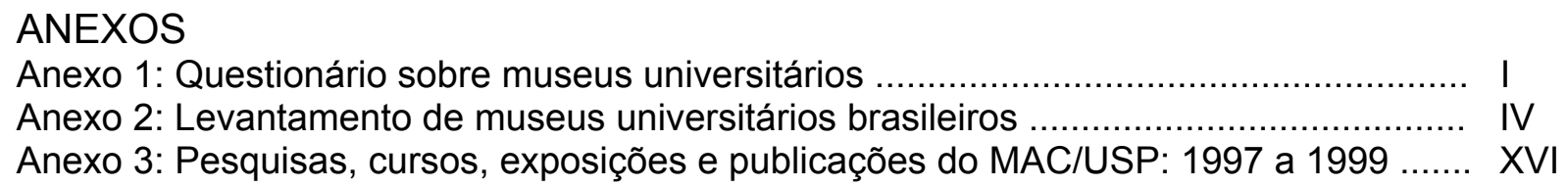

Lista das ilustrações (material de divulgação dos museus e fotos tiradas pela autora)

\section{Capítulo 1}

Museu Ashmolean de Oxford

Museu Universitário de Arqueologia e Antropologia da Universidade da Filadélfia, Pensilvânia Centro Universitário da Universidade de Laval, Quebec

Museu de Educação Louis-Philippe-Audet da Universidade de Montreal

Museu de Geologia da Universidade de Laval, Quebec

Museu Redpath da Universidade McGill, Montreal

Capítulo 2

Museu Histórico Prof. Carlos da Silva Lacaz, Faculdade de Medicina, USP

Museu Oceanográfico, USP

Museu de Anatomia Veterinária Prof. Plínio Pinto e Silva, USP

Museu de Geociências, USP

Capítulo 3

Galeria de Arte do Centro Cultural da Universidade de Sherbrooke, Quebec

Coleção da Universidade Bishop, Lennoxville, Quebec

Museu de Arte Brasileira da Fundação Armando Álvares Penteado, São Paulo

Galeria Brasiliana da Universidade Federal de Minas Gerais, Belo Horizonte

Galeria de Arte Espaço Universitário da Universidade Federal do Espírito Santo, Vitória

Museu de Arte Assis Chateaubriand da Universidade Estadual da Paraíba, Campina Grande

Capítulo 4

Instituto de Estudos Brasileiros, USP

Museu de Arte Contemporânea, USP 
INTRODUÇÃO 


\section{INTRODUÇÃO}

Desde 1980 participamos da vida no campus da Cidade Universitária da Universidade de São Paulo (USP). Inicialmente como aluna de graduação, posteriormente como funcionária e agora como aluna de pós-graduação continuamos a freqüentar o campus.

O tema de nossa pesquisa surgiu a partir da vivência como educadora em um museu da Universidade de São Paulo - Museu de Arqueologia e Etnologia (MAE) -, da observação de outros museus da USP, da inquietação em relação às funções e usos dos museus e coleções de universidades públicas.

Em nosso cotidiano no MAE percebíamos uma rica coleção, um conjunto bem formado de profissionais e um pequeno aproveitamento, tanto das coleções como do potencial dos profissionais, pela universidade e pelo público em geral. A falta de integração entre os museus e entre estes e outros órgãos da universidade também dificultava a realização de projetos pelo MAE.

Atendíamos cotidianamente escolares de ensino fundamental e médio que vinham visitar as exposições em visitas programadas por suas escolas. Em levantamentos sobre os visitantes do MAE, percebemos uma pequena quantidade de alunos e professores da USP, de famílias e turistas. A maioria dos visitantes era (e acreditamos que ainda é) de escolares.

As dúvidas surgiram - a quem deveriam servir os museus da USP? quais as suas funções - pesquisa, ensino e extensão? para quem? Como fazer a comunidade universitária se interessar e participar de atividades nos museus da USP? Será que temos que ampliar nossos públicos ou devemos estar satisfeitos com aqueles que nos visitam? Quais projetos têm prioridade - de pesquisa, de ensino ou de extensão? Afinal, a USP tem a salvaguarda dessas coleções e tem responsabilidade perante a sociedade de mantê-las e divulgá-las, ou não?

A partir desses questionamentos, procuramos conhecer outros museus universitários brasileiros e estrangeiros. Buscávamos possíveis modelos institucionais, formas de funcionamento, políticas culturais, relacionamentos com as comunidades universitárias e as não pertencentes à universidade, enfim, características que pudessem auxiliar uma análise crítica da situação dos museus da USP.

Para conhecer os museus universitários brasileiros tivemos que localizá-los e listá-los para posteriormente buscar as informações. Sabendo das dificuldades para 
obter dados pessoalmente - dadas as dimensões do país - e mesmo por correspondência - em virtude da pequena porcentagem de respostas a questionários assim enviados - procuramos fontes indiretas junto à Comissão de Patrimônio Cultural da USP (CPC/USP) e à Vitae Apoio à Cultura, Educação e Promoção Social (Vitae). A CPCNSP vinha coletando há alguns anos informações sobre os museus da USP e também sobre museus brasileiros compondo um Guia de Museus Brasileiros (que teve a sua primeira edição em 1996); a Vitae também vinha solicitando preenchimento de um cadastro pelos museus brasileiros com finalidade de mapeamento e posterior financiamento. Folhetos e contatos diretos com profissionais de alguns museus completaram nossas fontes. Assim conseguimos identificar mais de 125 museus universitários no Brasil. ${ }^{1}$ Esse grande número de museus já mostra por si a importância desse tipo de instituição.

Em levantamentos de museus estrangeiros, também fomos encontrando grande quantidade de museus universitários nos diversos continentes. Tivemos a oportunidade de conhecer pessoalmente uma série de museus da América do Norte, principalmente do Canadá. De outros países obtivemos informações de forma indireta, pela bibliografia ou por meio de respostas aos questionários.

No segundo semestre de 1998, surgiu um grupo organizado e internacional, preocupado em conhecer e melhorar as condições dos museus universitários. Por iniciativa de Peter Stanbury, da Austrália, foi organizada uma reunião durante a Conferência Internacional do ICOM em Melbourne para tratar da organização de um grupo de estudo de museus universitários ${ }^{2}$. A partir daí foi elaborada a proposta para criação de um comitê do Conselho Internacional de Museus (ICOM) exclusivamente para museus universitários, solicitação que foi aceita e será implementada experimentalmente a partir de julho de 2001. Percebemos assim um movimento mais amplo de valorização e reconhecimento dessas instituições. Além disso, a revista Museum da UNESCO dedicou dois números - 206 e 207 - do ano 2000 aos museus universitários.

\footnotetext{
${ }^{1}$ Em consulta ao Banco de Dados da CPC/USP em 23/11/99, fomos informados que entre os 840 museus cadastrados em sua base de dados, 109 eram universitários. Nós identificamos até agora 129 museus universitários.

${ }_{2}^{2}$ Peter Stanbury sistematizou informações sobre museus universitários de vários países em um site da internet (www.lib.mq.edu.au/mcm/world), no qual encontramos listas de museus universitários de países da Ásia (Malásia, Filipinas e Japão), Australásia (Austrália e Nova Zelândia), Europa (Bélgica, Espanha, Itália, Holanda e Grã-Bretanha), América do Norte (Canadá) e América do Sul (Brasil e Peru).
} 
Nas pesquisas sobre esses museus - brasileiros e estrangeiros - encontramos alguns pontos comuns, como as dificuldades financeiras, a falta de autonomia, a relação por vezes íntima ou por vezes distante com os departamentos afins (incluindo aí professores, alunos e funcionários), com a comunidade universitária e com a comunidade regional, o abandono das coleções, a falta de espaço para armazenamento e para exposição, a falta de profissionais especializados em atividades museológicas, entre outros.

Autoridades de alguns países vêm buscando soluções. No caso da Austrália foi criada uma comissão para fazer o diagnóstico da situação dos museus universitários do país e propor modificações. O trabalho iniciou-se em 1996 e vem trazendo resultados positivos, publicados em relatórios. Na Grã-Bretanha já havia sido feito um levantamento há trinta anos, e em 1987 foi criado o Grupo de Museus Universitários para valorização dessas instituições. Novos trabalhos foram elaborados na década de 1990 para mapear as coleções universitárias do país. ${ }^{3}$

No Brasil, em 1992, um grupo de profissionais de museus universitários organizou o I Encontro de Museus Universitários, em Goiânia, no qual foram discutidos vários problemas, e dele resultou a formação do Fórum Permanente de Museus Universitários. Várias sugestões e moções foram definidas ao final do Encontro, mas pouco foi concretizado. O Fórum continua a existir, reuniu-se uma outra vez na USP em 1997 mas não conseguiu realizar outra grande reunião como a de 1992.

Os museus universitários de diversos países, na última década, vêm sofrendo as conseqüências da crise das universidades que, públicas ou privadas, têm enfrentado grandes problemas decorrentes da diminuição de suas verbas. Assim, a já pequena parcela dos museus dentro do orçamento geral da universidade está cada vez menor. Para manter seu funcionamento, os museus precisaram criar mecanismos para

\footnotetext{
${ }^{3}$ Os relatórios australianos são: Cinderella Collections: University Museums and Collections in Australia. The Report of the University Museums Review Committee, 1996 e Transforming Cinderella Collections: The Management and Conservation of Australian University Museums, Collections \& Herbaria. The Report of the DCA / AV-CC University Museums Project Committee, 1998. O relatório da Grã-Bretanha foi feito em 1968: Universities and Museums: Report on the Universities in relation to their own and other Museums. Standing Commission on Museums and Galleries, Her Majesty's Stationery Office, London, 1968. Dois trabalhos publicados na Grã-Bretanha em 1999 exemplificam esse esforço: Beyond the Ark: Museums and Collections of Higher-Education Institutions in Southern England de K. Arnold-Foster e The management of Higher Education Museums, Galleries and Collections in the UK, de M. Kelly. No caso dos Estados Unidos, Laurence Vail Coleman, renomado profissional de museu, elaborou um livro voltado para diretores de museus universitários após extensa pesquisa de campo: College and University Museums: a message for colllege and university presidents. AAM, Washington DC, 1942.
} 
obtenção de patrocínios e financiamentos externos, da iniciativa pública e privada. Entretanto, muitas dessas instituições não estavam ou ainda não estão preparadas para competir nesse mercado, talvez por serem burocratizadas demais ou carecerem de profissionais para lidar com essa questão.

No caso dos museus da USP, identificamos vários tipos de museus - coleções para ensino e pesquisa, museus voltados para o público escolar, combinações dos dois anteriores, coleções guardadas sem utilização, entre outras situações. Os quatro museus que têm autonomia e são reconhecidos como tal - MAE, Museu Paulista (MP), Museu de Zoologia (MZ) e Museu de Arte Contemporânea (MAC) - são muito diferentes entre si, como veremos nos próximos capítulos.

Consideramos que um museu universitário, idealmente, deveria realizar todas as funções de um museu, de acordo com a definição do $\mathrm{ICOM}^{4}$, e além disso deveria:

- abrigar / formar coleções significativas para desenvolvimento de pesquisa, ensino e extensão;

- dar ênfase ao desenvolvimento de pesquisas a partir do acervo;

- manter disciplinas que valorizem as coleções e as pesquisas sobre as coleções;

- participar da formação de trabalhadores de museus;

- propor programas de extensão: cursos, exposições, atividades culturais, atividades educativas baseados nas pesquisas e no acervo;

- manter programas voltados para diferentes públicos: especializado, universitário, escolar, espontâneo, entre outros, dependendo da disponibilidade de coleções semelhantes na região e do interesse dos diferentes públicos. Esses programas também são frutos de pesquisas.

O museu universitário, estando mergulhado no meio acadêmico, deveria tirar o máximo de vantagens desse fato, pois a universidade como produtora de conhecimento, como espaço de experiência e de formação é uma riquíssima fonte de recursos para os museus universitários.

\footnotetext{
${ }^{4}$ Definição do ICOM, de acordo com seus Estatutos, adotados pela Assembléia Geral de 1989: "O Museu é uma instituição permanente, sem fins lucrativos, a serviço da sociedade e de seu desenvolvimento, aberta ao público, e que faz pesquisas concernentes aos testemunhos materiais do homem e de seu meio, adquirindo-os, conservando-os, comunicando-os e especialmente expondo-os com o propósito de estudo, educação e deleite."
} 
Partindo desse perfil ideal de museu universitário (e de universidade), pretendemos estudar as origens dos museus universitários, seu desenvolvimento e sua situação atual, tendo como alvo principal os museus da USP. Entretanto, por ser um universo muito amplo, deveremos fazer alguns recortes para que possamos de fato aprofundar as análises da situação atual. Assim, deveremos eleger como objeto principal os museus de arte universitários e especialmente os museus e coleções de arte da USP. O termo arte estará aqui restrito às artes visuais.

As questões que nortearão esse processo são: "Por que museus universitários de arte?" e "Por que museus de arte na USP?".

A hipótese inicial é de que a situação atual dos museus de arte da USP poderia ser modificada no sentido de disponibilizar esses acervos para diferentes públicos da melhor forma possível. Essas mudanças passariam pela definição de políticas culturais da USP para com os seus museus e também pela definição clara da missão de cada museu, gerando programas coerentes com suas metas.

No caso dos museus e coleções de arte, a discussão também gira em torno dos tipos de coleções, exposições e atividades museológicas ideais para serem desenvolvidas em um museu de arte universitário. Partiremos de um modelo ideal de museu universitário para depois discutirmos a situação encontrada e, a partir dela, elaborarmos novos modelos. As questões centrais dessa parte serão: "para que servem as coleções de arte?"; "a USP deve ter museus e coleções de arte?"; "quais as melhores políticas culturais para esses museus?".

A comparação da realidade dos museus e coleções universitários de diferentes países com os da Universidade de São Paulo poderá nos ajudar a responder a essas questões.

Nossa tese será desenvolvida em 5 capítulos.

Para responder à questão "Por que museus universitários?" no primeiro capítulo iremos investigar a origem e história desses museus nos diversos continentes e sua situação atual.

No segundo capítulo trataremos especificamente da formação dos museus e coleções universitários brasileiros e seu uso atual, detalhando o caso da Universidade de São Paulo. 
No terceiro capítulo trataremos dos museus e coleções de arte universitários de vários países, principalmente dos da América do Norte e do Brasil. Faremos uma breve exposição sobre o perfil dos museus de arte universitários do Brasil, deixando os da USP para o capítulo seguinte.

No quarto capítulo discutiremos o funcionamento do Museu de Arte Contemporânea e da Coleção de Artes Visuais do Instituto de Estudos Brasileiros e sua inserção na universidade.

$\mathrm{E}$, finalmente, no último capítulo retomaremos o modelo inicial proposto e, diante da discussão realizada, apresentaremos sugestões de possíveis políticas culturais para o MAC/USP.

Nossa pesquisa não pretende de maneira nenhuma esgotar esse tema, mas apenas servir como subsídio para a discussão da necessidade ou não de museus de arte para a Universidade de São Paulo e para outras universidades. Ao optarmos por discutir os museus de artes visuais estamos deixando de lado o imenso universo de museus de ciências exatas, biológicas e humanas das diversas universidades estrangeiras, brasileiras e da USP. Esse universo aparecerá de forma resumida nos primeiros capítulos da tese quando trataremos da história e situação atual dos museus universitários.

A escolha de museus de arte em detrimento dos museus de ciências biológicas, exatas e humanas se deve também pelo desafio a ser enfrentado. Em vários aspectos, principalmente no desenvolvimento de pesquisa e formação de coleções, esses outros museus estão muito bem definidos. Para geólogos, arqueólogos, zoólogos e mesmo historiadores da cultura material, a formação de coleções a partir da pesquisa é uma conseqüência "natural", enquanto no caso da pesquisa em museus de arte isso não ocorre. Os altos valores de mercado de obras de arte, agregados à difícil definição de políticas de aquisição, criam obstáculos para a formação e ampliação das coleções em museus de arte. Nos museus de ciências biológicas, exatas ou humanas, grande parte das coleções foi gerada pela pesquisa dentro das universidades, enquanto no caso dos museus de arte, a maior parte das coleções foi recebida por doação, como um pacote fechado. Essas são algumas das características que tornam a busca de políticas culturais para museus universitários de arte uma tarefa mais complexa porém, mais instigante. 


\section{CAPÍTULO 1}

Origens e desenvolvimento de museus universitários 


\section{CAPÍTULO 1}

\section{Origens e desenvolvimento de museus universitários}

Para entendermos o que é e o que deveria ser um museu universitário, pesquisamos suas origens e história e levantamos suas características atuais em diferentes países. Baseamos nossa investigação na bibliografia disponível e em contatos realizados com profissionais dos museus, tanto por correspondência como pessoalmente. Cada uma das fontes traz níveis diferentes de informações, sendo que, de maneira geral, as informações obtidas por meio da bibliografia tratam de temas mais gerais, enquanto as resultantes de contatos diretos trazem dados sobre museus específicos.

\section{Mas o que seria um museu universitário?}

A maioria dos autores, ao definir as tipologias dos museus, identifica com pequenas variações, as seguintes categorias: museus de arte, museus de história natural, museus de etnografia e folclore, museus históricos, museus de ciências e técnicas, museus de ciências sociais e serviços sociais, museus de comércio e das comunicações, e museus de agricultura e produtos da terra. (Classificação do ICOM). Mas podemos definir tipologias segundo diferentes critérios (León, 1978:114-170), como a partir das disciplinas (artes, história, etnologia, etc.) ou por sua propriedade privados e públicos - e dentro destas duas últimas categorias poderiam ser classificados em estatais, municipais, eclesiásticos e também universitários.

Estamos buscando saber o que poderia definir um museu universitário, ou seja, em que aspectos um museu universitário se diferencia de outros museus? Por enquanto admitiremos que uma coleção ou um museu universitário é caracterizado por estar parcial ou totalmente sob responsabilidade de uma universidade - salvaguarda do acervo, recursos humanos e espaço físico.

Para isso procuramos conhecer a formação e situação dessas instituições em diferentes países, iniciando na possível origem em Alexandria e continuando na Inglaterra do século XVII, quando o primeiro museu universitário foi fundado - o Ashmolean Museum de Oxford. 


\section{Origens?}

Antes de tudo é preciso dizer que a ligação entre museus e universidades remonta à tão famosa biblioteca de Alexandria, instituída cerca de 280 a.C., na qual identificamos tanto características de universidade como de museu.

A formação de coleções provavelmente faz parte das atividades da humanidade desde suas origens. Entretanto, sempre que se escreve sobre as origens da palavra museu, destaca-se o mouseion de Alexandria, onde coleções de objetos e livros, além de laboratórios, observatório, jardim botânico e zoológico estavam à disposição dos pensadores.

"Inspiradores do Museu e da biblioteca, Demétrio e Estratão transpõem para Alexandria, para torná-los instituições oficiais, os princípios que animavam o Liceu de Aristóteles e, ainda antes, a Academia de Platão: os de uma comunidade consagrada exclusivamente à busca da verdade, ou seja, ao culto das Musas." (Schaer, 1993:13-4) ${ }^{1}$

Os sábios membros do mouseion eram sustentados pelos reis para se dedicarem à pesquisa. O mouseion de Alexandria nasceu como uma instituição do Estado, com a função política de testemunhar a continuidade entre o novo reino e o império de Alexandre.

"No Museion de Alexandria se consumou a tragédia da cultura grega, mas foi também lá que se realizara a primeira relação institucional formal entre poder político e intelectuais pertencentes aos quadros do poder. A partir de Alexandria, Museion tornou-se, no mundo clássico, sinônimo de intelectualidade de estado e, como tal, foi respeitado pelos conquistadores romanos e combatido pelos revolucionários cristãos; como tal, seria amado pelos historiógrafos, pelos humanistas e pelos cientistas do Renascimento italiano." (Binni, 1989:11)

Não se sabe exatamente quem eram os membros do mouseion e como ele era mas, segundo descrição do século I a.C. (Estratão), situava-se em um grande palácio real construído em fins do século IV a.C. com pórticos, sala para discussão, vasto refeitório onde os sábios membros do mouseion faziam juntos suas refeições.

Para alguns autores, como Fernández (1993:51), o mouseion se apresenta como antecessor de centros pluridisciplinares de hoje e a pinakothéke, onde eram guardados as obras de arte, estandartes, troféus e tesouros, representa historicamente uma instituição mais parecida com a concepção de museu tradicional.

\footnotetext{
${ }^{1}$ As musas, filhas de Zeus e Mnemosine eram inspiradoras de poetas e sábios e dominavam uma atividade criativa: "Calíope à poesia épica, Clio à história, Euterpe à poesia lírica, Polímnia ao hino, Erato à poesia amorosa, Talia à comédia, Melpômene à tragédia, Urânia à astronomia, Terpsícore à dança." (Schaer, 1993:14)
} 
Não pretendemos nos aprofundar nessa questão das origens históricas dos museus, mas gostaríamos de chamar atenção para o fato de que aquilo que se designava mouseion durante o período helenístico é muito próximo de nossa idéia de universidade e continha coleções em sua constituição:

"Aquel recinto donde fraternizaban artistas, poetas y sabios en una especie de cooperación intelectual, contaba con un observatorio, salas de reunión, laboratorios, jardines zoológicos y botánicos y, sobre todo, con la famosa biblioteca en la que se guardaban unos ochocientos mil manuscritos. Era, sin duda, una especie de ciudad universitaria que no sólo concedía importancia al cultivo del intelecto, ya que la naturaleza era considerada como elemento indispensable para la formación humana." (Fernández, 1993:57, grifo nosso)

As diversas funções do mouseion, foram historicamente divididas em diferentes instituições: a universidade realiza o ensino superior; as bibliotecas guardam as fontes escritas e os museus preservam os objetos.

Entretanto, vários séculos separam o mouseion de Alexandria das universidades medievais, das quais derivam nossas universidades.

No século XII, na Europa, inspirados em grupos religiosos de ensino superior, formaram-se grupos de estudiosos de diferentes origens denominados de studia generali. Organizados como uma sociedade privada de busca do conhecimento de diversas áreas, esses grupos foram se estruturando e recebendo inicialmente reconhecimento informal das autoridades (século XIII) e posteriormente reconhecimento formal das autoridades eclesiásticas e civis passando a ser conhecidos como universidade (século XIV). Essa comunidade de professores e alunos não tinha local fixo para realizar suas funções que somente mais tarde seriam fixadas em prédios próprios que formariam o campus universitário. A existência de um local fixo de atividades é condição para a salvaguarda de coleções e a criação de museus universitários.

Da mesma maneira, os museus atuais, abertos ao público, são muito mais parecidos com os gabinetes de curiosidades medievais e com as galerias de arte renascentistas, do que com o mouseion de Alexandria.

Em várias versões da história geral dos museus, o ano de 1683 é dado como marco do início dos museus abertos ao público ${ }^{2}$, ocasião da abertura do Ashmolean Museum da Universidade de Oxford, na Grã-Bretanha.

\footnotetext{
${ }^{2} \mathrm{O}$ movimento de abertura ao público intensificou-se no século XVIII, em diversos países da Europa, quando o Estado passou a ter a salvaguarda de coleções privadas e as abriu para visitação pública. Louvre (França), Prado (Espanha), Belvedere (Áustria), entre outros.
} 
Os primeiros museus universitários formaram-se a partir da doação de grandes coleções particulares às universidades. A atitude do colecionador e/ou seus herdeiros, de passar a salvaguarda de uma coleção à universidade, pressupunha que a instituição era digna, adequada e competente para exercer essa função.

A formação de um museu universitário pode se dar de várias maneiras: pela aquisição de objetos ou coleções de particulares por doação ou compra, pela transferência de um museu já formado para responsabilidade da universidade, pela coleta e pesquisa de campo e pela combinação desses processos.

Apresentaremos a seguir diferentes processos de formação de museus universitários europeus e americanos e algumas dificuldades decorrentes da forma de criação.

\section{A universidade vista como guardiã segura e digna para coleções já formadas}

\subsection{Doações e heranças fundando museus universitários}

Na Grã-Bretanha, assim como nos Estados Unidos, grande parte das coleções dos museus universitários resultam de doações e heranças de ex-alunos, exprofessores e/ou grandes benfeitores das universidades. Em muitos casos, os doadores fazem exigências em relação ao uso, salvaguarda e apresentação de suas coleções, limitando a ação daqueles que recebem as coleções. Muitas vezes, é a partir da aceitação de uma coleção que a universidade vai criar cursos e atividades ligadas às disciplinas afins.

Em 1994 foi realizado um Seminário sobre a situação legal das coleções doadas a universidades e fundações britânicas ${ }^{3}$, em vista das vendas desses bens por algumas das instituições. Os debatedores diferenciavam, a princípio, a situação de uma universidade que já é estruturada em uma determinada área e recebe uma coleção afim como doação e/ou herança e outra que não desenvolve nem pesquisa nem ensino na área e recebe coleção que a "força" a desenvolver tal área/disciplina. Em ambos os casos, as universidades que tinham sido criadas para ensino e pesquisa vão ampliar a sua atuação, devendo assumir a responsabilidade pela preservação do patrimônio.

Inicialmente a abertura ao público era restrita tanto por horários como por nível sócioeconômico. 
"Hoje em dia, nos círculos educacionais, a tendência é ver a posse de bens móveis, de valor cultural ou científico, como subordinada aos propósitos originalmente declarados da instituição - numa universidade, o cultivo do saber e o provimento do ensino - mas foi sugerido às mesas redondas que o ato de aceitação de tais bens por uma doação, para sua preservação perpétua, representava a adoção de um novo objetivo específico para aquela instituição." (Peter Cannon-Brookes, 1994:341, grifo nosso)

No seminário, a discussão da legislação referente às doações volta ao século XVII, sempre colocando o problema do uso dos bens recebidos, das intenções do benfeitor e da propriedade legal dos bens. Tratando do caso da doação feita por Elias Ashmole à Universidade de Oxford, os autores destacam que o doador acreditava que a universidade seria a melhor guardiã das coleções que serviriam para o estudo da natureza. Além disso, no contrato de doação e durante o período em que geriu a coleção, Ashmole tentou garantir sua preservação por meio de inspeções periódicas obrigatórias, além de incentivar a criação de um Catálogo das Coleções e o registro/desenho das coleções perecíveis. Em 1683 quando o museu foi aberto ao público tinha, no mesmo prédio, uma sala de palestras e um laboratório para demonstrações. Foi também criada uma cadeira de História Natural e Química, cujo titular seria responsável pela coleção. Até hoje a Universidade de Oxford mantém o Ashmolean Museum, mas parte da coleção foi doada e vendida por seus curadores responsáveis. ${ }^{4}$

O Seminário evidenciou que nem sempre se pode dizer que uma coleção pode ser usada para ensino ou pesquisa da Universidade que a possui. Por exemplo, o Ashmolean Museum tem uma coleção de desenhos da Renascença e a Universidade não tem curso de artes ou história da arte. Mas esta coleção, pela sua qualidade, é de importância nacional.

Depois do Ashmolean Museum da Universidade de Oxford, outros museus universitários formaram-se também a partir de doações de coleções na Grã-Bretanha. São os casos do Sedgwick da Universidade de Cambridge, em 1727, o Hunterian da Universidade de Glasgow, em 1783 e o Manchester Museum aberto ao público em 1888. As coleções serviam ao curioso mundo acadêmico:

\footnotetext{
${ }^{3}$ University and Foundation Collections and the Law, realizado no Courtauld Institute Art, em Londres, Inglaterra.

${ }^{4}$ Em um texto sobre museus universitários, Lanfranco Binni chama atenção para o problema da falta de qualificação dos curadores desses museus e suas possíveis conseqüências. Para exemplificar conta o caso da destruição do único exemplar embalsamado da extinta ave dodô (Raphus cucculatus) por ordem do curador das coleções ornitológicas do Ashmolean em 1755. Por causa disso, nunca mais se pôde saber as cores originais desse animal. Apesar do limitado
} 
"Esses museus eram, indubitavelmente, manifestações práticas do espírito de curiosidade cientifica e de investigação acadêmica característicos da vida intelectual dos séculos XVIII e XIX". (Warhurst, 1992:93)

Muitas vezes as coleções foram doadas segundo contratos bastante claros sobre sua disposição e usos, mas seguindo convenções de cada época. Revendo as exigências e disposições contratuais hoje, algumas delas ${ }^{5}$ parecem retrógradas e pouco práticas. Como atualizar tais contratos sem desrespeitá-los?

Outra dificuldade é gerada pela crise financeira das universidades que leva ao questionamento sobre a manutenção das coleções ou a venda de obras. Os participantes do Seminário criticam aquelas instituições que utilizam a crise como desculpa para abandonarem sua função de salvaguarda de coleções.

Para enfrentar os problemas legais e financeiros, recomendou-se rever os papéis sociais a serem desempenhados pelas coleções e pelos museus universitários e, em seguida, planejar ações dentro desses parâmetros.

As universidades que receberam grandes coleções já formadas enfrentaram e ainda enfrentam dificuldades decorrentes da:

- ausência ou limitação de espaço físico adequado para abrigar as coleções;

- ausência de pessoal qualificado para garantir a salvaguarda das coleções;

- características/perfil das coleções que dificultam a pesquisa, ensino e/ou extensão a partir das mesmas.

Como veremos no capítulo 4, o MAC/USP que foi criado a partir da coleção do Museu de Arte Moderna de São Paulo (MAM/SP) enfrenta algumas dessas dificuldades.

valor desse espécime para a pesquisa biológica, o evento serve para mostrar o desconhecimento do significado das coleções por alguns curadores.

${ }_{5}$ Alguns doadores exigem que toda a coleção seja exposta conjuntamente, proibindo o empréstimo para outras instituições ou a mistura com obras de outras coleções. Há aqueles que doam dinheiro, mas restringem o tipo de obra que pode ser adquirida, sendo somente de um determinado período ou de uma determinada técnica. 


\section{Museu Aschmolean de Oxford}

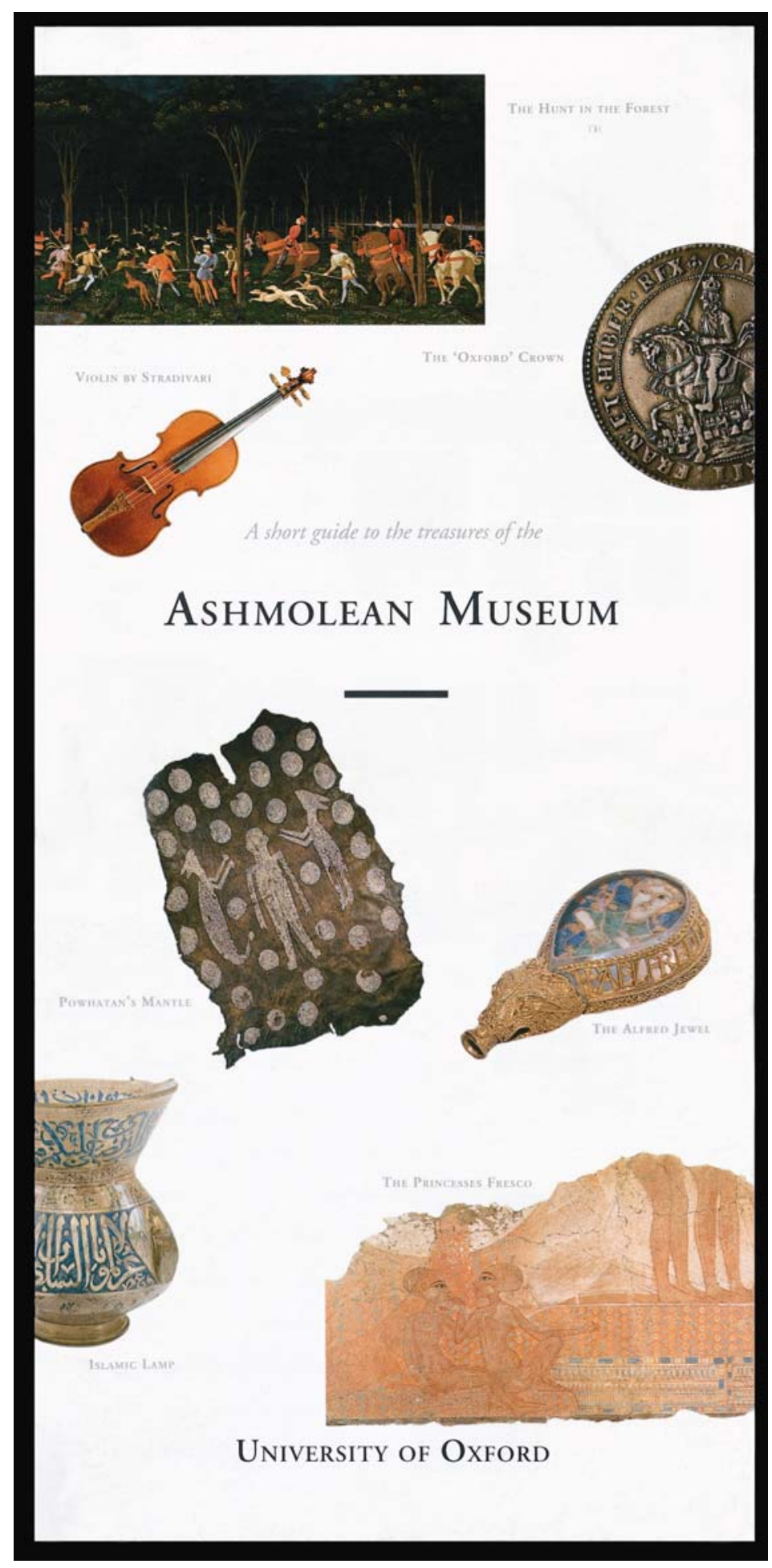




\subsection{Incorporação de coleções e museus na formação da universidade}

Em muitos países há museus universitários que foram criados pela incorporação de coleções e museus no momento de fundação da universidade. Apresentaremos aqui dois exemplos, um da Noruega e outro da Argentina, para ilustrar essa situação.

Os museus universitários são os mais antigos entre os grandes museus da Noruega.

A Noruega tem quatro universidades, todas com museus: de Oslo, fundada em 1811, de Bergen fundada em 1946, de Trondheim fundada em 1968 e de Troms $\varnothing$ fundada em 1968.

Quando a Universidade de Oslo foi criada, a rica coleção geológica de uma academia de mineradores foi incorporada e logo aberta ao público; pouco depois, a coleção zoológica também. Em 1814 foi criado o Jardim Botânico da universidade e no início do século XX as coleções de botânica, zoologia, paleontologia e geologia foram transferidas para um prédio localizado dentro do Jardim Botânico. Em 1850 foi criado o museu de História Antiga. Hoje a Universidade de Oslo tem sete museus - incluindo o de Etnografia e o de Numismática. Esses dois últimos e o de Antigüidades estão juntos, no centro de Oslo, um pouco distantes dos museus de ciências naturais. O Museu dos Navios Vikings também faz parte do de Antigüidades e fica em outra parte da cidade.

A história é diferente para as outras universidades: formaram-se a partir de coleções preexistentes. A Universidade de Bergen teve seu início no Museu Bergen que foi fundado em 1825 como um museu de história natural e antigüidades. Hoje o museu tem departamentos das áreas de história antiga e história natural.

Quando a Universidade de Trondheim foi fundada, a Sociedade Real Norueguesa de Ciências e Letras, criada em 1760, foi a ela incorporada. A Sociedade tinha um museu no qual, hoje, há departamentos de arqueologia e história natural. $\mathrm{O}$ departamento de arqueologia do museu é responsável por todos os cursos de arqueologia da universidade.

A Universidade de Troms $\varnothing$ foi fundada a partir do Museu de Troms $\varnothing$ criado em $1872 \mathrm{com}$ as áreas de história natural e história cultural, além de departamentos de cultura sami (da Lapônia), entre outros.

A explicação para a incorporação de museus pelas universidades ou a formação de universidades a partir de museus da Noruega é o fato de ser um pequeno país (4 milhões de habitantes numa área equivalente à da Grã-Bretanha), sendo importante utilizar os recursos já existentes e evitar duplicações. Esses museus já tinham um corpo de servidores altamente qualificado, fazendo pesquisas e atuando junto ao 
público. Hoje, praticamente todos os museus de história natural e arqueologia da Noruega são universitários.

As funções dos museus, segundo os regimentos das universidades norueguesas, são educar estudantes, fazer pesquisa e mediar o conhecimento (resultados de pesquisas) para o público em geral. Os servidores dos museus fazem parte da universidade com os mesmos direitos e obrigações de outros funcionários da universidade. Segundo uma pesquisadora, a valorização da pesquisa em detrimento das atividades de extensão é um dos principais problemas para o funcionamento dos museus universitários ${ }^{6}$ :

"... as pessoas da sociedade universitária recebem mais crédito por suas pesquisas do que pela mediação etc., o que é um problema difícil para os servidores de museus. O problema é que o pessoal de museu tem freqüentemente mais obrigações por causa dos museus. Como vocês provavelmente sabem por seu próprio país, ser ao mesmo tempo um excelente professor universitário, pesquisador e curador/educador de museu é um problema. E, normalmente, o museu é o lado que perde. A carreira é mais beneficiada fazendo pesquisa do que fazendo exposições." (Lauritzen, 1997:2)

Na Argentina, o Museu de La Plata que atualmente pertence à Universidade Nacional de La Plata (Federal) localiza-se nessa cidade, capital da Província de Buenos Aires. A cidade de La Plata foi planejada e criada para ser capital provincial em 1882 e em sua estrutura urbana foram previstos a universidade e o museu. Este recebeu as coleções de Francisco Moreno do Museo Antropológico y Arqueológico de Buenos Aires. O edifício do museu foi projetado por arquitetos europeus e construído em estilo neoclássico, entre 1884 e 1889. O museu foi aberto ao público em novembro de 1888. A universidade foi fundada em 1906 e nesse ano o museu foi incorporado a ela e seus pesquisadores passaram a ensinar nos cursos superiores. Desde sua fundação, o museu contou com pesquisadores, inicialmente europeus que formaram os cientistas argentinos.

Hoje, o museu faz parte da Faculdade de Ciências Naturais, mas tem diretor e conselho próprios. Na opinião da pesquisadora Mônica Lopez Ruf o museu deveria ser uma unidade independente e, segundo sua colega Maria Marta Reca, "Hace unos años inició sus trámites para independentizarse de la Facultad, cosa que logró en algunos aspectos". (Reca, 1997)

\footnotetext{
${ }^{6}$ Esse problema também ocorre na Universidade de São Paulo. No ano 2000 foram iniciados estudos pela comissão que coordena e supervisiona o desenvolvimento da carreira dos docentes (CERT) para incluir, entre os critérios de produtividade, a curadoria de exposições.
} 
A programação do museu deve ser aprovada por seu conselho e pelo departamento de Ciências Naturais da faculdade. O museu tem mais de 250 pesquisadores, sendo que a maioria é docente da Faculdade de Ciências Naturais. São 15 departamentos científicos - arqueologia, etnografia, antropologia, paleontologia, zoologia de vertebrados, zoologia de invertebrados, botânica, geologia, entre outros. A Divisão de Extensão tem 15 docentes universitários dedicados a:

“...atención de visitas pedagógicas, visitas al público en general, exposiciones para ciegos y disminuidos visuales, atención de discapacitados mentales leves y moderados, atención de enfermos mentales. Programan y coordinan material didáctico impreso de todo tipo. Colaboran con la Jefa en la atención de diarios, revistas, canales de televisión, radios y todos los medios de comunicación masiva. El Museo tiene varias páginas en INTERNET." (Ruf, 1997:3)

A visitação anual do museu é de cerca de 500 mil visitantes, ficando aberto ao público todos os dias com exceção de 1 de janeiro, 1 de maio e 25 de dezembro, das 10 às 18 horas. A maioria dos visitantes é argentina, sendo mais da metade escolares.

De acordo com um folheto de divulgação do Museo de La Plata, as suas coleções são comparáveis àquelas do British Museum, ficando atrás apenas dos museus de Ciências Naturais de Washington, Chicago e Nova lorque.

Seu edifício é imponente e muito espaçoso, abrigando as exposições, laboratórios, salas de aula, biblioteca, reservas técnicas e também um auditório. Uma construção realizada especificamente para ser museu aparece como exceção ao padrão de museus universitários com edifícios adaptados.

Tanto receber coleções já formadas após a criação da universidade, quanto adquirir coleções no momento da formação da universidade, acarretam problemas para o funcionamento dos museus, caso não tenha sido feito um bom planejamento como:

- ausência de recursos financeiros e humanos adequados;

- ausência de espaço físico adequado;

- ausência de um corpo de pesquisadores das áreas abrangidas pelas coleções;

- ausência de cursos relacionados com as coleções.

Veremos que, no caso da USP, algumas coleções foram incorporadas no momento de sua fundação sem a criação de cursos correspondentes ou construção de prédios para abrigá-las. 


\section{O ensino universitário cria necessidade de acesso a objetos e obras para formação dos alunos e para desenvolvimento de pesquisas - a universidade adquire coleções}

"Em Birmingham e Manchester, assim como em outras universidades públicas do final da época vitoriana, o ensino prático era firmemente baseado no objeto; os professores davam aulas a partir dos objetos. Não é por acaso que havia e ainda há uma categoria de professor universitário conhecida como 'demonstrador' ". (Hamilton, 1995:77)

O ensino superior de algumas disciplinas desenvolveu-se basicamente a partir de demonstrações, observações e análises de amostras - espécimens, objetos, obras.

"A semente, a partir da qual as coleções universitárias tipicamente se desenvolveram, foi o reconhecimento - na verdade a aceitação - do fato de que os objetos poderiam, de modo inigualável, soltar a língua do professor e ampliar a compreensão dos estudantes." (Hamilton, 1995:73)

No século XIX, as ciências naturais eram ensinadas por meio da descrição e classificação de espécimens de animais, vegetais e minerais (taxonomia). As universidades viam-se na obrigação de adquirir e/ou coletar coleções para realizar o ensino. Não bastava ver os espécimens em exposições, era preciso possibilitar a manipulação:

"Ensinar através do manuseio de espécimens, ou de sua observação de perto, era considerado mais benéfico do que olhar objetos em vitrinas durante visita a um museu nacional ou municipal local." (Warhurst, 1992:94)

A importância das coleções para o ensino foi diminuindo conforme a experimentação, e ciências como a microbiologia e a genética, foram sendo valorizados.

No século $X X$ essas coleções vêm perdendo vínculo com ensino e pesquisa, servindo apenas como coleções de referência de cada espécime ou com menor freqüência para ensino:

"Grandes coleções - de material ósseo, peles de aves, insetos e folhas de herbários - não são mais consideradas como absolutamente essenciais ao ensino de graduação, embora sejam úteis em alguns aspectos daquele ensino e para dar aos estudantes a sensação das coisas reais." (Warhurst, 1992:96)

Eventualmente essas coleções podem ganhar novos usos. Um exemplo é de uma coleção de insetos coletada no século XIX (Gorham Collection of British Beetles) e pertencente ao Museu local de Birmingham. Essa coleção foi emprestada para a 
Universidade para realização de estudos de sistemática e de ciências da terra, mas com o tempo foi perdendo sua importância nessa área. Mas essa mesma coleção adquiriu grande valor para os estudos de Arqueologia do Solo do Departamento de História Antiga e Arqueologia, nos quais vem sendo usada como material comparativo.

"Então, um século depois que o material tinha sido coletado para fins de identificação dos besouros, sua classificação e pesquisa, a mesma coleção desenvolveu novas linhas e valores, com os quais - apostamos - Gorham nunca teria sonhado." (Hamilton, 1995:78)

Recentemente, o diretor do Museu de Zoologia da USP, Miguel Trefaut Rodrigues, ressaltou uma nova função dessas coleções dentro do movimento de valorização da preservação do meio ambiente: só se pode fazer um bom projeto de preservação da natureza conhecendo as espécies que existiram e as que ainda povoam o ambiente e para isso é preciso especialistas, sistematas e coleções de referência.

"Atualmente, a preocupação crescente com aspectos conservacionistas exige que os museus zoológicos documentem, quando possível, a faixa das áreas que estão sendo alteradas. São registros valiosos, que além de permitir estudos clássicos sobre diversidade, variação geográfica, zoogeografia e evolução, fornecem elementos para a compreensão da ecologia de comunidades e a auto-ecologia". (Trefaut, 1999:31)

$\mathrm{Na}$ área de história, o documento escrito continua sendo prioritário para a pesquisa e para o ensino. Entretanto, o desenvolvimento de novas linhas de pesquisa nas últimas décadas, como a história do cotidiano, tem valorizado a cultura material como fonte e, conseqüentemente, os museus. Dessa maneira são poucos os museus de história universitários, mas há uma tendência de aumento.

No caso das artes, grande parte dos museus universitários foi criada antes da existência de cursos de artes. Há exceções nas quais as universidades formaram coleções para o ensino e pesquisa. Nesses casos, as coleções de arte são utilizadas para ensino e pesquisa de belas artes, história da arte e museologia.

"Na Universidade de Manchester, a Whitworth Art Gallery é usada anualmente por estudantes de pós-graduação, do curso de Estudos de Museus e Galerias de Arte, para aprender o processo de montagem de uma grande exposição de arte, em colaboração com a equipe da galeria e um designer profissional. Há muitas situações nas quais a equipe do museu universitário responsável pela curadoria faz palestras para os estudantes como parte do currículo de seus cursos acadêmicos." (Warhurst, 1992:98)

No entanto, as coleções de artes são vistas menos como recurso para ensino e mais como fonte de enriquecimento cultural do campus e da vida universitária. 
"Mas o estudo acadêmico de Belas Artes nunca poderá ser a razão de ser dessas coleções ou a medida de seu valor para as universidades." (Standing Commission on Museums and Galleries, 1968:10)

O maior problema ou risco para as coleções adquiridas para fins de ensino e pesquisa é a mudança de métodos e paradigmas de pesquisa das áreas por elas abrangidas. Esse processo é bastante claro para as ciências naturais, quando as transformações das ciências redundaram na mudança do ensino e no "engavetamento" de muitas coleções.

Nas artes, podemos perceber fenômeno semelhante quando a prática da observação e cópia de obras tão cara ao ensino da arte acadêmica, o que em conseqüência valorizava as coleções e museus, é substituída pela visão espontaneista da aprendizagem da arte que evitava o contato com obras a fim de que a inspiração natural de cada pessoa não sofresse influências externas.

\subsection{A pesquisa universitária coleta exemplares e cria coleções: arqueologia, história natural}

Uma das maneiras de aquisição de coleções nas áreas de antropologia e ciências naturais é a coleta de campo. O próprio ato de coletar faz parte da pesquisa desenvolvida por pesquisadores e professores universitários, muitas vezes acompanhados por seus alunos.

"A função de um museu universitário é atuar como auxiliar na pesquisa e na instrução de alunos avançados de uma matéria específica, e ser um dos laboratórios para pesquisadores de campo, e um substituto para o trabalho de campo." (apud Rolfe, 1969:7)

$\mathrm{Na}$ área de geologia, as atividades de campo são importantes para o ensino assim como a análise e estudo de amostras em laboratório. Alguns autores, como George $^{7}$, consideram também fundamental a exposição didática das coleções para o ensino.

Para o geólogo lan Rolfe, do Hunterian Museum da Universidade de Glasgow, o ideal seria um equilíbrio entre a pesquisa e o ensino. No caso da geologia, a pesquisa de campo vai gerando inúmeras coleções que, completadas com informações básicas

\footnotetext{
7 "Mas, como um museu didático, não precisa ser tão ambicioso, e desempenha sua função em vários departamentos já a preenche - quando põe em exposição, para estudo permanente do aluno de graduação, todos ou a maioria dos fósseis que se espera que ele conheça, e faz isto de várias maneiras, suplementando-a por modelos ampliados, dissecações e outros recursos museográficos, e explicando-a por um texto amplo e não demasiado técnico." (George, 1965, apud Rolfe, 1969:7)
} 
dadas pelos pesquisadores, formam as coleções do museu universitário. Ocorre que existem inúmeras coleções geológicas também em museus locais, regionais e nacionais britânicos, talvez não tão bem estudadas e documentadas. O autor destaca que houve um crescimento do número de pequenos museus em quase todos os departamentos de geologia das universidades, interpretando isso como um claro sinal do valor positivo dos museus para o ensino e pesquisa. Mas o autor relata que, para o ensino de geologia, apenas exibir amostras para os alunos não basta, uma vez que eles precisam lidar com os materiais em laboratório. Seguindo este raciocínio, lan Rolfe destaca que poderia se duvidar da necessidade de exposições na universidade já que "... os objetivos de tais exibições podem ser mais bem atendidos se o material for posto à disposição para estudo supervisionado em laboratórios." (p.8) Ele ainda reforça essa idéia ao afirmar que exposições de qualidade (high-level) são caras, ocupam muito tempo do pessoal, servem só para graduandos e ficam desatualizadas rapidamente.

Em Glasgow essa questão foi solucionada com a criação de uma exposição mais simples que apresentasse textos acessíveis, voltados para alunos da universidade que teriam aulas de geologia apenas no $1^{\circ}$ ano e para o público leigo.

O autor considera que é muito difícil um museu universitário ter um designer próprio e não acha isso tão necessário, pois num museu universitário o público já vem predisposto ao tema, ao conteúdo e assim a qualidade da museografia não precisa ser elevada:

"... parece inevitável que os padrões de exibição em museus universitários ficarão atrás daqueles dos museus mais públicos. Os museus universitários são dirigidos a um público mais empenhado e portanto têm menos necessidade de atrativos visuais." (Rolfe, 1969:9)

\subsection{Servir ou não servir para o ensino não universitário?}

No caso dos Estados Unidos, os museus universitários datam do início do século XIX. Suas funções básicas eram ensino e pesquisa universitários. Alguns autores divergem sobre a obrigação do museu universitário servir ao ensino do público não universitário.

Em 1938, Carl Guthe, diretor do Museu da Universidade de Michigan, apresentou a discussão sobre o papel dos museus de universidades públicas. Para ele, além da pesquisa e ensino, era preciso oferecer atividades e exposições extramuros, 
serviços de identificação de espécimes, visitas para grupos escolares, cursos de extensão e de formação de profissionais de museus.

Diferentemente, Laurence V. Coleman considerava que os museus universitários, públicos ou privados, deviam servir à comunidade universitária e excepcionalmente ao público em geral:

"Servir à comunidade não é a tarefa de um museu universitário, mas as circunstâncias muitas vezes nos levam a extrapolar esta lógica (...) serviço para o público geral às custas do trabalho efetivo com os alunos [da universidade] seria errado." (Coleman, 1939:174-5)

O argumento de que os cidadãos pagam impostos e, portanto, os museus das universidades públicas devem oferecer programas para a comunidade, usado por Guthe, foi rejeitado por Coleman, que afirmava que a fatia do imposto que vai para as universidades é somente para o ensino superior e não para outras faixas de escolaridade.

Coleman ampliou essa discussão em um livro voltado aos reitores das universidades, após ter visitado mais de 200 museus universitários norte-americanos. Publicado em 1942, o livro tem cinco partes: a primeira afirma a importância da existência de museus universitários para o ensino e pesquisa das universidades:

"Museus dignos de crédito são necessários em cada campus. Nos ramos da arte e das ciências biológicas e geológicas, que não podem ser negligenciados na educação superior, o material do museu é a única base sobre a qual se pode apoiar grande parte do ensino e da pesquisa; e as coleções, juntamente com providências adequadas para sua preservação e utilização, são essenciais. Outros ramos, especialmente a história, fazem algum uso de museus, mas a arte e as ciências naturais precisam de museus, para que não haja hiatos nos programas educacionais." (Coleman, 1942:3)

Em sua pesquisa Coleman identificou 700 museus e coleções universitárias de 400 universidades diferentes. Apenas 50 tinham prédios próprios e muitos estavam reduzidos a pequenas salas. Essa variedade de situações, segundo o autor, reflete as diferentes necessidades de cada departamento.

Coleman verificou que, quando são formados grandes museus centralizados, eles tendem a conquistar autonomia de programas de ensino e de pesquisa e se afastam dos departamentos. Nesse sentido, para o ensino eram mais interessantes os museus descentralizados e controlados pelos departamentos.

A segunda parte do livro foi dedicada aos museus de arte, a terceira aos de ciências e a quarta aos de história. Essa divisão reflete a opinião do autor de que os museus de diferentes áreas deveriam ser separados. 
Dos 700 museus, cerca de 100 eram de artes. As primeiras coleções de arte foram doadas às universidades em meados do século XIX e posteriormente foram criados cursos de história da arte e belas artes. ${ }^{8}$ Coleman reafirma que as coleções devem ser usadas para o ensino e para isso podem ser expostas de maneira simples:

"Dado que os arranjos são sempre feitos tendo em mente o estudante e não o visitante externo, as salas de exposição deveriam ser projetadas como locais de trabalho." (Coleman, 1942:23)

Apesar do autor enfatizar a relação direta do museu com o departamento de ensino, ele considera mais produtiva a administração independente do museu, podendo ser exercida por algum professor do departamento, mas com autonomia deste.

A maior parte dos museus encontrados era de ciências, cerca de 500. A maioria das coleções foi iniciada para o ensino e pesquisa, no início do século XIX. Como em outros países, o desenvolvimento da ciência experimental levou à desvalorização das coleções. Em alguns casos houve posteriormente a reutilização como coleções de referência para pesquisa e ensino.

O autor explica o pequeno número de museus universitários de história pela grande valorização do documento escrito. Segundo ele, graças ao desenvolvimento de uma nova tendência que valorizava fontes materiais, estariam se formando museus de história. $^{9}$

Stephen Borhegyi, em 1956, recuperou os dados de Coleman a fim de chamar atenção para o fato de que os museus universitários estavam perdendo sua função original, ou seja, ensino e pesquisa, já que a maior parte dos visitantes não era mais da universidade. Ele verificou que a diminuição do interesse do público universitário levou os museus a procurar novos públicos para justificar sua existência. Borhegyi apresentou algumas sugestões para atrair os universitários novamente: 1) Divulgar, treinar, favorecer o ensino e pesquisa no museu por meio de cursos oferecidos aos professores dos departamentos; 2) Tornar o museu mais atraente para os estudantes criando atividades que os atraiam.

\footnotetext{
${ }^{8}$ Há exceções, como o caso da Universidade de Harvard, que criou o curso de história da arte em 1870 e, sentindo a necessidade de obras para o curso, iniciou suas coleções em 1895. (Coleman, 1942:14)

${ }^{9}$ Em 1952, Hugo Rodeck enviou 527 questionários para museus de universidades dos EUA e recebeu 173 respondidos. Das universidades respondentes, $23 \%$ não tinham museus, $27 \%$ só tinham coleções de ensino e 50\% tinham museus. A maioria dos museus era de artes, seguidos pelos de ciências biológicas, geologia, antropologia e história. (Rodeck, 1952)
} 
Algumas das sugestões do autor foram colocadas em prática pelo museu da Universidade de Oklahoma, obtendo resultados positivos. ${ }^{10}$

Alfred Guthe identificou o público a quem ele serve como sendo o principal fator que diferencia um museu universitário dos outros:

"Como parte de uma instituição educacional maior, atende em primeiro lugar grupos de jovens entre dezessete e vinte e um anos (...) Portanto, o museu universitário deveria procurar suplementar o programa acadêmico geral da universidade de que faz parte. Isto pode ser feito mediante exposições de objetos, coleções para estudo, e pesquisa." (Guthe, A., 1966:103)

Ao longo do artigo, Guthe vai ampliando o público potencial do museu universitário, acrescentando professores, funcionários e público em geral. Este último teria interesse pelo museu caso ele apresentasse uma exposição clara com termos familiares (familiar terms) e, neste caso, o museu estaria preenchendo também o papel de um museu público.

Nesse artigo, encontramos uma contradição que persiste na própria discussão das funções do museu universitário, ou seja, Guthe define-o pelo tipo de público a que serve - comunidade universitária - mas ao mesmo tempo mostra que ele pode atrair e servir a vários outros públicos. Certamente os programas e exposições do museu deverão variar dependendo do público que se procura atingir. Esse fato fica bastante claro quando entramos na discussão sobre os museus universitários de arte, como veremos mais adiante.

\section{A universidade busca, adquire coleções para fortalecer sua imagem diante da sociedade, como guardiã da "cultura" local, universal... (arte, arqueologia, etc.)}

Algumas universidades adquirem coleções ou aceitam doações, principalmente de obras de arte, para se mostrarem como centros de alta cultura. Os museus de arte podem ter o papel de dar qualidade estética à vida do campus:

\footnotetext{
${ }^{10}$ Os exemplos das atividades desenvolvidas citados pelo autor são: pequenas exposições temáticas em locais de grande circulação do campus, participação em eventos comemorativos, concurso mensal para descobrir objeto misterioso, disponibilização de salas para eventos dos alunos, horários de funcionamento mais flexíveis, cooperação com jornal dos estudantes, divulgação em rádio e TV da universidade, cartaz atraente na porta do museu, loja com réplicas e publicações e palestras para público leigo. Como resultado, o museu recebeu cada vez mais ofertas de empréstimos e doações de objetos por parte de estudantes. (Borhegyi, March 1956:311)
} 
"Coleções de arte como as de Liverpool, Nottingham e Hull podem ser usadas para fins didáticos, mas conferem, principalmente, uma qualidade cultural e estética à vida universitária". (Warhurst, 1992:97)

A posse de valiosas coleções dava prestígio às universidades, tanto pelo fato de poderem utilizá-las para ensino e pesquisa como pela criação de uma imagem de patrocinadoras/protetoras das artes e ciências. Nas décadas de 60 e 70 muitas universidades britânicas tornaram-se responsáveis por museus e coleções que estavam com problemas financeiros e também adquiriram outras importantes coleções. Com a crise financeira das universidades nos anos 80 , passou-se a questionar a sua capacidade de gerir todo esse patrimônio.

Outra saída para apresentar-se como um espaço aberto às artes foi a criação de galerias de arte em várias universidades. Nessas galerias são realizadas exposições temporárias sobre os mais variados temas, trazendo publicidade e novos públicos para o campus. E ao mesmo tempo a universidade não acumula acervo, não tendo despesas para salvaguardá-lo. As galerias de arte da Universidade de Quebec em Montreal (UQAM) e da Universidade de Sherbrooke, no Canadá, são exemplos dessa prática. Ambas realizam exposições de arte contemporânea participando do círculo de arte de suas cidades e regiões. 


\section{O museu universitário serve como referência para a região assumindo um papel de museu municipal / estadual / regional}

Em algumas cidades, que não têm museus e coleções próprias, o museu universitário pode vir a preencher essa lacuna e assumir funções de museus municipais e regionais. Essa situação pode ser vantajosa para a cidade, mas algumas pessoas das universidades a consideram prejudicial ao público universitário, por ter que criar programas para outros públicos. Normalmente, quando a população local usufrui com freqüência do museu, o município passa a repassar verbas para a universidade.

$\mathrm{Na}$ Itália, por exemplo, os museus universitários se tornaram muito importantes para as regiões centro e sul do país, nas quais havia poucos museus científicos. Nesses locais, os museus universitários assumiram a função de divulgação das ciências para outros públicos:

"Em razão desse isolamento, os museus universitários, nascidos apenas com objetivo científico e para uso didático em nível universitário, defrontaram-se com a necessidade de se transformarem, de centros restritos de estudo, em centros com atividades bem mais amplas. De fato, foram-lhes confiadas tarefas que são próprias de qualquer museu, a tutela do patrimônio científico, a coleta não necessariamente para fins de pesquisa do material, e também um tipo de divulgação em nível não propriamente universitário." (Pinna, 1989:141)

Podemos perceber que as funções de um museu universitário estão ligadas à história da universidade, da formação da coleção e também da região em que se localiza. Esses fatores, aliados às políticas de ensino, pesquisa e extensão das universidades, são fundamentais para a construção do perfil do museu.

\subsection{Museu com vocação para ensino público não universitário}

Em 1971, Edmund Seyd publicou um artigo sobre o Museu da Universidade de Manchester explicando que é voltado tanto para o público universitário como para a comunidade local. Seyd comenta que o Museu de Glasgow (citado no item 4.1) é um típico museu universitário, pois suas coleções pertencem à universidade, com todas as responsabilidades inclusive financeiras que isso acarreta, e as exposições são voltadas para o público universitário. Já o Museu da Universidade de Manchester pertence à universidade mas parte de sua verba é proveniente da administração municipal.

Em Manchester não se pode ignorar o público não-universitário na forma de exibir as coleções. Seyd concorda em parte com a afirmação de Wittlin, quando afirma 
que o estudante universitário e o público em geral têm necessidades diferentes, que resultariam em formas diversas de exibição:

"A acomodação entre uma galeria para estudantes e uma exposição para o grande público é destinada ao fracasso. O estudante dirige-se à exposição com uma série de informações e com um objetivo específico em mente; o que a exposição the apresenta é apenas o suplemento de um modelo de significado já mais ou menos definido. Para o grande público, entretanto, o modelo, tanto de forma como de conteúdo, deve ser suprido pela exposição: uma experiência completa que pressupõe, por parte do espectador, nada mais que senso comum. Qualquer tentativa de conjugar os dois tipos contraditórios de exibição acaba deixando incompleta parte das implícitas funções de um ou do outro." (Wittlin, 1949, apud Seyd, 1971:180)

A princípio, Seyd admite a diferença entre o público especializado e o leigo, mas considera-a mais branda do que Wittlin, ou seja, considera possível conciliar numa mesma exposição discursos para os dois tipos de público. Além disso, lembra que estudantes de áreas diferentes são tão leigos como o público em geral, ou seja, um estudante de química sabe tanto sobre arte quanto qualquer pessoa do grande público.

Partindo da experiência das exposições do departamento de Zoologia, Seyd busca uma possível forma de conciliar, em uma mesma exposição, as diferentes necessidades desses dois tipos de público. Utilizando-se de vitrinas de 1886 nas quais se mostravam os objetos horizontalmente sob vidros e em gavetas, os responsáveis pelo museu decidiram adaptar painéis verticais na parte central dessas vitrinas, apresentando os temas de forma mais didática e simples para o público nãoespecializado.

Assim, os moluscos são apresentados nos painéis verticais, na linha do olhar, para o público geral, divididos em temas como "Conchas e o Homem"; "Conchas Gigantes" e "Principais conchas da Inglaterra", enquanto na parte horizontal as conchas aparecem divididas por classificação taxonômica, por usos científicos e técnicos e outros temas de interesse de estudantes universitários da área.

Em outras partes da exposição há conjuntos de vitrinas voltadas para estudantes e outras para público geral, com indicações claras dessas divisões dadas por cores e etiquetas indicando "exposição para estudantes" ("student display"). Os textos, eventualmente, são apresentados em letras maiores para o público geral e os detalhes científicos são dados em letras menores. Há também textos que se iniciam com frases como "O estudante deve notar..." enfatizando o público-alvo do texto.

O autor considera que essa forma de expor está respondendo às necessidades de ambos os tipos de público, mas destaca que o museu parece interessar muito mais 
ao público de fora da universidade do que ao de dentro. Entre 1968-69 foram 200.000 visitantes de fora. Ele afirma que há falta de interesse dos estudantes pelo museu, não por causa da maneira de expor, mas porque os conteúdos das disciplinas cada vez mais se afastam das coleções:

"... as abordagens da zoologia que mais interesse despertam nos estudantes universitários têm pouco ou nada a ver com espécimens de museu; por conseguinte, pequena parte do ensino universitário desses assuntos é feita no museu." (Standing Commission on Museum and Galleries, 1968, apud Seyd, 1971:182)

Seyd conclui que, no caso de Manchester, encontrou-se um caminho de conciliação entre dois tipos diferentes de público e que ambos têm oportunidade de aproveitar os mesmos objetos. Ele destaca a possibilidade contínua do visitante nãoespecializado interessar-se e ler os textos e observar as amostras voltadas para os estudantes e aprofundar seus conhecimentos na área.

"Membros do grande público, estudando a 'exibição pública' na galeria superior, não podem deixar, às vezes, de examinar o que é exposto na classificação taxonômica embaixo, e seu conhecimento e interesse nas conchas são perceptivelmente aprofundados. Igualmente, para o estudante só pode fazer bem se, ocasionalmente, ele levantar os olhos do material científico colocado lá para seu estudo, e encontrar seu horizonte sendo alargado pela percepção de que as conchas afetaram e ainda afetam o homem de muitos modos interessantes." (Seyd, 1971:182)

No caso desses museus com vocação para diversos públicos, o maior problema parece ser conciliar programas para os públicos diversos e manter uma integração com a universidade. O "perigo" existente é o museu servir cada vez mais à comunidade não universitária e perder seus vínculos com a universidade, fazendo com que pareça não ter sentido pertencer à universidade.

$\mathrm{Na}$ USP, alguns museus ampliaram de tal maneira seu atendimento ao público não universitário que perderam o vínculo com seus respectivos departamentos e institutos e correm risco de ser vistos como "desnecessários" por eles. O Museu Oceanográfico, por exemplo, não oferece nenhum programa para o Instituto Oceanográfico, ao qual pertence ${ }^{11}$.

\section{E hoje, qual o uso dessas coleções das universidades?}


Vimos até agora como foram criados diferentes museus universitários e apresentamos algumas dificuldades enfrentadas. Retomaremos a definição de museu $\mathrm{e}$ coleção para, em seguida, apresentar algumas características de museus universitários atuais.

Recentemente foi realizada na Austrália uma extensa pesquisa sobre os museus universitários do país, que objetivava fazer um diagnóstico da situação e dar sugestões para realização de melhorias. Os organizadores reconheceram a necessidade de definir claramente as diferenças entre museus e coleções para efeito das propostas de encaminhamento ${ }^{12}$.

\footnotetext{
${ }^{11}$ No ano 2000, o Museu Oceanográfico conseguiu uma maior atenção da direção do Instituto Oceanográfico, obtendo algumas vagas para contratação de pessoal e verbas para desenvolvimento de projeto de nova exposição.

12 The Report of the University Museums Review Committee. Cinderella Collections: University Museums \& Collections in Australia, 1996:206.
} 


\begin{tabular}{|c|c|c|}
\hline Termo & ignificado & Comentário \\
\hline $\begin{array}{l}\text { Museu } \\
\text { Universi- } \\
\text { tário } \\
\text { (e } \\
\text { Galeria) }\end{array}$ & $\begin{array}{l}\text { aquela unidade da universidade que adquire, } \\
\text { conserva, pesquisa, comunica e expõe } \\
\text { objetos, para estudo, educação e apreciação } \\
\text { (enjoyment), evidência material das pessoas e } \\
\text { de seu ambiente, e que exibe parte ou toda a } \\
\text { coleção em um espaço específico para isso } \\
\text { aberto ao público em horários regulares e } \\
\text { pode exibir material de outras fontes de vez } \\
\text { em quando. }\end{array}$ & $\begin{array}{l}\text { Espaço específico para isso } \\
\text { indica que a exposição pode ser } \\
\text { vista em um local (não } \\
\text { espalhada por todo o campus } \\
\text { em corredores ou em uma } \\
\text { variedade de espaços multi- } \\
\text { funcionais; como por exemplo, } \\
\text { ocorre freqüentemente com } \\
\text { obras de arte da universidade.) }\end{array}$ \\
\hline $\begin{array}{l}\text { Coleção } \\
\text { Universi- } \\
\text { tária } \\
\text { (e } \\
\text { Herbário) }\end{array}$ & $\begin{array}{l}\text { aquela unidade da universidade que adquire, } \\
\text { conserva, e pesquisa, para fins de estudo, } \\
\text { educação, apreciação, evidências materiais } \\
\text { das pessoas e de seu ambiente, as quais } \\
\text { estão exibidas de forma limitada ou não } \\
\text { expostas. Coleções que são mantidas apenas } \\
\text { ou principalmente para uso dos estudantes } \\
\text { universitários e que podem ter acesso restrito } \\
\text { a eles, podem ser denominadas coleções de } \\
\text { ensino. }\end{array}$ & $\begin{array}{l}\text { A intenção é indicar uma } \\
\text { coleção de ensino, pesquisa, } \\
\text { fonte, referência ou outros, que } \\
\text { tem espaço de exposição } \\
\text { limitado ou inexistente (inclui a } \\
\text { maioria das coleções de arte } \\
\text { das universidades sem galeria); } \\
\text { e aquelas coleções } \\
\text { universitárias cujar função } \\
\text { primária é pesquisa e/ou ensino. }\end{array}$ \\
\hline
\end{tabular}

Utilizando essas definições que diferenciam museu e coleção ${ }^{13}$, apresentaremos alguns tipos de museus e coleções universitários atuais a partir da pesquisa bibliográfica e de campo.

\subsection{Museus de História Natural: ensinar, pesquisar, ensinar...}

"...uma galeria de arte ou museu pode ser mantida elegantemente como uma jóia, mas isto, naturalmente, é em nome da cultura. E museus de história natural não são usualmente considerados veículos valiosos para a 'cultura'. Na verdade, porém, um museu moderno de história natural pode e deveria ser tanto prática como espiritualmente estimulante..." (Mayer-Oakes, 1960:6)

Enquanto os museus de arte desejam ser vistos como centros de pesquisa e ensino e não como decoração ou 'cultura geral', os museus de ciências parecem querer ampliar sua imagem de meros centros de ensino e pesquisa.

${ }^{13}$ Existem outras maneiras sugeridas de classificação dos museus universitários. Por exemplo, Grobman sugeriu, em 1960, classificar os "museus de campus" em 3 tipos: "museu de departamento" correspondente ao que chamamos coleção; "museu de college" seria um museu mais amplo que o departamental, a serviço do ensino de graduação e com apresentação voltada para o público em geral; e "museu universitário" que corresponderia ao museu universitário de maior porte e com autonomia em relação aos departamentos de ensino. (Grobman, A. apud Alva Gwyn Hoffer, 1971:26.) 
Os museus de ciências naturais tiveram seus acervos formados principalmente por meio de pesquisas de campo e suas coleções foram utilizadas para o ensino principalmente quando ainda se valorizava a sistemática. Como já vimos, o experimentalismo, a microbiologia, a genética, entre outras ciências, deixaram de usar grande parte das coleções para o ensino. Posteriormente algumas coleções foram revalorizadas por novas interpretações, como a descrição de seres vivos como base de abordagens ecológicas.

Nos EUA, assim como na Grã-Bretanha, grande parte dos autores afirma a importância desses museus para a comunidade universitária, sendo que outros públicos estariam em segundo plano.

"Um museu universitário difere de outros museus por ser centrado numa comunidade acadêmica recorrendo a docentes especialistas para recursos e pesquisa. (...) De muitos modos, é provavelmente importante para um museu universitário diminuir ou contrabalançar a atmosfera 'livresca' da universidade." (Mayer-Oakes, 1960:2)

Para o autor as funções de um museu universitário de ciências seriam:

"1) Ampliar o conhecimento

2) Disseminar o conhecimento

3) Fornecer serviços à(s) comunidade(s) representada(s) pelo museu." (Idem, p.2)

São muitos os artigos em que é expressa a importância das coleções para o ensino e pesquisa de geologia, arqueologia, antropologia, biologia, entre outras ciências. Diferentemente dos museus de artes, não existem dúvidas quanto ao valor educativo dessas coleções, seja para o ensino de graduação ou pós-graduação.

\subsection{Grandes museus abertos aos diversos públicos}

A ampliação dos programas para outros públicos não é uma unanimidade, mas há casos exemplares, como o Museu da Universidade de Philadelphia, Pennsylvania. O museu, dedicado à arqueologia e à antropologia, possui coleções de valor internacional trazidas de diversas expedições e desenvolve programas para os mais diversos públicos. Em artigo de 1962, seu diretor enumerava atividades como projeções de filmes, visitas guiadas, cursos, concertos, empréstimos de objetos para escolas e palestras e visitas monitoradas para grupos escolares (Matthews Jr., 1962). 

pública

7.2.1. O Museu da Universidade da Pennsylvania: pesquisa e educação

Robert Dyson (ex-diretor) descreve o perfil e as programações desse museu de antropologia. O University Museum da Universidade da Pennsylvania foi criado no final do século XIX para abrigar coleções obtidas a partir de pesquisas arqueológicas na Babilônia. Nasceu com tradição em pesquisa e em educação pública (public education) ligadas aos departamentos, mas independentes dos mesmos.

"Este duplo objetivo de educação universitária e pública caracterizou o desenvolvimento do museu desde sua fundação em 1887." (Dyson, 1990:62)

O Museu tem hoje uma das maiores coleções arqueológicas e etnográficas dos EUA (mais de 1 milhão de peças catalogadas), formadas pela coleta de pesquisa e por doações recebidas. As coleções são agrupadas em 10 seções, segundo regiões geográficas, e uma seção temática de Antropologia Física. Com um corpo de servidores de 150 pessoas, auxiliados por mais de 280 voluntários, o museu realiza pesquisas, faz publicações e programas para diversos públicos. Seu diretor reporta-se diretamente ao reitor da universidade e um Conselho, com participação de pessoas do próprio museu, da universidade e da comunidade, garante a autonomia da instituição. Instalado em prédios próprios, o museu tem espaços expositivos (para exposições permanentes e temporárias), laboratórios, salas de aula, auditórios, restaurante, lojas, biblioteca e arquivos. As coleções estão sempre sendo interpretadas e re-interpretadas por estudantes e pelo público, tanto em pesquisas como em exposições no museu, extramuros, em atividades em salas de aula de escolas e da universidade (empréstimos).

A curadoria das coleções é dividida entre os 23 professores-curadores que devem realizar pesquisa e ensino, sendo remunerados pelo museu e indicados para atividades de ensino nos departamentos acadêmicos. O museu não tem responsabilidade formal de ensino na universidade, pois sempre foi uma instituição independente. $\mathrm{O}$ curador precisa equilibrar o seu tempo entre a pesquisa, o ensino, as publicações e a participação em programas públicos do museu, assim o ideal é que seus temas de pesquisa sejam a base dos programas de que participa:

"Tornar bem sucedida esta divisão do trabalho envolve duas estratégias por parte do museu: primeira, programar com bastante antecedência, a fim de que o programa acomode o timing das atividades do curador - especialmente ausências no campo - e segunda, contínua especialização ou o interesse da pesquisa atual, para que a participação surja naturalmente a partir do que eles estão fazendo, em vez de ser acrescentada como carga adicional." (Dyson, 1990:64) 


\section{Museu Universitário de Arqueologia e Antropologia Philadelphia.Pennsylvania - 1998}
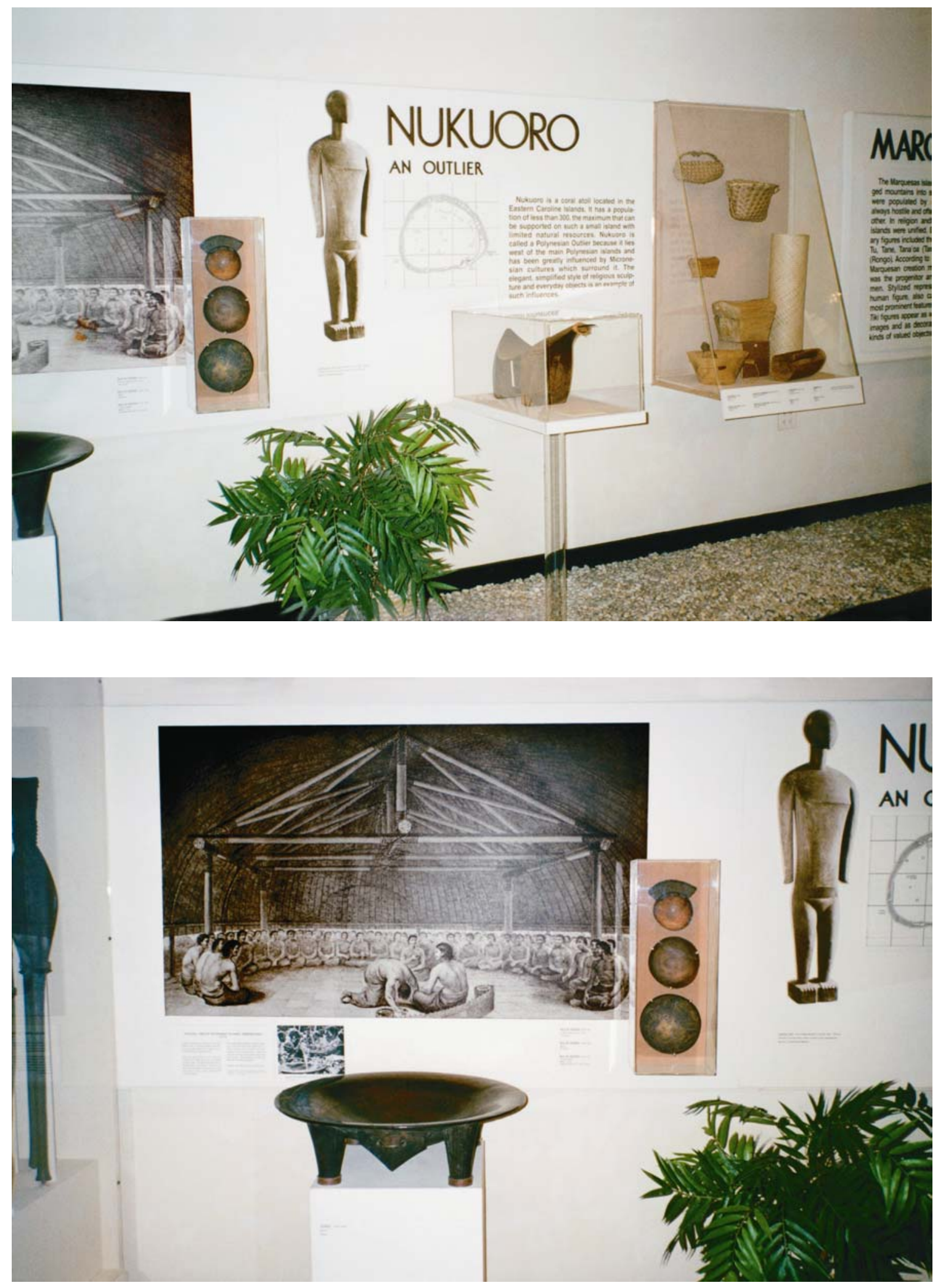

Módulo sobre povos da Polinésia: mesma museografia por várias décadas 
Os professores/curadores são pagos, como os outros da universidade, por seu trabalho acadêmico. Seus salários são sempre superiores aos dos funcionários do Museu. A equipe de especialistas (não docentes) do museu é bastante especializada, sendo que muitos fizeram cursos avançados nas suas áreas, além de mestrado e doutorado:

"... que Ihes permite interagir com a equipe de pesquisa, com compreensão e apreciação da significado do trabalho acadêmico". (Dyson, 1990:66)

Mas nem sempre tudo ocorre em harmonia: há tensão entre a pesquisa acadêmica e os programas públicos do museu, sendo que os funcionários acham que os professores dedicam tempo demais à pesquisa.

O museu oferece estágios para profissionais de museus e também tem um enorme número de voluntários, nas diversas áreas. Cerca de 40 voluntários trabalham como monitores orientando visitas de escolares e do público em geral. Além disso, 35 voluntários trabalham fora do museu, indo para escolas e instituições para deficientes, realizando atividades com professores e alunos. Os alunos de pós-graduação que estudam as coleções também trabalham voluntariamente e apresentam seminários.

A receita do museu é dividida entre a universidade (51\%), doações (20\%), renda (18\%) e outros fundos (11\%). O fato de pertencer à universidade traz alguns benefícios: a possibilidade de enriquecer as pesquisas e ensino com a colaboração de colegas das faculdades; a participação de ex-alunos da universidade no financiamento e permuta de exposições; a oferta pelo museu de cursos de extensão e a ajuda administrativa dada por órgãos competentes da universidade.

Entretanto há também desvantagens em pertencer a uma universidade:

"A maior desvantagem que experimenta um museu em ambiente universitário é a visão geral da maioria dos administradores, de que qualquer aumento nas despesas por parte da universidade deveria estar voltado para o papel do museu no ensino de graduação e de pós-graduação e não para gerência de coleções ou educação pública." (Dyson, 1990:68-9)

Isso traz dificuldades para o museu que quer ter programa agressivo na área de educação pública. A educação pública aproxima o museu da comunidade que passa a apoiar o museu. Esse deve trabalhar de maneira a melhorar a qualidade de vida da área onde atua, com o objetivo de valorizar o patrimônio cultural local.

"Um museu universitário deveria assim se tornar, caso já não o seja, um símbolo da preocupação da universidade com sua própria missão educacional mais ampla na sociedade. O museu deveria constituir uma janela - tanto para dentro como para fora da universidade - estabelecendo uma ligação importante entre a 
comunidade acadêmica e as comunidades vizinhas. A percepção clara deste papel é um poderoso argumento para o apoio contínuo de ambas as clientelas." (Dyson, 1990:69)

Os programas do museu são orientados pela idéia básica de mostrar questões/preocupações comuns da humanidade no mundo todo, de qualquer cultura e/ou tempo. As monitorias e cursos discutem temas variados e servem a diversos públicos: famílias, universitários, pessoas com interesses específicos.

Philadelphia, a cidade onde está o museu, tem sofrido mudanças em seu perfil populacional com o aumento de grupos de diferentes procedências/etnias: africanos, latino-americanos e asiáticos. Respondendo a estas modificações, o museu criou programas que visam auxiliar a adaptação dessas pessoas e mostrar que são bemvindas pela sociedade norte-americana.

As exposições são criadas a partir das pesquisas e dos interesses manifestados pelo público. Há uma exposição de longa-duração que mostra os aspectos mais importantes das coleções de diferentes áreas culturais. As exposições temporárias procuram exibir novas aquisições, resultados de pesquisas e eventualmente uma coleção emprestada.

Em nossa visita ao Museu, em 1998, percebemos variações entre as formas de apresentação das diferentes coleções. Algumas parecem ser mostradas como há mais de 50 anos e outras têm museografia recente. Isso se deve ao fato de que cada coleção, de cada área, tem diferentes curadores responsáveis que podem conseguir maiores ou menores verbas para modificar as formas de apresentação das exposições.

Os programas públicos (public programs) oferecem workshops em fins de semana, atividades ligadas às exposições temporárias, seminários, palestras, visitas também em fins de semana. Há dias dedicados a diferentes culturas em que são realizados espetáculos organizados por estudantes e por comunidades estrangeiras. Em todas as ocasiões há um esforço para levar os participantes por todo o museu, por meio de atividades que os levem a circular pelas diversas galerias.

Em 1981, iniciou sua prática de convidar as escolas da região a visitar o Museu e atualmente essas visitas somam mais de 40.000 estudantes por ano ${ }^{14}$. Os programas públicos do museu se iniciaram por meio de palestras em 1894, marcando o começo de um forte vínculo do museu com a comunidade local e regional. O Departamento de

\footnotetext{
${ }^{14}$ A visitação anual total no ano de 1997 foi de cerca de 200.000 pessoas.
} 
Educação do Museu foi criado em 1915 como Serviço de Ensino (Docent Service ${ }^{15}$ ) e no início dos anos 20 transformou-se em Departamento de Educação.

O setor de educação trabalha com as escolas, baseado no currículo escolar, fazendo atividades prévias em sala de aula antes da visita ao Museu, denominadas "Museum on the Go" e "Speakers Program". Essa atividade é realizada em todo o Estado da Pennsylvania, cuja Secretaria da Educação tem convênio com o Museu, desde 1966.

O museu também participa de programas em colaboração com bibliotecas e outras instituições de todo o país divulgando suas pesquisas e emprestando exposições e coleções.

Para Dyson, os desafios futuros são acadêmicos, financeiros e programáticos. Cada vez é mais difícil fazer trabalho de campo. A preservação da cultura material torna-se mais importante com o aumento de interesses étnicos. O museu, contando com a cultura material tornou-se uma opção ao mundo virtual:

"O conhecimento e os objetos preservados dentro de suas paredes se tornarão substitutos dos monumentos originais desaparecidos e da informação distorcida por inumeráveis propósitos de exploração." (Dyson, 1990:79)

Segundo o ex-diretor, são os antropólogos físicos que mais utilizam as coleções, enquanto os arqueólogos tendem cada vez mais a desenvolver trabalhos teóricos. Desde 1925 o Museu deixou de realizar coletas para seu acervo. Como não tem dinheiro para comprar novas coleções, o acervo só se amplia em caso de doações. Recentemente, um projeto de estudos da cultura Innuit, trouxe um grupo de artistas para o Museu, cujos debates foram registrados como parte do acervo do Museu.

O Museu produz e distribui uma série de publicações, entre elas a revista quadrimestral Expedition. Pelo catálogo das publicações do Museu, percebemos que incluem obras especializadas nas áreas de arqueologia e antropologia e publicações para professores e grande público.

Em um relatório publicado em 1996, o professor Jeremy Sablott (diretor a partir de 1994) expressou seu otimismo em relação ao Museu:

"Apesar de todas as contendas e incertezas do mundo de hoje, nunca houve uma época em que a missão - de pesquisa, educação, compreensão da diversidade humana e da história da humanidade - do Museu da Universidade da Pennsylvania fosse tão importante. Nesses tempos de contenção financeira, é grande o nosso desafio: devemos continuar engajados em pesquisa de alto nível e muitas vezes pioneira - e ao mesmo tempo tornar acessíveis a todos, e utilizáveis por todos, nossas coleções de fama mundial, e o conhecimento que

\footnotetext{
${ }^{15}$ Nos museus dos Estados Unidos, o termo "docent" sempre se refere ao trabalho voluntário.
} 
Museu Universitário de Arqueologia e Antropologia Philadelphia.Pennsylvania - 1998

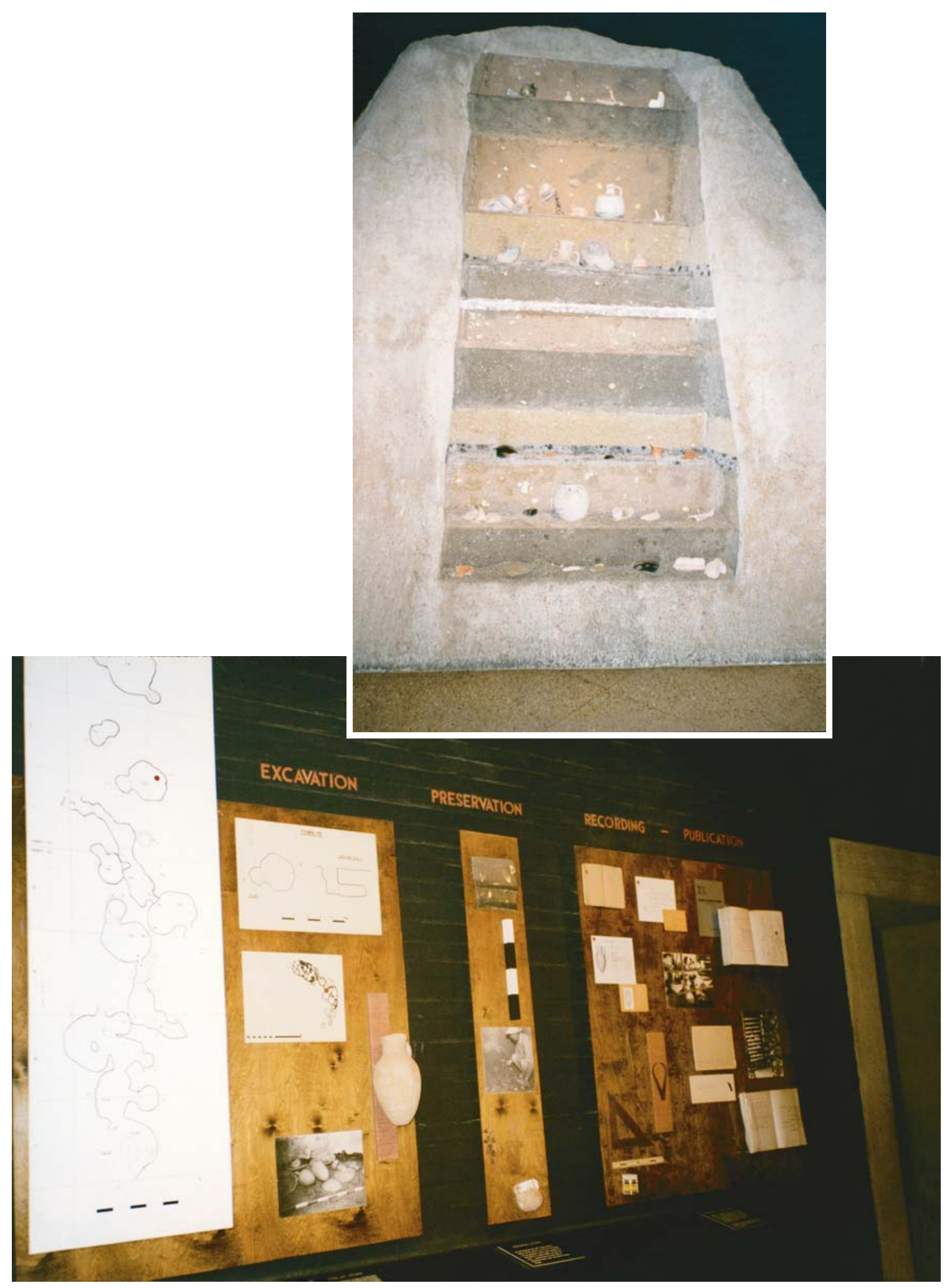


adquirimos. O Museu desempenha sua dupla missão, de pesquisa e educação, melhor, acredito, do que qualquer outro museu universitário neste país, e tenho satisfação em relatar que o Museu está florescendo e tem diante de si um grande futuro, apesar das restrições financeiras dentro das quais precisamos operar. A fim de manter nosso papel como um dos principais museus de arqueologia/antropologia do mundo, e atingir nossos objetivos ambiciosos, estamos ampliando nossos esforços para encontrar novas fontes de renda, e simultaneamente tornando nosso funcionamento tão eficiente quanto possível." (Sablott, 1996:3)

Localizado no campus da Universidade ${ }^{16}$, consegue atrair diferentes públicos escolares e grupos organizados durante a semana e famílias em fins de semana - que freqüentam a instituição. O ingresso não é cobrado mas uma contribuição é sugerida quando se entra no Museu. Pelas declarações do ex-diretor e do atual diretor do Museu, verificamos que a instituição consegue manter suas pesquisas e programas para o público apesar das dificuldades financeiras e do eventual desinteresse de alguns professores. Acreditamos que a renovação de algumas partes das exposições se deve ao interesse e empenho de alguns curadores em modernizar as formas de apresentação das coleções.

Como em outros museus norte-americanos, a participação de voluntários é fundamental para o cotidiano institucional. Na área de educação são eles que realizam as visitas guiadas e os programas extramuros, possibilitando atingir um grande público. Além disso, o Museu da Universidade da Pennsylvania conta com um grande número de associados que colaboram anualmente trazendo verbas para as atividades. Nos museus universitários brasileiros, as associações de amigos (naqueles que as têm) ainda trazem pouco em comparação ao que ocorre nos EUA.

A cidade de Philadelphia tem outros grandes museus de destaque - o Museu de Arte e o Franklin Institute of Science, entre outros - mas nas áreas de arqueologia e antropologia há apenas o Museu da Universidade. As coleções têm um valor importante para a comunidade regional e nacional pela sua originalidade ${ }^{17}$.

\subsection{Centro de exposições}

Um outro tipo de museu universitário encontrado é aquele que concentra em uma grande exposição as diferentes coleções da universidade. A Universidade de

\footnotetext{
${ }^{16} \mathrm{O}$ campus da universidade fica muito próximo da cidade, havendo circulação constante de ônibus em direção ao centro da cidade.

${ }^{17}$ Algumas coleções são reconhecidas internacionalmente pela sua originalidade.
} 
Museu Universitário de Arqueologia e Antropologia Philadelphia.Pennsylvania - 1998
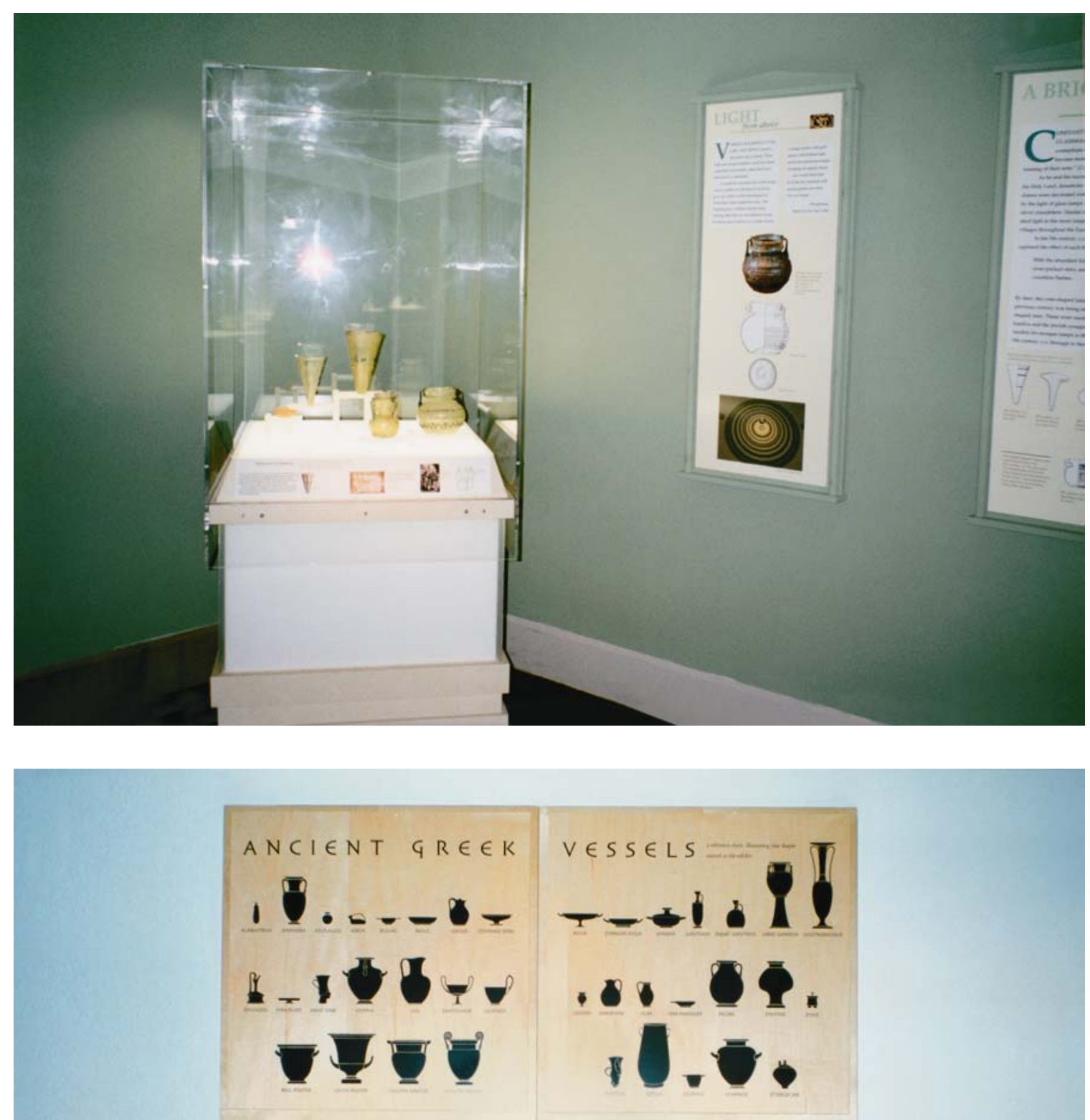

STAGES OF

PRODUCTION
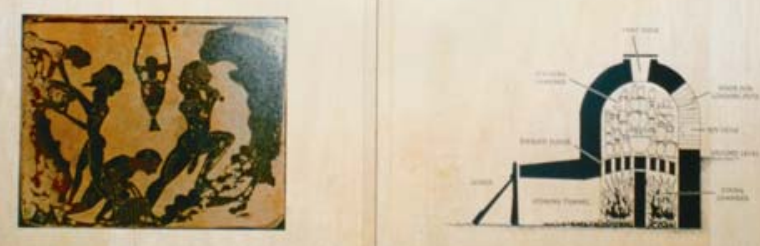

Exposição sobre Grécia Antiga: museografia renovada 
Laval (Canadá) tem um Centro Museográfico, onde exibe todas as coleções da universidade.

O Centro apresenta uma grande exposição sobre "A História do Mundo: origens e evolução" dividida em quatro partes: o universo, a terra, a vida e o homem. Os objetos fazem parte das coleções de geologia, entomologia, vertebrados e invertebrados, antropologia, arqueologia clássica, artes e herbário. A museografia pretende ser acessível a estudantes de ensino fundamental e médio e utiliza diferentes linguagens de apoio. São oferecidas visitas guiadas para escolares, sendo os monitores alunos da universidade. A visitação anual é de cerca de 17 mil pessoas. Nicole Brindle, responsável pelo Centro, explicou-nos que estava iniciando atividades mensais voltadas para famílias e também nos mostrou materiais que produz para auxiliar os professores de escolas a desenvolverem em sala de aula atividades relacionadas à visita ao Centro. Para estimular a visita dos universitários, ela convida os professores da universidade a pedir que seus alunos desenvolvam trabalhos baseados na exposição.

A Universidade Laval também centralizou fisicamente suas coleções. Elas ficam abrigadas no subsolo do prédio onde se encontra o Centro Museográfico e estão acessíveis a pesquisadores ${ }^{18}$. Cada coleção tem um professor de Departamento responsável e há uma profissional responsável pela manutenção do conjunto.

As dificuldades enfrentadas pela centralização das coleções relacionam-se com os espaços necessários para diferentes tipos de materiais, o risco de perder a história e especificidade de cada coleção e as dificuldades de criar temas de exposições que contemplem todas as áreas.

Uma situação semelhante de centralização, porém somente por meio de exposições, ocorre no Centro de Exposições da Universidade de Montreal (Canadá). O Centro é um espaço de exposições temporárias as quais integram as diversas coleções da universidade. As exposições têm temas que favorecem a interdisciplinaridade. No capítulo referente aos museus de arte, detalharemos melhor este modelo no item 2.3.

\subsection{O museu como centro formador de profissionais}

"A tarefa da universidade é educar, e não treinar."

\footnotetext{
${ }^{18}$ Com exceção do Herbário e a da maior parte da coleção de geologia que ficam juntos em outros locais.
} 


\section{Centro Museográfico}

Universidade de Laval.Quebec - 1998

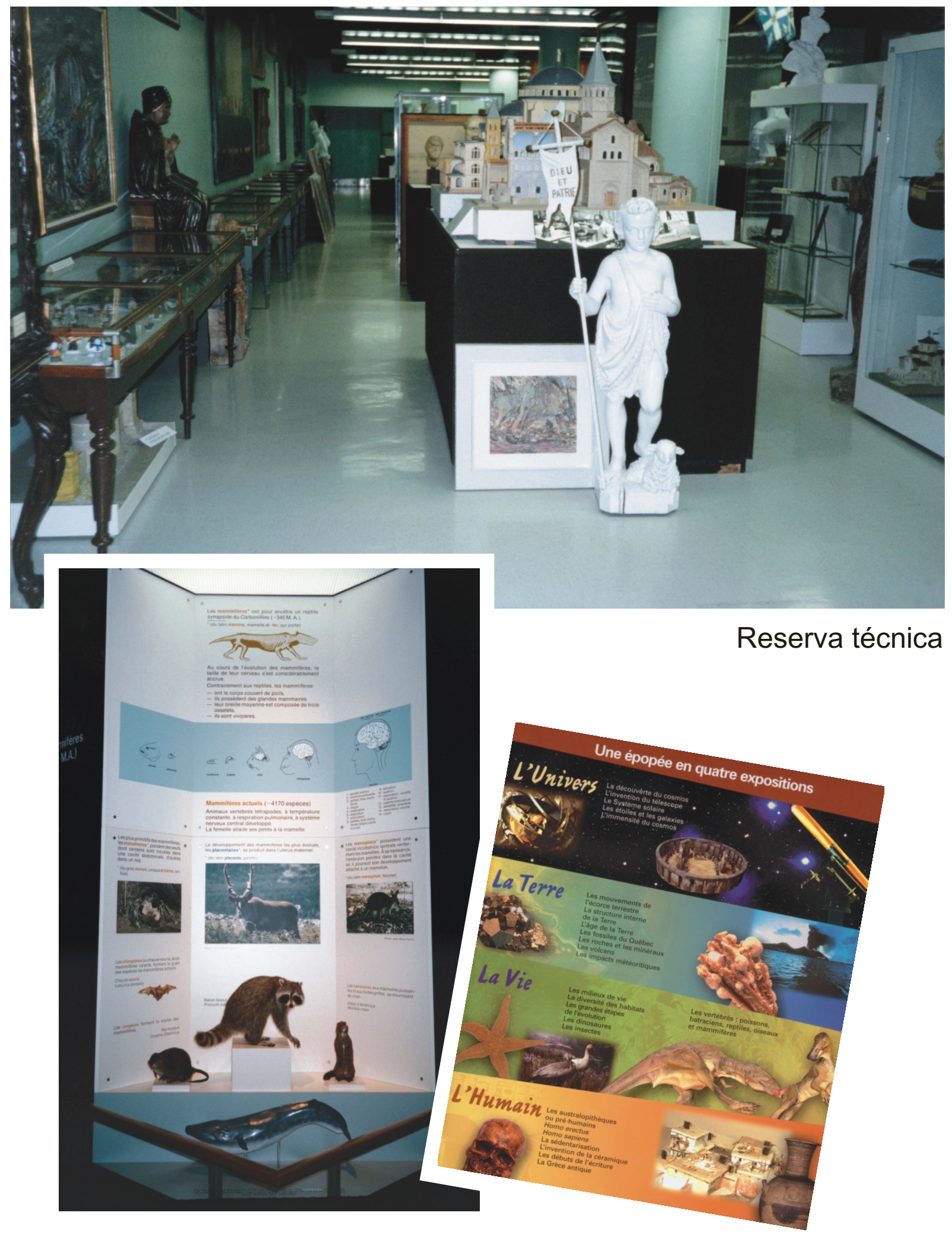

Acima e à direita: Exposição e seu folder 
Para podermos tratar da formação do profissional de museu é preciso esclarecer quem são esses profissionais. Preferimos utilizar o termo profissional de museu a museólogo por considerá-lo mais abrangente, envolvendo todas atividades de um museu - aquisição, documentação, pesquisa, conservação, comunicação e educação e claramente definido pelo $\operatorname{ICOM}^{19}$ :

"Los profesionales de museo son el conjunto de miembros del personal de los museos o de las instituciones que correspondan a la definición del artículo 2, párrafo 1 [definição de museu do ICOM citada na introdução], que hayan recibido una formación especializada o posean una experiencia práctica equivalente en cualquier campo relativo a la gestión y las actividades de un museo y las personas independientes que respeten el Código de Deontología Profesional Del ICOM y trabajen para museos, de acuerdo con la definición anterior, como asesores o profesionales, sin promover productos y equipos necesarios para los museos y sus servicios ni comerciar con ellos". (ICOM, Estatutos,1997:3)

Concordamos com o Código de Ética Profissional do $I C O M^{20}$, que afirma que os profissionais de museu exercem atividades muito diversificadas e devem ter uma formação contínua e de qualidade para desempenhar o seu trabalho adequadamente:

"El órgano rector debe reconocer el carácter diversificado de la profesión museística y el amplio abanico de especializaciones que abarca actualmente: conservadores-restauradores, científicos, personal del servicio educativo del museo, personal encargado del registro de las colecciones, especialistas en informática, encargados del servicio de seguridad, etc. Debe procurar que el museo utilice las competencias de estos especialistas cuando sea necesario y que se les reconozca como miembros de pleno derecho del personal profesional en todos los ámbitos.

Los miembros de la profesión museística deben recibir una formación universitaria, técnica y profesional adecuada para poder desempeñar su papel, que es importante, en el funcionamiento del museo y la protección del patrimonio y el órgano rector debe reconocer que es necesario contar con un personal bien formado y cualificado y permitirle recibir una capacitación adicional y reciclarse para mantener una capacidad de trabajo satisfactoria y eficaz." (ICOM, Estatutos, 1997:25)

Nesse sentido, a formação do profissional de museu aparece como um papel importante a ser desempenhado pelas universidades e por seus museus. Em vários cursos universitários para a formação de profissionais de museus, criados nos EUA, faziam parte do currículo estágios e atividades práticas nos museus universitários. Em

\footnotetext{
${ }^{19}$ Segundo o Estatuto do ICOM, aprovado em 1989 e modificado em 1995.

${ }^{20}$ Aprovado em Buenos Aires, Argentina, em novembro de 1986.
} 
alguns casos, todo o curso era ministrado dentro de um museu universitário, geralmente em nível de pós-graduação.

As discussões sobre formação do profissional de museu pareciam girar em torno do currículo: deve ser geral? dar ênfase a técnicas ou teorias? quando deve haver especialização?

Em 1958, Irving Reimann já identificava diferentes correntes de pensamento em relação à formação dos profissionais de museus. O curso mais antigo dos EUA, ainda em funcionamento, é o da Universidade de lowa, com uma formação voltada basicamente para atividades técnicas. Entretanto, diretores de museus como Hugo Rodeck pregavam uma formação cultural mais ampla, completada por um estágio de especialização em uma área técnica determinada. Rodeck também achava importante o caráter regional dos cursos que respondiam às necessidades locais.

Já Stephen Borhegyi (1958) sugeriu cursos com noções gerais de documentação, interpretação e exposição de objetos, com o reconhecimento da American Association of Museums (AAM). Essa associação deveria centralizar a coordenação e organização dos cursos novos ou em funcionamento, de maneira a garantir a qualidade da formação, responsabilizando-se também pela emissão de diplomas e certificados de validade nacional.

Reimann resume as opiniões obtidas:

"O breve levantamento das opiniões de alguns de nossos mais novos e mais velhos administradores de museus e professores mostra certamente uma quaseunanimidade de reação quanto aos problemas de treinamento museológico. Em resumo, os salários são baixos demais para que possamos, atualmente, exigir treinamento em nível de doutorado; é essencial uma experiência acadêmica com ênfase em pelo menos um campo de trabalho representado em museus, acrescida ao treinamento museológico geral; a maior necessidade é a de treinar o pessoal na operação e administração do museu muito pequeno; o treinamento museológico que deixa de enfatizar as responsabilidades do museu para com a comunidade é um pacote vazio embrulhado em ouropel."

O autor continua, afirmando o importante papel dos museus universitários para essa formação:

"Parece haver pouco espaço para dúvida de que as universidades equipadas com museus modernos são os instrumentos mais adequados para prover treinamento museológico fundamental combinado com os requisitos acadêmicos associados para assegurar base aceitável para uma carreira em museu." (Reimann, 1958:69)

O museu universitário nos parece ser o local ideal para a formação de profissionais de museus, uma vez que ele costuma ter pesquisadores/professores e profissionais nas diversas áreas museológicas. Entretanto, a falta de servidores das 
várias áreas (conservação, documentação, comunicação, educação), que também estejam preparados para o ensino, pode impedir o desenvolvimento de algumas disciplinas.

O que vemos na prática é o museu universitário, assim como museus não universitários, atuando na formação com o programa de estágios em diversos setores. Em São Paulo, assim como em todo o Brasil, a necessidade de cursos superiores de formação de profissionais de museus levou os museus da USP a criá-los: os mais recentes são o curso de especialização em Museus de Arte do MAC, que foi interrompido em 1998, e o curso de especialização em Museologia do MAE, iniciado em agosto de $1999 .^{21}$

\subsection{Coleções para ensino universitário}

A maior parte das universidades tem coleções, por vezes muito pequenas, que podem ou não estar sendo utilizadas para o ensino e que não configuram um museu por não serem exibidas ao público com regularidade. Apresentaremos a seguir alguns exemplos.

\footnotetext{
${ }^{21}$ Em 1999, a Universidade Estadual de Santa Catarina ofereceu um curso de especialização em Museologia, em Florianópolis. É possível que outras universidades estejam oferecendo cursos semelhantes.
} 


\section{Museu de Educação Louis-Phillippe-Audet Universidade de Montreal - 1998}

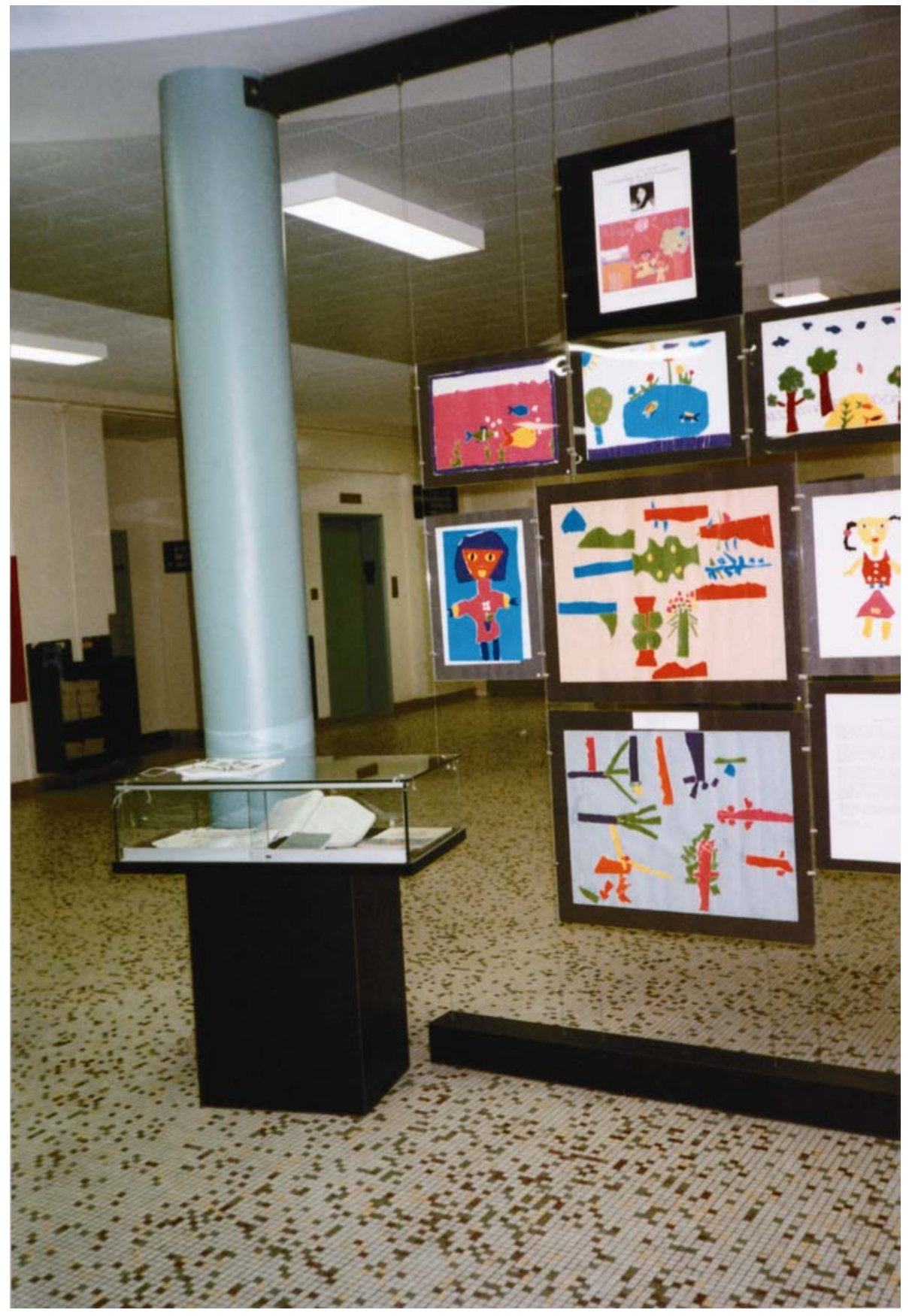




\subsection{1. “Museu" sem sede própria}

O Museu de Educação Louis-Philippe-Audet da Universidade de Montreal (Canadá) tem coleções de material didático e tem como objetivo a divulgação da história da educação:

"O Museu de Educação Louis-Philippe-Audet pretende transmitir às gerações atuais e futuras objetos pedagógicos ou escolares e os valores que lhes são conexos. Ele favorecerá assim uma determinada didática de museu pela transmissão de informações e de idéias, e visará, pelo conhecimento do passado, estabelecer um melhor relacionamento entre os educadores e seu ambiente, entre os futuros mestres e a história da educação. Sua rica coleção de manuais antigos permitirá aos estudantes documentar-se adequadamente para seus trabalhos de pesquisa e talvez incitará alguns deles a explorar um campo de estudo e de pesquisa pouco desenvolvido até agora." (Boisvert, 1992:13)

Criado pela Faculdade de Educação, o museu não tem sede própria. O acervo se encontra em uma sala junto às salas de professores e as exposições se dão no hall do segundo andar do prédio da Faculdade, onde circulam muitos alunos.

Os alunos de pós-graduação são estimulados a desenvolver projetos de exposição, recebendo créditos em troca de seu trabalho. O diretor, Marcel Boisvert, é professor aposentado e continua a cuidar do museu contando apenas com a ajuda de estudantes para catalogar o acervo e fazer as exposições.

Todas as exposições são temporárias, como a que pudemos ver, sobre a educação das crianças vietnamitas que emigraram para o Canadá. Bastante simples, ela apresentava principalmente os trabalhos das crianças, entre eles muitos desenhos.

Estima-se que circulem cerca de 4 mil alunos pelo prédio da Faculdade e, além deles, o público das exposições vem geralmente da comunidade envolvida na temática, nesse caso, os imigrantes vietnamitas.

\subsubsection{Coleção de ensino e pesquisa}

Freqüentemente, as universidades têm coleções para pesquisa e ensino que, guardadas em salas inacessíveis ao público em geral, só podem ser utilizadas por alunos e professores do departamento responsável. Os herbários geralmente estão incluídos nessa categoria, pelo uso que podem ter - identificação, descrição, classificação da flora - e pela fragilidade do material.

Visitamos o herbário da Universidade de Montreal (Herbier Marie-Victorin) pertencente ao Instituto de Pesquisa em Biologia Vegetal e localizado em um prédio dentro do Jardim Botânico da cidade. Os objetivos do Herbário são a coleta e 
preservação de espécimens da flora do Quebec e também de outras partes do país e do mundo. Também é depositário de exemplares correspondentes àqueles apresentados pelo Jardim Botânico.

O Herbário criou uma coleção didática utilizada para as aulas de botânica, enquanto a coleção principal é manuseada apenas por pesquisadores.

Eventualmente são emprestados exemplares para fazer parte de exposições de outras instituições.

\subsubsection{Museu de departamento e/ou coleção de ensino e pesquisa em exposição}

As ciências naturais, como a geologia, zoologia, botânica, utilizam-se de amostras para a pesquisa e ensino nas universidades. Geralmente a própria pesquisa de campo acaba formando coleções que posteriormente podem servir ao ensino e/ou como coleções de referência.

Esse é o caso do Museu de Geologia da Universidade de Laval. A coleção ${ }^{22}$ pertence ao Departamento de Geologia e fica alojada no prédio do Departamento, sendo que uma parte está exposta em corredores, outra guardada na reserva técnica e a coleção de referência está espalhada em gaveteiros dentro de salas de aula. Professores e alunos requisitam exemplares da coleção quando necessitam. A exposição, localizada no $4^{\circ}$ andar de um prédio do campus, ocupa um grande corredor com 35 vitrinas embutidas nas paredes e algumas mesas com amostras minerais de grande porte. Duas das vitrinas são utilizadas para exposições temporárias sobre pesquisas em desenvolvimento.

O museu recebe visitas de grupos de escolares que são guiados por estagiários (estudantes de geologia). Segundo o responsável pela coleção, anualmente 5 mil pessoas visitam o museu, sendo $60 \%$ universitários, $20 \%$ grupos de visitas guiadas, $15 \%$ amadores e interessados na área e $5 \%$ turistas. $^{23}$

\footnotetext{
${ }^{22}$ A coleção tem cerca de 40.000 minerais, rochas e fósseis.

${ }^{23}$ Alguns exemplares da coleção fazem parte da exposição do Centro Museográfico da Universidade, citado anteriormente.
} 


\section{Museu de Geologia Universidade de Laval . Quebec - 1998}

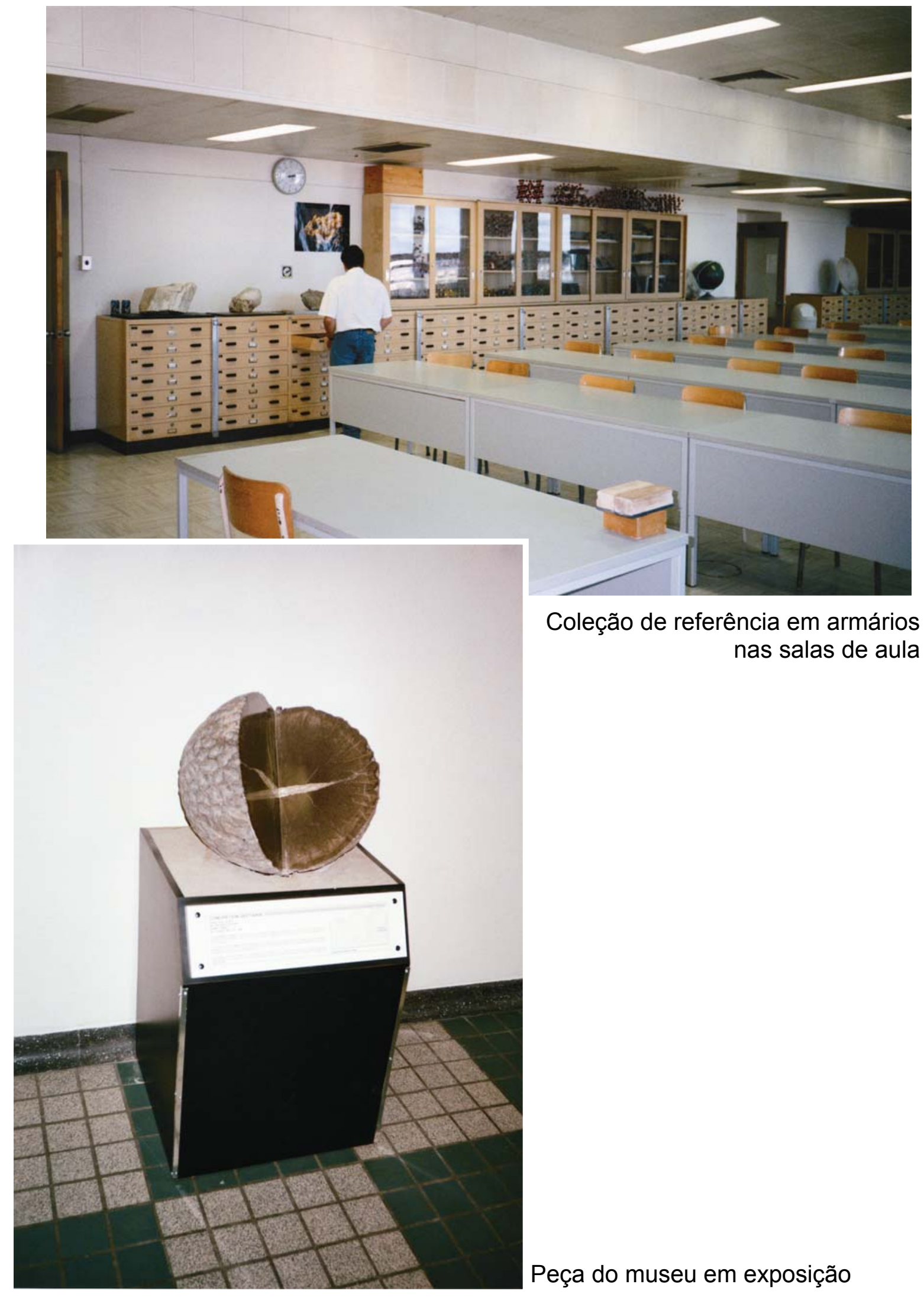




\subsubsection{Museu para divulgação da ciência}

Algumas universidades mantêm grandes coleções científicas em exposição para o público em geral. Em geral têm pesquisadores que continuam a utilizá-las, mas por vezes as coleções já não são temas de pesquisas e servem apenas para divulgação.

O Museu Redpath da Universidade McGill (Montreal, Canadá) parece ser um exemplo. O museu foi fundado em 1882 para preservar e exibir as coleções de Willian Dawson, um importante naturalista canadense. Criado inicialmente para os professores e estudantes universitários, o museu ampliou seu público em 1952 passando a atender estudantes do ensino fundamental e médio. Mas, em 1971, com os cortes de verbas da universidade, o museu reduziu o acesso e centralizou suas atividades em pesquisa e ensino. Em 1985/6 as portas do Museu Redpath foram novamente abertas, de forma limitada, ao grande público.

O Museu encontra-se em um imponente prédio neoclássico em ponto de destaque do campus, na região central da cidade de Montreal. A exposição apresenta uma grande sala com os espécimens organizados taxonomicamente. $O$ hall de entrada tem alguns painéis didáticos e explicativos. Aos nossos olhos a exposição parece ser muito antiga e tem manutenção inadequada. Certamente ela não está atualizada pelas pesquisas desenvolvidas.

A missão do Museu é desenvolver estudos de história e diversidade do mundo natural. Ele realiza ensino e pesquisa acadêmicos na mesma escala que os departamentos daquela universidade e também presta serviço a outras unidades.

"Os aspectos que o distinguem são a preservação e o zelar pelos objetos, o registro de sua existência, e o provimento de acesso a outras coleções. Através da exibição e interpretação públicas desses objetos, tanto desenvolve o ensino de graduação e pós-graduação, como atende a comunidade mais ampla, de cuja boa vontade continuada a Universidade eventualmente depende." (Welcome to the Museum, ; página da internet Redpath Museum)

As coleções do Museu são de paleontologia (150.000 fósseis), de vertebrados terrestres (1.500), de peixes (1.500), de invertebrados (32.000), de antropologia (17.000) e de mineralogia (16.000).

Além da exposição permanente, o Museu realiza exposições temporárias relacionadas com os cursos. Há disciplinas do departamento de biologia que são ministradas no museu, sob responsabilidade de seus professores/curadores. 


\section{Museu Redpath Universidade McGill - 1998}

Painel de entrada do museu

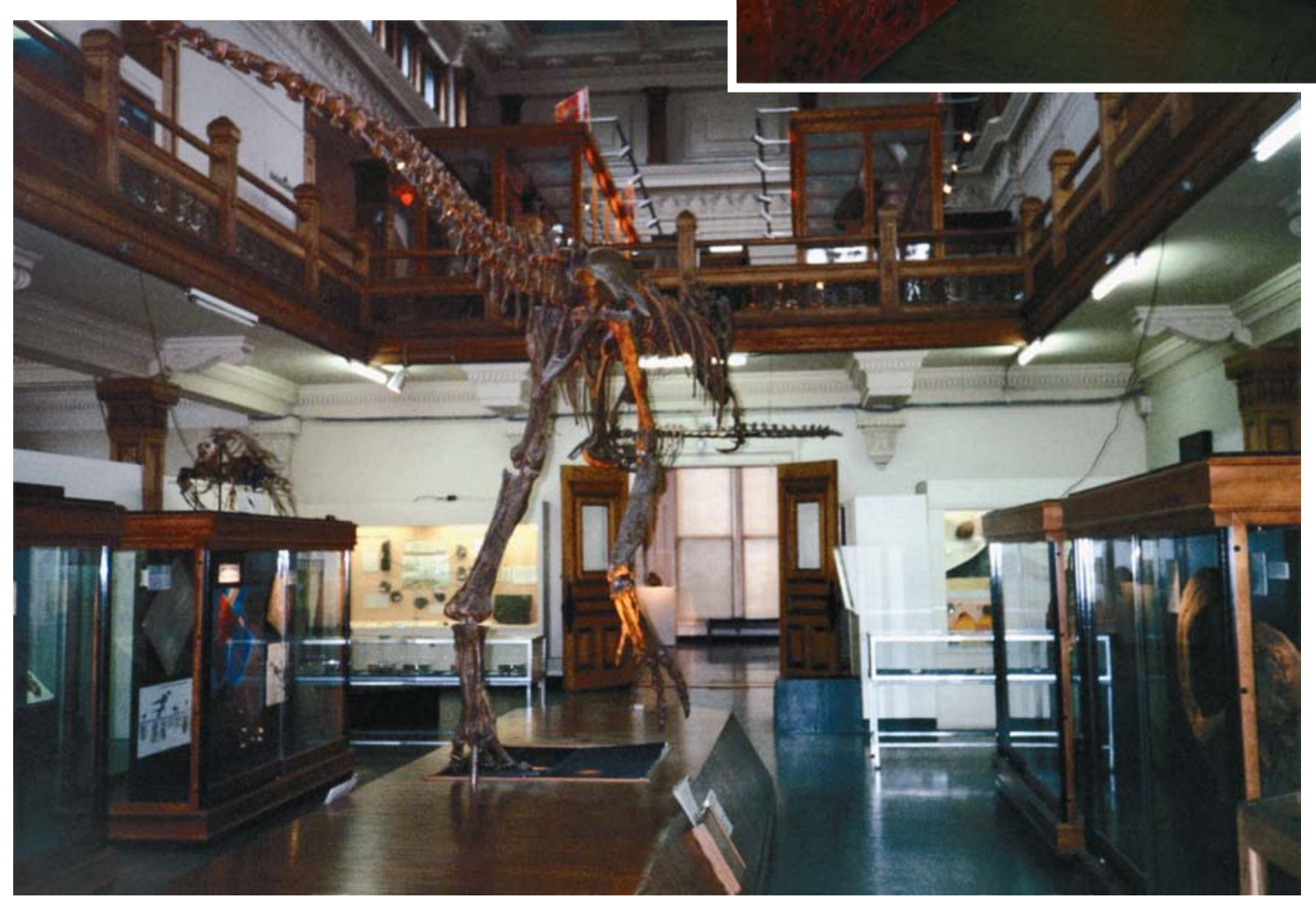

Esqueleto de dinossauro em destaque na exposição 


\subsubsection{Atualização do museu pelas pesquisas}

A Universidade Autônoma do México (UNAM) decidiu criar um museu de antropologia para divulgação dos estudos antropológicos e para "concienciar al mexicano para que conociera su patrimonio cultural heredado, al que debía cuidar, conservar e respetar".(Cabrero, 1987:9) O museu definiu como público alvo o estudante universitário. Nesse artigo sobre o museu, Cabrero considera que um museu universitário é sempre voltado aos estudantes e aos graduados. Ela cita a definição dada para museus universitários em um seminário realizado nos EUA (Brooklyn,) em 1952:

"Son ante todo establecimientos de enseñanza y frecuentemente contienen la documentación necesaria para investigaciones originales o presentan los resultados de éstas.

En la mayoría de los casos las colecciones están distribuidas en varios lugares, algunas accesibles a todos, mientras que otras reservadas a los investigadores. Sin embargo, salvo algunas excepciones, los museos universitarios no se destinan al público; la disposición de las colecciones es rigurosamente metódica. La designación de las piezas es técnica y se remite a manuales especializados. Raramente demuestran interés por una presentación artística, de colores combinados o una exposición de maquetas.

Estos establecimientos tienen reservadas a menudo, inmensas colecciones que permiten estudios comparativos e investigaciones; ofrecen valiosos medios para cursos de perfeccionamiento, organizados según la intención de los profesores, de los conservadores del museo y de los guías conferencistas." (apud Cabrero, 1987:27)

A autora reconhece que as funções dos museus universitários se ampliaram no decorrer dos anos, mas considera-os, fundamentalmente, como recurso educacional para as universidades.

O Museu de Antropologia da UNAM é dependente do Instituto de Investigações Antropológicas, que define a programação do museu. Os pesquisadores do Instituto auxiliam na curadoria e na elaboração dos textos e roteiros expositivos. As atividades de difusão incluem conferências, visitas guiadas, folhetos explicativos, projeção de filmes, sempre relacionados com os temas das exposições.

A possível explicação para a UNAM ter sentido necessidade de criar um museu de antropologia parece ser a importância da atualização oferecida pela pesquisa. $O$ Museu Nacional de Antropologia do México não realiza pesquisas e mantém as mesmas exposições há muitos anos, e talvez acabe ficando desatualizado. Há também 
a necessidade de apresentar as características do trabalho do antropólogo, elemento de destaque nas exposições do museu da UNAM. $^{24}$

\subsubsection{Coleções não utilizadas}

Uma situação freqüente nas universidades é o "engavetamento" de coleções por professores, departamentos e faculdades. Essas coleções ficam esquecidas e deixam de ser utilizadas e conservadas.

$\mathrm{Na}$ Itália, os museus universitários (todos de história natural) tiveram seu florescimento no século XIX, concentrando pesquisa e ensino científico de qualidade. Entretanto, sem terem conseguido autonomia da universidade para modernizar sua organização, atualmente não conseguem sequer cumprir as funções básicas de preservação das coleções.

Para G. Pinna, os museus universitários italianos representam o maior problema do sistema museológico científico do país. Para ele, esses museus em sua maioria não são organizados como museus e têm mais perfil de coleções privadas.

"Um problema que se pode, em substância, reduzir a uma única constatação de fato, a de que estas coleções, muitas vezes de relevante interesse, não são em absoluto museus. Sua estrutura é, de fato, na maior parte dos casos, a de uma coleção particular, de uma coleção que tem apenas fins de pesquisa científica e, pior ainda, de uma coleção que nada mais é senão o testemunho da atividade científica passada da instituição à qual pertence." (apud Binni, 1989:142)

O resultado disso é o fechamento dessas coleções para o público pela falta de interesse e de condições mínimas de preservação e exposição dos acervos. A direção dessas coleções está geralmente nas mãos dos chefes dos institutos aos quais pertencem, que priorizam o ensino e não têm qualquer experiência museológica.

\footnotetext{
${ }^{24}$ Em artigo recente sobre museus universitários no México, Yani Herreman (2000) historia a formação dos museus da UNAM, destacando o Museu Universitário de Ciências e Artes aberto em 1960. O Museu de Antropologia da UNAM não é citado e provavelmente está englobado no conjunto do que ela denominou "pequenos museus/gabinetes nos institutos, escolas e faculdades..." (Yani Herreman, 2000:38).
} 
Neste capítulo procuramos apresentar a formação e desenvolvimento de diversos museus universitários, que passaram a integrar as universidades respondendo às necessidades tanto daqueles que doaram coleções como das próprias universidades. Entretanto, muitas vezes as universidades adquiriram coleções sem preparação, sem planejamento ou reflexão, que acarretaram o aumento de suas responsabilidades e funções sem um aumento equivalente de verbas ou pessoal.

Raros são os casos de existência ou construção de edifícios especialmente para abrigar as coleções. Mais difícil ainda é a criação de cargos e funções específicas de museus pelas universidades. Geralmente seus servidores têm que ser enquadrados dentro das funções já existentes na universidade. $\mathrm{E}$, mais grave, os museus das universidades não têm cursos de formação para seus profissionais.

Apesar de todos os problemas, encontramos museus universitários por muitos países dos diversos continentes, e no Brasil eles são uma parcela considerável dos museus existentes.

No próximo capítulo apresentaremos a formação e desenvolvimento dos museus nas universidades brasileiras e detalharemos o caso da Universidade de São Paulo. 
CAPÍTULO 2

Museus da Universidade de São Paulo 


\section{CAPÍTULO 2 \\ Museus da Universidade de São Paulo}

No capítulo anterior apresentamos diversos exemplos de museus universitários no mundo ocidental, procurando destacar suas origem e perfil enquanto instituição. Certamente as características de cada museu universitário estão intimamente relacionadas com as da própria universidade à qual pertence.

\section{A formação das universidades}

No Brasil, as universidades formaram-se a partir da fusão de alguns Institutos e Escolas de nível superior. Os cursos de nível superior foram criados depois da vinda da família real em 1808, por atos de D.João VI: Academia Militar do Rio de Janeiro (1810), Escola de Medicina da Bahia (1832). Foram também fundadas as Faculdades de Direito de São Paulo e de Olinda (1827). Segundo Simon Schwartzman (1981) a maior parte dessas escolas foi criada com o objetivo de formar profissionais liberais, em detrimento da pesquisa e de uma formação cultural mais ampla. Para o autor, o estudo nessas escolas era etapa para "treinamento e acesso às posições políticas e burocráticas dos filhos da elite do país." (p.85)

No século XIX, a pesquisa científica era realizada prioritariamente em museus e institutos, ou seja, fora das universidades. Escreveu Fernando de Azevedo sobre as ciências no Brasil, no final do século XIX:

"Em um período em que as ciências matemáticas tomam novo impulso com Oto Alencar, entra em atividade o Museu Paraense Emílio Goeldi, em 1885. Hermann von Ihering é chamado para dirigir o Museu Paulista em 1893, que lhe dá alto cunho científico; Barbosa Rodrigues reorganiza o Jardim Botânico e Nina Rodrigues empreende na Bahia pela primeira vez um estudo rigorosamente científico de parte considerável de nossa população, constituída pelo elemento afro-americano. Além do Museu Nacional que passa por grandes transformações sob a impulsão de Batista Lacerda (1895-1915)". (Azevedo, apud Lília Schwarcz, 1989:27).

O museu mais antigo do país - o Museu Nacional do Rio de Janeiro - é hoje um museu universitário e em alguns aspectos teve uma trajetória exemplar. Criado em $1818^{1}$ ainda na época colonial, tornou-se um importante centro de pesquisas de história

\footnotetext{
${ }^{1}$ D. João também estimulou a criação do Jardim Botânico (1808 - RJ), da Biblioteca (1814 RJ) e do Museu de História Natural (Museu Real / 1818 - RJ), além de escolas técnicas.
} 
natural. $^{2}$ Seguindo os moldes europeus, o Museu abrigava coleções de História Natural doadas por colecionadores e trazidas de expedições pelo país e servia de entreposto para o envio de exemplares à Europa. Foi também um importante centro de pesquisa e ensino de História Natural, principalmente a partir dos anos 70 do século XIX, quando da criação da revista Archivos do Museu Nacional, até as duas primeiras décadas do século XX. O florescente e produtivo centro de pesquisas do século XIX foi perdendo aos poucos sua autonomia e importância para pesquisa científica no país frente à criação de institutos de pesquisas ${ }^{3}$ e escolas de nível superior, no início do século XX. A crise interna, a falta de verbas e pessoal, aliadas à insatisfação dos pesquisadores, culminou na incorporação do Museu à Universidade Federal do Rio de Janeiro, em 1946.

Durante o século XIX foram criadas outras escolas de nível superior, como a Escola Politécnica (1874 - RJ), a Escola de Minas (1875 - Ouro Preto , MG), Escola de Engenharia Mackenzie (1891 - SP), Escola Politécnica (1894 - SP) e a Escola Agrícola Luiz de Queiroz (1900 - Piracicaba, SP), a maioria posteriormente incorporada a universidades.

A primeira universidade do Brasil foi criada por decreto em 1920 por Epitácio Pessoa, mas só se concretizou na prática em 1935: a Universidade do Brasil, no Rio de Janeiro. ${ }^{4}$ Até esse ponto, as escolas de nível superior no Brasil e na América Latina em geral, eram mais um campo de treinamento para líderes políticos, não sendo necessariamente vanguardistas e progressistas em relação a assuntos educacionais, científicos e tecnológicos (Schwartzman, 1981:88).

Em reação a esse modelo buscou-se criar novos modelos de universidades e a criação da Universidade de São Paulo (1934) seria um exemplo disso. Da mesma forma, a Fundação Escola Livre de Sociologia e Política, criada em 1933 em São Paulo ${ }^{5}$, respondia à busca da elite por uma formação mais moderna e culta.

\footnotetext{
${ }^{2}$ Margaret Lopes mostra com muita clareza como era a pesquisa científica no Museu Nacional e em outros museus no século XIX em sua tese de doutorado: As Ciências Naturais e os Museus no Brasil no Século XIX, tese de doutorado, Depto de História, FFLCH/USP, 1993.

${ }^{3}$ Como por exemplo o Instituto Butantan (SP) e o Instituto Osvaldo Cruz (RJ), ambos criados em 1900.

${ }^{4} \mathrm{Na}$ "Cronologia de Ensino, Ciência e Cultura" apresentada por Marco A. Xavier, há referência, sem detalhes, da criação da Universidade do Rio Grande do Sul em 1883 e da Universidade de Minas Gerais em 7 de julho de 1927. Marco A. Xavier. Ocupação do campus Butantã da Universidade de São Paulo (1934-1954): representações de poder no espaço da universidade, dissertação de mestrado, FFLCH/USP, 1999:195-199.

${ }^{5}$ Nesse mesmo ano foram também criadas a Faculdade de Filosofia Sedes Sapientiae e a Escola Paulista de Medicina, também entidades privadas.
} 


\section{Os museus universitários no Brasil}

A maior parte dos museus universitários vai surgir no momento da criação das universidades ou posteriormente, a partir de coleções doadas ou formadas pelas pesquisas universitárias. Como veremos, grande parte dos museus identificados são da década de 50 ou posteriores, como também nossas universidades.

O primeiro desafio para nossa pesquisa, na busca dos museus universitários no Brasil era sua identificação: quais são, onde estão, como funcionam? Deparamo-nos com a falta de um inventário completo e/ou atualizado dos museus brasileiros. Procuramos então os levantamentos já realizados e os somamos a outras fontes encontradas, como folhetos de divulgação, comunicações em congressos, cadastros de instituições de financiamento para elaborar uma lista dos museus universitários no Brasil.

A bibliografia na qual se discute os problemas, os projetos, a atividade desses museus é praticamente inexistente, se compararmos à que encontramos nas publicações norte americanas e britânicas, entre outras. As revistas publicadas por alguns dos museus trazem grande número de artigos científicos sobre as pesquisas acadêmicas e poucos artigos na área de museologia.

Conseguimos elaborar uma listagem dos museus e preenchemos o nosso questionário padrão com as informações obtidas, porém temos muitas lacunas. A grande extensão do país e o pequeno número de respostas a questionários enviados por correspondência, dificultaram nosso trabalho.

A partir das fontes, pudemos identificar, com informações mínimas, 129 museus universitários no Brasil:

52 pertencentes a universidades federais

21 pertencentes a universidades estaduais (exceto USP)

08 pertencentes a universidades públicas regionais ou municipais

13 pertencentes a universidades privadas

35 pertencentes à Universidade de São Paulo

Para sistematizar as informações obtidas pelas várias fontes, definimos um formulário (Anexo 1) no qual incluímos os dados que conseguimos obter. Infelizmente, na maior parte dos casos, não conseguimos todas as informações solicitadas.

Em seguida, apresentamos tabela na qual informamos o nome do museu, universidade, área, ano de criação do museu e endereço. (Anexo 2) 
Se nos detivermos apenas no ano de criação, perceberemos que todos os museus foram fundados no século XX, com três exceções do século XIX: Museu Nacional/UFRJ, Museu de Zoologia/USP e Museu Paulista/USP. Esses três museus foram incorporados às universidades no século XX. Se verificarmos melhor, veremos que a grande maioria dos museus é bastante recente, criada a partir da década de 50 . Somente a Universidade de São Paulo tem coleções e museus datados das décadas de 20 e 30, e são poucos aqueles da década de 40.

Sabemos também que, no Brasil, as universidades são instituições novas ${ }^{6}$, o que explicaria o fato dos museus universitários serem tão recentes, se comparados com museus universitários de outros países ou mesmo outros tipos de museus brasileiros.

No quadro apresentado também destacamos a área científica e cultural coberta pelos museus. Dos 129 museus $^{7}$,

54 são de Ciências Naturais (zoologia, botânica, oceanografia, etc.)

31 são de História (local, institucional, regional, da saúde, etc.)

18 são de Antropologia (indígena, folclore, africana, afro-brasileira, etc.)

17 são de Arte (sacra, contemporânea, regional, etc.)

06 são Centro de Ciências ou de Ciência e Tecnologia

01 de Medicina

01 de Cartografia (FFLCH/USP)

01 de Arquitetura (FAU/USP)

O grande número de museus de ciências segue o padrão de outros países e é explicado pela formação de coleções para ensino e pesquisa pelos departamentos. ${ }^{8}$

\section{A Universidade de São Paulo}

O decreto de criação da Universidade de São Paulo (USP), de 1934, reunia em uma instituição vários cursos superiores já existentes no Estado de São Paulo (Medicina, Direito, Engenharia), instituições de ensino e pesquisa (Museu Paulista, Instituto Astronômico e Geofísico, entre outros), além da recém criada Faculdade de

\footnotetext{
${ }^{6}$ No final do século XIX, por exemplo, os Estados Unidos tinham 78 universidades, o Canadá 12, Bolívia e Colômbia 4 e Argentina, México e Peru 2. (Xavier, M. A., 1999:197)

${ }^{7}$ Alguns desses museus abrangem mais de uma área.

${ }^{8}$ Listas de museus universitários do Brasil e de outros países podem ser encontradas no endereço da internet: www.lib.mq.edu.au/mcm/world
} 
Filosofia, Ciências e Letras (FFCL). As funções explicitadas no decreto de criação incluíam o ensino, a pesquisa e a extensão. ${ }^{9}$

A USP surge como iniciativa da elite econômica e intelectual de São Paulo que desejava formar quadros para trazer novamente a liderança nacional para o Estado, ao mesmo tempo em que forneceria quadros intelectuais, técnicos e profissionais para a economia em ascensão.

Vários professores foram trazidos da Europa principalmente para a FFCL. A elite econômica e política preferia as carreiras tradicionais - Direito, Engenharia - ou os estudos de orientação francesa - História, Sociologia. Os cursos de Ciências foram mais procurados por emigrantes e estudantes de fora da Capital e de outros estados.

Para Daniel Pécaut, as elites dirigentes acreditavam que a arte de governar relacionava-se ao saber científico:

"A criação da Universidade de São Paulo, em 1934, dois anos após a derrota sofrida pelos paulistas em sua revolta armada contra o novo regime, faz parte do programa de transformação política mediante a constituição das novas elites." (Pécaut, 1990:30)

\footnotetext{
${ }^{9}$ A fundamentação do decreto de criação da USP e seus artigos 1 e 2 são os seguintes: "O doutor Armando de Salles Oliveira, Interventor Federal do Estado de São Paulo, usando das atribuições que lhe confere o decreto $n^{\circ} 19.398$, de 11 de novembro de 1930; e considerando que a organização e o desenvolvimento da cultura filosófica, científica, literária e artística constituem as bases em que se assentam a liberdade e a grandeza de um povo; considerando que somente por seus institutos de investigação científica de altos estudos, de cultura livre, desinteressada, pode uma nação moderna adquirir a consciência de si mesma, de seus recursos, de seus destinos; considerando que a formação das classes dirigentes, mormente em países de populações heterogêneas e costumes diversos, está condicionada a organizações de um aparelho cultural e universitário, que ofereça oportunidade a todos e processe a seleção dos mais capazes; considerando que em face do grau de cultura já atingido pelo Estado de São Paulo, com Escolas, Faculdades, Institutos, de formação profissional e de investigação científica, é necessário e oportuno elevar a um nível universitário a preparação do homem, do profissional e do cidadão, decreta:

Art. 1 Fica criada, com sede nesta Capital, a Universidade de São Paulo.

Art. 2 São fins da Universidade: a) promover, pela pesquisa, o progresso da ciência; b) transmitir, pelo ensino, conhecimentos que enriqueçam ou desenvolvam o espírito ou sejam úteis à vida; c) formar especialistas em todos os ramos de cultura, e técnicos e profissionais em todas as profissões de base científica ou artística; d) realizar a obra social de vulgarização das ciências, das letras e das artes, por meio de cursos sintéticos, conferências, palestras, difusão pelo rádio, filmes científicos e congêneres."

Para atingir os fins acima, o artigo 3 deste decreto dispôs sobre o agrupamento das seguintes instituições: Faculdade de Direito, pertencente ao Governo Federal e criada em 1827; Escola Politécnica, do Governo do Estado de São Paulo, criada em 1893; Faculdade de Farmácia e Odontologia do governo estadual, criada em 1899; Faculdade de Medicina do governo estadual, criada em 1913; Escola de Medicina Veterinária do governo estadual, criada em 1934; Instituto de Educação de 1933, originário do antigo Instituto Caetano de Campos, que participaria da USP pela sua escola de professores; Faculdade de Filosofia, Ciências e Letras, criada pelo decreto em questão; Instituto de Ciências Econômicas e Comerciais, que só se instalou em 1946; e a Escola de Belas-Artes. (A formação da Universidade de São Paulo, site www.usp.br, copiada em abril de 2000)
} 
As palavras de Julio de Mesquita Filho, em 1950, um dos mentores da criação da USP, confirmam a afirmação anterior:

“... depois da derrota de São Paulo em 1932 que significou um profundo golpe na democracia em nosso país, mais necessária se tornou, ainda, uma reforma profunda no país. Politicamente, não se poderia conseguir isso, mas a tarefa seria possível se se lograsse atingir a consciência dos moços. Assim, meditando no exílio, chegou-se à idéia de que, sem uma reforma total do ensino nacional, jamais o Brasil sairia do caos. A análise dos motivos que levaram o país ao círculo revolucionário, que culminou em 1930, estava a demonstrar à geração do orador que, caso the fosse possível retornar um dia ao poder, necessário se impunha reformar o mecanismo cultural do país, criando entre nós os órgãos e institutos que existiam nos países de civilização latina ocidental e aos quais incumbia a formação das elites pensantes. Todos conheciam a divisa da Faculdade de Filosofia: Scientia vinces, mas nem todos sabiam que, de fato, essa divisa queria significar: 'Vencido pelas urnas, Paulista, vencerás pela cultura', divisa que exprimia o pensamento íntimo dos fundadores da Universidade de São Paulo." (Pacheco e Silva, A. C. apud Xavier, M. A., 1999:20)

A USP, no momento de sua criação, anexou institutos de pesquisas e museus ${ }^{10}$, o que demonstrava a vontade de ampliar ao máximo as áreas de pesquisa e ensino da universidade recém criada. No discurso dos mentores da USP aparece sempre a idéia de que a Faculdade de Filosofia seria o núcleo em torno do qual girariam as outras faculdades, departamentos e institutos. ${ }^{11}$ Somente alguns dos institutos e museus foram, mais tarde, definitivamente incorporados à USP, como o Instituto Astronômico e Geofísico (IAG) em 1946, e outros passaram para outros órgãos públicos, como o Instituto Butantan que hoje pertence à Secretaria de Estado da Saúde.

Como vimos no capítulo anterior, com freqüência, as universidades foram consideradas as melhores guardiãs de acervos já formados e mesmo de museus já constituídos. A universidade era vista como um centro produtor e irradiador de conhecimento e com fontes inesgotáveis de recursos humanos e financeiros para manutenção desse extenso patrimônio. Em São Paulo, esse fenômeno ocorreu tanto no momento de criação da USP quanto nos anos 60 , quando da incorporação de outros museus.

\footnotetext{
${ }^{10}$ Instituto Biológico; Instituto de Higiene; Instituto Butantan; Instituto Agronômico de Campinas, Observatório do Instituto Astronômico e Geofísico; Museu de Arqueologia, História e Etnografia (Museu Paulista); Serviço Florestal. (A formação da Universidade de São Paulo, site www.usp.br, acessado em abril de 2000)

${ }^{11}$ Marco A. Xavier discute essa proposta em detalhes, chamando atenção para o fato de que a partilha do poder não seguia essa idéia da Faculdade de Filosofia como núcleo central, uma vez que nunca houve Reitor da USP procedente desta Faculdade. (Xavier, 1999)
} 
Como afirmou Aracy Amaral (1988), no início dos anos 60, antes do Golpe Militar, a USP vivia o "clima de efervescência do país" e considerava sua capacidade como ilimitada. Com a passagem gradual para o campus da Cidade Universitária, imaginava-se que a USP poderia crescer muito. Além disso, por influência de Eurípedes Simões de Paula e Sérgio Buarque de Holanda as artes e humanidades foram mais valorizadas. ${ }^{12} \mathrm{O}$ resultado foi a incorporação do Museu Paulista, da coleção de Pré-História coordenada por Paulo Duarte, a compra da biblioteca de Yan de Almeida Prado, que seria a base do Instituto de Estudos Brasileiros, e a fundação do Museu de Arte e Antropologia pela USP.

As unidades da USP só foram sendo transferidas para o campus da Cidade Universitária no final dos anos 60, mas a idéia de construir uma Cidade Universitária vinha sendo difundida e discutida desde os anos 30 . Nos diversos projetos de construção do campus da Cidade Universitária em São Paulo, havia referências a museus além de jardins botânico e zoológico. Nos textos de Ernesto de Souza Campos, participante ativo e grande defensor da construção da Cidade Universitária, encontramos referências a museus para uso dos alunos:

"Si alumnos de escolas diversas devem freqüentar cursos, laboratorios, gabinetes e museus communs, não podem ser afastadas essas differentes installações, sob pena de uma prejudicial perda de tempo e desnecessárias despezas de transportes, tanto para o pessoal como para material." (Ernesto S. Campos, 1938, apud Xavier, M. A. 1999:89)

O mesmo autor, em 1945, também apresenta a proposta da existência de um museu de história natural no campus para visitação do público em geral, quando enumera as condições estruturais necessárias para a desejada Cidade Universitária:

“(...) 6 - Fácil acesso ao público para ingresso, em determinados dias, nos jardins botânico e zoológico e museu de história natural. ${ }^{13 "}$ (Ernesto S. Campos, 1945, apud Xavier, M. A. 1999:121)

A passagem de museus para as universidades se dava em função da crença de que estavam sendo incorporados por instituições sólidas, com pesquisadores competentes e sem problemas de verbas ${ }^{14}$. Entretanto, verificamos que as

\footnotetext{
12 Maria José Elias também afirma que o reitor Antônio de Barros Ulhôa Cintra recebeu influência e apoio de Eurípedes S. de Paulo e Sérgio B. de Holanda para a incorporação pela USP de coleções e museus. (Elias, Maria José, 1999:68).

${ }^{13}$ Segundo M. A. Xavier (1999:128) em uma das plantas propostas para Cidade Universitária, realizada em 1937, a parte central do campus seria ocupada pela Faculdade de Filosofia, Colégio Universitário e Museu de História Natural.

${ }^{14}$ Essa crença continua, pois o bibliófilo Mindlin doou, recentemente, sua coleção de livros raros à USP.
} 
universidades não estavam preparadas para receber museus, tanto em relação às verbas quanto ao pessoal qualificado. Além disso, muitas vezes, o museu foi visto como concorrente e não colaborador dos departamentos já existentes, criando disputas entre os profissionais.

No caso do Museu Nacional, Esther Valente aponta a incorporação à Universidade Federal do Rio de Janeiro como uma perda de autonomia para o museu:

"Integrado à atividade educacional brasileira, o Museu Nacional teve reconhecimento e destaque. Com a perspectiva de difundir o resultado das investigações feitas pelos especialistas, os serviços do museu contemplavam não somente a classe dos estudiosos, mas todo mundo, incluindo também o simples homem do povo que percorre as salas de exposição por mera curiosidade. Todos tinham acesso a pôsteres, notas sobre história natural, guias de exposição, mapas, quadros murais, diapositivos, conferências, cursos públicos, projeção de filmes, etc. À nova divisão, denominada de História Natural, onde se inseriu o Serviço de Assistência ao Ensino, cabia a intermediação das demais seções do museu com o público, ficando a seu cargo as coleções didáticas de história natural. Pelo decreto de 1931, o Museu Nacional passa a ser instituto científico autônomo e de administração dependente do Ministério da Educação e Saúde Pública.

Após um período de revitalização, as reformas implementadas pelo museu, voltadas diretamente para a educação popular, serão abaladas por uma crise entre seus próprios pesquisadores, insatisfeitos com as condições profissionais em que se encontravam na instituição. As alterações administrativas sofridas pelo órgão na década seguinte vão debilitando o museu, que perde sua autonomia e acaba incorporado à Universidade do Brasil (UFRJ) pelo decreto $n$. $^{\circ} 8689$, de 16 de janeiro de 1946, sendo seu projeto inicial redefinido." (Valente, 1995:85-86)

No Museu Nacional, o visitante continua vendo as mesmas exposições criadas no início do século ${ }^{15}$, enquanto a pesquisa atual da UFRJ nas áreas de ciências naturais e antropologia é bastante avançada. Nesse caso parece que nem a universidade se beneficia do museu nem ele do fato de pertencer à universidade, o que também reduz a qualidade dos serviços ao público. ${ }^{16}$

A USP, como já citamos, também anexou, incorporou, absorveu e criou vários museus e coleções. Em muitos dos casos isso acarretou para a universidade

\footnotetext{
${ }^{15}$ Em palestra proferida em 1999, o diretor do Museu Nacional, Luiz Fernando Dias Duarte, disse que "As atuais exposições, montadas quase totalmente entre os anos 40 e 50, encontram-se desastrosamente envelhecidas. Na verdade, cerca de um terço do circuito tradicional encontra-se já fechado, desmontado por motivos de degradação física ou de desatualização científica." (Duarte, 1999:62). Diante dessa situação, está em discussão projeto de novas exposições que valorizem o acervo e a pesquisa do Museu e tenham como eixo a historicidade da instituição.

${ }^{16}$ Recentemente, algumas reformas foram iniciadas no prédio do Museu Nacional e um grande projeto de renovação da exposição permanente está inscrito para captação de verbas. (Museu da Quinta da Boa Vista ensaia renovação. O Estado de São Paulo, 8 de abril de 2000, p.C8)
} 
problemas de falta de espaço adequado, falta de pessoal qualificado, falta de recursos financeiros para novas aquisições, enfim, a criação de mais problemas para a USP.

\section{Museus da Universidade de São Paulo}

Atualmente, a Universidade de São Paulo reconhece como unidades autônomas apenas quatro de seus museus: Museu Paulista (MP), Museu de Zoologia (MZ), Museu de Arte Contemporânea (MAC) e Museu de Arqueologia e Etnologia (MAE). ${ }^{17}$ Além desses quatro museus, a USP conta com vários museus e coleções ligados a departamentos e institutos.

\subsection{Museu Paulista/USP e Museu de Zoologia/USP: origem comum, muitos "donos" e dificuldades}

Vários institutos, museus e coleções de ciências hoje pertencentes à USP têm sua origem na Comissão Geológica e Geográfica (CGG) de São Paulo. A Comissão, criada em 1886 pelo Presidente da Província de São Paulo com o objetivo de obter

\footnotetext{
${ }^{17}$ Até bem recentemente esses museus não tinham regimento próprio aprovado pelo Conselho Universitário e funcionavam com regimentos internos seguindo as normas da Resolução do Reitor Waldyr Muniz Oliva, de 1982. Segundo a Resolução, os Museus (na época eram apenas três - Paulista, de Zoologia e de Arte Contemporânea), tinham como finalidade:

“a) desenvolver e promover a cultura dentro dos campos específicos de atividades de cada Museu;

b) zelar pelo respectivo acervo, procurando sua ampliação e aperfeiçoamento;

c) promover pesquisas destinadas a aumentar o conhecimento das diferentes áreas de interesse de cada Museu;

d) propiciar o aperfeiçoamento científico e cultural de seus especialistas;

e) organizar exposições públicas;

f) manter intercâmbio didático e de pesquisas com os Departamentos que lhes são afins na Universidade de São Paulo, de acordo com o $\S 1^{\circ}$ do Artigo $8^{\circ}$ do Estatuto;

g) manter intercâmbio com Museus e outras Instituições nacionais ou estrangeiras;

h) promover atividades culturais diversas como prestação de serviços à comunidade;

i) promover cursos de difusão cultural, de extensão universitária ou de aperfeiçoamento sobre assuntos de suas áreas de interesse;

j) estreitar as relações existentes entre Museus da Universidade de São Paulo, enfatizando a pesquisa interdisciplinar em proveito de sua personalidade coletiva e do enriquecimento dos acervos." (Diário Oficial do Executivo, 09/01/82, Seção I, p.27)

Em 1988 foi elaborado o novo Estatuto da USP, que definia que esta é formada por unidades (Institutos, faculdades e escolas), órgãos de integração (museus, institutos especializados) e órgãos complementares (hospitais). Os 4 museus foram incluídos entre os órgãos de integração. No Estatuto de 1988 encontramos muito pouco sobre o que seriam os 'órgãos de integração": "Artigo $6^{\circ}$ - Os órgãos de Integração, voltados para o estudo de interesse intersetorial, compreendem Museus, Institutos Especializados e Núcleos de Apoio. $\S 1^{\circ}$ - Os órgãos de Integração desenvolverão programas de interesse geral, bem como os propostos pelos docentes de Unidades e Departamentos relacionados com seus objetivos." (Estatuto da Universidade de São Paulo, 1988:5).
} 
informações sobre geografia, relevo, solo, vias de comunicação, estrutura geológica e riqueza mineral, visava a exploração industrial e agrícola do território. Formada por equipes interdisciplinares, a CGG desenvolvia pesquisas para ocupação da província. Em 1893 foram anexadas à CGG as coleções pertencentes ao Estado ${ }^{18}$. A coleção de zoologia deu origem à Seção de Zoologia (28/02/1893) chefiada por Hermann von Ihering. No ano seguinte, com a decisão de criar o Museu Paulista (MP) no monumento do Ipiranga, a Seção de Zoologia é transferida para o Museu e desliga-se da CGG. Outras coleções, como as do Palácio do Governo, vão também compor esse novo museu.

Sob direção de Ihering, o Museu Paulista é aberto ao público no Ipiranga em 1895, apresentando coleções mineralógicas, zoológicas, arqueológicas, etnográficas e históricas. Sendo o diretor um zoólogo, ele lhe imprime um perfil de museu de ciências naturais.

Até aqui temos uma trajetória comum aos museus públicos: coleções particulares que são doadas ao Estado para formação de museus. Nesse caso específico, havia interesse das elites locais em criar marcos culturais grandiosos para valorizar o papel de São Paulo na formação da cultura nacional, reforçando o poder em ascensão do Estado.

A partir de 1917, com a gestão de Afonso d'Escragnolle Taunay, o Museu Paulista ganha a Seção de História Nacional e Etnografia e passa a ter essa área valorizada. Taunay tinha intenção de "transformar o Museu Paulista numa instituição voltada para a história nacional e regional." (Elias, 1999:67).

Em 1939, as coleções zoológicas do Museu Paulista foram transferidas para o Departamento de Zoologia da Secretaria da Agricultura. ${ }^{19} \mathrm{O}$ Museu Paulista ganhou assim um perfil de museu de ciências humanas, desfazendo-se das coleções de ciências naturais.

Os pesquisadores de zoologia continuaram a desenvolver suas pesquisas e as publicavam na Revista Arquivos de Zoologia , a partir de 1940, no lugar da Revista do Museu Paulista.

\footnotetext{
${ }^{18}$ No final do século XIX, parte da elite paulistana começa a investir na ciência e cultura e cria a Associação para o Progresso da Província de São Paulo, com vistas a formar um Museu Provincial e erguer um monumento pela independência do Brasil. Em 1890, a coleção Joaquim Sertório foi doada ao Estado que a coloca sob responsabilidade da CGG e será ela o núcleo principal da Seção de Zoologia. (Maria José Elias, Um museu para São Paulo. Anais do Museu Histórico Nacional, MinC/IPHAN, vol.29, 1997.)

${ }_{19}$ As coleções botânicas foram transferidas em 1927 para o Instituto Biológico de Defesa Agrícola. (Pesquisando São Paulo: 110 anos de criação da Comissão Geográfica e Geológica. Coordenação J. Régis Guillaumon. São Paulo, IG/SMA, MP/USP, IF/SMA, 1996.)
} 
O que se pode perceber é que as coleções, inicialmente particulares, passam às "mãos" de diversas instituições públicas, mais por pressões de algumas autoridades do que pela lógica da preservação, pesquisa e ensino.

E, somente em 1969, o Departamento de Zoologia da Secretaria da Agricultura foi incorporado à Universidade de São Paulo com a denominação de Museu de Zoologia (MZ). Para o ex-diretor (até 1997) José Luiz Moreira Leme, a passagem para a USP fez o museu sofrer

"transformações drásticas, como o grande corte de pessoal técnico e administrativo, deixado nos quadros da Secretaria da Agricultura (...). Tal transformação atingiu também seu nome, que, por questão de isonomia, passou a ser chamado de Museu de Zoologia da Universidade de São Paulo." (Leme, 1997:29)

O professor Moreira Leme, pesquisador, expressa com clareza a visão de grande parte dos seus colegas do $\mathrm{MZ}$, de que este não deveria ser um "museu", mas sim um centro de pesquisas:

"A expectativa inicial era de que o Museu pudesse ser incorporado, de alguma maneira, ao Instituto de Biociências, ou até mesmo ser considerado um Instituto isolado. Todas as tentativas de incorporação ou de isolamento pelo seu estabelecimento como um Instituto foram rejeitadas." (Idem, p.29)

Hoje, o Museu de Zoologia é um importante centro de pesquisas e depositário de coleções tipo (referência) fundamentais para a identificação dos animais. Atende preferencialmente ao público universitário - professores e pós-graduandos oferecendo cursos - disciplinas de graduação e extensão - e atividades de extensão. ${ }^{20}$

A exposição pública está defasada em relação à pesquisa. As coleções crescem com a coleta realizada pelas pesquisas de campo. Para o atual diretor do MZ:

"Visando enfrentar os desafios do próximo século, seria indispensável instalar o Museu de Zoologia em novo prédio no campus, mantendo seu acervo e permitindo seu crescimento, mas dotando-o de uma exposição pública arrojada e moderna que divulgue a história da vida ao público, que não pode ter acesso a esse tipo de conhecimento em outro local. Este museu, ainda que longe do ideal, lamentavelmente inexiste no Brasil e na maior e mais rica cidade brasileira." (Rodrigues, M. Trefaut 1999:33)

Enquanto o Museu de Zoologia busca construir sua nova sede no campus da Cidade Universitária, o Museu Paulista firma-se cada vez mais como um marco do bairro do Ipiranga e empreende uma série de reformas em seu prédio para melhor

\footnotetext{
${ }^{20}$ Os pesquisadores / docentes do MZ costumam dar cursos de pós-graduação no Instituto de Biociências da USP.
} 
abrigar suas coleções e para valorizar o próprio prédio, como no caso da nova e grandiosa iluminação externa inaugurada em fins de 1999.

Depois da saída das coleções de ciências naturais, o Museu Paulista tomou perfil histórico com suas exposições organizadas por Taunay. Até hoje há partes das exposições públicas que mantêm a forma de apresentação dada pelo antigo diretor.

Em 1963, o Museu Paulista é transferido da Secretaria de Educação e Saúde Pública para a USP. O MP desenvolvia então pesquisas nas áreas de história, arqueologia e etnologia.

Em 1989, as coleções arqueológicas e etnográficas do MP e seus respectivos pesquisadores são transferidos para o novo Museu de Arqueologia e Etnologia da USP que acabara de ser criado. Dessa maneira, o MP torna-se definitivamente um museu histórico.

Na gestão do professor Ulpiano Bezerra de Meneses (1989-1994) esse perfil fica bastante claro nas linhas do plano diretor proposto para 1990-1995. No Plano Diretor, Ulpiano Meneses enfatiza o fato de que o MP deve antes de tudo executar tarefas de um museu - com suas atividades tendo como "referência obrigatória e permanente a um acervo de coisas materiais" (Meneses, 1989 rev.1999). Além disso, trata-se de um museu universitário, que teria condições ideais para exercer as atividades museológicas devendo evitar "duas situações polares, igualmente redutoras e inaceitáveis - museu como exclusivo instituto de pesquisa e formação superior; museu como exclusivo veículo pedagógico e cultural -". (idem). E, finalmente, o MP é um museu histórico:

"Seus compromissos fundamentais, portanto, devem dizer respeito a questões históricas (isto é, relativas ao fenômeno da mudança), especificamente aquelas que a curadoria puder cobrir e, como é óbvio, centradas na sociedade brasileira (e seu segmento paulista), sem preconceitos cronológicos. Seu horizonte, portanto, não pode ser panorâmico: o Museu Paulista não deve ser um manual tridimensional de História do Brasil." (Museu Paulista, 1990:2)

Em maio de 1997, o Regimento do Museu Paulista foi publicado e no parágrafo sobre suas finalidades ele aparece como um

"...órgão de integração, com responsabilidades científicas, culturais e educacionais no domínio da História da Cultura Material da sociedade brasileira." (Título I, Art. $\left.1^{\circ}, 08 / 05 / 1997\right)^{21}$

\footnotetext{
${ }^{21}$ Diz o Art. 20: "Para a consecução de seus objetivos, o Museu Paulista deverá: I - manter, ampliar e organizar seu acervo museológico bem como documentação pertinente; II desenvolver pesquisas relacionadas com seu acervo, com domínios conexos e com os campos de atuação do Museu; III - promover exposições públicas de seu acervo e de acervos conexos, assim como receber exposições itinerantes; IV - promover atividades educacionais e culturais;
} 
Dentro da USP, tanto o MP quanto o MZ têm departamentos e institutos com ensino e pesquisa nas áreas afins - história e biologia. Entretanto, nunca houve uma integração sistemática entre os museus e os departamentos afins, seja na utilização de coleções dos museus para ensino nos departamentos, seja na participação de professores dos departamentos na pesquisa e exposição dos acervos dos museus.

Ulpiano Meneses chama atenção para os perigos da criação de relações hierárquicas entre os museus e os institutos afins:

“...o museu universitário, da USP ou qualquer outra universidade, deve servir à sociedade, em todos os seus segmentos, como qualquer outro museu e, além disso, desenvolver formas específicas de atendimento a necessidades próprias da universidade. Tanto imaginar o museu universitário como apenas um instrumento a serviço de departamentos ou institutos da Universidade (coleções ou recursos para ensino), ou como apenas um organismo científico sem nenhum compromisso especial com ela são posturas completamente equivocadas e nefastas. Vê-se portanto, nessa ótica, que um museu universitário, longe de afunilar suas formas de atuação, precisa multiplicá-las e torná-las mais eficazes e adaptadas a necessidades amplas e diversificadas." (Meneses, 1999:2)

$\mathrm{Na}$ opinião de Meneses, museus e departamentos afins deveriam ser complementares; assim o departamento de História necessita de um museu de História para suas pesquisa e formação. O historiador da cultura material (do museu) trabalha diferentemente do historiador do departamento e ambos deveriam se ajudar mutuamente. É importante então haver representantes do departamento no conselho do museu e vice-versa.

"Mas, qual a justificativa para não haver representação dos museus nos departamentos e unidades afins? A conceituação de órgãos de integração, nos Estatuto da USP, foi entendida, aleivosamente, como fundamentando uma inaceitável subordinação às unidades de ensino e pesquisa, subordinação que não beneficia a nenhuma das partes." (Meneses, 1999:5)

$\mathrm{Na}$ forma atual dos regimentos dos museus existe a autonomia do museu para a maioria das suas questões internas, decididas pelo Conselho Deliberativo e pela Direção. No Conselho Deliberativo de cada museu há participação de docentes representando as unidades afins; entretanto, como destaca Ulpiano Meneses, não há representantes dos museus nos Conselhos das unidades afins. Além disso, cada museu deve indicar uma lista tríplice para submeter ao Reitor na escolha de seu

V - oferecer disciplinas optativas de graduação, disciplinas de pós-graduação e cursos de extensão em seus diferentes níveis; VI - manter biblioteca e laboratórios especializados; VII promover publicações; VIII - colaborar na proteção e valorização do patrimônio cultural brasileiro." (Regimento do Museu Paulista, 08/05/1997) 
diretor; este deve ser no mínimo titular e até o momento não há titulares procedentes dos museus. Assim, os diretores indicados vêm dos departamentos afins. A titulação dos docentes dos museus tornou-se possível com a definição dos seus regimentos, permitindo que eles realizem exame de livre-docência e concurso de titular nos departamentos afins.

O fato dos museus Paulista e de Zoologia estarem localizados no bairro do Ipiranga, distante do campus da Cidade Universitária, também colaborou para o seu afastamento das rotinas da universidade.

Por outro lado, estando no Ipiranga, dentro de um parque muito visitado aos fins de semana, o MP e o MZ são muito mais acessíveis ao público em geral. O MP abre todos os dias exceto segundas feiras e é o museu mais visitado da cidade, seguido pelo Butantan (aqui não levamos em conta o Parque Zoológico de São Paulo). Em sua dissertação de mestrado, Teresa T. de Paula, servidora do Museu Paulista, chama atenção para o tipo de público do MP, que se diferencia dos outros do campus:

"O Museu Paulista quer se goste ou não é um museu da Universidade e não um museu universitário. Sua localização e histórico são e serão sempre predominantes. Um museu histórico, popular,... a segunda maior visitação do país. Nos meses de julho a outubro a média diária de visitação pode chegar a 3.000 pessoas, o que no Brasil é bastante raro. A situação entusiasmante, em teoria, é motivo de orgulho das autoridades universitárias e freqüentemente é utilizada para engordar discursos e relatórios sobre a atuação da USP junto a sociedade que a sustenta. Mas a realidade de quem ainda se importa, daqueles que lá trabalham por opção é quase sempre fonte de angústia e desapontamento. O Brasil que visita o museu, não é o Brasil que parece interessar à Universidade. É o Brasil feio, inculto, pobre, ao qual o discurso universitário não consegue atingir. É a pedra no sapato a nos apontar, cotidianamente, que há algo errado, muito errado. Curiosamente, lá no Ipiranga, talvez, estivesse a chance de realmente produzirmos, marcarmos pontos, construirmos alguma diferença. Mas a despeito dos discursos e cerimônias constantes, permanecemos trabalhando para nós mesmos, ignorando o verdadeiro patrão, o para quê e a razão de estarmos lá”. (Paula, T. 1998:84).

De um lado, temos os museus fora do campus com forte tradição na cidade, como o Museu Paulista e de Zoologia, freqüentados pelo público escolar ${ }^{22}$, pela população da cidade e de outras regiões. Na outra ponta, há museus dentro do campus, visitados por grupos de escolares durante a semana e poucos visitantes espontâneos, famílias ou turistas.

22 O Museu Paulista é visitado cotidianamente por grupos escolares. Entretanto, o MP não conta com programas de ação educativa permanente voltados para esse público ou outros tipos de público. 
Os museus sediados no campus da Cidade Universitária não abrem aos fins de semana - com algumas exceções que abrem meio período aos sábados ${ }^{23}$ - alguns fecham no horário de almoço e por vezes não estão muito visíveis para quem transita no campus. Tudo isso somado leva à pouca visitação de público espontâneo ${ }^{24}$ e a um número razoável de grupos organizados, principalmente de escolas, que freqüentam esses museus. ${ }^{25}$

O Museu de Arqueologia e Etnologia (MAE) sempre foi sediado dentro do campus da Cidade Universitária, tendo sido deslocado mais de uma vez até chegar ao atual prédio - antiga sede do FUNDUSP - adaptado para suas funções. O Museu de Arte Contemporânea (MAC) teve sua sede por muitos anos restrita ao terceiro andar do prédio da Bienal no Parque do Ibirapuera, até que passou a ocupar um espaço ao lado da Reitoria, no campus da Cidade Universitária e, mais recentemente, ampliou seus espaços com a construção de sua sede nesse campus ${ }^{26}$, em frente à Reitoria. Assim, o MAC está fragmentado em diferentes prédios nos quais apresenta diferentes exposições, o que dificulta suas operações, mas permite atingir diferentes públicos.

Além desses dois museus, existem na Cidade Universitária mais 16 coleções e museus de institutos e departamentos.

\subsection{Museu de Arqueologia e Etnologia: fusão de acervos e pessoal potencializa sua ação}

O MAE foi criado em 1989 com a fusão de acervos etnográficos e arqueológicos que pertenciam à USP e estavam em diferentes instituições: Museu Paulista, Instituto de Pré-História (IPH), Acervo Plínio Ayrosa e o antigo Museu de Arqueologia e Etnologia. As coleções pertencentes a estas instituições têm diferentes origens: As coleções do MP, como vimos, vieram inicialmente de particulares e da Comissão

\footnotetext{
${ }^{23}$ A partir de 2001 o MAC e o MAE passaram a abrir das 10 às 14 horas aos sábados e domingos, mas não foi providenciada infra-estrutura para isso, ou seja, não há ônibus, restaurantes ou bares abertos no campus aos domingos.

${ }^{24}$ Por falta de um termo melhor, adotamos o termo "público espontâneo" para denominar aquelas pessoas que visitam os museus por iniciativa própria e não como parte de um grupo previamente organizado. Esse termo e outros afins são amplamente discutidos no Dicionário Crítico de Política Cultural, de Teixeira Coelho (Iluminuras/FAPESP, 1997).

${ }^{25}$ A explicação para o maior número de grupos pode ser por se organizarem previamente para visitas externas, alugarem ônibus e se adaptarem às distâncias e horários pré-determinados pelas instituições visitadas.

${ }^{26} \mathrm{O}$ prédio foi inaugurado sem que sua estrutura estivesse totalmente adequada para abrigar o MAC. No ano 2000 o prédio passou por uma reforma. Foram programadas exposições em espaços alternativos, como a FIESP na Avenida Paulista, para manter o acervo acessível ao público durante a reforma.
} 
Geológica e Geográfica. Com a atuação de arqueólogos e etnólogos houve também a coleta de campo resultante das pesquisas. No caso do IPH as coleções arqueológicas provêm basicamente de pesquisas de campo e algumas são réplicas doadas ou adquiridas de instituições estrangeiras. O Acervo Plínio Ayrosa, que pertencia à FFLCH/USP era formado de coleções etnográficas resultantes de coleta de campo. E finalmente, as coleções de arqueologia clássica do antigo MAE foram resultantes de doações, permutas e compras; as etnográficas africanas foram compradas assim como coleções arqueológicas da Amazônia. A partir de 1983, o MAE adquire também coleções advindas de pesquisas arqueológicas em São Paulo.

Cabe lembrar que o antigo MAE, quando de sua criação em 1964, era denominado Museu de Arte e Arqueologia e tinha coleções de arqueologia clássica provinda de doações de museus europeus, além das coleções egípcia, pré-colombiana, e etnográficas africanas e afro-brasileiras. Em 1969 passou a ser denominado Museu de Arqueologia e Etnologia.

Após a fusão, o novo MAE ocupou os quatro andares do Bloco $D$ do Centro Residencial da USP (CRUSP) onde estavam os antigos MAE e IPH. Em 1993, mudouse para o antigo prédio do FUNDUSP na Cidade Universitária, que foi adaptado para abrigar o museu. Durante esse processo de mudança, o museu ficou fechado para o público, até dezembro de 1995, quando inaugurou sua exposição de longa duração "Formas de Humanidade".

O acervo do MAE cresce continuamente principalmente com as coleções advindas das pesquisas arqueológicas no Estado de São Paulo.

Em 1997 foi finalizado o Regimento do MAE no qual são expressas as finalidades da instituição:

"I - desenvolver atividades de ensino, pesquisa e extensão nas áreas de Arqueologia, Etnologia e Museologia;

II - promover a proteção e a valorização do patrimônio arqueológico, etnográfico e museológico do Brasil bem como das coleções de origem externa integrantes do seu acervo;

III - incentivar o intercâmbio científico e cultural com instituições afins." (Título I, art. $\left.1^{\circ}\right)$

As ações são realizadas pelas duas Divisões criadas: Divisão Científica e Divisão Cultural, enquanto a direção atua por meio do Conselho Deliberativo e da Diretoria. A Divisão Científica tem pesquisadores e especialistas em arqueologia e etnologia, além de documentação e conservação; a Divisão Cultural conta com pesquisadores e especialistas em museologia e educação. Esse amplo quadro de 
profissionais possibilita a realização de todas as atividades do processo museológico documentação, conservação, comunicação e educação, além da pesquisa científica.

A exposição é basicamente visitada por público escolar que vem em grupos organizados para visitas monitoradas ou livres. Eventualmente o MAE desenvolve exposições temporárias em seu prédio ou em outros espaços e também exposições itinerantes. Mesmo assim, a programação de exposições e de atividades para o público não-especializado parece estar aquém do potencial do corpo técnico e científico.

O quarto museu "órgão de integração" da USP é o Museu de Arte Contemporânea, criado a partir da doação do acervo do Museu de Arte Moderna de São Paulo.

\subsection{Museu de Arte Contemporânea: uma rica coleção doada à Universidade \\ O MAC foi criado em 1963 com a doação para a USP de uma importante} coleção de arte moderna - a qual incluía obras de Modigliani, Picasso, Chagall, Miró, Bracque, Leger, Morandi, De Chirico entre outras - pertencente ao Museu de Arte Moderna de São Paulo (MAM/SP), um museu privado ${ }^{27}$.

O novo museu foi instalado no $3^{\circ}$ andar do prédio da Bienal. Com o tempo, a coleção foi enriquecida pela aquisição de obras de arte contemporânea que recebiam o primeiro prêmio da Bienal de São Paulo e muitas outras doações, somando 8000 obras em 1999.

O Regimento do MAC (1997) apresenta suas finalidades:

"I - promover o estudo e a difusão do acervo, assim como a sua conservação, proteção, valorização e ampliação, bem como o seu conhecimento como patrimônio artístico brasileiro no Brasil e no Exterior;

II - desenvolver atividades de ensino, pesquisa e extensão nas áreas que the são afetas;

III - incentivar o intercâmbio científico e cultural com instituições afins." (Título I, art. $\left.1^{\circ}\right)$

As ações são realizadas pelas Divisões Técnico-Científica de Acervo, TécnicoCientífica de Educação e Arte e de Pesquisa em Arte - Teoria e Crítica. Assim como o MAE e o MP, os órgãos de direção são o Conselho Deliberativo e a Diretoria.

\footnotetext{
${ }^{27}$ Matarazzo Sobrinho, que respondia pelo MAM naquela época, também doou várias obras de sua coleção pessoal.
} 
As pesquisas são desenvolvidas em várias áreas: sobre as coleções, sobre conservação de obras contemporâneas e métodos de educação não formal em arte contemporânea. O MAC realiza várias exposições: exposições do acervo, exposições educativas e exposições individuais e coletivas de artistas contemporâneos.

O MAC procura ser física e intelectualmente acessível ao público. Entretanto, sua localização no campus da Cidade Universitária e seus horários de abertura restritos dificultam o acesso dos diversos tipos de público. Com relação aos programas para acessibilidade intelectual, o museu oferece diversos cursos de história da arte moderna e contemporânea; apreciação e interpretação da arte; ateliês para a comunidade e público em geral e um programa especial para treinar professores de ensino fundamental. Além disso, oferece matérias optativas de graduação sobre arte contemporânea e interpretação da arte. (Almeida, 2000)

O MAC continua com suas três sedes: uma no $3^{\circ}$ andar do Pavilhão da Bienal no Ibirapuera; uma pequena sede (conhecida como "maquinho") no campus da Cidade Universitária ao lado da Reitoria e quase em frente da sede principal, que deveria abrigar a maior parte das exposições, do acervo e das áreas de trabalho.

No quarto capítulo discutiremos detalhadamente a trajetória do MAC/USP dentro da USP, o perfil de seu acervo e seus principais problemas.

\section{Museu de arte, de história....como definir a tipologia?}

Cabe destacar aqui que, entre os quatro grandes museus, o único denominado e considerado de arte é o MAC. Já chamamos atenção para o fato do antigo MAE ter sido criado com o nome de Museu de Arte e Arqueologia, seguindo a tradição européia de pesquisa que encarava os objetos da antiguidade clássica como obras de arte. Isso é ainda visível nos grandes museus de arte europeus - Louvre, British Museum - nos quais as coleções de arqueologia clássica são apresentadas enquanto objetos de arte. $^{28}$

Descrevemos rapidamente a origem e situação de três museus de ciências da USP: um de ciências biológicas - MZ ; um de história - MP e um de antropologia MAE. Todos eles certamente contam com objetos em seus acervos que poderiam ser considerados obras de arte, principalmente o MP e o MAE.

\footnotetext{
${ }^{28}$ Krzysztof Pomian fez um interessante artigo (Musée arquéologique: art, nature, histoire. Le Débat, Paris, 49, 1988:57-68) tratando da diferença entre o museu "arqueológico-tecnológico" e o "arqueológico-artístico", que resenhamos em Mortara, 1989.
} 
No caso do MP, são inúmeras as telas, por exemplo, de Benedito Calixto, Pedro Américo, que retratam paisagens de São Paulo e eventos históricos. Essas obras foram incorporadas ao acervo como objetos históricos e não como obras de arte e assim serão lidas e expostas pelo MP. Ulpiano Meneses ao discutir a tipologia de um museu histórico critica as visões baseadas apenas na categoria dos objetos:

"Num museu de arte, uma tela, por exemplo, é documento plástico (mas sem considerar que a construção da visualidade integra a realidade histórica). Já no museu histórico, a mesma tela seria valorizada pelo tema, como documento iconográfico (mas ignorando a historicidade da matéria plástica). Foram critérios como esse que determinaram em 1904 e em momentos posteriores, a transferência de telas do Museu Paulista (hoje da USP, um museu então histórico, antropológico e biológico), para a Pinacoteca do Estado (um museu de arte)." (Meneses, 1994:16)

Do Museu Paulista foram dadas à Pinacoteca todas as telas que não apresentassem "temas históricos" (Meneses, 1991:12). Esse critério, adotado até os anos 50 , não corresponde às novas linhas de pesquisa histórica que se ampliaram nas últimas décadas, ampliando também as fontes e as formas de interpretação. Ulpiano Meneses faz um interessante exercício de interpretação da temática de uma tela de Calixto (1853-1927) - Fundação de São Vicente - encomendada para as comemorações do IV Centenário do Descobrimento. Em sua análise Meneses demonstra que a tela de Calixto é um importante documento histórico sobre a época na qual foi produzido e não sobre o século XVI, abordado pela temática:

"Em suma, esta tela de Calixto é importante documento histórico, mas não relativamente ao século XVI. (...)

Em compensação, a tela nos remete aos tempos em que foi produzida e consumida. Ela é, sim, documento das necessidades simbólicas vividas por Calixto e sua sociedade, no final do século passado, procurando inventar uma história para a nação ainda jovem - e já superados os ressentimentos com a antiga metrópole." (Meneses, U. B., 1991:13)

O MAE tem em seu acervo artefatos arqueológicos e etnográficos que também podem ser considerados obras de arte, como adornos plumários produzidos pelos grupos indígenas do Brasil, máscaras africanas, cerâmicas marajoaras, entre outros ${ }^{29}$.

${ }^{29}$ Citamos alguns exemplos de exposições de arte com objetos antropológicos: Neste ano 2000, na exposição "Brasil 500 Anos de Artes Visuais", apresentada em pavilhões do Parque do Ibirapuera em São Paulo, podemos vivenciar a proposta de apresentar objetos arqueológicos e etnográficos a partir de questões da arte. Na XIII Bienal de São Paulo (1975) foram apresentados artefatos de grupos do Xingu pertencentes às coleções dos irmãos Villas Bôas na exposição "Xingu Dia Xingu Noite Xingu Terra". A exposição "Tradição e Ruptura", realizada pela Fundação Bienal de São Paulo (1984-85), propunha reunir o maior número possível de obras de arte do Brasil, do período pré-colonial à contemporaneidade, incluindo assim objetos arqueológicos e etnográficos. 
Esses artefatos são documentados, pesquisados e expostos enquanto objetos etnográficos ou arqueológicos, deixando a discussão das questões estéticas em um segundo plano.

Concordamos com Ulpiano Meneses quando ele afirma que a tipologia de um museu (no caso histórico) é dada pelas questões da área de conhecimento definida para o museu e não pelo tipo de acervo:

"Segundo a tipologia museológica acima discutida, concebe-se correntemente o museu histórico como aquele que opera com objetos históricos. Se, contudo, é a dimensão do conhecimento que sobe à tona, é preciso retificar e dizer, como vimos, que o museu histórico deve operar com problemas históricos, isto é, problemas que dizem respeito à dinâmica na vida das sociedades.

Nessa ótica, o museu deveria servir-se também dos objetos históricos, e de qualquer objeto que lhe possa permitir formular e encaminhar os problemas que tiver selecionado como prioritários dentro de seu campo." (Meneses, 1994:21)

Para tanto, os pesquisadores de cada museu precisam ter clareza das linhas de pesquisa que desenvolvem e apresentar ao público exposições e programas coerentes com suas seleções de temas de pesquisa.

\section{A tardia organização regimental}

Como vimos, os quatro museus estão sob responsabilidade da USP desde a década de $60^{30}$, porém é somente no Regimento Geral da USP de 1990 que aparecem órgãos criados com a finalidade de coordenar os museus e aprovar seus regimentos ${ }^{31}$ e coordenar os planos diretores a serem desenvolvidos posteriormente. Os artigos $47 \mathrm{e}$ 48 dispõem sobre a "Coordenação de Museus" composta pelo Pró-Reitor de Cultura e Extensão, pelos Diretores dos Museus, por representantes das unidades afins e por um representante discente. Compete à Coordenação de Museus:

"I - traçar a política de integração entre os Museus e as Unidades de Ensino e Pesquisa;

II - fixar normas de funcionamento dos Museus e de atendimento ao público;

III - elaborar os regimentos dos Museus e submetê-los à aprovação do Conselho Universitário (Co);

IV - emitir parecer sobre os relatórios anuais de atividades dos Museus para apreciação do CoCEx ou dos demais Conselhos quando pertinente". (Regulamento Geral, 1990:30)

\footnotetext{
${ }^{30}$ Apesar do MAE ter sido criado em 1989, as instituições que o compuseram já faziam parte da USP anteriormente.

${ }^{31}$ Até aprovação dos Regimentos, os museus funcionavam, como vimos anteriormente, por regimentos internos seguindo as normas da Resolução do Reitor Waldyr Muniz Oliva, de 1982.
} 
Os artigos 49 e 50 do regulamento tratam dos órgãos de direção dos Museus Conselho Deliberativo e Diretoria - e das formas de ingresso e progressão na carreira docente. Nas disposições transitórias do regulamento ficou determinado que os Museus teriam 120 dias para elaborar seus regimentos e submetê-los ao Conselho Universitário. (Regulamento Geral, 1990:78)

O Conselho Universitário aprovou no $1^{\circ}$ semestre de 1997 o Regimento do MAE e do MP e em 1998 os Regimentos do MZ e MAC ${ }^{32}$. Em relação à carreira docente, os museus foram praticamente igualados às unidades de ensino, possibilitando a carreira acadêmica completa aos seus pesquisadores ${ }^{33}$. Cada museu ficou com um organograma diferente, respeitando-se assim a especificidade de cada um. Após a aprovação dos regimentos, novos diretores foram escolhidos a partir de listas tríplices saídas dos conselhos dos museus e não mais por nomeação direta do reitor. Essas mudanças, somadas à garantia de continuidade de normas, deram aos museus uma base mais estável para definirem seus planos diretores e programas de trabalho, além de facilitar a obtenção de financiamentos para projetos.

Aparentemente a USP está conseguindo resolver os problemas de organização e legislação de seus grandes museus. Entretanto, se levarmos em conta os "outros" museus, há muito ainda a discutir e deliberar, pois estes são apenas seções, apêndices de departamentos e institutos sem qualquer autonomia.

\section{Os outros museus e coleções: o que fazer?}

Nos últimos anos, foram estabelecidas legalmente as estruturas dos 4 grandes museus da USP, com a constituição de regimento e organograma. Ainda assim, há muito que fazer para ter mecanismos que garantam a continuidade de programas e 0 desenvolvimento de novas atividades de pesquisa, ensino e extensão. O que dizer dos outros museus e coleções da USP? Esses outros museus e coleções não têm autonomia para elaborar regimentos próprios, estando subordinados aos departamentos ou seções dos institutos aos quais pertencem.

Foram feitos vários levantamentos sobre coleções e museus da USP, cada um com diferentes objetivos; Em 1982, Walter Zanini coordenou um levantamento feito por seus alunos da ECA; posteriormente, a Comissão de Patrimônio Cultural da USP

\footnotetext{
${ }^{32}$ Passaram-se muito mais do que 120 dias...

${ }^{33}$ Foram abertos concursos de efetivação para os docentes que estavam há mais de 10 anos contratados pelos museus da USP e isso possibilitou sua progressão na carreira - poderão fazer concursos de livre-docência e titular nos próprios museus.
} 
realizou diversos levantamentos das coleções e museus, principalmente para conhecer o patrimônio sob responsabilidade da USP. ${ }^{34}$

Walter Zanini, que ministrou durante muitos anos a disciplina Elementos de Museologia na ECA/USP, ressalta a importância das várias coleções e a "ausência de uma consciência desse patrimônio cultural". Ele acha que não se deve esperar uma "solução geral e padronizada e tampouco se recomenda a perda de identidade de cada coleção". Para o autor,

"No âmbito de uma Universidade, entretanto, deve-se buscar uma harmonia na existência e funcionamento dessas coleções. É necessário, portanto, respeitar a autonomia de cada Unidade e simultaneamente oferecer um serviço geral de museologia que possa auxiliar a organização dessas coleções.

É importante também que seja dada maior atenção aos problemas de organização e um aumento substancial de recursos financeiros de acordo com as necessidades de cada Unidade, precedida de uma hierarquização de prioridades." (Zanini, 1982:3)

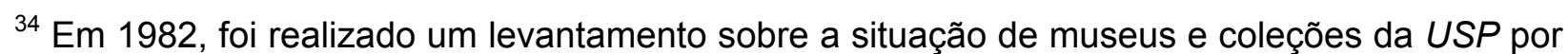
alunos da disciplina "Elementos de Museologia" (ECA/USP) ministrada pelo professor Walter Zanini. Foram pesquisadas dezessete "unidades":

1- Instituto Oceanográfico; 2 - Museu de Arte Contemporânea; 3 - Museu de Arqueologia e Etnologia; 4 - Museu Paulista; 5 - Museu de Zoologia; 6 - Instituto de Estudos Brasileiros; 7 Instituto de Pré-História; 8 - Instituto de Biociências (Herbário de fanerógamas e de algas marinhas; Coleção de Vertebrados, Invertebrados I e II); 9 - Instituto de Geociências; 10 Instituto Astronômico e Geofísico (não há dados no relatório); 11 - Faculdade de Filosofia, Letras e Ciências Humanas (Museu Plínio Ayrosa); 12 - Faculdade de Arquitetura e Urbanismo ('museu" da Biblioteca); 13 - Faculdade de Medicina e Veterinária (Museu de Anatomia e Museu de Patologia Animal); 14 - Escola Politécnica (não há dados no relatório); 15 - Escola Superior de Agricultura Luiz de Queiroz (Museu de Zoologia foi desativado vários anos antes); 16 - Escola de Educação Física (e Associação Atlética Acadêmica 'Ruy Barbosa'); 17 - Escola de Comunicações e Artes (Museu de Imprensa 'Júlio de Mesquita Filho' Setor Histórias em Quadrinhos e Museu do Folclore do Curso de Turismo).

Esse trabalho é um importante documento pois apresenta imagens e descrições dessas instituições, além de interessante introdução do professor Zanini.

A Comissão de Patrimônio Cultural da USP (CPC/USP) realizou vários levantamentos dos museus e das coleções da USP. Em 1996, publicou o Guia de museus Brasileiros no qual incluiu os seguintes museus da USP: 1) Acervo Didático do Departamento de Zoologia, 2) Centro Histórico-Cultural da Enfermagem Ibero-Americana, 3) Coleção de Artes Visuais Mário de Andrade, 4) Coleção Entomológica de Referência, 5)Estação Ciência, 6) Herbário, 7) Laboratório de Brinquedos e Materiais Pedagógicos, 8) Museu Ceroplástico Augusto Esteves, 9) Museu da Farmácia, 10) Museu de Anatomia Veterinária Prof. Dr. Plínio Pinto e Silva, 11) Museu de Arqueologia e Etnologia, 12) Museu de Arte Contemporânea, 13) Museu de Geociências, 14) Museu de Odontologia, 15) Museu de Peças Anatômicas Humanas, 16) Museu de Rochas, Minerais e Minérios, 17) Museu de Zoologia, 18) Museu Didático da Disciplina de Invertebrados I, 19) Museu e Aquário do Instituto Oceanográfico, 20) Museu Histórico Prof. Carlos da Silva Lacaz, 21) Museu Paulista, 22) Museu Técnico-Científico do Instituto Oscar Freire, 23) Museu Republicano Convenção de Itu (MP), 24) Museu do Centro Regional de Pesquisas Arqueológicas Mario Neme (MAE), 25) Centro de Recursos Hídricos e Ecologia Aplicada, 26) Museu de Instrumentos e Cálculo Numérico, 27) Museu Luiz de Queiroz. (CPC, 1996)
} 
Entre as várias coleções encontramos algumas claramente voltadas para o público em geral e outras apenas para especialistas e alunos da universidade. Nosso levantamento, apresentado em anexo, registra 35 museus e coleções pertencentes à USP. Diante da variedade de museus e coleções, cada um com história e identidade próprias, fica difícil propor uma solução única. E nem deveríamos.

A maioria desses museus e coleções (18) situa-se na Cidade Universitária, na Capital. Nove localizam-se em diferentes bairros da cidade de São Paulo e 8 estão nos campi do interior. Cada um desses museus e coleções funciona com maior ou menor autonomia, número de servidores, cooperação com departamentos afins, número de programas públicos. Essa heterogeneidade de realidades dificulta a ação coordenada da universidade e a definição de políticas culturais comuns que possam somar forças dos vários museus.

Apresentaremos aqui, de forma sucinta, a descrição de alguns desses museus e coleções para que se tenha uma idéia mais clara do que são na prática.

\section{escolar \\ 7.1. Centro de Ciência e Tecnologia: vulgarização da ciência para público}

A Estação Ciência foi criada para ser um centro dinâmico de ciências, apresentando módulos manipuláveis e interativos para ensino de ciências. Inaugurada em 1987 pertencia inicialmente ao CNPq, que posteriormente realizou convênio com a USP. Sem contar com acervo, foram criados cenários, jogos, mecanismos, maquetes, reproduções entre outras coisas para apresentar leis da natureza, mostrar o progresso da ciência e da técnica, vulgarizar o conhecimento científico de forma didática e estabelecer uma ligação entre ciência e tecnologia e a vida cotidiana. A exposição de abertura "O Homem, o planeta e a vida" apresentava questões de Geografia (O Planeta), Física (O Homem e os Mistérios do Cosmos), Meteorologia (O Homem e os Mistérios do Tempo), História (A cidade, artefato do Homem), Biologia (Os pássaros voltam à cidade), Matemática, Química (As invenções do Homem) além da "Praça Ecológica" e da "Área de Sensibilização Infantil". Cada parte foi feita por uma equipe da área e, no nosso entender, ficou muito difícil perceber uma unidade entre as diferentes disciplinas, mais parecendo um conjunto de pequenas exposições.

Localizada no bairro da Lapa, zona oeste de São Paulo, ao lado da estação de trem, a Estação Ciência é de fácil acesso e fica aberta aos fins de semana. A Estação Ciência já passou por algumas reformas, teve seu espaço expositivo ampliado e 


\section{Museu Histórico Prof. Carlos da Silva Lacaz Faculdade de Medicina Universidade de São Paulo -1998}

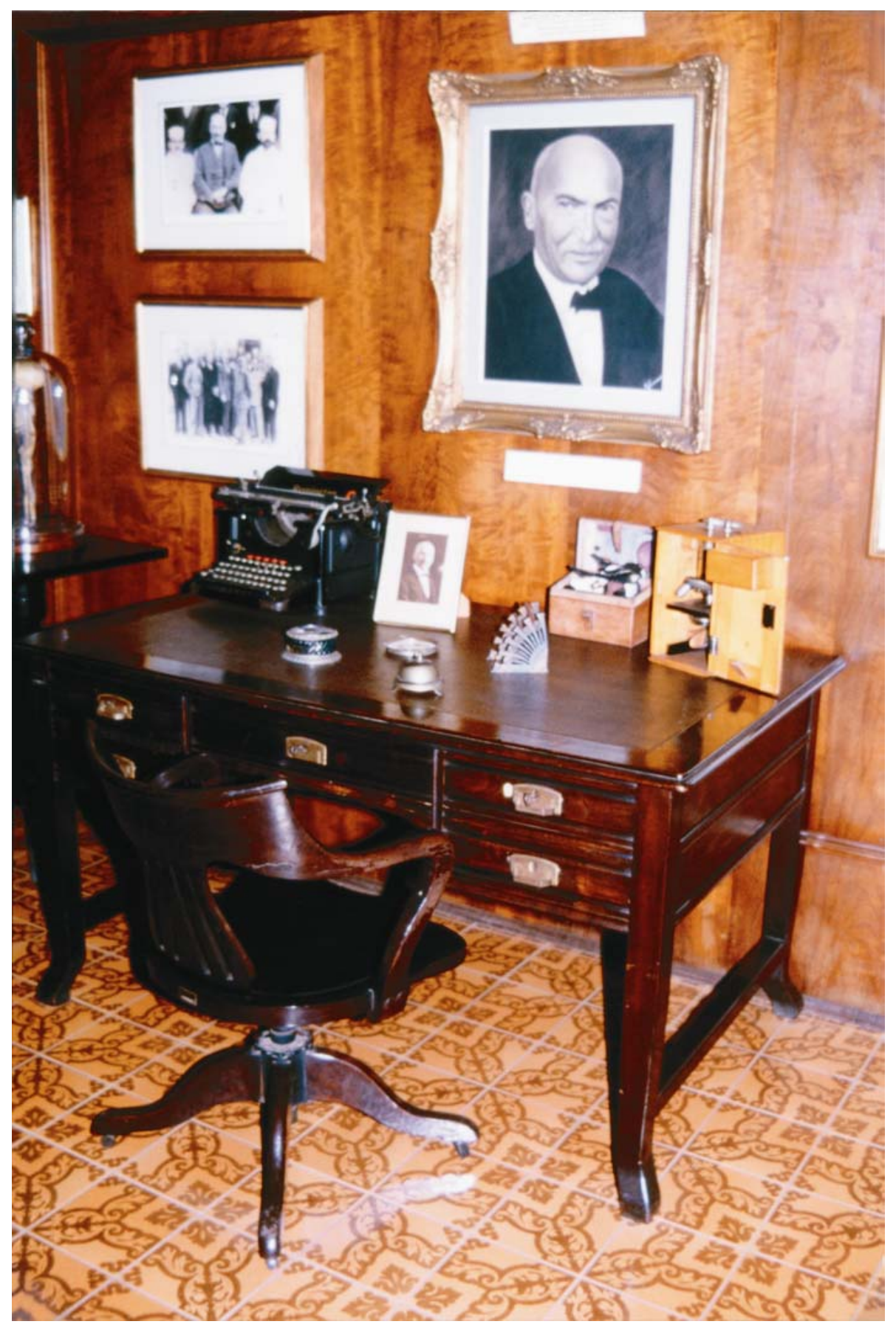


costuma abrigar exposições temporárias e eventos científicos voltados para a divulgação da ciência. Atende cotidianamente público escolar e também tem significativa visitação espontânea.

Atualmente a Estação Ciência é um Centro de Divulgação Científico-Cultural ligado à Pró-Reitoria de Cultura e Extensão e, apesar de ser um Centro de Ciências, aparece muitas vezes como um dos museus da USP, como veremos ainda neste capítulo, no Anuário Estatístico da USP.

\subsection{Coleção para público interno (?)}

A Faculdade de Medicina (FM) da USP conta com três museus, além da exposição permanente do "Culto ao Passado" com 60 pôsteres de grandes vultos da Medicina no $1^{\circ}$ andar. Há o Museu Histórico, o Museu Ceroplástico Augusto Esteves e o Museu Técnico Científico do Instituto Oscar Freire, todos situados no campus da Dr. Arnaldo (cidade de São Paulo).

O Museu Ceroplástico Augusto Esteves, criado em 1980 por iniciativa do antigo Departamento de Microbiologia e Imunologia da FM, apresenta modelos em cera de doenças cutâneas. São 31 módulos dispostos em forma de labirinto em um hall do corredor do $2^{\circ}$ andar do prédio da FM. Ao todo são 259 peças representando as mais diversas moléstias de pele. ${ }^{35}$

O Museu Histórico Prof. Carlos da Silva Lacaz foi criado pela Congregação da FM em 1977 e implantado sob a coordenação de Prof. Carlos da Silva Lacaz.

São várias as homenagens a personagens importantes da Faculdade de Medicina, como placas comemorativas, apresentação de retratos e/ou objetos pertencentes a eles, apresentação de obras por eles realizadas, etc. As atividades desses ex-alunos e antigos professores em outras áreas - como literatura, pintura - são mostradas por seus livros, suas obras e seus instrumentos de trabalho. As atuações de alguns médicos no exército, na administração pública e em outras instituições também são apresentadas.

Para os visitantes desavisados, as inúmeras salas do Museu parecem apresentar todo tipo de objetos e referências iconográficas, ficando muito difícil reconhecer o que se pretende em cada uma. A quantidade e diversidade de objetos de todo o Museu dificultam a leitura de qualquer discurso mais contínuo ou seqüencial.

35 Todas as peças foram executadas por Augusto Esteves entre 1940 e 1959 quando foi funcionário do Instituto Oscar Freire. (Mais detalhes em LACAZ, C. da S. (ed.) Museu Ceroplástico Augusto Esteves, FM/USP, 1983). 
Muitos objetos não são identificados nem com etiquetas e, para um visitante que desconhece as grandes figuras da Medicina e da Faculdade de Medicina da USP, fica mais difícil entender qual a relação de cada elemento com a História da Medicina.

Ao entrevistar o Prof. Lacaz, pudemos conhecer um pouco melhor o pensamento daquele que criou e organizou o Museu. Para ele, o Museu preserva e divulga a memória médica de São Paulo, cultura e memória médicas brasileiras e seus grandes vultos. Com freqüência, o Museu encabeça comemorações em datas importantes para a FM, aniversário de formaturas de turmas antigas, homenagens pela morte de antigos professores ou de vultos da Medicina. ${ }^{36}$

Para nós, o Museu nos parece um espaço para REMEMORAR, HOMENAGEAR E COMEMORAR pessoas da área da Medicina. Não há preocupação com os eventos, fatos, invenções e descobertas em si, mas está centrado nos indivíduos, nomeados um a um. Sua visitação é muito baixa, cerca de 600 pessoas por ano ${ }^{37}$ e não está aberto ao público escolar, pois fica no terceiro andar de um prédio onde se realizam aulas. ${ }^{38}$ Nessas condições mantivemos nossa dúvida de quem seria o público desse museu? Não seria mais interessante tornar-se um "Centro de Pesquisa Histórica", pois conta com fontes bibliográficas excelentes e acervo de cultura material que podem ser fontes para pesquisa. Assim não precisaria ter exposição permanente e poderia centrar esforços na pesquisa histórica.

\subsection{Coleção para ensino e pesquisa}

A área de botânica do Instituto de Biociências da USP criou, a partir de coleta e doações, um herbário de referência para estudo das diferentes espécies de plantas. $O$ acervo, formado por 140.000 amostras de plantas secas prensadas, teve seu núcleo inicial formado pelo professor Wilson Hoehne da Faculdade de Farmácia em 1932, tendo sido transferido para o Departamento de Botânica em 1950. O Herbário do Instituto de Biociências da USP serve basicamente aos professores e alunos para

\footnotetext{
${ }^{36} \mathrm{O}$ Prof. Lacaz e sua equipe publicam constantemente boletins e livros relacionados à História da Faculdade e de seus professores. Recentemente terminaram publicação sobre várias coleções do museu (Mazzieri, 2000). Além disso, o prof. Lacaz preside a Sociedade Brasileira de História da Medicina, criada em 1997. Anualmente o Prof. Lacaz coordena um curso de extensão de História da Medicina, sempre bastante procurado por interessados na área. Para Lacaz, a melhor maneira de conhecer e preservar a memória da Medicina seria a criação de uma linha de pesquisa com cursos de pós-graduação na área de História da Medicina. Entretanto ele considera muito difícil conseguir aprovar tal curso no âmbito da FM/USP

${ }^{37}$ Segundo informação da Comissão de Patrimônio Cultural da USP, a visitação de 1996 foi de 653 pessoas, de 1997561 pessoas e de 1998 foi de 581.

${ }^{38}$ Informação dada a autora por Berta Ricardo de Mazzieri, museóloga, em 22/06/1998.
} 


\section{Museu Oceanográfico Universidade de São Paulo -1997}

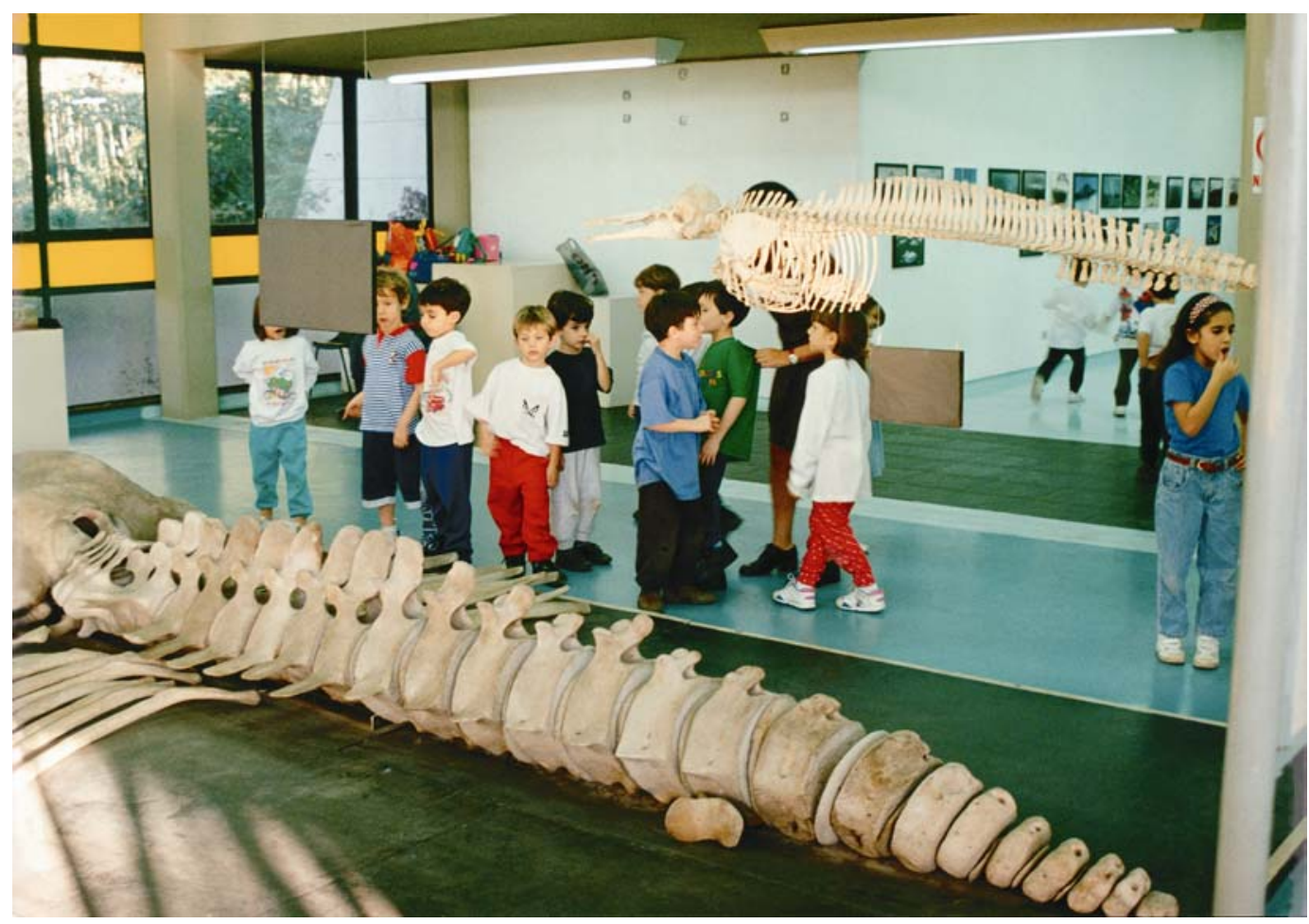

Exposição permanente: crianças imitam o movimento da baleia

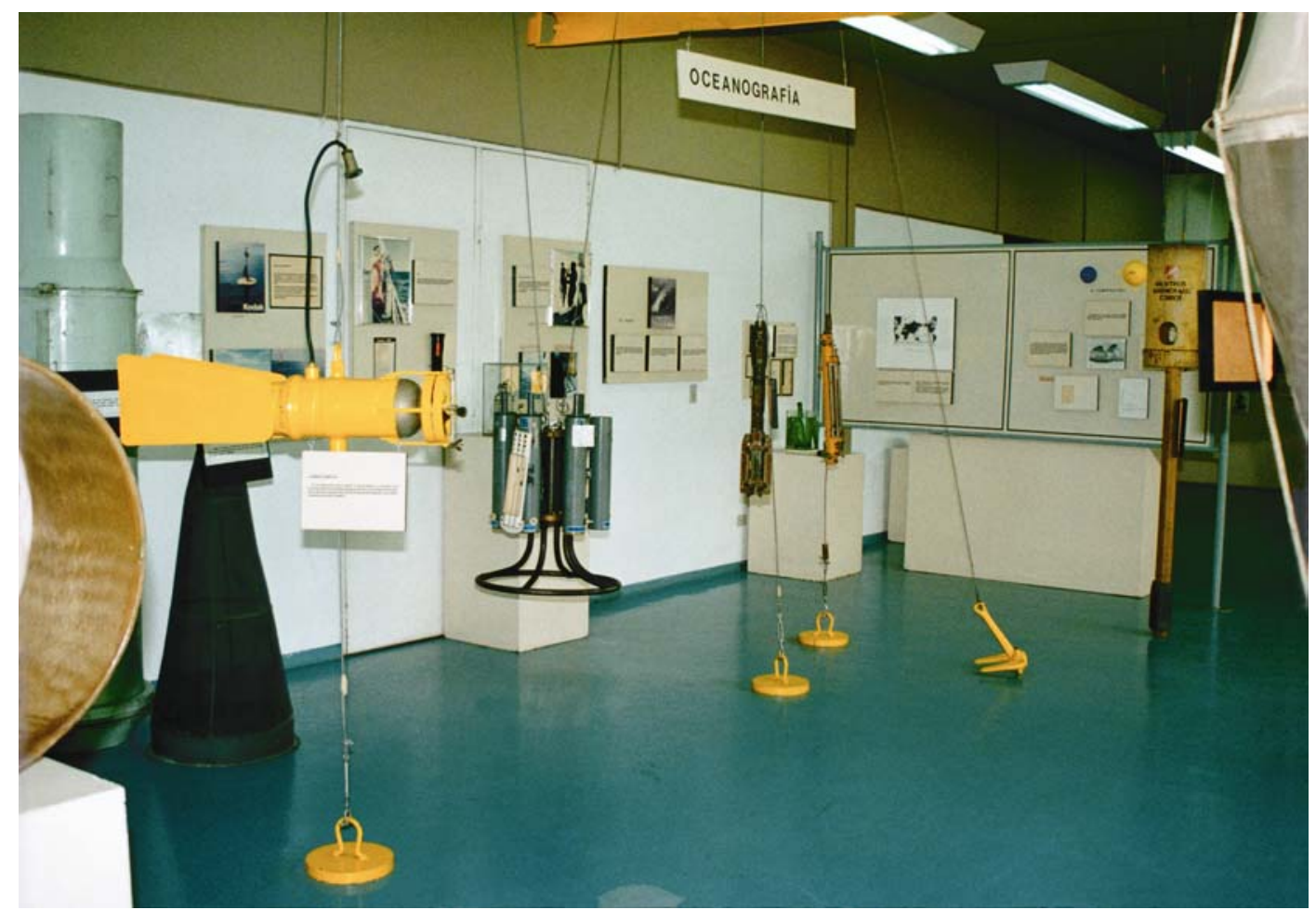

Exposição permanente: instrumentos para pesquisa oceanográfica 
ensino e pesquisa e não fica exposto ao público em geral, pois teria sua conservação ameaçada, não havendo espaço nem pessoal disponível para manutenção. A situação desse Herbário é semelhante à de outras universidades brasileiras e de fora do Brasil. A fragilidade dos espécimes conservados não permite manipulação ou exposição à luz freqüente.

Visitamos em Montreal o Herbário da Universidade de Montreal (Herbier MarieVictorin), que não realiza exposições. Naquele ano de 1998, alguns exemplares do Herbário serviram de inspiração para a produção de artistas contemporâneos, cujas obras foram apresentadas na Galeria da Universidade. Também encontramos uma situação semelhante em Sherbrooke (Canadá), onde a Galeria da Universidade ${ }^{39}$ realizou um trabalho conjunto de artistas com os botânicos para a criação de obras a partir de alguns exemplares da coleção. Estes foram também expostos, mas com proteção especial contra a luminosidade. Com essa proposta a diretora acredita ter conseguido um diálogo entre a ciência e a arte.

Consideramos que, no caso da USP, o Herbário poderia continuar a exercer as funções atuais, mas buscando o aperfeiçoamento do acesso à pesquisa e ensino. Eventualmente algum exemplar poderia ser emprestado para fazer parte de uma exposição, desde que não significasse risco de deterioração. Dessa maneira, essa coleção estaria preservada e manteria sua vocação para ensino e pesquisa universitários.

\subsection{Museus e Coleções voltadas para público externo}

As coleções que não costumam ser utilizadas sistematicamente para ensino e pesquisa dos departamentos e que têm grande apelo público, como as do Museu Oceanográfico e do Museu de Medicina Veterinária, precisam encontrar soluções diferentes.

O Museu Oceanográfico pertence ao Instituto Oceanográfico da USP (IO/USP) e apresenta uma exposição voltada para o público escolar (Fundamental e Médio) sobre

\footnotetext{
${ }^{39}$ A Galeria de Arte do Centro Cultural da Universidade de Sherbrooke é assumidamente um espaço para exposições de arte contemporânea. Foi construída com apoio da Prefeitura da cidade para ser um local de divulgação das artes, sendo que a Universidade não tem nenhum curso na área de artes. Sua diretora há mais de 15 anos, Johanne Brouillet, afirmou que tem tido sucesso em sua empreitada e que recebe anualmente dezenas de propostas de exposições para selecionar. A galeria é uma referência para a arte contemporânea regional e nacional. Localiza-se no campus, que é distante da cidade, e recebe cerca de 31 mil visitantes por ano. A coleção de arte da Universidade de Sherbrooke encontra-se espalhada pelas diferentes dependências do campus. A diretora da Galeria não é responsável pelas coleções.
} 


\section{Museu de Anatomia Veterinária Prof. Plínio Pinto e Silva Universidade de São Paulo -1998}

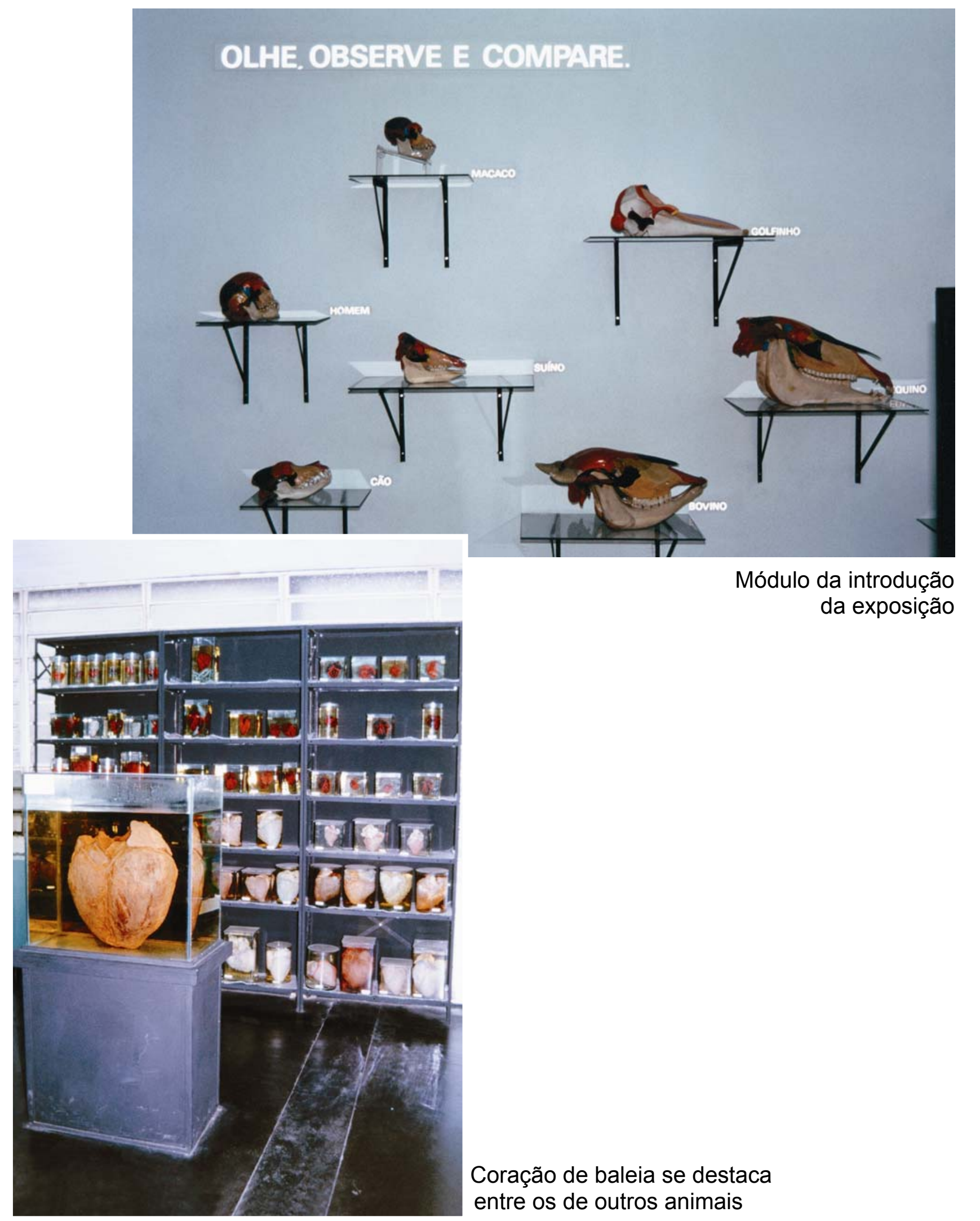


a Oceanografia - Física, Química e Biológica - por meio de equipamentos, fotografias, gráficos, desenhos, preparações biológicas e aquários marinhos ${ }^{40}$. Os equipamentos mostrados não são mais utilizados nas pesquisas e as coleções são especialmente doadas e/ou coletadas para as exposições, exercendo função de comunicação e educação, não sendo objeto de pesquisa acadêmica. As atividades educativas promovidas pelo museu estão voltadas para o público escolar e outros públicos externos à USP, como grupos de $3^{a}$ idade, pré-escola ou deficientes. Alguns possíveis caminhos para melhorar o museu, em nossa opinião, são: 1) Aprofundar a relação com os públicos atuais, elevando a qualidade das exposições e programas educativos; 2) Atrair professores e alunos do IO/USP para coordenar exposições e atividades no museu voltadas para o público em geral e/ou especializado; ou 3) Estabelecer relações com professores e alunos do IO/USP para formação de coleções para ensino e pesquisa e criação de exposições e programas voltados para o público especializado. Pela identidade e imagem criadas pelo Museu Oceanográfico ao longo dos anos, parece-nos que a primeira opção seria a mais viável em curto prazo, pois não demandaria modificações na "cultura" do museu e de seu público, porém as duas outras opções aproveitam mais o fato de o museu ser universitário e poderiam ser complementares à primeira.

O Museu de Anatomia Veterinária Prof. Plínio Pinto e Silva, da Faculdade de Medicina Veterinária (FMV), teve sua coleção formada inicialmente para o desenvolvimento de aulas de anatomia veterinária. As peças conservadas sempre estiverem expostas em corredores, mas em 1984 passaram a compor o Museu. Assim como o Museu Oceanográfico, seu maior público é de estudantes de ensinos fundamental e médio, externos à USP. Porém, várias peças expostas ainda são utilizadas para fundamentar aulas dadas na FMV e alguns alunos fazem estágios no Museu como monitores.

\subsection{Museus e coleções para públicos interno e externo}

A situação do Museu de Geociências do Instituto de Geociências da USP é um pouco diferente. Localizado no primeiro andar do prédio do Instituto, no campus da Cidade Universitária, ele apresenta basicamente amostras de minerais, minérios, meteoritos, fósseis e rochas. Apesar de receber continuamente visitas de alunos de

\footnotetext{
${ }^{40}$ Devemos destacar que, na cidade de São Paulo e arredores, não existe coleção semelhante àquela do IO/USP, o que a torna de interesse do público externo à USP.
} 


\section{Museu de Geociências Universidade de São Paulo -1998}

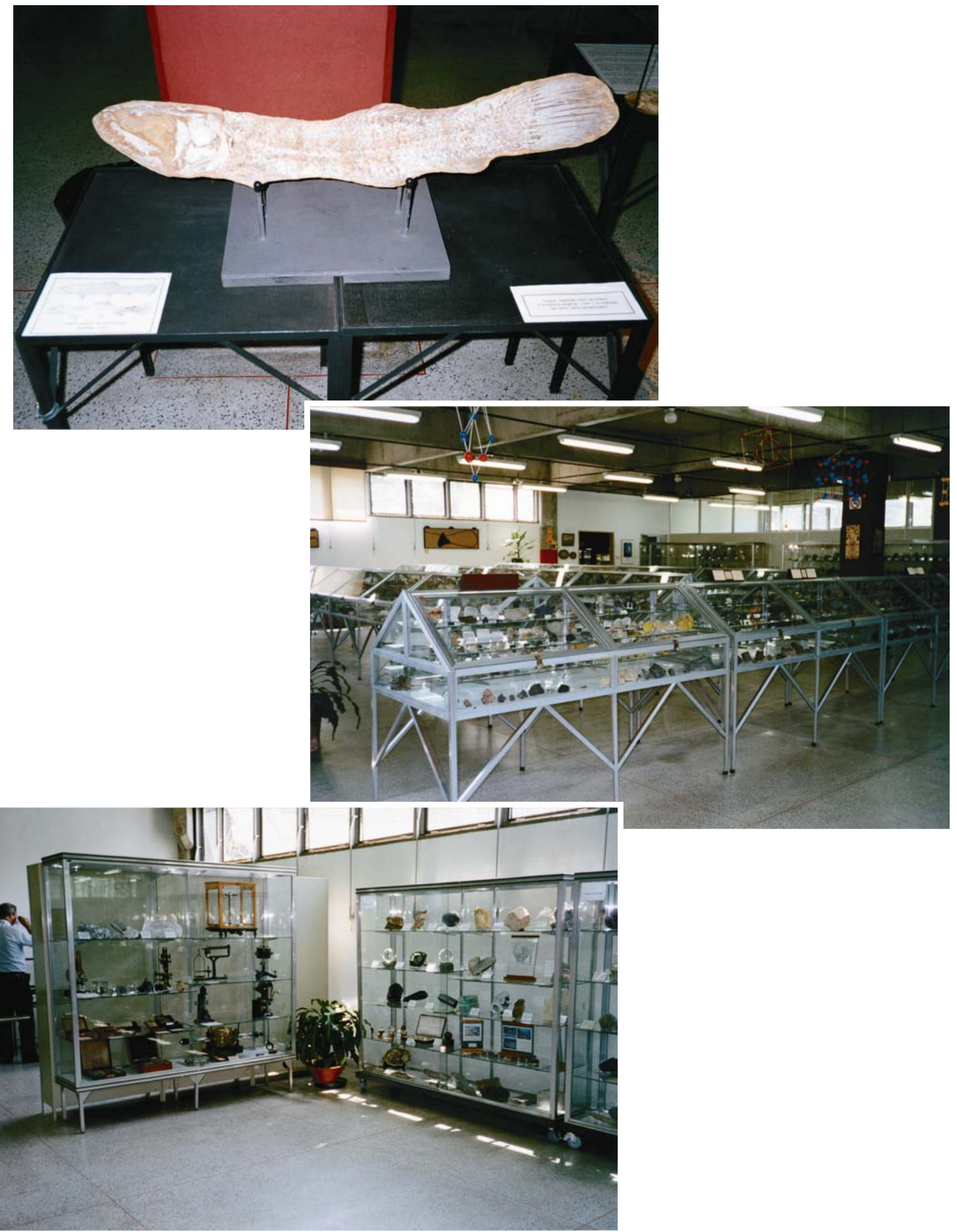

Exposição Permanente 
ensinos fundamental e médio, o Museu mantém relação próxima com o Instituto, mantendo parte da exposição voltada especificamente para os alunos do Instituto e emprestando amostras para os professores darem aulas práticas ${ }^{41}$. É comum o Museu realizar exposições temporárias sobre as pesquisas desenvolvidas por professores e alunos do Instituto de Geociências. No caso deste museu, a diretoria teria grande interesse em ter um espaço expositivo fora da Cidade Universitária, para poder ampliar seu atendimento ao público externo.

Nos três museus apresentados acima, Oceanográfico, Anatomia Veterinária e Geociências, não existe pesquisa sistemática das coleções / acervos. No caso do Museu de Anatomia Veterinária, algumas peças se prestam para estudos anatômicos comparativos / descritivos. Assim, eles não se realizam enquanto espaços de pesquisa, como seria de se esperar de um museu universitário.

Poderíamos pensá-los reunidos, formando algo semelhante ao Centro Museográfico que vimos na Universidade de Laval ${ }^{42}$, no qual a exposição foi elaborada de forma didática assumidamente para o público de ensinos fundamental e médio. Poderíamos somar ainda outras coleções como as do Instituto de Biociências, do Instituto de Ciências Biomédicas, da Faculdade de Medicina entre outras.

Um dos problemas de centralizar tais coleções seria a perda da identidade, da história de cada uma e também, provavelmente, criar-se-iam algumas duplicações para manutenção das peças necessárias para o ensino nos departamentos e institutos.

Recentemente, foram elaboradas propostas de formação de uma rede entre os museus e coleções da USP e a formação de um centro para exposições: um novo museu de ciências ${ }^{43}$. Para saber das possibilidades de sua criação, foi formada uma equipe de estudo e realizado um diagnóstico sobre a situação dos museus e coleções da USP. Esse diagnóstico, coordenado pela professora Maria Cristina Bruno,

\footnotetext{
${ }^{41}$ A exposição permanente fica em ampla sala e as peças estão em armários/vitrinas com estantes de vidro, permitindo a melhor visualização das amostras. Reconhecido pela própria diretora do museu, há um número excessivo de objetos por vitrina, mas essa quantidade segue a classificação química que organiza a coleção. O aluno de Geociências e o especialista procuram todos esses tipos apresentados, enquanto o leigo se perde num "mar de pedras".

${ }_{42}$ Apresentamos breve descrição no primeiro capítulo desta tese.

${ }^{43}$ O Grupo de Trabalho coordenado pelo professor Ernst Hamburger considerava como “ pressuposto para a criação do novo museu a formação de uma rede de ações museológicas que articulasse as unidades, museus, acervos e coleções da Universidade tendo como ponto de partida a consolidação de uma sede central." (Bruno, 2000:10)
} 
apresenta, com uma ampla documentação, a situação de 29 museus e coleções da $\mathrm{USP}^{44}$. A equipe reconheceu a importância da história de cada coleção:

"Ao construirmos o conhecimento, explicitado neste diagnóstico, percebemos que a USP tem uma vocação museológica e que os museus, acervos e coleções evidenciam e simbolizam a trajetória desta Universidade, além de representarem fortes agentes para o ensino, pesquisa e extensão. Por um lado, alguns desses recortes patrimoniais representam resistência e, por outro, difundem e refletem a importância da mudança. Entretanto, todos são significativos para a construção da memória desta Universidade e podem contribuir para o cumprimento de suas funções." (Bruno, 2000:6)

E também considerou suficiente o patrimônio museológico da USP para a formação de um novo museu de ciências:

"E desvelar as entranhas uspianas nos fez reconhecer que o pretendido novo formato de um museu de ciências terá uma base muito sólida, em função das potencialidades museológicas da USP, e sua configuração poderá ser compatível com um centro de interpretação da realidade." (Bruno, 2000:6)

Aparentemente a proposta do novo museu de ciências foi adiada, uma vez que após a realização do diagnóstico, finalizado em maio de 2000 , nenhuma nova atitude foi tomada.

Em nossa opinião, caberia aos órgãos centrais da USP apoiar a estruturação e continuidade dos programas de todos os museus, pequenos e grandes, desde que se mantenham afinados com os objetivos gerais da universidade e que sejam desenvolvidos com a máxima qualidade.

\subsection{Pouco apoio, mas números levados em conta}

Detectamos os seguintes problemas recorrentes nesses museus: número insuficiente de servidores; servidores não especializados para o trabalho museológico; falta de espaço apropriado para abrigar, pesquisar e expor coleções; verbas insuficientes para manutenção mínima; ausência de regimentos e estatutos reconhecidos pelo poder central das universidades que garantam a continuidade dos projetos e programas; e grande descompasso com a pesquisa e ensino desenvolvidos pelos departamentos.

\footnotetext{
${ }^{44}$ O critério para seleção dos museus e coleções da USP foi definido pela equipe: "Excluíramse deste Diagnóstico tanto aquelas unidades que se recusaram a atender a equipe ou a Comissão de Patrimônio Cultural, como as que não possuíam ou deixaram de apresentar potencialidades museológicas, o que foi constatado no decorrer do processo de trabalho (...)" (Bruno, 2000:17)
} 
Normalmente, quando as autoridades universitárias se referem aos museus da USP, deixam de lado esses museus e coleções e tratam apenas dos 4 com autonomia. Entretanto, quando se trata de relatar os serviços prestados pela USP, o número de pessoas atendidas, as autoridades levam em conta todos os museus e coleções, mesmo aqueles que se resumem a vitrinas em corredores de departamentos.

Nos dados oficiais da USP, como os do Anuário Estatístico da USP (1999), encontramos mais museus e coleções do que aparecem nos levantamentos citados, na contabilização de público atendido. Na tabela 9.40 "Atendimento à Comunidade pelos Museus das Unidades - 1994/1998" são apresentados o número de visitantes e de escolas atendidas por 28 Unidades de Ensino e Pesquisa, 3 Centros e Institutos Especializados, 2 Hospitais e Serviços Anexos, 4 Museus e 2 Órgãos Centrais de Direção e Serviço. (Em Anexo)

Entre as unidades de Ensino e Pesquisa encontramos números, como da Escola de Educação Física e Esportes, nos quais 100 visitantes foram em 1994 e 1 escola foi atendida e nenhum outro visitante nos anos seguintes. No caso da Faculdade de Ciências Farmacêuticas constam 250 visitantes em 1994, 3 escolas em 1998 e nada mais. A Faculdade de Zootecnia e Engenharia de Alimentos e o Instituto de Física e Química de São Carlos aparecem na lista mas não tiveram nenhum visitante ${ }^{45}$. O fato é que essas unidades não têm museus abertos à visitação, mas algumas vitrinas com objetos, coleções e/ou pequenas exposições que eventualmente são abertas ao público. Já os museus do Instituto de Geociências, do Instituto Oceanográfico, do Instituto de Biociências e da Faculdade de Medicina Veterinária e Zootecnia apresentaram um número crescente de visitantes.

Entre os 4 grandes museus (MAC, MAE, MP e MZ) percebemos uma grande oscilação da visitação, com um pico de 612 mil em 1995 e uma queda para 338 mil em 1996.

A soma de todos esses visitantes é apresentada na primeira tabela (1.01) do Anuário, entre os indicadores de desempenho de 1989 a 1998: crescimento com oscilações, em 10 anos, de 489 mil visitantes para 607 mil (24\%) com um pico de mais de 1 milhão em $1992 .^{46}$

\footnotetext{
${ }^{45}$ Em São Carlos, existe o Centro de Divulgação Científica e Cultural (CDCC) do Instituto de Física e do Instituto de Química que atendeu centenas de professores e milhares de alunos e visitantes em atividades como cursos, excursões, orientações para trabalhos científicos, empréstimo de materiais, conforme tabela 9.42 do Anuário Estatístico da USP apresentada em anexo.

${ }^{46}$ Os números referentes à visitação e atendimentos dados pela Estação Ciência aparecem em separado, conforme apresentamos em Anexo.
} 
Percebemos assim que, para as autoridades universitárias, mesmo não tendo autonomia jurídica, os museus e coleções das unidades são importantes pelo patrimônio que possuem e pelo atendimento ao público.

\section{Retomando: museus e universidades}

Gostaríamos de terminar este capítulo retomando algumas idéias do professor Ulpiano Bezerra de Meneses, a respeito dos museus universitários.

Museu e universidade são complementares, existindo algumas disciplinas (arqueologia, geologia, etnologia entre outras) que dependem das coleções e recursos dos museus. Ulpiano Meneses salientou a especificidade do museu universitário que conta com possibilidades de intercâmbio, através da articulação de programas de pesquisas e docência. Com essa integração sairiam ganhando a comunidade universitária e a comunidade em geral. Para o autor, os museus universitários constituem recurso privilegiado para "prestação de serviços à comunidade". (Meneses, 1968:47)

Ulpiano Meneses resumiu as vantagens do museu universitário: acesso direto às coleções para pesquisa; colaboração entre especialistas de museu e universidade; museu como laboratório para formação específica e pedagógica; e formação museológica. Mas o autor alertou para o fato de que, apesar das vantagens acima descritas, os museus universitários sofrem de deformações, entre as quais a transformação do museu num instituto de pesquisas ou em recurso para formação universitária e a negligência na curadoria das coleções, principalmente quando os responsáveis trabalham em tempo parcial.

Mais de 20 anos depois, no texto com propostas de reformulação para o Museu Paulista, Ulpiano Meneses expressa mais algumas de suas opiniões acerca dos museus universitários. A primeira é de que a pesquisa é base fundante de qualquer museu, a pesquisa como "produção de conhecimento novo, cientificamente obtido." Uma exposição deve apresentar o "conhecimento em curso de produção e de cujo processo a exposição é parte integrante." Por partir de suas coleções, a pesquisa está baseada na curadoria ${ }^{47}$, que por meio de suas atividades atingiria uma "matriz".

"Portanto, não se trata de discutir o falso dilema, que ainda hoje está presente entre nós, quanto à natureza, principalmente do museu universitário, como órgão

\footnotetext{
47 Ulpiano Meneses denomina curadoria o conjunto de todas as atividades referentes ao processo museológico: aquisição, documentação, pesquisa, conservação, comunicação e educação.
} 
de pesquisa, ou então plataforma de 'comunicação' (ou 'educação'). A especificidade do museu - e seu grande trunfo, que outras instituições não têm condições de reproduzir, ao menos com a mesma eficácia - é que ela se perfaz na solidariedade de funções científico-documentais, culturais e educacionais. A curadoria, assim, teria que ser a matriz conceitual que alimentasse operacionalmente essa solidariedade, segundo a qual, no museu, qualquer atividade ou função depende de todas as demais funções e atividades." (Meneses, 1989/1999:3)

Assim, a pesquisa do acervo seria a base diferenciadora do museu em relação às outras instituições e aos departamentos de ensino da universidade. Entretanto, para Meneses, coleções não são museus e essas podem servir à pesquisa e à docência dos departamentos sem se tornar uma instituição. Para ele, a USP já tem um número suficiente de museus - quatro - e não deveria criar qualquer novo museu.

Concordamos, em parte, com as afirmações de Ulpiano Meneses. Ter a pesquisa como geradora e unificadora das outras atividades do museu universitário parece ser o grande potencial desse tipo de museu, entretanto não é o que vivenciamos na prática e não sabemos se seria possível conseguir que esse processo de trabalho de fato ocorra. Os pesquisadores, sejam de museus ou de institutos com museus, muitas vezes supervalorizam os meios acadêmicos de divulgação - as revistas científicas - e colocam em segundo plano as atividades museológicas tanto de curadoria quanto de documentação. A própria USP continua a valorizar apenas as publicações de artigos, teses, conferências, cursos e participação em congressos para avaliar seus pesquisadores, não levando em conta a participação nas atividades curatoriais e na concepção de exposições. Nesse sentido seria necessário transformar a "cultura" da própria universidade, o que parece uma tarefa hercúlea, mas que tem alguns indicadores positivos, como a criação dos regimentos dos museus, da Comissão de Patrimônio Cultural e de outros órgãos gestores nesses últimos 10 anos.

Quanto aos "não-museus" (museus e coleções de faculdades, institutos e departamentos) consideramos alguns caminhos possíveis. A fusão das coleções científicas com a criação de um grande museu de ciências poderia levar à duplicação de coleções, quando sabemos que a USP já é responsável pela Estação Ciência e que várias dessas coleções são utilizadas para ensino e pesquisa.

Concordamos com o professor Walter Zanini quando afirma que não é possível ter uma solução única. Como já dissemos anteriormente, algumas coleções poderiam deixar de ser exposições e passar a servir como centro de referência e documentação, como o Museu Histórico da Faculdade de Medicina; outros poderiam ficar exclusivamente para o ensino universitário, aperfeiçoando suas formas de acesso aos 
estudantes e professores, como o Herbário e as coleções de Anatomia do Instituto de Ciências Biomédicas. Já museus como os do Instituto Oceanográfico e de Medicina Veterinária poderiam ser aperfeiçoados museograficamente, para tornar suas exposições ainda mais didáticas para o público escolar, e poderiam servir também como laboratório de pesquisas pedagógicas - ensino de ciências e educação em museus. 


\section{CAPÍTULO 3}

Museus de Arte Universitários: como são? 


\section{CAPÍTULO 3}

\section{Museus de Arte Universitários: como são?}

Neste capítulo pretendemos apresentar mais detalhadamente o surgimento dos museus universitários de arte, dando maior destaque para o caso dos museus de arte brasileiros.

As coleções de arte sempre foram utilizadas para o ensino da arte - inicialmente das técnicas e de história da arte e, mais recentemente, de apreciação artística.

Entretanto, historicamente, há uma grande quantidade de museus de arte criados nas universidades antes mesmo destas oferecerem cursos de arte ou história da arte, ou seja, desvinculados de propostas de ensino universitário.

Uma outra discussão, muito presente nos Estados Unidos, refere-se a qual deveria ser o perfil do acervo de um museu de arte universitário: com obras de diversos períodos para possibilitar um panorama da história da arte? com uma boa seleção de um determinado período/estilo/país/autor? com trabalhos de alunos e professores da própria universidade?

Consideramos essas questões fundamentais para podermos discutir qual seria 0 papel e o perfil de um museu universitário de arte, em qualquer lugar do mundo.

\section{Museus de arte são minoria entre os museus universitários}

Consultando a lista de museus universitários de vários países e contando quantos são de arte e quantos são de outras áreas, percebemos que os de arte existem em menor número. Na Itália não consta nenhum museu de arte universitário; na Holanda, as obras de arte aparecem nos museus da história de cada universidade (University History Museum), geralmente relacionadas às personalidades das universidades e não a "museu ou galeria de arte". Na Bélgica, dos 26 museus universitários, 5 são de arte; na Espanha, de 42 museus, 9 são de arte e áreas afins. No Peru, de 19 museus, 4 são de arte; nas Filipinas, de 30 museus, 4 são de arte. No Japão, de 51 museus, 8 são de arte. Na Nova Zelândia não há museu de arte entre os 31 museus existentes. Na Austrália já há uma proporção maior: 51 museus de arte do total de 265.

Uma exceção parece ser a Grã-Bretanha, pois quase todas as universidades que têm museus abrigam coleções de arte (artes plásticas, artes decorativas, artes 
orientais, etc.) que constituem museus e galerias ou fazem parte de museus de várias áreas. São ao todo 52 museus e coleções de arte em um total geral de 95 museus ${ }^{1}$.

No caso dos Estados Unidos e do Canadá, temos dados incompletos ${ }^{2}$, mas pelas referências e grande quantidade de artigos encontrados, as galerias de arte e museus de arte são bastante populares nas universidades desses países.

\section{Tipos de museus de arte universitários}

Identificamos alguns tipos de museus universitários de arte: galerias e museus abertos a diversos públicos, centro de exposições, coleções para ensino universitário, coleções para decoração do campus. Para exemplificar apresentaremos breve descrição de museus e galerias do Canadá, que pudemos conhecer pessoalmente ${ }^{3}$ e dos EUA e da Inglaterra, descritos na bibliografia.

\subsection{Galeria de Arte com acervo voltada para diversos públicos}

As coleções de arte de uma universidade podem compor o acervo de um museu de arte. Esse é o caso da Galeria Leonard e Bina Allen da Universidade Concórdia (Canadá). Localizada no mesmo prédio da biblioteca do campus (que fica na região central da cidade de Montreal) exibe obras do acervo (cerca de 3.000 obras de artistas canadenses) e exposições temporárias. Seus funcionários são na maioria estudantes de mestrado em Artes. Outros alunos realizam pesquisas com o material da Galeria. A ênfase é dada para a arte contemporânea, principalmente a produzida na região.

1 Dados obtidos no site www.lib.mq.edu.au/mcm/world organizado por iniciativa de Peter Stanbury.

${ }^{2}$ Laurence V. Coleman (1942) identificou 700 museus universitários entre eles 100 de arte. Ele explica que os de arte eram mais recentes do que de outras áreas. Hugo Rodeck (1952) analisou as respostas de 173 questionários respondidos por universidades e afirmou que a área de arte foi a que apresentou mais museus. John Coolidge (1956) afirmou que havia cerca de 150 museus de arte universitários nos EUA, significando naquele momento um universitário de arte para cada dois museus de arte não universitários. Em dissertação de 1971, Alva G. Huffer contabilizou 80 museus de arte entre 260 museus universitários pesquisados. Em 1980, Muriel Christison afirma que em 10 anos (1970-80) um número crescente de universidades e colleges passaram a ter museus de arte nos EUA. John Morris Dixon (1995) chama atenção para o fato de que nos anos 90 houve um boom de construções de museus e galerias em campi de universidades.

Brigid Brink, secretária da "Association of College and University Museums and Galleries (ACUMG)" informou que no banco de dados da ACUMG constam 899 museus universitários, entre os quais 535 são museus e galerias de arte. Brigid ressalta que os dados são exclusivamente de associados e portanto não podem ser considerados completos, porém são bastante representativos da realidade do país. (mensagem enviada em 25/10/00)

${ }^{3}$ As visitas foram realizadas em setembro de 1998, com apoio da FAPESP. 
A galeria recebe cerca de 20 mil visitantes por ano, entre eles turistas, estudantes universitários, funcionários da universidade e público em geral. ${ }^{4}$

\subsection{Galeria de arte sem acervo para diversos públicos}

A Galeria de Arte do Centro Cultural da Universidade de Sherbrooke (Canadá) é assumidamente um espaço para exposições de arte contemporânea. Foi construída com apoio da Prefeitura da cidade para ser um local de divulgação das artes, mesmo porque a Universidade não tem nenhum curso na área de artes. Sua diretora há 15 anos, Johanne Brouillet, afirmou que vem tendo sucesso em sua empreitada e que recebe anualmente dezenas de propostas de exposições para selecionar. A galeria é uma referência para a arte contemporânea regional e nacional. Localiza-se no campus, distante da cidade, e recebe cerca de 31 mil visitantes por ano. Quando estivemos lá, foi inaugurada uma exposição de arte (L'Herbier de Monique Mongeau, 5 de setembro a 15 de outubro de 1998) a partir do Herbário da Universidade, da qual professores e alunos do Departamento de Biologia participaram na seleção de espécimens ameaçados de extinção, ao lado de artista que criou obras inspiradas em exemplares da coleção. Com essa proposta a diretora acreditava ter conseguido um diálogo entre a ciência e a arte. ${ }^{5}$

Por outro lado, a Universidade de Sherbrooke possui uma coleção de obras de arte que se encontra espalhada pelas diferentes dependências do campus e que não é de responsabilidade da diretora da Galeria.

Algumas universidades possuem coleção de arte muito pequena ou pouco significativa, mas têm espaço para exposições de arte e cursos de Belas Artes e/ou História da Arte. Desenvolvem exposições temporárias com obras emprestadas ou cedem seu espaço para exposições itinerantes. Normalmente essas galerias de arte têm pouquíssimos funcionários fixos, não têm corpo de pesquisadores e podem ou não ter relações com os departamentos afins.

\footnotetext{
${ }^{4}$ Estava sendo iniciado, no segundo semestre de 1998, um programa para visitas escolares monitoradas por estagiários.

${ }^{5}$ No texto do catálogo elaborado por Johanne Brouillet ela afirma: "Este catálogo é o reflexo dessa aventura marcada pelo respeito mútuo da diferença e das especificidades de cada uma das disciplinas. (...) No encarte há as pranchas reproduzindo as obras de Monique Mongeau com a ficha de identificação da espécie vegetal ameaçada de desaparecer. Foi a partir dessas pesquisas que a artista preparou a exposição. Aqui Arte e Ciência partilham uma mesma preocupação: a proteção do meio ambiente." Apresentação do catálogo "L'Herbier de Monique Mongeau", Université de Sherbrooke, Canadá, 1998.
} 


\section{Galeria de Arte do Centro Cultural Universidade de Sherbrooke.Quebec - 1998}
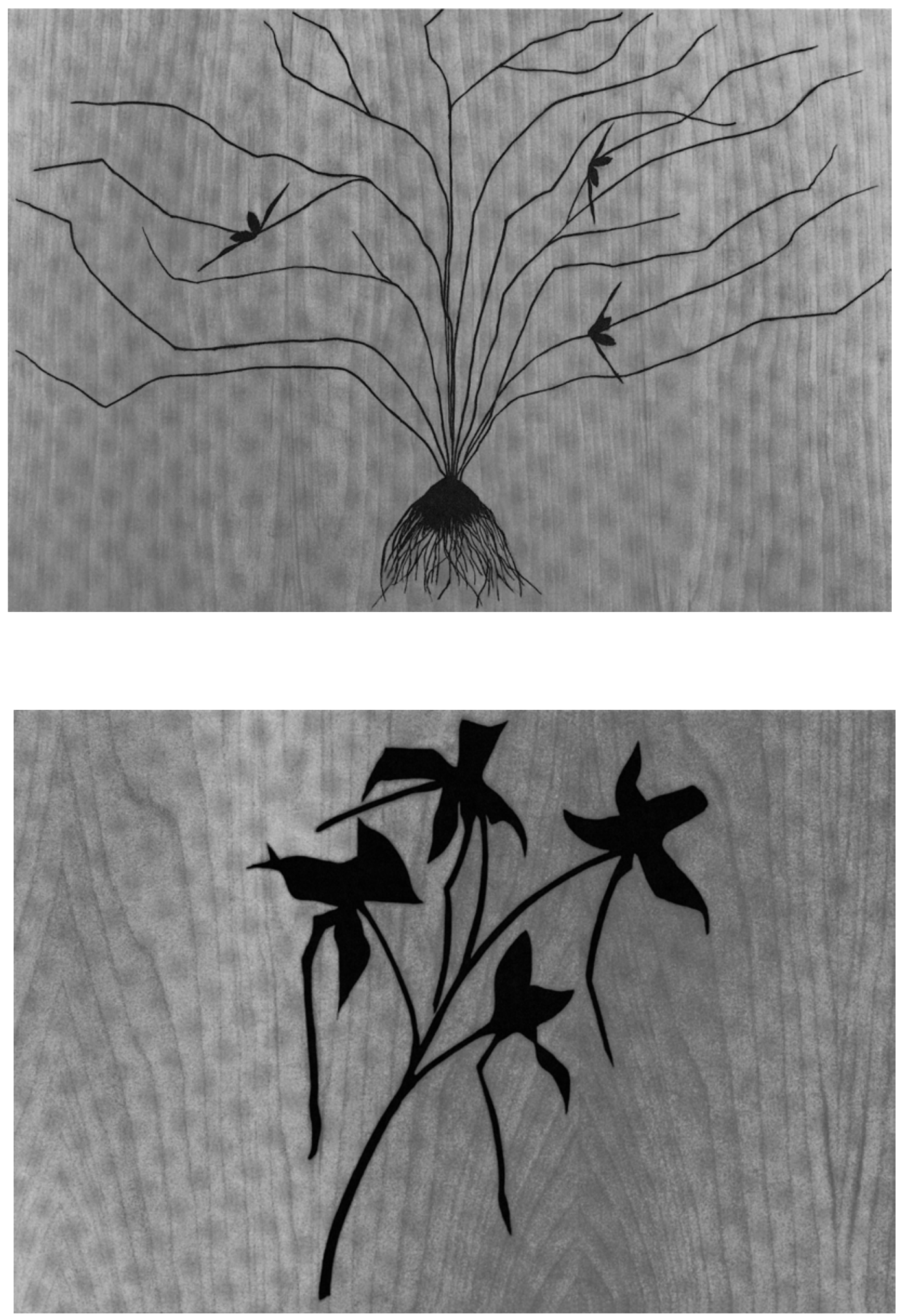

Exposição L'Herbier de Monique Mongeau où la recontre de deux disciplines Obras de Monique Mongeau a partir de exemplares do herbário da universidade 
Um exemplo é a Galerie de I'UQAM (Université du Québec à Montreal Canadá). Localizada dentro de um dos prédios da Universidade, dirigida por uma professora do Departamento de Belas Artes (Louise Déry), a Galeria apresenta exposições de artistas contemporâneos, participando do circuito das artes da cidade. A interação com os departamentos afins é dada pela possibilidade de os professores e alunos sugerirem e organizarem exposições. Há também vagas para estagiários de museologia. O público estimado é de 40 mil pessoas por ano, sendo cerca de $50 \%$ de universitários e $50 \%$ da comunidade da arte.

\subsection{Centro de exposições sem acervo próprio}

Outra situação das galerias de arte é o centro de exposições, ou seja, um espaço para divulgar as diferentes coleções da universidade. Muitas vezes não é responsável por nenhuma coleção específica, apenas pela divulgação de todas as coleções.

O novíssimo Centro da Universidade de Montreal (Canadá) procura congregar as coleções de diferentes áreas da universidade ${ }^{6}$ em um único espaço expositivo. Para isso está criando propostas que permitam a interdisciplinaridade. A primeira exposição foi realizada a partir de objetos selecionados de cada coleção que foram reinterpretados por diferentes artistas contemporâneos. Segundo sua diretora, Andrée Lemieux, sua missão é:

"(...) difundir, junto ao grande público, as produções científicas, artísticas e outras dos membros da comunidade universitária ou de artistas convidados, valorizar as coleções existentes e solicitar novas doações. Ele acolhe exposições do exterior cujos assuntos sejam relacionados com as preocupações da comunidade." (Lemieux, 1998:4)

A proposta é de que o Centro seja uma interface entre as coleções dos departamentos e o público. Para a diretora, o primeiro passo foi dado com a reunião dos responsáveis por cada uma das coleções que passaram a compor um grupo. Em

\footnotetext{
${ }^{6}$ A Universidade de Montreal tem as seguintes coleções:

450 obras de arte e 350 desenhos de vestuário de teatro canadense;

500 instrumentos musicais de todo o mundo (Faculdade de Música);

1000 artefatos odontológicos (Depto. de Medicina Dentária);

50 objetos de design industrial canadenses e europeus;

1.000.000 espécimens da fauna entomológica, principalmente do Quebec (Depto. de Ciências Biológicas);

750000 espécimens de plantas de todo o mundo (Depto. de Ciências Biológicas);

2500 artefatos etnográficos do Canadá, África e América do Sul (Depto. de Antropologia);

74000 Documentos e livros raros (Serviço de bibliotecas).
} 
seguida está sendo desenvolvido um sistema para que se possa ter um inventário único de todas as coleções. Como no caso anterior, o Centro tem pouquíssimos funcionários, e contrata o serviço de terceiros quando necessário.

\subsection{Centro de divulgação da área}

O Centro de Design da Universidade de Quebec (Canadá) não tem acervo. Trata-se de um espaço criado pelos professores para experimentação de técnicas de design que se consolidou como uma referência na área. Atualmente realiza exposições temporárias que buscam discutir as questões acadêmicas. Segundo o responsável pelas exposições, Georges Labrecque, seus objetivos são:

"Contribuir para o desenvolvimento de uma cultura do design tanto no âmbito da comunidade universitária como do grande público. Apresentar exposições originais ou itinerantes, nos domínios da arquitetura, design industrial, design gráfico, design de interior e design urbano;

Contribuir para o avanço do debate sobre design pela organização, em complementação às exposições, de conferências públicas, seminários e colóquios;

Favorecer a combinação de suas atividades com aquelas dos meios de design provincial, nacional ou internacional." (Resposta ao questionário, 1998)

A visitação anual é de cerca de 11 mil pessoas, principalmente estudantes e profissionais da área de design.

\subsection{Coleção para decoração do campus}

A Universidade Bishop (Lennoxville, Quebec, Canadá) tem coleções de arte mas elas se encontram em diferentes espaços como elementos de decoração. Há pinturas expostas nas bibliotecas, salas de reunião e corredores; esculturas nos jardins e em pátios. E uma parte das coleções fica guardada na reserva técnica.

A Galeria de Arte da Universidade Bishop se caracteriza por oferecer seu espaço para exposições de obras de artistas contemporâneos. Localizada ao lado do teatro da universidade, tem espaço próprio porém pequeno.

A Universidade tem curso de Belas Artes e na ocasião das exposições, quando um artista é convidado a falar sobre seu trabalho, os professores e alunos costumam participar do evento. Eventualmente, alunos expõem seus trabalhos na galeria. $\mathrm{Na}$ ocasião de nossa visita (setembro 1998), estava sendo desenvolvido um novo projeto, 


\section{Universidade Bishop \\ Lennoxville • Quebec}

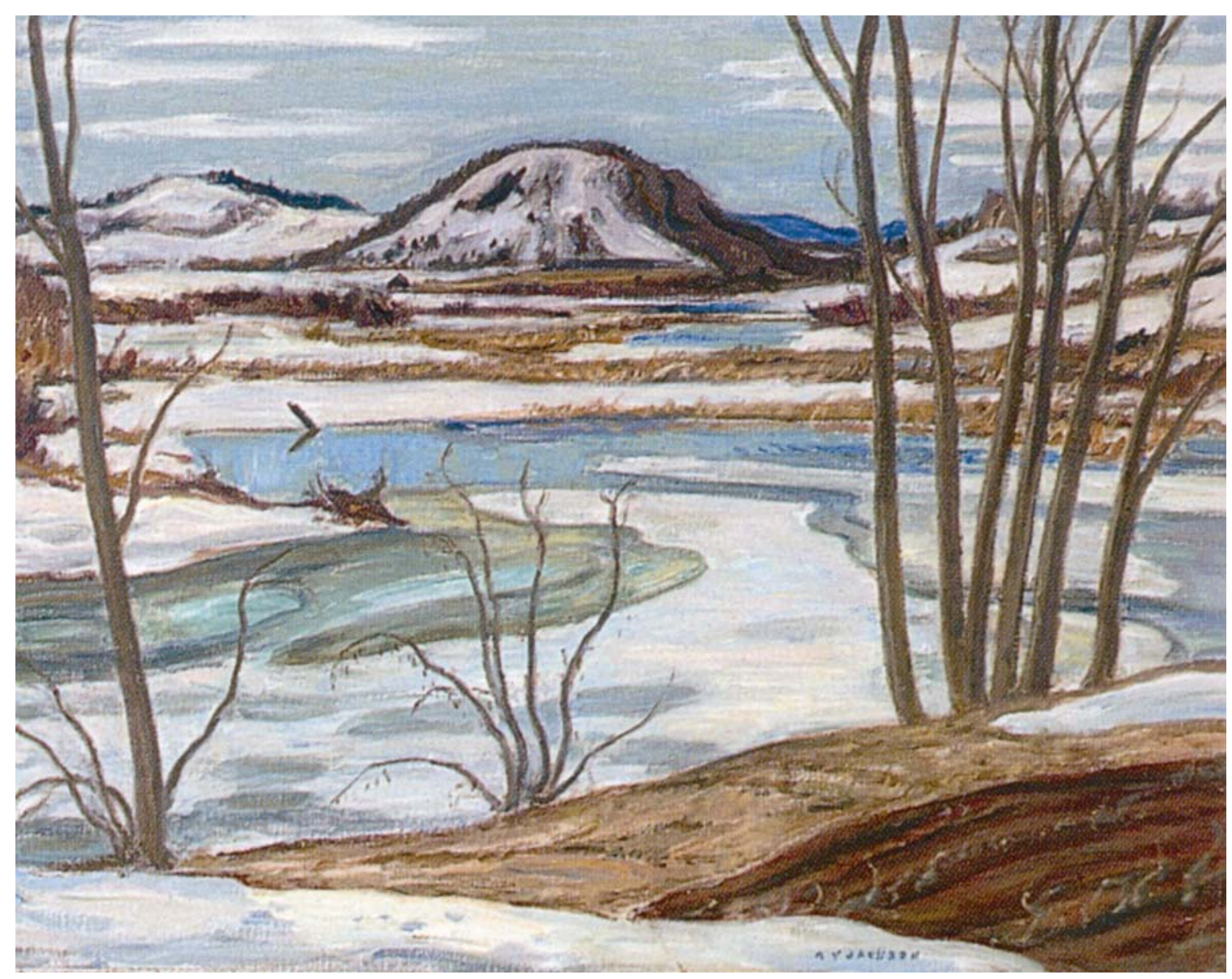

Spring Freshet at Ripon, Québec 1969

Obra de Alexander Young Jeckson da coleção da universidade 
no qual a Galeria deveria servir mais à comunidade universitária, ao ensino e à pesquisa.

Para Warhurst, algumas das coleções de universidades da Grã-Bretanha podem ter o papel de dar qualidade estética à vida do campus:

"Coleções de arte como as de Liverpool, Nottingham e Hull podem ser usadas para fins didáticos, mas conferem , principalmente, uma qualidade cultural e estética à vida universitária." (Warhurst, 1992:97)

As universidades, assim como outras grandes instituições, acumulam obras de arte em seus gabinetes de trabalho e nem se dão ao trabalho de registrá-las como parte de coleções, deixando muitas vezes a própria instituição de saber o que possui de fato.

\subsection{Coleção para formação em nível superior}

Existem universidades que oferecem cursos de museologia (museum studies) e artes, entre outros, que utilizam seus museus como espaço de ensino e formação profissional de seus alunos:

"Na Universidade de Manchester, a Whitworth Art Gallery é usada anualmente por estudantes de pós-graduação, do curso de Estudos de Museus e Galerias de Arte, para aprender o processo de montagem de uma grande exposição de arte, em colaboração com a equipe da galeria e um designer profissional. Há muitas situações nas quais a equipe do museu universitário responsável pela curadoria faz palestras para os estudantes como parte do currículo de seus cursos acadêmicos." (Warhurst, 1992:98)

Esses são alguns tipos de museus e coleções universitários de arte possíveis, sendo que há variações e combinações conforme as especificidades e história de cada um.

Apresentaremos, a seguir, algumas discussões referentes aos museus de arte universitários presentes na bibliografia norte-americana, para depois apresentarmos a situação brasileira. Infelizmente, no Brasil há pouquíssimos textos publicados discutindo o papel, os problemas e o perfil dos museus universitários de arte. 


\section{EUA: museu universitário sem curso e curso sem museu}

Nos Estados Unidos, o primeiro museu universitário de arte criado foi o de Yale - Yale's Gallery of Fine Arts - construído em 1832 para servir às aulas de pintura e desenho ${ }^{7}$. O departamento de história da arte dessa universidade foi criado nos anos 1940 e só foi se aproximar do museu com o desenvolvimento da pesquisa acadêmica na área.

No caso da Universidade de Harvard, onde o ensino de história da arte se iniciou nos Estados Unidos, em 1869, o museu foi criado posteriormente: o primeiro segmento do Fogg Museum foi aberto em 1895, mas somente em 1927 o museu se transferiu para seu atual prédio e tornou-se um "museu moderno utilizável" (Barbara Y. Newson, 1978:514) $)^{8}$

Nos Estados Unidos, em geral, os museus de arte universitários têm relações com departamentos de arte e de arquitetura, mas são mais próximos do departamento de história da arte. Muitas vezes, as aulas de história da arte são dadas nos museus, os alunos participam de projetos do museu e professores fazem curadorias e catálogos. ${ }^{9}$

Do ponto de vista do ensino da história da arte, além da utilização de $\operatorname{slides}^{10}$ na sala de aula e da utilização do museu da universidade ${ }^{11}$, é possível complementar a

\footnotetext{
${ }^{7}$ Haveria uma coleção anterior: Segundo John Coolidge (1956), a Pennsylvania Academy of Fine Arts, fundada em 1806, adquiriu obras de arte e funcionava como anexo de uma escola de arte. Entretanto, Bárbara Newson considera a coleção da Academia um "museum studio school" limitada à formação da prática artística e não um museu aberto ao público. (p.568).

${ }^{8}$ O Metropolitam Museum de Nova lorque, criado em 1970, foi o primeiro grande museu de arte não universitário dos EUA. A partir do século XIX, nos museus de arte dos EUA, assim como ocorria no Louvre desde 1793, a educação em arte era vista como a cópia de obras. Somente nos anos 1930, os artistas passaram a valorizar sua própria expressão e, nos anos 1970, a cópia passou a ser considerada um sinal de anacronismo, lazer ou prática para amadores. (p.572).

${ }^{9}$ Certamente há exemplos de integração entre os museus de arte e outros departamentos como os de história, literatura inglesa, teatro, música, arte-educação, entre outros, citados por Newson, 1978:514-515.

10 Barbara Newson considera a utilização do slide em sala de aula uma das causas da separação entre a pesquisa acadêmica e obras originais: "Slides podem reunir num só local monumentos inamovíveis, afrescos que não podem ser descolados da parede, objetos que se encontram em lados opostos do globo. (...) Poucos desenvolvimentos tecnológicos mudaram de forma tão dramática a base de um campo de estudos humanísticos. Os slides permitiram aos departamentos universitários de história da arte, em todo o país, atuar com sucesso sem dispor de museus ou coleções substanciais de qualquer espécie". (Newson, 1978, 513).

${ }^{11}$ As vantagens da existência de um museu no campus seriam dadas pela organização de exposições e disponibilização do acervo principalmente para o ensino e pesquisa da própria universidade. Os professores podem auxiliar na seleção para aquisição, participar como curadores e os alunos podem desenvolver estágios e pesquisas no museu. As desvantagens são dadas pelo perfil do acervo, normalmente restrito por falta de verbas, que limitaria as possibilidades de pesquisa e ensino. Além disso, as manipulações constantes de obras para ensino e pesquisa podem ser prejudiciais para a conservação das mesmas. (Newson, 1978)
} 
vivência com obras de arte criando programas junto a museus públicos da região ou possibilitando estágios temporários de alunos em outros museus.

Segundo John Coolidge (1956), diretor do Fogg Art Museum da Universidade de Harvard, os museus de arte acadêmicos (academic art museums ${ }^{12}$ ) foram criados nos Estados Unidos, principalmente entre o fim do século XIX e o primeiro terço do XX, com os objetivos de: 1. Dar subsídios para o ensino de arte na universidade com a aquisição de coleção própria, uma vez que o campus ficava distante dos centros urbanos; 2. Propiciar aos estudantes contato direto com obras de artes pois raramente tinham convivência anterior com arte; 3. Fornecer obras originais para o ensino.

Considerando que essas funções originais já não justificavam a manutenção dos museus, uma vez que haveria menor isolamento do campus com a expansão das cidades e com o desenvolvimento de visitas escolares aos museus, o autor sugeriu novas funções para esses museus, voltadas para formação: 1. Formação de estudantes por meio de estágios; 2. Aperfeiçoamento de especialistas e 3. Formação de amadores (trained amateurs) que seriam o principal suporte dos museus no futuro.

Em vários artigos sobre museus de arte universitários aparece a justificativa de formação de coleções pela inexistência ou grande distância de qualquer museu de arte que tenha coleções apropriadas para o ensino. Charles Odergaard (1963), Reitor da Universidade de Washington, chamava atenção para esse fato ao propor uma revisão dos objetivos do museu da Universidade de Washington em Seattle (EUA), uma vez que a cidade também oferecia um ótimo museu de arte.

Outros autores defendem a necessidade de exposições específicas para os alunos das universidades, sem interferência de textos ou de outros visitantes. Em 1940, Neumeyer, diretor do Mills College Art Gallery (EUA), apresentou sua visão do que deveria ser uma galeria de arte universitária. Defendeu a criação de exposições que valorizassem as obras em si, possibilitando uma experiência estética para o visitante, denominada por ele de 'visualização' (visualization), em oposição à apresentação das obras contextualizadas como ilustração da história da arte. A galeria de arte deveria expor as pesquisas desenvolvidas pela universidade, além de treinar estudantes, sempre servindo ao ensino universitário. Trabalhos de professores e alunos, e arte contemporânea em geral também deveriam ter espaço na galeria.

${ }^{12}$ Coolidge inclui nesse conceito tanto os museus de colleges como de universidades. Os colleges são instituições voltadas para a formação profissional ou para a preparação para cursos universitários daqueles estudantes egressos dos cursos de nível médio (High School dos EUA). 
Norman James, do Departamento de Arte do Washington College em Maryland (EUA), preocupou-se basicamente com o estudante universitário de artes, ao destacar a importância do museu para a formação dos alunos. Para o autor, não há nada que substitua a vivência com a obra original, seja ela do passado ou contemporânea. A experiência com a obra deve ser em ambiente calmo, sem textos longos que possam distrair, sem grupos barulhentos participando de visitas guiadas.

"O problema mais difícil com que se defronta um professor, ao levar sua turma a certos museus, é o de fazer com que o estudante olhe para um quadro. Entre os perigos contam-se setores de reprodução vastos e imponentes, e uma profusão de informações escritas. Nenhum deles atrapalha se oferecido em escala modesta, mas às vezes não é o caso. E um estudante ocupado no processo complicado de análise de um panorama de Cézanne pode ser solicitado a se afastar para que um grupo guiado de sócias de clube lance um olhar casual ao mesmo quadro. Mas a tentação mais sinistra são os fones de ouvido instrucionais. A visão de homens e mulheres sendo guiados eletronicamente por um museu como partes de um mecanismo, enquanto o Grande Irmão Ihes fala o que devem olhar, não só aumenta os horrores de nossa época, mas se opõe a tudo o que a arte propõe" (James, 1960:17)

James criticou os museus que utilizavam técnicas da mass media para atrair público, como distribuir panfletos como se estivessem vendendo seguros. Autores como Neumeyer e James, que propõem exposições que apresentem as obras sem textos ou contextualização e que são contrários à vulgarização da arte, aparecem constantemente na bibliografia, até hoje. A diferença é que, no caso do museu universitário, a justificativa passa pela utilização por estudantes de artes e áreas afins, que já dominariam os códigos da arte. Essa é uma discussão que extrapola os museus universitários, atingindo os museus de arte em geral.

No artigo de Brett Waller (1980), da época em que dirigia o Museu de Arte da Universidade de Michigan (EUA), podemos perceber a importância das áreas de ensino em arte para a definição do acervo e política de exposições dos museus de arte universitários dos EUA. Waller sugere que os museus deixem claras suas metas e funções e seus programas para não ficarem sendo pressionados por demandas de professores "artistas" e de professores de história da arte. Os primeiros desejam expor seus trabalhos e sempre acham as exposições voltadas demais para a história. Já aqueles ligados à história reclamam de lacunas do acervo que impedem o contato com obras de diversas épocas. Estes últimos recorrem com maior freqüência às reproduções e diapositivos para conhecerem grande quantidade de obras. Waller critica a desvalorização da obra original e o pouco exercício do olhar dos historiadores 
da arte; entretanto, também critica os artistas e "connoisseurs" que pretendem tudo saber apenas com o olhar ${ }^{13}$ :

"... não se deve subestimar o conhecimento. Quem sabe mais vê mais. Por outro lado, não se deve superestimar o conhecimento. De nada adianta àquele que não pode ver." (Friedlander, apud Brett Waller, 1980:19)

Como diretor do Museu de Arte da Universidade de Michigan, Brett Waller considera que o caminho para sair das disputas entre os diferentes grupos é pela definição clara da política do museu, por meio de regimentos, planos de ação que esclareçam suas propostas de trabalho. No caso do Museu da Universidade de Michigan, a proposta é de servir à comunidade universitária, entendida como estudantes e professores universitários, residentes da cidade e região e cidadãos do Estado de Michigan. Os públicos mais freqüentes do museu são:

1. Historiadores da Arte - estudantes e professores: para eles o museu deve ser um laboratório de pesquisa acadêmica e ensino e as exposições ideais são as que tratam de períodos da história estudados.

2. Artistas - estudantes e professores: o museu oferece contato com obras contemporâneas e possibilita o estudo de diferentes técnicas e obras.

3. Estudantes preparando-se para a carreira em museus: o museu oferece o acervo para ser estudado e o seu corpo de funcionários deve ser competente, acessível e qualificado para orientar.

4. Estudantes e professores da Universidade: o museu apresenta obras de arte enquanto artefatos culturais e históricos e suas exposições mostram as diferenças culturais de diversos períodos e locais.

Esses quatro grupos são os mais assíduos porém são minorias entre os visitantes do Museu de Arte da Universidade de Michigan. A maior parte do público não é especialista e, geralmente, está em busca de obras consagradas. Para o autor, esse público deve ser servido mas não deve ser priorizado. A maior parte das exposições é relacionada com programas de pesquisa e ensino de diferentes departamentos. Freqüentemente os professores são chamados para serem curadores de exposições e as aquisições também seguem a pesquisa e o ensino.

\footnotetext{
${ }^{13}$ Brett Waller apresenta essa disputa como a velha rivalidade entre a pesquisa pura e aplicada ou entre o historiador da arte e o connoisseur: "Ao denominar o connoisseur de 'lacônico historiador da arte' e o historiador da arte de 'loquaz connoisseur', Panofsky descreveu o relacionamento entre ambos como comparável 'àquele entre dois vizinhos que têm o direito de atirar no mesmo bairro, sendo que um é dono da arma e o outro de toda a munição' . O que Panofsky diplomaticamente deixou de salientar é que as posições de tiro que tais vizinhos assumem estão freqüentemente em lados opostos do campo." (Brett Waller, 1980:18-19)
} 
"Nosso objetivo básico é criar uma coleção de obras de arte originais da mais alta qualidade estética, em várias mídias, envolvendo a história mundial da arte (chegando até e incluindo a atualidade) e iluminando aspectos significativos das culturas e períodos de suas respectivas origens." (Waller, 1980:21)

$\mathrm{Na}$ conclusão de seu artigo, Brett Waller reafirma a importância do museu desempenhar um papel vital para o ensino e pesquisa da universidade, sob risco de não sobreviver aos cortes de verbas e reformas universitárias. Além disso, o museu não deve se transformar em "decoração" para festas, pois parecerá um ornamento que pode ser descartado a qualquer momento. E finalmente, ele considera que o principal desafio para o museu de arte universitário é conquistar a população de estudantes não especialistas, para aprenderem como entender e apreciar arte, garantindo o crescimento do público futuro de museus e melhorando a qualidade da vida cultural dos cidadãos.

A qualidade do acervo e dos programas e a manutenção financeira dos museus de arte universitários nos EUA são motivos de preocupação que aparecem em vários artigos. Mary Hill (1966), curadora do Williams Hays Ackland Memorial Center da Universidade da Carolina do Norte, afirma que a missão do museu de arte é prover originais ou reproduções de alta qualidade para o ensino. Ela enfatizou a questão financeira como determinante da política institucional, uma vez que são as doações, heranças e verbas disponíveis que definem o tipo de coleção que um museu pode ter. $\mathrm{E}$, se o museu é financiado pela universidade, ele deveria servir a ela prioritariamente. Para a autora, as aquisições não deveriam ser vistas como investimentos; seria importante adquirir obras típicas de determinado período e obras que sejam significativas para a pesquisa acadêmica. Hill lembrou que o museu não deveria ser um depósito de doações indesejadas e para isso deve sempre ter uma clara política de aquisição.

Para Muriel Christison (1980), diretora do Krannert Art Museum da Universidade de Illinois, cada vez mais os museus de arte passam a fazer parte de universidades e faculdades (universities e colleges), contando com especialistas na área, os quais procuram manter esses museus dentro dos padrões aceitáveis para museus de arte.

Para ela, o museu universitário apresenta as características de uma instituição acadêmica: falta de autonomia para definir sua política e obter recursos financeiros; chefia exercida por pessoas sem formação na área museológica; pressão dos departamentos para uso do espaço, das coleções e também de verbas. Essas características causam problemas como o desvio de verbas ou a venda de objetos do acervo; violação de ética profissional, recepção de doações por motivos políticos; uso 
de obras de arte para decorar salas de trabalho que não apresentam condições de segurança; interferência de professores para realização de exposições, pesquisas e aquisições que são de seu próprio interesse; tentativa do departamento de artes em controlar o museu.

Diante de tantos problemas, um grupo de diretores de museus de arte (Association of Art Museum Directors - AAMD) se reuniu e elaborou propostas para o estabelecimento de políticas claras para museus universitários. Christison participou da elaboração das propostas que apresenta na seqüência do artigo.

Propõe-se basicamente que qualquer museu de arte universitário tenha um corpo mínimo de funcionários e responsáveis para que se adeque aos padrões mínimos definidos pela American Association of Museums (AAM). Ou seja, o museu deve ser uma instituição permanente sem fins lucrativos; ser essencialmente educacional ou estético nos propósitos (essentially educational or aesthetic in purpose), ter corpo de servidores profissionais e realizar a aquisição, preservação e exibição pública de suas coleções em horários regulares.

O diretor do museu deve ter formação na área de museologia e arte e ter autonomia de decisão, reportando-se diretamente à administração central da universidade e não ao chefe de um departamento. $O$ diretor também deve ter a palavra final sobre aquisições, programações e assuntos referentes ao funcionamento do museu. Para exercer suas atividades, o diretor poderá recorrer a outros profissionais da universidade, funcionários e voluntários, para que o bom funcionamento do museu seja garantido.

As propostas demonstram a preocupação de diretores de museus com seu espaço de trabalho e poder, afirmando que, por estarem nas universidades, esses museus saem perdendo com a interferência de departamentos afins. Consideramos que este pode ser um sinal de que havia (ou há) conflitos de interesses entre os professores dos museus e dos departamentos de ensino. E, também, que a autonomia do museu universitário pode significar um afastamento dos departamentos afins.

A partir das pesquisas realizadas por Bárbara Newson e sua equipe, foram identificados, nas relações entre museus de arte e universidades dos Estados Unidos, os seguintes problemas recorrentes (Newson 1978):

- a universidade desvaloriza a carreira em museus

- a pesquisa universitária não se baseia em obras, mas em livros e teorias

- os museus não valorizam a qualificação acadêmica

- não há incentivo no museu para pesquisa acadêmica 
- um curador não tem ano sabático ou apoio à pesquisa como um professor universitário

- um curador ganha menos que um professor universitário e tem menos liberdade.

Os problemas encontrados nos Estados Unidos no final da década de 1970 parecem muito semelhantes aos nossos problemas em relação aos museus universitários hoje. Percebemos, nessa breve apresentação sobre os EUA, que é fundamental conhecer que tipo de ensino de arte foi e é proposto por nossas universidades para podermos entender a relação dos departamentos de ensino e pesquisa com os museus universitários.

Um exemplo positivo de ampla colaboração entre o Departamento de História da Arte e a Galeria de Arte foi descrito por Newson (1978) a partir de visitas e entrevistas realizadas em 1973/74 em Yale. Segundo relata, todos os alunos de graduação em arte e de pós-graduação em história da arte participam de atividades no museu utilizando objetos originais, em uma cooperação contínua entre departamento e museu.

"Estudiosos e profissionais do museu, que freqüentemente divergem quanto a uso e interpretação das obras de arte, formam às vezes campos opostos. Em Yale, entretanto, um relacionamento de trabalho entre departamento e galeria foi consolidado por pressupostos comuns". (Newson, 1978:519)

Segundo o titular do departamento, Egbert Haverkamp-Begemann, a cooperação baseava-se no princípio de que as obras de arte são a fonte primária da disciplina:

"A não ser que levemos a obra de arte original, estamos destinados a nos meter em dificuldades e a estimular generalizações, abstrações e visões teóricas que são falhas... Portanto, o envolvimento dos estudantes com as obras de arte é essencial..." (Newson, 1978:519)

Enquanto nos EUA os cursos de História da Arte vão se multiplicar e criar a necessidade de contato com obras de arte (seja sua imagem em slides, obras originais, reproduções), aqui no Brasil a História da Arte não se desenvolve enquanto área/departamento de ensino e portanto não observamos essa demanda de imagens de obras de arte no ensino superior.

Aracy Amaral explica que a pesquisa em História da Arte no Brasil passou por diferentes prioridades temáticas no tempo: nos anos 40 o SPHAN (Serviço do Patrimônio Histórico e Artístico Nacional) deu prioridade aos estudos sobre arte e arquitetura colonial brasileira; a partir dos anos 60 os estudos passam a priorizar o século XX. No início dos anos 90, a USP desenvolveu interesse especial pela arte da 
América Latina. Pouco se estuda sobre a arte da antiguidade, arte medieval, renascentista e oriental.

Os currículos dos cursos de graduação em Artes Plásticas e Educação Artística e, eventualmente, de Arquitetura e de História, das universidades brasileiras incluem disciplinas de História Geral da Arte e História da Arte Brasileira. No caso da Universidade de São Paulo (USP), Aracy Amaral lamenta a desvalorização dessa área:

“..., até hoje um historiador da arte sente-se como um outsider na USP: há História da Arte no Departamento de História, na Escola de Comunicações e Artes, na Faculdade de Arquitetura e Urbanismo. (...) Falta-Ihes o 'seu' instituto, e hoje, rápidas reuniões e encontros nacionais e, para alguns poucos, internacionais, visam preencher as lacunas de um convívio necessário para complementar a formação autodidata." (Aracy Amaral, 1993:14)

No Brasil, a discussão sobre o ensino da arte é separada dos debates em relação aos museus de arte. Assim como não temos uma tradição na área de História da Arte, são poucas as reflexões sobre a relação dos museus com o ensino de nível superior $^{14}$.

Mario Pedrosa foi um dos poucos que propôs a criação de um museu de arte para ampliar o ensino de artes e comunicações, como veremos a seguir.

\section{Brasil: $O$ ensino utiliza coleções ?}

Mario Pedrosa considerava fundamental um museu de arte para a vida universitária e defendeu a instalação de um museu de arte moderna na cidade universitária, no Rio de Janeiro. ${ }^{15} \mathrm{O}$ museu de arte seria o catalisador das atividades criativas da universidade, dando suporte aos cursos de artes e comunicações dados nos anexos, Instituto de Artes e Escola de Comunicações, além de ter ao seu lado emissoras de rádio e televisão. Esse "Centro Artístico" seria liderado pelo museu de arte e seria um dos conjuntos arquitetônicos do "core" universitário, somando-se aos conjuntos do poder - Reitoria e Prefeitura - e do centro de atividades intelectuais Biblioteca Central.

\footnotetext{
${ }^{14}$ Por exemplo, no congresso "O Ensino das Artes nas Universidades" realizado em 1992, na Universidade de São Paulo, organizado pelo MAC/USP, ECA/USP e FAU/USP, discutiu-se mais questões teóricas e metodológicas e não foram apresentadas reflexões sobre as relações entre os museus e a universidade ou a utilização de obras originais para o ensino da arte.

É importante ressaltar que foi discutido o ensino da arte em geral, englobando artes plásticas, música, fotografia, cinema e suas relações com a tecnologia, a propaganda, a profissionalização.

${ }^{15} \mathrm{O}$ artigo aqui comentado é de 1967, tendo sido reeditado no início dos anos 90 pelo Boletim do MAC/USP.
} 
Para Pedrosa, a produção científica de um museu era similar à da universidade,

"O que as distingue é que o Museu dá também a conhecer o resultado de suas pesquisas, expondo-as diante do público sem tardança.

Aquele, com efeito, não conserva as suas pesquisas no círculo estreito dos especialistas, e antes as mostra ao Público, para que tenham impacto imediato sobre a sensibilidade geral." (Pedrosa, 1967:32)

Esse impacto sobre a sensibilidade seria o grande poder criativo e educativo do museu de arte. Pedrosa considerava que o museu proporcionaria um "terceiro caminho de aprendizagem" diferente dos livros e dos meios de comunicação de massa, por oferecer a experiência visual direta com a arte:

"Com efeito, o traço distintivo único desse papel educador é que, por suas coleções, suas exposições, seu apelo constante, ininterrupto, a todo o complexo sensorial do visitante, o museu dá primazia ou prioridade absoluta ao contato real do homem com os objetos, as coisas. A experiência do aprendizado é assim necessariamente ativa, viva. Somente por esse processo, e só nele, as noções abstratas, as palavras, as teorias e explicações intelectuais vêm a posteriori, isto é, após uma experiência sensorial, vivencial consumada." (Idem, ibid.)

Finalmente, Pedrosa defendia a idéia de que o museu deveria ser de arte moderna, pois era a partir dela que se poderia iniciar o estudo das sensibilidades contemporâneas e em seguida as do passado:

“...deve-se partir para o estudo da história da arte, das artes de hoje, isto é, do esforço realizador e criativo, que se faz na atualidade.

O homem moderno participa do mesmo drama criador dos homens de outras eras; e vive de mitos e motivações semelhantes aos do passado. " (Idem, ibid.)

Infelizmente as propostas de Pedrosa não se concretizaram, nem no Rio de Janeiro $^{16}$ nem em outras universidades. Algumas têm museus de arte moderna/contemporânea, como a USP, mas esses museus estão longe de representar o centro criativo e artístico da universidade e/ou de centralizar os cursos de artes e comunicações, como veremos no item 5 deste capitulo.

Uma das possíveis explicações para a não utilização sistemática de coleções para o ensino da arte deriva das concepções de ensino da arte desenvolvidas no Brasil. Devemos ressaltar, entretanto, que as primeiras escolas de arte no Brasil estavam associadas a coleções de arte.

\footnotetext{
${ }^{16}$ A UFRJ tem um museu de arte - Museu D. João VI - fundado em 1979 e ligado à Escola de Belas Artes (EBA). Seu acervo reúne obras da Academia Imperial de Belas Artes ligadas à missão artística francesa e ao desenvolvimento do ensino artístico no Brasil nos séculos XIX e XX. (Cadastro Vitae, 1997)
} 


\section{1. $O$ ensino da arte no Brasil e sua relação com as coleções de arte}

No Brasil, os primeiros museus de arte estão associados ao ensino da arte, basicamente de técnicas artísticas em que as obras das coleções serviam como referência e modelo para cópias.

A associação de coleções de obras de arte ao ensino da arte intensifica-se no século XIX, quando as coleções européias, que hoje compõem grandes museus nacionais e regionais, serviam de modelos para os estudantes copiarem.

"Durante a maior parte do século, os museus de arte são considerados primeiramente como coleções de modelos destinados aos artistas. As Salas de 'mestres antigos' são invadidas por copistas e estudantes. Os regulamentos indicam em geral que o 'grande público' só tem acesso lá aos domingos, às vezes outro dia da semana.

O British Museum, o Museu de Berlim, o Louvre são dotados de ateliês de modelagem, que difundem em outros museus e escolas de Belas Artes as cópias de suas esculturas, suportes do aprendizado do desenho." (Schaer, 1993:85-6)

Essa tradição foi a mesma que norteou a Coroa Portuguesa e aqueles que a rodeavam quando se estabeleceram no Brasil, a partir de 1808. Artistas franceses e portugueses foram os primeiros professores da Academia Imperial de Belas Artes no Brasil.

A formação da Academia iniciou-se quando D. João VI adquiriu 54 obras da missão francesa no Brasil, em 1816, e decretou a criação da Escola Real de Ciências Artes e Ofícios, no Rio de Janeiro. Entretanto, as aulas só iriam ocorrer mais de 10 anos depois (na então denominada Academia Imperial de Belas Artes) e a coleção só seria instituída como museu 121 anos depois, em 1937, como o Museu Nacional de Belas Artes. Uma parte da coleção da Academia seria transferida para a Universidade Federal do Rio de Janeiro para a formação do Museu D. João VI dessa universidade.

Na Bahia, em São Paulo e Pernambuco, os atuais museus de arte estaduais foram criados a partir de coleções, inicialmente pertencentes a Liceus de Artes e Ofícios e, posteriormente, separadas como instituições autônomas.

Nessa trajetória, verificamos a passagem de coleções de escolas de artes para museus autônomos do estado ${ }^{17}$, com exceção de parte da coleção da Academia Imperial de Belas Artes.

\footnotetext{
${ }^{17} \mathrm{Na}$ Bahia, o Liceu de Artes e Ofícios foi inaugurado em 1872 e a coleção ganhou autonomia como Pinacoteca do Estado somente em 1931. Em São Paulo a coleção foi inaugurada em 1905 no Liceu e em 1938 ganha autonomia como Pinacoteca do Estado. Em Pernambuco coleção é associada ao Liceu em 1930 e o Museu do Estado é criado em 1940. (Maria Cecília F. Lourenço, 1999:88-96.)
} 
No início do século XIX, a arte era vista como atividade da elite $^{18}$, que foi a principal freqüentadora da Academia Imperial de Belas Artes, no Rio de Janeiro. Em meados do século XIX, com o acirramento das lutas contra a escravidão diminuiu a visão negativa do trabalho manual e, com o desenvolvimento industrial, houve a valorização das artes aplicadas à indústria. (Barbosa, 1978)

Assim, o ensino da arte gravitou entre a cópia de obras já existentes e o desenho geométrico, incentivado principalmente como técnica para formação de pessoas que poderiam aperfeiçoar a indústria brasileira e pelo ideário do positivismo, tão caro a vários intelectuais brasileiros dos séculos XIX e XX.

Ainda segundo Ana Mae Barbosa, as propostas de Benjamin Constant referentes ao ensino de desenho na reforma do ensino de 1890 , baseavam-se no cientificismo positivista:

"O Desenho e as Aritméticas estavam associados e representavam etapas preparatórias do ensino de Geometria, como se pode depreender do enunciado da lei que recomendava o ensino da Aritmética e Desenho seguido da Geometria Prática. O Desenho aparecia presente no currículo apenas pelas suas possíveis contribuições ao estudo da ciência e já de início era com ela conectado, pelo menos nominalmente, o que obviamente foi uma interpretação radical das idéias de Comte, baseada principalmente nos objetivos por ele propostos e não na metodologia por ele apontada." (Barbosa, 1978:69)

Essa concepção de ensino da arte como ensino de desenho geométrico continua no século $X X$ e é de certa forma reforçada nas primeiras décadas pelas idéias de Rui Barbosa. Segundo Ana Mae Barbosa, os pareceres de Rui Barbosa sobre ensino de desenho tinham orientação mais liberal:

"A educação popular para o trabalho era a finalidade precípua, e as recomendações metodológicas se dirigiam à necessidade de desenvolver conhecimentos técnicos de desenho acessíveis a todos os indivíduos, para que estes, libertados de sua ignorância, fossem capazes de invenção própria. Educar o 'instinto de execução' para que este não fosse empecilho à objetivação da invenção era o princípio básico que repercutiu profundamente na metodologia do ensino da Arte no século XX." (Barbosa, 1978:60)

Apesar da existência de outras propostas para o ensino da arte, o desenho geométrico como ensino da arte nas escolas perpetua-se até o final do século $\mathrm{XX}{ }^{19}$.

\footnotetext{
${ }^{18}$ Naquele momento, a prática artística não era encarada como um trabalho manual, mas como uma atividade de lazer, um hobby.

${ }^{19}$ Outras correntes de ensino da arte desenvolveram-se nas primeiras décadas do século XX, porém não foram tão fortes para se perpetuarem em larga escala. Por exemplo, a Pedagogia Experimental (1914-1927) valorizava a "livre expressão da criança como um instrumento de investigação de seus processos mentais (inteligência, tipologia psicológica) e não como uma
} 
Um indício claro disso foi dado pela pesquisa, realizada em 1983, com 2.500 professores de educação artística da rede pública de São Paulo: o desenvolvimento da criatividade do aluno era o objetivo principal declarado pelos professores e estes identificavam a criatividade com a espontaneidade, a autoliberação e originalidade. Outra pesquisa ${ }^{20}$ mostrou que a principal fonte para o ensino era o livro didático. Como o livro didático era voltado para o ensino de desenho geométrico, havia uma enorme contradição entre o discurso e a prática.

O discurso desses professores sobre a autoliberação e originalidade são decorrentes da difusão das idéias que valorizavam a "livre-expressão" da criança. A liberdade de expressão artística da criança foi defendida inicialmente pelos modernistas:

“... nossa primeira grande renovação metodológica no campo da arte-educação se deve ao movimento de arte moderna de 1922. Mario de Andrade e Anita Malfatti foram os introdutores das idéias da livre-expressão para a criança. Anita orientando classes para jovens e crianças em São Paulo, e Mario de Andrade promovendo programas e pesquisas na Biblioteca Municipal de São Paulo, escrevendo artigos a respeito em jornais e introduzindo no seu curso de História da Arte na Universidade do Rio de Janeiro, estudos sobre a arte da criança. A idéia da livre-expressão, originada no expressionismo, levou à idéia de que a arte na educação tem como finalidade principal permitir que a criança expresse seus sentimentos e à idéia de que a arte não é ensinada mas expressada." (Barbosa, apud Pessi, 1990:33)

Mais tarde, a partir do final da década de 40, a livre-expressão foi difundida pelo grupo liderado por Augusto Rodrigues, fundador da "Escolinha de Arte", no Rio de Janeiro, em 1948. Influenciado também pelas idéias de Herbert Read e educadores norte-americanos, Augusto Rodrigues e um grupo de professores de arte ensinavam arte para crianças com os seguintes pressupostos:

“...a finalidade do professor não é ensinar o que a criança deve fazer, obrigando-a a concluir trabalhos ou seguir técnicas. Não. Seu objetivo é completamente outro: é proporcionar às crianças ambiente favorável ao seu desenvolvimento, estimulando-Ihes a auto-expressão, inclusive promovendo os meios materiais e as oportunidades para a aprendizagem das diversas artes, sem, no entanto, anularIhes a iniciativa com disciplinas e teorias. O princípio básico da Escolinha é respeitar a individualidade de seus pequeninos alunos.

(...)

Esse critério de apelar para a espontaneidade da criança, de deixar que ela se exprima como queira, num ambiente em que vê outras crianças desenhando, pintando e modelando, não só lhe aguça a percepção plástica e colorida das

\footnotetext{
atividade considerada em si mesmo importante; concebia o desenho da criança como um produto interno que reflete sua organização mental (...)" (Barbosa, s.d.:13)

${ }^{20}$ Pesquisa com 150 professores de arte, entre 1983 e 1985, realizada por Maria Heloísa T. S. Ferraz e Idméia Próspero citada por Barbosa, 1993:11.
} 
coisas, como the traz diante de si mesma a certeza de que adquire dignidade nova. Ela mesma descobre suas falhas e encontra sua própria disciplina." (MEC, apud Pessi, 1990:29)

A difusão das idéias da Escolinha se deu principalmente pelo curso oferecido a professores a partir de 1961 - Curso Intensivo de Arte-educação - que foi o único curso dessa área para professores até 1971.

Pela Lei de Diretrizes e Bases da Educação, promulgada em 1971, as artes passaram a ser obrigatórias nos níveis de ensino fundamental e médio. Entretanto, as universidades não tinham cursos de licenciatura em artes, ofereciam apenas cursos para "preparar professores de desenho". (Barbosa, 1993:9). Foram criados, a partir de 1973, os cursos de Licenciatura em Educação Artística de dois anos de duração. ${ }^{21}$

Assim, tanto dentro da visão do ensino da arte como desenho geométrico como do ensino da arte como livre-expressão, os professores não sentem necessidade de utilizar obras originais para o ensino da arte. Os professores não ensinam apreciação artística nem história da arte e poucos utilizam imagens na sala de aula. "Visitas a exposições são raras e em geral pobremente preparadas." (Barbosa, 1993:12)

O ensino superior também não valoriza a utilização de obras originais e segue dando prioridade para a formação de educadores dentro das idéias da livre-expressão. A baixa qualidade da formação de professores de educação artística levou algumas universidades a criar cursos de especialização a partir de 1983.

"A idéia da auto-expressão e do preconceito contra a imagem no ensino de arte para crianças é dominante nestes cursos." (Barbosa, 1993:15)

Se o ensino não valoriza a imagem para desenvolvimento de leitura e apreciação faz-se desnecessária a criação de coleções e museus universitários para o ensino da arte.

Somente no final da década de 80 e nos anos subseqüentes, novas concepções de arte-educação, difundidas no Brasil principalmente pelas publicações e apresentações em congressos de Ana Mae Barbosa, valorizavam a leitura da obra e relativizavam a livre-expressão para o ensino da arte. As propostas da "metodologia triangular" baseavam-se na apreciação e leitura da obra, além do fazer artístico. Por

\footnotetext{
${ }^{21}$ Ana Mae Barbosa informou, em 1993, que existiam, no Brasil, 78 cursos de licenciatura em educação artística, sendo 39 deles no estado de São Paulo. (Barbosa, 1993:10) Segundo o MEC, em 1998 havia no Brasil 96 cursos de Educação Artística, 3 de Belas Artes, 9 de Artes Plásticas, 2 de Artes Visuais, 6 de Desenho e Plástica, 1 de Arte e Educação e 1 de Museologia. (Dados obtidos na página da internet <www.inep.gov.br/censo/1998/superior> acessada em 22/10/2000)
} 
meio de publicações, seminários e congressos, essas idéias foram sendo difundidas no Brasil, e conquistaram professores e educadores de museus de arte.

Como toda nova abordagem de ensino, fazia-se necessária a capacitação dos professores para que fosse difundida de forma adequada. Além disso, uma vez que se baseava em leitura de obras, os museus deveriam formar também seus educadores, quando eles ali estavam presentes ${ }^{22}$, para essa nova situação. ${ }^{23}$

Além dos cursos de especialização, as universidades oferecem cursos de pósgraduação (mestrado e doutorado). Atualmente existem três universidades que oferecem mestrado em Artes (UNB, USP e UNICAMP) e quatro em Artes Visuais (UFBA, UFMG, UFRJ e UFRGS); apenas a USP oferece doutorado em Artes e a UFRGS e UFRJ oferecem doutorado em Artes Visuais. ${ }^{24}$

"A produção plástica brasileira, apesar de seu extraordinário desenvolvimento, não tem estado articulada ao sistema universitário e à pós-graduação. A pesquisa, tendo como objeto o fato artístico e seu processo, desenvolveu-se de forma pouco sistemática e integrada." ${ }^{25}$ (Bulhões, 1993:94)

É importante ressaltar, que parte das teses defendidas na área de arte foram realizadas por profissionais de museus, universitários ou não, evidenciando um dos meios de aproximação da universidade com os museus. ${ }^{26}$

\footnotetext{
${ }^{22}$ Ainda hoje são poucos os museus, de qualquer área, que têm educadores em seu corpo permanente de funcionários. Na maior parte das vezes, a ação educativa é realizada por estagiários e monitores contratados temporariamente ou por um funcionário "polivalente" que exerce várias funções ao mesmo tempo. Infelizmente não existe nenhum levantamento de dados para fundamentar essa afirmação.

${ }^{23}$ Denise Grinspum discute a importância de novas abordagens no ensino da arte para a ação educativa dos museus de arte no Brasil, em sua dissertação de mestrado Discussão para uma proposta de política educacional da Divisão de Ação Educativo-Cultural do Museu Lasar Segall, ECA/USP, 1991 e na tese de doutorado Educação para o Patrimônio: Museu de Arte e Escola Responsabilidade compartilhada na formação de públicos, FEUSP, 2000.

24 Dados da CAPES, obtidos na página da internet: <www.capes.gov.br/cursos>, em 22/10/2000.

${ }^{25}$ Em 1993, havia no Brasil, na área de artes plásticas, um curso de doutorado (oferecido pela Escola de Comunicações e Artes da USP) e seis de mestrado, sendo que apenas dois reconhecidos pela CAPES (o curso da ECA/USP e Escola de Belas Artes da UFRJ).

${ }^{26}$ Alguns exemplos, da ECA/USP, são: CINTRA, Maria Christina S.L.R. Leitura de fragmentos. Relato de uma experiência completa a partir de um acervo incompleto. Dissertação de Mestrado, ECA/USP, 1990. FERRARI, Elly A. R. P. Leitura de obra de arte contemporânea: o processo de leitura como construção do sentido nas atividades educativas da exposição Cachorros do MAC-USP, Dissertação de Mestrado, ECA/USP, 1999. FRANCOIO, Maria Ângela S. Museu de Arte e Ação Educativa: Proposta de uma Metodologia Lúdica, Dissertação de Mestrado, ECA/USP, 2000. GRINSPUM, Denise. Discussão para uma proposta de política educacional da Divisão de Ação Educativo-Cultural do Museu Lasar Segall. Dissertação de Mestrado, ECA/USP, 1991. GROSSMANN, Martin. Interação entre Arte Contemporânea e ArteEducação; Subsídios para a Reflexão e Atualização das Metodologias Aplicadas. Dissertação de Mestrado, ECA/USP, 1988. SANT'ANNA, Renata. Páginas da história: a criança, o livro e a
} 
Os museus, por sua vez, são por definição instituições voltadas para a educação e, principalmente a partir do século XX, passaram oferecer atividades educativas em suas exposições e cursos relacionados às áreas cobertas por seus acervos.

\subsection{0 ensino da arte em museus não-universitários ${ }^{27}$}

Em São Paulo, museus de arte-não universitários, criados por iniciativa privada no final da década de 1940, como Museu de Arte de São Paulo (MASP) e Museu de Arte Moderna de São Paulo (MAM/SP), logo que foram abertos passaram a oferecer cursos para o público em geral. Ambos davam cursos em diversas áreas - música, cinema, literatura, artes plásticas - a partir de uma visão mais ampla da produção artística.

O MASP ofereceu em 1947 três cursos: História da Arte, Monitores para Museus e Vitrinista. Organizou em 1948 o Clube de Arte Infantil, e ofereceu curso de música; em 1949, curso de cinema. Em 1951 e 1952 o MASP organizou o Instituto de Arte Contemporânea, primeira escola de desenho industrial do Brasil. ${ }^{28}$

Entre 1948 e 1958 o MAM/SP "realiza quase cem conferências, cursos sistemáticos de história da arte..." (Lourenço, 1999:111), oferece cursos de Filosofia, Estética e cria cursos de monitoria para as Bienais. Entre 1952 e 1959 manteve a Escola de Artesanato.

Nos anos 80 a oferta de cursos na área de arte por parte de museus e centros culturais se amplia, com atuação do Centro Cultural São Paulo, o Museu Lasar Segall, o SESC Pompéia e o Museu de Arte Contemporânea da USP, entre outros.

A discussão sobre o papel educativo dos museus já está bastante amadurecida e tem sido amplamente pesquisada dentro dos museus e nas universidades. ${ }^{29}$ Nossa

arte, Dissertação de Mestrado, ECA/USP, 2000. TOJAL, Amanda P. F. Museu de Arte e Público Especial. Dissertação de Mestrado, ECA/USP, 1999.

${ }^{27} \mathrm{O}$ ensino da arte em museus não-universitários é comum em todo o mundo. Nos EUA, por exemplo, muitos museus criaram cursos logo após sua criação: O Metropolitan Museum de Nova lorque oferecia palestras para adultos em 1872, dois anos após sua criação; o Boston Museum of Fine Arts utilizou salas vazias para dar aulas para adultos em 1976; e em alguns casos os programas educativos foram iniciados antes do estabelecimento do museu, como o Toledo Museum (1903) e o Cleveland Museum (1915). (Newson, 1978:13)

${ }^{28}$ Associação de Arte-educadores, A História da arte-educação em São Paulo: primeiro livro de registros. São Paulo, 1986:37 e 47.

${ }^{29}$ No Brasil, na área de Museologia, a maior parte das dissertações e teses tem como tema central ou trata em alguma parte a educação em museus. Algumas delas são: ALENCAR, Vera Maria Abreu de. Museu-Educação: Se faz caminho ao andar... Dissertação de Mestrado, PUC/RJ, 1987. ALMEIDA, A. M. A relação do público com o Museu do Instituto Butantan: análise da exposição: "Na Natureza não existe vilões". Dissertação de Mestrado. ECA/USP. 
discussão refere-se especificamente ao tipo de ação educativa adequada para museus universitários. Essa ação seria mais ampla do que a de museus não universitários por ter que abranger necessariamente o público universitário.

Os museus universitários são formados a partir da doação de coleções públicas ou privadas para instituições voltadas para o ensino, mas não necessariamente o ensino da arte. No Brasil, os museus de arte universitários têm poucas atividades voltadas para o público universitário da área de arte, sendo que muitas vezes os museus foram incorporados às universidades muito antes da criação de cursos de arte.

1995. BRUNO, Maria Cristina Oliveira. O Museu do Instituto de Pré-História: um museu a serviço da pesquisa científica. Dissertação de Mestrado, FFLCH/USP, 1984. CAZELLI, Sibele. Alfabetização científica e os museus interativos de Ciências. Departamento de Educação. PUC/RJ. 1992. CINTRA, M. C. R. Olho Vivo - Arte-Educação na exposição Labirinto da Moda: uma aventura infantil. São Paulo: Tese de Doutorado, ECA/USP, 2000. FREIRE, Beatriz Muniz. O encontro Museu/Escola: o que se diz e o que se faz. Dissertação de Mestrado. Departamento de Educação. PUC/RJ. 1992. GASPAR, Alberto. Museus e centros de ciências: conceituação e proposta de um referencial teórico. Tese de Doutorado, FEUSP, 1993. GRINSPUM, D. Educação para o Patrimônio: Museu de Arte e Escola Responsabilidade compartilhada na formação de públicos, Tese de Doutorado, FEUSP, 2000. HEIZER, A.L. Uma casa exemplar: Pedagogia, Memória e Identidade no Museu Imperial de Petrópolis. Dissertação de Mestrado, Departamento de Educação, PUC/RJ. 1994. LOPES, Maria Margaret. Museu: uma perspectiva de educação em geologia. Dissertação de Mestrado, Faculdade de Educação/UNICAMP, Campinas, 1988. OCAMPO, Liana R. Teresa. Os cegos e os museus: a utilização do museu como espaço educacional para deficientes visuais. Dissertação de Mestrado, Centro de Educação e Humanidades, Universidade Estadual do R.J. 1987. SANTOS, M.C.T.M. Processo Museológico e Educação: construindo um Museu didático comunitário, em Itapuã. Tese de Doutorado, UFBA, 1995. TAMANINI, Elizabete. Museu Arqueológico de Sambaqui: um olhar necessário, Dissertação de Mestrado, FE/UNICAMP, 1994.. VALENTE, Maria Ester Alvares. Educação em Museus. O público de hoje no museu de ontem. Dissertação de Mestrado, Departamento de Educação, PUC/RJ. 1995. 


\section{Coleções de universidades do Brasil: afastadas do ensino universitário?}

Vejamos a data de abertura ao público dos museus de arte universitários a partir de levantamento realizado por nós em 1998 e atualizado com as fontes disponíveis ${ }^{30}$ :

\begin{tabular}{|l|c|c|c|}
\hline Nome do Museu & Universidade & Área do acervo & $\begin{array}{c}\text { Data } \\
\text { abertura }\end{array}$ \\
\hline 1.Museu de Arte Sacra da Bahia & UFBA & Arte Sacra & 1959 \\
\hline 2.Museu de Arte da UFC - MAUC & UFC & Arte Contemporânea & 1961 \\
\hline 3.Museu de Arte Brasileira - MAB & FAAP / SP & Arte & 1961 \\
\hline $\begin{array}{l}\text { 4.Museu de Arte Contemporânea - } \\
\text { MAC }\end{array}$ & USP & Arte Contemporânea & 1963 \\
\hline 5.Galeria Brasiliana & UFMG & Arte & 1966 \\
\hline $\begin{array}{l}\text { 6.Museu de Arte Assis Chateaubriand } \\
\text { - MAAC }\end{array}$ & UEPB & Arte & 1967 \\
\hline 7.Coleção de Artes Visuais - IEB & USP & Arte & 1968 \\
\hline 8.Museu do Seridó & UFRN & Arte Sacra / História & 1968 \\
\hline 9.Galeria de Arte Espaço Universitário & UFES & Arte Contemporânea & 1978 \\
\hline 10.Museu de Arte e de Cultura Popular & UFMT & Arte Contemporânea & 1974 \\
\hline 11.Museu da Gravura Brasileira & URCAMP/ RS & Arte - Gravura & 1977 \\
\hline 12.Museu de Arte Popular & UFPB & Arte local & 1978 \\
\hline 13.Museu D. João VI & UFRJ & Arte & 1979 \\
\hline 14.Galeria de Arte UNICAMP & UNICAMP / & Arte Contemporânea & 1984 \\
\hline 15.Museu Regional de Arte & SEFS / BA & Arte & 1985 \\
\hline 16.Pinacoteca & UFPB & Arte local & 1987 \\
\hline 17.Museu de Arte Leopoldo Gotuzzo & UFPel / RS & Arte local & 1996 \\
\hline
\end{tabular}

Os museus de arte universitários foram criados nos últimos 42 anos, sendo o Museu de Arte Sacra da UFBA o mais antigo de todos, fundado em 1958 e aberto ao público em 1959. O Museu de Arte Sacra da UFBA e o Museu D. João VI da UFRJ apresentam obras do período colonial e também do século XIX, enquanto todos os outros dão ênfase às manifestações artísticas do século XX, incluindo a arte popular.

A maior parte dos museus foi constituída para valorizar e divulgar a arte regional, com exceção do Museu de Arte Brasileira da FAAP, a Galeria Brasiliana da UFMG, o Museu de Arte Contemporânea da USP, Coleção de Artes Visuais do IEB, Museu D. João VI e o Museu Regional de Arte da UEFS. Estes são resultantes de doações de coleções já formadas por iniciativa de pessoas de fora das universidades. No caso de São Paulo e Rio de Janeiro, impera ainda a vontade dessas cidades definirem-se como as metrópoles brasileiras. Indicador dessa intenção são os museus históricos com

${ }^{30}$ Gostaríamos de chamar atenção para as fontes: os cadastros preenchidos pelos museus para a Vitae e/ou CPC/USP muitas vezes procuram mostrar o museu melhor do que ele realmente é, alterando ou "embelezando" algumas informações. Além disso, alguns desses formulários foram preenchidos há mais de quatro anos, trazendo dados desatualizados. Por isso, procuramos manter contato direto com profissionais desses museus e encontrar documentos que complementassem os dados, de maneira a nos aproximar de um quadro mais próximo da "real" condição de cada museu. 
pretensões de contar a história nacional ${ }^{31}$, tanto no Rio de Janeiro (Museu Histórico Nacional) como em São Paulo (Museu Paulista) ${ }^{32}$.

A Galeria Brasiliana, em Belo Horizonte, resultou da campanha de formação de museus regionais encabeçada por Assis Chateaubriand. Dois museus, localizados fora das capitais, são resultantes dessa mesma campanha dos anos 60 - O Museu Regional de Arte da UEFS e o Museu Assis Chateaubriand da UEPB. Além desses, estão localizados fora das capitais dos estados os seguintes museus: Museu do Seridó em Caicó/RN, Museu da Gravura Brasileira em Bagé/RS, Museu Leopoldo Gotuzzo em Pelotas/RS e Galeria de Arte da UNICAMP em Campinas/SP.

As chamadas "galerias" praticamente não têm acervo e são prioritariamente espaços para exposições temporárias - Galeria de Arte da UNICAMP e Galeria de Arte da UFES. ${ }^{33}$

Dos 17 museus de arte universitários, 2 pertencem a entidades privadas, 4 a universidades estaduais e o restante a universidades federais.

Apresentaremos a seguir o perfil desses museus, salientando sua formação, objetivos e procurando possíveis relações de trabalho com as faculdades, institutos e departamentos de áreas afins. A ordem é cronológica de incorporação pelas universidades, e os museus da USP serão apresentados no próximo capítulo.

\subsection{Museu de Arte Sacra da UFBA}

A Universidade Federal da Bahia (UFBA) foi criada em 1946, como Universidade da Bahia, englobando as escolas de nível superior existentes e foi federalizada em 1950. Entre as escolas que a formaram estão a Faculdade de Medicina da Bahia criada em 1808, a Faculdade de Farmácia (1832), a Escola de Belas Artes (1877), a Faculdade de Filosofia, Ciências e Letras (1943), entre outras.

\footnotetext{
${ }^{31}$ Nos outros estados brasileiros, encontramos com freqüência museus que tratam da história do próprio estado e/ou da região, sem pretensões de contar a história de todo Brasil. O exemplo mais recente, em São Paulo, de vontade de ser o pólo cultural central do Brasil foi a "Mostra do Redescobrimento", realizada em 2000, que pretendia mostrar a arte brasileira, desde suas primeiras manifestações até a atualidade.

${ }^{32}$ Da mesma forma, o Museu Imperial de Petrópolis (RJ) pretende dar conta de parte da história do Brasil.

${ }^{33}$ Várias outras Escolas de Belas Artes têm galerias, aqui não consideradas por falta de informação, por serem muito recentes ou por serem apenas um espaço para apresentar trabalhos dos estudantes. Exemplos são a Galeria da EBA da UFMG, as galerias do Centro Cultural da Universidade Estadual de Feira de Santana, assim como os corredores da ECA/USP, sempre repletos de trabalhos de alunos de várias áreas.
} 
Atualmente a UFBA é responsável pelos seguintes museus: Museu de Arqueologia e Etnologia, Museu Afro-Brasileiro, Memorial da Medicina Brasileira e Museu de Arte Sacra, todos localizados em Salvador.

Quando o Museu de Arte Sacra (MAS) foi criado, a UFBA já contava com cursos nas áreas de Artes e Ciências Humanas; entretanto, o MAS teve um percurso próprio, independente do ensino e pesquisa universitários. Localizado na região central de Salvador, no Convento de Santa Teresa, é uma referência importante para a arte sacra brasileira.

Em 1972, o então diretor do MAS, Dom Clemente Maria da Silva-Nigra ${ }^{34}$, atribuía ao fundador da UFBA, o professor Edgard Rego Santos, a realização do MAS. O convênio entre a Arquidiocese e a UFBA previa que a universidade se responsabilizaria pela restauração e manutenção do imóvel, enquanto a Arquidiocese deixaria as peças litúrgicas e imagens para a exposição. ${ }^{35}$

Para Dom Clemente,

"Com a instalação do Museu de Arte Sacra no Convento de Santa Teresa, a Universidade Federal da Bahia não quis apenas conservar e expor o que a Bahia e o Brasil têm de mais apreciável e de mais rico em arte colonial, mas sobretudo pretende estudar e difundir as lições dessa mesma história de arte por meio de cursos e conferências, pesquisas e publicações." (Silva-Nigra, 1972:9)

O prédio do $M A S$, antigo convento, já é em si um importante documento do período colonial, contando com elementos arquitetônicos e decorativos dos séculos XVII e XVIII. O acervo é composto por esculturas, pinturas, prataria e azulejos, além da decoração e mobiliário originais do convento, somando cerca de 2000 peças $^{36}$.

"Um bom número de objetos expostos foi adquirido pela Universidade Federal, enquanto o resto pertence ao Arcebispado e ao Mosteiro de São Bento." (SilvaNigra, 1972:13)

Reconhecido nacionalmente e internacionalmente como tendo um acervo de valor histórico para a arte sacra, o MAS é muito procurado por turistas que visitam Salvador. $^{37}$

\footnotetext{
${ }^{34}$ Silva-Nigra foi diretor do Museu de Arte Sacra entre 1959 e 1972.

${ }^{35}$ A UFBA teria também que dar à Arquidiocese mais dinheiro para que esta terminasse a construção de seu novo seminário além de pagar um aluguel mensal enquanto durasse o convênio de 60 anos. Na época, entre 1959 e 1960, catedráticos e estudantes protestaram contra os gastos com o MAS. (Maia, 1987:14 e 16)

${ }^{36}$ Número obtido no Formulário CPC/Vitae, 2000. Durante a gestão de Silva-Nigra foram conseguidos empréstimos de mais obras de outras igrejas e conventos da Bahia, como a Igreja Matriz do Santíssimo Sacramento do Passo ou do Convento dos Perdões. (Maia, 1987:6)

37 Segundo Pedro Moacir Maia, diretor do MAS em 1987, "consta o Museu quase obrigatoriamente do programa das personalidades que vêm à Bahia, como a Rainha da
} 
O MAS têm museólogos, conservadores e historiadores da arte entre seus servidores. Tem biblioteca especializada com livros e periódicos. É sede de inúmeros congressos por sua ótima localização (centro da cidade) e ambiente agradável ${ }^{38}$. Mantém alguns vínculos com o ensino universitário:

"Nele são dadas matérias do curso de museologia da UFBA e tem organizado outros cursos e ciclos de conferências sobre a arte cristã e assuntos relacionados." (Maia, 1987:6)

Maria Célia Moura Santos ${ }^{39}$ relata algumas experiências educativas desenvolvidas pelos alunos do Curso de Museologia da UFBA, no Museu de Arte Sacra, a partir de 1974. Todas as atividades surgiram pela iniciativa dos professores e alunos de Museologia que convidaram escolas públicas para participar. Em 1974, desenvolveram visitas guiadas com palestra anterior nas escolas; em 1978 o projeto envolveu apenas uma classe de ensino fundamental, que participou durante um ano de atividades na área de Educação Artística, envolvendo aprendizagem do uso da argila, visita ao Museu de Arte Sacra, visita à fábrica de cerâmica e discussão da obra de Frei Agostinho da Piedade, um ceramista beneditino do século XVII. Em 1980, Maria Célia e os alunos de Museologia realizaram quatro diferentes programações com escolares para comparar a qualidade da aprendizagem ${ }^{40}$. Em 1983, os alunos de Museologia treinaram alunos de Magistério para utilizar o Museu de Arte Sacra como recurso didático. (Santos, 1987)

Todos os programas foram experimentais e serviram para a formação dos alunos participantes da disciplina "Ação Cultural e Educativa dos Museus", ministrada pela professora Maria Célia M. Santos. A professora se refere ao Museu de Arte Sacra como "museu-escola" para o Curso de Museologia, entretanto nos parece que o museu

Inglaterra, reis e presidentes, príncipes e ministros, embaixadores e dignitários eclesiásticos, professores e intelectuais, escritores e artistas, críticos de arte e diretores de outros museus." (Maia, 1987:6)

${ }^{38}$ Maria Cecília F. Lourenço (1999:41) comenta que em 1993, quando desejou visitar o MAS, não pôde pois haveria um casamento naquele dia e a visitação fora interrompida.

Lembro-me que quando visitei o MAS nos anos 80 havia um enorme bolo de casamento no pátio de entrada e a visitação deveria terminar mais cedo para a realização da cerimônia.

${ }^{39}$ A museóloga Maria Célia M. Santos iniciou suas atividades no Museu de Arte Sacra como voluntária, ainda no tempo de estudante, entre 1973 e 1974. Continuou trabalhando na área educativa voluntariamente por quase 10 anos, dividindo seu tempo com as aulas que ministrava no Curso de Museologia da UFBA. O trabalho no Museu de Arte Sacra foi incentivado pelo então diretor do museu, Valentin Calderon, que fora o criador do Curso de Museologia da UFBA, em 1970.

${ }^{40}$ Essa pesquisa fez parte da dissertação de mestrado de Maria Célia M. Santos Museu Escola: Uma experiência de Integração, Faculdade de Educação, UFBA, 1981. 
foi mais um "cenário" dos projetos educativos voltados para professores e alunos de ensino fundamental e médio, do que um centro criador de programas experimentais. ${ }^{41}$

Acreditamos que no caso do Museu de Arte Sacra, a originalidade de sua sede e de seu acervo garanta a manutenção da instituição, independente da sua situação em relação à universidade. ${ }^{42}$

\subsection{Museu de Arte da UFC (MAUC)}

A Universidade Federal do Ceará (UFC) foi criada em 1954 e instalada em 1955, englobando as Faculdades de Direito, Farmácia, Medicina e Agronomia. Seu primeiro reitor, o professor Antônio Martins Filho, foi o mentor da criação do Museu de Arte da UFC, em 1961, instalado inicialmente no campus de Benfica ${ }^{43}$, defronte à Reitoria. Além do MAUC, a UFC é responsável também pelo Museu Artur Ramos localizado em Fortaleza.

Para formar seu acervo, Martins Filho contratou artistas cearenses para realizar coletas e compras no Brasil (especialmente Ceará) e no exterior. O acervo conta com obras da arte popular cearense, como cerâmica decorativa e utilitária, ex-votos, esculturas em pedra sabão, madeira, ferro e couro e matrizes de xilogravuras de capas de cordel além de obras estrangeiras.

$\mathrm{Na}$ Europa, ainda no início dos anos 60, foram adquiridas coleções de gravuras japonesas e reproduções de impressionistas, de manuscritos persas, peças egípcias, gregas, romanas e da renascença. ${ }^{44}$. Algumas obras foram obtidas por permutas, após exposição da coleção de xilogravuras de cordel, em alguns países europeus. Também foram adquiridos slides.

Artistas contemporâneos brasileiros também fizeram parte da formação do acervo, entre eles Antonio Bandeira (34 obras), Aldemir Martins (50), Raimundo Cela (240), Sérvulo Esmeraldo (76), Francisco da Silva (42) e Nearco Araújo (38). O MAUC

\footnotetext{
${ }^{41}$ Maria Célia Santos afirma que após a morte de Valentin Calderon as atividades educativas continuaram mas os diretores que o sucederam não tinham a mesma aproximação com o Curso de Museologia. (Santos, 2001)

${ }^{42}$ As peças do acervo do MAS são tombadas pelo Instituto do Patrimônio Histórico e Artístico Nacional.

${ }^{43}$ Atualmente a UFC é formada por 3 campi em Fortaleza: Benfica, Pici e Porangabuçu.

${ }^{44}$ As reproduções não são consideradas parte do acervo do museu. (Pedro Eymar B. Costa, 2001).
} 
também tem 100 peças de imaginária barroca dos séculos XVIII, XIX e XX de várias procedências. Atualmente tem cerca de 4.000 peças no total. ${ }^{45}$

Segundo o atual diretor do MAUC, Pedro Eymar B. Costa ${ }^{46}$, depois de 1964, o MAUC teve pouca verba para aquisições e o crescimento do acervo se deu pela doação de artistas.

Apesar de contar com obras estrangeiras, o MAUC foi criado com a idéia de apresentar e divulgar a arte cearense ${ }^{47}$ :

"Art. $2^{\circ}$ - O Museu de Arte da Universidade terá como finalidade:

a) manter um acervo de produções artísticas, em todos os gêneros, notadamente de autores nascidos ou residentes no Ceará;

b) promover exposições de artes plásticas, visando a elevação do nível cultural do povo;

c) patrocinar cursos, conferências, palestras e debates sobre assuntos e problemas ligados às artes, em geral;

d) manter seções especializadas de arte popular e arte sacra, subdividindo-as tanto quanto necessário, para maior unidade das coleções;

e) realizar salões de arte, com prêmios, para artistas do Ceará e de todo o País;

f) preservar o patrimônio artístico do Ceará e estimular, por todos os meios ao seu alcance, o desenvolvimento das artes plásticas no Estado; (...)"

(Universidade do Ceará, Resolução n 104, 18/07/1961)

Chama atenção aos nossos olhos a finalidade descrita em "b": elevar o nível cultural do povo por meio de exposições de arte... Essa postura elitista de camadas que se consideram mais cultas que a "massa" foi muito bem criticada por Hannah Arendt:

"No que respeita à sobrevivência da cultura, decerto ela está menos ameaçada por aqueles que preenchem o tempo livre com entretenimentos do que por aqueles que o ocupam com fortuitas artimanhas educacionais para melhorar sua posição social." (Arendt, 1979:259)

A autora nos explica que a idéia de elevação do status social por meio da cultura foi difundida na Europa, quando as classes médias enriqueceram e procuraram ser valorizadas pela aristocracia no final do século XVIII:

\footnotetext{
${ }^{45}$ Dado informado verbalmente pelo diretor Pedro Eymar B. Costa, em 10/01/2001. No texto "Formação do Acervo", enviado como anexo do formulário CPC/Vitae 1999, constava o número total de 3.000 peças.

${ }^{46}$ Pedro Eymar B. Costa dirige o MAUC desde 1987. Ele é formado em Arquitetura pela UFC, com especialização em Conservação pelo CeCOR.

${ }^{47} \mathrm{O}$ mentor do MAUC e reitor à época, Martins Filho, tinha como lema "o universal pelo regional", segundo depoimento de Pedro Eymar Costa (2001).
} 
"Nessa luta por posição social a cultura começou a desempenhar enorme papel como uma das armas, se não a mais apropriada, para progredir socialmente e para 'educar-se', ascendendo das regiões inferiores, onde a realidade estaria situada, para as regiões superiores e supra-reais onde o belo e o espírito estariam em seu elemento." (Arendt, 1979:254)

Hannah Arendt não condena o uso da arte para fins de auto-aperfeiçoamento ou mesmo para decorar e cobrir "vazios" das paredes:

"Em ambos os casos o objeto artístico foi empregado para finalidades dissimuladas. Tudo está bem enquanto se permaneça cônscio de que tais empregos, legítimos ou não, não constituem o relacionamento apropriado com a arte." (Arendt, idem:255)

Arendt denominou essas pessoas que buscam a cultura de forma utilitária de "filisteus" e acrescentou:

"O que irritava no filisteu educado não era que lesse os clássicos, mas que ele o fizesse movido pelo desejo dissimulado de auto-aprimoramento, continuando completamente alheio ao fato de que Shakespeare ou Platão pudessem ter a dizer-Ihes coisas mais importantes do que a maneira de se educar; o lamentável era que ele escapasse para uma região de 'pura poesia' para manter a realidade fora de sua vida - coisas 'prosaicas' como uma crise de batatas, por exemplo ou para contemplá-las através de um véu de 'doçura e luz'." (Arendt, idem, ibidem)

Consideramos fundamental refletir sobre os objetivos expressos nos regimentos dos museus estudados, mesmo que muitos permaneçam apenas como palavras escritas, pois a universidade tende muitas vezes a ter uma postura pedante e propor-se a ser a grande "educadora" das camadas menos "cultas", incorrendo assim em propostas autoritárias e desinteressantes para o público-alvo.

A abertura do MAUC, com toda pompa possível, contou com a presença do Governador do Ceará, Parsifal Barroso, que expressou outra finalidade do museu:

"Deixo consignado o meu sentimento de aplauso à iniciativa da UFC ao criar o 'Museu de Arte' que deve ser a semente das futuras Escolas de Artes." 48 (Formulário CPC/Vitae, 1999)

Em 1965 foi transferido para uma sede própria na mesma região, ficando próximo a outros equipamentos culturais da UFC - Rádio, Casas de Cultura, cursos de Arquitetura, Comunicação Social, História, Biblioteconomia, compondo o "Pólo Cultural do Benfica".

\footnotetext{
${ }^{48}$ Apesar das intenções declaradas em 1961, Universidade Federal do Ceará não criou curso de Arte (seja de Belas Artes ou Educação Artística). Ela oferece atualmente cursos de Arquitetura, Comunicação e Estilismo e Moda. (Catálogo geral de instituições de nível superior, MEC, 1993 e depoimento Pedro Eymar Costa, 2001.)
} 
O MAUC está vinculado à Pró-Reitoria de Extensão da UFC, como órgão suplementar e

“...mantém a preocupação constante de desenvolver e fortalecer as artes plásticas no Estado, papel este observado desde sua fundação quando firmou-se como importante centro de preservação da cultura artística cearense, quer das expressões mais populares quer daquelas de caráter erudito.

Desenvolveu progressivamente uma política de difusão das produções artísticas através de uma abertura permanente aos eventos temporários bem como vem abrindo caminhos pedagógicos para o ensino do desenho da pintura e da gravura, sendo nesta área um dos pioneiros no Estado" (MAUC, página internet, 2000)

As aulas de pintura e gravura são oferecidas em oficinas desvinculadas do ensino de arte da UFC. Elas são dadas ao público em geral, conforme a exposição em andamento, muitas vezes com participação dos artistas apresentados.

Uma ligação mais forte com os estudantes da UFC se dá pela Bolsa Arte, um convênio do MAUC com a Pró-Reitoria de Assuntos Estudantis. Tendo existido entre 1971 e 1981 foi reativada em 1997. Os alunos são selecionados por meio de provas de "habilidade artística e relacional" nas artes plásticas e participam de experimentos de criação coletiva (MAUC, página internet, 2000). Atualmente são 20 alunos participantes dessa criação coletiva ${ }^{49}$ e que trabalham 12 horas semanais no MAUC, auxiliando na manutenção das atividades básicas, uma vez que o museu vem perdendo funcionários. ${ }^{50} \mathrm{O}$ site do museu na internet foi criado e é mantido pelos estagiários do museu.

Raras vezes, professores da UFC levam seus alunos para aulas no espaço expositivo do MAUC. Alguns professores da área de História, que desenvolvem pesquisas sobre a participação do Ceará na produção de borracha para os aliados durante a Segunda Guerra (1943), utilizam vasto material depositado no MAUC: cartazes de divulgação para recrutamento de trabalhadores cearenses (mais de 50.000 participaram para fugir do longo período de seca), recortes de jornais de época e registros gráficos do trabalho realizados por artistas. $O$ acervo não é tema de qualquer pesquisa em arte, sendo muito raramente objeto de interesse de alguns alunos de Ciências Sociais.

\footnotetext{
49 Pedro Eymar Costa descreveu esse trabalho coletivo como uma "experimentação", um "berço" cilíndrico, não plano e não horizontal, que discute o conceito de fronteira. (2001)

${ }^{50}$ Segundo o atual diretor, Pedro Eymar Costa, o MAUC tinha mais de 10 funcionários e ficou com apenas 4. Além dos estudantes, alguns servidores da UFC, com colaboração da Superintendência de Recursos Humanos, prestam serviços ao museu e também participam de atividades de criação coletiva. (Pedro Eymar Costa, 2001)
} 
O MAUC ficou em processo de reforma por dois anos, desde janeiro de 1998, sendo reaberto em janeiro de 2000 e está apresentando parcialmente obras do seu acervo. No ano de 1997 teve 6.850 visitantes $^{51}$ e em 2000 cerca de $6.000 .^{52}$ Uma parcela significativa dos visitantes é composta por estudantes de escolas públicas, que participam de visitas guiadas por estagiários do MAUC.

Atualmente, Fortaleza oferece outros museus de arte como opção: o Museu de Arte Contemporânea (MAC) e Memorial da Cultura Cearense, ambos em espaços novos criados como parte do Centro Dragão do Mar de Arte e Cultura, um novo pólo cultural da cidade. Essas instituições contam com acervo limitado e oferecem eventos prontos em "pacotes" que vêm de fora.

Inaugurado em 1998, o Centro Cultural Banco do Nordeste apresenta também mostras de artes plásticas contando com vasto acervo e visitação diária de cerca de 500 pessoas, na maioria estudantes de escolas públicas. ${ }^{53}$

O MAUC, talvez por contingências, acabou se aproximando da comunidade universitária e seu funcionamento atual depende da participação de estudantes e servidores da UFC. Nesse sentido, ele se tornou mais significativo para a comunidade universitária. Entretanto, não realiza pesquisa sistemática sobre ou a partir de seu acervo, obrigação de qualquer museu, e mais ainda de um museu universitário. As declarações do atual diretor mostram que o verdadeiro "desmanche" das instituições federais tornam o trabalho cotidiano uma luta pela sobrevivência e manutenção das atividades mínimas. O planejamento das exposições nunca é determinado em longo prazo, pelo temor da falta de verbas ou de possíveis problemas estruturais, como goteiras e quebra de sistema de climatização.

\subsection{Museu de Arte Brasileira - FAAP}

Em São Paulo, o Museu de Arte Brasileira (MAB) da Fundação Armando Álvares Penteado (FAAP) foi criado em 1947 e aberto ao público em 1961.

O MAB formou-se a partir da coleção do conde Armando Álvares Penteado, o qual exigiu em seu testamento que também se criasse uma escola. A solução foi a transferência do curso para formação de professores de desenho, então existente no MASP, em fins de 1958, para a FAAP. ${ }^{54}$ Apesar da intenção do MAB fazer a

\footnotetext{
${ }^{51}$ Dado de visitação do Formulário CPC/Vitae 1999.

${ }^{52}$ Dado obtido em depoimento de Pedro Eymar Costa, 2001.

${ }^{53}$ Ariadne Araújo, 2000:71-72.

${ }^{54}$ Maria Cecília F. Lourenço, 1999:225.
} 
divulgação da coleção deixada pelo conde, a maioria das exposições (sempre temporárias) ali realizadas desde sua abertura ao público apresenta uma parcela mínima da coleção da FAAP complementada por obras emprestadas para os eventos.

$O$ acervo do MAB tem cerca de 2.300 obras de 475 artistas brasileiros, sendo a maioria das obras das décadas de 1960 a 1980. Tem algumas poucas produções coloniais e um conjunto maior de obras de artistas ligados ao Modernismo, como Di Cavalcanti, Tarsila do Amaral, Brecheret, Ismael Nery, Goeldi e Anita Malfatti. Concentra a maior coleção de obras de Flávio de Carvalho. Pinturas e desenhos compõem 36 e $33 \%$ do acervo respectivamente, seguido de gravuras (23\%), esculturas $(5 \%)$ e "diversos" $(3 \%){ }^{55}$

Atualmente, a FAAP oferece cursos em diversas áreas das ciências humanas e exatas $^{56}$, além do curso de Artes Plásticas (Licenciatura e Bacharelado). Não se caracteriza como uma universidade pela pequena variedade de cursos existentes, pela ausência de pesquisa institucional e carreira acadêmica ${ }^{57}$. O MAB não oferece qualquer tipo de curso. ${ }^{58}$

Para o nosso estudo, interessa-nos conhecer as relações do museu com os departamentos de ensino afins e com a pesquisa. No caso da FAAP, afirma-se sobre o MAB:

"É função do museu a produção de conhecimento, quer por meio do estudo de seu acervo, propondo mostras elucidativas de sua composição, quer propondo e/ou abrigando exposições que levantem questões relevantes sobre a produção artística." (página da internet do MAB/FAAP, 2000)

Certamente todos os museus devem realizar pesquisas, entretanto em um museu universitário a pesquisa sistemática deveria ser uma de suas atividades principais. No caso do MAB, a pesquisa eventual é realizada pela diretora técnica Maria Izabel Branco Ribeiro e por sua equipe, visando a concepção e montagem de

${ }^{55}$ O MAB também tem obras de Rebollo, Mário Zanini, Bonadei, Portinari, Segall, Volpi, De Fiori e Lívio Abramo, representantes de "um segundo momento do modernismo"; e Lygia Clark, lanelli, Mabe, Renina Katz, Flexor e Tomie Ohtake com obras dos anos 50. Dados obtidos na página da internet da FAAP - MAB, 2000.

${ }^{56}$ Administração, Direito, Economia, Engenharia e Tecnologia.

${ }^{57}$ A FAAP tem um Plano de carreira pelo qual o professor é enquadrado segundo sua titulação. A FAAP não remunera seus professores para realizarem pesquisas, entretanto vários deles desenvolvem pesquisas de mestrado, doutorado como alunos de outras instituições.

${ }^{58}$ As recentes exposições promovidas no espaço do MAB/FAAP têm sido acompanhadas por atividades educativas oferecidas para escolas e outros grupos organizados. As duas ex-alunas que coordenam esse trabalho deverão ser contratadas pelo MAB em 2001. (Ribeiro, 2001) 
exposições ${ }^{59}$. Apesar de Maria Izabel Ribeiro ser professora de História da Arte na FAAP, no museu ela não exerce a função de docente / pesquisadora.

A diferença maior está no fato da FAAP não ser uma universidade e não ter a pesquisa como uma de suas prioridades. Assim, a maior parte dos professores vai à faculdade apenas para dar aulas e é remunerada por hora/aula. ${ }^{60}$

A equipe do MAB procura envolver em suas atividades os alunos e professores dos cursos afins - Artes Plásticas, Comunicações e Moda. Anualmente há uma exposição de artes em conjunto com a Faculdade de Artes Plásticas (estava na 32a edição em 2000) e novos projetos vêm sendo criados para que os alunos participem de atividades no MAB, por meio de estágios e exposições temporárias.

No caso da FAAP, a instalação de um curso de desenho não garantiu uma relação profícua entre o ensino e as atividades museológicas. Haveria a chance, neste caso, de criação de disciplinas que envolvessem o acervo do museu e também do museu ser um espaço de formação para atividades museológicas. Isso ainda não ocorre como uma prática institucional. ${ }^{61}$

A visitação do MAB aumentou visivelmente nos últimos anos: em 1997, 13.055, em 1998, 27.379, em 1999 chegou ao máximo de 82.549 visitantes e em 2000 houve uma queda para 35.358 pessoas. Em 1997 a exposição que atraiu maior público (4.213 pessoas) foi a de obras de Jean Cocteau (O Mundo de Jean Cocteau), em 1998 a retrospectiva de Di Cavalcanti (Di Cavalcanti 100 Anos) trouxe mais de 10.000 visitantes ao MAB e em 1999 houve 40.162 visitantes para "Brasileiro que nem eu. Que nem quem?" e mais de 20.000 para "Ícones - A Alma da Rússia". ${ }^{2}$ As exposições de acervo não atraem tanto público: em agosto e setembro de 1997 a exposição "Modernismo Modernistas" atraiu 385 visitantes e em 1999 a mesma exposição trouxe 977 pessoas ao MAB. Na opinião da diretora, o aumento de público se deve à

${ }^{59}$ Um exemplo, relatado por Maria Izabel Ribeiro, foi a concepção da exposição "Herança Barroca" em 1997. Ela partiu de um altar barroco do acervo do MAB para buscar a utilização de motivos barrocos e/ou de inspiração barroca no artesanato atual, como ocorre em algumas peças da prataria baiana. O ponto de partida foi uma peça do acervo e a exposição contou com obras barrocas e trabalhos atuais e foi montada em Brasília. (M. Izabel Branco Ribeiro, 2001)

${ }^{60}$ Para a diretora do $M A B$, o museu não tem um corpo técnico com pesquisas como há no MAC/USP, onde já trabalhou há alguns anos. M. Izabel, por exemplo, realiza pesquisa de doutorado como aluna da ECA/USP e seu objeto são as coleções de Theon Spanudis, pertencentes à USP. (Ribeiro, 2001)

${ }^{61}$ Em conversa informal, no mês de setembro de 2000, com o professor de Gravura da FAAP, Cláudio Mubarak, ficamos sabendo que atualmente ele leva seus alunos ao MAB para dar uma aula a partir de obras originais do acervo. Segundo ele, essa prática é recente e começou porque uma de suas alunas que trabalhava como estagiária no MAB sugeriu e facilitou 0 acesso às obras.

${ }^{62}$ Dados de visitação fornecidos pela diretora técnica M. Izabel Branco Ribeiro em 2001. 
intensificação da divulgação, à melhoria da qualidade das exposições e do espaço expositivo, ao trabalho educativo sistemático e ao horário que facilita o acesso, inclusive de espectadores do teatro - de $3^{a}$ a $6^{a}$ das 10 às 21 horas e sábados e domingos da 13 às 18 horas. (Ribeiro, 2001)

Percebemos na política de exposições temporárias a intenção de criar eventos que atraiam público. Entretanto, o acervo é deixado em segundo plano e isso pode indicar a dificuldade em criar conjuntos para exposição e/ou a falta de pesquisas que resultem em propostas de exposições.

\subsection{Galeria Brasiliana - UFMG}

A Universidade Federal de Minas Gerais (UFMG) foi criada em 1927 e sua Escola de Belas Artes em 1957. A UFMG é responsável pelos Centro de Memória da Medicina de Minas Gerais, Museu de História Natural e Jardim Botânico e pela Galeria Brasiliana.

A Galeria Brasiliana se formou em 1966 como resultado da doação à UFMG da Coleção Brasiliana, por Assis Chateaubriand, dentro da campanha de formação de museus regionais por ele encabeçada.

A proposta de criar museus regionais inicia-se em 1965, no contexto do regime militar, e se propõe seguir os seguintes critérios, conforme matérias dos jornais controlados por Chateaubriand, pesquisadas por Maria Cecília Lourenço:

"Em primeiro lugar ratificam a cada reportagem a necessidade de se estender a todas as regiões brasileiras a formação de coleções, levando-lhes a arte de outras regiões, daí o nome (regional), e também, de aglutinar os valores locais, circulando-os pelo território nacional, discurso consoante com a ideologia política em que se apregoa o proteger, como eufemismo de controlar e submeter. Declaram, já em fevereiro de 1966, o período a ser selecionado para reunir peças, fixando-o a partir da Semana de 22, ou seja, se prevê um acento moderno - o que de fato ocorre, porém apenas nas aquisições, ao contrário das doações, gerando desvios. Igualmente acenam com o sempre desejado extravasar de fronteiras, projetando-os no exterior e trazendo inovação, o que não esconde nossa situação de colonizados." (Lourenço, 1999:239)

Os acervos são constituídos por obras doadas pela elite local, empresários, banqueiros e industriais das capitais, por artistas e pelos mentores - Chateaubriand e Yolanda Penteado. O primeiro museu regional inaugurado foi o Museu Regional Dona Beja, em Araxá (MG), em dezembro de 1965. Em seguida foi criada a Galeria Brasiliana, em janeiro de 1966, junto à Universidade Federal de Minas Gerais. Em dezembro de 1966 foi inaugurado o Museu de Arte Contemporânea de Olinda (PE). 
Em março de 1967 foi aberta a Pinacoteca Rubem Berta em Porto Alegre (RS), que depois, em 1971, seria doada à Prefeitura de Porto Alegre e, em 1982, passaria para o Museu de Arte do Rio Grande do Sul.

Em Feira de Santana (BA) foi criado o Museu Regional de Arte em março de 1967. Desde 1985 o Museu Regional de Feira de Santana pertence à Universidade Estadual de Feira de Santana (UEFS) e em 1990 o acervo de arte popular passou para o museu Casa do Sertão da mesma universidade. Em 20 de outubro de 1967 foi inaugurado o Museu Regional Pedro Américo (em 1987 passa a ser denominado Museu de Arte Assis Chateaubriand) como órgão da Universidade Estadual da Paraíba (UEPB).

A Galeria Brasiliana foi inicialmente instalada no saguão de entrada da Biblioteca Estadual e depois de alguns meses seria transferida e incorporada pela reitoria da UFMG. Contava com objetos de arte, livros e documentos raros. Havia, por exemplo, 10 aquarelas do alemão Friedrich Hagedon de paisagens do Rio de Janeiro do século XIX; entre os documentos destacava-se o testamento de 1533 de Martim Afonso de Souza e uma coleção de autógrafos da monarquia portuguesa e brasileira; objetos de prata do período colonial e do século XIX, objetos sacros e livros do século XVII também faziam parte dessa eclética coleção. ${ }^{63}$

Além da Coleção Brasiliana, a UFMG recebeu como doação diversas coleções, tanto de livros, objetos, como de obras de arte ${ }^{64}$. Essas coleções encontram-se guardadas em uma sala apropriada no prédio da Biblioteca Central e são acessíveis somente para pesquisadores autorizados.

Em 1997, de 19 de junho a 8 de agosto, a Galeria Brasiliana compôs a exposição de inauguração da Galeria de Arte da Escola de Belas Artes (EBA) no campus da Pampulha. Na ocasião, foi feito um pequeno catálogo com comentários sobre obras da coleção, mostrando sua diversidade - "A 'Coleção Brasiliana' não é

${ }^{63}$ Assis Chateaubriand doou à Faculdade de Direito da UFMG, também em 1966, uma biblioteca contendo todas as obras de Camilo Castelo Branco e 15 mil volumes da Biblioteca do Instituto de Direito Comparado. (Marco Elizio Paiva, A Galeria Brasiliana, Folheto informativo:2000.)

${ }^{64}$ Entre essas coleções estão: Coleção Luiz Camilo de Oliveira Netto; Coleção Linhares; Coleção Arduino Bolívar; Coleção Henriqueta Lisboa; Coleção Oswaldo França Júnior; Coleção Murilo Rubião. (Paulo da Terra Caldeira. As coleções especiais da UFMG, Folheto da exposição de inauguração da Galeria da Escola de Belas Artes, 1997). 
uma coleção homogênea" - e riqueza - "ela preserva preciosidades de grande importância para a história da arte brasileira”. 65

Em 2000, a Escola de Belas Artes inaugura um novo espaço expositivo na região central de Belo Horizonte, no Conservatório da UFMG. Nesse espaço, está sendo exibida a Galeria Brasiliana e uma seleção da Coleção de Arte Contemporânea da UFMG. Essa coleção foi recebida em doação da Sociedade Amigas da Cultura em 1970 "com o objetivo de colaborar na criação de um núcleo artístico que fortalecesse o acervo do futuro Museu da UFMG"66. A coleção é composta por mais de 100 obras de artistas brasileiros e estrangeiros, com destaque para obras de artistas mineiros dos anos 60 .

Apenas algumas obras foram selecionadas para essa primeira exposição ${ }^{67}$, com critérios didáticos. Pretende-se fazer

“ (...) rearranjos periódicos da coleção para dar ao público uma compreensão do acervo como um todo e prolongada atratividade a este novo espaço cultural da cidade.

As outras obras recolhidas na reserva técnica do Conservatório UFMG aguardam, assim, a vez de contar suas histórias" 68

Como a Galeria Brasiliana foi recentemente inaugurada, ainda é muito cedo para podermos avaliar suas atividades. Muitas delas estão em fase de planejamento e não

${ }^{65}$ Entre os conjuntos de obras da Galeria Brasiliana que "devem ser destacados" estão: 1. Friedrich Hagedorn, 10 aquarelas guachadas de 1852-1856; 2. Henri Nicolas Vinet, Paisagem do Rio de Janeiro de 1856; 3. Leon Righini, Paisagem Amazônica de 1870; 4. Carlos Balliester, Vista da Guanabara de 1909; 5. Pedro Weingartner, 3 pinturas de 1926; 6. Pintura popular anônima século XIX; 7. Ex-voto português de 1683; 8 . Nossa Senhora dos Índios do século XVI; 9. Índio da Ilha Monka Riva, gravura perdida em 1968; 10. O Salvador, escultura do século XIX; 11. Crucifixo com imagem de Cristo do século XVIII; São Pedro Mártir, escultura do século XVIII; 13. Pia Batismal do século XVIII; 14. Par de castiçais de procissão do século XVII; 15. Nossa Senhora da Boa Morte do século XVIII; 16. Cabeça de Santo em cobre e prata portuguesa do século XVII; 17. Incensório em prata cinzelada do século XVIII; 18. Coroa de Nossa Senhora em prata do século XVIII; Côco ou "cuité" do século XIX; 20. Enfeites em prata para arreata do século XIX; 21. Testamento de Martim Afonso de Souza de 1533 a 1538; 22. Autógrafos de Portugal e Brasil dos séculos passados; 23. Manuscrito sobre nobres famílias de Portugal de 1643. Marco Elizio Paiva. A Galeria Brasiliana. Galeria Brasiliana: Catálogo da exposição de inauguração da Galeria da Escola de Belas Artes da UFMG, 1997.

${ }^{66}$ Marco Elizio Paiva. Coleção de Arte Contemporânea da UFMG. Folheto da exposição da Coleção de Arte Contemporânea da UFMG na Galeria Sociedade Amigas da Cultura, 2000.

${ }^{67}$ Terezinha Soares, Sara Ávila, Maria Helena Andrés, Inimá, Lótus Lobo, Celso Renato, Mário Silésio, José Ronaldo Lima, Jader Barroso, Petrônio Bax, Nello Nuno, Jarbas Juarez, Wilde Lacerda, Marlene Trindade e Nemer são alguns dos artistas mineiros representados e Angel Carretero e Victorio Gomes representam artistas estrangeiros que se agregaram ao ambiente mineiro. Marco Elizio Paiva. Coleção de Arte Contemporânea da UFMG. Folheto da exposição da Coleção de Arte Contemporânea da UFMG na Galeria Sociedade Amigas da Cultura, 2000. ${ }^{68}$ Idem, ibidem. 


\section{Galeria Brasiliana \\ Universidade Federal de Minas Gerais}

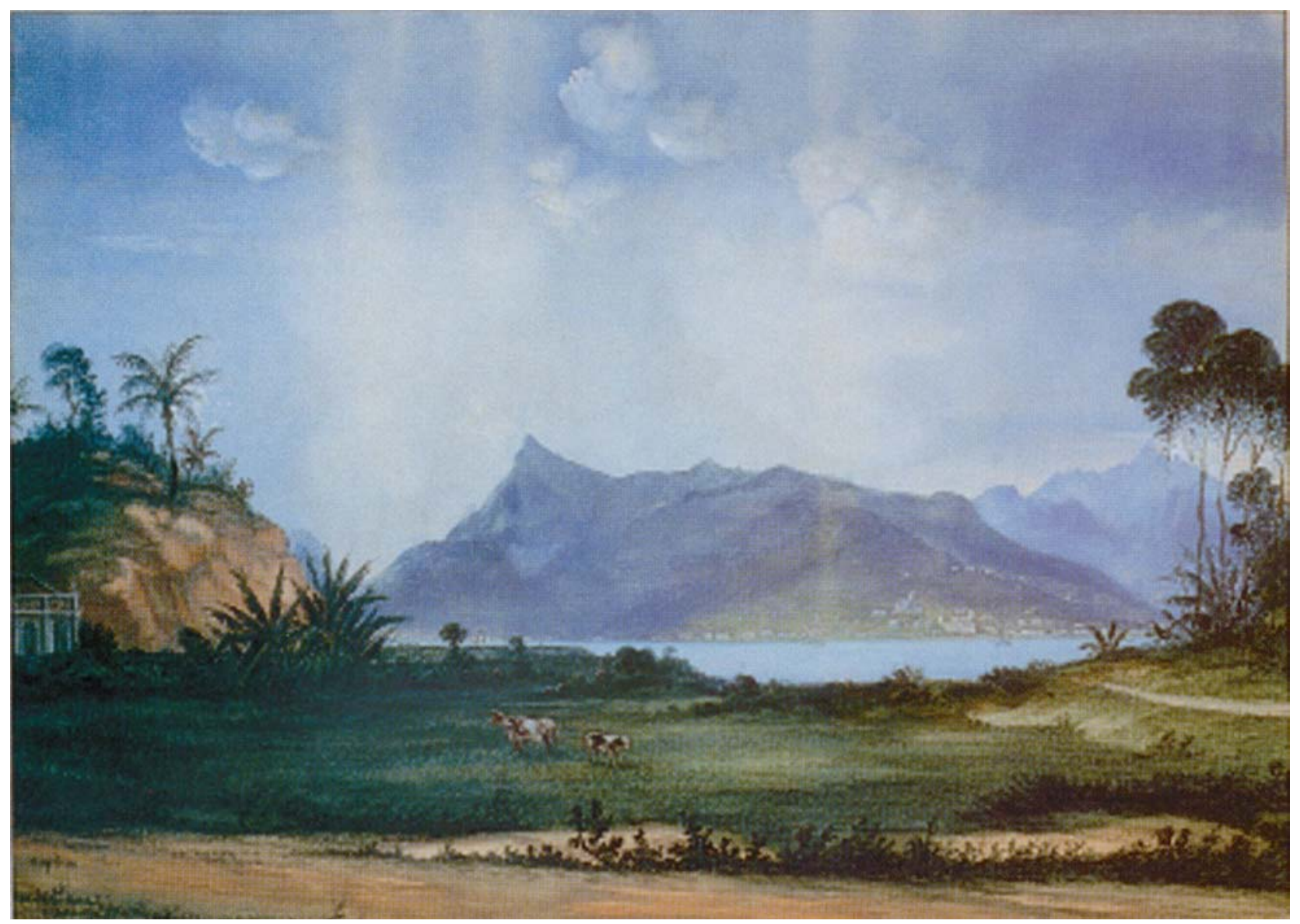


foram colocadas em prática. Nenhum curso foi dado até o início de 2001 e, para o público, é oferecida apenas a exposição.

A Galeria é uma etapa de um projeto de museu. As reformas do prédio do Conservatório Mineiro de Música estão sendo feitas com vistas a abrigar no futuro um museu. A UFMG, além de ter cursos de formação na área de arte, é um importante centro de formação de conservadores / restauradores, fatores muito positivos para o estudo e preservação de suas coleções. Entretanto, a Galeria ainda não organizou todas as suas coleções e as pesquisas estão sendo realizadas mais no sentido de documentar e conservar as obras do que em história, teoria ou crítica de arte. $\mathrm{O}$ ecletismo do acervo pode dificultar novas pesquisas, uma vez que as obras provêm de colecionadores e de doações de fora da universidade, que tiveram critérios de seleção estranhos à pesquisa e ao ensino acadêmicos.

A seleção de obras feita por colecionadores geralmente é pautada pelo gosto pessoal e pelo mercado e resulta na aquisição de obras de diferentes artistas, de diversas procedências e épocas. Isso impede a formação de "séries" ou grupos que possam ser objeto de pesquisas, pois a lógica do conjunto foi dada pelo gosto de uma pessoa. Esse problema ocorre em diversos museus e foi apontado por Teixeira Coelho ao falar sobre o MAC/USP:

"Ter uma obra de cada é típico de colecionadores privados e não de um Museu; ter uma obra de cada é típico do pensamento enviesado que norteia o colecionismo e que faz do colecionismo muito mais um fenômeno de psicologia individual (e de psicologia individual problemática, para dizê-lo claramente) que de estética ou história da arte" (Teixeira Coelho, 1999:29)

Discutiremos a coleção do MAC/USP no próximo capítulo, mas consideramos fundamental destacar que muitos museus de arte, universitários ou não, sofrem dificuldades para o desenvolvimento de pesquisas, exposições e programas educativos por terem adquirido coleções privadas de "uma obra de cada". 


\subsection{Museu de Arte Assis Chateaubriand - MAAC}

A Universidade Estadual da Paraíba (UEPB) tem sede em Campina Grande, a maior cidade do interior nordestino. O Museu de Arte Assis Chateaubriand é atualmente um órgão suplementar da UEPB. ${ }^{69}$

O Museu de Arte Assis Chateaubriand (MAAC) foi fundado em 1967 com o nome de Museu Regional Pedro Américo, em Campina Grande, Paraíba, dentro da campanha de criação de Museus Regionais de Arte encabeçada por Assis Chateaubriand e Yolanda Penteado nos anos 60. Desde aquela ocasião fazia parte da Universidade.

Assim como os outros museus regionais, conta com obras doadas e compradas a partir de renda de doações obtidas por Chateaubriand e seus amigos. $O$ acervo inicial de 150 obras, selecionado pelo marchand do Rio de Janeiro Jean Boghici apoiado pelo paraibano Drault Ernanny, congrega artistas nacionais - Portinari, Anita Malfatti, Di Cavalcanti, Rego Monteiro, Carybé - com destaque para artistas paraibanos como Pedro Américo e Santa Rosa. ${ }^{70}$

As primeiras exposições, em 1967 e 1968, apresentaram

“(...) o acervo inicial e empreendem-se mostras ecléticas, sem um claro princípio regulador, por um lado congregando artistas locais e da galeria Relevo do Rio, por outro, de arte sacra e dos alunos da Escolinha de Artes local, revelando-se ainda na busca de caminhos." (Lourenço, 1999:251)

A partir de 1968, o museu organiza uma Feira de Arte Popular do Nordeste que depois vai se consolidar com a instituição da Semana de Folclore Nacional de Campina Grande, sempre em agosto. Nos anos 70 oferece atividades educativas como visitas guiadas e ateliês, sendo que em 1971 iniciam-se os cursos de artes plásticas para adultos e crianças. Os ateliês continuam até hoje na Oficina de Arte e Criatividade.

Em 1976, o MAAC é transferido para sua sede especialmente construída, no parque do Açude, contando com espaço para reserva técnica.

\footnotetext{
${ }^{69}$ Até 1988, quando a UEPB foi estadualizada, ela era denominada Universidade Regional do Nordeste.

${ }^{70}$ Os modernos das coleções iniciais são: Portinari, Di Cavalcanti, Nery, Malfatti e Rego Monteiro. Artistas projetados por bienais: Babinsky, Cravo Junior, Mabe, Aldemir, Arthur Luiz Piza, Carybé, Andrade Filho, Grassmann, Andrés, José Antonio da Silva e Krajcberg. Artistas nipo-brasileiros: Ohtake, Yoshitane Nakamura, Waichi Tsukaka, Wakabayashi e o japonês Foujita. Artistas paraibanos: Pedro Américo, Francisco Aurélio de Figueiredo Melo, Santa Rosa, Antônio Dias, Córdula, Chico Pereira, Ivan Freitas, José Altino de Lemos Coutinho, Manuel Alexandre Filho, José Martins Lucena e Miguel Guilherme dos Santos. (Lourenço:1999:252-8) O acervo é de 462 peças, com obras da arte brasileira dos séculos XIX e XX e de arte estrangeira do século XX. (Guia de Museus Brasileiros, Comissão de Patrimônio Cultural / USP, 2000)
} 
$\mathrm{Na}$ opinião de M. Cecília F. Lourenço, no caso do MAAC, a Universidade Estadual da Paraíba proporcionou a possibilidade de diversificação de atividades e mostras, além de sedimentar a tradição de cursos oferecidos.

"A relação do museu com a universidade, ao contrário de Feira de Santana, revela-se produtiva até a atualidade, permitindo a diversificação de atividade e de mostras, que na atual gestão de [Mariene Braz Barros] Cavalcante se pauta pela qualidade, totalizando um número significativo (172), entre agosto de 1989 e dezembro de 1996, denotativo do esforço de continuidade. A tradição de cursos se mantém, atingindo cinqüenta, em distintas modalidades. Forma-se a biblioteca, edita-se catálogo das obras (1993), elaboram-se pesquisas e instala-se o ateliê de restauro, com profissionais habilitados para intervir nas obras e elaborar políticas de salvaguarda, procurando, com dificuldades, também superar a falta de recurso e de equipamentos tanto para a própria atividade quanto para a necessária documentação." (Lourenço, 1999:251)

Em 1997, o MAAC conquistou mais um espaço expositivo, a "Galeria do Museu Assis Chateaubriand", no edifício da Reitoria, onde expõe obras do acervo inicial. O prédio dos anos 20 foi restaurado e localiza-se no centro de Campina Grande. No texto do Reitor da UEPB, Sebastião Guimarães Vieira, a propósito da recuperação do prédio para atividades culturais, percebemos sua visão da universidade como um centro de saber que irradia seus conhecimentos para "formar" a população:

"A partir desse instante, o velho prédio da Floriano Peixoto é devolvido ao centro da cidade com sua renovada missão de contribuir para o aprimoramento cultural das novas gerações, oferecendo uma lição de saber aos que se dedicam às manifestações artísticas como forma de preservação das suas raízes.

(...) O importante, vencidas todas essas etapas, é que de agora em diante o novo espaço cumpra a sua função didático-pedagógica de desenvolver ainda mais a formação cultural de Campina Grande, universalizando assim um bem que é patrimônio de toda a comunidade." (Vieira, 1997)

Esse discurso mostra com clareza a percepção que o dirigente da universidade tem sobre sua relação com a comunidade - é uma relação didática, de quem tem o saber para quem deve recebê-lo, sem nenhum diálogo ou reciprocidade. Já havíamos visto essa postura no Regimento do MAUC (item 5.2), artigo $2^{\circ}$, item b, no qual se propõe a "elevação do nível cultural" do povo, porém esse era datado de 1961. Essa postura pedante (dos profissionais) da universidade parece ser contínua e freqüentemente permeia suas propostas de atividades voltadas para a comunidade em geral.

Outro aspecto comum com o MAUC (Ceará), é o de que as oficinas oferecidas pelo MAAC estão desvinculadas do ensino universitário, desenvolvendo trajetórias próprias. Conforme informação da página do MAAC na internet, ele 
"Oferece à comunidade atividades de exposição do Acervo e de artistas (individuais e coletivas), oficinas de arte para adultos e crianças, sessão de vídeos, seminários, cursos e palestras e apóia movimentos artísticos-culturais." (UEPB, página internet, 2000)

O MAAC se tornou um pólo cultural da região, incentivando e divulgando a arte e os artistas paraibanos. Não tem uma relação forte com os departamentos de ensino, mas oferece muitas atividades para a comunidade em geral. O museu tem mais de 10 funcionários, entre eles um arte educador, uma museóloga e dois restauradores. (Negrão, 2001) Esse quadro técnico é muito maior do que qualquer um dos outros museus de universidades públicas, apresentados neste capítulo.

A UEPB não tem curso de Arte na graduação, entretanto oferece a disciplina de História da Arte em curso de Comunicação Social, ligado ao Centro de Ciências Sociais Aplicadas. A professora dessa disciplina é também a museóloga do MAAC - Maria Cristina Gomes Negrão. Ela é a única docente a desenvolver pesquisa no MAAC, tendo feito seu mestrado sobre o artista Antonio Dias. Segundo ela,

"Algumas aulas da disciplina são dadas tendo como referência a exposição sobre arte brasileira montada na galeria do museu (obras do século XIX até década de 60). A pesquisa do acervo pelos alunos está em fase inicial, e também através da disciplina." (Negrão, 2000)

Apesar de não existir nenhum programa oficial que ligue a área de ensino ao museu, as relações vêm se desenvolvendo por iniciativa de uma profissional do museu que também é professora da UEPB. Os programas de estágios também não são institucionalizados, ocorrendo por iniciativa de professores e de forma voluntária pelos alunos.

A visitação parecia estar diminuindo pelos dados obtidos até 1995: Em 1992 48.586 pessoas visitaram o MAAC, em 1993 foram 16.169, em 1994 foram 18.320 e em 1995, 14.130. ${ }^{71}$ Entretanto, o número de visitantes é elevado se compararmos com os outros museus universitários de arte, excetuando-se os de São Paulo, e se levarmos em conta a localização fora da capital paraibana. Essa mesma localização faz do MAAC uma das poucas instituições a apresentar esse tipo de obras e a oferecer atividades voltadas para a arte fora do eixo das capitais nordestinas ${ }^{72}$, tornando-o atraente.

Um outro fator positivo do MAAC é o fato de que está sempre expondo seu acervo, tanto na exposição permanente como em temporárias, favorecendo revisões e

\footnotetext{
${ }^{71}$ Dados obtidos no Formulário CPC/Vitae 1999.

72 O Museu de Arte Contemporânea de Pernambuco, em Olinda é uma dessas instituições.
} 
Museu de Arte Assis Chateaubriand Universidade Estadual da Paraíba

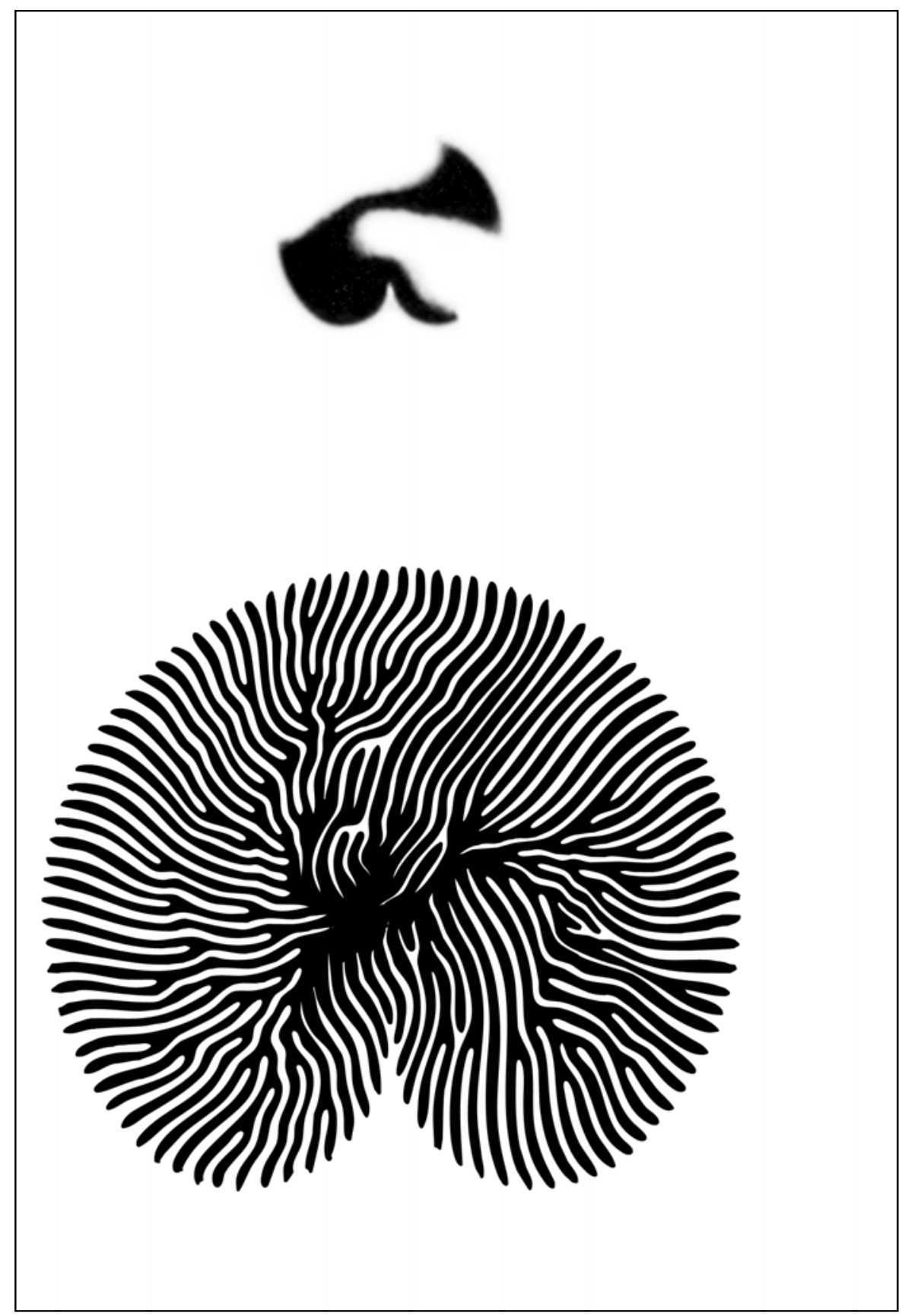

Monotipia de Ivan Serpa doada pelo autor em 1969 
discussões. Certamente há lacunas nas coleções e, também, há carência de verbas para aquisições, verbas que deveriam vir do estado da Paraíba. A equipe do museu mostra-se competente para conservar e dinamizar o acervo e para atrair público para as diversas atividades culturais, de forma a transformar o MAAC num "Centro Cultural"73 regional, o que pode ser evidenciado pela intensa visitação.

\subsection{Museu do Seridó - UFRN}

A Universidade Federal do Rio Grande do Norte (UFRN) foi criada em $1958 \mathrm{com}$ a fusão das Faculdades de Farmácia e Odontologia, Direito, Medicina, Filosofia, Ciências, Letras e Engenharia, tendo sido federalizada em 1960. Atualmente a estrutura dos cursos é organizada em Centros Acadêmicos.

A UFRN é responsável também pelo Museu Câmara Cascudo e pelo Museu do Mar Onofre Lopes, ambos localizados em Natal.

Além do campus da capital, dois outros campi do interior - Caicó (criado em 1973) e Currais Novos (criado em 1977) - compõem a estrutura da UFRN. Esses dois campi do interior constituíram-se no Centro Regional de Ensino Superior de Seridó (CERES), em 1977.

Depois de vários anos de dificuldades para integrar os dois campi, em 1993 foi feito novo esforço e o CERES passou a ser organizado em 3 departamentos nos 2 campi. Atualmente, em Caicó, onde está o Museu do Seridó, são oferecidos os cursos de Ciências Contábeis, Geografia, História, Matemática e Pedagogia.

O Museu do Seridó foi criado em 1960 pelo Padre Antenor Salvino de Araújo com objetivo de preservar elementos da história regional. Pertencente inicialmente à diocese, teve seu acervo formado por doações das famílias locais. ${ }^{74}$ Desde 1973 está sediado no prédio do antigo Senado da Câmara e Cadeia doado pela Prefeitura. Em 1977, com a formação do CERES no campus de Caicó e o funcionamento do curso de História, o Museu passou para administração da UFRN.

\footnotetext{
${ }^{73}$ Entendemos aqui "centro cultural" no sentido dado por Teixeira Coelho, como de uso informal no Brasil, em comparação a "espaço cultural" e "casa de cultura": "(..) o centro cultural é geralmente uma instituição mantida pelos poderes públicos, de porte maior, com acervo e equipamento permanentes (salas de teatro, de cinema, bibliotecas, etc.), voltada para um conjunto de atividades que se desenvolvem sincronicamente e oferecem alternativas variadas para seus freqüentadores, de modo perene e organizado." (Teixeira Coelho, 1997:168)

${ }^{74} \mathrm{O}$ acervo é formado por mobiliário, obras sobre papel, arte sacra, armaria, ferraria, objetos líticos, porcelana, cerâmica, produtos industrializados, couro, mobiliário, paramentos, alfaias, fotografias, somando cerca de 1000 peças. (Iracema Nogueira Batista, 2001:2)
} 
"A partir daí, vários projetos foram elaborados com vistas à ampliação e melhorias das instalações físicas, envolvendo pesquisadores, intelectuais, professores e estudantes da região e do Estado. Face às dificuldades apresentadas, as metas propostas não foram atingidas." (Brito, 2000:1)

Foi somente em 1993 que se conseguiu revitalizar o museu com apoio financeiro vindo de fora da UFRN. O acervo foi contextualizado a partir de um tema central "Seridó, terra nossa de cada dia", dividido em 5 núcleos expositivos, sendo 2 deles voltados para a arte local: "Devoção e arte do Seridó" e "Ofício e Arte do Seridó". O primeiro trata das devoções seridoenses como o folguedo dos Negros Rosários. O segundo pretende mostrar ofícios antigos do Seridó, como ferreiro, seleiro, louceiro.

O museu busca estimular a visitação e ampliar os conhecimentos a respeito da história regional. Criou projetos voltados para escolas da região e oferece seu espaço para eventos da comunidade.

Existe uma forte relação de colaboração entre o Museu e o Curso de História. Alunos da disciplina de História do Rio Grande do Norte desenvolveram textos e vídeo para professores e alunos de ensino fundamental dentro do projeto "A Escola vai ao Museu". 75

Pelos projetos propostos e atividades desenvolvidas, o Museu do Seridó configura-se hoje mais como um museu de história regional do que um museu de arte em geral ou arte sacra, pelo enfoque dado ao acervo na atual exposição e seus desdobramentos.

"A distribuição do acervo é de acordo com a história do homem do Seridó, sua colonização, o motivo que o levou a interiorizar-se proveniente do litoral nordestino, suas atividades e modo de vida.

Durante as visitações, o seridoense sente-se à vontade, pois revive toda a sua história, bem como, a das gerações passadas.

Portanto, classificamos o Museu do Seridó como sendo histórico." (Iracema Nogueira Batista, 2001:2)

As únicas pesquisas desenvolvidas no museu são as da diretora Iracema Nogueira Batista: uma sobre o cotidiano do engenho de rapadura e outra sobre estilos da imaginária do Seridó, esta última a partir do acervo do museu. O Museu do Seridó

\footnotetext{
75 "Os textos produzidos serão encaminhados aos professores de $3^{\mathrm{a}}$ e $4^{\mathrm{a}}$ séries do $1^{\circ} \mathrm{Grau}$ menor (a princípio, somente 05 escolas públicas serão incluídas no projeto, a título de experiência), para servirem de fundamentação à prática docente. As aulas sobre aspectos históricos do município de Caicó e da região do Seridó deverão ser ministradas no Museu. (...) Dessa forma, o Projeto 'A Escola vai ao Museu' contribui significativamente para a viabilização da proposta conceitual, transformando o Museu num eficaz instrumento de apoio ao ensino fundamental capaz de atender às aspirações da comunidade seridoense no tocante ao conhecimento de sua história." O Museu do Seridó: A história que se faz presente de Paula Sônia de Brito, página da internet do CERES, 2000.
} 
tem um perfil de museu público, voltado para a comunidade e suas relações com a universidade são para promover atividades para a comunidade.

A visitação do museu é pequena: em 1997 foram 1.204 visitantes, em 1998, 769, em 1999, 1.583 e em 2000, 444 visitantes $^{76}$.

O Museu do Seridó só tem dois funcionários: a diretora e a vice-diretora. A diretora do museu, Iracema Nogueira Batista, lamenta principalmente a falta de espaço físico para o desenvolvimento das atividades do museu, além do "descaso" por parte da UFRN e até dos alunos e professores de História.

A manutenção das atividades deve-se ao esforço dessas funcionárias: a diretora realizou vários cursos de formação em museologia para poder desempenhar suas funções no museu. No museu são desenvolvidas, de forma não sistemática, as atividades básicas definidas pelo ICOM para o funcionamento de um museu.

\subsection{Galeria de Arte Espaço Universitário - UFES}

A Universidade Federal do Espírito Santo (UFES) foi criada em 1954 com a fusão da Faculdade de Farmácia e Odontologia, Faculdade de Direito, Escola de Educação Física, Escola Politécnica, Escola de Belas Artes, Faculdade de Filosofia, Ciências e Letras e Instituto de Música. Em 1961 foi federalizada. A UFES tem sob sua responsabilidade o Museu Solar de Monjardim e a Galeria de Arte Espaço Universitário, ambos em Vitória.

O Museu Solar de Monjardim, criado em 1980 pelo IPHAN e administrado pela Universidade Federal do Espírito Santo (UFES), foi resultado da transferência dos acervos do Museu Capixaba ${ }^{77}$ e do Museu de Arte Sacra para a UFES. Seu acervo tem cerca de 4.500 peças de arte e história do século XIX e iconografia da Cidade de Vitória dos séculos $\mathrm{XIX}$ e $X X^{78}$ Sua principal exposição é o próprio prédio, antiga residência da elite do século XIX. Segundo seu regimento interno

“... é uma instituição destinada a resgatar o modo de vida nas residências rurais brasileiras no século XIX bem como difundir a história do Brasil através da

\footnotetext{
${ }^{76}$ Em 2000 o Museu do Seridó esteve fechado por 6 meses para reforma. A maior parte do público visitante é formada por alunos do ensino fundamental, a comunidade em geral e em menor escala estudantes de nível superior. (Iracema Nogueira Batista, 2001:1)

77 O Museu Capixaba, criado em 1939, pertencia ao Estado do Espírito Santo e passou à UFES em 1967 com a denominação de Museu de Arte e História. (Fernanda de Camargo e Almeida. Guia dos Museus do Brasil, 1972:88)

${ }^{78}$ São peças de mobiliário, prataria, arte sacra, cristais e vidros, objetos de uso pessoal, objetos de cozinha, indumentária, armas, leques, cerâmica, documentos, fotografias, entre outras. (Formulário CPC/Vitae 1999)
} 
aquisição, preservação, pesquisa, exposição e difusão de evidência do processo histórico." (Regimento Interno do Museu Solar de Monjardim, cópia de 1996)

O Museu Solar de Monjardim oferece várias atividades para o público em geral, como palestras, lazer educativo, seminários e aulas de educação patrimonial, além de se propor como um espaço para a comunidade no projeto 'o museu é seu' com capoeira, coral e cinema. ${ }^{79}$

Pelos temas das pesquisas desenvolvidas - pesquisas históricas, projetos de memória oral - e pelo fato de oferecer estágio para a área de História, o museu tem um perfil mais voltado para história do que para arte.

A UFES oferece cursos de arte em seu Centro de Artes. O Centro de Artes foi criado em 1962 com a federalização da Escola de Belas Artes, fundada em 1951. Os cursos existentes são de Artes Plásticas, Educação Artística, Arquitetura e Urbanismo e Desenho Industrial.

A UFES realizou em 1974 o I Salão de Arte Universitária do Espirito Santo e nos anos seguintes deu continuidade ao evento, apoiada pela FUNARTE. Com o sucesso das atividades, a UFES considerou importante consolidar um espaço para exposições temporárias para promover o trabalho de artistas locais ou não, e criou em 1978 o Espaço Universitário realizando o Salão Nacional de Artes Plásticas.

Em 1992 foi criada a Coordenação de Artes Plásticas ligada à Secretaria de Produção e Difusão Cultural (SPDC) da UFES. Segundo suas Normas de Funcionamento, ela tem como objetivos:

"a) Constituir um acervo de obras de arte contemporâneas significativas e de relevância no cenário estadual, nacional e/ou internacional que demonstrem claramente a qualidade da produção artística a partir de 1978, data da primeira doação e ano da fundação da Galeria de Arte Espaço Universitário, que sirvam de núcleo ao Museu de Arte da Universidade Federal do Espírito Santo;

b) Incentivar o desenvolvimento da cultura artística no Estado do Espírito Santo, proporcionando aos artistas capixabas, de outros estados e de outros países, locais apropriados para a apresentação dos seus trabalhos;

c) Promover confrontos entre a produção artística local, nacional e internacional através de exposições, eventos e demonstrações;

d) Ensejar o contato da comunidade capixaba com manifestações artísticas;

e) Proporcionar contatos entre artistas, estudantes de arte e interessados, através de palestras, seminários, debates, depoimentos e outras atividades; (...)

h) Promover atividades extensionistas dentro da filosofia de atuação da Coordenação de Artes Plásticas para aperfeiçoamento de alunos do Centro de Artes;

\footnotetext{
${ }^{79}$ Dados sobre atividades obtidos no Formulário CPC/Vitae 1999.
} 
(...)"

(UFES, Normas de Funcionamento da Coordenação de Artes Plásticas, In Mendes, 2000:Parte 2.)

Pelas Normas propostas, a UFES pretende ser um centro de divulgação da arte de referência para o Espírito Santo. Apenas os itens "e" e "h" fazem referência aos estudantes em geral e aos estudantes do Centro de Artes, respectivamente, sugerindo que a Galeria poderia servir para o "aperfeiçoamento de alunos".

A Coordenação de Artes Plásticas tornou-se responsável pela Galeria de Arte e Espaço Universitário, desdobrada em três setores: Galeria de Arte, Setor de Acervo ${ }^{80} \mathrm{e}$ Setor Educativo e Pesquisa. Em 1992 recebeu apoio da VITAE para equipar e instalar reserva técnica no Espaço.

"Ainda dentro de sua linha de ação, a Galeria de Arte Espaço Universitário, nestes últimos 20 anos, promoveu o artista local, ofereceu ateliê livre de Artes Plásticas e cursos; implantou uma oficina de artes gráficas que até hoje presta serviço a toda Universidade, e sobretudo incentivou o interesse da comunidade universitária pelo fenômeno artístico." (Mendes, 2000:Parte 1)

O acervo é composto por obras doadas por artistas expositores ao longo dos anos, somando 617 obras, incluindo pinturas, desenhos, gravuras, esculturas, fotografias, tapeçaria e mosaicos. Entre os artistas de "renome nacional" com obras no acervo estão: Renina Katz, Maria Tomazelli, Rubens Grillo, Dionísio Del Santo, Fayga Ostrower, Darel, Paulo Herkennhoff, Ligia Pape, Antonio Henrique Amaral, Abelardo Zaluar Scliar, Arlindo, entre outros. ${ }^{81}$ (Mendes, 2000)

Enquanto o Museu Solar de Monjardim parece ser um museu mais voltado para a pesquisa histórica, a Galeria de Arte tem o perfil de uma galeria para apresentação de exposições temporárias (cerca de 6 por ano), com pequeno acervo próprio. Os objetivos definidos pelas Normas destacam sua vocação para divulgar a arte contemporânea para a comunidade local e não especialmente para desenvolver e divulgar pesquisas da universidade. A visitação é de 1.000 a 1.500 pessoas por exposição, ou seja, mais de 6.000 visitantes por ano.

"(...) muito mais do que expor obra de arte, o Setor de Galeria se estrutura como serviço que informa e forma a comunidade em geral, principalmente na área de

80 A Coordenação tornou-se responsável por todo o acervo da UFES, incluindo obras pertencentes ao Centro de Artes. O Centro de Artes mantém a Galeria de Arte e Pesquisa voltada para a divulgação das pesquisas / obras de professores e alunos. Atualmente a Galeria de Arte e Pesquisa está desativada. Ela diferencia-se do Espaço Universitário por ter uma vocação "mais didática". (Neusa Mendes, 2001)

${ }^{81}$ As 617 obras estão divididas em: 150 desenhos, 107 fotografias, 103 pinturas, 97 gravuras, 91 "Arte Postal", 48 "Objeto/Escultura/Mosaico", 13 cerâmicas e 8 tapeçarias. (Mendes, 2000, Parte 4) 


\section{Galeria de Arte Espaço Universitário Universidade Federal do Espírito Santo}

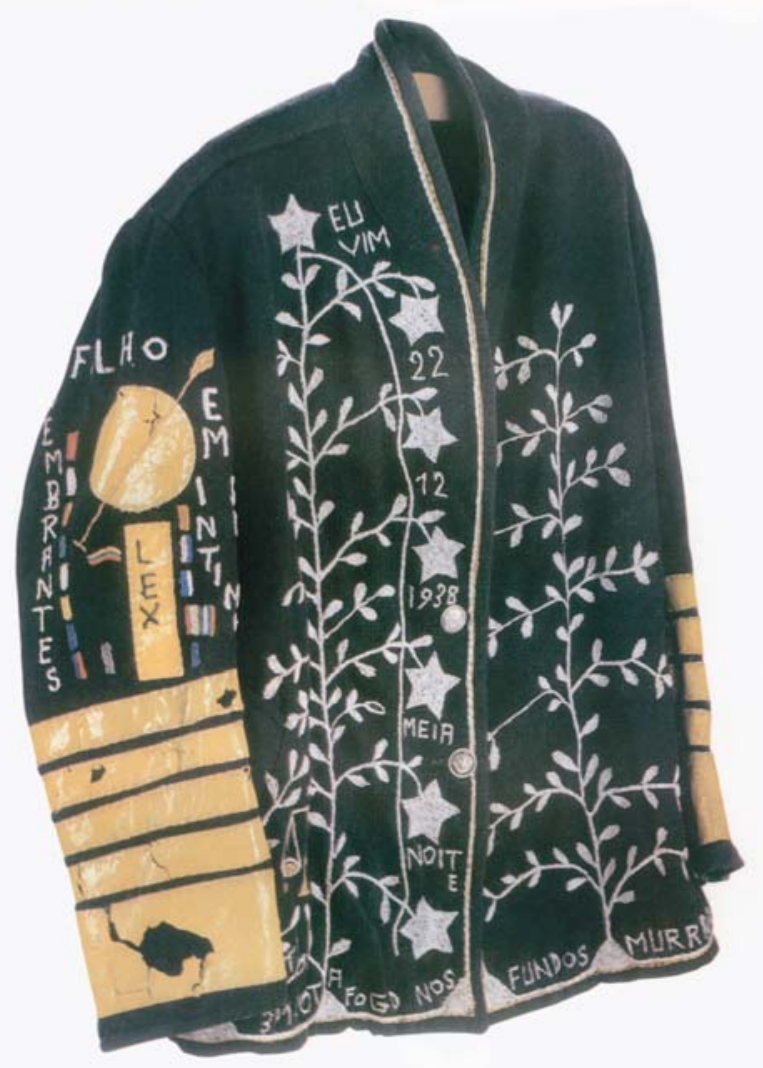

Arthur Bispo do Rosário - EU VIM 
ensino de $1^{\circ}$ e $2^{\circ}$ graus. O universitário participa do processo atuando como monitor do projeto de extensão, colaborando dinamicamente no diálogo da criança, adolescente e adultos artistas ou não." (Mendes, 2000:Parte 5)

Como já vimos em exemplos de galerias de universidades do Canadá, a Galeria da UFES está voltada para a divulgação da arte contemporânea e tem uma política de exposições "rotativas" de curta duração (cerca de dois meses), mantendo fortes relações com o meio artístico e com a comunidade externa à universidade (escolas) e oferecendo aos alunos de arte da UFES alguns estágios e a oportunidade de vivenciar a produção artística contemporânea. Seu acervo limitado não é objeto de estudos e está em formação.

Assim como em outros museus de arte universitários brasileiros já apresentados nesse capítulo, há uma tendência a transformar a galeria e/ou museu da universidade num pólo de divulgação da arte contemporânea regional ${ }^{82}$, tornando o museu um espaço de exposições com poucos compromissos com a pesquisa e o ensino universitários, mesmo quando existem cursos da área de arte oferecidos pelas mesmas universidades. Ao compararmos às finalidades propostas pelo Regimento do MAC/USP, veremos uma grande diferença: o MAC/USP se propõe a "promover o estudo e difusão do acervo..." ${ }^{\text {"3 }}$ e não se tornar um centro de valorização e divulgação da arte de São Paulo e de sua região.

\subsection{Museu de Arte e de Cultura Popular - UFMT}

Desde sua criação em 1970, a Universidade Federal do Mato Grosso (UFMT) desenvolve políticas acadêmicas norteadas pelas especificidades regionais, dando ênfase à "educação pública, meio-ambiente, preservação da memória regional, ciência e tecnologia e saúde pública." ${ }^{84}$ Além do campus na capital Cuiabá, a UFMT tem outros campi em Rondonópolis, Médio Araguaia e Sinop, e ainda oferece cursos especiais para outras cidades do estado.

Segundo o informe da UFMT ${ }^{85}$, ela oferece diversos serviços para a população, como um hospital, editora, biblioteca, teatro, orquestra, coral, cineclube, zoológico, ateliê livre de artes plásticas e também os museus Rondon e de Arte e Cultura Popular.

\footnotetext{
${ }^{82}$ Em Vitória do Espírito Santo não há Museu de Arte Contemporânea.

${ }^{83}$ Regimento do MAC/USP, D.O.E., São Paulo, 107(203), 4 de dezembro de 1997.

${ }^{84}$ Dados obtidos na página da internet da UFMT, 2000.

${ }^{85}$ Dados obtidos na página da internet da UFMT, 2000.
} 
O Museu de Arte e Cultura Popular da Universidade Federal do Mato Grosso foi criado em 1974 pela Fundação da UFMT. Os objetivos institucionais foram definidos como:

"1 - Implantar no campus da UFMT um centro de informações sobre arte contemporânea e sobre cultura popular, objetivando a produção de conhecimento das mesmas, que possa gerar estímulos capazes de provocar novas propostas de conhecimento e criatividade;

2 - Proporcionar através do testemunho de acervo possibilidade de visão dinâmica das manifestações vivas e em evolução na arte e na cultura popular no Estado de Mato Grosso e quando possível no país;

3 - Possibilitar acesso a informações sobre produtores (artistas e artesãos), produção e tradição populares, visando a avaliação técnico-pedagógica de seus conteúdos no fornecimento e captação de subsídios, no intercâmbio de informações, na oferta de eventos vários e no desenvolvimento da política artístico-cultural.

4 - Possibilitar aos professores e alunos da UFMT, bem como à coletividade mato-grossense em geral, um envolvimento nas atividades do museu, através de uma ação motivadora que satisfaça a necessidade de informação e formação à nível (sic) de outra forma de conhecimento do mundo;

5 - Estimular a arte mato-grossense contribuindo para o aparecimento de novos valores, bem como, atualizar o público mato-grossense tornando-o receptivo para a arte contemporânea." (Formulário Vitae, 1997)

O acervo foi formado por obras doadas por artistas locais e brasileiros participantes de mostras desde 1974, sendo a maioria de pinturas de artistas do Centro-Oeste do Brasil, somando 260 obras $^{86}$ (Formulário Vitae, 1997).

Como no caso da UFES, o Museu da UFMT pretende ser um centro de valorização e divulgação da arte regional:

"O Museu de Arte e de Cultura Popular da UFMT foi criado para propiciar, através do testemunho do seu acervo, a possibilidade de uma visão dinâmica das manifestações vivas e em evoluções na arte e na cultura popular no Estado de Mato Grosso e, quando possível, no país." (Página internet da UFMT, 20/01/2001)

A diferença em relação à UFES é a intenção de trabalhar tanto com a arte quanto com a cultura popular locais. No organograma do MACP da UFMT há a Divisão

\footnotetext{
${ }^{86}$ Cerca de 200 obras são de Arte Contemporânea, sendo as restantes de Arte Popular. (Ageo Villanova, 2001) Na exposição virtual da página da Coordenação de Cultura, são apresentadas obras de artistas em 6 salas, divididos por ordem alfabética: sala 1: Adir Sodré, Alcides Pereira dos Santos, Aleixo Cortez, Benedito Nunes, Clóvis Ingaray, Conceição Silva, Dalva Maria de Barros; sala 2: Fábio Lacerda, Gervane de Paula e Humberto Espíndola; sala 3: Ignês M. Corrêa da Costa, Ilton Antunes da Silva, João Sebastião Costa, Jader da Silva, José Pereira; sala 4: Marcio Aurélio, Maty Vitart, Miguel Pena; sala 5: Raphael Rueda, Regina Veloso, Sito, Sebastião Silva e sala 6: Vitória Basaia e Vivaldino Miranda. (Página internet Coordenação de Cultura UFMT, acesso em 20/01/01)
} 
de "Artes Visuais e Produção" e a de "Cultura Popular", evidenciando essa dupla proposta. (Formulário Vitae, 1997)

Os alunos do Instituto de Linguagens e Departamento de Artes da UFMT realizam trabalhos a partir das exposições do museu, sendo algumas mostras temas de aulas dos professores. Entretanto não há um trabalho sistemático que una museu e departamentos de ensino.

As pesquisas são voltadas para o desenvolvimento de exposições, sem um aprofundamento teórico e crítico em longo prazo. Segundo o atual supervisor do museu, Ageo Villanova ${ }^{87}$, não há pesquisadores no museu e estágios são oferecidos apenas para alunos da Escola Técnica de Turismo. (2001)

O museu oferece aulas de pintura e desenho gratuitamente para o público em geral, tendo orientado cerca de 100 alunos por ano em seu ateliê livre. O professor é um funcionário do museu e o material é trazido pelos alunos.

Nas exposições são oferecidas visitas monitoradas para grupos, desenvolvidas por uma funcionária do museu com formação em história.

As exposições temporárias são realizadas a partir da seleção de propostas feitas por artistas ao Conselho do museu, encabeçado pela ex-supervisora do museu Aline Figueiredo.

O museu está localizado no campus, há dois anos em um prédio que está sendo adaptado para acomodar as obras e exposições. No ano de 2000, o Museu de Arte e de Cultura Popular recebeu 9.000 visitantes. (Villanova, 2001)

Segundo a ex-supervisora do museu, Aline Figueiredo, o museu conseguiu atrair as pessoas da cidade para o Campus

“... suas exposições conceituadas são assunto para imprensa em eventos que não se traduzem em meras vernissages mas atuam como força motriz de sua política cultural que incentiva sobretudo o espírito crítico." (Formulário Vitae, 1997)

\subsection{Museu da Gravura Brasileira - URCAMP / RS}

A Universidade da Região da Campanha (URCAMP) localiza-se no sul do Rio Grande do Sul, sendo que vários dos seus campi estão nas fronteiras com Uruguai e Argentina. Sua sede principal fica na cidade de Bagé, onde se localizam o Museu da Gravura Brasileira, o Museu Patrício Correa da Câmara e o Museu Dom Diogo de

\footnotetext{
${ }^{87}$ Ageo Villanova foi durante muito tempo funcionário da área administrativa do Museu de Arte e de Cultura Popular da UFMT e recentemente passou a ser supervisor do museu.
} 
Souza, mantidos pela URCAMP. Todos eles estão sob responsabilidade da "Curadoria de Museus" ligada à Pró-Reitoria de Pesquisa e Extensão.

"O Museu da Gravura Brasileira foi fundado em 1977, a partir de uma coleção de gravuras do chamado 'grupo de Bagé' - Glênio Bianchetti, Danúbio Gonçalves, Carlos Scliar e Glauco Rodrigues." (página internet da URCAMP, 2000) Essa coleção pertence à Fundação Attila Taborda, mantenedora da URCAMP. Suas exposições temporárias ou de acervo apresentam gravuras de artistas brasileiros, com destaque para a produção local. Seu acervo é de cerca de 800 obras, provindas exclusivamente de doação de artistas.

As finalidades propostas pelo seu Regimento são:

"O Museu da Gravura Brasileira, da Curadoria de Museus da Fundação Attila Taborda, tem por finalidade recolher, adquirir, estudar, conservar, comunicar e expor, para fins de estudo, educação, cultura e lazer, gravuras de autoria de artistas brasileiros." (Regimento do Museu da Gravura Brasileira, 1979)

O prédio onde se localiza foi construído para esse fim em 1976. O público visitante em 1996 foi de 4.500 pessoas, em 1997, 4.300 e em 1998, 4.800 pessoas.

Esse museu é o único museu de arte universitário do Brasil especializado em apenas uma técnica, a gravura. Essa especialização se deve mais ao fato da fundação mantenedora da URCAMP ter uma coleção dessa área resultante de movimento de artistas locais do que qualquer especialização do ensino de gravura da universidade, como indicam suas finalidades.

A URCAMP oferece curso de Educação Artística em seu campus de Bagé com habilitação para Artes Plásticas desde 1976, entretanto há apenas indicação vaga de atividades conjuntas entre o Museu da Gravura Brasileira e o Centro de Ciências da Educação, Comunicação e Artes que oferece o curso de Educação Artística:

"O Curso de Educação Artística e Artes Plásticas utiliza o Museu da Gravura para pesquisas de disciplinas afins, assim como o Centro Livre de Artes que oferece cursos de Extensão dentro da Universidade e comunidade em geral." (Lourdes Helena Rosa, depoimento 26/10/2000)

Instituição privada, assim como a FAAP de São Paulo, a URCAMP teve suas coleções provindas da fundação mantenedora (Attila Taborda). Neste caso, as coleções formaram três museus diferentes, geridos pelo mesmo setor da universidade, independente das diferenças dos seus acervos - história regional e gravura. Suas atividades estão voltadas para a preservação e divulgação dos acervos e não para pesquisa dos mesmos. 


\subsection{Museu de Arte Popular e Pinacoteca UFPB}

A UFPB tem sob sua responsabilidade o Museu de Cultura Popular, o Museu de Arte Popular e a Pinacoteca localizados no campus de João Pessoa e o Museu do Brejo Paraibano no campus de Areia. Além disso, o Núcleo de Arte Contemporânea (NAC), criado em 1978, mantém uma galeria de arte.

O Museu de Arte Popular foi criado em 1978 a partir da Jornada de Contadores de Estórias, quando surgiu a idéia de criar um espaço para resgatar o folclore e arte popular da Paraíba. O acervo tem 1.500 peças de arte popular, cordel e folclore. O acervo é apresentado em uma sala de exposição permanente e também na Galeria de Arte Popular Tenente Lucena. ${ }^{88}$

A coordenação do Museu é de responsabilidade do Núcleo de Pesquisa e Documentação da Cultura Popular (NUPPO) da UFPB. Além de manter o museu, o NUPPO realiza seminários, oficinas de artesanato, encontros de contadores de estórias, mantém uma ampla biblioteca da área com acervo fonográfico e iconográfico para pesquisa e o grupo de Balé Popular.

"O NUPPO tem como principais objetivos compreender, preservar, divulgar e promover a cultura popular, através de equipes multidisciplinares, constituídas de servidores, docentes e alunos da Universidade. Procura colaborar no estudo da cultura popular da região e contribuir para o desenvolvimento da consciência, em âmbito estadual, de preservação e apoio às manifestações populares. Promove também a museologia, objetivando preservar os bens culturais móveis regionais, e atua em estudos conjuntos com outros órgãos públicos." (Universidade Federal da Paraíba, Manual do NUPPO, 1999:6)

A partir das informações obtidas, consideramos que o Museu de Arte Popular tem seu acervo voltado para questões de antropologia, mais do que de arte, uma vez que faz parte de um núcleo de estudos de cultura popular. Além disso, interessa-se pelas manifestações locais e regionais, sendo voltado para a comunidade.

O Museu de Arte Popular diferencia-se dos outros museus até agora descritos pelo fato de que está ligado a um núcleo de pesquisa, o que lhe garante o desenvolvimento de pesquisas sistemáticas sobre a temática do museu.

A Pinacoteca da UFPB está subordinada ao Departamento de Artes do Centro de Ciências Humanas, Letras e Artes e foi criada em 1987. Formada por iniciativa de professores, técnicos e artistas plásticos, a Pinacoteca pretendia formar um acervo de artes plásticas tornando-se um centro de pesquisa e divulgação. Entre os objetivos determinados no momento de sua criação estavam:

\footnotetext{
${ }^{88}$ Dados obtidos no Formulário CPC/Vitae 1999.
} 
"2 - Instalar uma biblioteca especializada, documentação e arquivo, cinemateca e videoteca.

3 - Recolher por compra, doação, legado, empréstimo ou transferência, obras plásticas de artistas nacionais e estrangeiros, do passado ou do presente, considerados de alto nível ou representantes de sua época.

4 - Expor convenientemente o seu patrimônio artístico de modo a se constituir um centro dinâmico de estudo e difusão das artes plásticas no Estado da Paraíba.

5 - Desenvolver linhas de pesquisa, cursos regulares ou periódicos, conferências, simpósios, seminários e congressos que venham contribuir para 0 aprimoramento, conhecimento, apreciação e crítica das Artes Plásticas.

(...)

9 - Editar impressos, livros, folders e material áudio-visual de difusão científica, cultural e educacional." (Universidade Federal da Paraíba, Regimento Pinacoteca, 1987, artigo $2^{\circ}$ )

O acervo, majoritariamente de artistas paraibanos, tem 178 obras entre pinturas, gravuras, desenhos e cerâmicas, e foi formado a partir de doações. (Lívia Carvalho, 2001) Sem espaço próprio, a Pinacoteca foi instalada provisoriamente em uma ala da Biblioteca Central, no campus da UFPB. Os alunos do curso de Educação Artística participam da documentação das obras do acervo. Além disso, desenvolvem pesquisa na área de semiótica dentro de um Programa de Apoio às Licenciaturas (PROLICEN). ${ }^{89}$

A Pinacoteca oferecia, em 1996, cursos de História da Arte, curso de Desenho da Figura Humana para a comunidade universitária, cursos de reciclagem para professores de Educação Artística das redes públicas assim como visitas guiadas para estudantes de ensino fundamental e médio das redes municipal e estadual de ensino. Em 1994 a Pinacoteca recebeu 869 visitantes e, em 1995, 726. ${ }^{90}$

A UFPB mantém um Núcleo de Arte Contemporânea (NAC) desde 1978, ligado à Pró-Reitoria Para Assuntos Comunitários. O NAC oferece cursos permanentes de gravura, litografia e serigrafia e realiza seminários, debates e palestras com freqüência. Em sua galeria, situada fora do campus em um casarão antigo, são realizadas exposições temporárias de arte contemporânea. Em 1999 o NAC recebeu 2.761 visitantes e em 2000, 3.988. Entre os visitantes estão o público em geral, artistas, estudantes da UFPB e do ensino fundamental e médio. As poucas obras doadas por artistas ao NAC são utilizadas para decorar as salas do Núcleo, da Reitoria, Biblioteca,

\footnotetext{
${ }^{89}$ Dados obtidos no Formulário Vitae, 1996.

${ }^{90}$ Dados obtidos no Formulário Vitae, 1996.
}

Segundo a coordenadora da Pinacoteca, Lívia Carvalho, a maior parte dos visitantes é de estudantes, funcionários e professores por causa de sua localização numa área de grande circulação do campus. Os registros de visitação são feitos por livro de assinaturas e, segundo ela, poucos visitantes se preocupam em assinar. Além disso, no período de recesso e em caso de greve não há visitação, como ocorreu em 2000, período em que a visitação anual registrada foi de apenas 130 pessoas.(Carvalho, 2001) 
etc $^{91}$. Alguns alunos da UFPB desenvolvem estágios no NAC. (Lívia M. Carvalho, 2000)

Tanto a Pinacoteca como a Galeria do NAC têm como acervo obras doadas, especialmente de artistas locais. A UFPB assim como a maior parte das universidades brasileiras, recebe cada vez menos verbas para sua manutenção. Assim, as verbas para possíveis aquisições são nulas e os acervos dependem da doação para crescer, e acabam por ter um perfil regional pela participação dos artistas locais. Apesar da Pinacoteca ter como objetivo (item 2) a coleta de obras nacionais e estrangeiras, na prática a coleção fica restrita aos artistas locais.

A UFPB se destaca em relação às outras universidades com coleções de arte pelo fato de manter dois núcleos de pesquisa ligados às coleções - de arte popular e de arte contemporânea. Entretanto, os professores não são lotados nem na Pinacoteca, nem no NAC, mas sim em seus departamentos, dispondo de algumas horas para desenvolver esses trabalhos. A Pinacoteca está intimamente ligada às atividades de ensino de Arte da UFPB, servindo seu acervo para o desenvolvimento de aulas como para o trabalho de documentação e pesquisa em Semiótica pelos professores e alunos. Assim, as coleções de arte da UFPB parecem estar servindo tanto à comunidade em geral como ao ensino e à pesquisa universitários.

Como em outros museus universitários ou não, a dificuldade maior é a de ampliação de acervo, totalmente dependente de doações. Essa limitação poderia acabar por restringir as possibilidades de pesquisas e levar à busca de outros temas estranhos às coleções da UFPB.

\subsection{Museu D. João VI - UFRJ}

A Universidade Federal do Rio de Janeiro (UFRJ) é responsável pelo Museu Nacional, Museu da Escola de Engenharia e Museu D. João VI, os dois últimos localizados no campus da llha do Fundão, no Rio de Janeiro.

O Museu D. João VI foi criado em 1979 e oficializado em 1980, subordinado à Escola de Belas Artes (EBA). Seu acervo foi formado com peças da Academia Imperial de Belas Artes, ligadas à atuação da missão artística francesa e ao desenvolvimento do ensino artístico no Brasil nos séculos XIX e XX. O acervo, basicamente de artes

\footnotetext{
${ }^{91} \mathrm{Na}$ opinião de L. Carvalho, o NAC possui acervo significativo de pedras litográficas e de litogravuras, em termos regionais. (Carvalho, 2001)
} 
visuais, tem cerca de 10.000 peças além de 9.000 documentos, principalmente sobre o ensino artístico no Brasil. ${ }^{92}$

As finalidades definidas pelo seu Regimento são:

“I - Reunir, conservar, preservar, classificar, divulgar e expor os bens que constituem e que vierem a constituir o acervo do Museu, integrando o patrimônio artístico e documental da Escola de Belas Artes.

II - Divulgar a memória do ensino artístico no Brasil.

III - Promover exposições de caráter educativo e cultural, conferências, cursos livres, seminários, atividades de pesquisa, concursos, publicações, comemorações e outras atividades culturais, concernentes ao funcionamento do Museu, visando promover, estimular e difundir o conhecimento das artes e outros interesses próprios dos cursos ministrados na Escola de Belas Artes.

IV - Colaborar para a otimização do desempenho das atividades didáticas a cargo da UFRJ, atuando como um laboratório de estudos da graduação e da pósgraduação.

V - Desenvolver e manter relações de intercâmbio cultural no país e no exterior, notadamente com instituições congêneres." (Universidade Federal do Rio de Janeiro, Regimento do Museu D. João VI, s.d., grifo nosso)

De acordo com o Regimento, o Museu D. João VI deve servir aos interesses didáticos dos professores da EBA, servindo como um laboratório de estudos para as diversas disciplinas. Dos regimentos e textos sobre museus de arte universitários no Brasil, esse é o primeiro a explicitar o uso do espaço para a experimentação e para o ensino universitário em suas finalidades. Em outros trechos do Regimento encontramos a estreita relação da pesquisa e ensino da EBA com o Museu:

"Artigo terceiro - O Coordenador, no exercício da Coordenadoria, superintende todas as atividades do Museu(...)

Artigo quarto - O Coordenador é designado pelo Diretor da Escola de Belas Artes, (...)

Parágrafo primeiro - A escolha do Coordenador deve recair, preferentemente, em ocupante da carreira do magistério, pertencente à Escola de Belas Artes e lotado no Departamento de História e Teoria da Arte/BAH.

(...)

Artigo décimo sétimo - O setor de Pesquisa e Curadoria é composto por docentes e técnicos lotados na EBA, que desenvolvam seus estudos ligados ao acervo do Museu, à Graduação e à Pós-Graduação pela figura do Curador.

Artigo décimo oitavo - O Curador é designado pelo Coordenador do Museu, ouvido o Conselho Consultivo e deve, preferentemente, pertencer aos quadros da Universidade." (UFRJ, Regimento Museu D. João VI, s.d.)

\footnotetext{
92 Dados obtidos no Formulário Vitae, 1997 e Formulário CPC/Vitae 1999.

Um dos critérios para dividir o acervo da antiga Escola de Belas Artes em 1937, foi deixar os documentos e obras (pintura acadêmica, obras de professores da escola, exercícios de alunos) mais relacionadas ao ensino com a EBA e as outras obras ficariam para o Museu Nacional de Belas Artes. Posteriormente o Museu D. João VI recebeu doações como a coleção do português Jerônimo das Neves e de alguns ex-professores. (Almir Paredes, 2001)
} 
Na prática, o diretor do museu deve ser o diretor da EBA e todas as propostas do coordenador do museu devem ser aprovadas pela EBA, sendo assim, uma relação de submissão do museu em relação à Escola de Belas Artes. ${ }^{93}$

A exposição inaugural (1979) apresentava um roteiro didático da história da Escola, desde a chegada da Missão Artística Francesa até os professores atuantes na época. A Coleção Jerônimo das Neves, a coleção de medalhas e o acervo Girardet foram apresentados em três conjuntos separados. (Paredes, 1999:68)

O Museu $D$. João $\mathrm{VI}$ está no $2^{\circ}$ andar do prédio da Reitoria, na Ilha do Fundão, distante do centro da cidade do Rio de Janeiro. O principal público é formado por alunos da EBA que, somados ao público em geral, perfazem cerca de 1.000 visitantes por ano. Raramente o museu realiza exposições temporárias e apenas uma pequena parte do acervo está em exposição. ${ }^{94}$

A documentação histórica sobre a Academia Imperial de Belas Artes e as obras pertencentes ao museu permitem uma série de pesquisas sobre a história do ensino da arte e suas expressões. Como vimos, o regimento sugere que o coordenador do museu pertença ao Departamento de História e Teoria da Arte, valorizando as linhas de pesquisa dentro dessas áreas.

As pesquisas, ainda de acordo com o regimento, são realizadas pelo corpo docente da EBA e o acervo do museu deve servir aos professores para o ensino. Consideramos essas regras propostas pelo regimento do Museu D. João VI coerentes com a proposta de trabalho de um museu universitário. Entretanto, na prática, são poucos professores que desenvolvem pesquisas e somente professores de História da Arte e de Desenho utilizam o acervo para suas aulas. Os alunos de mestrado consultam documentação do Museu D. João VI, uma vez que o programa é de História da Arte e deve ser sempre do Brasil. O programa de doutorado, iniciado recentemente, tem uma tese a ser defendida em 2001, realizada pela professora e ex-coordenadora do museu Cybele V. Neto Fernandes, na qual utilizou material do acervo como fonte. (Paredes, 2001)

Devemos ponderar também que, apesar de ter um rico acervo do século XIX, não é o único desse período no Rio de Janeiro, pois o Museu Nacional de Belas Artes

\footnotetext{
${ }^{93}$ De acordo com o professor Almir Paredes, o último coordenador do museu perdeu seu cargo por tentar tomar decisões de forma autônoma, sem submete-las à diretoria da EBA. Em 2000, ficou definido que um colegiado de 3 pessoas coordenaria o museu - Os museólogos e professores da EBA Valdir Soares e Sônia Gomes Pereira e o professor aposentado Almir Paredes. (Paredes, 2001)

${ }^{94}$ Dados obtidos no Formulário Vitae 1997. Em abril de 2001 fomos informados que o museu só poderia ser visitado mediante solicitação por escrito e agendamento prévio.
} 
concentra grande quantidade de obras do século XIX no Brasil. Dessa forma, o fato de estar em local de difícil acesso não prejudica tanto o público em geral, pela existência de acervos equivalentes em outros museus mais centrais.

\subsection{Galeria de Arte UNICAMP}

A Galeria de Arte da Universidade Estadual de Campinas (UNICAMP) foi criada em 1983 e aberta ao público em 1984. Inicialmente, um Conselho de professores e artistas da cidade de Campinas desenvolveu o projeto de formação do acervo, obtido principalmente pela doação de obras de artistas contemporâneos de Campinas. Em 1990, o Conselho passou a contar apenas com professores, alunos e funcionários do Instituto de Artes da UNICAMP.

A Galeria está atualmente instalada no prédio da Biblioteca Central da UNICAMP, com espaço adaptado para exposição e reserva técnica. O acervo tem cerca de 210 obras de artistas brasileiros, sendo 148 pinturas, 50 gravuras, 8 desenhos, 3 objetos e 1 escultura. Algumas obras estão expostas na Reitoria e em outros locais da UNICAMP. ${ }^{95}$

A Galeria realiza exposições de seu acervo uma vez por ano e no período restante (10 a 11 meses) apresenta obras de artistas previamente selecionados pelo Conselho e obras de professores e alunos da UNICAMP. Também realiza exposições no campus e em outros pontos de Campinas $^{96}$. Organiza palestras, seminários e debates sobre arte, voltadas para o público universitário a partir das exposições promovidas. Entre as finalidades estabelecidas por seu regimento estão:

"I - desenvolver e promover a cultura, a pesquisa e o ensino das artes plásticas, num contexto contemporâneo, histórico e informativo;

II - organizar exposições públicas;

III - zelar pelo respectivo acervo, promovendo a sua ampliação e aperfeiçoamento;

IV - promover pesquisas destinadas a aumentar o conhecimento das diferentes áreas de interesse da Galeria, unidades de ensino e pesquisa da Universidade, como também Núcleos e Centros;

$\mathrm{V}$ - propiciar o aperfeiçoamento científico e cultural de seus especialistas e funcionários;

$(\ldots)$

VIII - promover atividades culturais como prestação de serviços à comunidade;

\footnotetext{
${ }_{95}^{95}$ Dados obtidos no Formulário CPC/Vitae 1999.

${ }^{96}$ Em 1997, por exemplo, a galeria produziu exposição no Centro de Convivência Cultural de Campinas, no Hall de entrada do Shopping Ouro Verde, no hall de entrada da Biblioteca Central da UNICAMP e na Faculdade de Educação da UNICAMP. Relatório de atividades de 1997, anexo Formulário CPC/Vitae 1999.
} 
IX - promover cursos de difusão cultural, de extensão universitária ou de aperfeiçoamento sobre assuntos de suas áreas de interesse;

$X$ - estreitar as relações existentes entre a Galeria, os Núcleos e os Centros afins existentes na Universidade, enfatizando a pesquisa interdisciplinar em proveito de sua personalidade coletiva e do enriquecimento do acervo. (...)" (Instituto de Artes, Regimento Interno da Galeria de Arte UNICAMP, s.d.)

Muitas das finalidades não são efetivadas na prática. A Galeria trabalha em função das exposições temporárias, não existindo pesquisas de seu acervo nem professores que dêem aulas na Galeria. A participação dos professores do IA se dá principalmente pela sugestão de artistas para exposição e na seleção destes, caso façam parte do Conselho.

Um dos fins que nos parece muito importante e original em relação aos outros museus e galerias estudados é o quinto $(\mathrm{V})$, que prevê o aperfeiçoamento dos especialistas e funcionários da Galeria. A princípio, tal objetivo parece ser corriqueiro para um órgão de uma universidade, entretanto no cotidiano dos museus universitários, nem sempre seus especialistas e funcionários encontram compreensão da importância dos estudos de graduação e pós-graduação para seu aperfeiçoamento profissional. $\mathrm{Na}$ prática, os funcionários da Galeria não dispõem de tempo para realizar cursos, uma vez que são dois técnicos de nível superior que realizam todas as atividades, apoiados eventualmente por funcionários operacionais do Instituto de Artes. ${ }^{97} \mathrm{Em}$ relação aos museus da USP, não foram poucos os colegas que tiveram que brigar para poder assistir cursos e realizar pesquisas de pós-graduação em seu horário de trabalho. Infelizmente, nos regimentos dos museus da USP não há qualquer menção sobre essa questão, deixando em aberto para que cada direção decida qual política adotar. ${ }^{98}$

A Galeria é coordenada por um docente especialista em Artes Plásticas da UNICAMP designado pelo Diretor do Instituto de Artes (IA) a partir de uma lista tríplice elaborada pelo Conselho de Arte. O Conselho, como exposto acima, é formado por docentes, um representante dos funcionários e um representante discente, todos do IA. A estruturação mostra sua subordinação ao IA, pois são seus docentes que compõem a direção da Galeria, definem as linhas de pesquisa ${ }^{99}$ e a programação. Segundo o artigo 21 do Regimento Interno:

\footnotetext{
${ }^{97}$ Depoimento de Vera Semaniuc, técnica de nível superior, 2001.

${ }^{98}$ Esse problema não afeta apenas os servidores de museus da USP mas também de outros órgãos da universidade. No caso do Museu de Arqueologia e Etnologia da USP, por exemplo, durante a gestão do professor Adilson Avansi de Abreu, foi regulamentada uma norma interna sobre os períodos para assistir cursos e desenvolver pesquisas para os especialistas.

${ }_{99} \mathrm{Na}$ prática o Conselho atua na seleção de portfolios de artistas para exposições e não propõe linhas de pesquisa.
} 
"Os especialistas e docentes da Área Científica designados para exercício na Galeria, terão autonomia individual na escolha de seu campo de pesquisa, respeitadas as limitações decorrentes da área de atividade da respectiva Galeria, de seus recursos materiais e campo de interesse da Galeria." (UNICAMP, Regimento Interno Galeria de Arte da UNICAMP, s.d.)

A Galeria conta com pequeno acervo e realiza principalmente exposições com obras vindas de fora e de trabalhos de professores, alunos e ex-alunos do IA. Sua atuação parece ser muito semelhante às galerias de arte de universidades norteamericanas, inclusive pelo fato de que algumas de suas obras servem para decorar os prédios da universidade. Apresenta a arte contemporânea sempre com ênfase em artistas de Campinas e região. A visitação em 1997 foi de 4.600 pessoas e em 1998 de 5.200 pessoas. $^{100}$

\subsection{Museu Regional de Arte / UEFS}

A Universidade Estadual de Feira de Santana (UEFS) na Bahia tem sob sua guarda o Museu Casa do Sertão e o Museu Regional de Arte, ambos localizados em Feira de Santana. A UEFS foi criada em 1970 e instalada em 1976 na cidade de Feira de Santana, na Bahia.

O Museu Casa do Sertão, inaugurado em 1978, pretende preservar a cultura sertaneja, a história e tradição da região de Feira de Santana. Seu acervo reúne peças em couro, fibra, palha, barro, madeira e metal relacionadas ao trabalho com o gado e outras atividades locais. O Museu também possui uma discoteca de músicas sertanejas, títulos e temas de Literatura de Cordel e matrizes de xilogravura. Incorporou recentemente o Centro de Pesquisa e Documentação de Feira de Santana - CPDOFS - reforçando mais ainda seu perfil de centro de pesquisa de história regional. ${ }^{101}$

Já o Museu Regional de Arte, desde sua criação, é voltado para a arte. Fundado em 1967 dentro da campanha de Assis Chateaubriand de formação de museus regionais $^{102}$, foi incorporado a UEFS em 1985. Seu acervo era formado inicialmente por 30 obras de artistas ingleses modernistas doadas por Assis Chateaubriand, obras de artistas modernos brasileiros (como Rego Monteiro, Di Cavalcanti e Graciano), obras

\footnotetext{
${ }^{100}$ Números obtidos no Formulário CPC/Vitae 1999.

101 Dados obtidos na página da Internet da UEFS, 2000.

102 Como já explicado no item 5.4. deste capítulo, os museus eram denominados "regionais", mas as obras que constituíram seus acervos iniciais provinham de várias regiões do Brasil e mesmo de outros países, de onde o nome "regional" perde seu significado. No caso de Feira de Santana, o museu manteve o termo regional em seu nome, ao contrário dos museus de Belo Horizonte e Campina Grande.
} 
de artistas baianos (como Genaro de Carvalho, Cravo Junior) e artesanato regional em couro $^{103}$. Mais tarde, a coleção de artesanato seria transferida para o Museu Casa do Sertão da UEFS. (Lourenço, 1999)

Em 1995 o Museu Regional de Arte passa a ocupar a parte histórica do Centro Universitário de Cultura e Arte (CUCA) "dotado de excelentes instalações físicas com ambiente climatizado." 104 Nesse espaço, reinaugurado em maio de 1999, o acervo foi exposto em três segmentos: modernistas ingleses, modernistas brasileiros (exceto baianos) e modernistas baianos. Nessa época foram contratados dois historiadores para trabalhar no Museu, além de um museólogo. A coleção de modernistas ingleses já foi emprestada para algumas exposições no Brasil, mas o Museu Regional de Arte não tem espaço para receber exposições de fora. Em alguns períodos o próprio acervo é exposto de maneira diferente seguindo outras temáticas.

As coleções não estão sendo objeto de pesquisas. Há alguns estudos de identificação para realizar a documentação das obras, mas nenhuma pesquisa específica. Os professores de Arte da UEFS raramente realizam visitas com seus alunos para ilustrar alguma aula, mas não há nenhuma relação permanente com os departamentos de ensino. No início de 2001, o Museu se encontra novamente em reformas emergenciais ocasionadas por fortes chuvas que danificaram os telhados e estruturas internas do prédio. ${ }^{105}$

O CUCA da UEFS pretende ser um centro de "excelência na pesquisa e democratização do saber cultural e artístico nas suas mais variadas linguagens" (Página da internet da UEFS, 2000). Entre as instalações do CUCA estão oficinas, sala de vídeo, experimentoteca, laboratório de informática, teatro e duas galerias de arte: Galeria de Arte Carlo Barbosa e Galeria de Arte Caetano Veloso. As atividades do CUCA são de extensão, voltadas para a comunidade em geral.

A Galeria de Arte Carlo Barbosa expõe artistas locais e regionais novos e também renomados, abrindo-se também para a venda de obras. Alguns desses artistas doaram obras para o Museu Regional de Arte. A Galeria de Arte Caetano Veloso foi

103 Segundo o historiador Walney Costa Oliveira (2001), o acervo continua praticamente o mesmo, tendo sido ampliado por algumas doações pois o Museu não dispõe de verbas para aquisição. Foi recentemente instalado um Conselho de aquisição para selecionar as obras oferecidas em doação, para levar a um crescimento quantitativo e também qualitativo do acervo.

${ }^{104}$ Página da internet da UEFS, 2000. O estado de conservação das obras, há 5 anos atrás, foi considerado "delicado, sem conservação" pela professora Maria Cecília F. Lourenço (1999). Foi então feito um trabalho de restauração das obras, por profissionais especialmente contratados, que está em sua fase final (Walney Oliveira, 2000).

${ }^{105} \mathrm{O}$ museu fica em um prédio histórico. A previsão é de que o Museu Regional de Arte reabra no mês de maio de 2001. 
criada em 1998 e "surgiu da necessidade de viabilizar o antigo Museu Regional de Santo Amaro." Sem acervo inicial, a galeria realiza exposições periódicas e está formando acervo permanente. (Página da internet da UEFS, 2000)

A criação dessas galerias parece responder mais às necessidades da cidade do que da própria universidade, mesmo com a existência de um Museu de Arte Contemporânea municipal. Ao contrário do Museu Casa do Sertão que se afirma como um espaço para "viabilização da pesquisa histórica em nível de graduação e pósgraduação sobre Feira de Santana e região" ${ }^{106}$, nem o Museu Regional de Arte, nem as galerias parecem ter projetos relacionados ao ensino universitário, sendo mais voltados à comunidade em geral.

\subsection{Museu de Arte Leopoldo Gotuzzo - UFPel}

A Universidade Federal de Pelotas (UFPel) no Rio Grande do Sul, tem sob sua responsabilidade o Museu de Ciências Naturais Carlos Ritter e o Museu de Arte Leopoldo Gotuzzo, ambos em Pelotas.

A coleção do pintor e desenhista Leopoldo Gotuzzo foi doada à Escola de Belas Artes D. Carmen Trápaga Simões na década de 50. Essa era uma escola privada que foi agregada à UFPel em 1969 juntamente com o seu acervo, que passaria a pertencer ao Instituto de Letras e Artes. Em 1983, com a morte do artista, novas obras e objetos foram doados em testamento a um futuro museu. O Museu Leopoldo Gotuzzo (MALG) foi inaugurado em 1986 e atualmente está subordinado ao Instituto de Letras e Artes (ILA).

O acervo é de cerca de 600 obras, entre desenhos, pinturas, gravuras, esculturas e fotografias das coleções Leopoldo Gotuzzo, Trápaga Simões, Dr. João Gomes de Mello, coleção de ex-alunos da antiga Escola de Belas Artes e coleção Século XX. Assim, apesar do nome permanecer "Leopoldo Gotuzzo" o museu tem obras de outros artistas.

Quando da abertura do Museu, em 1986, já existia o Curso de Licenciatura em Artes e o Curso de Graduação em Pintura, Escultura ou Gravura no Instituto de Letras e Artes da UFPel. Entretanto, só em 1992, O MALG passou a integrar a estrutura administrativa do ILA da Universidade. Atualmente, no ILA, existem os seguintes cursos de graduação: Licenciatura em Artes, Licenciatura em Letras, Design Gráfico, Artes Visuais e um Curso de Pós-Graduação em Artes: Patrimônio Cultural.

${ }^{106}$ Página da internet da UEFS, 2000. 
A chefia do museu é subordinada ao ILA. Segundo a programadora cultural do MALG, professora Maria Cristina Padilha Leitzke,

"A partir deste ano [2000], foram propostas algumas atividades em parceria com os Cursos do ILA e demais departamentos acadêmicos. (...) diferentes ações vêm sendo realizadas junto ao Museu visando cada vez mais a aproximação da comunidade universitária. Diferentes cursos vêm sendo oferecidos (História da Arte, Leitura de Imagens, História-arte-arquitetura da cidade de Pelotas, entre outros). No primeiro semestre deste ano, as aulas de duas disciplinas dos cursos de artes do ILA, foram realizadas nos espaços do Museu tendo como temas as obras de nosso acervo. Enfim, as expectativas são muitas. Foi, inclusive, lançado um jogo da memória, através do projeto LUDOTECA do DAV/ILA, tendo como referencial as obras do acervo do Museu. Desde o ano de 1994 os alunos dos cursos de artes do ILA estão realizando estágios no Museu. Inicialmente, eram apenas os bolsistas do PET- Programa Especial de Treinamento(artes e arquitetura). Atualmente, além dos bolsistas do PET contamos, também, com a participação de estudantes do Curso de Licenciatura em Artes que atuam junto aos projetos do Museu. Pretende-se, ainda, para o próximo ano, ampliar ainda mais esta atuação, inclusive, para os estudantes de outras áreas afins. (Leitzke, M. C., 2000)

Essa aproximação se deve ao esforço da equipe do museu ${ }^{107}$ e parece que está em um caminho muito promissor. A dúvida é se a limitação do acervo não poderia também limitar as atividades em conjunto com o ILA. Para a programadora cultural do MALG, Maria Cristina Leitzke, muitos alunos e professores do ILA desprezam o acervo do museu pelo fato das obras serem basicamente figurativas, enquanto o Curso de Artes Visuais valoriza a formação do artista voltado para a arte conceitual. Esses alunos e professores freqüentam o MALG quando são realizadas exposições temporárias de artistas contemporâneos, mas evitam o acervo. Em contrapartida, a população da cidade admira o acervo do MALG e reclama das exposições de arte contemporânea porque não entende a arte conceitual.

Para os profissionais do MALG fica o desafio de valorizar um acervo datado propondo novas leituras à comunidade universitária e, ao mesmo tempo, criar meios para a população entender e apreciar a arte conceitual. ${ }^{108}$

O MALG, assim como outros museus aqui apresentados, tem uma clara limitação de acervo, que prejudica ou até inviabiliza propostas de desenvolvimento de pesquisa e ensino universitários. Esses museus acabam por se voltar para a

\footnotetext{
107 A programadora cultural M. Cristina Leitzke fez o curso de pós-graduação de UFPel em Patrimônio e seu trabalho denominou-se "O MALG e a comunidade estudantil da UFPel: o Museu como lugar de Educação". Desde sua entrada no MALG, em 1994, vem se preocupando com essa questão e agora o MALG conseguiu efetivar algumas ações concretas.

${ }^{108} \mathrm{Em}$ novembro de 2000 foi oferecido à comunidade em geral o curso "História da Arte Moderna e Contemporânea" visando amenizar essa dificuldade de compreensão da população.
} 
comunidade, oferecendo atividades de extensão para escolas de ensino fundamental e médio e para outros segmentos da sociedade, afastando-se cada vez mais dos departamentos de ensino e da pesquisa universitária.

\section{Considerações sobre os museus de arte universitários brasileiros}

Por meio da breve descrição dos museus de arte universitários do Brasil podemos perceber algumas questões recorrentes e alguns elementos mais específicos.

A grande maioria dos museus foi formada por coleções e iniciativas de fora das universidades e/ou de fora dos departamentos de arte e disciplinas afins. Certamente isso dificulta o estabelecimento de relações de trabalho entre os departamentos de ensino e os museus. Percebemos uma tendência à regionalização das coleções, na valorização de artistas locais e na coleta de peças de arte popular local, financeiramente mais viável dentro do contexto universitário de constante carência de verbas.

As coleções abrigam prioritariamente artistas brasileiros, à exceção daqueles museus que têm obras do período colonial - D. João VI da UFRJ e o Museu de Arte Sacra da UFBA -, aqueles formados pela campanha de museus regionais de Assis Chateaubriand - Museu de Arte Assis Chateaubriand da UEPB, Galeria Brasiliana da UFMG, Museu Regional de Arte da UEFS -, e o Museu de Arte Contemporânea da USP.

São poucas as coleções desses museus que se destacam no cenário nacional: as exceções são o Museu de Arte Sacra da UFBA e o Museu de Arte Contemporânea e a Coleção de Artes Visuais do IEB da USP. Os outros se destacam em seus estados e/ou regiões, como o Museu Assis Chateaubriand da UEPB.

Os mais recentes, principalmente as Galerias da UNICAMP e da UFES, tem acervo formado por doações de artistas locais e apresentam basicamente exposições temporárias. No caso da Galeria Brasiliana da UFMG, a coleção básica é eclética e tem obras de artistas estrangeiros, mas as coleções contemporâneas são basicamente doações da sociedade local, principalmente de obras de artistas mineiros.

Os acervos desses museus favorecem a pesquisa acadêmica? Essa pergunta é difícil de ser respondida, entretanto há indicações de que a heterogeneidade, a ausência de séries e conjuntos significativos (do mesmo autor, de um mesmo estilo, de um período ou local, etc.) dificultam o desenvolvimento de pesquisas sistemáticas. Nenhum dos museus brasileiros descritos neste capítulo contam com docentes ou 
pesquisadores em tempo integral, com exceção de seus diretores que ficam somente durante o período de sua gestão ou professores temporariamente lotados em cargos de confiança.

Se as pesquisas são raras, não é possível oferecer sistematicamente cursos seja disciplina de graduação ou pós-graduação, seja de extensão.

Os cursos oferecidos pelos museus e galerias são voltados para a comunidade em geral e seus conteúdos são prioritariamente técnicos, como gravura, pintura ou bordado. Os professores desses cursos são, muitas vezes, os artistas expositores ou convidados e não professores ligados aos museus e galerias. Dessa forma, o ensino é basicamente voltado para a extensão e não para a formação universitária, com ênfase para o atendimento de escolas de nível fundamental e médio.

Todos os museus parecem sofrer de falta de verbas para aquisição, dependendo de doações de obras ou de dinheiro para comprá-las. Também parece ser uma unanimidade a obrigação de receber determinadas doações sem que necessariamente correspondam ao perfil e/ou política de aquisição da instituição. Entre os museus de arte contemporânea, o MAC/USP parece ser o único que não desenvolve ações para continuidade de aquisição de acervo por meio de exposições e doações de artistas locais. $^{109}$

São poucos os museus que contam com profissionais das diversas áreas da museologia: documentação, conservação, museografia e educação. O MAAC/UEPB tem arte educador, museólogo e dois restauradores, mas contratou recentemente empresa para realizar restauração de obras de seu acervo. (Negrão, 2001) No caso da UFMG, por exemplo, as obras da Galeria Brasiliana puderam ser restauradas porque a universidade tem um importante centro de ensino de restauro. No geral, os museus têm poucos servidores e contam com o auxílio de estagiários e bolsistas. Uma exceção, como veremos, é o MAC/USP, que tem mais de 100 servidores. Cabe ressaltar novamente aqui o regimento da Galeria da UNICAMP que prevê, ainda que em teoria, a formação de seus servidores além da liberdade para escolha de tema de pesquisa.

Com exceção do Museu $D$. João VI da UFRJ, que está no $2^{\circ}$ andar do prédio da EBA e do Museu de Arte Popular e da Pinacoteca da UFPB, que também estão em salas adaptadas, todos os outros têm espaços próprios, entretanto são poucos aqueles que estão em espaços construídos adequadamente para abrigar o museu.

\footnotetext{
${ }^{109}$ O MAC/USP definiu no final do ano 2000 uma política para aquisições que será apresentada no próximo capítulo.
} 
Quanto às relações com os departamentos de ensino afins, vimos que a maior parte desses museus não cultiva relações sistemáticas com as áreas de ensino de arte. $^{110}$ Devemos lembrar aqui que o Museu $D$. João $\mathrm{VI}$ aparece totalmente subordinado à Escola de Belas Artes, assim como as Galerias da UNICAMP e da UFES e a Pinacoteca da UFPB. Entretanto, isso nem sempre significa que as coleções e exposições estejam sendo utilizadas pelos departamentos de ensino e que os profissionais dos museus atuem dentro dos departamentos de ensino. Os esforços recentes apresentados pela equipe do Museu Leopoldo Gotuzzo merecem atenção no sentido de conhecermos seus resultados em médio e longo prazo. ${ }^{111} \mathrm{O}$ MAC/USP se diferencia dos outros museus por ter pesquisadores próprios, que podem desenvolver a carreira acadêmica, oferecer disciplinas para a graduação e cursos de especialização no museu.

Dentro desse cenário de museus de arte universitários do Brasil, o MAC/USP e a Coleção de Artes Visuais do IEB parecem se destacar pela originalidade e qualidade dos seus acervos em âmbito nacional. O MAC, como veremos, destaca-se por ter um corpo técnico especializado em diversas áreas da museologia além de pesquisadores; o IEB, destaca-se por suas pesquisas e suas coleções não só de artes visuais mas também de livros e documentos, fundamentais para o estudo da cultura brasileira.

\footnotetext{
${ }^{110}$ O MAS serviu como museu-escola para os alunos de ação cultural do Curso de Museologia da UFBA, mas sempre com a iniciativa dos professores de Museologia e não dos profissionais do museu.

111 Se essas ações dependerem apenas da vontade de alguns funcionários e não forem institucionalizadas, elas correm maior risco de ser interrompidas.
} 
CAPÍTULO 4

Museu e coleção de arte da USP: Coleção de Artes Visuais do Instituto de Estudos Brasileiros e Museu de Arte Contemporânea 


\section{CAPÍTULO 4}

\section{Museu e coleção de arte da USP: Coleção de Artes Visuais do Instituto de Estudos Brasileiros e Museu de Arte Contemporânea}

Neste capítulo apresentaremos uma descrição da Coleção de Artes Visuais do Instituto de Estudos Brasileiros (IEB) e do Museu de Arte Contemporânea (MAC), ambos da Universidade de São Paulo, destacando os aspectos que consideramos fundamentais em um museu universitário.

É importante ressaltar que a Universidade de São Paulo possui outros espaços para exposição de arte, como o Centro Universitário Maria Antonia (CEUMA) e as "galerias" das faculdades, como as da Escola de Comunicações e Artes (ECA), Faculdade de Educação (FE) e da Faculdade de Arquitetura e Urbanismo (FAU). No caso do CEUMA, as exposições podem ser produtos de pesquisas de diferentes departamentos da USP, assim como de artistas convidados. As galerias das faculdades costumam apresentar trabalhos / obras de seus alunos e professores, divulgando as atividades da própria unidade. Assim, nenhum desses espaços possui acervo próprio, considerado aqui uma das condições para ser um museu, objeto de nosso estudo.

$\mathrm{Na}$ introdução da tese, definimos as características desejáveis para um museu universitário. Consideramos que um museu universitário, idealmente, deveria realizar todas as funções de um museu, de acordo com a definição do $\operatorname{ICOM}^{1}$, e além disso deveria:

1) abrigar / formar coleções significativas para desenvolvimento de pesquisa, ensino e extensão;

2) dar ênfase ao desenvolvimento de pesquisas a partir do acervo;

3) manter disciplinas que valorizem as coleções e as pesquisas sobre as coleções;

4) participar da formação de trabalhadores de museus;

\footnotetext{
${ }^{1}$ Definição do ICOM, de acordo com seus Estatutos, adotados pela Assembléia Geral de 1989: "O Museu é uma instituição permanente, sem fins lucrativos, a serviço da sociedade e de seu desenvolvimento, aberta ao público, e que faz pesquisas concernentes aos testemunhos materiais do homem e de seu meio, adquirindo-os, conservando-os, comunicando-os e especialmente expondo-os com o propósito de estudo, educação e deleite."
} 


\section{Instituto de Estudos Brasileiros Universidade de São Paulo - 2001}

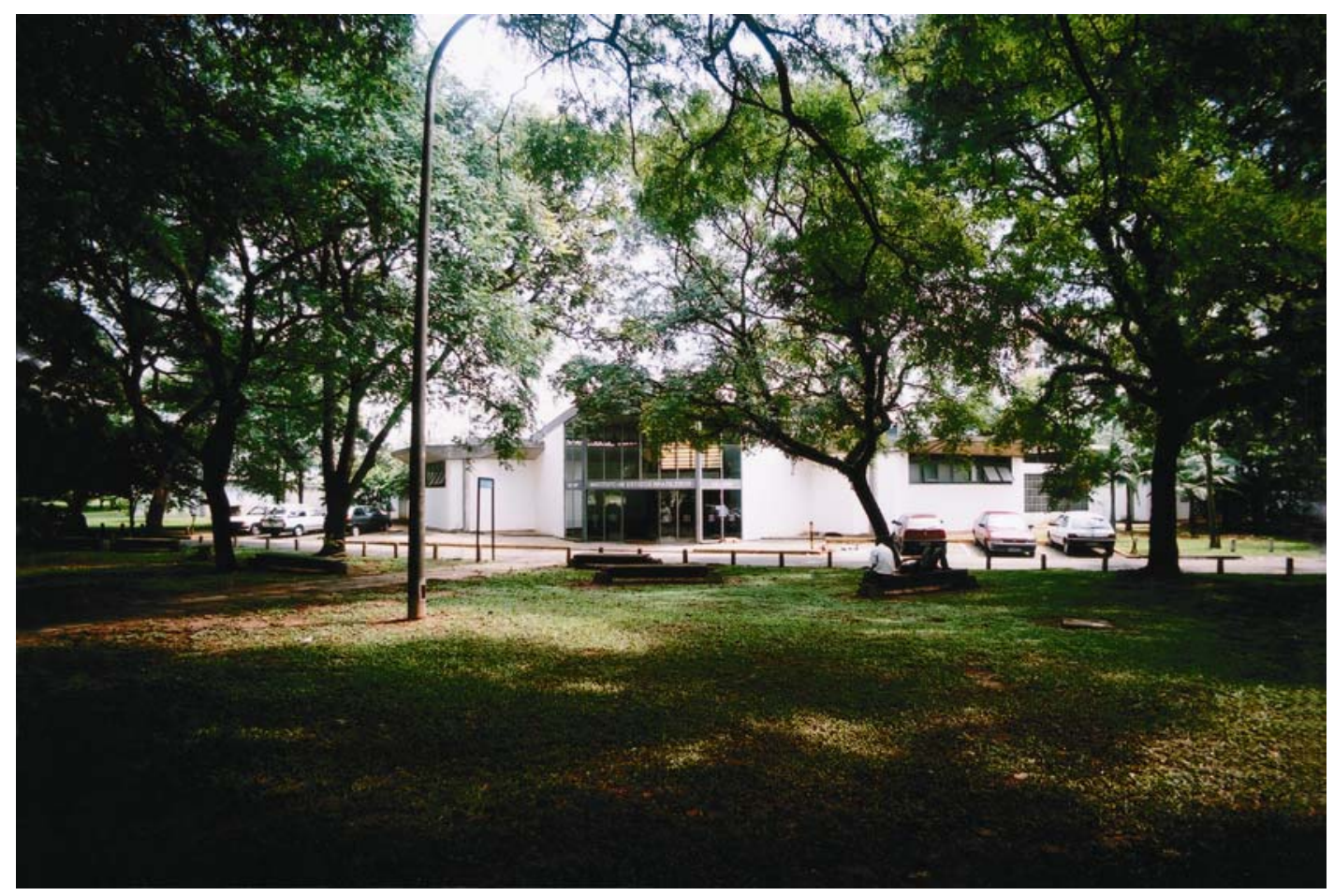

Vista da fachada

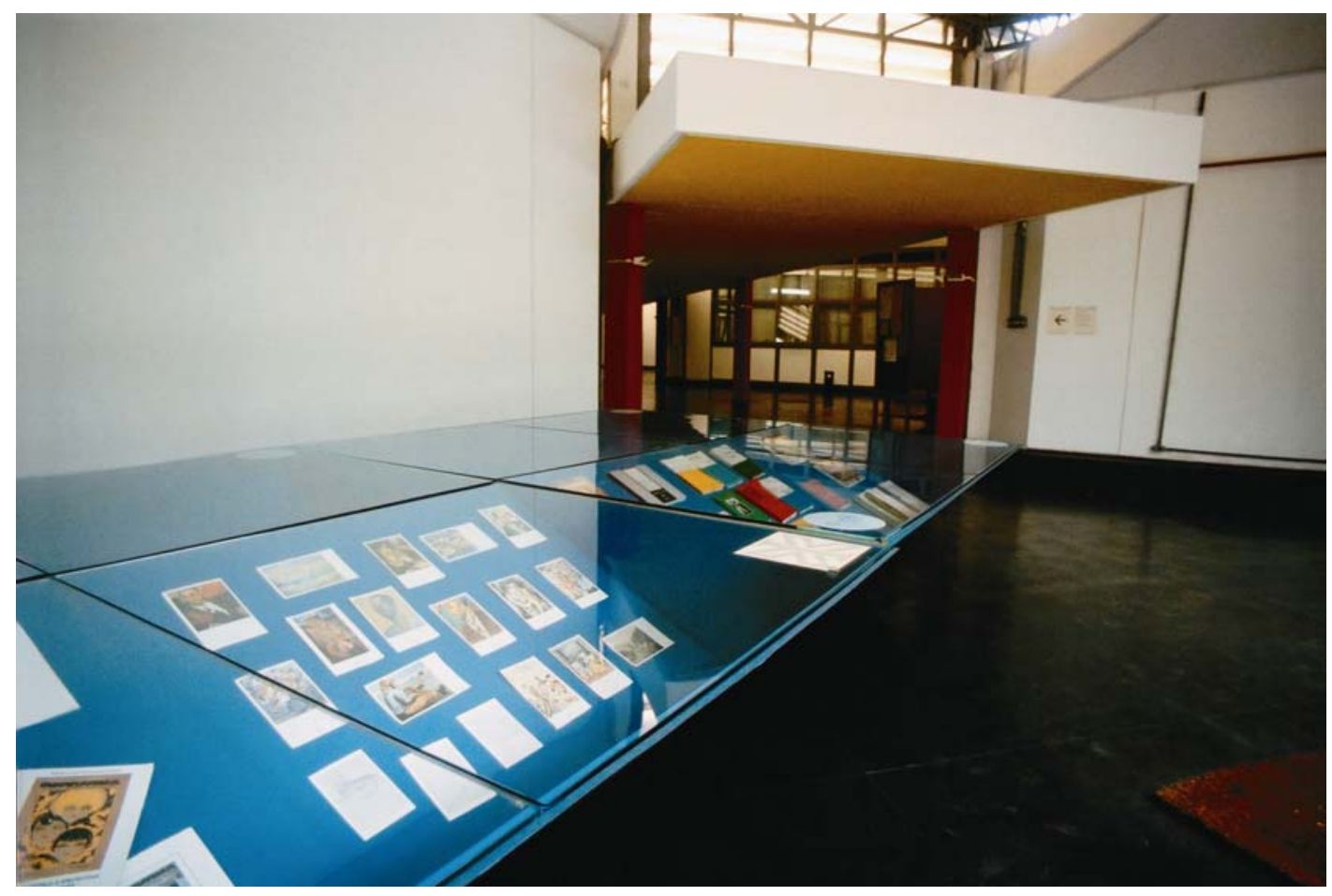

Hall de entrada 
5) propor programas de extensão: cursos, exposições, atividades culturais, atividades educativas baseados nas pesquisas e no acervo;

6) manter programas voltados para diferentes públicos: especializado, universitário, escolar, espontâneo, entre outros, dependendo da disponibilidade de coleções semelhantes na região e do interesse dos diferentes públicos. Esses programas também são frutos de pesquisas.

No panorama dos museus de arte universitários brasileiros, apresentado no capítulo anterior, pudemos verificar que nenhum deles consegue realizar todas as atividades previstas pelo ICOM e nem todas aquelas que elencamos como típicas de um museu universitário. As causas são variadas, mas derivam principalmente do perfil dos acervos, da carência de funcionários especializados, da falta de verbas próprias e da falta de pesquisadores e docentes com dedicação integral aos museus e galerias.

A Coleção de Artes Visuais (CAV) do IEB tem obras nacionais importantes e está dentro de um instituto de pesquisas com diversos docentes integralmente dedicados a ele, sendo que dois deles dedicam-se ao estudo da arte. A Coleção de Artes Visuais está sob responsabilidade de uma especialista ${ }^{2}$.

O MAC/USP tem um corpo de funcionários capacitado para realizar todas as funções previstas pelo ICOM e também tem docentes com dedicação integral que desenvolvem pesquisas e que oferecem disciplinas de graduação e cursos de extensão no museu.

Para apresentar a descrição da Coleção de Artes Visuais do IEB e a do MAC, seguiremos os itens do nosso questionário, completando-os quando considerarmos necessário. Veremos, então, como são essas instituições e se elas se configuram como "museus universitários" pelos parâmetros propostos por nós.

\footnotetext{
${ }^{2} \mathrm{Na}$ Universidade de São Paulo, o termo "especialista" se refere aos servidores de nível superior que não estão na carreira docente.
} 


\section{A Coleção de Artes Visuais do Instituto de Estudos Brasileiros}

O questionário foi respondido pela especialista Eliane M. Paschoal da Silva (2000), exceto as perguntas 9 e 18, respondidas pelo diretor Murillo Marx (2000). Acrescentamos alguns dados históricos, regimentais e de acervo retirados de outras fontes.

\subsection{Dados gerais}

\section{Caracterização}

1. Designação oficial:

Instituto de Estudos Brasileiros - Universidade de São Paulo.

\section{Endereço}

Av. Prof. Mello Moraes, trav. 8 n. 140, Cidade Universitária, São Paulo SP

3. Ano de fundação

IEB: 1962

4. Unidade da USP a que pertence

IEB-USP

\section{O IEB tem regimento?}

O primeiro Regimento do IEB foi aprovado pelo Conselho Universitário em 29 de setembro de 1981 e foi publicado em 07/10/1981. Em 21 de outubro de 1996 foi aprovado o novo regimento ${ }^{3}$, publicado no Diário Oficial em 23/10/1996.

6. Breve histórico do museu

O Instituto de Estudos Brasileiros foi criado em 1962 por iniciativa de Sérgio Buarque de Holanda, que

“... pretendia estabelecer na Universidade um centro interdisciplinar de pesquisa e documentação sobre a história e a cultura do país. Para tanto, destacava, entre seus principais objetivos: 1. propiciar o desenvolvimento de trabalhos conjuntos de professores e pesquisadores que, espalhados por várias unidades da USP, estudavam, cada um em sua área, aspectos da cultura brasileira; 2. abrigar estudiosos que desenvolvessem pesquisas permanentes e de longa duração; 3. também preenchendo uma lacuna na Universidade, esse centro interdisciplinar deveria ser capaz de colher, preservar e organizar fontes primárias para os estudos brasileiros, colocando-as a serviço da pesquisa." (Batista, 1997:13)

A primeira coleção adquirida pelo IEB, de Yan de Almeida Prado, continha documentos e livros. Foi por ocasião da aquisição da coleção de Mário de Andrade, em 1968, que o IEB passou a contar com 1.200 objetos e obras de arte que vieram a

\footnotetext{
${ }^{3} \mathrm{O}$ novo regimento propõe duas finalidades diferentes do anterior, nova estrutura interna para o IEB e descreve as novas regras da carreira docente, estabelecidas no Estatuto da USP.
} 
compor o núcleo inicial da Coleção de Artes Visuais. A partir de 1981, o IEB passou receber novas doações de objetos e obras de arte que foram incorporados ao acervo ${ }^{4}$. A coleção de Mário de Andrade continua sendo a mais importante.

\section{Quais são os objetivos institucionais? (do IEB)}

"Instituição interdisciplinar de pesquisa e cultura do país, capaz de colher, preservar e organizar fontes primárias para os estudos brasileiros, colocando-se a serviço da pesquisa." (Silva, 2000)

De acordo com o novo Regimento, o IEB é um Instituto Especializado ${ }^{5}$ e a sua finalidade é:

"O IEB tem por finalidade a pesquisa da cultura brasileira em seus múltiplos aspectos e, para tanto, deverá:

I - Desenvolver métodos e técnicas de investigação em Ciências Humanas, Letras e Artes, assim como realizar, em caráter permanente, pesquisas relacionadas com os estudos brasileiros.

II - Divulgar os resultados obtidos mediante projetos, palestras, cursos, seminários, intercâmbios, estágios, exposições, publicações.

III - Promover cursos de Pós-Graduação nos níveis Mestrado e Doutorado, disciplinas de Graduação, bem como cursos de Extensão Universitária;

IV - Preservar, organizar e divulgar seu acervo, colocando-o a serviço da atividade de pesquisa e da coletividade" (Regimento do IEB, artigo $2^{\circ}, 1996$ )

8. Qual a área cultural/científica abrangida pelo museu ou coleção?

"Arte e arquitetura no Brasil, Cultura brasileira, Cultura popular." (Silva, 2000)

9. Qual a relação do museu com os departamentos afins? (do IEB)

“É grande e se deseja sempre maior. Na prática, depende dos projetos em andamento, comuns ou não. Institucionalmente, também a relação é muito forte. Não apenas com os Departamentos, mas com as próprias Unidades. Ex.: As 6 Unidades afins são maioria em Conselho Deliberativo." (Murillo Marx, 2000)

\footnotetext{
${ }^{4}$ Coleção Maria Thereza L A. Camargo de instrumentos musicais; Coleção Anita Malfatti, desenhos e matrizes de gravuras; Coleção Carlos Alberto Passos, caricaturas sobre Mário de Andrade; Coleção Bernardino Ficarelli, modelos, fotos e desenhos de ateliê; Coleção Mariana Quito, gravuras; Coleção Heloísa e Graciliano Ramos, desenhos e gravuras; e algumas poucas doações avulsas. (Instituto de Estudos Brasileiros, 1997:164-170)

${ }^{5}$ De acordo com o Regimento Geral da USP (1990), os Institutos Especializados são Órgãos de Integração, assim como os museus. São 5 Institutos Especializados: Centro de Biologia Marinha, Centro de Energia Nuclear na Agricultura, Instituto de Eletrotécnica e Energia, Instituto de Estudos Avançados e Instituto de Estudos Brasileiros (artigo 7). Os institutos especializados estão ligados diretamente à Reitoria e, diferentemente dos museus, não se submetem à Coordenação de Museus. Os órgãos de direção dos institutos especializados são semelhantes aos dos museus (diretoria e conselho deliberativo), assim como a forma de designação de seus diretores e as formas de ingresso e progressão na carreira. (artigos 51 e 52)

${ }^{6}$ O Conselho Deliberativo do IEB tem 9 membros de outras unidades: 3 membros da FFLCH, 1 da Faculdade de Educação, 2 da ECA, 1 da FAU, 1 da FEA e 1 da Faculdade de Direito. Do IEB são 8 membros: 5 docentes e 3 servidores não docentes.
} 


\section{Recursos Humanos}

10. Responsável pelo museu ou pela coleção: (Coleção de Artes Visuais)

Eliane Maria Paschoal da Silva. Técnica especializada de nível superior, Especialista em Conservação. (Silva, 2000)

11. Qual é a estrutura científica? Qual é a estrutura administrativa? Como é o organograma do museu? (Coleção de Artes Visuais)

Dois Técnicos de Nível Superior, um Técnico de Nível médio e um vigia. (Silva, 2000)

12. Há funcionários contratados exclusivamente para atender ao público? Quantos? Em que funções?

Não. (Silva, 2000)

13. Número de funcionários:

Total: 54 (Silva, 2000)

14. São utilizados serviços de terceiros? Quais?

Tradução, projetos gráficos, fotógrafos, manutenção de equipamentos: ar condicionado, sistema de combate a incêndio, etc. (Silva, 2000)

15.0 museu tem estagiários? Em que áreas? Quantos?

Um na área de documentação e outro na área de conservação. (Silva, 2000)

Recursos Financeiros

16. O museu tem verbas próprias anuais?

Participa da verba destinada ao Instituto. (Silva, 2000)

17. Qual a procedência das verbas?

Governo do Estado de São Paulo repassa as verbas destinas às universidades estaduais. (Silva, 2000)

18. Como as verbas são distribuídas?

“Dentro das categorias orçamentárias USP (padrão para Unidades de Ensino e Órgãos de Integração), as verbas são distribuídas em função dos projetos planejados para o exercício em termos de eventos e atividades." (Marx, 2000)

19. Como são constituídas as coleções? (através de aquisições, doações, etc.)

Aquisições eventuais e doações. (Silva, 2000)

\section{Instalações}

20. As instalações são próprias? (X) cedidas( ) alugadas ( ) em construção ( ) Quais são suas principais características?

Edifício térreo, privilegiando as áreas de consulta e guarda dos acervos. 
21. Como está distribuído o espaço entre recepção, área científica, área administrativa, área de exposições, reserva, biblioteca, auditórios, etc.? (se possível anexar planta)

Arquivo: Consulta, armazenamento, triagem e sala dos arquivistas. Biblioteca: consulta, depósitos, sala dos bibliotecários. Coleção de Artes Visuais: salas de exposição, reserva técnica, sala de triagem e montagem de obras, sala dos museólogos. Salas de pesquisa, Diretoria, sala do Conselho Deliberativo. Sala de informática, sala de aula, sala de Difusão Cultural. Administração: sala de pessoal, tesouraria e do Assistente técnico de direção. (Silva, 2000)

\section{$\underline{\text { Acervo }}$}

22. Qual é a natureza das coleções?

Coleção de arte brasileira. Arte (pintura, desenho, gravura, escultura). Arte popular (objetos da cultura popular), Arte sacra. (Silva, 2000)

23. Há peças de destaque no acervo? Quais?

Obras representativas do modernismo brasileiro. (Silva, 2000)
24. Número de peças (2500)
( ) adquiridas ( ) doadas
( ) outras

"Coleção Mário de Andrade, 1200 peças. Coleção Anita Malfatti, 500. Coleção Graciliano Ramos, 16. Coleção Maria Tereza A.C. Lemos, 31. Coleção Carlos Alberto Passos, 22. Coleção Bernardino Ficarelli, 226. Coleção Mariana Quito, 188. E outros. “ (CPC, 2000:421)

25. Há profissionais de documentação? Sim Quantos? Um (Silva, 2000)

26. Há profissionais de conservação / restauração? sim Quantos? Um (Silva, 2000)

27. Há algum setor técnico específico para este tipo de museu? Qual?

Setor de pesquisa, com especialistas na área de arte, história e cultura brasileira. (Silva, 2000)

28. A coleção está catalogada / documentada?

Sim. (Silva, 2000)

29. As coleções estão sendo pesquisadas? ( ) Não ( $X) \operatorname{Sim}$

Por pesquisadores $(X)$ do museu $(X)$ da unidade $(X)$ de outras unidades da USP $\quad(X)$ de fora da USP

\section{Atividades públicas}

30. Qual é o horário de trabalho? de $2^{\mathrm{a}}$ a $6^{\mathrm{a}} \mathrm{f}$. das 9 às $18 \mathrm{hs}$.

31. Qual o horário de visitas para o público? de $2^{\mathrm{a}}$ a $6^{\mathrm{a}} \mathrm{f}$. das 14 às 17 hs.

32. Há biblioteca no IEB? sim Qual a área de especialização e o número de volumes da biblioteca? 
Com 115.000 volumes, e um arquivo com 250.000 documentos. (Silva, 2000)

Quantos funcionários trabalham na biblioteca?

5 funcionários. (Silva, 2000)

33. Quais as publicações e edições do museu/Instituto?

Catálogos de exposições, Catálogo Geral do Acervo, Guia dos Acervos, e o Instituto possui a "Revista do IEB", Cadernos de Pesquisa, etc.

34. Há exposição permanente / longa duração? Sim Temática: Modernismo Brasileiro.

35. Organizam-se exposições temporárias? Sim. Qual o tema e a duração das duas últimas? Centenários Modernistas (Silva, 2000)

36. Oferece cursos de extensão, graduação, outros?

Curso de Especialização de Arquivos, Disciplinas Optativas e Cursos de Difusão Cultural. (Silva, 2000)

37. Quais os outros programas oferecidos ao público?

Consultoria Técnica, empréstimo de obras, reprodução de obras, hemeroteca, fichas catalográficas, catálogos, documentação fotográfica, etc. (Silva, 2000)

38. Qual o tipo de público que freqüenta o museu? (estudantes de $1^{\circ}$ e $2^{\circ}$ graus, professores, universitários, turistas....)

Estudantes de graduação, Pós-graduação, Pesquisadores, e visitantes do Brasil e exterior. (Silva, 2000)

39. Qual a freqüência aproximada de visitantes (anual)?

Cerca de 700 pessoas.

A partir das respostas ao questionário e de outras informações levantadas, faremos uma análise da Coleção de Artes Visuais do IEB, no sentido de verificar se ela se configura como um museu universitário de arte, a partir do modelo inicialmente proposto. 


\subsection{As coleções}

As coleções de artes visuais do IEB são de alta qualidade, com destaque para a Coleção Mário de Andrade, considerada a mais importante do IEB, que é composta por

“... peças que testemunham sua época, suas atividades e interesses. Entre elas, pinturas, desenhos, gravuras e esculturas, em sua maioria da Arte Moderna brasileira e, esporadicamente, algumas obras de arte européia. Ao lado dessas, também colecionou imagens religiosas, objetos indígenas e outros de influência africana; objetos populares de diferentes regiões do Brasil, e mesmo os produzidos pelo comércio e população paulistas durante a Revolução de 1932." (Instituto de Estudos Brasileiros, 1997:149-150)

A Coleção Mário de Andrade foi dividida em quatro séries, seguindo a organização do inventário do escritor:

1 - Artes Plásticas: 664 peças, incluindo "pinturas, gravuras, desenhos e esculturas das mais representativas realizadas pelas duas primeiras gerações da Arte Moderna brasileira. (...) Entre eles: Anita Malfatti, Brecheret, Di Cavalcanti, Tarsila, Segall, Ismael Nery, Cícero Dias, Guignard, Portinari, Goeldi, Lívio Abramo, Clóvis Graciano, Rebolo, Volpi e Pancetti." (IEB, 1997:150) Há também algumas obras de artistas estrangeiros, especialmente gravuras.

2 - Arte Religiosa: 80 peças abrangendo os séculos XVII ao XX, incluindo imagens religiosas em diversos materiais recolhidas no Brasil entre 1910 e 1940.

3 - Arte Popular: 150 peças dos séculos XIX e XX de procedência variada, ligadas aos estudos de Mário de Andrade.

4 - Objetos da Revolução de 1932: 300 peças dos anos 1932 a 1934, incluindo objetos utilizados pelos revolucionários e outros referentes ao evento. (IEB, 1997)

Além da Coleção Mário de Andrade, outras coleções também são fundamentais para o estudo da arte brasileira:

"Desde a criação do Instituto, Artes Plásticas foi uma área particularmente representativa do acervo, reconhecido como fonte de referência obrigatória para os que pesquisam a arte brasileira. Merecem especial destaque, nessa área, as coleções Mário de Andrade (recebida em 1968), Theon Spanudis (1987) ${ }^{7}$ e Anita Malfatti (1989)." (Almeida, M.C.B. 1998:107)

O IEB se diferencia dos outros museus até agora estudados pelo fato de contar com documentação de artistas e intelectuais em seu arquivo, além de vasta biblioteca com volumes que pertenciam a esses intelectuais e artistas. O IEB costuma receber o

\footnotetext{
${ }^{7}$ As 453 obras do colecionador Theon Spanudis foram doadas ao MAC/USP em 1979. Sua biblioteca e arquivos pessoais foram legados ao IEB, depois de sua morte em 1986. (IEB, 1997:46)
} 


\section{Instituto de Estudos Brasileiros Universidade de São Paulo - 2001}
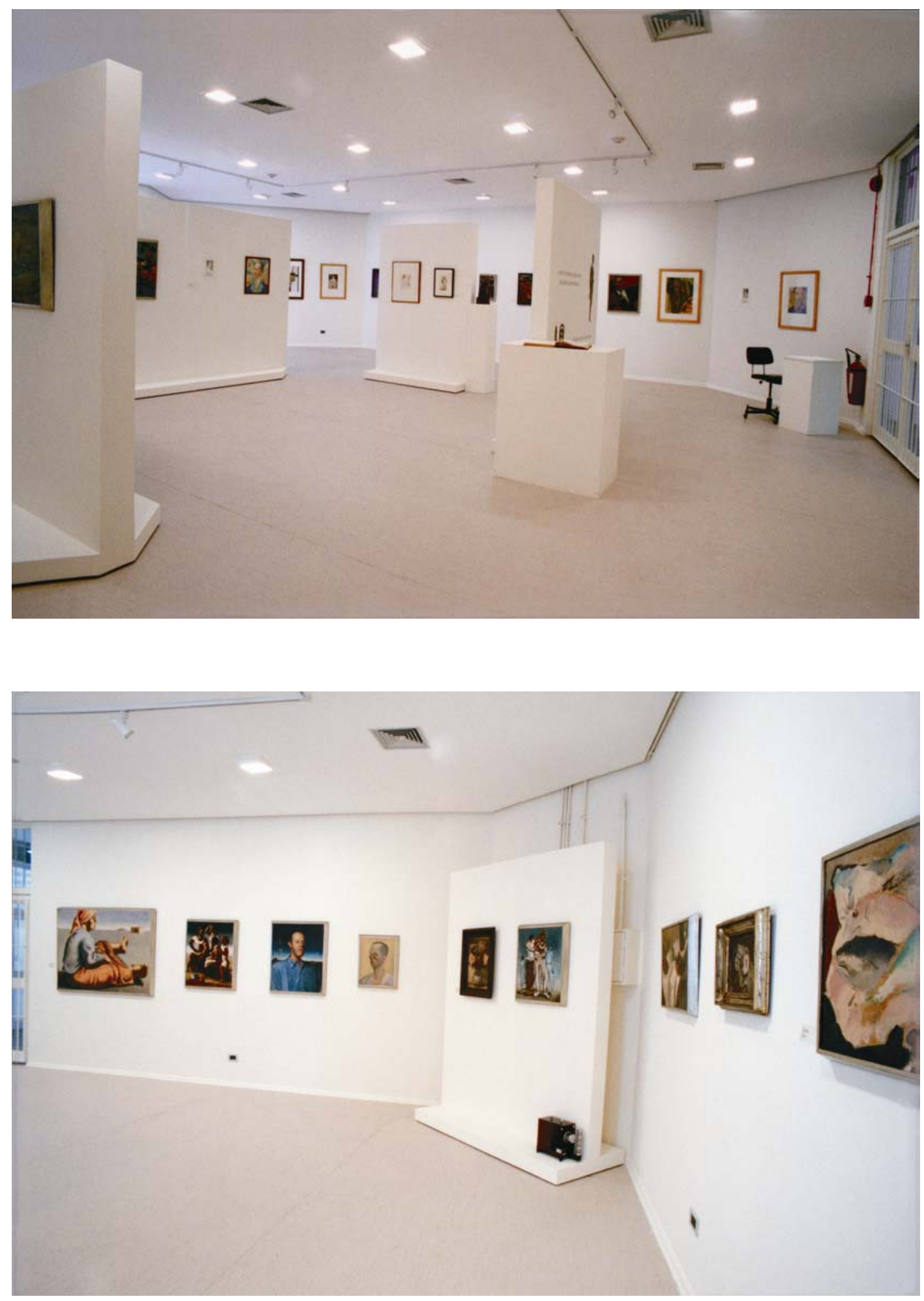
legado desses expoentes da cultura brasileira em conjuntos - objetos, publicações e documentos.

Assim, o IEB, além de possuir obras de arte, tem um importante acervo documental sobre a arte brasileira:

"(...) o IEB se destaca como fonte altamente relevante para os que pesquisam arte brasileira. Pela natureza da instituição, voltada principalmente à documentação e à pesquisa, pelo trabalho integrado que vem desenvolvendo e pelo potencial do acervo, o IEB - com seu Arquivo, sua Biblioteca e sua Coleção de Artes Visuais - parece constituir um centro de competência dentro da Universidade" (Almeida, M.C.B. 1998:108)

Os acervos da biblioteca e do arquivo se completam com as obras de arte. Isso se torna evidente para a Coleção Mário de Andrade, na qual os cerca de 30.000 documentos do arquivo pessoal ${ }^{8}$, somados aos mais de 17.600 volumes de sua biblioteca, auxiliam na compreensão e na crítica das obras de arte e objetos de sua coleção.

No caso da Coleção Theon Spanudis, o IEB ficou com documentos que registram sua trajetória como crítico de arte e poeta e suas relações com artistas brasileiros, assim como sua biblioteca de obras sobre arte, catálogos de exposições, entre outros títulos ${ }^{9}$, e o MAC/USP ficou com as obras que completam o legado desse crítico.

A Coleção Anita Malfatti é formada por seu arquivo de manuscritos, recortes de jornais, fotografias, "constituindo-se em material essencial para pesquisa da vida e obra da artista, referência inicial do Modernismo brasileiro." (IEB, 1997:94) A parte de artes visuais é composta por cadernos de desenhos da pintora e matrizes de gravura. ${ }^{10}$

Dessa maneira, o pesquisador pode encontrar fontes para estudo da arte brasileira em diversos suportes, ampliando as formas de análise do objeto escolhido.

Podemos afirmar que o IEB conta com coleções significativas para 0 desenvolvimento de pesquisas, o primeiro item das características desejadas para um museu universitário.

"O fato dos acervos do IEB serem compostos de Coleções de intelectuais brasileiros, tem permitido o estudo das obras de arte em confronto com os documentos do Arquivo e obras da Biblioteca, possibilitando conhecer em

\footnotetext{
${ }^{8} \mathrm{O}$ arquivo "Reúne uma gama de informações valiosas para os estudos do Modernismo e da vida literária e cultural do eixo Rio-São Paulo durante praticamente quatro décadas." (IEB, 1997:77)

${ }^{9} \mathrm{O}$ arquivo Theon Spanudis tem cerca de 2.450 documentos e a biblioteca 4.000 volumes entre livros e revistas. (IEB, 1997)

${ }^{10} \mathrm{O}$ arquivo soma cerca de 2.000 documentos e a coleção de artes visuais tem cerca de 500 desenhos e 20 matrizes de gravuras. (IEB, 1997)
} 
detalhes a história da obra e/ou do artista em relação a seu colecionador e/ou criador. Este relacionamento contribui para o desenvolvimento de pesquisas, de métodos de documentação, de levantamento da história oral, auxiliando na construção mais precisa da História da Arte no Brasil." (IEB, Internet, acessado em 30/01/2001)

Não há, entretanto, uma clara política de aquisição de obras. Por ser tratar de um centro interdisciplinar de estudos da cultura brasileira, o IEB poderia receber coleções de diferentes áreas e épocas. Um critério básico vem definindo a formação do acervo: a aquisição de coleções de intelectuais brasileiros de destaque, feitas por eles ou de sua propriedade. (Marta R. Batista, 2001)

As coleções são divididas entre Arquivo (documentos), Biblioteca (livros e revistas) e Artes Visuais (obras e objetos), porém são registradas como parte da coleção original. ${ }^{11}$ Isso dificulta um pouco a consulta, mas preserva a contextualização de cada elemento dentro do conjunto de uma coleção de um artista e/ou intelectual brasileiro.

\subsection{As pesquisas}

O Regimento de 1996 definiu a estrutura do IEB: Conselho Deliberativo, Diretoria, Divisão Científica e Serviços de Apoio.

A Divisão Científica é composta pelos docentes do IEB e todos aqueles que lá estejam pesquisando, com programas aprovados pelo Conselho Deliberativo.

As pesquisas devem estar dentro de "áreas temáticas" organizadas nas seguintes especialidades:

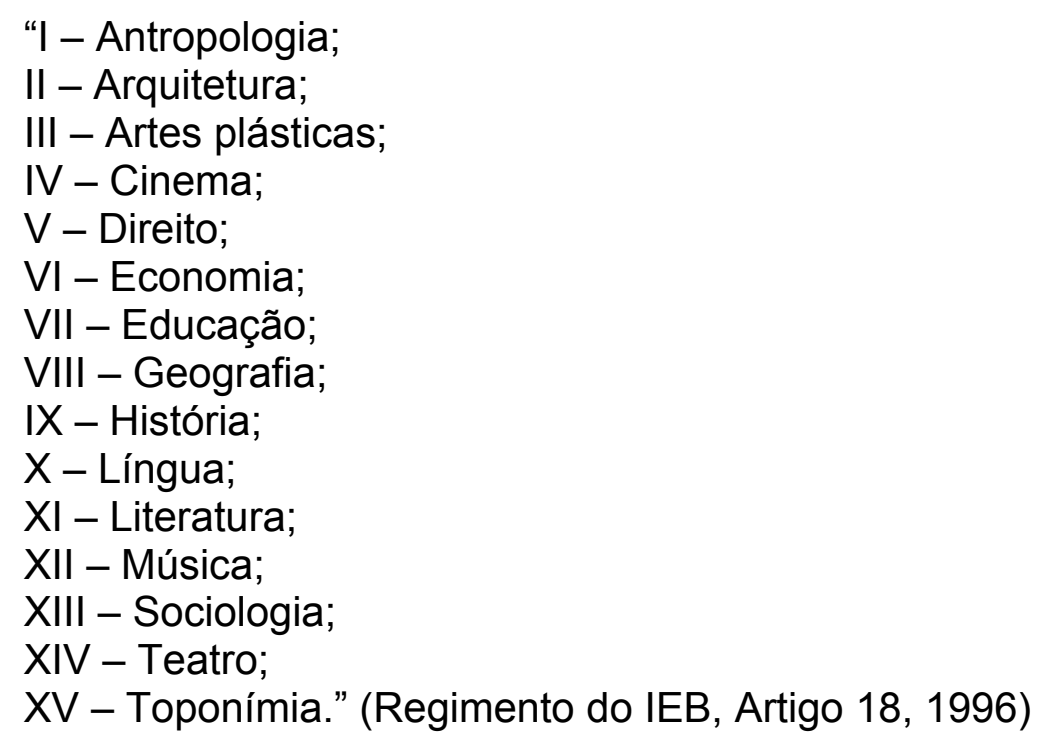

\footnotetext{
${ }^{11}$ Assim, um documento da Coleção Mario de Andrade, uma obra de arte ou um livro, terá sempre o código MA, as peças de Bernardino Ficarelli, por BF, Anita Malfatti, AM, etc.
} 
As obrigações dos docentes são de pesquisar, estimular pesquisas interdisciplinares e ministrar cursos e disciplinas. Para coordenar a Divisão Científica foi instituída a Câmara Científica $(\mathrm{CaC})$ composta por todos os docentes e presidida por um de seus membros. Dessa forma definiu-se uma instância de diálogo entre docentes e Conselho Deliberativo.

No início de 2001, o IEB está com sete ${ }^{12}$ pesquisadores / docentes ${ }^{13}$ : Benedito Heloiz Nascimento e Lucy Maffei Hutter da área de História; Telê Porto Ancona Lopez e Yêdda Dias Lima de Literatura; Flávia Camargo Toni de Música; e Marta Rossetti Batista e Mayra Laudanna de Artes Plásticas. Além desses pesquisadores, duas outras professoras desenvolvem projetos de pesquisa no IEB: Diana Gonçalves Vidal da Faculdade de Educação da USP e Maria Cecília Naclério Homem da Faculdade de Arquitetura e Urbanismo da USP.

A ênfase nas pesquisas, baseadas no acervo, é uma das características esperadas de um museu universitário. No caso do IEB, isso é uma prática que já vem ocorrendo ao longo dos anos. Não só o acervo de Artes Visuais como o Arquivo e a Biblioteca $^{14}$ são objeto de pesquisas sistemáticas empreendidas pelos docentes do IEB e, às vezes, por outros pesquisadores. As pesquisas se dão nas áreas de História, Literatura, Artes Plásticas e Música.

"Por seu trabalho individual e interdisciplinar, pesquisando continuamente junto às fontes primárias, os docentes têm desenvolvido importantes projetos de organização e exploração de acervos, com bolsistas e financiamento das principais agências de fomento - FAPESP, CNPq, VITAE, FUNDAP, BID e COSEAS. Resgatando fatos esquecidos de nosso passado, contribuindo para a construção da memória brasileira, os docentes do IEB desenvolvem métodos e técnicas de pesquisa em disciplinas específicas, pouco exploradas no Brasil, tais como: Arquivologia, Paleografia, Codicologia/Crítica Genética, Musicologia, Documentação e Pesquisa Museológica e Crítica Textual.

(...) Entre as pesquisas contínuas, ao longo dos anos, destacam-se linhas e temáticas, tais como: modernismo na literatura, artes plásticas e música; história da imigração no Brasil; história econômica; estudo de periódicos brasileiros e de obras raras; cultura popular; preparo de edições críticas. Este cabedal acumulado

\footnotetext{
${ }^{12} \mathrm{Na}$ resposta à questão 11 foram considerados apenas os 4 funcionários diretamente ligados à Coleção de Artes Visuais. Já na resposta 13 indica-se o número total de funcionários do IEB: 54.

${ }^{13}$ A carreira de pesquisador foi extinta na USP e, aqueles que ainda são enquadrados dessa forma, deverão realizar concursos para docência para adequar-se às novas regras. Ao passar para a carreira docente, esses professores deverão cumprir carga horária de aulas semelhante às dos departamentos, ou seja, 8 horas semanais a cada semestre, ou ter uma justificativa para não fazê-lo. No caso dos museus e institutos são poucas as disciplinas de graduação e pós-graduação oferecidas, dificultando o cumprimento dessas metas ditadas pela Reitoria.

${ }_{14}$ Inicialmente, em 1968, o Arquivo era integrado à Biblioteca. Com o crescimento do acervo, em 1974, foi estabelecido como um setor independente.
} 
de conhecimento tem sido transmitido às novas gerações, sobretudo aos bolsistas e pós-graduandos, orientandos dos docentes e a outros estudiosos através das publicações, cursos e exposições. " (Página da internet do IEB, acessada em 29/01/2001)

Uma das características do IEB é o contínuo incentivo à pesquisa interdisciplinar, entre os pesquisadores do IEB e com pesquisadores de outras unidades e também de fora da USP.

Os temas das pesquisas individuais ou em grupo, finalizadas ou em andamento, desenvolvidas pelas docentes do IEB da área de Artes Plásticas, Marta Rossetti Batista e Mayra Laudanna, segundo informações divulgadas na página da internet do IEB e nos relatórios institucionais de 1997, 1998 e 1999, são os seguintes ${ }^{15}$ :

\section{Marta Rossetti Batista}

1 - Guia de Acervos do IEB - ABC do IEB. - terminada e publicada em 1997. (Relatório IEB, 1997)

2 - Coleção Mário de Andrade: Artes Plásticas, $2^{a}$ edição. - terminado, publicado em 1998. (Relatório IEB, 1998)

3 - História comparada das sociedades urbanas: políticas urbanas e dimensão cultural das cidades brasileiras e francesas. - terminada (1995 -1998)

Esse projeto tem a participação de pesquisadores franceses e brasileiros de diversas instituições e visa a "Elaboração de uma história urbana do Brasil e da França com o estabelecimento de análises comparativas e publicação dos resultados." (Página da Internet do IEB, 29/01/2001)

A publicação de dois livros sobre políticas urbanas em cidades brasileiras em 1998 e 1999, pelo IEB, foi resultado dessa pesquisa. No segundo volume há um artigo de Marta R. Batista intitulado São Paulo: esculturas nos espaços públicos 1900-1925. (Relatório IEB, 1999)

4 - Acervo Flávio Império: ordenação e catalogação das obras e documentos. Pesquisa e desenvolvimento do Banco de Dados. - terminada e publicada.(1995-1998)

"Visando estudar a obra, dimensionar a importância do artista e contribuir para o conhecimento de seu tempo, a presente etapa do Projeto se propõe a 1) levantar, ordenar e descrever seu acervo pessoal doado ao IEB; 2) documentar e catalogar a obra do artista em mãos de colecionadores e instituições brasileiras e 3) implantar e desenvolver um Banco de Dados que torne acessível aos pesquisadores as informações resultantes do trabalho." (Página da internet do IEB, 29/01/2001)

\footnotetext{
${ }^{15}$ Decidimos elencar algumas das pesquisas já encerradas para podermos avaliar o tipo de trabalho que vem sendo desenvolvido.
} 
5 - Cadernos do IEB - organização da publicação que teve os primeiros três títulos publicados em 1999.

\section{6 - Organização e descrição do Arquivo Anita Malfatti - em andamento}

"O projeto tem como objetivo organizar, descrever e indexar as séries e subséries que compõem o Arquivo Anita Malfatti. Elaborar o 'Inventário Analítico', visando colocar à disposição dos consulentes material primário de relevância para o estudo da artista, do modernismo e da arte brasileira do período entre-guerras." (página da internet do IEB, acessada em 29/01/2001)

7 - Catálogo Coleção Mário de Andrade: arte religiosa e objetos populares. - em andamento. (Relatório IEB, 1999)

Para Marta Rossetti Batista existem dois tipos de pesquisa ligadas aos acervos do IEB. O primeiro seria realizado pelo corpo de servidores do IEB visando a "organização e exploração dos acervos, com equipes coordenadas pelos docentes/pesquisadores (das áreas de Literatura, Artes Plásticas e Música ${ }^{16}$ ) e pelos técnicos especializados, contando com bolsistas e auxiliares" (Relatório IEB, 1997) para organizar o material para que pesquisadores possam consultá-lo. Resultantes dessas pesquisas, são os catálogos das coleções e outras documentações que facilitam o acesso às informações aos usuários do IEB. O segundo tipo é a pesquisa individual, desenvolvida por servidores do IEB, de outras unidades da USP e de fora da USP que utilizam o material previamente organizado, nas diversas áreas, como história, música, artes visuais, literatura para produção de teses, publicações, exposições, etc.

Marta Rossetti Batista realiza o primeiro tipo de pesquisa, trabalhando a partir do acervo do IEB para torná-lo mais acessível aos usuários e interessados.

No primeiro semestre de 2001, Marta Rossetti Batista pretende terminar um segundo catálogo da coleção de Mário de Andrade ${ }^{17}$, incluindo os objetos sacros, populares, indígenas, africanos e instrumentos musicais, favorecendo assim o acesso a essa coleção. Marta R. Batista sempre trabalhou voltada para a coleção de Mário de Andrade e de Anita Malfatti, com a perspectiva de torná-las acessíveis ao maior número de pesquisadores. (Batista, 2001)

\footnotetext{
${ }^{16}$ Ressalte-se aqui que os docentes de História não realizam esse tipo de pesquisa, o que pudemos comprovar na leitura dos relatórios do IEB.

17 "Catálogo da Coleção Mário de Andrade: arte religiosa e objetos populares".
} 
Marta Rossetti Batista já foi curadora de diversas exposições realizadas no $\mathrm{IEB}^{18}$, mas em 1998 e 1999 não realizou nenhuma curadoria no Instituto. Para cada uma das exposições das quais foi curadora, a pesquisadora elaborou textos para folhetos ou catálogos. Marta R. Batista foi ainda diretora do IEB entre 1994 e 1998, passando a gestão para Murillo Marx $^{19}$ em junho de 1998, ano em que assumiu (setembro) a presidência da Comissão Executiva das Comemorações USP: Brasil 500 anos.

\section{Mayra Laudanna}

1 - A inserção de Ernesto de Fiori na modernidade alemã dos anos 20 e 30 e sua contribuição para a arte brasileira do final dos anos 30 e início dos anos 40. terminada.

Esse estudo pretende contribuir para a história da arte brasileira e investigar dados sobre movimentos artísticos europeus do início do século. ${ }^{20}$

2 - Ernesto de Fiori, uma retrospectiva. - terminada.

"Curadoria da exposição retrospectiva organizada na Pinacoteca do Estado de São Paulo. Seleção das obras, organização do catálogo e da exposição, treinamento de monitores. " (Página da internet do IEB, 29/01/2001)

3 - Oswaldo Goeldi: preparo de edição. - terminada.

"Reunião do material produzido durante as comemorações do centenário do gravador: Mesa redonda na FAAP, Curso de Difusão no IEB, visando edição." (Página da Internet do IEB, 29/01/2001)

4 - Raphael Galvez - biografia. - terminada e publicada. (Relatório IEB, 1999)

5 - Ennio Angelo Bertoncini: elaboração de texto para folheto. - terminado. (Relatório IEB, 1999)

6 - Catálogo "Os ítalos e brasileiros da Pinacoteca" - texto publicado. (Relatório IEB, 1999)

7 - Antônio Hélio Cabral - texto publicado. (Relatório IEB, 1999)

\footnotetext{
18 Alguns exemplos: 100 obras-primas da Coleção Mário de Andrade: pintura e escultura, outubro a dezembro de 1993; Centenários Modernistas III: Lasar Segall (1891-1957), setembro e outubro de 1991; Novas doações: Coleção Bernardino Ficarelli, outubro a dezembro de 1992; O Jovem Di (1917-1935), abril a julho de 1997.

19 Os diretores anteriores foram: Sérgio Buarque de Holanda (1963-1964), Egon Schaden (1965-1967), José Aderaldo Castello (1967-1981), Myriam Ellis (1982-1986), Ruy Gama (19861990) e José Sebastão Witter (1990-1994).

20 Essa pesquisa resultou na tese de doutoramento de Mayra Laudanna, A recepção de Ernesto de Fiori pela crítica de arte, defendida na FFLCH/USP, em dezembro de 1997.
} 
8 - Escultores brasileiros do fim do século XIX até o $2^{\circ}$ decênio do século $X X$. em andamento (Relatório IEB, 1999)

9 - Vida e obra de Alex Fleming - elaboração de ensaio a ser publicado (Relatório IEB, 1998). Esse trabalho levou o artista a doar 60 gravuras à Coleção de Artes Visuais do IEB.

10 - Curadoria da exposição de Sérgio de Moraes realizada no IEB (24/11 a 17/12/1999) - gravuras e politipias. (Relatório IEB, 1999)

11 - Curadoria da exposição de Carlos Bracher (02 a 30/04/1998) para lançamento do livro de João Adolpho Hansen sobre o artista. (Relatório IEB, 1998)

12 - Curadoria de duas exposições na Pinacoteca do Estado, em 1999: Os ítalobrasileiros e Antônio Hélio Cabral. (Relatório IEB, 1999)

Mayra Laudanna procura desenvolver pesquisas que possam trazer novas obras para o acervo e novas informações sobre artistas. Assim, realiza muitas pesquisas fora do IEB, em conjunto com professores de outras unidades, resultando em exposições que podem ser montadas no IEB ou fora dele ${ }^{21}$. As informações coletadas sobre artistas estão sendo sistematizadas e depois estarão à disposição do público que consulta arquivos do IEB. Seus interesses extrapolam o Brasil, que seria o universo definido como alvo das pesquisas do IEB. Para ela, falar de arte brasileira do início do século XX certamente implica em expandir as pesquisas para a Europa e estudar alguns artistas europeus. (Laudanna, 2001)

Mayra Laudanna não segue uma linha de pesquisa definida previamente. Por ser docente do IEB deveria trabalhar dentro do tema cultura brasileira, mas procura ampliar esse conceito por seu interesse pessoal na Alemanha do período 1900-1930. Realizou a curadoria de várias exposições no IEB redigindo os textos dos catálogos. ${ }^{22}$ A exposição sobre Rugendas, em 1991, reuniu materiais do arquivo, biblioteca e da coleção de artes visuais, resultando numa exposição exemplar em termos de integração de fontes dos acervos do IEB.

\section{Pesquisa dos servidores não-docentes ligados à Coleção de Artes Visuais}

A pesquisa coordenada pela especialista em conservação Eliane Maria Paschoal da Silva junto à Coleção de Artes Visuais está ligada às atividades museológicas, que

\footnotetext{
${ }^{21}$ Um exemplo foi a exposição do artista mineiro Carlos Bracher, planejada a partir de iniciativa do professor da FFLCH Sérgio Miceli e realizada no IEB com o lançamento simultâneo de um livro sobre o artista, em 02/04/1998.

${ }_{22}$ Desenhos de escritores Modernistas da Coleção Mário de Andrade, 1992; Johann Moritz Rugendas, 1991; Mariana Quito, 1993.
} 
incluem colaboração no preparo e montagem de exposições, os cuidados com a preservação e conservação das obras, a realização de exames periódicos e acondicionamento das peças do acervo, além do fichamento técnico/documental, mantendo atualizado o histórico de cada obra. (Página da Internet do IEB, 29/01/2001) O tipo de pesquisa realizada por Eliane M. P. Silva, segundo descrito no site da instituição, parece-nos mais um trabalho de rotina, um trabalho técnico. É possível que, para isso, a especialista tenha desenvolvido procedimentos específicos que podem ter sido resultantes de pesquisas, mas em nossa opinião a manutenção da coleção em si se configura mais como a sistematização e análise de técnicas museológicas que poderiam contribuir para a exposição e conservação de acervos de natureza semelhante pertencentes a outras instituições. ${ }^{23}$ Esse trabalho torna acessível preservado, legível, documentado - o acervo do IEB para que outras pessoas possam obter informações a partir dele.

Os servidores não-docentes participam da maior parte das pesquisas que envolvem os acervos do IEB, em conjunto com os docentes. São eles que mantêm a organização das coleções e que lidam com os usuários das mesmas.

Os museus e institutos de pesquisas, após a elaboração de seus regimentos atualizados pelo novo regimento da USP, deveriam definir seus planos diretores, nos quais as linhas de pesquisa são um dos elementos principais. Até o início de 2001, o IEB não havia definido as suas linhas de pesquisa. Isso pode se dever, como afirma Marta R. Batista (2001), ao fato de muitos docentes desenvolverem determinados temas de pesquisa há mais de 20 anos e terem dificuldade de sair desse universo.

A definição de linhas de pesquisa garantiria uma produção sistemática dentro dos assuntos ligados ao acervo e facilitaria a determinação de critérios para cursos, exposições, e aquisição de coleções. Como o IEB trata da "cultura brasileira" ele se torna um espaço para qualquer tipo de pesquisa que envolva o Brasil, dentro das 15 especialidades definidas pelo regimento, ou seja, o IEB comporta pesquisa em quase tudo sobre o Brasil, dificultando a criação de uma identidade institucional. Por outro lado, os seus acervos são ricos em possibilidades de pesquisa e deveriam ser fontes para novas pesquisas, sempre que possível.

\footnotetext{
${ }^{23}$ Gostaríamos de ressaltar que acreditamos no desenvolvimento de pesquisas ligadas às áreas de conservação, documentação, comunicação e educação em museus, muitas delas originadas por problemas percebidos no trabalho cotidiano. Um exemplo na área de conservação foi apresentado na dissertação de mestrado de Teresa Toledo de Paula (1998) e outros da área de educação serão citados na parte seguinte, referente ao MAC/USP.
} 
Se as pesquisas se afastarem dos acervos, a divulgação dos mesmos para o público ficará prejudicada e as exposições, cursos e publicações tratarão de temas estranhos ao IEB. Não se trata aqui de propor um "fechamento" das linhas de pesquisa dentro dos acervos, mas de procurar valorizar ao máximo aquilo que o IEB tem de específico para definir suas atividades.

Um outro problema pode surgir do movimento inverso: os pesquisadores que se dedicam somente a um dos acervos / artistas / autores se tornam tão especializados que têm dificuldade em participar de projetos mais amplos ou acabam por se tornar "proprietários" de determinadas coleções.

\subsection{As atividades de extensão: cursos, exposições e publicações}

O IEB oferece atividades para o público universitário como as disciplinas optativas de graduação e para o público em geral como cursos de extensão, exposições e publicações.

\subsubsection{Cursos}

Anualmente o IEB, em conjunto com a ECA, oferece um Curso de Especialização em Organização de Arquivos, além das disciplinas de graduação. Em 2001, o curso de especialização estará em sua $15^{\text {a }}$ edição. Sua duração é de 544 horas/aula ${ }^{24} \mathrm{e}$ :

"O objetivo do curso é capacitar pessoal de nível superior para atuar em organização de arquivos públicos e privados, partindo do estudo da produção e avaliação de documentos: processos técnicos, disseminação da informação e políticas de arquivo." (Página da internet do IEB, 29/01/2001)

Esse curso cumpre a função de formar especialistas em arquivos para diversas instituições, inclusive museus. Assim, o IEB tem um importante papel na formação de profissionais de museus, voltados para a área de organização de arquivos.

O IEB costumava oferecer um grande número de cursos de Difusão Cultural, entretanto, nos últimos três anos foram poucos. Os motivos da diminuição de cursos relacionam-se com a falta de pessoal e também com a política de avaliação docente da USP, que não valoriza cursos de Difusão Cultural. Para efeito de contagem de horas/aula, o professor deve ministrar disciplinas de graduação ou pós-graduação, não contando as horas dedicadas aos cursos de difusão.

${ }^{24} \mathrm{O}$ curso é dado em 3 meses, sempre no primeiro semestre, com 8 horas de aula por dia. 
Em 1997 foram dois cursos de Difusão: O imperador do púlpito: Antonio Vieira 300 anos depois, com vários professores, entre 12 e 16 de maio e Manuscritos e correspondências entre 17 e 24/09. Em 1998 houve apenas um curso sobre Garcia Lorca entre 18 e 22 de maio. Em 1999 não houve nenhum curso de difusão no IEB.

Desde 1996, os docentes do IEB oferecem disciplinas optativas ${ }^{25}$ para a graduação. $\mathrm{Na}$ área de arte, a professora Marta Rossetti Batista registrou inicialmente a disciplina "A arte brasileira no entre-guerras". Em 1998, Mayra Laudanna ministrou a disciplina A obra pictórica de Ernesto de Fiori; em 1999 Marta R. Batista ofereceu A arte religiosa no entre-guerras e, no segundo semestre, de 2000 Mayra Laudanna ministrou a disciplina " $A$ arte brasileira nos decênios 30 e 40 a partir da contribuição italiana do início do século" e pretende oferecer uma diferente em $2001 .^{26}$

O IEB entrou com pedido na Reitoria para poder desenvolver um curso em nível de pós-graduação, entretanto ainda não foi autorizado. Assim, oferece apenas disciplinas de graduação. Alguns de seus pesquisadores, que em 2000 fizeram concurso para entrar na carreira docente ${ }^{27}$, não tinham até então obrigação de dar aulas e orientar na pós-graduação ${ }^{28}$.

\footnotetext{
${ }^{25} \mathrm{Na}$ USP, as disciplinas optativas não precisam ser oferecidas todos os anos, como acontece com as obrigatórias.

${ }^{26}$ Em 2000, o IEB ofereceu também as disciplinas Paleografia I, Imigração italiana no Brasil e Gêneros híbridos: memórias, carta e crônica. (Página da internet do IEB, 05/02/2001)

No segundo semestre de 2001, Mayra Laudanna pretende oferecer disciplina sobre a história da gravura, baseada na pesquisa que realizou com o professor da FFLCH/USP Leon Kossovitch. (Mayra Laudanna, 2001)

${ }^{27}$ Como já foi comentado anteriormente, os pesquisadores dos museus e institutos não tinham status de docentes, apenas equiparação salarial. O novo estatuto da USP permitiu igualar a carreira dos museus à dos departamentos de ensino e no ano 2000 foram iniciados os concursos para regularização da situação dos pesquisadores dos museus e institutos.

Marta Rossetti Batista não fez o concurso e nos contou como foi sua história funcional na USP, mostrando a dificuldade da universidade compreender a especificidade dos trabalhos de museus e institutos: ela entrou no IEB em 1966 e prestou concurso de ingresso em 1968. Naquela época não se podia utilizar o termo "pesquisador" e então todos foram contratados como "historiógrafos". Na década de 70 os "historiógrafos" tiveram seus salários equiparados aos de docentes por causa de uma pesquisadora de geografia que processou a USP. Em seguida, a USP abriu a possibilidade dos "historiógrafos" entrarem na carreira docente pelos departamentos, exigindo análise de currículo e mestrado. Nesse momento, Marta não tinha mestrado e seu pedido para a FAU foi recusado. Mais tarde, já com mestrado (1980), não foi aceita pela FAU porque a Reitoria entendia que o prazo da portaria anterior tinha acabado. Os docentes do IEB, que passaram para os departamentos tiveram seus salários e produção científica administrados pelos departamentos, prejudicando as atividades do IEB. Durante a gestão de Marta R. Batista (anos 90) ela solicitou aos departamentos os docentes de volta para o IEB e conseguiu. Marta permanece então como "historiógrafa" com salário equiparado aos docentes e pretende assim ficar até sua aposentadoria. (Batista, 2001)

${ }^{28} \mathrm{O}$ concurso foi feito por Mayra Laudanna e Flavia Camargo Toni que estavam com contratos precários.
} 


\section{Instituto de Estudos Brasileiros Universidade de São Paulo - 2001}
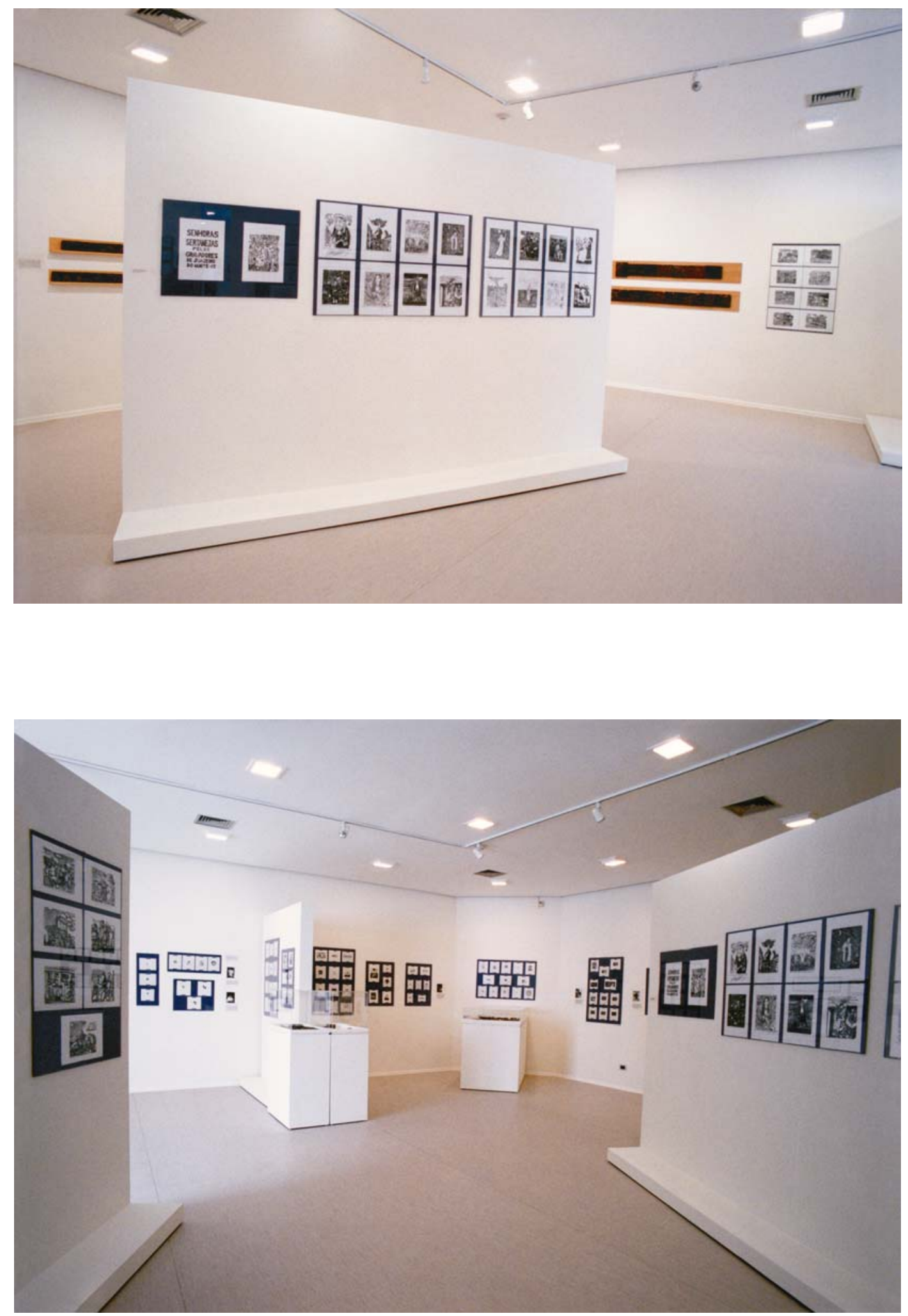
$\mathrm{Na}$ área de Artes Plásticas, nem Mayra Laudanna, nem Marta Rossetti Batista orientam alunos de pós-graduação ${ }^{29}$. Os docentes das áreas de literatura e história já tinham entrado na carreira docente quando pertenciam a departamentos da FFLCH, e mantiveram aulas na pós-graduação e a orientação de alunos nesses departamentos ${ }^{30}$.

A área de ensino do IEB, inicialmente voltada para o público em geral por meio de cursos de difusão, foi aos poucos se voltando para o público universitário com a criação de disciplinas optativas de graduação. Além disso, para os alunos de graduação, o IEB oferece estágios em várias áreas, incluindo em conservação e documentação da Coleção de Artes Visuais (Bolsa COSEAS).

Não podemos deixar de mencionar que o IEB costuma sediar palestras sobre literatura, artes, música e história, além de promover seminários nas áreas de pesquisa - literatura, artes, música, biblioteconomia, arquivística, entre outras ${ }^{31}$. Seus pesquisadores apresentam trabalhos nesses eventos, divulgando-os e mantendo-se atualizados.

\subsubsection{Exposições}

Segundo o Regimento do IEB (1996), cabe tanto à Câmara Científica (CaC) como à Comissão de Serviços de Apoio (CSA) propor ao Conselho Deliberativo do IEB "publicações, exposições e eventos de sua competência" (artigos 23 e 42).

Desde 1997 a CaC e CSA passaram a funcionar, entretanto, ainda não há uma rotina clara para a definição da programação de exposições do IEB. Normalmente, no início de cada ano, a área de Difusão Cultural solicita aos docentes e especialistas que sugiram exposições e depois coordena o calendário.

O IEB não tem equipe especializada em montagem de exposições e, para realizá-las, servidores de diferentes setores se organizam. Quando se trata de acervo da Coleção de Artes Visuais, as especialistas responsáveis - em conservação e documentação - participam necessariamente das montagens.

\footnotetext{
${ }^{29}$ Marta Rossetti Batista já deu aulas de pós-graduação na ECA, e quando solicitou autorização para orientar pela ECA não conseguiu e, desde então, dedica-se às pesquisas e ensino no IEB. Costuma participar, como examinadora, de bancas de tese.

${ }^{30}$ Por exemplo, a professora Telê Ancona Lopes, de Literatura e o professor Benedito Heloiz Nascimento, de História, que já haviam prestado concurso de livre-docência na FFLCH.

${ }^{31}$ Alguns exemplos: $X X$ Colóquio Brasileiro de História da Arte e Seminário Internacional sobre arquivos pessoais, em 1997; Conferência sobre os arquivos de Marcel Proust da Biblioteca Nacional da França e conferência sobre a literatura espanhola e as gerações 1898 e 1927, em 1998; Conferência sobre os arquivos de Paul Valéry da Biblioteca Nacional da França e conferência sobre Pierre Monbeig, em 1999. (IEB, 2000)
} 
O IEB conta com três diferentes espaços para exposição: dois espaços da Coleção de Artes Visuais (CAV) e um espaço do Arquivo e Biblioteca (Saguão).

O IEB mantém obras da Coleção Mário de Andrade permanentemente expostas, representando o seu acervo de Artes Visuais. Num segundo espaço realiza exposições temporárias e no saguão do arquivo e biblioteca apresenta mostras ligadas a esses dois acervos - documentos, fotografias, publicações. Complementando sua programação de exposições, o IEB costuma apresentar exposições (semelhantes às temporárias, com reproduções) durante seminários ou em espaços culturais. Em 1997 apresentou duas exposições em congressos - um nacional e outro internacional, uma na Funarte do Rio de Janeiro e outra no Museu da Imagem e do Som de Ribeirão Preto. E, finalmente, o IEB empresta documentos, fotos e obras para fazerem parte de exposições em outras instituições brasileiras e estrangeiras.

As exposições realizadas no IEB a partir de 1997 foram:

Em 1997, a sala 1 (CAV) ficou com a Exposição Permanente da Coleção Mário de Andrade, exceto em agosto e setembro quando houve a exposição de Blaise Cendrars. Na sala 2 (CAV) foram apresentadas as exposições Cenas da vida brasileira (fevereiro e março), O jovem Di (abril e junho) e Saudades da minha terra - Blaise Cendrars (agosto e setembro, ocupando também a sala 1 ). ${ }^{32}$

No saguão do Arquivo e Biblioteca foram realizadas as seguintes exposições, em 1997: Fui médico, rebelde, soldado - exposição fotográfica sobre Guimarães Rosa $^{33}$ com lançamento da Revista do IEB sobre 50 anos de Sagarana (março e abril) e Acervo IEB-USP - exposição fotográfica para lançamento $A B C$ do IEB (setembro).

Até final de agosto de 1998, na sala 1, foi apresentada a Exposição Permanente de acervo, interrompida apenas durante o mês de abril. Em 2 de abril foi aberta, nas duas salas, a exposição Do Catálogo (2 a 30/04), inaugurada por ocasião da publicação da $2^{\mathrm{a}}$ edição do Catálogo da Coleção Mário de Andrade. Também em 2 de abril foi aberta a exposição de pinturas de Carlos Bracher (2 a 30/04) no saguão da biblioteca e arquivo, onde também foram apresentadas: Monumento a F. García Lorca...uma história parada no ar entre 18/05 e 30/10 e Fotógrafos presentes no arquivo do IEB 1870-1940 entre 21/09 e 30/10.

\footnotetext{
32 Informações dadas por Ana Paula Lima, encarregada do Setor de Artes Visuais, em $12 / 03 / 2001$.

${ }^{33}$ Essa exposição foi também apresentada na Universidade do Porto em Portugal, de 8 a 11/05/1997, em São Caetano do Sul, de 12/02 a 20/03/1998 e no Colégio Dumont Villares em 23/10/99. (Relação de atividades do IEB, 2000)
} 
Essa última exposição citada é um exemplo da divulgação do trabalho realizado pela equipe do Arquivo do $\mathrm{IEB}^{34}$. Maria Helena Pinoti Schiesari, arquivista do IEB, explica:

"Essa mostra pretende trazer ao público resultados do trabalho de conservação do acervo fotográfico do Arquivo do IEB-USP e enfatiza a importância da fotografia como documento histórico e fonte de pesquisa." (IEB, 1999: apresentação)

Durante mais de dois anos, entre 25 de agosto de 1998 e 12 de dezembro de 2000, o IEB reformou os espaços expositivos, reabrindo-os em dezembro de 2000: um espaço para exposições temporárias e outro para o acervo, com nova iluminação e climatização, somando a área de $260 \mathrm{~m}^{2}$.

Em 1999 foram realizadas apenas exposições no saguão da Biblioteca e Arquivo: Jorge Luis Borges - Documentos e obras raras da Coleção Alejandro Vaccaro (16/04 a 14/05) e Linóleos e politipias de Sérgio de Moraes (24/11 a 17/12), esta última com curadoria de Mayra Laudanna, com obras não pertencentes ao IEB. No caso da exposição sobre Borges, foram realizadas outras atividades, como mesa-redonda, conferência e apresentação de Coral por ocasião da abertura da mostra. Para a exposição de Sérgio de Moraes foi realizado um workshop sobre lineogravura.

Ainda em 1999, foram organizadas duas vitrinas na entrada do IEB com as publicações do Instituto.

Em dezembro de 2000, com a reabertura das salas climatizadas e com nova iluminação, foi retomada a Exposição Permanente de acervo na sala 1 e apresentada uma exposição Xilogravura: os percursos da criação popular, de coleções pertencentes ao IEB.

No saguão da Biblioteca e Arquivo foi aberta, em dezembro de 2000, a exposição da Coleção do Maestro Camargo Guarnieri, doada ao IEB.

Apesar da pequena equipe e da ausência de especialistas em museografia, o IEB consegue manter exposição permanente de acervo e também promover exposições temporárias e extra-muros. Certamente, se tivesse equipe maior haveria possibilidade de realizar mais exposições. Entretanto, o pequeno número de

\footnotetext{
${ }^{34}$ Essa exposição foi apresentada posteriormente no Centro Universitário Maria Antonia/USP e no Centro de Divulgação Científica e Cultural - CDCC /USP São Carlos.

Exposições como essa estão à disposição para empréstimo: Eu sou Trezentos, Sou Trezentos e Cinqüenta de ampliações fotográficas do Arquivo Mário de Andrade; Graciliano Ramos (Centenário de Nascimento) de ampliações fotográficas do Arquivo Graciliano Ramos, entre outras. (IEB, página da Internet, acessada em 29/01/2001)
} 


\section{Instituto de Estudos Brasileiros Universidade de São Paulo - 2001}
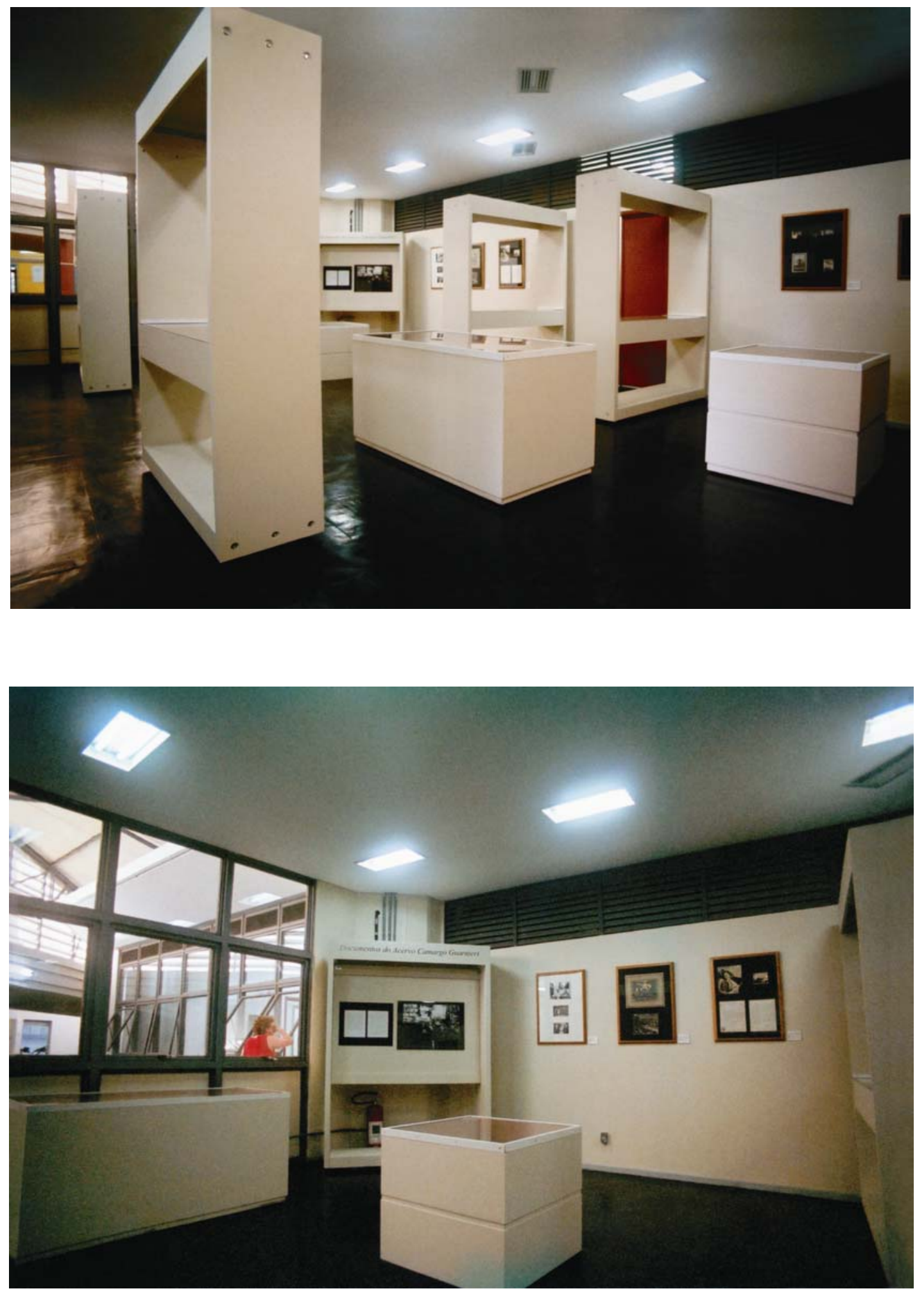
pesquisadores também restringe as possibilidades temáticas, uma vez que são poucas as pesquisas que alimentariam a programação.

Percebemos que as áreas que realizam pesquisas ligadas diretamente aos acervos - artes plásticas, literatura e música - são aquelas que propõem exposições e eventos no IEB. Dessa maneira, a área de História, que conta com dois pesquisadores, pouco contribui para a difusão do acervo do IEB, seja em pesquisa, publicações ou exposições.

\subsubsection{Publicações}

Em 1965, três anos após a criação do IEB, saiu a primeira publicação avulsa, um trabalho de Carlos Drummond (Contribuição do bororo à toponímia brasileira) seguido por diversas publicações nos anos seguintes, que até 1974 somavam 30 publicações. Houve então uma parada e as publicações foram retomadas em 1981, mas em menor quantidade, dependendo de patrocínio para coedição. Os títulos incluem as áreas de antropologia, história, artes, literatura, assinados por pesquisadores do IEB e também de outras unidades. Segundo Marta Rossetti, a seleção das publicações era determinada pelo Conselho do IEB, que por muito tempo foi composto na maioria por membros da FFLCH/USP.

A Revista do Instituto de Estudos Brasileiros foi criada em 1966, publicada anualmente, apresentando artigos das diversas áreas da "cultura brasileira". Em alguns anos - 1972, 1975, 1988, 1992, 1994, 1995 e 1996 - a Revista foi semestral, sendo que a mais recente, número 42, foi publicada em 1997. Por ser uma revista de caráter interdisciplinar, sempre teve dificuldade de penetração e, em 1990, o Conselho Editorial definiu que deveria ter um núcleo temático, que poderia ser uma pessoa, um evento, um conceito, abordado de forma interdisciplinar. Até o início de 2001, apesar de contar com artigos suficientes, a Revista do IEB número 43 ainda não estava pronta, provavelmente por falta de pessoal para executar o trabalho.

Durante a gestão de Marta Rossetti Batista, foi planejada (Relatórios 1997 e 1998) a edição dos Cadernos do IEB, que deveriam ser publicações mais baratas e com linhas definidas - instrumentos de pesquisa, cursos e conferências, documentação, entre outros. Em 1999 foram publicados os primeiros três Cadernos e um quarto saiu em 2000.

O IEB tem um número bastante elevado de publicações que apresentam os trabalhos de seus pesquisadores e também de outras instituições, sempre relacionados 
ao estudo da cultura brasileira. Revistas especializadas geralmente atingem um público especializado, acadêmico e não o público em geral. As publicações mais simples, como os catálogos de exposições, começaram a ser editadas de forma mais sistemática nos anos 1990, sendo mais acessíveis ao público não especializado.

Todo tipo de material impresso pode ser um importante instrumento de divulgação de uma coleção e das pesquisas realizadas sobre ela, incluindo aí artigos científicos, catálogos, folhetos, cartazes e cartões postais. Entretanto, a quantidade de informações contidas em cada um desses meios é muito diferente como também é diferente o público que atingem.

Novamente percebemos a força do IEB enquanto instituto de pesquisa refletido nos tipos de publicação: em sua maioria especializada e em menor quantidade voltada para o público em geral. ${ }^{35}$ Veremos que, o arquivo e a biblioteca são também utilizados preferencialmente pelo público acadêmico.

\subsection{O público}

O IEB oferece ao público o contato com os seus acervos, por meio de exposições e por consulta direta.

A Coleção de Artes Visuais costuma atender consulentes - curadores, pesquisadores - e também apresenta as exposições para o público em geral, atendendo também as escolas. Em 1997 houve 8 consulentes, 1.055 visitantes das exposições e 5 atendimentos para escolas. Em 1998, 10 consulentes, 449 visitantes e 5 escolas atendidas. Em 1999 houve 5 consulentes e nenhum visitante e em 2000, 17 consulentes.

Já a Biblioteca atendeu 1.426 usuários em 1997, 1.618 em 1998 e 1.675 em 1999. O Arquivo atendeu 172 consulentes em 1997, 150 em 1998 e 176 em 1999. Em ambos os casos a maioria dos usuários é de pesquisadores que estão realizando teses, dissertações e outros trabalhos acadêmicos, principalmente na área de História.

Tanto o público da biblioteca como do arquivo são altamente especializados e o espaço para o público em geral se limita às exposições.

O prédio do IEB não está em lugar de destaque no campus da USP, ficando um pouco escondido e também não abre ao público em fins de semana. Todos esses fatores diminuem as possibilidades de acesso de novos públicos.

${ }^{35}$ O IEB costuma sediar lançamentos de livros, como o livro de José de Souza Martins sobre Florestan Fernandes, lançado em 25/11/98 ou o Guia de Museus da Comissão de Patrimônio Cultural da USP, em 12/12/00. 


\section{6. $O$ prédio}

Inicialmente instalado no prédio dos Departamentos de História e Geografia, o IEB foi transferido, no início dos anos 1980, para um dos blocos de moradia estudantil (CRUSP) no campus da Cidade Universitária. Ocupava os dois primeiros pisos e o Instituto de Pré-História e o Museu de Arqueologia e Etnologia ocupavam os outros quatro andares. Esse espaço, totalmente inadequado para abrigar coleções, foi adaptado na medida do possível permitindo o acesso aos acervos. O espaço expositivo era bastante restrito, porém foi sempre mantida a exposição permanente de obras do acervo, só retiradas para realização de exposições temporárias.

Em 1993 o IEB mudou para sua atual sede, próxima ao conjunto residencial da USP, em espaço de $2.800 \mathrm{~m}^{2}$, construído no local onde se encontravam anteriormente as "colméias". Desse total, $260 \mathrm{~m}^{2}$ são para exposições da Coleção de Artes Visuais permanente e temporárias.

Conforme desenho da planta do prédio, aqui apresentado, pode-se visualizar a distribuição do espaço, ocupado em grande parte pelo acervo numeroso de obras da biblioteca.

Para as atividades do IEB, essa mudança foi fundamental pois garantiu a sua continuidade. Ainda assim, faltam espaços para salas de aula e a localização é desfavorável por estar escondido entre os prédios do conjunto residencial e o restaurante central.

\subsection{Uma parte de um instituto: considerações sobre a Coleção de Artes}

\section{Visuais do IEB}

Retomando as informações apresentadas anteriormente, podemos afirmar que o IEB se configura como um instituto de pesquisas e não como um museu. Suas atividades giram em torno dos acervos - a maior parte - com ênfase para a pesquisa. Entretanto, a divulgação é voltada para públicos especializados e o dobro de consulentes da Biblioteca em relação aos visitantes das exposições atesta essa situação.

Nos últimos anos, entretanto, a Revista deixou de sair, o número de publicações diminuiu assim como o de cursos de difusão, indicando uma queda no poder de divulgação do IEB. Ao mesmo tempo, em 1996, o Instituto iniciou a oferta de disciplinas optativas de graduação passando a atingir diretamente alunos da graduação, antes só alcançados por meio de estágios ou pelas visitas às exposições. Ao longo do tempo, 
isso poderia estimular um maior número de pesquisas de pós-graduação relacionadas aos acervos do IEB, dinamizando a instituição. Outro caminho para ampliar as pesquisas seria a instalação de um curso de pós-graduação específico do IEB - já solicitado à Reitoria - mas que demandaria a contratação de mais docentes para completar um quadro mínimo de ofertas de disciplinas, ou a realização de parcerias com outras unidades da USP.

A Coleção de Artes Visuais é uma parte de um instituto de pesquisas, que desenvolve pesquisa em várias áreas. Assim, nas respostas ao questionário, quando perguntamos sobre os cursos oferecidos, a resposta refere-se ao IEB como um todo e não à Coleção. O mesmo se repetiu quando se falou sobre distribuição de verbas, relação com departamentos, serviços prestados, entre outros.

Biblioteca, Arquivo e Coleção de Artes Visuais do IEB são fonte obrigatória de pesquisa para historiadores da arte que se dedicam aos séculos XIX e primeira metade do XX. As obras de arte também são vistas como parte do legado de intelectuais e artistas brasileiros depositados no IEB. A Coleção Mário de Andrade, significativa para o estudo do modernismo brasileiro, pode ter como objeto de pesquisa as cartas de Mário de Andrade para outros intelectuais, para artistas, suas críticas aos artistas, além das obras de sua coleção, todos sob responsabilidade do IEB.

O IEB cumpre claramente a função de pesquisa nos moldes de um museu universitário, entretanto sua vocação parece ser mais de um instituto e menos de um museu, pois as atividades de extensão - exposição e educação - ficam em um segundo plano. As suas coleções (não só de obras, mas de documentos ligados à arte) são objeto de inúmeras pesquisas acadêmicas e algumas visam a concepção de exposições, mas a realização de exposições baseadas em pesquisa do acervo ocorre com pouca freqüência. 


\section{O Museu de Arte Contemporânea (MAC)}

O Museu de Arte Contemporânea da USP tem a melhor coleção de artistas modernos e contemporâneos entre os museus universitários brasileiros. Seu corpo de funcionários é enorme e diversificado se comparado ao dos outros museus de arte universitários ou não. Tudo isso o torna um interessante objeto de estudo e o apresenta como o museu de arte universitário no Brasil com maior potencial para desempenhar todas as funções de um museu, previstas pelo ICOM, e também as específicas de um museu universitário, conforme propusemos no início de nosso trabalho.

\subsection{Dados Gerais}

A maioria das respostas ao questionário foi dada por Maria Helena Pires Martins, responsável pela Divisão de Ensino e Ação Cultural; as respostas sobre a biblioteca e a administração foram dadas pelos respectivos responsáveis em 1999.

\section{Caracterização}

1. Designação oficial:

Museu de Arte Contemporânea da Universidade de São Paulo.

2. Endereço

Rua da Reitoria, 160. Cidade Universitária, São Paulo SP.

3. Ano de fundação

1963.

4. Unidade da USP a que pertence

5. O Museu tem regimento?

Aprovado pelo Conselho Universitário em 25/11/97 (publicado no Diário Oficial em 04/12/1997). O MAC sugeriu algumas modificações do Regimento, não aprovadas pela Coordenadoria de Museus até início de 2001.

Segundo o Regimento, as finalidades e constituição são:

"Artigo $1^{\circ}$. O Museu de Arte Contemporânea da Universidade de São Paulo (MAC) é um Órgão de Integração, com as seguintes finalidades:

1 - Promover o estudo e a difusão do acervo, assim como a sua conservação, proteção, valorização e ampliação, bem como o seu conhecimento como patrimônio artístico brasileiro no Brasil e no Exterior;

II - Desenvolver atividades de ensino, pesquisa e extensão nas áreas de Museologia da Arte, Teoria e Crítica de Arte e Educação e Arte Contemporânea em museus;

III - Incentivar o intercâmbio científico e cultural com instituições afins. 
Artigo $2^{\circ}$. O Museu de Arte Contemporânea constitui-se de três divisões técnicocientíficas, a saber:

I - Divisão Técnico-Científica de Acervo;

II - Divisão Técnico-Científica de Educação e Arte;

III - Divisão de Pesquisa em Arte - Teoria e Crítica." (Regimento do MAC/USP,

D.O. E. , 04/12/1997)

\section{Breve histórico do museu}

"O Museu de Arte Contemporânea da USP é um dos mais importantes museus de arte moderna e contemporânea da América Latina. Seu acervo possui cerca de 8 mil obras - entre óleos, desenhos, gravuras, esculturas, objetos e trabalhos conceituais - de mestres da arte do século XX como Picasso, Matisse, Miró, Kandinsky, Modigliani, Calder, Braque, Henry Moore, Tarsila do Amaral, Di Cavalcanti, Volpi, Brecheret, Flávio de Carvalho, Manabu Mabe, Antonio Dias e Regina Silveira, entre tantos outros. O MAC foi criado em 1963, quando a Universidade de São Paulo recebeu de Francisco Matarazzo Sobrinho, então presidente do Museu de Arte Moderna de São Paulo, o acervo que constituía o MAM. Além desse acervo que se transferiu para a USP, Matarazzo e sua mulher, Yolanda Penteado, doaram suas coleções particulares ao novo museu." (Miranda, Sérgio, 2001)

\section{Quais são os objetivos institucionais?}

As finalidades são expressas no Regimento citado na resposta à pergunta 5.

8. Qual a área cultural/científica abrangida pelo museu ou coleção?

"Arte moderna brasileira e internacional constitui a maior parte do acervo e contemporânea constitui a menor parte." (Martins, M.H.P., 1999)

9. Qual a relação do museu com os departamentos afins?

"Historicamente, as relações tem sido nulas - mesmo sendo o diretor oriundo da ECA ou FAU - as relações acabaram sendo sempre com uma determinada linha de pesquisa à qual ele pertence e menos com os departamentos / escolas como um todo.

A atual administração (1998-2002) está tentando reverter essa situação - além da ligação com a linha de ação cultural do CBD/ECA - está-se procurando contato com os departamentos de Artes (plásticas, cênicas e música) da ECA, com o departamento de História da Arte da FAU e com as disciplinas de arte (sociologia da arte, estética) da Filosofia." (Martins, M. H. P., 1999)

\section{Recursos Humanos}

10. Responsável pelo museu ou pela coleção:

Diretor do museu: José Teixeira Coelho. As coleções estão sob responsabilidade da Divisão Científica.

11. Qual é a estrutura científica? Qual é a estrutura administrativa? Como é o organograma do museu?

Diretoria. Divisões técnicas. Administração. Biblioteca. Serviços Gerais. 
12. Há funcionários contratados exclusivamente para atender ao público? Quantos? Em que funções?

A Divisão de Ação Cultural e Extensão tem 4 educadores, 1 docente, 1 pesquisador e todos atendem o público além de fazer pesquisa. (Martins, M.H.P., 1999) 13. Número de funcionários:

$\begin{array}{ll}\text { pessoal científico: } & 35 \\ \text { pessoal administrativo : } & 76 \\ \text { total: } & 111\end{array}$

14. São utilizados serviços de terceiros? Quais?

Sim. Montadores, faxineiras e serviços de jardinagem.

15.O museu tem estagiários? Em que áreas? Quantos?

Biblioteca $=7$. Divisão Técnico-Científica de Educação e Arte=15. Divisão Científica=14; Informática=1. Centro de Atualização Biográfica dos artistas do MAC/USP $=3$. Total $=40$.

\section{Recursos Financeiros}

16. O museu tem verbas próprias anuais?

Sim.

17. Qual a procedência das verbas?

Governos estadual e federal (convênio).

18. Como as verbas são distribuídas?

Custeio e projetos (convênios).

19. Como são constituídas as coleções? (através de aquisições, doações, etc.)

Principalmente doações, desde a primeira coleção doada por Matarazzo, a coleção de Theon Spanudis e doações de artistas e outras pessoas. Há também obras provenientes do prêmio aquisição da Bienal.

Instalações

20. As instalações são próprias? (X) cedidas( ) alugadas( ) em construção( ) 21. Quais são suas principais características?

São 3 espaços: a sede na USP, o Anexo junto à Reitoria da USP, onde ficam as exposições didáticas, e o $3^{\circ}$ andar do prédio da Bienal no Ibirapuera, onde são feitas exposições temporárias. Este último espaço não pertence à USP mas sim à Prefeitura de São Paulo que cede o uso.

22. Como está distribuído o espaço entre recepção, área científica, área administrativa, área de exposições, reserva, biblioteca, auditórios, etc.? (se possível anexar planta) 


\section{Museu de Arte Contemporânea Universidade de São Paulo - 2001}

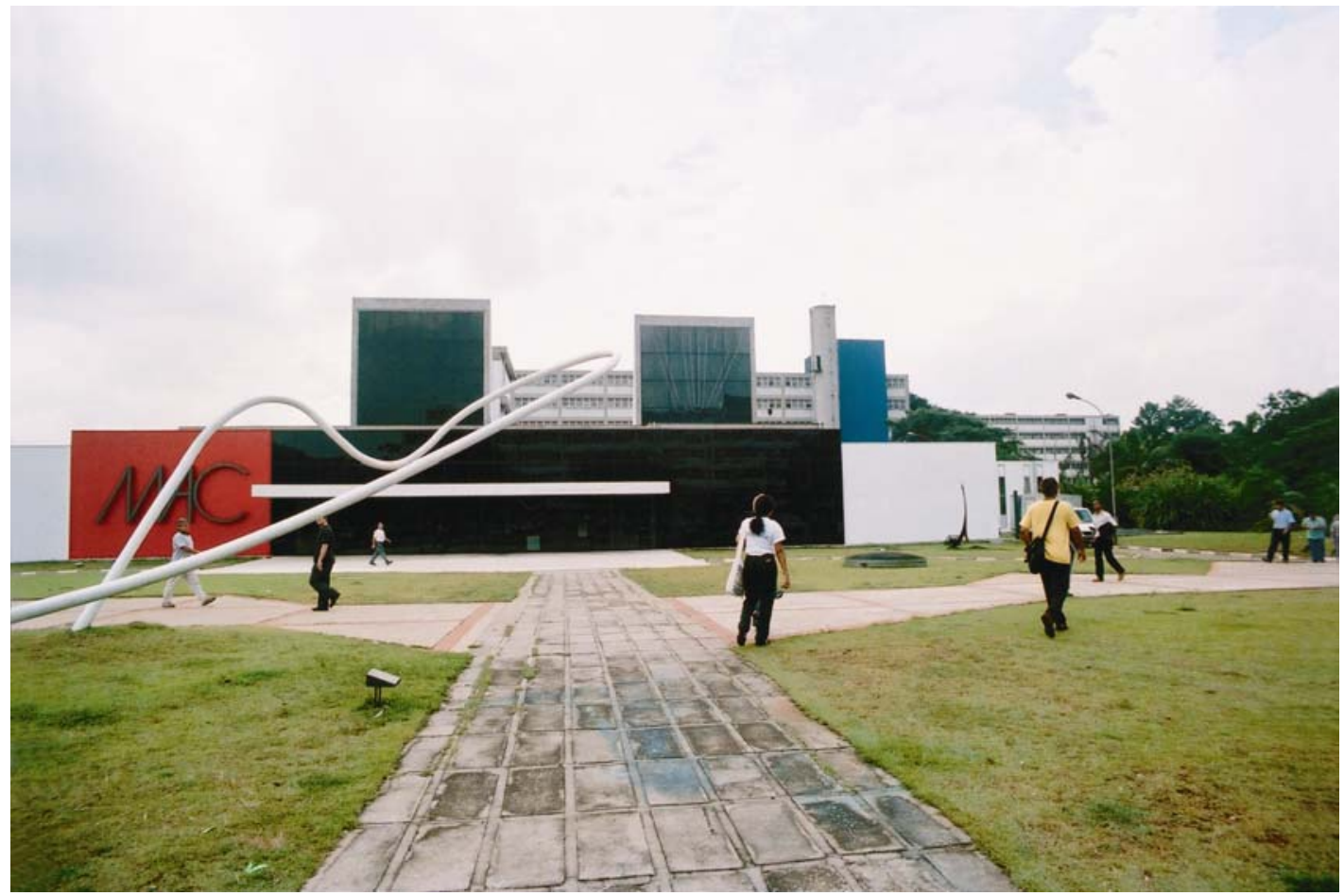

Fachada MAC - Sede

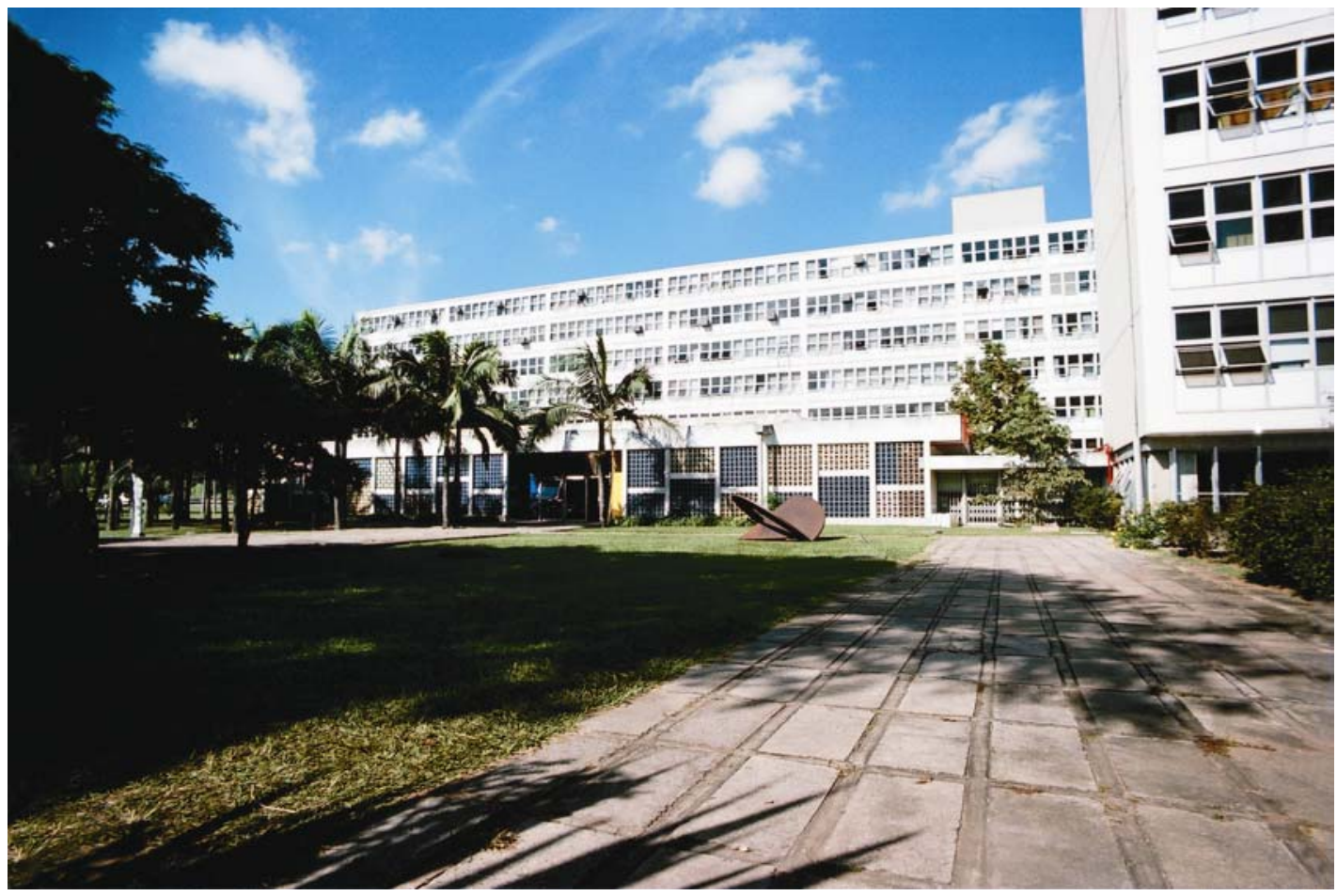

Fachada MAC - Anexo 
A instituição não pode ceder cópia de plantas por motivo de segurança.

\section{Acervo}

23. Qual é a natureza das coleções?

Arte Moderna e Contemporânea. Pinturas, esculturas, desenhos, gravuras, fotos, objetos e novas mídias.

24. Há peças de destaque no acervo? Quais?

Auto-retrato de Modigliani, O Enigma de um dia de DeChirico, Estrada de Ferro Central do Brasil de Tarsila do Amaral, A Negra de Tarsila do Amaral, as Naturezas Mortas de G. Morandi, a Natureza Morta de Bracque, a Boba de Anita Malfatti e muito mais. (Martins, M.H.P., 1999)

25. Número de peças (8.000) （）adquiridas ( ) doadas （）outras

26. Há profissionais de documentação? Sim. Quantos? Um.

27. Há profissionais de conservação / restauração? Sim. Quantos? Três.

28. Há algum setor técnico específico para este tipo de museu? Qual? Não.

29. A coleção está catalogada / documentada? Sim.

30. As coleções estão sendo pesquisadas? ( ) Não ( $X$ ) Sim

Por pesquisadores (X) do museu ( ) da unidade ( ) de outras unidades da USP ( ) de fora da USP

\section{Atividades públicas}

31. Qual é o horário de trabalho? Das 8:00 às 18:00 horas.

32. Qual o horário de visitas para o público? $3^{a}$ a $6^{a}$ das 10 às 19 horas (MAC Sede e Anexo). $3^{\mathrm{a}}$ a domingo das 12 às 18 horas (MAC Ibirapuera) em 1999.

33. Há biblioteca no museu? Sim. Qual a área de especialização e o número de volumes da biblioteca?

Área de especialização: Arte século XX. Há 5052 livros sobre artes plásticas, 181 títulos de periódicos, 22.681 slides, 27.862 catálogos de exposições, 1.400 pastas com recortes de jornais sobre artistas do acervo e 4.000 cartazes.

34. Quantos funcionários trabalham na biblioteca?

4 funcionários e 7 estagiários.

35. Quais as publicações e edições do museu/Instituto?

Catálogos; livros de arte infantis (em colaboração com outras editoras).

36. Há exposição permanente / longa duração? Sim. Temática: Arte Moderna e Contemporânea. (Martins, M.H.P., 1999) 
37. Organizam-se exposições temporárias? Sim. Qual o tema e a duração das duas últimas? Heranças Contemporâneas III - 25/08 a 20/12/99; As exposições didáticas: "Poética das Formas" - 17/05/99 a 05/2001 e "Ciranda dos Bichos" - 17/05/99 a 05/2001. (Martins, M.H.P., 1999)

38. Oferece cursos de extensão, graduação, outros?

Sim. São 4 disciplinas optativas de graduação; cursos de extensão / divulgação sobre Arte Moderna e Contemporânea, Monitoria em Arte, História da Arte para professores de Educação Básica e Arte e Educação Especial.

39. Quais os outros programas oferecidos ao público?

Atelier : Lazer com Arte para a Terceira Idade.

40. Qual o tipo de público que freqüenta o museu? (estudantes de $1^{\circ}$ e $2^{\circ}$ graus, professores, universitários, turistas....)

Estudantes de ensino fundamental (maioria); ensino médio; turistas; professores de arte; alunos de cursos de arte; público geral. (Martins, M.H.P., 1999)

41. Qual a freqüência aproximada de visitantes (anual)?

Em 1998: Nos 3 prédios do MAC: 110.000 e no Sesi-FIESP: 85.000 (Martins, M.H.P., 1999)

\subsection{Histórico}

A doação de coleções de arte para a USP não foi acompanhada da criação de cursos nas áreas afins. O MAC foi criado, em 1963, a partir da doação da coleção (1.236 peças) que antes formava o MAM/SP, 19 obras da coleção Yolanda Penteado e Francisco Matarazzo Sobrinho, doações do British Council e da Aliança Brasil-Japão e das obras adquiridas nas Bienais.

Para Aracy Amaral, o início dos anos 60 foi um período de efervescência do país, no qual a universidade se sentia com força para criar e incentivar as mais variadas iniciativas. Em relação a museus, a USP, nesse período, recebeu a coleção de Pré-História de Paulo Duarte, fundou o Museu de Arqueologia e Antropologia a partir de outras doações, deu os primeiros passos para a incorporação do Museu Paulista e comprou a biblioteca de Yan de Almeida Prado que seria uma das bases do IEB. A USP estava passando suas unidades para o campus da Cidade Universitária com a idéia de que ainda poderia crescer muito.

Em 1963 a USP recebeu uma carta formal de Francisco Matarazzo Sobrinho oferecendo a coleção do MAM e também algumas de suas coleções pessoais para a 
USP. Estava dado o desafio para a universidade: manter a vitalidade e o perfil de espaço animador das artes que o MAM conseguira nos anos 50. Para dirigir o novo museu foi indicado o professor Walter Zanini e a sede seria o $3^{\circ}$ andar do prédio da Bienal.

"O desafio que se configurava era de não perder o espírito dessa entidade que passava para a USP com o nome de MAC e que fôra o MAM de São Paulo. $O$ que se tem parcialmente conseguido até agora: o MAC sempre foi veiculador das novas tendências, a despeito de ser da Universidade. Na verdade, o importante, acima de tudo, é que o MAC mantenha sempre sua chama de um museu na Universidade e não de um museu universitário, atrelado a um Departamento de uma escola de Artes. Como no Brasil não chegam a dez os museus de arte vinculados a universidades devemos nos mirar, quem sabe, na experiência norteamericana, bem como no questionamento de sua situação e desempenho. Escrevendo sobre o assunto, John R. Spencer menciona o caráter ambíguo dos museus universitários norte-americanos, que embora sejam sempre considerados 'o símbolo da cultura no campus', são igualmente sempre os primeiros a terem seus orçamentos cortados nas primeiras antevisões de crise (tanto na área de espetáculos como na área de artes visuais)." (Aracy Amaral, 1988:32-33, grifo nosso)

Para Aracy Amaral, que foi diretora do MAC/USP de 1982 a 1986, um museu universitário tem intrinsecamente atuação restrita e limitada; e o MAC só poderia manter sua ação de veicular novas tendências da arte se não se tornasse um "museu universitário".

Na opinião de Aracy Amaral, para os artistas e os críticos brasileiros, o

"MAC transcende a Universidade pelo valor de sua coleção e por sua atuação ao longo de décadas, e uma vinculação de natureza burocrática que afete sua plena autonomia não seria nunca desejável para as atividades deste Museu que, na verdade, é um patrimônio nacional como acervo artístico, ao lado das coleções do Museu Nacional de Belas Artes e do MASP." (Amaral, 1988:34)

Cada um dos diretores do MAC centralizou suas ações em uma área. Walter Zanini (1963 a 1978) buscou adquirir obras internacionais tanto nas Bienais como em outros locais, dando ênfase para a arte conceitual da década de 70. Para Cristina Freire, atualmente pesquisadora do MAC/USP, o 'Mac do Zanini' dos anos 60 e 70, foi um "tempo" no qual experimentos foram expostos:

"(...) o MAC se configurava como um dos poucos locais onde os experimentos envolvendo, não raro, as imposturas em relação à noção instituída de arte eram aceitos. O espaço sagrado do museu foi mesmo transformado em loteamento para acolher as criações individuais e coletivas." (Freire, 1999:25) 
As palavras de Walter Zanini sobre a função de um museu de arte contemporânea, no texto de apresentação da exposição da Jovem Arte Contemporânea de 1972 (JAC), traduzem essa prática:

“(...) os dirigentes de instituições museológicas tornaram-se absolutamente cônscios da impossibilidade de suas entidades continuarem a manter-se exclusivamente na condição de órgãos técnicos de apropriação, preservação e exposição de objetos de arte, ou seja, de órgãos expectantes de produtos destinados às suas salas contemplativas de exposição. Se essas tarefas museológicas prosseguem, e com uma complexidade crescente, outros elementos despontaram no dia-a-dia do museu impelido num primeiro tempo a tomar consciência da explosão das categorias técnico-estilísticas tradicionais e a seguir a fazer face à multiplicidade de proposições que se definem como realidades transitórias, ou seja, fora do sentido individual e permanente visado como regra na dialética anterior da expressão artística. Mais ainda, a realidade filtrada e transcendente do museu vê-se cada vez mais confrontada à existencialidade profana das coisas e esta constatação certamente obrigará a reformular seus interesses ditados por uma filosofia unicamente preocupada com as mais belas essências produzidas pela humanidade." (Zanini, apud Freire, C. 1999:53)

Cristina Freire segue afirmando que o MAC, na gestão de Zanini, se tornou um fórum de debates de artistas e

"Ao mesmo tempo em que mantinha contatos estreitos com artistas não apenas brasileiros, mas de todas as latitudes, conseguia, como diretor, recursos da reitoria da Universidade para adquirir obras muitas vezes de caráter conceitual. É significativo observar que, pela não compatibilidade com as categorias tradicionais, estes trabalhos não foram assimilados à coleção do museu, ou seja, nunca mais foram exibidos ou devidamente pesquisados." (Freire, 1999:58)

Entre 1978 e 1982 o MAC foi dirigido por Wolfgang Pfeiffer, que recebeu as coleções de Mohalyi e Spanudis. No primeiro ano de sua gestão o MAC Ibirapuera ficou fechado para reformas do prédio. Professor de História da Arte da ECA/USP, Wolfgang Pfeiffer acreditava que o museu deveria acolher obras de artistas já consagrados e não deveria ser espaço para experimentações. Ainda assim, organizou além das retrospectivas, algumas exposições de jovens artistas e definiu um espaço específico para a apresentação de resultados de teses de mestrado da ECA/USP. (Banco Safra, 1990:18)

Aracy Amaral (1982 a 1986) procurou preencher lacunas das coleções nacionais e internacionais, adquirindo principalmente pinturas dos anos 80. O MAC/USP adquiriu menos obras pois já não havia verbas para comprar nas Bienais e também porque concentrava as verbas e esforços na construção da nova sede do MAC na Cidade Universitária. 
Em 1983, o MAC instalou-se de forma precária em espaço adaptado ao lado da Reitoria (atual MAC-Anexo ou Maquinho) no campus, fincando raízes na Cidade Universitária. Nesse espaço, passou-se a apresentar exposições do acervo internacional do MAC, enquanto no Ibirapuera apresentavam-se obras de artistas nacionais.

Em 1985 foi feito o projeto de Carlos Lemos para a sede do MAC no campus e a obra foi iniciada, mas em seguida interrompida.

A ex-diretora também priorizou a implantação de setores museológicos, como por exemplo o setor de Arte-Educação ${ }^{36}$, e a realização de publicações durante sua gestão. Nesse período, também foi criada a Associação de Amigos do MAC (AAMAC) que daria apoio para a compra de algumas obras.

"Encarava nessa época, como diretora do MAC, como prioridade um de minha gestão a construção do MAC na Cidade Universitária. A prioridade 2, consistia na estruturação do museu como entidade, realizada, em divisões, de acordo com o regimento nos museus da USP, e a prioridade 3, publicações e eventos. Entendia que a crônica falta de verbas e de público visitante pela própria dificuldade de acesso ao museu no Ibirapuera seriam, assim, a meu ver, superadas. Pois um museu bem visitado é um museu que merece ser atendido pelos poderes públicos, tanto ao nível de pessoal técnico como de equipamentos e novas aquisições, um dos grandes problemas do MAC. Pois caso não seja atendido neste item 'Aquisições', o Museu estará condenado a ser um museu 'datado' e sua contemporaneidade deixará de ser real.” (Aracy Amaral, 1987:48)

Após a gestão de Aracy Amaral, a arte-educadora Ana Mae Barbosa passa a dirigir o MAC, entre 1987 a 1993.

Diferentemente de Aracy Amaral, Ana Mae Barbosa partia do princípio que o MAC é um Museu Universitário:

"Temos muita preocupação em definir o MAC como Museu Universitário que, portanto, tem um compromisso muito forte com a pesquisa e, no nosso caso, com a pesquisa da imagem e da história. Isto não deve se refletir só na honesta catalogação do acervo e exaustiva coleta de dados sobre os artistas da coleção, mas também, na necessidade de traduzir, em linguagem acessível a todas as classes sociais, as pesquisas de Arte e em Arte realizadas na Universidade.

Este Museu deve ser uma porta de comunicação da Universidade com o público, não só universitário, mas principalmente, com aquele público que não conseguiu entrar na Universidade ou que já saiu dela." (Barbosa, 1990:7)

Ana Mae Barbosa afirma, no prefácio do livro publicado pelo Banco Safra (1990), que sua gestão propôs e deu andamento às seguintes metas:

${ }^{36}$ O Setor de Arte-Educação do MAC/USP foi previsto desde a gestão de Zanini, mas foi implantado em 1985, com a contratação de Martin Grossmann e o início do projeto "monitoriaatelier". (Grossmann, 1988) 
1 - intensificar o diálogo internacional

2 - priorizar exposições coletivas de jovens artistas

3 - apresentar projetos expositivos resultantes de pesquisa em História da Arte e/ou Poética Visual

4 - desenvolver projetos especiais

5 - valorizar o acervo

6 - aumentar a visibilidade do museu na USP

Ana Mae Barbosa descreve uma série de atividades e projetos que exemplificam a prática das metas propostas, que se iniciaram em 1988 e seriam continuadas até o final de sua gestão em 1993. Citaremos alguns exemplos a seguir.

Vários projetos foram desenvolvidos no sentido de atrair novos públicos para o MAC, entre eles exposições concebidas por artistas/arte-educadores "que fazem o povo se ver refletido no museu ou que os encaminhe ao museu." (Barbosa, 1991:92) Luiza Olivetto e Roberto Loeb fizeram em 1987 a exposição Carnavalescos e em 1988 a Estética do Candomblé.

"Já a equipe de artistas Cildo Oliveira, Lucia Py e Lucia Porto pretendendo dessacralizar a entrada do museu, em 1987, fizeram trabalhos escultóricos no jardim do MAC, na Cidade Universitária, que representavam uma leitura dos elementos arquitetônicos que cercam o museu." (Barbosa, 1991:92)

Para a ex-diretora, esses e outros projetos conseguiram trazer novos públicos para o MAC, sinalizado pelo aumento do número de visitantes: em 1986 foram 19 mil, em 1987, foram 30 mil; em 1988, 31 mil e em 1989 foram 76.015 visitantes. (Barbosa, 1990:8)

Ana Mae Barbosa afirma que durante sua gestão, houve empenho na realização de exposições que partiam de pesquisas em artes, antropologia, fotografia, fazendo do MAC uma porta de disseminação da pesquisa na universidade. Professores de diferentes departamentos foram convidados para serem curadores de exposições, assim como algumas teses sobre artistas foram transformadas em exposições. ${ }^{37}$

\footnotetext{
${ }^{37}$ Foram transformadas ou apoiaram a concepção de exposições as seguintes pesquisas da ECA/USP: baseadas em mestrados Modernismo em Minas Gerais de Yvone Luzia Vieira e Gravuras de Fayga Ostrower de Maria Helena Lemmi; a tese de Lucia Helena B. Rezende foi utilizada para a exposição de 10 anos da morte de Yolanda Mohalyi; em poéticas visuais, as teses de doutorado de Percival Tirapelli (até aqui todos orientados por W. Pffeifer), Carmela Gross e Evandro Carlos Jardim (os dois orientandos de W. Zanini) e as dissertações de mestrado de Diana Domingues (orientada por Julio Plaza) e Anna Barros (orientada por Regina Silveira) foram apresentadas no MAC/USP. Também teriam sido feitas exposições baseadas em pesquisas históricas realizadas pelos pesquisadores do MAC. (Barbosa, 1990:6)
} 
A política implantada por Ana Mae Barbosa visava dar espaço para as diversas correntes da arte contemporânea, para o multiculturalismo. Assim, não somente o universo dominante da arte, mas também o universo da produção dos negros, dos trabalhadores, dos carnavalescos, das mulheres foram expostos naquele período.

"Alguns me dizem que a preocupação do MAC com a etiologia da arte através de 3 projetos que investigam as determinantes do padrão estético das massas, a manifestação estética das minorias e o olhar do outro público, que não vai a museus por inibição e vergonha de sua incultura formal, incomoda os artistas que têm sua árvore genealógica definida porque eles passam a ter menos espaço no Museu. Não é verdade. O número de exposições tem crescido consideravelmente nos últimos anos. Se em 1986 houve apenas 6 exposições temporárias no MAC, em 1989 houve 25, das quais apenas 4 se vinculam à etiologia da arte ou, como mais comumente se diz, às manifestações estéticas não-eruditas. As outras foram dedicadas aos artistas da cultura dominante." (Barbosa, Ana Mae, 1990:2) ${ }^{38}$

Sobre a dificuldade de aquisição de obras, Ana Mae Barbosa nos contou que durante sua gestão conseguiu um acordo de comodato, por 50 anos, com uma galeria de arte permitindo a vinda de muitas obras para o MAC. Ela lamentou que muitos artistas decidem doar obras menores ao museu e não trabalhos de alta qualidade. Isso acaba prejudicando o próprio artista, a longo prazo, quando curadores internacionais vêm aos museus em busca de obras para exposições de artistas brasileiros e latinoamericanos. (Barbosa, 1998)

Uma das propostas de Ana Mae Barbosa foi a de "inter-relacionar curadoria, pesquisa e arte-educação" considerando que todas "têm responsabilidade de facilitar a comunicação e a apreciação do público." (Barbosa, 1991:87) (39 $^{39}$

Para reforçar os quadros do MAC, por meio do processo de contratação de recém doutores estimulado pela USP, a então diretora solicitou uma pesquisadora da área de música e uma de teatro. O MAC pôde então oferecer disciplinas para alunos de graduação relacionando seu acervo com música, teatro e literatura. Para Ana Mae, Barbosa esse tipo de curso, que oferece alternativas aos oferecidos pelos departamentos de ensino, é fundamental para atrair os alunos da própria universidade ao museu. (Barbosa, 1998)

Em 1992, durante a gestão de Ana Mae Barbosa, foi inaugurado o novo prédio do MAC na Cidade Universitária, ainda que de forma parcial e precária. Trataremos dos prédios no item 2.6 deste capítulo.

\footnotetext{
38 Ana Mae Barbosa complementa afirmando que também as exposições de acervo aumentaram "Em 1989 fizemos 34 exposições da coleção e, de 87 para cá, a exposição mais destacada de cada ano tem sido sempre do acervo." (1990:2)

${ }^{39}$ Ana Mae Barbosa cita como exemplos bem sucedidos dessa política as exposições As Bienais no Acervo do MAC (1987/88) e Mário de Andrade e as Crianças. (1991:87)
} 
A diretora seguinte foi a professora Lisbeth Rebollo Gonçalves (1994-1998), e em março de 1998 assumiu o atual diretor José Teixeira Coelho Neto, ambos originários da ECA/USP.

Durante a I Semana de Museus da USP, em maio de 1997, Lisbeth Rebollo Gonçalves apresentou um relato das atividades realizadas no MAC e suas metas de curto, médio e longo prazos. Em curto prazo pretendia aprovar o organograma, climatizar o MAC-Sede e adequar a reserva técnica do MAC-lbirapuera. Em médio e longo prazo, a ex-diretora propõe:

1) construção de um bloco anexo ao existente na Cidade Universitária;

2) modernização tecnológica;

3) implementação de cursos de graduação e pós-graduação;

4) trabalhar a imagem "identitária" do museu;

5) afirmar conhecimento do museu no exterior;

6) adquirir obras contemporâneas e

7) criar Fundo para custeio de eventos no MAC. (Gonçalves, 1999:24)

O Regimento do MAC foi aprovado em 1997, mas as outras metas propostas não foram realizadas e/ou concluídas durante a gestão de Lisbeth Rebollo Gonçalves ${ }^{40}$.

A gestão de Teixeira Coelho, iniciada em 1998 está em andamento, e será descrita com detalhes nos próximos itens. Ressalte-se que durante sua gestão, o MAC fez parceria com o Centro Cultural SESI/FIESP e com isso tem realizado exposições na Avenida Paulista, e em dezembro de 2000, reabriu sua sede na Cidade Universitária depois de reforma e climatização do prédio.

\subsection{As coleções}

Como já foi explicado anteriormente, a coleção inicial do MAC/USP provém da doação do acervo do MAM/SP em 1963, acrescida de obras da coleção particular de Francisco Matarazzo Sobrinho. Mais tarde, entre 1978 e 1982, o MAC recebeu 26 obras do espólio de Yolanda Mohalyi e 364 obras da coleção Theon Spanudis. O acervo ficou então com obras de diferentes épocas, estilos e valores.

\footnotetext{
${ }^{40}$ O Regimento foi aprovado mas o Organograma correspondente não. Assim, oficialmente, o MAC funciona com um Organograma que foi parcialmente aprovado em 1988, no qual docentes e especialistas se dividem em duas grandes divisões - Científica e de Difusão Cultural. Como a aprovação de um novo organograma implicaria em criação de cargos de chefia, a Reitoria procura dificultar ao máximo esse processo.
} 
Em 1988, segundo Aracy Amaral, o MAC contava com 4.323 obras, sendo 3.120 nacionais e 1.150 estrangeiras e ainda 580 de "índole conceitual" (Amaral, 1988:44)

Novas doações e compras foram enriquecendo o acervo do MAC: em 1996 contava com 5.462 obras, sendo 4.224 nacionais e 1.238 estrangeiras, de mais de mil artistas diferentes. (Almeida, M.C.B.,1998)

Diversos autores ${ }^{41}$ salientaram a representatividade das coleções de arte moderna e contemporânea nacional e internacional do MAC, como sendo a mais importante no Brasil. Com obras de 1906 até 1998, o MAC "oferece uma experiência significativa do que foi e é a arte deste século" (Teixeira Coelho, 2000:168).

"Hoje, seu acervo de aproximadamente oito mil obras é constituído por obras ordenadas em seis grandes conjuntos: pinturas, desenhos, gravuras, esculturas, objetos e obras conceituais em novas mídias.

Dentre essas obras, devem ser destacadas o Auto-retrato de Modigliani, a Estrada de Ferro Central do Brasil e A Negra de Tarsila do Amaral, A Boba de Anita Malfatti, Figuras de Picasso, Natureza Morta de Morandi, O enigma de um dia, de De Chirico, O Paradoxo do Santo de Regina Silveira. A lista de artistas presentes na coleção é verdadeiramente impressionante: Chagall, Miro, Hans Arp, Kandinsky, Lhote, Bracque, Max Ernst, Portinari, Di Cavalcanti, Flávio de Carvalho etc. Todos os movimentos e tendências da arte do século XX estão igualmente representados, às vezes com um conjunto de obras significativas, como é o caso da Arte Conceitual, às vezes com poucas obras.

Como vemos, a riqueza do acervo nos permite dizer que o MAC tem a melhor coleção de arte moderna e contemporânea do país e, por isso, tem a obrigação de torná-la acessível ao público externo à comunidade acadêmica." (Martins, 2000)

Quatro grandes publicações sobre as coleções do MAC/USP, além de apresentarem listagens e imagens das obras, têm comentários e análises do perfil do acervo do museu: O catálogo geral, de 1973; O Perfil de um Acervo, organizado por Aracy Amaral, de 1988; o livro MAC/USP do Banco Safra de 1990; e o Catálogo geral:1963-91, publicado em 1992. Os catálogos de exposições retrospectivas de acervo aprofundam ainda mais informações sobre partes do acervo. Nosso papel aqui não é apresentar todo o acervo, ou mesmo analisar a qualidade e perfil do acervo, mas tratar das características que favorecem ou não a atuação do MAC enquanto museu universitário.

A maior parte das obras do MAC foi adquirida por doação. Em 1997, a pesquisadora do MAC Gabriela Wilder fez um balanço das aquisições do MAC nos cinco anos anteriores: foram 605 obras, sendo $66 \%$ doadas por artistas, $25 \%$ doadas por terceiros, $8 \%$ em comodato de 20 anos com marchand, $0,7 \%$ comodato com

${ }^{41}$ Entre eles, diretores do MAC/USP: Aracy Amaral, 1988; Barbosa, 1990; Teixeira Coelho, 2000. 
artistas e 0,3\% compradas pela Associação de Amigos do MAC. Entre as obras, $72 \%$ são obras sobre papel, $13 \%$ tridimensionais, $9 \%$ telas e $6 \%$ fotografias. Para Gabriela Wilder, a maior quantidade de obras em papel pode ser explicada pelo seu custo baixo. A pesquisadora esclarece ainda que parte das doações foram feitas a partir da solicitação dos profissionais do MAC para complementar as coleções existentes, sendo fruto de pesquisas e não da escolha do doador/artista. (Wilder, Gabriela, 1999:52)

Para um museu, adquirir obras por meio de doações pode ser muito bom por não ter custos imediatos. Entretanto, cada obra que entra no museu significa novos custos para preservação, estudo e divulgação. Assim, os critérios de seleção de obras deveriam levar em conta as necessidades das coleções do museu combinadas com as condições de preservação das obras. No caso de obras sobre papel, apesar de ocuparem pouco espaço e serem muitas vezes mais baratas, o custo para acondicionamento e exposição podem ser muito maiores do que para grandes obras tridimensionais, dada a fragilidade do suporte.

Um outro problema das doações advém das condicionantes que muitas vezes acompanham as doações. Apresentamos esse problema quando tratamos da formação de museus na Grã-Bretanha, nas quais muitas obras foram condicionadas à exposição permanente ou mesmo a não exposição em conjunto com obras de outras épocas. Em conversa com o diretor do Museu de Arte da Universidade Federal do Ceará (MAUC), Pedro Eymar Costa, ele descreveu a dificuldade que teve em retirar obras doadas por Aldemir Martins ao MAUC da única sala do museu climatizada para lá instalar a reserva técnica. $\mathrm{O}$ artista havia feito a doação com a condição de que as obras teriam que ter uma sala independente e permanente de exposição. Costa complementa afirmando que essas obras de Aldemir Martins doadas com condicionantes nem são as melhores obras do artista que o MAUC possui! (Eymar, 2001)

No caso do MAC, por exemplo, a Coleção Theon Spanudis foi doada mediante cláusula de que deve ser exposta - como conjunto - pelo menos uma vez ao ano. Os filhos de Lasar Segall doaram duas de obras de Lasar Segall com a condição de que pelo menos uma esteja sempre em exposição.

Teixeira Coelho lamenta o fato do MAC/USP ter recebido doações com condicionantes e considera que a autonomia do museu poderia impedir tais situações:

"A autonomia de um museu deve ser de fato ampla. Exemplo são as doações feitas com cláusulas inamovíveis que limitam a liberdade que todo museu deve ter na manipulação das obras de seu acervo. Um museu não pode receber uma obra com a condição de mantê-la permanentemente exposta." (Teixeira Coelho, 1999:29) 
O diretor do MAC considera ainda muito grave o fato do museu não poder dispor da obra para venda ou troca caso considere adequado:

"Um museu não pode receber uma obra com a condição de não aliená-la jamais; uma obra não tem o mesmo valor em toda parte e em todas as circunstâncias; o valor de uma obra depende em grande parte do cenário onde se apresenta; assim, para um museu pode ser mais importante desfazer-se de determinada obra, que teria muito mais sentido num outro contexto, para em troca adquirir outras que iluminam mais e diversamente obras já em seu poder." (Teixeira Coelho, 1999:29)

Nesse ponto chegamos à questão da política de aquisição do MAC. Como ela se processa? Por muitos anos, os vários diretores e críticos vêm denunciando a pequena quantidade de aquisições do MAC, que assim perderia seu caráter de museu de arte contemporânea. No início da formação das coleções do MAC, ainda como MAM/SP, havia a aquisição constante de obras expostas nas Bienais, que permitiram um crescimento do acervo com obras significativas. Mas não houve continuidade e, em 1963 ,

“(...) o MAC-USP passa a viver sob a contradição de manter-se como uma instituição museológica especializada em arte contemporânea nacional e internacional (a partir do acervo recebido do MAM) e a falta de subsídios para mantê-lo atualizado nesta condição." (Chiarelli, 1987:46)

Novas coleções particulares foram doadas, com destaque para a Coleções Spanudis e Mohalyi. Mas ainda era pouco.

No caso da arte internacional, Tadeu Chiarelli afirma:

"desprestigiado pela própria Universidade, o Museu hoje em dia parece estar condenado - em termos de acervo internacional - a apenas preservar (e com dificuldades) o que herdou do MAM, e o pouco que seus diretores conseguiram, seja através de aquisições ou doações." (Chiarelli, 1987:47)

Em busca de uma política de aquisições, o MAC definiu, em 2000, um Programa de Novas Aquisições, no qual

"Pretende rever as lacunas mais marcantes, abrangendo tanto o segmento nacional como internacional. Nessa primeira fase, o programa focaliza ausências significativas de artistas contemporâneos brasileiros de grande projeção nacional e internacional, como Waltércio Caldas, Sandra Cinto, Rochelle Costi, Vik Muniz, Rosângela Rennó, Edgard de Souza, Ana Maria Tavares e Tunga. A exceção, nessa relação, é a presença de Nelson Leirner, artista especialmente convidado para apresentar uma obra recente. Isso se deve pelo fato do MAC contar com importantes obras desse artista. (...)

Para viabilizar a empreitada, o MAC, com o apoio de sua associação de amigos AAMAC - procurou os artistas e suas respectivas galerias (Galeria Brito Cimino, Galeria Luisa Strina, Casa Triângulo e Galeria Camargo Vilaça). O MAC 
considera essencial o envolvimento de todos estes agentes no processo de sensibilização dos eventuais apoiadores desse programa, com o qual a coleção se renova e o museu responde ao seu desígnio." (Grossmann, 2000)

Entretanto, o MAC ainda não conta com verba alocada para as aquisições pretendidas. Mas está dado o importante passo de definição de política de aquisição, que fundamenta doações, compras, comodatos, evitando a incorporação ao acervo de obras não significativas ou adequadas para o MAC. Ainda falta pormenorizar essa política e conseguir verbas para colocá-la em prática.

Uma outra atividade intrinsecamente ligada à aquisição é a pesquisa, pois um museu só pode definir aquilo que "falta" em seu acervo se o conhece em profundidade e se também conhece a produção artística. Gabriela Wilder, pesquisadora do MAC, coloca com clareza a função da pesquisa:

"O MAC-USP, assim como todos os museus em geral, precisa orientar o desenvolvimento de sua coleção baseando-se em pesquisa científica. Escolhas precisam ser feitas e devem ser assumidas por especialistas fundamentados em pesquisas constantes e sempre divulgadas por meio de cursos e exposições, catálogos, publicações e discutidas e aprofundadas em painéis e seminários." (Wilder, 1999:53)

Pesquisas sistemáticas e em profundidade, sobre o acervo, os artistas já representados e os ausentes, poderão alimentar as bases para a política de aquisição e até os critérios de prioridade para restaurações e documentação.

Veremos, a seguir, quais são as pesquisas que vêm sendo realizadas no MAC nos últimos anos e se elas corresponderiam às expectativas correspondentes a um museu universitário.

\subsection{As pesquisas}

Segundo Gabriela Wilder, uma das responsabilidades de um museu universitário estaria na pesquisa para aquisição:

"É justamente nessa área que se situa a grande responsabilidade de um museu universitário, ou seja, na da prospecção e acompanhamento, na análise e na crítica do fazer das diferentes vertentes e linguagens. Dentro das clássicas funções dos museus de seletores, preservadores, pesquisadores e divulgadores da memória coletiva, cabe aos curadores de um museu de arte contemporânea a responsabilidade de localizar tendências, identificar os artistas seminais e organizar exposições essencialmente didáticas." (Wilder, 1999:52) 
Mas a pesquisa do MAC/USP não pode visar apenas a aquisição. Ela deve ser voltada também para as coleções já existentes, podendo incluir abordagens de história da arte, teoria da arte, crítica de arte, educação, psicologia, entre outras.

Concordamos com a posição da professora Haiganuch Sarian, pesquisadora do MAE/USP, ao situar a pesquisa no museu universitário:

"Não há Universidade sem produção e reprodução do saber, de modo que a pesquisa científica é um propulsor de todas as suas atividades. Assim vemos também que, nos Museus Universitários, investigações conduzem o especialista aos trabalhos de campo, de laboratório, de gabinete, alimentando a formação de coleções e orientando-os à aquisição de coleções. Mas a pesquisa em Museus Universitários vai além, pois a par do grande investimento técnico para a constituição das coleções, há a pesquisa rigorosa sobre estas coleções. E não se trata apenas de estudar as coleções originárias de pesquisas de campo modernas e sistemáticas, mas de dar um sentido científico a todas as coleções existentes nos Museus, para que se possa transformá-las em agentes de informação." (Sarian, 1999:34)

Haiganuch Sarian parte de sua experiência como arqueóloga e seria preciso repensar suas colocações para a especificidade de museus de arte e, mais ainda, para museus de arte contemporânea. A formação de coleções se dá de maneira bem diversa, uma vez que não se encontram obras de arte contemporânea em "escavações" de campo. O pesquisador em arte contemporânea deve sair a campo para pesquisar, mas vai precisar de dinheiro ou da boa vontade do artista para obter as obras pertinentes para o museu. A pesquisa muitas vezes se inicia sem a presença da obra, ao contrário do arqueólogo que parte do objeto "encontrado".

O número de pesquisadores do MAC vem aumentando: em 1986 havia apenas um mestre, em 1990 eram quatro professores doutores, quatro mestres e vários mestrandos; e em 2000 eram cinco professores doutores (um com livre docência), um doutor (especialista), seis mestres sendo dois doutorandos (um pesquisador e cinco especialistas) e dois mestrandos. ${ }^{42}$

Concordamos com Cristina Freire, pesquisadora do MAC/USP, quando ela afirma que falar em pesquisa em um museu de arte contemporânea implica necessariamente em desenvolver constantemente novas metodologias. Cristina Freire considera ainda que, mesmo as atividades tradicionalmente atribuídas à curadoria em museus $^{43}$, deveriam ser renovadas conceitualmente para um museu de arte

\footnotetext{
${ }^{42}$ Não incluímos aqui os três professores que são da ECA/USP e estão no MAC para uma gestão (1998-2002): o diretor Teixeira Coelho (titular), o vice-diretor Martin Grossmann (doutor) e a diretora da Divisão de Ensino e Ação Cultural Maria Helena Pires Martins (livre-docente).

${ }^{43}$ Nesse caso, Cristina Freire se refere à definição de curadoria dada pelo MAE/USP, por ocasião da I Semana de Museus da USP, em 1997: “(...) ciclo completo de atividades relativas
} 
contemporânea. Assim, a preservação de obras contemporâneas que foram realizadas para serem efêmeras não pode ser pensada da mesma maneira que a preservação de obras feitas para "durar"; a documentação precisa criar novos conceitos e termos pois aqueles tradicionalmente utilizados em museus de arte já não são suficientes. (Freire, 1999)

No início de 2001, o MAC/USP contava com os seguintes docentes/pesquisadoras $^{44}$ : Maria Cristina Freire, Daisy Peccinini Alvarado, Kátia Canton e Helouise Lima Costa ${ }^{45}$ da Divisão de Curadoria; Carmen Sylvia Guimarães Aranha e Gabriela Suzana Wilder da Divisão de Ensino e Ação Cultural. No MAC/USP, assim como no IEB e em outras unidades da USP, especialistas também desenvolvem pesquisas: Isis Baldini Elias e Magali Melleu Sehn da Divisão de Preservação e Documentação; Amanda Pinto Tojal, Maria Ângela S. Francoio e Renata Sant'Anna da Divisão de Ensino e Ação Cultural. ${ }^{46}$

Apresentamos, em anexo, um quadro das pesquisas que vêm sendo realizadas no MAC nos últimos anos (1997 a 1999), tomando como base os Relatórios institucionais.

As pesquisas da Divisão de Curadoria são voltadas, em geral, para a produção de exposições, a partir do acervo do MAC/USP ou de outras instituições. Das três pesquisas de Daisy Peccinini de Alvarado, duas produziram exposições sobre o acervo do MAC (Arte Brasileira dos Anos 20 ao 70 e da Tela à Instalação). Nesses casos, as pesquisas favorecem o aprofundamento do conhecimento do acervo do MAC e sua divulgação.

A terceira, voltada para a criação de banco de imagens e base de dados sobre o MAC, está diretamente relacionada ao trabalho de documentação do museu não havendo, entretanto, integração com a Divisão de Preservação e Documentação. O

ao acervo, compreende a execução e/ou orientação científica das seguintes tarefas: a) formação e desenvolvimento das coleções; b) conservação física das coleções; c) estudo e documentação; d) comunicação e informação." (Freire, 1999:55)

${ }^{44}$ Assim como no caso do IEB e em outros museus, os pesquisadores do MAC deverão passar por concurso para ingressar na carreira docente. Como pesquisadores, os que têm doutorado costumam participar de bancas examinadoras de dissertações e teses e também orientam bolsistas de iniciação e aperfeiçoamento. Entretanto, apenas Daisy Peccinini de Alvarado orienta alunos de pós-graduação, no Instituto de Artes da UNICAMP.

${ }^{45}$ A pesquisadora foi transferida para a ECA/USP em 2000, mas voltou para o MAC no início de 2001.

${ }^{46}$ As equipes do MAC adotaram para uso cotidiano - relatórios, fichas técnicas em folhetos e catálogos, as denominações de divisões e setores que estão propondo nas modificações do Regimento. Assim, em vez de "Divisão técnico-científica de acervo" usam "Divisão de Preservação e Documentação"; em vez de "Divisão técnico-científica de Educação e Arte" utilizam "Divisão de Ensino e Ação Cultural"; e em vez de "Divisão de Pesquisa em Arte" usam "Divisão de Curadoria". 
mesmo ocorre com a pesquisa que Silvia Meira ${ }^{47}$ desenvolvia para formar base de dados biográficos de artistas do MAC.

Esse problema de falta de integração já foi apontado por Christina Barbosa de Almeida, por prejudicar a instituição:

"Esta falta de integração de projetos desenvolvidos em salas vizinhas reflete a falta de planejamento, de políticas e de unidade de direção dentro do Museu, deixando espaço a projetos pessoais que não são, de fato, assumidos institucionalmente, mas que também não são suspensos: desenvolvem-se à revelia da política e dos interesses da instituição - ou melhor, nas brechas ocasionadas pela falta de política e de transparência de interesses da instituição e em óbvia dispersão de recursos de terceiros, já de si tão escassos. Com isso, permite-se a duplicação de atividades que acaba sendo favorecida pelo financiamento externo que esses projetos obtêm, pelo fato de serem seus proponentes pesquisadores vinculados à atividade acadêmica e de pesquisa." (Almeida, 1998:188)

Assim, projetos que são relevantes para o MAC poderiam ser muito mais produtivos, mais eficientes se deles participassem todas as áreas que se relacionam à proposta de pesquisa. Outro exemplo de duplicação é dado pelos trabalhos de Kátia Canton voltados ao público infantil, pois esses deveriam integrar a área educativa desde sua concepção, para serem de fato incorporados pela instituição, e não serem só da pesquisadora.

Não queremos negar a importância da pesquisa individual, desde que ela não seja assumida como institucional. Quando tratamos do IEB, Marta Rossetti diferenciou com clareza os dois tipos de pesquisa: a institucional é realizada para organização e exploração do acervo e integra docentes, técnicos e estagiários, produzindo documentação que torna o acervo mais acessível. Mesmo com as diferenças de vocação entre o IEB e o MAC, esses dois tipos de pesquisa também se aplicam ao MAC. Entretanto, não identificamos pesquisas que integram as equipes, a não ser aquela desenvolvida por Cristina Freire, a partir das coleções de arte conceitual do MAC.

Consideramos a pesquisa realizada por Cristina Freire a partir das coleções de arte conceitual do MAC exemplar enquanto pesquisa em museu universitário: a pesquisa gerou novas categorias para a documentação e preservação, incluiu como patrimônio do MAC obras que antes estavam "sem lugar certo" e transformou o conhecimento produzido em exposição, catálogo, folheto e livro (Freire, 1999). A exposição Arte conceitual e conceitualismos: anos 70 no acervo do MAC/USP (27/06 a

\footnotetext{
${ }^{47}$ A pesquisadora saiu do MAC/USP em 1999.
} 
20/08/2000), apresentada no Centro Cultural FIESP, apresentou essas obras que estavam esquecidas no MAC desde os anos 70 e trouxe elementos para discutir a arte do período e o próprio perfil de MAC. Contou com a pesquisa na área de Conservação feita por Isis Baldini Elias ${ }^{48}$, e na área de documentação feita por Cristina Cabral ${ }^{49}$.

As demais pesquisas da Divisão de Curadoria, mesmo que ligadas ao acervo do MAC, só envolvem as outras áreas do museu quando da necessidade de montagem das exposições e do desenvolvimento de atividades educativas.

Na Divisão de Ensino e Ação Cultural, Carmen Aranha desenvolve pesquisas que já geraram vários materiais didáticos (disponíveis em papel e na internet) e cursos voltados para professores.

Gabriela Wilder desenvolve trabalhos com o público infantil e pesquisa As artes visuais do século XX como compreensão e exercício da diversidade: uma contribuição para a educação infantil em famílias de baixa renda, no programa de doutorado da ECAVUSP.

As pesquisas desenvolvidas pelas educadoras fazem parte de programas da Divisão e também foram elaboradas conceitualmente em dissertações de mestrado: Amanda Tojal coordena o programa Museu e Público Especial e em 1999 defendeu sua dissertação na ECA/USP; Maria Ângela S. Francoio coordena o programa Museu, Educação e o Lúdico e apresentou sua dissertação na ECA/USP em 2000; e Renata Sant'Anna coordena a Coleção OLHARTE e defendeu sua dissertação, também na ECA/USP, em 2000. ${ }^{50}$ Essas pesquisas têm sido divulgadas em congressos, publicações e por meio de cursos de formação. Os programas continuam e provavelmente gerarão novos trabalhos científicos.

No caso da área de educação, há o desenvolvimento de programas e projetos de pesquisa coordenados pelos especialistas, que precisariam formar equipes que garantissem a continuidade dos programas, mesmo com uma eventual saída do

${ }^{48}$ Os desafios enfrentados para a conservação das obras conceituais para a exposição foram descritos por Isis Baldini Elias em comunicação apresentada no $X$ Congresso da ABRACOR. Isis afirmou que o trabalho levou à "reavaliação dos métodos adotados na conservação e/ou restauro de obras de arte contemporânea sobre papel" e que "o trabalho ainda não esta concluído e, por isso, muitas outras questões poderão ainda ser consideradas". (Elias, 2000)

${ }^{49}$ Cristina Cabral (documentação) considera que fez apenas uma classificação preliminar das obras selecionadas pela pesquisadora Cristina Freire. Um projeto completo de catalogação e conservação das obras conceituais foi encaminhado à FAPESP e aguarda parecer.

50 Trataremos desses programas nos itens 2.5.2., 2.5.3. e 2.7. deste capítulo. As teses defendidas foram: Francoio, Maria Ângela S. Museu de Arte e Ação Educativa: Proposta de uma Metodologia Lúdica. São Paulo, Dissertação de Mestrado, ECA/USP, 2000. Sant'Anna, Renata. Páginas da história: a criança, o livro e a arte, Dissertação de Mestrado, ECA/USP, 2000. Tojal, Amanda P. F. Museu de Arte e Público Especial, Dissertação de Mestrado, ECA/USP, 1999. 
educador. O programa não pode ser "de tal pessoa", mas sim da Divisão. Um maior intercâmbio entre os educadores também poderia resultar em trabalhos conjuntos enriquecidos pelas experiências individuais.

Na Divisão de Preservação e Documentação, a conservadora Isis Baldini Elias desenvolve pesquisa de mestrado sobre "resíduos de intervenções em papel" e a conservadora Magali Melleu Sehn faz mestrado, estudando a "tecnologia de objetos tridimensionais do acervo do MAC", ambas na ECA/USP. ${ }^{51}$

O MAC conta com um excelente corpo de servidores, muitos desenvolvendo pesquisas de alta qualidade, com financiamento do CNPq e da FAPESP, entre outras agências, faltando a integração dessas pessoas com objetivos comuns, favorecendo a produtividade da instituição. Uma das formas para orientar essa integração seria a definição de linhas de pesquisa institucionais, que envolvessem as várias áreas, garantindo sua qualidade e continuidade. As linhas de pesquisa foram aprovadas em reunião do Conselho em dezembro de 2000 e março de 2001, precisando ainda ser ratificadas: Área de Concentração: Mediação Cultural em museus de arte moderna e contemporânea; Linhas de pesquisa 1 - Curadoria em museus de arte moderna e contemporânea e 2 - Públicos de arte: teoria e prática da mediação.

Outro caminho interessante seria a integração, na pesquisa, com outras unidades.

A primeira poderia ser a ECA/USP. Salta aos olhos o número de servidores do MAC que fazem ou fizeram suas teses na ECA/USP, além de seu atual diretor e exdiretores serem também originalmente da ECA/USP, apenas de departamentos diferentes. Por que não há uma integração institucional com a ECA? Provavelmente porque os projetos de pesquisa são considerados pessoais e não como parte de programas institucionais. Dessa forma, a iniciativa para criar laços mais fortes entre as unidades deveria ser iniciada por atos individuais, mais tarde seguidos da participação institucional? Ou deveríamos nos conformar com essa constante falta de capacidade de integração na universidade?

Os projetos que integram diferentes unidades da USP deveriam ser estimulados por suas unidades, mas dependem na prática da iniciativa dos docentes em criar projetos e colaboradores. As agências financiadoras já vêm estimulando projetos interdisciplinares com linhas de financiamento específicas para tal. Falta então a vontade de se abrir para fora, expor suas atividades e envolver colegas de outras

\footnotetext{
${ }^{51}$ A especialista em documentação, Silvana Karpinski, já desenvolvia pesquisa de doutorado no Departamento de História da FFLCH/USP quando entrou no MAC, com tema distante de sua atual prática no MAC: História da Independência.
} 
unidades. Com isso, o MAC poderia ganhar muito na qualidade de seus trabalhos, no avanço das questões discutidas e no reconhecimento pelos pares da universidade de centro gerador de pesquisas.

\subsection{As atividades de extensão: cursos, exposições e publicações}

Fizemos um levantamento dos cursos, exposições e publicações realizadas pela equipe do MAC/USP entre os anos de 1997 e 1999, elencados em anexo. A partir desses dados faremos alguns comentários sobre a adequação dessa política de extensão, no caso de um museu universitário.

\subsubsection{Cursos}

O MAC/USP sempre ofereceu cursos de difusão cultural e, assim como o IEB e outros museus da USP, com o novo estatuto da USP, pôde oferecer disciplinas optativas para a graduação a partir de 1996.

Em 1993, foi criado o curso de especialização (pós-graduação latu sensu) Estudos de Museus de Arte, que foi interrompido em junho de 1998, por não corresponder às exigências da Reitoria em relação a cursos desse nível.

Além dos cursos oferecidos pelo MAC, seus professores e especialistas costumam dar cursos e palestras em congressos ou em outras instituições.

Entre os cursos dados no MAC, destacam-se aqueles relacionados ao acervo e às pesquisas desenvolvidas a partir dele e aqueles com temáticas relacionadas ao MAC e ao seu programa. Se lembrarmos dos cursos oferecidos pelos outros museus de arte universitários do Brasil citados no capítulo 3, veremos que o MAC é aquele que mais trabalha a partir de seu acervo, atendendo a diferentes parcelas de público.

Os cursos de extensão (foram 10 entre 1997 e 1999) são ministrados principalmente pelos especialistas ${ }^{52}$ ou por professores convidados. Destacam-se aí os cinco cursos da área de educação, voltados para profissionais da área. Houve apenas um curso envolvendo a prática artística, em 1997 (Desenho e Pintura). Em 2000, essa linha foi retomada com um curso de desenho durante a exposição O Papel da Arte, que teve muita procura, devendo ser continuada, voltada para crianças e adultos (Martins, 2000). Outro curso da área de educação oferecido em 1999 - Monitoria em Artes - foi muito bem sucedido e, a partir da avaliação dos professores e alunos foi

${ }^{52} \mathrm{O}$ especialista não pode ministrar disciplinas de graduação e, normalmente, um docente é responsável pelo curso que ministra, de acordo com as regras da USP. 
transformado em um curso de Especialização (360 horas) em 2000. Houve apenas um curso da área de preservação e documentação entre 1997 e 1999.

As cinco disciplinas optativas de graduação são ministradas pelas docentes e pesquisadoras, em sua maioria da Curadoria, sendo assim as temáticas são mais relacionas ao acervo e às suas pesquisas. Os cursos de Cristina Freire, assim como o de Carmen Aranha da Divisão de Ensino e Ação Cultural, são voltados para as questões da apreensão e recepção da arte moderna e contemporânea; os cursos ministrados por Daisy Peccinini discutem parcelas do acervo do MAC inseridas no contexto da história da arte e o curso de Kátia Canton é mais geral, discutindo a interdisciplinaridade nas artes.

O MAC/USP deveria oferecer disciplinas e cursos que the dessem uma identidade, um perfil diferenciado dos departamentos que oferecem disciplinas na área de Arte. Assim, as disciplinas oferecidas constantemente, que partem do acervo e/ou especificamente da arte contemporânea, são adequadas para criar um perfil para os cursos do MAC. Outra vertente importante é dos cursos de extensão, que trabalham questões da prática museológica específicas de um museu de arte, raramente oferecidos pelos departamentos, e são voltados para parcelas específicas do público professores, educadores, terapeutas ${ }^{53}$, etc. - ou para o público em geral. Cursos gerais sobre teoria e história da arte podem concorrer com similares nos departamentos afins e não deveriam ser priorizados.

É importante que, tanto cursos de extensão como disciplinas de graduação, sejam oferecidos repetidas vezes, para que os alunos saibam onde encontrar esses cursos. Se a cada ano o elenco for modificado, fica difícil para o MAC assumir um perfil claro diante da comunidade da USP e do público em geral.

Com seus cursos o MAC atinge alunos de graduação, professores de educação infantil, ensino fundamental e médio, terapeutas e várias outras parcelas do público, cumprindo com sua função de museu universitário. Entretanto, seria possível expandir ainda mais esse leque, atraindo professores da USP, por exemplo, em cursos e palestras que sugerissem novas abordagens para o estudo do acervo do MAC e para o ensino a partir do acervo. ${ }^{54}$

${ }^{53}$ Está em fase de formalização (abril de 2001) a participação do MAC em curso de Especialização em Terapia Ocupacional da Faculdade de Medicina da USP. O MAC costuma ministrar uma disciplina do curso de Terapia Ocupacional e oferece estágios em seus programas para alunos do curso.

${ }^{54}$ Essa era uma das duas estratégias sugeridas por Stephen Borhegyi, em 1956, para atrair os universitários novamente: 1) Divulgar, treinar, favorecer o ensino e pesquisa no museu por meio de cursos oferecidos aos professores dos departamentos; 2) Tornar o museu mais 
Criar mais variedade de cursos é importante, mas é preciso manter linhas relacionadas ao acervo e às pesquisas, para que o MAC não perca sua identidade enquanto museu universitário de arte contemporânea.

A qualidade dos cursos é garantida pela contínua pesquisa. Com o aprofundamento das pesquisas, em linhas claras, seria importante a criação de cursos de pós-graduação latu sensu, que formassem profissionais nas áreas de museologia, curadoria, documentação, conservação e educação em arte, nas quais o MAC tem profissionais desenvolvendo pesquisas.

\subsubsection{Exposições}

O MAC conta com três espaços expositivos próprios: o $3^{\circ}$ pavimento do prédio da Bienal no Ibirapuera, o MAC-Anexo no campus da Cidade Universitária e o MACSede, também no campus.

As exposições são de diferentes tipos: de acervo, geralmente mais longas; temporárias, de curta duração, contando com obras emprestadas ou do acervo; educativas, de acervo e/ou obras emprestadas adaptadas para determinados públicos; e instalações, obras em novas mídias.

Entre os anos de 1997 e 1999 houve uma diminuição do número de exposições apresentadas pelo MAC, com ligeiro aumento em $2000^{55}$ :

\begin{tabular}{|c|c|c|c|c|c|}
\hline Ano & Acervo & Temporária & Educativa & Instalação & Total \\
\hline $\mathbf{1 9 9 7}$ & 9 & 12 & 4 & 2 & 27 \\
\hline $\mathbf{1 9 9 8}$ & 5 & 8 & 2 & - & 15 \\
\hline $\mathbf{1 9 9 9}$ & 1 & 3 & 2 & 2 & 8 \\
\hline $\mathbf{2 0 0 0}$ & 6 & 3 & 2 & 0 & 11 \\
\hline
\end{tabular}

Durante o ano 2000, o prédio do MAC-Sede esteve fechado para reformas e o espaço do Ibirapuera ${ }^{56}$ foi ocupado para a realização da exposição Mostra do Redescobrimento, nas comemorações dos 500 anos da chegada dos europeus ao

atraente para os estudantes criando atividades que os atraiam, conforme apresentado no item 4.2 do capítulo 1 desta tese.

${ }^{55}$ Os dados de 1997 a 1999 foram obtidos nos relatórios institucionais e os de 2000 foram obtidos pela internet, na página do MAC/USP, acessada em 05/02/2001. Quando uma exposição ocorre em meses de anos diferentes ela aparece em ambos os anos.

${ }^{56}$ Em 1998, o MAC do Ibirapuera foi ocupado pela Bienal durante alguns meses; em 1999, entre setembro e dezembro o espaço foi novamente ocupado para a realização da Bienal de Arquitetura. Em 2001 será ocupado novamente para a exposição 50 Anos de Bienal. 


\section{Museu de Arte Contemporânea Universidade de São Paulo - 2001}

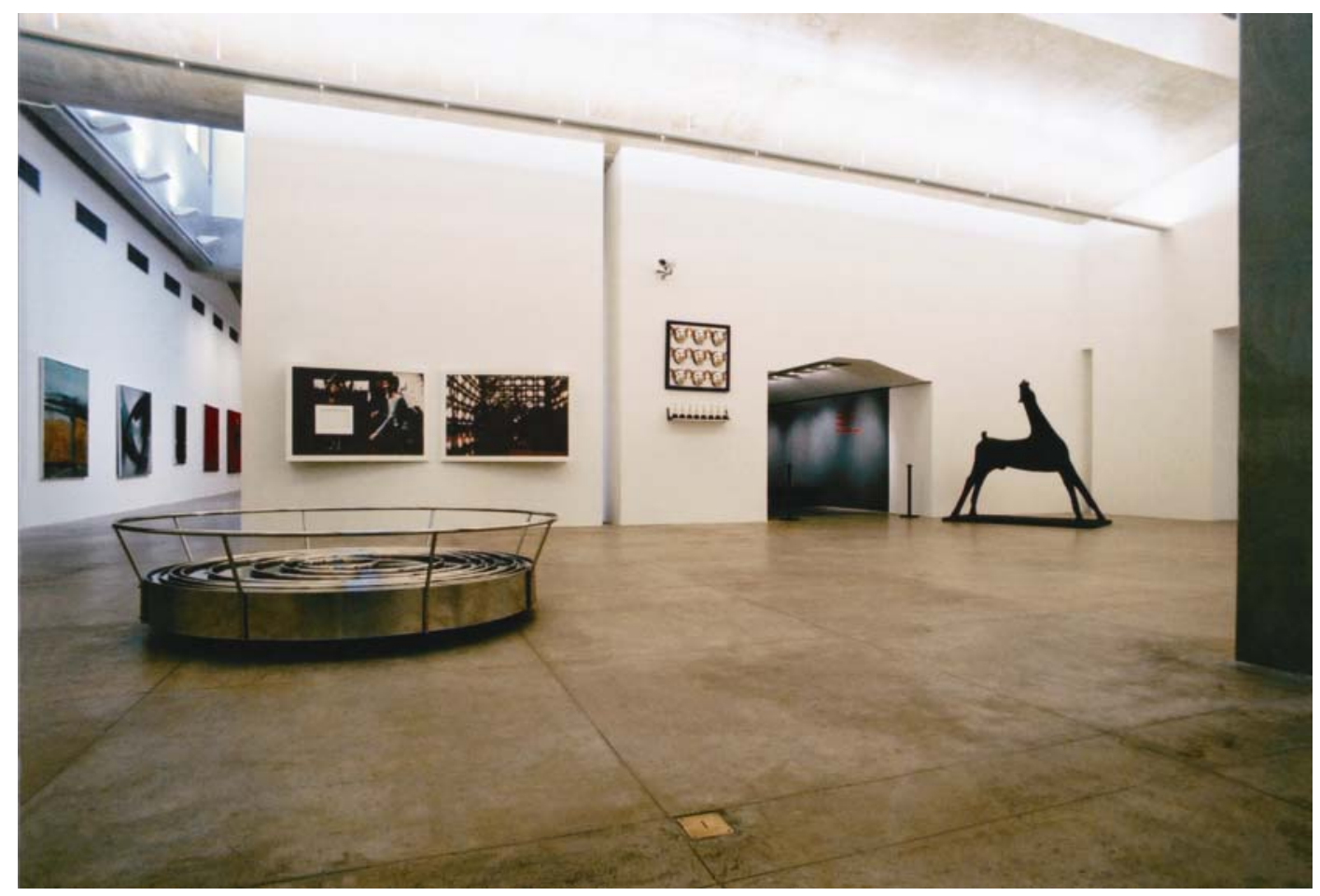

Exposição permanente: Galeria 2 - Arte contemporânea

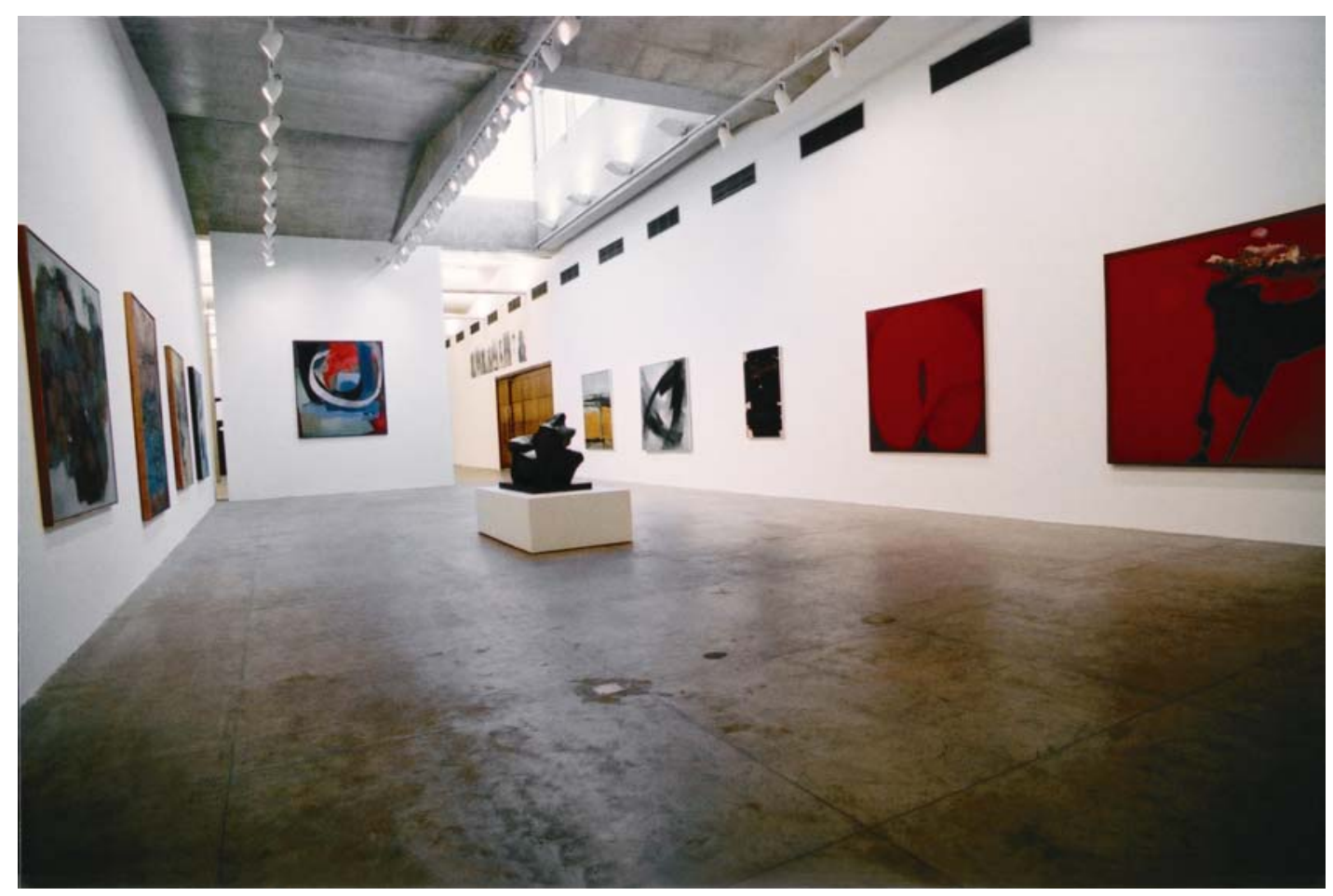

Exposição permanente: Galeria 1 - Abstracionismo 

Brasil. Nesse ano, o MAC realizou somente exposições no Anexo e também na Galeria SESI no Centro Cultural FIESP, na Avenida Paulista.

As exposições de acervo são fundamentais, dada a qualidade das coleções do MAC.

Até 1999, as exposições de acervo eram organizadas separadamente com obras nacionais e internacionais, cronologicamente organizadas ou em retrospectivas de diferentes artistas e grupo de artistas, partindo das pesquisas realizadas pela Divisão de Curadoria.

Entre 1997 e 1998 foram realizadas onze exposições de acervo, sendo quatro delas de arte brasileira com recortes cronológicos - Brasil Anos 20 a 70, etc. - e uma de acervo internacional. Duas são retrospectivas de artistas (Di Cavalcanti e Rafael França), duas temáticas resultantes de pesquisas de curadoras ( $A$ cidade dos Artistas e Da Tela à Instalação), uma sobre movimento artístico (Phases) e uma de cartazes da Biblioteca.

Em 1999, a exposição "Brasil no século da arte", com curadoria de Teixeira Coelho e Martin Grossmann, procurou inovar no partido

"adotando um critério que permite ao público ver o que faziam ao mesmo tempo, ou quase ao mesmo tempo, um artista brasileiro e outro francês ou italiano ou inglês ou colombiano - e que assim revelam todos, coerentes com as grandes linhas do pensamento artístico deste século, artistas não deste ou daquele lugar mas do mundo e, se a expressão não soar demasiadamente estranha, da arte. (Teixeira Coelho, 2000:167-168)

Outra inovação são as pequenas exposições denominadas "Obras em contexto" ${ }^{57}$, assim explicadas por Teixeira Coelho:

"Complementando o partido assumido nesta exposição, aqui e ali o visitante encontrará 'Obras em contexto', nichos onde uma peça é confrontada com documentos e informações de natureza estética, política, filosófica ou outra que ampliam seu significado inicial." (Teixeira Coelho, 2000:168)

Consideramos muito importante que um museu universitário possa ser um espaço para experimentação em teoria e história da arte e nas diversas áreas da museologia - documentação, preservação, museografia, educação - e novas propostas de organização de exposições são sempre benvindas para colocar em pauta novas abordagens e metodologias e promover diferentes relações do público com as obras de arte.

\footnotetext{
${ }^{57}$ Em 2000, foram as seguintes: Iran do Espírito Santo, abril a junho, A Negra e o Caipira, de junho a setembro e Disciplinando Soulages, de setembro a janeiro de 2001. (Página da internet do MAC, acessada em 5/02/2001)
} 
Enquanto uma exposição de longa duração permite a avaliação da exposição e dos programas educativos e sua inclusão planejada em cursos de extensão e disciplinas de graduação, as exposições temporárias trazem novos públicos, novas temáticas e experimentações artísticas e museográficas.

As 23 exposições temporárias realizadas pelo MAC entre 1997 e 1999 tratam de artistas como Gerda Brentani e Jesus Raphael Soto (9 delas), da arte de diferentes países, como da Croácia ou Polônia (6 exposições) e da arte brasileira (2 exposições). Três exposições foram resultantes do projeto de pesquisa "Heranças Contemporâneas" e uma exposição foi fruto da produção de livros infantis, ambas de Kátia Canton. Uma apresentou os trabalhos dos estudantes selecionados para o Projeto Nascente da USP e outra artistas emergentes selecionados pela crítica. Parte dessas exposições vem pronta - um pacote trazido de fora e não relacionado diretamente às pesquisas do museu - e outra é fruto de pesquisas.

Para um museu de arte contemporânea, é fundamental estar aberto para exposições de artistas emergentes, além de abrigar mostras de outros museus, proporcionando uma discussão sobre a arte contemporânea que não está presente em seu acervo. A reforma do prédio do MAC-Sede, com climatização, permitirá a recepção de exposições nacionais e internacionais, que condicionam sua vinda às condições da infra-estrutura dos prédios. Seria importante aliar às exposições seminários, debates, que tragam especialistas para trocar experiências e alimentem novas discussões. Mais importante do que estar com ambiente climatizado para receber alguma exposição "blockbuster", é poder proporcionar debates e interpretações dessas exposições, permitindo a formação dos profissionais da área e também do público.

É preciso destacar três exposições temporárias de artistas que fazem parte do programa "Obra em Contexto", já citado anteriormente.

Essa proposta de contextualização da obra de arte, parte do princípio que todas as obras seriam mais bem compreendidas / apreciadas se estivessem contextualizadas, mas isso tornaria inviável, na prática, uma exposição com muitas obras:

"Para um museu empenhado em estabelecer sólidas pontes entre a obras e o público, o ideal seria a situação em que cada uma de suas peças se apresentasse assim contextualizada; a limitação do espaço permite mostrar apenas exemplos isolados do que sempre se deveria fazer. A contextualização da obra: essa é ou deveria ser a idade atual de um museu na contemporaneidade." (Teixeira Coelho, 2000:168) 
Um exemplo de como se processa a "obra em contexto" é dado por Helouise Costa, ao explicar a proposta da exposição Arte Degenerada de Paul Klee (08/1998 08/1999):

"Na edição que se inaugura em agosto, o MAC apresenta a gravura 'A Santa da Luz Interior' de Paul Klee. Essa obra esteve na exposição 'Arte Degenerada', organizada pelo regime nazista em 1937. A exposição atual retoma características museográficas que na época foram utilizadas, como o modo não convencional de disposição de obras e textos e o uso de grandes letreiros com frases de impacto. A proposta é resgatar o papel político que a gravura de Klee desempenhou, permitindo uma leitura que vá além da questão puramente estética." (Helouise Costa, página da internet do MAC/USP, acessada em 31/03/2001)

Nesse caso a contextualização se deu por uma leitura histórica da obra e a "reconstituição" de alguns elementos da forma em que foi exibida em 1937. Esse partido nos parece bastante apropriado para apresentação de obras de arte e está sendo uma forma de integrar outros pesquisadores, de fora do MAC, para criar contextualizações a partir de abordagens de diferentes áreas - sociologia, filosofia, história, psicologia, etc. ${ }^{58}$

As exposições educativas são resultado de pesquisas e visam públicos específicos. Dentro do projeto Museu e Público Especial, entre 1997 e 1999 foram duas exposições do "Toque revelador", especialmente projetadas para portadores de deficiências, apresentadas sempre no MAC/Anexo. As outras quatro exposições foram concebidas para o público infantil, sendo duas delas parte do projeto Museu, Educação e o Lúdico, contando com espaço lúdico e jogos para crianças.

Exposições de longa duração, voltadas para público infantil, são raramente encontradas em museus de arte, sendo mais freqüentes em museus de ciências ${ }^{59}$. São iniciativas fundamentais para a formação da criança envolvida no universo da arte, que no futuro poderá se sentir capaz de visitar museus, escolher seu percurso e o que aprecia, partindo de sua própria experiência.

Mais raras ainda são as exposições para público especial de deficientes, como são as exposições do "Toque revelador". Essas iniciativas, dentro de programas de longa duração, correspondem ao que se poderia esperar de um museu universitário: partindo de pesquisas científicas, desenvolver metodologias e práticas novas que

\footnotetext{
58 Jorge Coli fez A Negra e o Caipira e Tadeu Chiarelli fez Disciplinando Soulages.

${ }^{59}$ No Chile, o Museu Artequín composto por reproduções, é totalmente voltado ao público infantil. Nesse caso a exposição é para esse público. Na maior parte dos museus de arte, os programas educativos atendem ao público infantil, "adaptando" as exposições para essa faixa etária.
} 


\section{Museu de Arte Contemporânea Universidade de São Paulo - 2001}

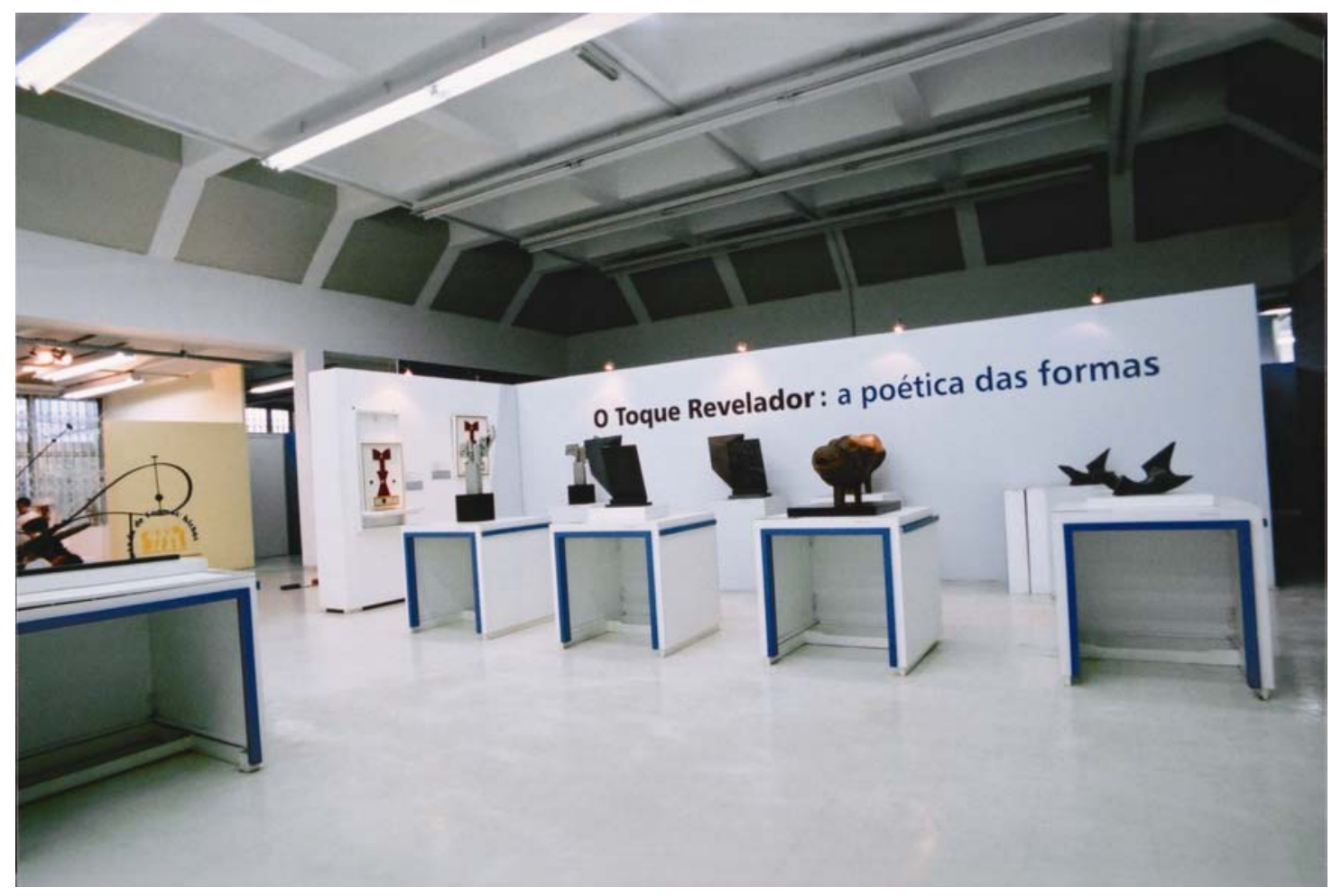


envolvem diferentes parcelas de público e que podem servir de modelo para novas iniciativas. $^{60}$

\subsubsection{Publicações}

As publicações do MAC/USP estão em grande parte relacionadas com as exposições e eventos: são catálogos, folders, cartazes e convites de divulgação. $O$ museu não tem uma revista especializada, como tem o MAE, o IEB, o Museu Paulista, entre outros museus.

Desde sua criação, o MAC/USP, assim como outros museus, procurou publicar catálogos de suas exposições ${ }^{61}$. Os catálogos são a possibilidade de perpetuação das imagens e idéias propostas em uma exposição. Permitem que o leitor "revisite" a exposição e mesmo "visite" sem ter ido pessoalmente. Os catálogos das exposições de acervo servem também para documentar as obras do museu e podem trazer novos visitantes, em busca de obras conhecidas por meio deles.

Publicar catálogos nem sempre é possível, pela freqüente falta de recursos materiais e geralmente requer parcerias e patrocínios.

Em 1986, foi editado o primeiro "Cadernos do MAC" - Estratigrafia do mural 'A Santa Ceia' de Antonio Gomide - de autoria de Augusto Froehlich e Reginaldo Mariano, que foi seguido, no mesmo ano, por mais um número apenas - Arte e Computação. MAC-USP com depoimento do professor Giorgio Moscati a respeito de sua experiência de trabalho com Waldemar Cordeiro.

Em 1992, houve empenho na criação da Revista do MAC, que não passou de um número. A MAC Revista pretendia "contribuir para a compreensão do papel da arte e do conhecimento da arte no contexto da vida universitária", apresentando artigos de especialistas de fora do MAC, com exceção de artigo da então diretora Ana Mae Barbosa, reproduzido de um de seus livros ( $A$ Imagem no ensino da Arte, 1991). Com 64 páginas e uma tiragem de mil exemplares, a revista pretendia ser semestral, mas talvez tenha sido atropelada pela mudança de gestão do MAC, em 1993.

\footnotetext{
${ }^{60}$ A partir desse trabalho desenvolveram-se projetos para públicos especiais na última Bienal (1998) e na Mostra do Redescobrimento (2000), em São Paulo, além de projetos para o SESC do Maranhão, sempre com orientação da equipe do MAC-USP, coordenada por Amanda Tojal. ${ }^{61} \mathrm{Em} O$ Perfil de um acervo, organizado por Aracy Amaral, há uma lista de todas as publicações do MAC até 1988, pp.385-387.
} 
Dessa forma, os pesquisadores do MAC costumam publicar artigos em revistas especializadas $^{62}$ ou nos catálogos das exposições promovidas pelo MAC e por outros museus. Costumam também escrever artigos para jornais e revistas de grande circulação, sobre arte em geral, política cultural, eventos que ocorrem na cidade, entre outros temas. São poucos aqueles que publicaram livros.

Nos três anos estudados - 1997 a 1999 - foram poucas as publicações "acadêmicas" dos servidores do MAC, mas há um grande número de textos publicados em catálogos e em jornais e revistas de grande divulgação. Certamente a quantidade de títulos "científicos", que é valorizada nas avaliações dos docentes feitas pela Reitoria, é pequena, se comparada aos docentes de unidades de ensino.

No Brasil, são poucas as revistas de museus de arte e seria muito produtivo se o MAC editasse uma revista sobre museus de arte contemporânea, na qual pudesse oferecer espaço a seus pesquisadores e pesquisadores de fora para divulgarem suas idéias. Além disso, poderia fazer um balanço anual de suas atividades, ampliando as possibilidades de acesso a essas informações.

Muitos dos textos que aparecem em folders estão no site do MAC na internet, acessíveis mesmo após a realização das exposições, sendo assim a rede mundial uma excelente mídia para divulgação de pequenos textos temáticos.

Uma outra linha de publicações do MAC vem dos programas educativos: catálogos em braile para o público deficiente visual; materiais didáticos para professores em folders e na internet, "catálogos" das exposições dos grupos de terceira idade $^{63}$ e a coleção OLHARTE.

Essa coleção, coordenada pela educadora Renata Sant'Anna, compõe-se de "livros de arte para crianças que apresentem os elementos da vida e da obra de artistas do acervo, favorecendo o contato do público infantil com a coleção do MAC/USP." Entre 1992 e 1999 foram publicados quatro volumes: Picasso, Tarsila, Goeldi e Maria Martins, sendo que os dois últimos ganharam o prêmio Jabuti. (Martins, 2000)

Esses livros foram escritos e ilustrados por diferentes autores, sendo que apenas o livro sobre Maria Martins teve o texto de Kátia Canton, pesquisadora do MAC. Eles não pressupõem pesquisas sobre os artistas tratados e servem como divulgação do acervo para crianças, para estimulá-las a ir ao museu.

${ }^{62}$ Como já comentamos anteriormente, a USP considera os artigos em revistas científicas como "produção", enquanto textos de catálogos ou em folders são desconsiderados para a avaliação dos docentes. A quantidade média de artigos em revistas científicas dos docentes do MAC deve ser menor do que a de docentes de unidades de ensino.

63 Trataremos com mais detalhes dos programas educativos referidos indiretamente aqui, no item 2.7 sobre públicos. 


\subsection{Os prédios: estrutura e localização}

Desde a criação do MAC/USP, quando ele ficou sediado no prédio da Bienal, os diretores planejam construir uma sede definitiva para o museu. Como já citamos anteriormente, o espaço do MAC no prédio da Bienal é continuamente solicitado para a realização de grandes exposições da Fundação Bienal impedindo a programação sistemática de atividades públicas - sejam exposições, ateliês ou cursos.

O Pavilhão da Bienal projetado por Oscar Nyemeyer não é adequado para abrigar um museu principalmente pela excessiva entrada de luz pelas fachadas de vidro. O MAC, instalado no terceiro andar, fez várias adaptações e reformas a fim de melhorar as condições de exposição e salvaguarda das obras, além de criar salas de trabalho. A área total é de cerca de $5.493 \mathrm{~m}^{2}$ com pé direito de $4,95 \mathrm{~m}$, sendo o acesso pela rampa externa ou pela porta que une com a Bienal. ${ }^{64}$

Para "sair" do Pavilhão da Bienal, foram feitos alguns projetos visando a construção do MAC no campus da Cidade Universitária. Para os ex-diretores do MAC o problema de uma falta de sede própria - uma vez que o espaço do lbirapuera é cedido - sempre foi enfrentado com dificuldades.

Em 1975, Zanini encomendou um projeto para Jorge Wilheim e Paulo Mendes da Rocha e a construção do prédio do MAC foi iniciada, na Praça do Relógio. Mas foi logo interrompida e as bases ali colocadas ficaram enterradas.

No início dos anos 1980, Aracy Amaral conseguiu que a Reitoria cedesse o espaço em que funcionava seu protocolo para instalar uma sede provisória do MAC na Cidade Universitária. Denominado MAC Anexo, o prédio era um grande pavilhão térreo com $900 \mathrm{~m}^{2}$ que foi adaptado com a construção de copa, secretaria, sanitários e um depósito interno, além de sofrer modificações na fachada para controle de entrada de luz. (Celani, 1989) Inicialmente, o espaço foi utilizado para exposição permanente de acervo, mas acabou abrigando também exposições temporárias.

Em 1985, Aracy Amaral solicitou para Carlos Lemos um novo projeto para o MAC no campus, o qual aproveitaria a estrutura de um dos prédios residenciais não acabados. A obra foi iniciada, mas com a reivindicação do prédio pelos estudantes, a obra foi interrompida e o projeto só seria revisto no final da década de 1980, já na

\footnotetext{
${ }^{64} \mathrm{O}$ espaço do Ibirapuera é bastante problemático para a exposição e preservação das obras: "Os principais problemas do Museu dizem respeito à entrada excessiva de luz no espaço expositivo, o que faz com que o espaço acabe por influenciar a distribuição das obras. (...) O maior problema da sede do Ibirapuera é que o edifício não possui nenhuma inércia térmica, devido às suas fachadas de vidro, ou seja, quando faz calor ele armazena calor e quando faz frio ele permite a entrada de frio." (Celani, 1989:49 e 52)
} 


\section{Museu de Arte Contemporânea Universidade de São Paulo - 2001}

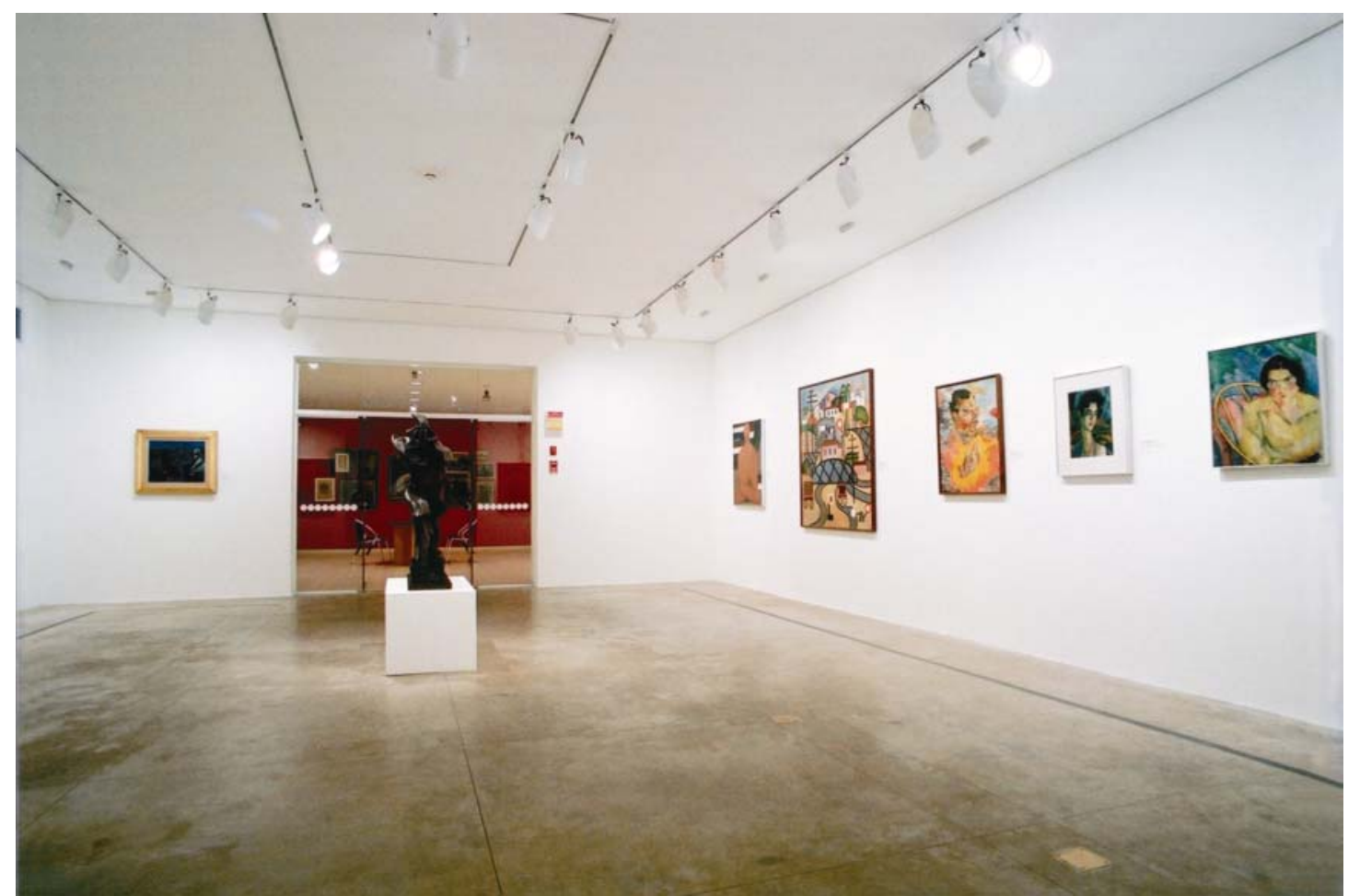

Exposição permanente: Galeria 7

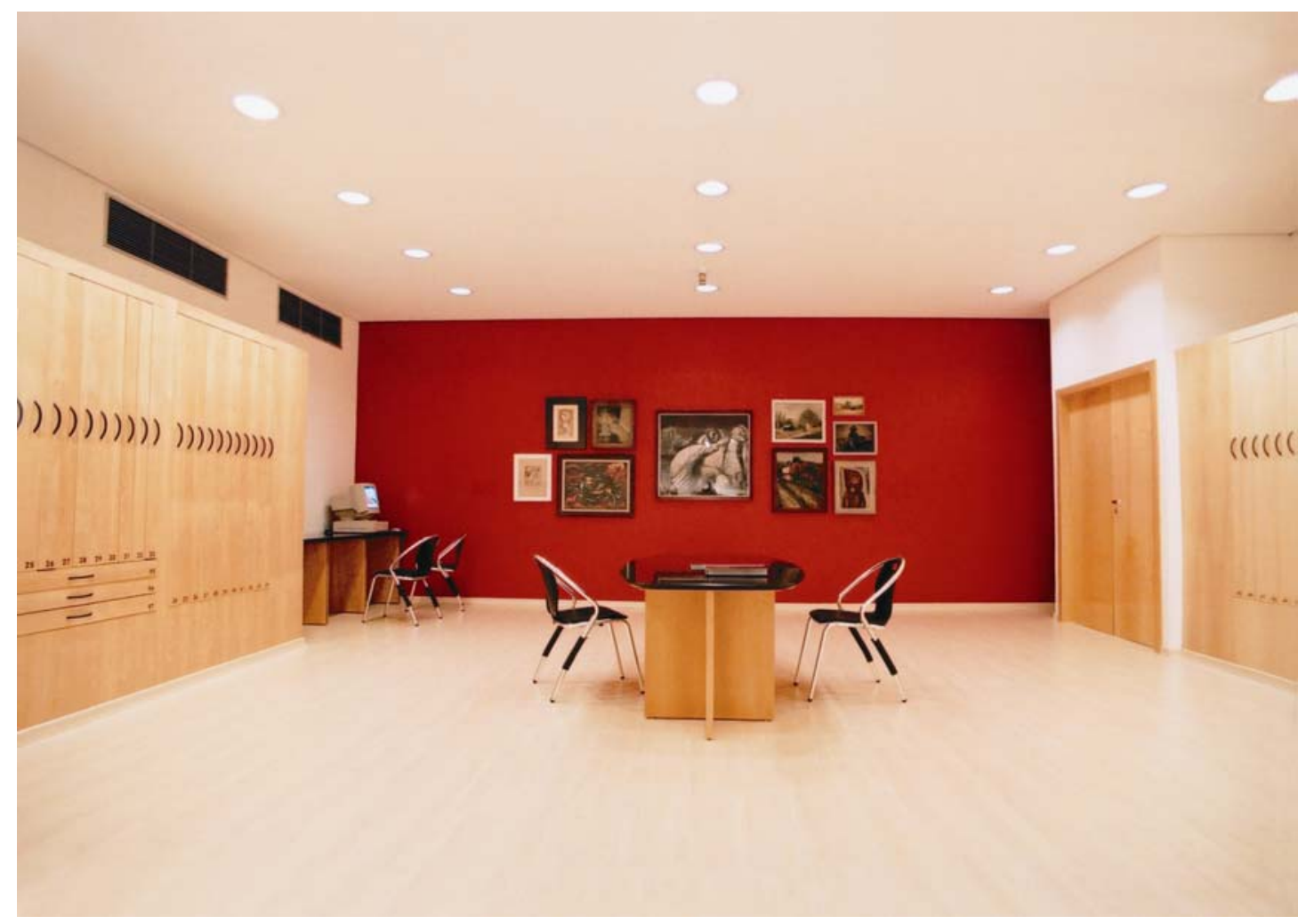

Exposição permanente: Gabinete de Papel 
gestão de Ana Mae Barbosa ${ }^{65}$. A retomada das obras, em 1988, se deu com apoio da Fundação Banco do Brasil e da Reitoria, e o projeto, agora bem menor, foi terminado pela equipe do FUNDUSP - Fundo de Construção da USP. (Miranda, 2000)

Em 1992 foi inaugurado o prédio do MAC no campus, o primeiro a ser construído especialmente para abrigar um museu da USP. Mas, o que se inaugurava era apenas parte do conjunto previsto e ainda sem as condições básicas de infraestrutura para poder abrigar o acervo adequadamente. $E$ sem possibilidade de expansão, dada a sua localização.

Assim, o MAC continuou a utilizar três espaços: Ibirapuera, Anexo e a Sede.

No ano 2000, o MAC conseguiu financiamento da FAPESP para reformar sua sede, incluindo a climatização da exposição e reserva técnica e a inclusão de algumas salas de trabalho. Numa área total de cerca de $3.800 \mathrm{~m}^{2}$, a área da Curadoria foi ampliada $\left(160 \mathrm{~m}^{2}\right)$, assim como o Laboratório de Conservação de Papel $\left(90 \mathrm{~m}^{2}\right)$ e o Laboratório de Conservação de Telas $\left(80 \mathrm{~m}^{2}\right)$. A reforma promoveu a melhora da salvaguarda das obras com a construção de reserva técnica para esculturas, ampliação de reserva técnica de pintura e papel, climatização, proteção contra incêndio e iluminação adequada. ${ }^{66} \mathrm{O}$ desenho aqui apresentado dá uma idéia da distribuição espacial.

$\mathrm{Na}$ parte expositiva, que soma cerca de $1000 \mathrm{~m}^{2}$, aumentou-se a metragem linear com a construção de paredes internas, dividindo o espaço em galerias. Duas salas têm o pé direito mais alto para exposição de obras contemporâneas de grande porte.

Foi construído o Gabinete de Papel que permite a exposição de 420 obras em um espaço de $80 \mathrm{~m}^{2}$. Ali o público pode ter acesso às obras em papel que são muito sensíveis à luz e devem ser mantidas em gavetas e painéis fechados.

O prédio foi reinaugurado em dezembro de 2000.

Ainda assim, o MAC deverá manter o Anexo para completar as áreas necessárias para suas atividades, e gradualmente, deverá desocupar o prédio da Bienal, pois sempre teve problemas para mantê-lo.

\footnotetext{
${ }^{65}$ Durante sua gestão, Ana Mae Barbosa tentou conseguir outro espaço para o MAC, como o primeiro andar da Bienal, o antigo prédio da Light (Eletropaulo) no centro da cidade ou mesmo o espaço hoje utilizado pela Pinacoteca do Estado no Ibirapuera. Ela considerou que nesses espaços o MAC conseguiria maior visibilidade e seria bem mais acessível ao público de fora da universidade.

${ }^{66}$ As áreas de reserva passaram de $400 \mathrm{~m}^{2}$ para um total de $700 \mathrm{~m}^{2}$, sendo $400 \mathrm{~m}^{2}$ da reserva de pintura, $200 \mathrm{~m}^{2}$ da reserva de escultura e $100 \mathrm{~m}^{2}$ da reserva para papel.
} 
A atual gestão conseguiu, também em 2000, a cessão de um terreno da Prefeitura de São Paulo, no bairro da Água Branca, onde pretende construir uma nova sede. Teixeira Coelho considera fundamental o MAC "sair" da USP, estar presente em um local mais acessível ao público, como tem ocorrido com as exposições do MAC no prédio da FIESP, na avenida Paulista.

Pretende-se realizar um concurso internacional de arquitetura para o projeto do prédio, para o qual deverão se buscar verbas na USP, nos governos municipal, estadual e federal e nas agências financiadoras de pesquisa.

Para o público, a diversidade de endereços parece interessante, mas também pode causar desconforto, por não se saber aonde ir, para ver o quê. Desde a gestão de Aracy Amaral, houve a política de manter no MAC-Anexo exposições do acervo internacional e no MAC-lbirapuera, do nacional. Na gestão de Lisbeth Rebollo, com a criação de exposições educativas, o MAC-Anexo passou a apresentar essas exposições, enquanto a Sede abrigava as de acervo e o Ibirapuera as temporárias. Para um potencial visitante, não é fácil acompanhar essas modificações e ele pode acabar frustrado por não encontrar, no prédio que resolveu visitar, as obras desejadas.

Um problema da localização no campus da Cidade Universitária é as constantes modificações na política de abertura do campus nos fins de semana, pela Reitoria. Durante muitos anos, a Cidade Universitária se configurou como um grande espaço de lazer para os paulistanos, em fins de semana, abrigando inclusive grandes espetáculos musicais aos domingos. Entretanto, em 1995, a Reitoria resolveu "fechar" a Cidade Universitária, inicialmente construindo muros, fechando portões e depois proibindo a circulação aos fins de semana.

Muitos foram os protestos e debates sobre o assunto ${ }^{67}$, e a Reitoria argumentava que a USP é um "espaço público especial" podendo ser fechada por falta de condições de infra-estrutura e de segurança para acolher esse público. A Praça do Relógio, que antes servia para crianças empinarem pipas e grupos jogarem futebol, foi reestruturada como um grande jardim, com diferentes ecossistemas brasileiros.

Recentemente, o campus foi reaberto aos fins de semana, mas somente para atividades culturais que estejam planejadas e não para se tornar um parque de lazer.

\footnotetext{
${ }^{67}$ Vários artigos e cartas foram publicados nos jornais de São Paulo, com opiniões a favor e contra o "fechamento" do campus. Crônicas de Marcelo Coelho ("USP merece invasão dos sem-parque". Folha de São Paulo, 02/02/1996:5-10) e de Mathew Shirts ("A Praça do Relógio é do povo". O Estado de São Paulo, 01/02/97:C2 e "O campus é do povo". O Estado de São Paulo, 02/11/97:C2) provocaram manifestações dos leitores /usuários do campus.
} 
Cada pessoa que entra com seu veículo ${ }^{68}$ deve informar aonde vai ao segurança da entrada do campus. São poucas as pessoas que sabem e que se dispõem a ir visitar os museus do campus nestas condições. ${ }^{69}$

Para os museus localizados no campus, a restrição de abertura os torna mais distantes da população. Em alguns casos, como o MAE, a exposição fica fechada nos horários de almoço, dificultando ainda mais a visita.

A idéia de ter uma sede fora do campus, construída para tal, certamente potencializará o aumento do número de visitantes do MAC. Atualmente, tanto o Museu Paulista quanto a Estação Ciência, que estão fora do campus, localizados no Ipiranga e Lapa respectivamente, recebem por volta de 200 mil visitantes por $a^{70}{ }^{70}$ o que poderia ocorrer com o MAC.

\subsection{Os públicos}

"O museu aberto a todos, como uma herança pública, monumento de um passado esplendoroso, instrumento da glorificação suntuosa dos grandes do passado: liberdade fictícia, pois a entrada livre é também facultativa, reservada àqueles dotados da faculdade de se apropriar das obras, que têm o privilégio de utilizar esta liberdade e que se encontram lá legitimados em seu privilégio, ou seja, na propriedade dos meios de se apropriar dos bens culturais ou, para falar como Max Weber, no monopólio da manipulação dos bens de cultura e dos signos institucionais de saúde cultural." (Bourdieu \& Darbel, 1969:166-7)

Tivemos a oportunidade de desenvolver duas pesquisas com os visitantes do MAC. Em 1991 fizemos uma pesquisa durante exposição de fotografias sobre a arquitetura de museus da Alemanha ${ }^{71}$, que ocorreu no MAC-Anexo (Cidade Universitária). Naquela ocasião identificamos o perfil do público como sendo bastante

${ }^{68}$ É preciso ir de carro pois a circulação de ônibus no campus é interrompida aos fins de semana, outra dificuldade para o potencial visitante.

${ }^{69}$ Em 30/01/2001, em reportagem do Estado de São Paulo - "USP abre aos domingos, mas ninguém sabe" - alertava-se para o fato da pouca divulgação e da falta de infra-estrutura no campus nos fins de semana, pois as lojas dos museus não abrem, não há lanchonetes abertas ou circulação de ônibus.

${ }^{70}$ A Estação Ciência recebeu 204 mil, 162 mil e 198 mil visitantes em 1997, 1998 e 1999 respectivamente. O Museu Paulista teve, nesses mesmos anos, 223 mil, 233 mil e 240 mil. Entretanto, a localização somente não garante visitação a um museu. O caso do Museu de Zoologia/USP, também no Ipiranga evidencia isso: muito próximo ao Museu Paulista, mas oferecendo uma exposição desatualizada, o MZ recebeu em 1997, 44 mil e em 1998, 46 mil visitantes. (Anuário USP, 2000)

71 "Novas construções de museus na República Federal da Alemanha", 7 a 30/06 de 1991. Os questionários para os visitantes foram deixados à saída e preenchidos espontaneamente. A amostra foi de 55 respondentes. 
especializado - arquitetos, designers, fotógrafos, artistas plásticos - enfim, profissionais de áreas afins ao tema da exposição. Essas pessoas foram visitar o MAC por causa do tema da exposição temporária, que atraiu principalmente arquitetos e fotógrafos.

Cristina Freire também realizou, em 1991, uma pesquisa com o público do MAC (Ibirapuera e Cidade Universitária) com uma amostra de 111 visitantes de mais de 15 anos de idade. Desses, 73\% tinham nível superior. (Freire, 1993)

Em 1992, realizamos uma outra pesquisa com visitantes do MAC, tanto do espaço do Ibirapuera quanto do MAC-Anexo (Cidade Universitária) ${ }^{72}$. Naquela ocasião, o MAC do Ibirapuera apresentava parte do acervo de arte brasileira e na Cidade Universitária estavam expostas obras de artistas estrangeiros. Realizamos muitas das entrevistas em fins de semana, buscando o público espontâneo. Quando verificamos a escolaridade dos respondentes, percebemos um grande número de pessoas (70\%) com nível superior completo ou incompleto e poucas pessoas de baixa escolaridade. Também verificamos que a renda familiar dos visitantes é alta - 68\% dos respondentes têm renda de 5 a mais de 10 salários mínimos - se comparada à população de São Paulo. Esse tipo de evidência nos mostrava que apesar das iniciativas para "popularizar" o MAC, o público visitante ainda é em sua maioria uma elite econômica e de maior escolaridade. Mesmo no Ibirapuera, um parque onde circulam milhares de pessoas das mais diferentes faixas econômicas e de escolaridade, apenas uma parte decide visitar o MAC. Na Cidade Universitária observamos que havia muita circulação de pessoas, ciclistas, famílias próximas ao MAC, mas eram poucos que se "arriscavam" a entrar no museu. E sempre havia os casos daqueles que entravam apenas para usar os banheiros.

Constatamos, assim como Cristina Freire, que o nível de escolaridade "é um fator de distinção do público visitante do museu”. (Freire, 1993) Bourdieu e Darbel, em extensa pesquisa de público de museus europeus, nos anos 1960, identificaram essa característica, afirmando que o público que possui "capital cultural" para freqüentar museus é o mesmo que alimenta as distinções que os levam a se sentir bem nesses espaços, ao contrário daqueles que não tem esse "capital". Assim, esse grupo privilegiado procura manter as características dos museus para legitimar e perpetuar essa diferenciação.

\footnotetext{
72 O trabalho foi feito em grupo - Maria Christina B. Almeida, Myrla Fonsi, Ubirajara D. da Motta e Zilda M. Moreira Rangel. Conseguimos somar 100 respondentes entre as duas sedes. Os questionários eram distribuídos ao final da visita e o visitante preenchia diante dos pesquisadores.
} 
Muitos anos se passaram, muitas grandes exposições (Blockbusters) foram apresentadas em São Paulo ${ }^{73}$, mas ainda há uma grande parcela da população que não se sente à vontade de entrar em museus ou de planejar uma visita a um museu como opção de lazer. ${ }^{74}$

Hoje, a Cidade Universitária está aberta parcialmente ao público aos domingos, mas já sabemos que não basta apenas estar aberta ou os museus estarem abertos (e serem gratuitos). É preciso ser convidativos à entrada das pessoas, atraentes, acessíveis, visíveis, senão serão poucos aqueles que se sentirão à vontade para entrar nos museus.

Para efeito de comparação, levantamos o número de visitação de alguns museus de arte de São Paulo: Museu de Arte Brasileira (MAB/FAAP), Pinacoteca do Estado, Museu de Arte Moderna (MAM/SP) e Museu Lasar Segall (MLS). Os números de visitação geral são os seguintes ${ }^{75}$ :

\begin{tabular}{|c|c|c|c|c|c|}
\hline Ano & MAC/USP & MAB/FAAP & Pinacoteca & MAM/SP & MLS \\
\hline $\mathbf{1 9 9 7}$ & 103.939 & 13.055 & 51.599 & 97.240 & 9.144 \\
\hline $\mathbf{1 9 9 8}$ & 111.000 & 27.379 & 135.535 & 142.491 & 9.610 \\
\hline $\mathbf{1 9 9 9}$ & 125.859 & 82.549 & 162.850 & 172.109 & 12.076 \\
\hline $\mathbf{2 0 0 0}$ & 64.904 & 35.358 & 94.414 & 301.958 & 8.085 \\
\hline
\end{tabular}

O MAC/USP recebe um significativo número de visitantes, comparado com outros museus de arte da cidade de São Paulo, e teve um aumento nos últimos anos, mas não tão significativo como o da Pinacoteca do Estado e do Museu de Arte Moderna, talvez por causa do fechamento de seus prédios (No primeiro semestre de 1999 o Ibirapuera ficou fechado e, em 2000, foram fechados o Ibirapuera e a Sede) e pela diminuição do número de exposições.

Um indicativo de que os prédios fechados - Ibirapuera e Sede - significam uma diminuição de público, pode ser visto pela diferença de visitação total nas diferentes sedes do MAC, em 1997 e 1998:

\footnotetext{
${ }^{73}$ Exposições como a de Rodin na Pinacoteca do Estado, de Monet no MASP e a Mostra do Redescobrimento no Ibirapuera.

${ }^{74}$ Por exemplo, realizamos em 2000 uma pesquisa de público no Museu Lasar Segall e 79\% dos 206 entrevistados (todos acima de 15 anos de idade) tinham nível superior completo ou incompleto.

${ }^{75}$ Os dados do MAB/FAAP foram fornecidos pela diretora Maria Izabel Branco Ribeiro; os da Pinacoteca pela vice-diretora Maria Luiza Moraes; os do MAM foram obtidos na Biblioteca e com Carlos Barmack e os do MLS foram fornecidos pela direção do museu. No caso do MLS referem-se exclusivamente à exposição de longa duração. Infelizmente não conseguimos obter dados do MASP.
} 


\begin{tabular}{|c|c|c|c|c|c|}
\hline Ano & Sede & Anexo & Ibirapuera & Pinacoteca & Total \\
\hline $\mathbf{1 9 9 7}$ & 48.234 & 36.220 & $19.485^{*}$ & - & 103.939 \\
\hline $\mathbf{1 9 9 8}$ & 70.000 & 3.000 & $30.000^{* *}$ & $8.000^{* * *}$ & 111.000 \\
\hline
\end{tabular}

* abril a dezembro

** janeiro a 13 de setembro

*** espaço temporariamente cedido: outubro a 23 de novembro

O MAC-Sede e o MAC-Ibirapuera eram os prédios que mais recebiam visitantes, e portanto, seu fechamento levou a uma diminuição de público.

O que compensou o fechamento do prédio do Ibirapuera e do MAC-Sede, em 2000, foi a utilização do Centro Cultural FIESP, na avenida Paulista, região de fácil acesso para o público.

Um outro motivo para o aumento de público do MAC não ter sido tão grande quanto de outros museus da cidade poderia ser a diminuição do número de exposições de acervo e temporárias oferecidas, como vimos no item 2.5.2.

O público visitante pode ser dividido entre "espontâneo", ou seja, indivíduos e/ou pequenos grupos que visitam segundo seu interesse cada exposição e os "grupos organizados", geralmente de escolares, que participam de visitas monitoradas, com roteiros previamente definidos.

Uma parte do público do MAC/USP é constituída por grupos de escolares do ensino fundamental e médio. São poucos os alunos e funcionários da própria universidade que visitam o MAC. ${ }^{76}$

Um estudo feito por alunos da ECA/USP, no final de 1998, para saber porque alunos, professores e funcionários da USP visitavam ou não o MAC, obteve

“(...) resultados [que] apontam para disponibilidade em termos de tempo aos finais de semana e horário de almoço; como principal motivação para visitação o oferecimento de cursos e palestras, eventos musicais, oficinas e ateliers (...)" (Martins, M.H.P., 2000)

Esses resultados levaram à Divisão de Ensino e Ação Cultural preparar, em 1999, diferentes atividades para os calouros, que foram convidados a interpretar, procurar no site do MAC na internet, desenhar e discutir as obras que haviam escolhido. Surpreendentemente, essas atividades atraíram mais os alunos de ciências do que os de humanidades. Em seguida, pretendem convidar cada escola para uma visita, oferecendo atividades para professores, funcionários e alunos. Pretendem

\footnotetext{
${ }^{76}$ Não há um estudo sistemático sobre o perfil dos visitantes do MAC. A contagem dos grupos organizados é mais rigorosa pois é registrada pelos monitores que atendem os grupos. Já os visitantes espontâneos são contados por números de roleta, por onde também passam usuários da Biblioteca, do Café e de pessoas que entram nos prédios para ir aos escritórios.
} 
também oferecer palestras na exposição, de meia hora, no horário do almoço às sextas-feiras, procurando atrair as pessoas que almoçam no restaurante do museu. ${ }^{77}$

Nos dois últimos anos, o número de pessoas participantes de grupos organizados vem crescendo mais que o público espontâneo, devido à política de atendimento massivo do Centro Cultural FIESP. Em 1999, por exemplo, foram 557 grupos atendidos somando 18.030 pessoas atendidas na Galeria do SESI/FIESP. Em 2000, o número de pessoas atendidas por visitas monitoradas alcançou $20 \%$ do público total das exposições.

\begin{tabular}{|c|c|c|c|}
\hline Ano & Espontâneo & Em grupos & Total \\
\hline $\mathbf{1 9 9 7}$ & 100.307 & $3.632(3,4 \%)$ & 103.939 \\
\hline $\mathbf{1 9 9 8}$ & 107.083 & $3.917(3,5 \%)$ & 111.000 \\
\hline $\mathbf{1 9 9 9}$ & 103.970 & $21.889(17,4 \%)$ & 125.859 \\
\hline $\mathbf{2 0 0 0}$ & 51.607 & $13.297(20,5 \%)$ & 64.904 \\
\hline
\end{tabular}

O MAC/USP se destaca, entre outras instituições, por ter um programa educativo permanente voltado para público deficiente - sensorial, físico e mental Museu e Público Especial, composto por exposições e monitoria especializada. Esse trabalho, iniciado em 1991, fruto de pesquisa da educadora Amanda Pinto Tojal, foi tema de sua dissertação de mestrado, defendida em 1999 na ECA/USP.

Um outro programa que já vem sendo realizado desde 1988 é Lazer com arte para a terceira idade, coordenado pelo educador Sylvio Coutinho. Trata-se de um trabalho de longa duração (anual) voltado para a prática da arte contemporânea, no qual os idosos visitam museus, apreciam obras e desenvolvem seu próprio trabalho, normalmente apresentado em exposição coletiva ao final do ano.

As crianças da pré-escola e séries iniciais do ensino fundamental também são alvo de um projeto especial Museu, Educação e o Lúdico, desenvolvido pela educadora Maria Ângela Serri Francoio, no qual utiliza jogos e dinâmicas lúdicas "para facilitar a observação e a apreciação da obra de arte" e ampliar "o tempo de permanência da criança no museu". (Martins, 2000) A pesquisa da especialista foi apresentada em sua dissertação de mestrado, defendida em 2000, na ECA/USP.

Um outro espaço de contato com o público é o virtual: cada vez mais pessoas acessam a página da internet do MAC. Em 1999 foram 21.058 visitantes do site do

\footnotetext{
${ }^{77}$ As propostas para a programação a partir de 2001 foram explicitadas na palestra dada em 2000, por Maria Helena Pires Martins, diretora da Divisão de Ensino e Ação Cultural do MAC, no Instituto Cultural Itaú. Nela são apresentadas propostas voltadas para o público potencial da USP, comunidade em geral e público escolar - estudantes e professores.
} 
MAC e em 2000 foram 38.891. Quase que diariamente encontramos reportagens em jornais e revistas tratando do aumento do número de usuários da internet e da importância de estar presente na rede mundial. Um museu pode ser conhecido ou revisto por meio dessa mídia, que certamente trará novos visitantes.

O MAC dispõe de um site bastante rico \{www.mac.usp.br\}, lançado em 1997, com informações atualizadas sobre suas atividades e também uma retrospectiva dos anos anteriores. Além disso, disponibiliza na rede alguns materiais didáticos, elaborados pela pesquisadora Carmen Aranha. Os textos básicos das exposições também se encontram disponíveis, mantendo os usuários da rede informados sobre as propostas das exposições, dos cursos e das pesquisas em andamento.

Na parte do site dedicada às exposições, normalmente apresentam-se os textos da curadoria e direção do museu e algumas obras ${ }^{78}$. A exposição de Volpi (1996) disponibiliza um banco de imagens de obras do autor aos navegantes da rede, assim como a exposição Brasil no Século das Artes oferece reproduções de várias obras do acervo do MAC.

Assim, o MAC já possui vários meios de comunicação com diversos públicos, podendo ainda ampliar esse diálogo por meio de uma revista própria, publicação de outros materiais impressos e desenvolvimento do seu site.

\subsection{Considerações sobre o MAC}

Concordamos com Christina Barbosa de Almeida, quando afirma, ao comparar o MAC/USP com o Museu Lasar Segall, o MAM/SP, o MASP e a Pinacoteca do Estado

"O MAC diferencia-se dos demais museus aqui estudados pela ênfase nas atividades de pesquisa, como não poderia deixar de ocorrer em se tratando de um museu universitário. Paralelamente à pesquisa, desenvolve cursos de extensão e especialização, (...) bem como outras atividades voltadas para públicos especiais, que envolvem sempre a pesquisa e a produção de conhecimento e informação.

Seu quadro de pessoal, com mais de cem servidores em novembro de 1997, oferece grande diversidade de funções, tanto técnicas, como administrativas e docentes, contemplando a necessidade das diferentes áreas de atuação do Museu, e apresenta grande número de servidores com títulos acadêmicos, contribuindo para reforçar a importância atribuída às atividades de ensino e pesquisa dentro do Museu." (Almeida, C.1998:177)

Consideramos que o MAC/USP se destaca de outros museus de arte de São Paulo e de outros museus universitários brasileiros de arte pela qualidade de seu

${ }^{78}$ Em 1998, Christina Almeida (1998:189) considerava pequena a quantidade de imagens de obras do acervo no site, problema que parece resolvido atualmente. 
acervo de arte moderna e contemporânea, pela quantidade e qualidade das pesquisas desenvolvidas sobre seu acervo, pela quantidade e qualidade de cursos oferecidos e pela inovação de algumas de suas exposições.

Em 1999, o MAC contava com 103 servidores assim divididos: quatro na Diretoria: diretor, vice e duas secretárias; cinco assessores (dois de informática, um de projetos especiais e dois de relações públicas); cinqüenta e duas pessoas na área administrativa $^{79}$; oito servidores na Divisão de Preservação e Documentação, entre eles uma pesquisadora, quatro especialistas, uma técnica em museu, uma secretária e uma auxiliar administrativa; nove na Divisão de Ensino e Ação Cultural, sendo três pesquisadores, quatro especialistas e duas secretárias; nove na Divisão de Curadoria, sendo três pesquisadoras e três especialistas e três secretárias; doze no Serviço de Museografia $^{80}$ e quatro na Biblioteca ${ }^{81}$. O MAC contava ainda, em 1999, com 51 estagiários, bolsistas e voluntários.

Mesmo com 50\% do quadro trabalhando na área administrativa, o MAC/USP conta com número significativo de trabalhadores das áreas especializadas e de pesquisa. Nos museus de arte universitários do Canadá que visitamos, raramente o número de funcionários chegava a 20 , havendo uma prática de terceirização mas também uma otimização dos trabalhos. Entretanto, o tamanho de seus acervos está longe das oito mil obras do MAC. Um museu universitário de antropologia de porte bem maior, como o Museu da Universidade Pensilvânia, na Filadélfia (capítulo 1, item 7.2), conta com um corpo de 150 funcionários, somado ainda com um exército de 280 voluntários, para um acervo de mais de 1 milhão de objetos.

Consideramos que um número muito grande de funcionários, principalmente nas áreas administrativas, pode acabar por burocratizar e engessar a instituição. Esse não é só problema do MAC, mas de outros museus e também de outras unidades da USP.

Voltamos aqui para as preocupações expressadas por Aracy Amaral, quando preferia pensar o MAC como um museu na universidade e não universitário, com temor dessa paralisação dada pela burocracia.

Aracy Amaral sugeriu em 1987 a transformação da MAC em fundação para "resolver ou apontar uma solução para os problemas de aquisição e ativação" (p.48). O mesmo fez Teixeira Coelho em 1999:

\footnotetext{
${ }^{79} 32$ vigilantes, 6 ajudantes de serviços gerais, 3 secretárias, 2 auxiliares administrativos, 2 motoristas, 2 copeiras, 1 contador, 1 técnico de finanças, 1 almoxarife e 1 engenheiro que é o diretor da Divisão.

${ }^{80} 6$ especialistas, 3 técnicos de manutenção, 2 técnicos em museu e uma secretária.

${ }^{81} 2$ especialistas e 2 técnicos em documentação.
} 
"Uma fundação parece a única saída para um museu de arte contemporânea, que não pode nunca ser da universidade e nem universitário, encontrar o modo de existir para a comunidade e com a comunidade. O que está em jogo na arte é muito mais imediatamente do interesse e do alcance da comunidade do que a maior parte daquilo que é próprio da universidade. O que está em jogo é a condição de existência de um museu contemporâneo de arte numa universidade que não vem tendo a oportunidade de ser historicamente contemporânea do presente." (p.30)

Acreditamos que existe chance de existência de um museu de arte contemporânea na USP, desde que a direção da universidade dê o devido valor ao patrimônio que possui e se responsabilize por ele, como escreveu Tadeu Chiarelli, há 14 anos, referindo-se a propostas para implementar aquisições no MAC:

"Estas propostas na verdade passam ao largo do problema maior do Museu, não resolvido ainda: a falta de uma política coerente da Universidade de São Paulo para o MAC-USP, a partir do pleno reconhecimento do seu valor como centro de pesquisa e preservação da produção artística contemporânea. Antes que a Fundação Bienal reveja seus estatutos em proveito do MAC-USP, antes que as empresas se unam para ampliar o acervo internacional do Museu é necessário que a própria Universidade assuma ser ela a principal responsável pelos destinos do Museu." (Chiarelli, 1987:47)

Outro fator importante para viabilizar o MAC seria a integração com os departamentos de ensino, potencializando o que a universidade tem de melhor - o ensino e a pesquisa.

Trataremos no próximo capítulo sobre os possíveis caminhos a serem trilhados pelo MAC e, eventualmente, por outros museus universitários de arte. 
CAPÍTULO 5

MAC/USP: manter ou não na universidade? 


\section{CAPÍTULO 5}

\section{MAC/USP: Manter ou não na universidade?}

$\mathrm{Na}$ introdução da tese colocamos as questões que norteariam nossa pesquisa:

"Por que museus universitários de arte?"

"Por que museus de arte na USP?".

"Para que servem as coleções de arte?"

"A USP deve ter museus e coleções de arte?"

"Quais as melhores políticas culturais para esses museus?".

Para discutir os possíveis caminhos a serem tomados pelo MAC/USP, é importante retomar alguns pontos tratados anteriormente nesta tese.

Os museus criados a partir da doação de coleções já formadas, como o MAC e em menor intensidade o IEB, sofrem conseqüências decorrentes da

- ausência ou limitação de espaço físico adequado para abrigar as coleções;

- ausência de pessoal qualificado para garantir a salvaguarda das coleções;

- ausência de um corpo de pesquisadores das áreas abrangidas pelas coleções;

- características/perfil das coleções que dificultam a pesquisa, ensino e/ou extensão a partir das mesmas.

- ausência de cursos nas unidades de ensino relacionados com as coleções.

Essas "ausências" levaram o MAC a trilhar um longo caminho para formar e lou adequar seu espaço físico, seu pessoal, suas linhas de ensino e este processo ainda continua após 37 anos de existência. Em parte isso se deve à USP, que resiste em assumir suas responsabilidades sobre esse patrimônio e parece ter dificuldades em adotar uma política cultural para seus museus e instituições afins.

O MAC já teve diferentes sedes e agora acaba de reformar sua sede no campus e receber empréstimo de um terreno da prefeitura de São Paulo para construir um novo prédio; na USP, o departamento de ensino da arte foi instituído anos depois da criação do MAC; os professores que atuam no MAC têm que ser pesquisadores, docentes e curadores, exigindo uma formação mais completa do profissional; a USP criou vários 
mecanismos legais para organizar o funcionamento dos museus, mas ainda há muito por fazer... esses são alguns dos elementos da situação do MAC/USP que retomaremos aqui.

\section{Cidade no museu ou museu na cidade?}

Como vimos, a USP tem sob sua responsabilidade inúmeras coleções, com destaque para aquelas dos quatro museus reconhecidos como unidades autônomas MAC, MAE, MP e MZ. Trata-se de um universo variado de milhões de objetos / obras / exemplares que a própria universidade desconhece em sua totalidade e tem dificuldade de compreender seu papel dentro da dinâmica universitária. E ainda, dá pouca verba e pouca autonomia para os museus que abrigam as coleções:

“(...) é preciso apontar para a especificidade dos Museus da USP, cada um deles com origens e trajetórias diferentes, seja em seus objetivos e atividades, seja na formação de seu pessoal científico, educacional, curatorial, técnico e administrativo, incluindo seus diretores. (...) Os (des)caminhos e (des)encontros dos nossos Museus têm demonstrado que a USP ainda não lhes deu foros de cidadania, nivelando-os do ponto de vista estrutural e gerencial às suas outras unidades; ora, os Museus têm a sua identidade e requerem uma política diferente para que haja a real visibilidade naquilo que só eles, unidades especiais no mundo acadêmico, podem oferecer: vale dizer, a interface entre a ciência e o público através de seus acervos, principal fonte para o exercício da função tripartite da universidade - pesquisa, ensino e extensão de serviços à comunidade. $O$ conjunto harmonioso destas três funções, em Museus Universitários, constitui a meu ver, a verdadeira Curadoria, que se afigura como um processo inerente à programação geral de cada um desses Museus." (Sarian, 1999:33)

Museus podem e devem cumprir um importante papel dentro da vida universitária, para o ensino e a ampliação do universo de opções culturais de seus alunos, funcionários e professores. Museus de arte na universidade podem ser polarizadores de atividades artísticas e culturais do campus, como sugeriu Mario Pedrosa em 1967. Na proposta de Mario Pedrosa, o Museu de Arte Moderna deveria ser o centro de um conjunto arquitetônico que abrigaria também um Instituto de Artes, Escola de Comunicação Visual e Auditiva, Desenho Industrial, Teoria da Informação, estúdios de Rádio e Televisão, auditórios, orquestras e Imprensa Universitária.

Vimos que em várias propostas arquitetônicas para o campus da Cidade Universitária, antes de sua implantação, havia projetos da inserção de museus, de zoológico e jardim botânico. Entretanto, a prática resultou em diferentes divisões do espaço e sucessivas construções sem planejamento prévio. Até agora, o único prédio 
construído para abrigar um museu é o do MAC, com as restrições já apresentadas no capítulo anterior. Os outros museus estão dentro ou fora do campus em prédios adaptados.

Hoje, planeja-se construir um conjunto de museus próximo à saída da Avenida Corifeu de Azevedo Marques, projeta-se a instalação de uma Fundação para abrigar a coleção do bibliófilo Mindlin ${ }^{1}$ próxima à Reitoria, perpetuando-se a separação entre instituições similares que poderiam formar um "centro" cultural dentro do campus.

Aracy Amaral lutou, durante sua gestão, para trazer o MAC para dentro do campus porque acreditava que seria possível "criar uma empatia até então inexistente entre a comunidade universitária e esse museu fruto da generosidade de Matarazzo Sobrinho." (Amaral, 1999:18) O prédio foi construído, parcialmente, e inaugurado na gestão seguinte, em 1992. E para Aracy Amaral, não adiantou trazer para dentro do campus o MAC:

"Estávamos enganados. A Universidade não se motivou com a vinda do Museu para o campus. E os diretores que nos sucederam mantiveram duas sedes para o MAC da USP, e hoje, embora reconheçamos que o lugar de fato do MAC é na cidade, e não dentro do espaço da Universidade indiferente, ainda hoje é difícil enfrentar a possibilidade de projetar e construir um edifício específico para o MAC." (Amaral, 1999:18)

Aracy, onze anos antes, já chamava atenção para essa questão, ao citar a fala de um representante da Argentina em seminário sobre arte e universidade: ele salientou que na América Latina havia falta de comunicação e de compreensão das artes e outras formas de cultura nas universidades. Ele considerava difícil levar a arte para todos os estudantes da universidade ${ }^{2}$ afirmando que,

“...do ponto de vista de execução, acho que o fenômeno artístico projeta-se melhor na cidade do que na universidade." (Oteiza, As artes e a universidade, Conselho de Educação Superior das Repúblicas Americanas, Nova lorque, 1964 apud Aracy Amaral, 1988)

Novamente aparece a idéia de que a universidade não é o melhor local de divulgação das artes. Inclui-se aí tanto a universidade enquanto instituição responsável como seu campus, enquanto lugar para sediar o museu.

\footnotetext{
${ }^{1}$ Esse projeto não tem qualquer relação com o Departamento de Biblioteconomia da ECA/USP, que sequer foi consultado.

${ }^{2}$ Nos últimos 3 anos (1999-2001), a Divisão de Ação Educativa do MAC/USP promoveu uma atividade voltada para os "calouros", no início do período letivo, oferecendo programas para os Centros Acadêmicos das diversas unidades de ensino. O objetivo básico é "levar o aluno ingressante a conhecer os recursos informacionais do MAC - biblioteca, o site - bem como a apreciação das obras expostas." (Martins, 2000) Os resultados dessa ação só poderão ser avaliados depois de alguns anos.
} 
Consideramos que é possível manter um museu de arte contemporânea da universidade e no campus, desde que a instituição seja de fato assumida enquanto responsabilidade da universidade, dando-lhe recursos materiais e humanos para preservar e divulgar suas coleções de maneira adequada ${ }^{3}$. Além disso, o campus precisa ser um local aberto ao público, com acesso por transporte particular e público em amplos horários. Um museu universitário tem o potencial de ter programações muito mais variadas e com conteúdos fundamentados em pesquisas do que outros museus.

Citamos, no capítulo anterior, a sugestão de Aracy Amaral e Teixeira Coelho de tornar o MAC uma fundação, desvinculando-o da USP e dando-Ihe autonomia. Esse seria o caminho para tirar o museu da responsabilidade da universidade e a construção de sede fora do campus o colocaria definitivamente fora da universidade.

Seria esse o melhor caminho? Quem financiaria o museu? Ele continuaria depender de verbas públicas?

Tornando-se uma fundação, o MAC certamente ganharia autonomia, mas perderia uma série de verbas conseguidas pelo fato de ser um museu universitário, que conta com pesquisadores. Também perderia a possibilidade de desenvolver o ensino superior e estabelecer vínculos com a formação de profissionais de artes e de museus.

Para melhorar a situação do MAC/USP é preciso que a USP assuma sua responsabilidade e que a comunidade universitária como um todo passe a valorizar esse patrimônio tão rico que está a seu lado.

\section{Desafios para a universidade}

Caminhos para melhorar a qualidade de museus universitários não podem ser imaginados sem antes passar pelas instituições que são responsáveis por eles, as universidades. Não é possível que o museu desenvolva adequadamente seu trabalho museológico, inúmeras pesquisas, cursos, exposições e publicações de qualidade sem que a universidade dê apoio político e recursos material e humano.

A universidade é uma instituição que precisa se atualizar diante dos novos desafios colocados pela sociedade, senão ela poderá se isolar cada vez mais e perder

\footnotetext{
${ }^{3}$ Atualmente, a USP paga os salários dos servidores, as contas de luz, água e telefone e auxilia na manutenção predial, mas não dá verba específica para aquisição de obras ou desenvolvimento de exposições. Para isso, o MAC depende de apoio da iniciativa privada e/ou doações. Mobiliário para Biblioteca, laboratórios de restauro, exposições educativas têm sido apoiadas principalmente pela FAPESP e pela VITAE.
} 
seu sentido. No editorial da revista Museum International dedicada aos museus universitários, Márcia Lord apresenta alguns dos pontos apresentados no relatório da Comissão Internacional da UNESCO de Educação para o Século XXI, coordenada por Jacques Delors, sobre as pressões sofridas pelas universidades e, portanto, por seus museus:

"O ensino superior é, ao mesmo tempo, uma das forças propulsoras do desenvolvimento econômico e o ponto central de educação de uma sociedade. É tanto um acervo como uma fonte criadora de conhecimento. Além disso, é o principal instrumento para transmitir a experiência acumulada, cultural e científica, da humanidade. Num mundo onde os recursos do conhecimento irão progressivamente predominar sobre os recursos materiais como fatores de desenvolvimento, a importância do ensino superior e das instituições de ensino superior só pode crescer. Além disso, o efeito da inovação e do progresso tecnológico significa que as economias irão cada vez mais exigir competências que requerem estudos de alto nível ...

(...)

Como centros autônomos para pesquisa e criação de conhecimento, as universidades podem se dedicar a algumas das questões relativas ao desenvolvimento com que se defronta a sociedade. Elas educam os líderes intelectuais e políticos e os chefes de empresas do futuro, assim como muitos dos professores. Em seu papel social, as universidades podem usar sua autonomia a serviço do debate sobre as grandes questões éticas e científicas com que se defrontará a sociedade do futuro, e servir de elos com o resto do sistema educacional ao oferecer oportunidades adicionais de aprendizado para adultos e ao agir como um centro para estudo, enriquecimento e preservação da cultura. Há uma pressão crescente sobre o ensino superior para atender preocupações sociais, enquanto as outras características preciosas e indispensáveis das universidades - sua liberdade acadêmica e sua autonomia institucional - também têm sido foco de atenção. Essas características, embora não garantam a excelência, são um pré-requisito para a mesma ...

Assim, todos deveriam poder contar mais ou menos diretamente com o ensino superior para o acesso à herança comum do conhecimento e às descobertas mais recentes. A universidade deve aceitar uma espécie de contrato moral com a sociedade em troca dos recursos que a sociedade lhe atribui ...

Além de preparar grande número de jovens, seja para a pesquisa seja para ocupações especializadas, a universidade deve continuar a ser a fonte na qual o crescente número de pessoas, que encontram na sua própria curiosidade uma forma de dar sentido a suas vidas, possam satisfazer sua sede de saber. A cultura deve ser aqui considerada em seu sentido mais amplo, estendendo-se desde a parte mais matemática da ciência até a poesia, através de todos os campos da mente e da imaginação." (Lord, 2000:3)

Propõe-se aqui que a universidade mantenha-se como formadora de profissionais qualificados e como pólo irradiador cultural para a sociedade em geral. Ela deve participar dos debates de temas que estão em pauta na sociedade, colocando-se de forma autônoma e livre sobre eles. 
Como vimos no desenrolar desta tese, os museus universitários foram criados, em grande parte, por iniciativas de fora das universidades ou de pequenos grupos dentro das universidades, mas raramente como uma política institucional planejada.

Com algumas exceções, os museus criados a partir de coleções de departamentos, principalmente das áreas de ciências naturais e humanas, têm pouco espaço no campus e pouca autonomia dentro dos departamentos. As suas coleções eram objeto de estudo e também costumavam ser utilizadas para o ensino superior. Somente aqueles museus universitários que se tornaram muito grandes e com coleções significativas nacional e internacionalmente, conseguiram maior autonomia ${ }^{4}$.

No caso dos museus universitários de arte, eles vieram de fora das universidades, muitas vezes "prontos" - lotes de heranças, doações de coleções já formadas - sem qualquer relação com o ensino de arte na universidade.

Por que as universidades aceitaram essas doações? Muitas vezes para aumentar o seu prestígio ou para prestigiar os doadores, e outras vezes visavam o fortalecimento da área de arte e a futura criação de cursos.

Por que a USP aceitou a coleção do MAM/SP em 1963? Provavelmente para aumentar o seu prestígio e na crença de poder ilimitado para crescer fisicamente e poder abrigar diversas coleções. As incorporações de coleções são atos burocráticos, mas que estão embasados nas convicções daqueles que deles participam. Francisco Matarazzo Sobrinho acreditava que a USP era a instituição mais adequada para receber aquela rica coleção e o então Reitor da USP, Ulhôa Cintra, acreditava que a universidade poderia abrigar aquela coleção adequadamente. ${ }^{5}$ Naquela época, a USP não dispunha nem de espaço adequado, nem de pessoal especializado ou verbas alocadas para a manutenção do museu. O MAC foi "erguido" durante a gestão de Zanini, ainda que com pouquíssimos funcionários. Foi na gestão de Aracy Amaral que sua estrutura foi ganhando conteúdo, com a contratação e formação de pessoal e ampliação das atividades museológicas.

Idealmente, na universidade, um museu de arte contemporânea poderia ser um importante pólo de discussão dos percursos da arte do presente e do passado recente, de forma autônoma das pressões externas do mercado e crítica de arte. Além disso, proporcionaria a experiência com a obra de arte original para a comunidade

\footnotetext{
${ }^{4}$ Como o Museu da Universidade da Filadélfia, na Pensilvânia.

${ }^{5}$ Essa crença continua viva, mesmo que parcialmente. A USP, recentemente, fez um acordo com o colecionador José Mindlin para abrigar uma Fundação privada com as suas coleções de livros, sediada no campus. Nesse caso o colecionador considerou a universidade como local ideal para socializar suas coleções, porém preferiu manter o poder sobre elas por meio de uma fundação.
} 
universitária e o público em geral, por meio de exposições. Seminários, debates e publicações poderiam aprofundar essas discussões, voltadas para públicos mais especializados.

Mas um museu público pode sofrer pressões internas e também externas como alertou Carol Duncan:

“(...) os museus de arte públicos são instituições mediadoras situadas entre as comunidades críticas e acadêmicas de um lado e de outro lado os conselhos, o público visitante assim como autoridades oficiais que, de maneira geral, esperam que o museu confirme suas próprias idéias sobre arte. A maioria dos museus e seus curadores estão no meio deste fogo cruzado. Por um lado compartilham o teor das discussões presentes nos círculos acadêmicos mas, por outro lado, como são funcionários de uma instituição pública ligada ao governo, trabalham sob pressão de manter o conhecido em termos de idéias sobre arte e sobre a própria instituição, além de ter que também preservar a memória de seus valores e crenças mais universais. Portanto, especialmente no que tange às coleções permanentes, os museus tendem a reafirmar noções amplamente difundidas e aceitas da arte e história da arte. À exceção de poucos museus públicos de arte, isto se traduz hoje em narrativas conservadoras." (apud Freire, C. 1999:58)

Um exemplo recente, em 2000, se deu em Nova Iorque, nos Estados Unidos. O Museu do Brooklyn expôs algumas obras contemporâneas polêmicas e consideradas ofensivas por grupos católicos e conservadores, fazendo com que o prefeito da cidade tentasse interferir / censurar, uma vez que parte da verba do museu é originária dos cofres da prefeitura de Nova lorque. Como o caso teve muita repercussão na mídia, o museu acabou recebendo muito mais público do que de costume. No final de março de 2001, o prefeito decidiu instituir uma comissão para censura de exposições em museus que recebem obras públicas, reiniciando a polêmica.

O fato da USP ter certa autonomia em relação ao governo estadual diminui um pouco a pressão do poder público citada por Carol Duncan, mas por estar no meio acadêmico, aumenta a pressão sofrida dessa área.

O MAC, no final de 2000 e início de 2001, foi alvo de manifestações dos estudantes da USP que consideraram algumas participações da iniciativa privada em programas do museu, como um caminho para a privatização e indício de que o poder público estava abandonando a instituição ${ }^{6}$. Houve também manifestações no livro de

\footnotetext{
${ }^{6}$ As manifestações ocorreram na reabertura do MAC-Sede em dezembro de 2000 e em um evento da empresa Nokia, em março de 2001. Em ambas oportunidades, houve grande tumulto e vandalismo por parte dos manifestantes, que chegaram a agredir pessoas e roubar alimentos, bebidas e equipamentos. Em ambos os casos, houve pouca repercussão na imprensa, pela política da Reitoria da USP de manter essas questões internamente sem colocá-las em debate público.
} 
visitantes contra o tipo de arte exibida no MAC. Nota-se aí parte das pressões indicadas por Carol Duncan, que são características das instituições públicas.

Cabe aos dirigentes dos museus e das universidades lidar com essas pressões, mantendo uma linha de ação sistemática para o museu, para que este se imponha enquanto entidade autônoma.

Existe uma forte pressão da sociedade sobre as universidades para que elas respondam às necessidades das comunidades que as mantêm. Os museus são instituições que poderiam sediar esse elo com a sociedade, através de ações educativas e culturais.

\section{Arte no museu e na universidade: como integrá-las?}

Na USP, o curso de Artes da Escola de Comunicações e Artes foi criado em 1970, sem qualquer relação com o MAC. Mesmo seus diretores sendo professores da $\mathrm{ECA}^{7}$, encontramos apenas na iniciativa de Wolfgang Pffeifer em fazer uma sala para exposições de teses da ECA, uma ação institucional visando integração ${ }^{8}$. Seria natural pensar na integração da ECA, da FAU, da FFLCH em projetos de pesquisa, exposições e ensino do MAC.

A última vez que o MAC expôs trabalhos de alunos da USP foi em 1997, durante a exposição dos finalistas do Projeto Nascente de Artes Visuais, no MAC-lbirapuera. (Relatório MAC, 1997). Outras instituições culturais em São Paulo têm abrigado exposições de trabalhos de alunos de graduação e pós-graduação da ECA/USP, divulgando sua produção artística ao público. Consideramos que o MAC não deve ter como função prioritária a divulgação de trabalhos artísticos de alunos da USP, mas a abertura de espaço para esses trabalhos poderia aumentar o vínculo do museu com as

\footnotetext{
${ }^{7}$ Todos os diretores do MAC foram ou são professores da ECA/USP. Zanini passou para a ECA nos anos 70, Aracy Amaral foi professora da ECA passando depois para a FAU/USP. Wolfgang Pffeifer foi professor da ECA, assim como Ana Mae Barbosa, Lisbeth Rebollo Gonçalves e Teixeira Coelho, que ainda o são.

8 Em 2000, a Galeria Mônica Filgueiras e o Centro Cultural São Paulo apresentaram exposições decorrentes da tese de doutorado de Branca de Oliveira (ECA/USP); O Centro Universitário Maria Antônia apresentou trabalhos de Ana Maria Tavares e Marie Ange Bordas, resultantes de suas teses de doutorado e mestrado (ambos na ECA/USP), respectivamente. (Estado de São Paulo, 13/07/2000, p.D16)

Em fevereiro de 2001, a Casa das Rosas abrigou a exposição Projeto de Graduação - Artes Plásticas - Universidade de São Paulo, com trabalhos de 10 formandos da ECA/USP. (Estado de São Paulo, 06/02/2001, p.D5)

Em abril de 2001, o Jornal da USP anunciou: "Galeria de Arte da ECA volta, com força total, a expor trabalhos artísticos de alunos e professores de várias unidades da USP" (23 a 29/04/2001, p.13).
} 
unidades de ensino, e conseqüentemente com alunos de graduação. Certamente essas exposições trariam novos públicos ao MAC.

Atualmente, os cursos de graduação em Artes Plásticas da ECA/USP formam alunos nas habilitações de Escultura, Gravura, Multimídia e Intermídia, Pintura (Bacharelado) e Educação Artística (Licenciatura). Para que os alunos tenham contato com as obras do MAC e/ou seus projetos de pesquisa, o aluno precisará contar com a sorte de ter algum professor que se interesse em apresentar o acervo da instituição, fazer uma das disciplinas optativas ou engajar-se em algum programa de estágio oferecidos pelo museu. Não existe nenhum programa institucionalizado que faça com que os alunos da ECA participem de atividades no MAC.

Seria de grande valia se o ensino na área de artes plásticas pudesse valorizar as obras pertencentes à USP, proporcionando a convivência com obras originais para seus alunos. Deve-se ressaltar que, nesse caso, seria necessária a realização de exposição de longa duração ${ }^{9}$ ou de exposições sistemáticas de acervo no campus. Além do MAC, o IEB poderia contribuir para essa convivência, uma vez que conta com importante coleção de arte moderna.

A oferta de cursos diferenciados, baseados na coleção e/ou que tratem de arte contemporânea com enfoques diversos daqueles oferecidos pelos departamentos de ensino podem trazer estudantes de graduação e pós-graduação ao MAC. Cursos que abordem a parte prática (atelier) também são muito atraentes, pois as disciplinas práticas de graduação da ECA não estão abertas a estudantes de outros cursos.

Até a instalação da sede do MAC no campus (1992), a biblioteca do MAC continuava sediada no MAC-Ibirapuera, dificultando o acesso dos alunos que estudam na Cidade Universitária. Uma vez instalada no campus, a biblioteca passou a ser bastante freqüentada por alunos da USP, principalmente da FFLCH, ECA e FAU ${ }^{10}$. Assim, abre-se um outro espaço de convivência entre as unidades e os alunos que, indo à Biblioteca, poderão "dar uma olhada" na exposição da Sede e vir a se interessar pela programação do MAC.

Programas institucionais podem garantir essa convivência dos alunos da ECA, como também da FAU e da FFLCH com o MAC, não dependendo da "boa vontade" de um professor ou do interesse individual dos alunos.

\footnotetext{
${ }^{9}$ A exposição permanente do MAC estava em finalização de montagem no início de maio de 2001.

${ }^{10}$ Dados sobre usuários levantados por Christina Barbosa Almeida, entre janeiro e junho de 1997. (Almeida, 1998:183)
} 


\section{Os profissionais de um museu de arte universitário}

Pesquisas devem ser realizadas em todos os museus, mas num museu universitário elas devem ser seu "coração". Sem elas não é possível realizar exposições, catálogos, cursos ou qualquer atividade inovadora com qualidade. Mas as pesquisas em museu têm faceta diferente das pesquisas nos departamentos de ensino, pois partem de um acervo determinado. Algumas são voltadas para a prática museológica - pesquisas aplicadas em documentação, conservação, museografia e educação - e outras voltadas para a área do museu, nesse caso, a arte contemporânea - teoria da arte, história da arte, recepção da arte, etc. Os professores de um museu universitário devem ter uma atuação mais complexa do que um professor de departamento:

"A projeção do conhecimento científico, ao lado de sua transmissão através do ensino e da divulgação, situaria o profissional de Museus Universitários numa posição ímpar no meio acadêmico: estou cada vez mais convicta de que ele é o pesquisador que percorrerá o caminho pelo qual sua pesquisa será apresentada ao público, proporcionando a principal fonte de todas as atividades museológicas e museográficas no seu campo de estudo.

Assim sendo, produção e reprodução do saber se expressariam nos Museus Universitários, por meio de responsabilidades inerentes à natureza de um Museu, de tal modo que Professores destas instituições fossem igualmente Curadores Curator-professors -, para lembrar a designação americana, e suas atividades deveriam respeitar os princípios básicos que particularizam um Museu e uma Universidade. Estes princípios básicos são os que regem o processo curatorial, um ciclo de responsabilidades solidárias que, nestes Museus, só conseguirão a sua plenitude em projetos institucionais e com profissionais de dupla qualificação: a de Docente e de Curador." (Sarian, 1999:34)

A complexidade da atuação do docente de museu nos leva a perguntar se ele deveria ter o mesmo estatuto que os docentes de departamentos de ensino. Será que ele precisa ter a mesma carga horária de aulas que o professor de Unidade de ensino? Será que precisa ter o mesmo número de artigos publicados em revistas "científicas" que um pesquisador de Unidade de ensino?

Seria importante que a USP passasse a considerar "curadoria de exposições" e "textos de catálogos" como fundamentais para a produtividade de um docente de museu. A curadoria poderia equivaler a um capítulo de livro, por exemplo.

Vejamos o caso da professora Marta Rossetti Batista (IEB/USP): ela é uma excelente pesquisadora de museu, produtora de exposições, catálogos e documentação de coleções que são fundamentais para proporcionar acesso ao público a essas mesmas coleções; fez mestrado e doutorado em temas relacionados com as coleções do IEB, defendidos na ECA/USP; entretanto, ela não é credenciada como 
orientadora de pós-graduação e começou a ministrar cursos de graduação pelo IEB apenas a partir de 1996. O fato de não estar orientando na pós-graduação impede que ela participe da formação de novos pesquisadores de forma sistemática, mas ao orientar alunos em estágios de iniciação e aperfeiçoamento pode desenvolver essa faceta do trabalho do docente. O tempo que ela deixou de dedicar ao ensino foi utilizado para a pesquisa e documentação do acervo do IEB. Consideramos que nesse caso, o fato da pesquisadora não precisar seguir a carreira docente da maneira como fazem os docentes de unidades de ensino foi positivo para o tipo de trabalho que ela desenvolve no IEB.

Outro problema refere-se aos especialistas. Muitos deles desenvolvem pesquisas acadêmicas e pesquisas aplicadas de alta qualidade, são titulados (mestrado ou doutorado) e no entanto não podem propor cursos ou disciplinas de graduação por não estarem na carreira docente. Esses especialistas costumam dar cursos de extensão no MAC ou fora dele, participar de seminários e congressos, publicar artigos, proferir palestras, participar de bancas de tese e dar assessorias. ${ }^{11}$ Se a USP tivesse maior flexibilidade, poderia dar melhor condição para que esses especialistas formassem novos profissionais e divulgassem suas pesquisas para os estudantes.

\section{O que o museu deve ensinar?}

Os cursos oferecidos pelos museus deveriam ser diferentes daqueles dados pelas unidades de ensino? Como seria no caso do MAC?

Cursos de prática artística - atelier de pintura, gravura, escultura - são oferecidos para os alunos de Artes Plásticas da ECA/USP e não oferecem vagas para alunos de outros cursos.

Isso significa que o MAC, ao oferecer cursos de prática artística pode estar cobrindo uma lacuna na USP, proporcionando aos alunos de graduação oportunidade para vivenciar a prática artística. A indicação do interesse dos alunos se deu pela rapidez com que as vagas oferecidas para o curso de Atelier de Desenho foram preenchidas em 2000. Essa área é uma excelente "fatia" do ensino de arte que poderia ser explorada pelo MAC, nunca perdendo de vista o perfil de seu acervo e as linhas de

\footnotetext{
${ }^{11}$ No caso do IEB, percebemos que a especialista Neuma Barreto Cavalcante tem atuação e produção semelhante a de outros docentes do IEB. Na página da internet do IEB ela está incluída como pesquisadora e não técnica, entretanto o seu enquadramento funcional é como técnica. Certamente essa situação se repete em outros institutos, museus e unidades da USP.
} 
pesquisa que estão sendo definidas. A reforma da Sede permitiu a liberação de espaço para a instalação de mais um atelier no MAC-Anexo.

Tanto na ECA/USP quanto na FAU/USP são oferecidas disciplinas de História da $A_{r t e}{ }^{12}$ para alunos de graduação dessas unidades e são poucas as vagas para alunos de outros cursos. Além disso, o programa dessas disciplinas raramente trata da arte contemporânea, que seria uma das áreas tratadas por cursos do MAC. Ou seja, se um aluno da USP (de fora da ECA e FAU) quiser ter aulas de história da arte ou crítica de arte que envolva arte contemporânea, precisará buscar cursos no MAC/USP.

O MAC conta com excelentes coleções de arte moderna e contemporânea e poderia oferecer cursos baseados nas pesquisas sobre suas coleções e seus desdobramentos. A abertura de sua exposição permanente permitirá o desenvolvimento de cursos sistemáticos que envolvam a apreciação de suas obras.

Se nos basearmos na proposta vigente na USP de transformar todos os pesquisadores de museu em docentes, seria necessária a mudança na atuação dos pesquisadores do MAC.

O perfil dos pesquisadores do MAC precisaria ser completado com o lado "docente" no sentido acima colocado. Além de ministrar disciplinas de graduação, deveriam atuar na formação de pós-graduandos, participando de programas de pósgraduação em departamentos de ensino ou criando cursos específicos para o MAC. Esses cursos de pós-graduação podem ter duas vertentes: os voltados para o mercado de trabalho / de especialização e aqueles stricto sensu, formadores de pesquisadores.

Atualmente o MAC oferece um curso do primeiro tipo, voltado para a formação de monitores em arte. Há uma ampla gama de possibilidades de cursos de pósgraduação, de ambos os tipos, que poderiam ser oferecidos pelo MAC, a partir da implantação e desenvolvimento de suas linhas de pesquisa.

Com isso o MAC seria também um centro formador de profissionais e pesquisadores, cumprindo seu papel de museu universitário.

12 O Departamento de Artes Plásticas da ECA/USP oferece as disciplinas História da Arte no Brasil I e II e Evolução das Artes Visuais I, II, III e IV. O Departamento de Comunicações e Artes da ECA/USP oferece a disciplina Estética e História da Arte I e II. Na FAU/USP, o Departamento de História da Arquitetura e Estética do Projeto oferece Arte e Arquitetura no Brasil nos três primeiros séculos, Arte e Arquitetura no Brasil nos séculos 19 e 20, História da Arte (optativas) e as obrigatórias História da Arte I e II. 


\section{Possíveis caminhos para o MAC/USP}

Continuamos a acreditar que existe espaço para um museu de arte contemporânea na universidade, assim como para outros tipos de museus. Não faz sentido, depois de 37 anos sob custódia da USP nos quais, mesmo que precariamente, a universidade preservou e ampliou as coleções e construiu infra-estrutura para mantêlas, passar agora esse patrimônio para uma fundação.

A USP é um locus privilegiado para um museu de arte pelo fato da instituição ter orçamento vultuoso e contar com cursos nas áreas de arte, arquitetura e história, entre outros afins, que poderiam dinamizar suas atividades. O MAC, por sua vez, tem um conjunto de servidores qualificados nas várias áreas da museologia aplicada e em pesquisa. Faltariam mais ações positivas por parte do poder central da USP e por parte da direção do MAC, além do esforço dos servidores no sentido de assumir as políticas propostas para o museu.

Do poder central seria importante dar autonomia ao MAC além de mais verbas, facilitando a agilização das decisões e a implementação dos programas. Outra questão é relacionada ao Regimento do museu. Ele foi aprovado conforme sugerido pela gestão de Lisbeth Rebollo Gonçalves e a atual gestão, de Teixeira Coelho, tem tentado sem sucesso realizar modificações ${ }^{13}$. Independente do mérito das propostas, fica evidente que é preciso ter uma discussão ampla sobre o Regimento do MAC e dos outros três museus para que não se tente fazer modificações a cada gestão. O Regimento, somado ao Plano Diretor com metas de médio e longo prazo, garantiriam a continuidade dos programas independentemente das mudanças de direção e mesmo dos servidores.

Entre os elementos fundamentais do Plano Diretor, destacamos a definição das linhas de pesquisa, que serviriam de base para a política de aquisições e para a montagem dos cursos e exposições. Internamente, o MAC precisaria incorporar mais docentes-pesquisadores-curadores para fortalecer a produção acadêmica e permitir a criação de cursos de pós-graduação.

Os servidores do MAC deveriam participar e assumir as políticas delineadas pelo conjunto do museu. É preciso que todos trabalhem na mesma direção para que

\footnotetext{
${ }^{13}$ Para que o Regimento seja modificado, é preciso ser aprovado pela Coordenação de Museus e depois pelo Conselho Universitário. As modificações propostas pela atual gestão não passaram ainda pela Coordenação de Museus. Algumas das propostas visavam ampliar a participação da comunidade, com representantes dos críticos de arte, da AAMAC, artistas, enfim, pessoas de fora da USP.
} 
venha a público um museu com perfil definido, metas claras, autonomia e identidade dentro do quadro geral da USP e entre os museus de arte da cidade e do país.

Um passo importante para a construção dessa identidade acaba de ser dado com a abertura ao público da exposição permanente de acervo na Sede reformada, em maio de 2001.

Ao longo deste trabalho descrevemos vários tipos de museus de arte universitários:

- Galeria de Arte com acervo voltada para diversos públicos

- Galeria de arte sem acervo para diversos públicos

- Centro de exposições sem acervo próprio

- Centro de divulgação da área

- Coleção para decoração do campus

- Coleção para formação em nível superior

O MAC não corresponde exatamente a nenhum desses tipos, mas apresenta-se como combinação de alguns deles: é uma galeria de arte com acervo que serve a diversos públicos, faz o papel de um centro de divulgação da arte moderna e contemporânea e está no campus em um prédio de destaque. Entretanto, poderia ter uma atuação mais intensa naquilo que já realiza e deveria ampliar sua atuação na formação dos graduandos e pós-graduandos. 
BIBLIOGRAFIA GERAL 


\section{BIBLIOGRAFIA GERAL}

\section{Livros, teses e artigos}

Abreu, Adilson Avansi. (org) Quantos Anos faz o Brasil? São Paulo, EDUSP, 2000.

Almeida, Adriana M. \& Martins, Maria Helena P. University and museum in Brazil: a chequered history. Museum International, UNESCO, 52(2), n.206, 2000:28-32.

Almeida, Maria Christina B. Por uma rearquitetura dos serviços de informação em arte na cidade de São Paulo, tese de doutorado, ECA/USP, 1998.

Alvarado, Daisy Peccinini. Arte Pública e Paisagem Urbana em megacidades: São Paulo nos anos 90. Heliana Angotti Salgueiro (Coord.), Paisagem e Arte: a invenção da natureza, a evolução do olhar, São Paulo, CNPQ/FAPESP/CBHA, 2000:363-367.

Amaral, Aracy. 500 anos de carência, Anais II Semana de Museus da USP (30/08 a 03/09/1999), USP,1999:15-21.

Amaral, Aracy. A História de uma Coleção. Amaral, A. (organização) Perfil de um Acervo: Museu de Arte Contemporânea da Universidade de São Paulo, Techint, São Paulo, 1988.

Amaral, Aracy. Indefinições a enfrentar e prioridades na pesquisa sobre arte brasileira. Pillar, A. D. et al. Pesquisa em artes plásticas, Porto Alegre, Ed. Universidade/UFRGS/ANPAP, 1993:9-15.

Amaral, Aracy. Museu contemporâneo é Museu atualizado. Guia das Artes Plásticas, São Paulo, Casa Editorial Paulista, nº 7, 1987:48.

American Assembly, Columbia University. On understanding art museums, New Jersey, Prentice-Hall, 1975.

Araújo, Ariadne. Fortaleza: a fila tímida na entrada do museu. Arte \& Informação, ano 1, $\mathrm{n}^{\circ} 2$, agosto:2000:70-73.

Arendt, Hannah. A crise da cultura: sua importância social e política, Entre o passado e o futuro, São Paulo, Perspectiva, $2^{a}$ ed., 1979:248-281.

Arnold-Foster, Kate. 'A developing sense of crisis': a new look at university collections in the United Kingdom, Museum International, vol.52 (3):10-14.

Arnold-Foster, Kate. Beyond the Ark: Museums and Collections of Higher-Education Institutions in Southern England, South Eastern Museums Service (Western Region), 1999.

Associação de Arte-educadores. A História da arte-educação em São Paulo: primeiro livro de registros, São Paulo, 1986:37 e 47.

Banco Safra. O Museu de Arte Contemporânea da Universidade de São Paulo, São Paulo, Banco Safra, 1990.

Barbosa, Ana Mae T. B. Arte-Educação na Cultura Brasileira. Arte \& Linguagem: língua e literatura na educação, São Paulo, Editora da PUC/Cortez, s.d.:5-22. (Cadernos PUC/SP, 14)

Barbosa, Ana Mae T. B. Arte-Educação no Brasil, São Paulo, Ed. Perspectiva/Sec. Cultura, Ciências e Tecnologia do Estado de São Paulo, 1978. 
Barbosa, Ana Mae T. B. Política Cultural como Prefácio, O Museu de Arte Contemporânea da Universidade de São Paulo, São Paulo, Banco Safra, 1990:5-10.

Barbosa, Ana Mae T. B.; Ferrara, Lucrecia D. \& Vernaschi, Elvira (orgs.) O Ensino das Artes nas Universidades, São Paulo, EDUSP, 1993.

Barbosa, Ana Mae. A Multiculturalidade da Arte e Do Museu. MAC Arte Contemporânea, Suplemento especial do Jornal da USP, Ano I, n8, março/abril 1990:1-2.

Barbosa, Ana Mae. Arte-Educação no Museu de Arte Contemporânea da USP: um Estudo de Caso, A imagem no ensino da arte: anos oitenta e novos tempos, São Paulo, Perspectiva/Fundação lochpe, 1991:83-93.

Batista, Marta Rossetti \& Lima, Yone Soares de. Coleção Mário de Andrade: artes plásticas. $2^{\mathrm{a}}$ ed. Ver. E ampl. São Paulo, Instituto de Estudos Brasileiros, USP, 1998.

Batista, Marta Rossetti. Formação do Acervo - IEB. Instituto de Estudos Brasileiros / USP, ABC do IEB: Guia Geral do Acervo, São Paulo, Edusp, 1997:13-20.

Binni, L. \& Pinna, G. Museo: storia e funzioni di una macchina culturale dal '500 a oggi. Itália, Garzanti, 1989.

Boisvert, M. Le Musée de l'Éducation Louis-Philippe-Audet, Univ. de Montréal, 1992.

Borhegyi, S. F. A Museum Training Program, Museums Journal, 58, July 1958:78-80.

Borhegyi, S. F. American University Museums, Museums Journal, 55(12) March 1956:309-311.

Borhegyi, S. F. The Public Relations function in American College and University Museums, The Museologist, 59, June 1956:2-6.

Bourdieu, P. \& Darbel, A. L'amour de l'art: les musées d'art europèens et leur public, Editions Minuit, Paris, 1969.

Bulhões, Maria Amélia. A pós-graduação e a pesquisa em artes plásticas no Brasil, Pesquisa em artes plásticas, Porto Alegre, Ed. Universidade/UFRGS/ANPAP, 1993:93-100.

Cabrero, M.T. El museo universitario de antropología, México, UNAM, 1987.

Cannon-Brookes, P. (Ed.) University \& Foundation Collections and the Law: proceedings of a Seminar Held at the Coultard Institute Art, London, 23 June 1994. Museums Management and Curatorship, 13(4), 1994:340-407.

Chiarelli, Tadeu \& Grossmann, Martin. A história da arte na USP: essa desconhecida. Comunicações e Artes, São Paulo, ECA/USP, ano 11, 14, 1985:215-228.

Chiarelli, Tadeu. MAC: Da Opulência à Precariedade. Guia das Artes Plásticas, São Paulo, Casa Editorial Paulista, $n^{\circ} 7,1987: 46-47$.

Christison, Muriel B. Professional Practices in University Art Museums, Museum News, January/February 1980:30-40.

Coleman, L. V. College and University Museums. The Museum in America, AAM, Washington DC, vol.1, chap.X, 1939:165-176.

Coleman, L. V. College and University Museums: a message for college and university presidents, AAM, Washington DC,1942. 
Comissão de Patrimônio Cultural. Guia de Museus Brasileiros, São Paulo, USP, 1996.

Comissão de Patrimônio Cultural. Guia de Museus Brasileiros, São Paulo, EDUSP / Imprensa Oficial, 2000.

Coolidge, John. The Academic Art Museums of America. Museums Journal, 56, October 1956:167-171.

Dixon, John Morris. Campus Culture, Progressive Architecture, Cleveland, March 1995:68-77.

Duarte, Luiz Fernando Dias. Processos de Classificação Social nas Coleções de um museu de ciências: O caso do Museu Nacional, Rio de Janeiro. Anais II Semana de Museu da USP (30/08 a 03/09/1999), USP, 1999:59-64.

Dyson, R. H. Public Education: The Experience of the University Museum at the University of Pennsylvania. Solinger (ed.) Museums and Universities: New Paths for Continuing Education, New York, Nucea/American Council on Education/Macmillan Publishing Company, 1990:59-80

Elias, Isis Baldini. Acervo Conceitual MAC-USP, Anais do X Congresso da ABRACOR, Rio de Janeiro, 2000:181-190.

Elias, Maria José. Trajetória da Curadoria no Museu Paulista. Anais da I Semana de Museus da Universidade de São Paulo (18 a 22 de maio de 1997), USP, 1999:67-71.

Elias, Maria José. Um museu para São Paulo. Anais do Museu Histórico Nacional, MinC/IPHAN, vol.29, 1997.

Fernández, L. A. Museología: introducción a la teoría y práctica del museo. Madrid, Istmo, 1993.

Freire, Cristina. Além dos mapas: os monumentos do imaginário urbano contemporâneo. São Paulo, SESC/Annablume, 1997.

Freire, Cristina. Em busca do 'Contemporâneo' no Museu - O desafio do Museu de Arte Contemporânea da USP, Anais da I Semana dos Museus da Universidade de São Paulo de 18 a 22 de maio de 1997, USP, 1999: 55-58.

Freire, Cristina. Espaço e lugar: os registros da paisagem urbana na arte contemporânea. Heliana Angotti Salgueiro (Coord.), Paisagem e Arte: a invenção da natureza, a evolução do olhar, São Paulo, CNPQ/FAPESP/CBHA, 2000:357-362.

Freire, Cristina. Museu. Público. Arte Contemporânea. Um triângulo nem sempre amoroso, ARTEunesp, São Paulo, 9, 1993:131-146.

Freire, Cristina. Poéticas do processo: arte conceitual no museu, São Paulo, lluminuras, 1999.

Gonçalves, Lisbeth Rebollo. Plano Diretor do Museu de Arte Contemporânea da Universidade de São Paulo aprovado pelo Conselho Administrativo em 9 de junho de 1997. Anais da I Semana dos Museus da Universidade de São Paulo de 18 a 22 de maio de 1997, USP, 1999:17-26.

Grinspum, Denise. Discussão para uma proposta de política educacional da Divisão de Ação Educativo-Cultural do Museu Lasar Segall, Dissertação de Mestrado, ECA/USP, 1991. 
Grinspum, Denise. Educação para o Patrimônio: Museu de Arte e Escola Responsabilidade compartilhada na formação de públicos, Tese de Doutorado, FEUSP, 2000.

Grossmann, Martin. Interação entre Arte Contemporânea e Arte-Educação; Subsídios para a Reflexão e Atualização das Metodologias Aplicadas, Dissertação de Mestrado, ECA/USP, 1988.

Grossmann, Martin. Programa de novas aquisições: coleção MAC/USP, Museu de Arte Contemporânea. O MAC ainda Melhor, publicado por ocasião da reinauguração da sede na Cidade Universitária, 2000.

Guillaumon, J. Régis (Coordenação). Pesquisando São Paulo: 110 anos de criação da Comissão Geográfica e Geológica. São Paulo, IG/SMA, MP/USP, IF/SMA, 1996

Guthe, A. The Role of a University Museum, Curator, 9(2), 1966:103-105.

Guthe, C. The Role of a State University Museum. Museum News, 15(18), March 1938:7-10.

Hamilton, J. The Role of the University Curator in the 1990s. Museum Management and Curatorship, 14(1), 1995:73-79.

Herreman, Yani. University and Museum in Mexico: a historical partnership. Museum International, UNESCO, 206, vol.52(2), 2000.

Hill, Mary D. The University Art Museum, Curator, 9(2), 1966:114-118.

Huffer, Alva Gwyn. Administration of the museum in selected colleges and universities in the United States, Tese de Doutorado, Arizona State University, 1971.

Instituto de Estudos Brasileiros / USP. ABC do IEB: Guia Geral do Acervo, São Paulo, Edusp, 1997.

James, N. The Museum and the College Student. The Museologist, 77, December 1960:15-18.

Karpinski, Silvana \& Uliana, Dina Elisabete. Centro de referência em arte contemporânea: uma proposta de trabalho e a experiência do arquivo e da biblioteca do Museu de Arte Contemporânea da USP, Anais II Semana de Museus da USP (30/08 a 03/09/1999), USP, 1999: 145-147.

Kelly, M. The management of Higher Education Museums, Galleries and Collections in the UK, University of Bath School of Management, 1999.

Labrador, Ana P. Educating the muses: university collections and museums in the Philippines, Museum International, vol.52 (3): 4-9.

Leme, José Luiz Moreira. Museu de Zoologia da Universidade de São Paulo. Anais I Semana dos Museus da Universidade de São Paulo. USP, 1997:29.

León, A. El museo. Teoría, praxis, utopía. Madrid, Cátedra, 1978.

Lord, Marcia. Editorial, Museum, n² 207, vol 52(3), 2000:3.

Lourenço, Maria Cecília F. Museus Acolhem Moderno, São Paulo, Edusp, 1999.

Maia, Pedro Moacir (Org.) O Museu de Arte sacra da Universidade Federal da Bahia, São Paulo, Banco Safra, 1987. 
Martins, Maria Helena Pires. Ensino e Ação Cultural no Museu de Arte Contemporânea da Universidade de São Paulo, Anais do Seminário Internacional sobre Ação Educativa em Instituições Culturais: Metas e métodos da ação educativa nos espaços culturais dedicados às artes visuais, Itaú Cultural, 28 de novembro a 1 de dezembro de 2000, no prelo.

Matthews Jr., K. The University Museum, The Museologist, 83, June 1962:10-11.

Mayer-Oakes, W. J. Musings about Museums, The Museologist, 75, June 1960:2-6.

Mazzieri, Berta R.; Piedade, Silvia C. \& Lacaz, Carlos S. Faculdade de Medicina da Universidade de São Paulo: testemunhos de sua história, São Paulo, Fundo Editorial BYK, 2000.

Meneses, Ulpiano B. Pintura Histórica: documento histórico?. Como explorar um museu histórico: armas, mobiliário, veículos, pinturas. Museu Paulista/USP, 1991:12-13.

Miranda, Sérgio. Um prédio para resgatar a história do MAC, Museu de Arte Contemporânea. O MAC ainda Melhor, publicado por ocasião da reinauguração da sede na Cidade Universitária, 2000.

Mortara, Adriana A. Museus Arqueológicos - Notas de Leitura. Revista de Pré-História, IPH/USP, 7, 1989:187-188.

Neumeyer, A. The function of the College Art Gallery. Museum News, 17(18), March 15, 1940:6-8.

Newson, Barbara Y. \& Silver, Adele Z. (eds.) The Art Museum as Educator: a collection of studies as guides to practice and police. University of California Press, Berkeley, 1978.

O Estado de São Paulo, 8 de abril de 2000, p.C8.

Odegaard, C. E. The University and the Museum, Museum News, 42(1), September 1963:31-34.

Page, Dominique S. \& Bary, Marie-Odile. (org.) Scénographier l'art contemporain et propos sur la muséographie (Stages M.N.E.S.), Lyon, Diffusion Presses Universitaires de Lyon, 1986.

Paredes, Almir. O Museu da Escola de Belas Artes - Dom João VI, Arquivos da Escola de Belas Artes / UFRJ, 1999:65-70.

Paula, Teresa Toledo. Inventando moda e costurando história: pensando a conservação de têxteis no museu paulista/usp. Dissertação de mestrado, ECA/USP, 1998.

Pécaut, Daniel. Os intelectuais e a política no Brasil: entre o povo e a nação. Ática, São Paulo, 1990.

Pedrosa, Mario. A Função do Museu no Core Universitário. Revista GAM: Galeria de Arte Moderna, n³, fevereiro 1967:31-33. (republicado no Boletim Museu de Arte Contemporânea, 198?.)

Pessi, Maria Cristina A. S. Questionando a Livre-Expressão: História da Arte na Escolinha de Arte de Florianópolis, Florianópolis, Fundação Catarinense de Cultura, 1990.

Reimann, I. G. Training Museum Personnel in a University, Curator, 1(2), 1958:63-70.

Rodeck, $\mathrm{H}$. Present situation among college and university museums. Museum News, January, 1, 1952:4-6. 
Rodrigues, Miguel Trefaut. Realidade e Desafios dos Acervos Musealizados da USP: O Museu de Zoologia. Anais II Semana de Museus da USP (30/08 a 03/09/1999), USP, 1999:31-33.

Rolfe, W.D I. A university's museum. Museums Journal, 69(1), 1969:7-10.

Santos, Maria Cecília Loschiavo. (org.) Universidade de São Paulo: Alma Mater Paulista - 63 anos, São Paulo, EDUSP/Imprensa Oficial, 1998.

Santos, Maria Célia Moura T. Museu, Escola e Comunidade - Uma integração Necessária, Salvador, UFBA, 1987.

Sarian, Haiganuch. Curadoria sem curadores? Anais da I Semana dos Museus da Universidade de São Paulo de 18 a 22 de maio de 1997, USP, 1999:33-35.

Schaer, Roland. L'invention des musées, França, Gallimard / Réunion des Musées nationaux, 1993 (Découvertes Gallimard 187).

Schuster, J. Mark Davidson. The audience for American Art Museums, National Endowment for the Arts, Research Division Report \#23, Washington, Seven Locks Press, 1992.

Schwarcz, Lília K. M. O Nascimento dos Museus Brasileiros 1870-1910. Organização Sérgio Miceli. História das Ciências Sociais no Brasil, vol.1, IDESP/Vértice/Finep, São Paulo, 1989:20-71.

Schwartzman, Simon Ciência, universidade e ideologia: a política do conhecimento. Zahar, São Paulo, 1981.

Seyd, E.L. A university museum and the general public. Museums Journal, 70(4), 1971:180-2.

Silva-Nigra, Dom Clemente Maria. Museu de Arte Sacra da Bahia, Rio de Janeiro, Agir Editora, 1972.

Teixeira Coelho, J. Para um Museu Contemporâneo de Arte. Anais II Semana de Museus da USP (30/08 a 03/09/1999), USP, 1999:27-30.

Teixeira Coelho. As idades moderna e contemporânea no Brasil, Avansi (org) Quantos Anos faz o Brasil? São Paulo, EDUSP, 2000: 152-169.

Teixeira Coelho. Dicionário Crítico de Política Cultural, São Paulo, Iluminuras/FAPESP, 1997.

Teixeira Coelho. Gabinete de papel, Museu de Arte Contemporânea. O MAC ainda Melhor, publicado por ocasião da reinauguração da sede na Cidade Universitária, 2000.

Teixeira Coelho. MAC Século 21, Museu de Arte Contemporânea. O MAC ainda Melhor, publicado por ocasião da reinauguração da sede na Cidade Universitária, 2000.

Tirrel, Peter B. Dealing with change: university museums of natural history in the United States, Museum International, vol.52 (3):15-20.

Trefaut, M. Realidade e Desafios dos Acervos Musealizados da USP: Museu de Zoologia. Anais II Semana dos Museus da Universidade de São Paulo, USP, 1999:31-33.

Valente, Maria Esther Alvarez. Educação em Museu: O Público de hoje no museu de ontem, dissertação de mestrado, Depto. De Educação, PUC/RJ, 1995. 
Waller, Brett. Museums in the Groves of Academe. Museum News, 58(3), January/February 1980:17-23.

Warhurst, A. University Museums. In Thompson, J.M.A. (Ed.) Manual of Curatorship: a Guide to Museum Practice. Oxford, Butterworth-Heinemann, 2nd ed.,1992:93100.

Wilder, Gabriela Suzana. Formação e desenvolvimento das coleções: problemas e desafios - o caso do Museu de Arte Contemporânea da Universidade de São Paulo, Anais da I Semana dos Museus da Universidade de São Paulo de 18 a 22 de maio de 1997, USP, 1999:51-53.

Xavier, Marco Antônio. Ocupação do campus Butantã da Universidade de São Paulo (1934-1954): representações de poder no espaço da universidade, dissertação de mestrado, FFLCH/USP, 1999.

Zanini, Walter. Situação dos Museus e Coleções da Universidade de São Paulo: Levantamento realizado entre agosto e novembro de 1982. Trabalho realizado na disciplina "Elementos de Museologia", sob a orientação do Prof. Dr. Walter Zanini, do Departamento de Artes Plásticas da Escola de Comunicações e Artes da USP, 1982, 2 volumes.

\section{Regimentos, estatutos e relatórios}

Celani, Maria Gabriela C. O Espaço em museus construídos e adaptados: uma tentativa de análise comparativa em alguns casos brasileiros, FAU/USP, dat., 1989 (relatório de pesquisa sob orientação de Aracy Amaral).

ICOM (International Council of Museums). Estatutos / Código de Deontología Profesional, Paris, 1997.

Instituto de Estudos Brasileiros. Levantamento de todas as atividades de difusão cultural realizadas pelo IEB, 2000.

Instituto de Estudos Brasileiros. Relatório Anual, 1997.

Instituto de Estudos Brasileiros. Relatório Anual, 1998.

Instituto de Estudos Brasileiros. Relatório Anual, 1999.

Museu de Arte Contemporânea. Relatório Anual, 1996.

Museu de Arte Contemporânea. Relatório Anual, 1997.

Museu de Arte Contemporânea. Relatório Anual, 1998.

Museu de Arte Contemporânea. Relatório Anual, 1999.

Museu Paulista. Plano Diretor do Museu Paulista da USP (1990-1995), USP, dat. 1990.

Museu Solar de Monjardim, Regimento Interno, datilografado, 1996.

Regimento do Instituto de Estudos Brasileiros. Diário Oficial do Estado, Seção I, São Paulo, 23/10/1996.

Regimento do Instituto de Estudos Brasileiros. Revista do Instituto de Estudos Brasileiros, (23), 1981:149-153.

Regimento do Museu de Arqueologia e Etnologia. Diário Oficial do Estado, Seção I, São Paulo, 107 (90), 14/05/1997. 
Regimento do Museu de Arte Contemporânea. Diário Oficial do Estado, Seção I, São Paulo, 107 (233), 04/12/1997.

Regimento do Museu Paulista. Diário Oficial do Estado, Seção I, São Paulo, 107 (90), 14/05/1997.

Sablott, J. Director's Report. University of Pennsylvania Museum of Archaeology and Anthropology Report: July 1, 1994 - June 30, 1996.

Standing Commission on Museums and Galleries. Universities and Museums: Report on the Universities in relation to their own and other Museums, Her Majesty's Stationary Office, London, 1968.

The Report of the University Museums Review Committee. Cinderella Collections: University Museums \& Collections in Australia, 1996.

Universidade de São Paulo, Anuário Estatístico Sumário 1999, disponível no endereço eletrônico www.usp.br, 2000.

Universidade de São Paulo, Estatuto da Universidade de São Paulo, 1988.

Universidade de São Paulo, Regimento Geral, 1990.

Universidade do Ceará, Resolução nº 104, de 18 de julho de 1961.

Universidade Estadual de Campinas, Regimento Interno Galeria de Arte da UNICAMP, s.d.

Universidade Federal do Rio de Janeiro, Regimento do Museu D. João VI, s.d.

\section{Catálogos e folhetos}

Brouillet, Johanne. L'Herbier de Monique Mongeau où la rencontre de deux disciplines. Apresentação do catálogo "L'Herbier de Monique Mongeau", exposição da Galerie d'art du Centre Culturel, Université de Sherbrooke, Canadá, 5/09 a 18/10/1998.

Instituto de Estudos Brasileiros. 100 obras-primas da Coleção Mário de Andrade: pintura e escultura. Catálogo de exposição, outubro a dezembro de 1993. (Curadoria de Marta Rossetti Batista)

Instituto de Estudos Brasileiros. Centenários Modernistas III: Lasar Segall (1891-1957). Folheto de exposição, setembro e outubro de 1991. (Curadoria Marta Rossetti Batista)

Instituto de Estudos Brasileiros. Desenhos de escritores modernistas na Coleção Mário de Andrade. Folheto de exposição, agosto/setembro de 1992. (Curadoria Mayra Laudanna)

Instituto de Estudos Brasileiros. Goeldi e seu tempo. Catálogo de exposição. 1995. (Curadoria de Mayra Laudanna).

Instituto de Estudos Brasileiros. Johann Moritz Rugendas. Catálogo de exposição, 1991. (Curadoria de Mayra Laudanna)

Instituto de Estudos Brasileiros. Mariana Quito. Catálogo de exposição, 1993. (Curadoria de Mayra Laudanna)

Instituto de Estudos Brasileiros. Mostra Fotográfica: Fotógrafos Presentes no Arquivo do IEB/USP 1870-1940. Catálogo exposição realizada no Centro de Divulgação 
Científica e Cultural de São Carlos, abril e maio de 1999. (Curadoria de Maria Helena Pinoti Schiesari)

Instituto de Estudos Brasileiros. Novas doações: Coleção Bernardino Ficarelli. Folheto de exposição, outubro a dezembro de 1992. (Curadoria de Marta Rossetti Batista)

Instituto de Estudos Brasileiros. O Jovem Di (1917-1935). Catálogo de exposição, abril a julho de 1997. (Curadoria de Marta Rossetti Batista)

Museu de Arte Contemporânea da USP. Arte Brasileira: 50 anos de história no acervo do MAC USP, Catálogo de exposição, setembro de 1996 a fevereiro de 1997. (Curadoria de Lisbeth Rebollo Gonçalves e Elvira Vernaschi)

Museu de Arte Contemporânea da USP. Arte Conceitual e Conceitualismos: anos 70 no acervo do MAC USP, Folheto de exposição realizada no Centro Cultural FIESP, junho a agosto de 2000. (Curadoria de Cristina Freire)

Museu de Arte Contemporânea. Catálogo Geral das Obras, 1973. (Introdução de Walter Zanini)

Museu de Arte Contemporânea. Catálogo Geral: 1963-1991, 1992.

Museu de Arte Contemporânea. O MAC ainda Melhor, publicado por ocasião da reinauguração da sede na Cidade Universitária, 2000.

Universidade Federal da Paraíba, Manual do NUPPO, João Pessoa, 1999.

Universidade Federal de Minas Gerais, Galeria Brasiliana, Folheto informativo, 2000.

Universidade Federal de Minas Gerais, Galeria Brasiliana: Catálogo da exposição de inauguração da Galeria da Escola de Belas Artes, 1997.

Vieira, Sebastião Guimarães. Uma lição de saber. Folheto Universidade Estadual da Paraíba transforma antigo grupo escolar em Casa da Cultura de Campina Grande, Governo do Estado/UEPB,1997.

\section{Outros documentos}

Almeida, A. M. Exposições Fotográficas: Experiências de Avaliação. Trabalho realizado para o curso do professor Boris Kossoy, ECA/USP, julho de 1991, dat.

Almeida, A. M.; Almeida, M. C. B.; Fonsi, M.; Rangel, Z. M. M. \& Motta, U. D. MAC/USP: Um Estudo do público e do gosto. Trabalho realizado para curso do professor José Teixeira Coelho, ECA/USP, 1992, dat.

Barbosa, Ana Mae. Entrevista concedida à autora, em dezembro de 1998.

Batista, Iracema Nogueira. Respostas às perguntas da autora sobre o Museu do Seridó, enviadas por escrito em 12/02/2001.

Batista, Marta Rossetti. Depoimento sobre o IEB/USP, concedido à autora em 07/03/2001.

Brink, Brigid. Resposta à pergunta sobre quantidade de museus universitários de arte nos EUA. Mensagem de correio eletrônico, recebida em 25 de outubro de 2000.

Brito, Paula Sônia. O Museu do Seridó: a história que se faz presente, Página da internet CERES - Museu do Seridó, UFRN, 2000. 
Bruno, Maria Cristina (Coord.) Diagnóstico sobre as potencialidades museológicas da USP, Universidade de São Paulo, dat., 2000.

Carvalho, Lívia Marques. Depoimento sobre Pinacoteca e Núcleo de Arte Contemporânea da UFPB, enviado por escrito em 31/10/2000.

Carvalho, Lívia Marques. Depoimento sobre Pinacoteca e Núcleo de Arte Contemporânea da UFPB, enviado por correio eletrônico, 24/01/2001.

Costa, Pedro Eymar B. Depoimento com esclarecimentos sobre MAUC, enviado por correio eletrônico em 10/01/2001.

Grossmann, Martin. Depoimento à autora sobre o MAC/USP, concedido em 14/02/2001.

Labrecque, Georges. Resposta ao questionário sobre museus universitários, Montreal, setembro de 1998.

Laudanna, Mayra. Depoimento sobre atividades no IEB/USP, concedido à autora em 19 de fevereiro de 2001.

Lauritzen, E. Resposta ao questionário sobre museus universitários, enviada pela Internet - Universidade de Oslo, Noruega, 28/01/97.

Leitzke, Maria Cristina Padilha. Respostas a levantamento sobre museus universitários de arte. Mensagens de correio eletrônico recebidas em 18 e 20 de outubro de 2000.

Lemieux, A . Rapport annuel du Centre d'Exposition de l'Université de Montréal, mimeo, 1998.

Martins, Maria Helena Pires. Resposta ao questionário, por escrito, 25/091999.

Marx, Murillo. Respostas a duas perguntas do questionário, por escrito, 17/02/2000.

Mendes, Neusa. Depoimento sobre Espaço Universitário e Galeria da UFES, enviado por correio eletrônico em 23/01/2001.

Mendes, Neusa. Projeto de livro de memória das Artes Plásticas da Galeria de Arte Espaço Universitário da UFES apresentado para o Fundo Nacional de Pesquisa, UFES, 2000.

Meneses, Ulpiano B. Museu e Pesquisa: Preliminares para uma proposta de reformulação do Museu Paulista da USP. São Paulo, 1989, revisão 1999, dat. (enviado a autora em conjunto com entrevista em 05/02/1999).

Meneses, Ulpiano B. Resposta ao questionário da autora, enviada por escrito em 05/02/1999.

Miranda, Sérgio. Breve Histórico [MAC]. Página da Internet do MAC/USP, acessada em 29/01/2001.

Negrão, Maria Cristina Gomes. Novas informações sobre o MAAC, enviadas por escrito em 24/01/2001.

Negrão, Maria Cristina Gomes. Respostas a levantamento sobre museus universitários de arte, enviada por correio eletrônico em 22 de outubro de 2000.

Oliveira, Walney da Costa. Depoimento sobre o Museu Regional de Arte, dado verbalmente em 24/01/2001.

Paredes, Almir. Depoimento sobre o Museu D. João VI, dado verbalmente em 24/01/2001. 
Reca, M. M. Resposta ao questionário, enviada por escrito - Museo de La Plata, Argentina - 1997.

Ribeiro, Maria Izabel Branco. Depoimento sobre o MAB/FAAP, entrevista em 01/02/2001.

Rosa, Lourdes. Depoimento sobre o Museu da Gravura, enviado por escrito em 30/10/2000.

Ruf, M. L. Resposta ao questionário, enviada por escrito - Museo de La Plata, Argentina - agosto de 1997.

Santos, Maria Célia Moura. Resposta à pergunta sobre sua atuação no Museu de Arte Sacra, enviada por correio eletrônico, em 07/05/2001.

Semaniuc, Vera. Depoimento sobre a Galeria de Arte da UNICAMP, dado verbalmente em 24/01/2001

Silva, Eliane Maria Paschoal da. Resposta ao questionário, enviada por correio eletrônico, em 7/02/2000.

Universidade de São Paulo. A formação da Universidade de São Paulo, site www.usp.br, copiada em abril de 2000.

Villanova, Ageo Luis Bastos. Depoimento sobre o Museu de Arte e de Cultura Popular da UFMT, dado verbalmente em 09/02/2001.

Formulário Vitae - 1996 e 1997

Galeria de Arte - UFES

Museu D. João VI - UFRJ

Museu de Arte Assis Chateubriand da Universidade Estadual da Paraíba - MAAC

Museu de Arte Brasileira da FAAP - MAB

Museu do Seridó - UFRN

Museu Solar de Monjardim - UFES

\section{Formulário CPC/Vitae 1999}

Coleção de Artes Visuais do Instituto de Estudos Brasileiros - USP.

Museu D. João VI - UFRJ.

Museu de Arte Assis Chateaubriand da UEPB - MAAC.

Museu de Arte Brasileira da FAAP - MAB.

Museu de Arte da Universidade Federal do Ceará - MAUC (formulário e anexos). 


\section{Páginas da internet}

CAPES <www.capes.gov.br>

FAAP - MAB <http://www.faap.br>

IEB <www.ieb.usp.br>

MAC <www.mac.usp.br>

MEC <http://www.mec.gov.br> <www.inep.gov.br/censo/1998/superior>

Redpath Museum. <www.mcgill.ca/Redpath>

UEPB - MAAC <http://www.uepb.rpp.br>

UFBA <http://www.ufba.br>

UFC - MAUC <http://www.ufc.br>

UFES - Centro de Artes <http://www.ufes.br>

UFMT <http://www.ufmt.br>

UFRN - CERES - Museu do Seridó <http://www.ufrn.br>

UNICAMP - Galeria de Arte <www.unicamp.br>

USP <www.usp.br> 
ANEXO 1

QUESTIONÁRIO SOBRE MUSEUS UNIVERSITÁRIOS 


\section{Levantamento de dados: questionário utilizado}

\section{LEVANTAMENTO DE DADOS SOBRE OS MUSEUS E COLEÇÕES UNIVERSITÁRIAS}

O presente questionário tem por finalidade coletar dados dos museus e coleções de diferentes universidades para minha pesquisa de doutorado junto à Universidade de São Paulo (Brasil). Agradeceria muito que as questões fossem respondidas pois esses dados auxiliarão no estudo e diagnóstico das condições atuais desses museus.

Obrigada

Adriana Mortara Almeida

\section{Caracterização}

1. Designação oficial:

2. Endereço:

3. Ano de fundação:

4. Instituição mantenedora:

5. Unidade da universidade a qual pertence:

6. O museu tem regimento?

Data:

7. Breve histórico do museu:

8. Objetivos institucionais:

9. Qual a área cultural/científica abrangida pelo museu ou coleção?

10. Qual a relação do museu com os departamentos afins?

\section{Recursos Humanos}

11. Responsável pelo museu ou pela coleção:

12. Qual é a estrutura científica? Como é o organograma do museu?

13. Há funcionários contratados exclusivamente para atender ao público? Quantos? Em que funções?

14. Número de funcionários: pessoal técnico / científico:

pessoal administrativo:

outros:

\section{Total:}

15. São utilizados serviços de terceiros? Quais?

16. O museu tem estagiários? Em que áreas? Quantos?

Observações:

\section{Recursos Financeiros}

17. O museu tem verbas próprias anuais?

18. Qual a procedência das verbas?

19. Como são constituídas as coleções? (através de aquisições, doações, etc.) Instalações

20. As instalações são próprias? ( ) cedidas ( ) alugadas ( ) em construção ( )

21. Quais são suas principais características?

22.Como está distribuído o espaço entre recepção, área científica, área administrativa, área de exposições, reserva, biblioteca, auditórios, etc.? (se possível anexar planta) 
23. Há instalações / salas exclusivas para atendimento do público? Com que tipo de equipamento? Acervo

24. Qual é a natureza das coleções e quantidade?

25. Há profissionais de documentação?

Quantos?

26. Há profissionais de conservação / restauração?

Quantos?

27. Há algum setor técnico específico para este tipo de museu? Qual?

28. A coleção está catalogada / documentada?

29. As coleções estão sendo pesquisadas?
( ) Não
( ) $\operatorname{Sim}$

Por pesquisadores ( ) do museu

( ) da unidade

( ) de outras unidades da universidade

( ) de fora da universidade

30. Quais os temas de pesquisa?

Atividades públicas

31. Qual é o horário de trabalho?

32. Qual o horário de visitas para o público?

33. Há biblioteca no museu?

Qual a área de especialização e o número de volumes da biblioteca?)

34. Quais as publicações e edições do museu?

35. Há exposição permanente / longa duração?

Temática:

36. Organizam-se exposições temporárias?

Qual o tema e duração das duas últimas?

37. Oferece programas para o público escolar? Quais?

38. Oferece cursos de extensão, graduação, outros?

39. Quais os outros programas oferecidos ao público?

40. Quais os tipos de público que freqüentam o museu? ( estudantes de $1^{\circ}$ e $2^{\circ}$ graus, professores, universitários, turistas....)

41. Qual a freqüência aproximada de visitantes (anual)?

Observações:

Local:

Data:

Nome e cargo do respondente:

Muito obrigada! Favor enviar para Adriana Mortara Almeida

Av. Pedroso de Morais, 144 ap.702 São Paulo SP CEP: 05420-000 Brasil

e-mail: mortara@usp.br tel/fax: 55-11-38137633 
ANEXO 2

LEVANTAMENTO DE MUSEUS UNIVERSITÁRIOS BRASILEIROS 
LISTA DE MUSEUS DE UNIVERSIDADES FEDERAIS - BRASIL

\begin{tabular}{|c|c|c|c|c|c|}
\hline & NOME DO MUSEU & $\begin{array}{l}\text { UNIVERSI- } \\
\text { DADE }\end{array}$ & ÁREA & $\begin{array}{c}\text { ANO } \\
\text { CRIAÇÃO }\end{array}$ & ENDEREÇO \\
\hline 1 & $\begin{array}{l}\text { Museu de Antropologia e Folclore Théo } \\
\text { Brandão }\end{array}$ & UFAL & Antropologia & 1975 & $\begin{array}{c}\text { Praça Visconde de Sinimbu, 206, Centro 57020-720 } \\
\text { Maceió, AL }\end{array}$ \\
\hline 2 & Memorial da Medicina Brasileira & UFBA & História da saúde & 1982 & $\begin{array}{c}\text { Praça XV de Novembro s/n } \\
\text { Terreiro de Jesus. Antiga Faculdade de Medicina } \\
\text { 40025-010 Salvador, BA }\end{array}$ \\
\hline 3 & Museu Afro-Brasileiro & UFBA & Antropologia & 1974 & $\begin{array}{l}\text { Praça Terreiro de Jesus, Antiga Faculdade de Medicina } \\
\text { - Centro Histórico 40025-010 Salvador, BA } \\
\text { Site: } \frac{\text { http://www.ufba.br/instituicoes/ceao/ }}{\text { e-mail: ceao@ufba.br }}\end{array}$ \\
\hline 4 & Museu de Arqueologia e Etnologia & UFBA & Antropologia & 1974 & $\begin{array}{c}\text { Praça Terreiro de Jesus } \mathrm{s} / \mathrm{n}^{\circ}, \text { Antiga Faculdade de } \\
\text { Medicina - Centro Histórico 40025-010 Salvador, } \\
\text { BASite: www.ufba.com.br/ }\end{array}$ \\
\hline 5 & Museu de Arte Sacra da Bahia & UFBA & Arte Sacra & 1959 & $\begin{array}{c}\text { Rua do Sodré, } 276 \text { - Largo } 2 \text { de Julho, Centro 40060- } \\
240 \text { Salvador, BAe-mail: mas@ufba.br }\end{array}$ \\
\hline 6 & Museu Artur Ramos & UFC & Antropologia & 1981 & $\begin{array}{l}\text { Av. Perimetral s/n Messejana } \\
60830-641 \text { Fortaleza, CE }\end{array}$ \\
\hline 7 & Museu de Arte da UFC & UFC & $\begin{array}{c}\text { Arte } \\
\text { Contemporânea }\end{array}$ & 1961 & $\begin{array}{l}\text { Avenida da Universidade, 2854, Benfica 60020-181 } \\
\text { Fortaleza, CE }\end{array}$ \\
\hline 8 & Galeria de Arte Espaço Universitário & UFES & $\begin{array}{c}\text { Arte } \\
\text { Contemporânea }\end{array}$ & $197 ?$ & $\begin{array}{c}\text { Av. Fernando Ferrari s/n } \\
\text { Campus da Universidade - Goiabeiras } \\
29060-900 \text { Vitória, ES }\end{array}$ \\
\hline 9 & Museu Solar Monjardim & UFES & História e arte & 1980 & $\begin{array}{l}\text { Av. Paulino Muller, s/nº, Jucutuquara } \\
\text { 29042-571 Vitória, ES }\end{array}$ \\
\hline 10 & Museu Antropológico & UFGO & Antropologia & 1970 & $\begin{array}{c}\text { Av. Universitária, 1166, Setor Universitário 74605-010 } \\
\text { Goiânia, GOSite: http://www.museu.ufg.br/ }\end{array}$ \\
\hline 11 & Museu de Malacologia & UFJF & Ciências Naturais & 1966 & $\begin{array}{c}\text { Campus Universitário - Martelos 36036-330 Juiz de } \\
\text { Fora, MGSite: http://www.ufif.br/malaco/index.html } \\
\text { e-mail: malaco@icb.ufjf.br }\end{array}$ \\
\hline 12 & Museu de História Natural & UFJF & Ciências Naturais & 1989 & $\begin{array}{c}\text { Museu de História Natural Academia / CESRua Halfeld, } \\
\text { 1179, Centro 36016-000 Juiz de Fora, MG } \\
\text { Site: http://www.academia.com.br/museus.htm e-mail: } \\
\text { academia@zaz.com.br } \\
\end{array}$ \\
\hline 13 & Museu Herbário CESJ & UFJF & Ciências Naturais & $?$ & 36036-000 Juiz de Fora, MG \\
\hline
\end{tabular}




\begin{tabular}{|c|c|c|c|c|c|}
\hline 14 & Museu Bi Moreira & UFLA & História local & 1983 & $\begin{array}{l}\text { Campus Histórico da UFLavras Caixa Postal } 37 \\
\text { 37200-000 Lavras, MG }\end{array}$ \\
\hline 15 & Museu de Mineralogia & UFLA & Ciências Naturais & 1970 & $\begin{array}{c}\text { Campus Universitário Depto. De Ciências do Solo } \\
\text { UFLavras } \quad 37200-000 \text { Lavras, MG }\end{array}$ \\
\hline 16 & $\begin{array}{l}\text { Centro de Memória da Medicina de } \\
\text { Minas Gerais }\end{array}$ & UFMG & História saúde & 1977 & $\begin{array}{l}\text { Av. Alfredo Balena } 190 \text { Centro } \\
\text { 30130-100 Belo Horizonte, MG } \\
\text { e-mail: humelo@lcc.ufmg.br }\end{array}$ \\
\hline 17 & $\begin{array}{l}\text { Museu de História Natural e Jardim } \\
\text { Botânico da UFMG }\end{array}$ & UFMG & $\begin{array}{l}\text { Ciências Naturais } \\
\text { / Antropologia }\end{array}$ & 1995 & $\begin{array}{l}\text { R. Gustavo da Silveira, 1035, Santa Inês 31080-010 } \\
\text { Belo Horizonte, MGe-mail: mhnjb@reitoria.ufmg.br }\end{array}$ \\
\hline 18 & Galeria Brasiliana & UFMG & Arte & $\begin{array}{l}1967 \\
\text { reabert } \\
2000\end{array}$ & $\begin{array}{c}\text { Av. Afonso Penna, } 1534 \text { Centro30130-002Belo } \\
\text { Horizonte, MG }\end{array}$ \\
\hline 19 & $\begin{array}{l}\text { Museu de Arte e de Cultura Popular da } \\
\text { UFMT }\end{array}$ & UFMT & $\begin{array}{c}\text { Arte } \\
\text { Contemporânea } \\
\text { Cultura Popular }\end{array}$ & 1974 & $\begin{array}{l}\text { Av. Fernando Côrrea da Costa } \\
\text { 78000-100 Cuiabá, MT }\end{array}$ \\
\hline 20 & Museu Rondon & UFMT & Antropologia & 1972 & $\begin{array}{l}\text { Br } 16 \text { Km } 5 \text { Cidade Universitária } \\
78060-900 \text { Cuiabá, MT }\end{array}$ \\
\hline 21 & $\begin{array}{l}\text { Museu de Ciência e Técnica } \\
\text { (inclui o antigo Museu de Mineralogia) }\end{array}$ & UFOP & $\begin{array}{l}\text { Ciências Naturais } \\
\text { / Técnicas }\end{array}$ & 1995 & $\begin{array}{c}\text { Museu de Ciência e Técnica da Escola de Minas / } \\
\text { UFOP Praça Tiradentes, } 20 \text { 35400-000 Ouro Preto, MG } \\
\text { e-mail: museuct@ouropreto.feop.com.br }\end{array}$ \\
\hline 22 & Museu da Universidade Federal do Pará & UFPA & História Regional & 1983 & $\begin{array}{c}\text { Avenida Governador José Malcher, 1192, Nazaré } \\
66060-230 \text { Belém, PA }\end{array}$ \\
\hline 23 & Museu da Cultura Popular & UFPB & Cultura Popular & 1980 & $\begin{array}{c}\text { Prédio da Reitoria - Andar Térreo - Campus I, Castelo } \\
\text { Branco I 58059-900 João Pessoa, PB }\end{array}$ \\
\hline 24 & Museu de Arte Popular & UFPB & Arte Local & 1978 & $\begin{array}{c}\text { Prédio da Reitoria - Andar Térreo - Campus I, Castelo } \\
\text { Branco I 58059-900 João Pessoa, PB }\end{array}$ \\
\hline 25 & Museu do Brejo Paraibano & UFPB & História Local & 1978 & $\begin{array}{c}\text { Centro de Ciências Agrárias Campus III } \\
58397-000 \text { Areia, PB } \\
\end{array}$ \\
\hline 26 & Pinacoteca & UFPB & Arte local & 1987 & $\begin{array}{c}\text { Pinacoteca da UFPB } \\
\text { Biblioteca Central Campus I } \\
55059-900 \text { João Pessoa, PB }\end{array}$ \\
\hline 27 & Museu de Arte Leopoldo Gotuzzo & UFPel & Arte & 1996 & $\begin{array}{l}\text { Rua Félix da Cunha, } 818 \\
96015-000 \text { Pelotas, RS } \\
\text { www.ufpel.br/malg }\end{array}$ \\
\hline 28 & $\begin{array}{l}\text { Museu de Ciências Naturais Carlos } \\
\text { Ritter }\end{array}$ & UFPel & Ciências Naturais & $\begin{array}{l}1970 \\
1988 \\
\text { aberto }\end{array}$ & $\begin{array}{c}\text { Rua Marechal Deodoro, 823, Centro 96020-200 } \\
\text { Pelotas, RS }\end{array}$ \\
\hline
\end{tabular}




\begin{tabular}{|c|c|c|c|c|c|}
\hline 29 & $\begin{array}{l}\text { Museu de Arqueologia e Etnologia de } \\
\text { Paranaguá }\end{array}$ & UFPR & Antropologia & 1962 & $\begin{array}{c}\text { Rua XV de Novembro, 575, Centro 83203-300 } \\
\text { Paranaguá, PRSite: mae proec.ufpr.br } \\
\text { e-mail: mae@proec.ufpr.br }\end{array}$ \\
\hline 30 & Museu D. João VI & UFRJ & Arte & 1979 & $\begin{array}{l}\text { Av. Brigadeiro Trompowisky, } \mathrm{s} / \mathrm{n}^{\circ}-2^{\circ} \text { andar, Cidade } \\
\text { Universitária 21941-590 Rio de Janeiro, RJ } \\
\text { Site: http://www.acd.ufri.br/djoaovi } \\
\text { e-mail: djoaovi@acd.ufrj.br }\end{array}$ \\
\hline 31 & Museu da Escola de Engenharia & UFRJ & História Ciências & 1977 & $\begin{array}{c}\text { Av. Brigadeiro Trompowisky s/no, Ilha do Fundão } \\
\text { 21945-970 Rio de Janeiro, RJSite: http://www.ee.ufrj.br/ } \\
\text { e-mail: museuee@ @ct.ufrj.br }\end{array}$ \\
\hline 32 & Museu Nacional & UFRJ & $\begin{array}{l}\text { Ciências Naturais } \\
\text { / Antropologia }\end{array}$ & 1818 & $\begin{array}{l}\text { Quinta da Boa Vista s/n São Cristóvão } \\
20940-000 \text { Rio de Janeiro, RJ }\end{array}$ \\
\hline 33 & Museu Câmara Cascudo & UFRN & $\begin{array}{l}\text { Ciências Naturais } \\
\text { / Antropologia }\end{array}$ & 1960 & $\begin{array}{l}\text { Av. Hermes da Fonseca, 1398, Tirol 59015-001 Natal, } \\
\text { RNe-mail: museucc@mcc.ufrn.br }\end{array}$ \\
\hline 34 & Museu do Mar Onofre Lopes & UFRN & Ciências Naturais & 1973 & $\begin{array}{c}\text { Praia da Mãe Luiza s/n Via Costeira } \\
59014-100 \text { Natal, RN } \\
\text { e-mail: sankaran@ncc.ufrn.br }\end{array}$ \\
\hline 35 & Museu do Seridó & UFRN & $\begin{array}{c}\text { Arte sacra / } \\
\text { História }\end{array}$ & 1968 & $\begin{array}{l}\text { Rua Amaro Cavalcante, } 123, \text { Centro } \\
59300-000 \text { Caicó, RN }\end{array}$ \\
\hline 36 & Museu Luiz Englert & UFRS & Ciências Naturais & 1945 & $\begin{array}{c}\text { Rua Sarmento Leite, 425, Centro 90050-170 Porto } \\
\text { Alegre, RS }\end{array}$ \\
\hline 37 & Museu Oceanográfico & UFRS & Ciências Naturais & 1978 & $\begin{array}{l}\text { Av. Tramandaí } 976 \\
95625-000 \text { Imbé, RS }\end{array}$ \\
\hline 38 & Museu Universitário da UFRS & UFRS & História regional & 1983 & $\begin{array}{l}\text { Av. Paulo da Gama, } 1102^{\circ} \text { andar } \\
90040-060 \text { Porto Alegre, RS }\end{array}$ \\
\hline 39 & $\begin{array}{l}\text { Museu Universitário Professor Oswaldo } \\
\text { Rodrigues Cabral }\end{array}$ & UFSC & Antropologia & 1965 & $\begin{array}{c}\text { Campus Universitário Trindade - Florianópolis, } \\
\text { Trindade 88040-900 Florianópolis, SCe-mail: } \\
\text { museu@cfh.ufsc.br }\end{array}$ \\
\hline 40 & $\begin{array}{l}\text { Museu do Homem Sergipano (ex Museu } \\
\text { de Antropologia) }\end{array}$ & UFSE & Antropologia & $\begin{array}{c}1968 \\
\text { abert1984 }\end{array}$ & $\begin{array}{l}\text { Praça Camerino, 227, Centro } \\
\quad 49015-060 \text { Aracaju, SE }\end{array}$ \\
\hline 41 & $\begin{array}{l}\text { Museu Educativo Gama d'Eça e Victor } \\
\text { Bersani }\end{array}$ & UFSM & $\begin{array}{l}\text { Ciências Naturais } \\
\text { / Antropologia }\end{array}$ & 1968 & $\begin{array}{c}\text { Rua do Acampamento, 81, Centro 97050-001 Santa } \\
\text { Maria, RSSite: http://www.ufsm.br/museuedu e-mail: } \\
\text { museuedu@yahoo.com }\end{array}$ \\
\hline 42 & $\begin{array}{l}\text { Centro de Documentação e Pesquisa } \\
\text { em História }\end{array}$ & UFU & História & 1987 & $\begin{array}{l}\text { Av. Universitária s/no, Santa Mônica 38408-170 } \\
\text { Uberlândia, MGe-mail: cdhis@ufu.br }\end{array}$ \\
\hline
\end{tabular}




\begin{tabular}{|c|c|c|c|c|c|}
\hline 43 & Herbarium Uberlandense & UFU & Ciências Naturais & 1986 & $\begin{array}{c}\text { Departamento de Biociências, Campus Umuarama - } \\
\text { Umuarama 38400-902 Uberlândia, MGe-mail: } \\
\text { schiavini@ufu.br }\end{array}$ \\
\hline 44 & Museu de Imagem e Som & UFU & $\begin{array}{l}\text { História. Música } \\
\text { e Fotografia }\end{array}$ & $\begin{array}{c}\text { 96:fechad } \\
\text { o }\end{array}$ & $\begin{array}{c}\text { Av. Universitária s/n Bloco Q Campus Santa Mônica } \\
38400-902 \text { Uberlândia, MG }\end{array}$ \\
\hline 45 & Museu de Minerais e Rochas & UFU & Ciências Naturais & 1987 & $\begin{array}{l}\text { Av. Universitária s/n Bloco Q Campus Santa Mônica } \\
38400-902 \text { Uberlândia, MG }\end{array}$ \\
\hline 46 & $\begin{array}{l}\text { Museu de Zoologia (Museu de História } \\
\text { Natural) }\end{array}$ & UFU & Ciências Naturais & 1985 & $\begin{array}{l}\text { Campus Umuarama Bloco 2D } \\
\text { 38400-902 Uberlândia, MG }\end{array}$ \\
\hline 47 & Museu do Índio & UFU & Antropologia & 1987 & $\begin{array}{l}\text { Rua Carajás, 296, Lídice 38400-076 Uberlândia, MG } \\
\text { e-mail: musindio@ufu.br }\end{array}$ \\
\hline 48 & $\begin{array}{l}\text { Museu Aléxis Dorofeef - Minerais, } \\
\text { Rochas e Solos }\end{array}$ & UFV & Ciências Naturais & 1993 & $\begin{array}{l}\text { Vila Gianetti, 31, Campus UFV } \\
\text { 36571-000 Viçosa, MG }\end{array}$ \\
\hline 49 & Museu de Anatomia Animal Comparada & UFV & Ciências Naturais & $?$ & $\begin{array}{l}\text { Vila Gianetti, 29, Campus UFV } \\
36571-000 \text { Viçosa, MG }\end{array}$ \\
\hline 50 & $\begin{array}{l}\text { Museu de Zoologia João Moojen de } \\
\text { Oliveira }\end{array}$ & UFV & Ciências Naturais & 1940 & $\begin{array}{l}\text { Vila Gianetti, 32, Campus UFV } \\
\text { 36571-000 Viçosa, MG } \\
\text { e-mail: rfeio@mail.ufv.br } \\
\end{array}$ \\
\hline 51 & $\begin{array}{l}\text { Museu Histórico da Universidade } \\
\text { Federal de Viçosa }\end{array}$ & UFV & $\begin{array}{l}\text { História local e } \\
\text { institucional }\end{array}$ & 1983 & $\begin{array}{c}\text { Vila Gianetti, 53, Campus UFV 36571-000 Viçosa, MG } \\
\text { e-mail: dacufv@mail.ufv.br }\end{array}$ \\
\hline 52 & Museu de Geociências & UNB & Ciências Naturais & 1960 & $\begin{array}{c}\text { Campus Darcy Ribeiro. Instituto Central de Ciências - } \\
\text { Asa Norte 70910-900 Brasília, DF } \\
\text { Site: http://www.unb.br/ig/exte/museu.htm } \\
\text { e-mail: rxedi@unb.br }\end{array}$ \\
\hline
\end{tabular}


LISTA DE MUSEUS DE UNIVERSIDADES ESTADUAIS - BRASIL (EXCETO USP)

\begin{tabular}{|c|c|c|c|c|c|}
\hline & NOME DO MUSEU & UNIVERSIDADE & ÁREA & ANO CRIAÇÃO & ENDERECO \\
\hline 1 & $\begin{array}{l}\text { Museu Histórico Regional de } \\
\text { Apucarana }\end{array}$ & UECEApucarana / PR & $\begin{array}{l}\text { História } \\
\text { Regional }\end{array}$ & 1976 & $\begin{array}{c}\text { Rodovia do Café - Km } 03 \text { saída Apucarana/Curitiba, } \\
\text { Vila Nova } 86800-000 \text { Apucarana, PR }\end{array}$ \\
\hline 2 & $\begin{array}{l}\text { Museu Entomológico Hipólito } \\
\text { Schneider }\end{array}$ & UECentro-Oeste / PR & $\begin{array}{l}\text { Ciências } \\
\text { Naturais }\end{array}$ & 1971 & $\begin{array}{c}\text { Rua Presidente Zacarias, 875 Campus Universitário } \\
\text { de Guarapuava } 85015-430 \text { Guarapuava, PR }\end{array}$ \\
\hline 3 & Museu Regional de Arte & UEFS / BA & Arte & $\begin{array}{c}1967 \\
1985 \mathrm{p} / \text { UEFS }\end{array}$ & $\begin{array}{l}\text { Av. Prof. Germiniano Costa s/n } \\
44100-000 \text { Feira de Santana, BA } \\
\text { site: www.uefs.br/ }\end{array}$ \\
\hline 4 & Museu Casa do Sertão & UEFS / BA & $\begin{array}{l}\text { História } \\
\text { Regional }\end{array}$ & 1978 & $\begin{array}{c}\text { Av. Universitária, s } / \mathrm{n}^{\circ}, \mathrm{Km} \mathrm{03,} \mathrm{BR} 116 \text { - Norte } \\
\text { Campus Universitário } \\
\text { 44031-460 Feira de Santana, BA } \\
\text { site: www.uefs.br/ }\end{array}$ \\
\hline 5 & $\begin{array}{l}\text { Museu Histórico de Londrina } \\
\text { Padre Carlos Weiss }\end{array}$ & UEL / PR & $\begin{array}{l}\text { História. Local } \\
\text { Antropologia }\end{array}$ & 1970 & $\begin{array}{l}\text { R. Benjamin Constant, 900, Centro 86010-350 } \\
\text { Londrina, PRSite: http://www.uel.br/ ; } \\
\text { http://www.londrina.pr.gov.br/turismo } \\
\text { e-mail: bibmuseu@uel.br }\end{array}$ \\
\hline 6 & Museu da Bacia do Paraná & UEM / PR & História. Local & 1979 & $\begin{array}{c}\text { Avenida Colombo, 5790, Bloco Q } 02 \text { - Zona } 07 \\
\text { 87020-900 Maringá, PR } \\
\text { e-mail: pecuem@npd-lab.uem.br }\end{array}$ \\
\hline 7 & Museu de Geologia & UEM / PR & $\begin{array}{l}\text { Ciências } \\
\text { Naturais }\end{array}$ & 1993 & $\begin{array}{c}\text { Av. Colombo, 5790, Zona } 7 \text { 87020-900 Maringá, PR } \\
\text { e-mail: dge@npd-lab.uem.br }\end{array}$ \\
\hline 8 & $\begin{array}{l}\text { Museu de Arte Assis } \\
\text { Chateaubriand - MAAC }\end{array}$ & UEPB & Arte & 1967 & $\begin{array}{c}\text { Parque Evaldo Cruz, s/nº, Centro 58109-970 } \\
\text { Campina Grande, PB } \\
\text { www.uepb.rpp.br/ }\end{array}$ \\
\hline 9 & Museu Campos Gerais & UEPG / PR & História. Local & 1983 & $\begin{array}{c}\text { Rua Sarmento Leite, 425, Centro 90050-170 } \\
\text { Porto Alegre, RS }\end{array}$ \\
\hline 10 & $\begin{array}{l}\text { Museu Regional de Vitória da } \\
\text { Conquista }\end{array}$ & UESBA / BA & $\begin{array}{l}\text { História local / } \\
\text { Glauber Rocha }\end{array}$ & 1991 & $\begin{array}{c}\text { Praça Tancredo Neves, 114, Centro 45000-000 } \\
\text { Vitória da Conquista, BASite: http://www.uesb.br/ e- } \\
\text { mail: museu@uesb.br }\end{array}$ \\
\hline 11 & Museu de Ciência e Tecnologia & UNEB / BA & $\begin{array}{l}\text { Ciências / } \\
\text { Tecnologia }\end{array}$ & 1977 & $\begin{array}{l}\text { Av. Jorge Amado, s/nº, Boca do Rio 41710-050 } \\
\text { Salvador, BASite: http://www.uneb.br/ } \\
\text { e-mail: seeb.uneb.mct@cpu0011.ba.gov.br }\end{array}$ \\
\hline 12 & $\begin{array}{l}\text { Museu da Faculdade de } \\
\text { Odontologia do Campus de } \\
\text { Araraquara }\end{array}$ & UNESP / Araraquara & $\begin{array}{c}\text { História. } \\
\text { Odontologia }\end{array}$ & 1970 & $\begin{array}{c}\text { Rua Humaitá, 1680, Centro 14801-903 Araraquara, } \\
\text { SP Site: http://www.unesp.br/polos/foar/museu } \\
\text { e-mail: museu@foar.unesp.br }\end{array}$ \\
\hline 13 & $\begin{array}{l}\text { Centro de Assistência } \\
\text { Toxicológica }\end{array}$ & UNESP / Botucatu & Medicina & $?$ & $\begin{array}{c}\text { Caixa Postal } 520 \text { Distrito Rubião Junior } \\
\text { 18618-000 Botucatu, SP } \\
\text { Site: www.laser.com.br/ceatox } \\
\text { e-mail: ceatox@laser.com.br }\end{array}$ \\
\hline
\end{tabular}




\begin{tabular}{|c|c|c|c|c|c|}
\hline 14 & Museu de História Natural & UNESP / Botucatu & $\begin{array}{l}\text { Ciências } \\
\text { Naturais }\end{array}$ & $?$ & $\begin{array}{c}\text { Distrito de Rubião Junior, s/n } \\
\text { 18618-000 Botucatu, SP }\end{array}$ \\
\hline 15 & HRCB - Herbarium Rioclarense & UNESP / Rio Claro & $\begin{array}{l}\text { Ciências } \\
\text { Naturais }\end{array}$ & 1978 & $\begin{array}{l}\text { Av. 24-A } 1515 \text { Caixa Postal } 199 \\
\text { 13506-900 Rio Claro, SP } \\
\text { e-mail: reimonte@life.ibrc.unesp.br }\end{array}$ \\
\hline 16 & $\begin{array}{l}\text { Museu de Ciências da } \\
\text { Natureza }\end{array}$ & UNESP / Rio Claro & $\begin{array}{l}\text { Ciências } \\
\text { Naturais }\end{array}$ & 1989 & $\begin{array}{c}\text { Av. 24-A } 1515 \\
\text { 13506-900 Rio Claro, SP }\end{array}$ \\
\hline 17 & $\begin{array}{l}\text { Coleção de Fósseis, Minerais e } \\
\text { Rochas }\end{array}$ & UNESP / S.J.R. Preto & $\begin{array}{l}\text { Ciências } \\
\text { Naturais }\end{array}$ & ? & $\begin{array}{c}\text { Rua Cristóvão Colombo } 2265 \\
15054-000 \text { São José do Rio Preto, SP }\end{array}$ \\
\hline 18 & $\begin{array}{l}\text { CEMIP - Centro de Manejo } \\
\text { Integrado de Pragas }\end{array}$ & UNESP/ Jaboticabal & $\begin{array}{l}\text { Ciências } \\
\text { Naturais }\end{array}$ & 1986 & $\begin{array}{c}\text { Rodovia Carlos Tananni Km } 5 \text { Campus Jaboticabal } \\
\text { 14870-000 Jaboticabal , SP } \\
\text { e-mail: cemip@fcav.unesp.br }\end{array}$ \\
\hline 19 & Galeria de Arte UNICAMP & UNICAMP / Campinas & Arte & 1984 & $\begin{array}{c}\text { R. Sérgio Buarque de Holanda, s/no, Cidade } \\
\text { Universitária/Barão Geraldo } 13083-970 \text { Campinas, } \\
\text { SPSite: http://www.iar.unicamp.br/ } \\
\text { e-mail: galeria@iar.unicamp.br }\end{array}$ \\
\hline 20 & Museu do Folclore & UNIMONTES / MG & Antropologia & 1993 & $\begin{array}{l}\text { R. Ângelo de Quadros, } 1050 \\
\text { 39401-089 Montes Claros, MG }\end{array}$ \\
\hline 21 & Museu Histórico Regional & UNIMONTES / MG & Antropologia & 1993 & $\begin{array}{l}\text { R. Ângelo de Quadros, } 1057 \\
\text { 39401-089 Montes Claros, MG }\end{array}$ \\
\hline
\end{tabular}

Obs: O Museu de Ciências da Natureza (UNESP Rio Claro), em carta para a CPC/USP, sugeriu que fosse excluído do Guia de Museus pelo fato de sua coleção não ter crescido nos últimos anos. Normalmente essa coleção só abre ao público uma vez ao ano no dia de casa aberta da UNESP. 
LISTA DE MUSEUS DE UNIVERSIDADES PÚBLICAS (REGIONAIS, MUNICIPAIS) - BRASIL (EXCETO ESTADUAIS)

\begin{tabular}{|c|c|c|c|c|c|}
\hline & NOME DO MUSEU & UNIVERSIDADE & ÁREA & $\begin{array}{c}\text { ANO } \\
\text { CRIAÇÃO }\end{array}$ & ENDEREÇO \\
\hline 1 & $\begin{array}{l}\text { Museu Antropológico Diretor } \\
\text { Pestana }\end{array}$ & FIDENE / ljuí / RS & Antropologia & 1961 & $\begin{array}{l}\text { Rua Germano Gressler, 96, São Geraldo 98700- } \\
000 \text { ljuí, RS e-mail: madp@super.unijui.tche.br }\end{array}$ \\
\hline 2 & Museu Amazônico & FUA / AM & $\begin{array}{l}\text { História Regional / } \\
\text { Antropologia }\end{array}$ & $\begin{array}{c}1975 \text { e } \\
1991\end{array}$ & $\begin{array}{l}\text { Rua Ramos Ferreira, } 1036 \text { Centro } \\
69010-120 \text { Manaus, AM }\end{array}$ \\
\hline 3 & $\begin{array}{l}\text { Museu Oceanográfico Professor } \\
\text { Eliézer de Carvalho Rios }\end{array}$ & FURS / RS & Ciências Naturais & 1953 & $\begin{array}{c}\text { Rua Heitor Perdigão, } 10 \text { 96200-580 } \\
\text { Rio Grande, RS } \\
\text { e-mail: museu@brfurg.bitnet }\end{array}$ \\
\hline 4 & Museu Universitário Gama Filho & UGF / RJ & História Institucional & 1984 & $\begin{array}{l}\text { Rua Manoel Vitorino, } 625 \mathrm{ON}-4^{\circ} \text { andar } \\
20748-900 \text { Rio de Janeiro, RJ }\end{array}$ \\
\hline 5 & $\begin{array}{l}\text { Museu da Universidade de } \\
\text { Taubaté (antigo Museu do Homem } \\
\text { Caipira) }\end{array}$ & UNITAU / SP & História / Antropologia & 1997 & $\begin{array}{l}\text { Av. Nove de Julho, } 199 \\
12020-200 \text { Taubaté, SP }\end{array}$ \\
\hline 6 & $\begin{array}{l}\text { MOVI - Museu Oceanográfico do } \\
\text { Vale do Itajaí }\end{array}$ & UNIVAL / SC & Ciências Naturais & 1993 & $\begin{array}{l}\text { Rua Uruguai, 458, Centro 88302-202 Itajaí, SC } \\
\text { e-mail: movi@mbox1.univali.rct-sc.br }\end{array}$ \\
\hline 7 & Museu de Paleontologia & URCariri / CE & Ciências Naturais & 1985 & $\begin{array}{c}\text { Centro de Pesquisas Paleontológicas da Bacia } \\
\text { do AraripePraça da Sé, 105, Centro } \\
63100-000 \text { Crato, CE }\end{array}$ \\
\hline 8 & Museu de História Natural da Urca & $\begin{array}{l}\text { URCariri / Crato / } \\
\text { CE }\end{array}$ & Ciências Naturais & 1966 & $\begin{array}{c}\text { Museu de História Natural } \\
\text { Rua Coronel Antônio Luiz, 1161, Pimenta } \\
63100-000 \text { Crato, CE } \\
\end{array}$ \\
\hline
\end{tabular}


LISTA DE MUSEUS DE UNIVERSIDADES PRIVADAS - BRASIL

\begin{tabular}{|c|c|c|c|c|c|}
\hline & NOME DO MUSEU & UNIVERSIDADE & ÁREA & $\begin{array}{c}\mathrm{ANO} \\
\mathrm{CRIAÇÃO}\end{array}$ & ENDEREÇO \\
\hline 1 & Museu de Arte Brasileira & FAAP / SP & Arte & 1961 & $\begin{array}{l}\text { Rua Alagoas, 903, Higienópolis 01242-902 } \\
\text { São Paulo, SP } \quad \text { Site: http://www.faap.br/ }\end{array}$ \\
\hline 2 & $\begin{array}{l}\text { Museu Histórico e Antropológico } \\
\text { da Região do Contestado }\end{array}$ & FUContestado / SC & $\begin{array}{l}\text { História Regional } \\
\text { Antropologia }\end{array}$ & 1974 & $\begin{array}{l}\text { R. Getúlio Vargas, } 100 \text { Esplanada do Contestado } \\
\text { 89500-000 Caçador, SC }\end{array}$ \\
\hline 3 & Museu da Cultura & PUC / SP & Antropologia & 1991 & $\begin{array}{c}\text { Rua Monte Alegre, } 984 \\
\text { 05014-901 São Paulo, SP }\end{array}$ \\
\hline 4 & $\begin{array}{l}\text { Centro de Cultura e Arte - Museu } \\
\text { Universitário }\end{array}$ & PUCCAMP / SP & Antropologia & 1987 & $\begin{array}{l}\text { Rodovia D. Pedro I, KM 136, Parque das } \\
\text { Universidades 13020-904 Campinas, SP } \\
\text { Site: http://www.puccamp.br/ cca } \\
\text { e-mail: cca@acad.puccamp.br }\end{array}$ \\
\hline 5 & Museu de Ciências naturais & PUCMG / MG & Ciências Naturais & 1983 & $\begin{array}{c}\text { Av. Dom José Gaspar, 500, Coração Eucarístico } \\
\text { 30535-610 Belo Horizonte, MG } \\
\text { e-mail: museu@pucminas.br }\end{array}$ \\
\hline 6 & Museu de Ciências e Tecnologia & PUCRS & Centro de Ciência & 1999 & $\begin{array}{l}\text { Av. Ipiranga, } 668190619-900 \\
\text { Porto Alegre, RS } \\
\text { Site: http://sagres.mct.pucrs.br } \\
\text { e-mail: mct@pucrs.br }\end{array}$ \\
\hline 7 & Museu Dom Bosco & $\begin{array}{l}\text { UC Dom Bosco / } \\
\text { MT }\end{array}$ & $\begin{array}{l}\text { Ciências Naturais } \\
\text { Antropologia }\end{array}$ & 1951 & $\begin{array}{c}\text { Rua Barão do Rio Branco, 1843, Centro 79002-173 } \\
\text { Campo Grande, MS Site: http://www.unibosco.br/ } \\
\text { e-mail: museudb@unibosco.br }\end{array}$ \\
\hline 8 & Museu de Ciências Naturais & Uni Caxias Sul / RS & Ciências Naturais & 1984 & $\begin{array}{c}\text { Rua Francisco Getúlio Vargas, } 1130 \\
95001-970 \text { Caxias do Sul, RS } \\
\end{array}$ \\
\hline 9 & $\begin{array}{l}\text { Museu Zoobotânico Augusto } \\
\text { Ruschi - MUZAR }\end{array}$ & UPFundo / RS & Ciências Naturais & 1975 & $\begin{array}{c}\text { Campus I, BR 285, Km 71, São José 99001-970 } \\
\text { Passo Fundo, RS Site: http://www.upf.tche.br/ } \\
\text { e-mail: muzar@upf.tche.br }\end{array}$ \\
\hline 10 & Museu da Gravura Brasileira & URCAMP / RS & Arte & 1977 & Cel. Azambuja, 18 E, Centro 96415-100 Bagé, RS \\
\hline 11 & Museu Dom Diogo de Souza & URCAMP / RS & $\begin{array}{c}\text { História } \\
\text { Antropologia } \\
\end{array}$ & 1955 & $\begin{array}{l}\text { Rua Emílio Guilayn, 759, Centro } \\
\text { 96415-100 Bagé, RS }\end{array}$ \\
\hline 12 & $\begin{array}{l}\text { Museu Patrício Corrêa da } \\
\text { Câmara }\end{array}$ & URCAMP / RS & História Local & 1979 & $\begin{array}{c}\text { Estrada Municipal, BR } 423 \\
\text { 96415-000 Bagé, RS }\end{array}$ \\
\hline 13 & $\begin{array}{l}\text { Museu Regional do Alto Uruguai } \\
\text { Herbário Balduíno Rambo } \\
\text { Museu de História e Antropologia }\end{array}$ & $\begin{array}{l}\text { URIntegrada de } \\
\text { Erechim/ RS }\end{array}$ & $\begin{array}{c}\text { Ciências Naturais } \\
\text { História } \\
\text { Antropologia }\end{array}$ & 1985 & $\begin{array}{c}\text { Avenida Sete de Setembro, 1621, Centro 99700-000 } \\
\text { Erechim, RS Site: http://www.uri.com.br/ } \\
\text { e-mail: emz@uri.com.br }\end{array}$ \\
\hline
\end{tabular}


LISTA DE MUSEUS DA UNIVERSIDADE DE SÃO PAULO / USP - BRASIL

\begin{tabular}{|c|c|c|c|c|c|}
\hline & NOME DO MUSEU & $\begin{array}{l}\text { UNIDADE DA } \\
\text { USP }\end{array}$ & ÁREA & $\begin{array}{c}\text { ANO } \\
\text { CRIAÇÃO }\end{array}$ & ENDEREÇO \\
\hline 1 & $\begin{array}{l}\text { Aquário de Biologia Marinha - São } \\
\text { Sebastião }\end{array}$ & CEBIMAR & Ciências Naturais & 1955 & $\begin{array}{c}\text { Centro de Biologia MarinhaRodovia Manoel } \\
\text { Hypólito do Rego (SP 55), km 131,5 11600-000 } \\
\text { São Sebastião, SP Site: http://www.usp.br/cbm } \\
\text { e-mail: cebimar@edu.usp.br }\end{array}$ \\
\hline 2 & $\begin{array}{l}\text { Centro Histórico-Cultural da } \\
\text { Enfermagem Ibero-Americana }\end{array}$ & EE & $\begin{array}{l}\text { História saúde / } \\
\text { institucional }\end{array}$ & 1992 & $\begin{array}{l}\text { Av. Dr. Enéas de Carvalho Aguiar, 419, } \\
\text { Cerqueira César 05422-970 São Paulo, SP }\end{array}$ \\
\hline 3 & $\begin{array}{l}\text { Centro de Memória da Escola de } \\
\text { Enfermagem de Ribeirão Preto }\end{array}$ & EERP & $\begin{array}{l}\text { História saúde / } \\
\text { institucional }\end{array}$ & 1989 & $\begin{array}{c}\text { Av. Bandeirantes, } 3.900 \\
\text { 14040-902 Ribeirão Preto, SP }\end{array}$ \\
\hline 4 & $\begin{array}{l}\text { Centro de Recursos Hídricos e Ecologia } \\
\text { Aplicada }\end{array}$ & EESC & Ciências Naturais & $?$ & $\begin{array}{l}\text { Av. Dr. Carlos Botelho, } 1465 \\
\text { 13569-230 São Carlos, SP }\end{array}$ \\
\hline 5 & Museu da Biblioteca da FAU & FAU & Arquitetura & 1982 & $\begin{array}{c}\text { Rua do Lago, } 876 \text { Cidade Universitária } \\
\text { 05508-900 São Paulo, SP }\end{array}$ \\
\hline 6 & Museu da Farmácia & FCF & Ciências Naturais & 1992 & $\begin{array}{c}\text { Av. Prof. Lineu Prestes, } 580 \text { - Bloco 13-A, } \\
\text { Cidade Universitária 05389-900 São Paulo, SP } \\
\text { Site: http://www.fcf.usp.br/ } \\
\text { e-mail: fcf@edu.usp.br }\end{array}$ \\
\hline 7 & Museu da Faculdade de Direito & FD & $\begin{array}{c}\text { História } \\
\text { institucional }\end{array}$ & 1999 & $\begin{array}{l}\text { Largo São Francisco, } 95 \text { Centro } \\
\text { 01005-010 São Paulo, SP }\end{array}$ \\
\hline 8 & Museu da Educação e do Brinquedo & FE & $\begin{array}{l}\text { História } \\
\text { Pedagogia / } \\
\text { Brinquedos }\end{array}$ & 1985 e 1988 & $\begin{array}{c}\text { Av. da Universidade, } 308 \text { - Bloco B - sala 38/42, } \\
\text { Cidade Universitária 05508-900 São Paulo, SP } \\
\text { Site: http://www.fe.usp.br/laboratorios/labrimp } \\
\text { e-mail: labrimp@edu.usp.br }\end{array}$ \\
\hline 9 & $\begin{array}{l}\text { Laboratório de Ensino de Ciências do } \\
\text { Departamento de Psicologia da } \\
\text { Educação }\end{array}$ & FFCLRP & Centro de Ciência & 1981 & $\begin{array}{c}\text { Av. dos Bandeirantes, } 3900 \text { Bloco H salas } 6 \text { e } 7 \\
\text { 14040-901 Ribeirão Preto, SP }\end{array}$ \\
\hline 10 & $\begin{array}{l}\text { Coleção de Imagens de Radar - } \\
\text { Laboratório de Geomorfologia }\end{array}$ & FFLCH & Cartografia & 1967 & $\begin{array}{c}\text { Departamento de Geografia } \\
\text { Av. Professor Luciano Gualberto, } 403 \text { Cidade } \\
\text { Universitária 05508-900 São Paulo, SP }\end{array}$ \\
\hline 11 & Museu Ceroplástico Augusto Esteves & FM & Ciências Naturais & 1980 & $\begin{array}{c}\text { Av. Dr. Arnaldo, } 455 \text { - } 4^{\circ} \text { andar, Cerqueira César } \\
\text { 01246-903 São Paulo, SP }\end{array}$ \\
\hline 12 & $\begin{array}{l}\text { Museu Histórico Prof. Carlos da Silva } \\
\text { Lacaz }\end{array}$ & FM & $\begin{array}{c}\text { História saúde / } \\
\text { institucional }\end{array}$ & 1977 & $\begin{array}{c}\text { Av. Dr. Arnaldo, } 455 \text { - } 4^{\circ} \text { andar, Cerqueira César } \\
\text { 01246-903 São Paulo, SP }\end{array}$ \\
\hline 13 & $\begin{array}{l}\text { Museu Técnico Científico do Instituto } \\
\text { Oscar Feire }\end{array}$ & FM & Ciências Naturais & 1931 & $\begin{array}{l}\text { Rua Teodoro Sampaio, 115, Cerqueira César } \\
\text { 05005-000 São Paulo, SP }\end{array}$ \\
\hline
\end{tabular}




\begin{tabular}{|c|c|c|c|c|c|}
\hline 14 & $\begin{array}{l}\text { Museu de Anatomia Veterinária } \\
\text { Professor Dr. Plínio Pinto e Silva }\end{array}$ & FMVZ & Ciências Naturais & 1984 & $\begin{array}{l}\text { R.Prof. Lúcio Martins Rodrigues, travessa 4, } \\
\text { Bloco 7,Cidade Universitária 05508-900 } \\
\text { São Paulo, SP e-mail: tele@ @usp.br }\end{array}$ \\
\hline 15 & Museu de Odontologia & $\mathrm{FO}$ & Ciências Naturais & 1994 & $\begin{array}{l}\text { Av. Prof. Lineu Prestes, } 2227 \\
05508-900 \text { São Paulo, SP }\end{array}$ \\
\hline 16 & Coleção Entomológica de Referência & FSP & Ciências Naturais & 1937 & $\begin{array}{l}\text { Avenida Doutor Arnaldo, 715, Cerqueira César } \\
\text { 01246-904 São Paulo, SP }\end{array}$ \\
\hline 17 & $\begin{array}{l}\text { Acervo Didático de Vertebrados do } \\
\text { Departamento de Zoologia }\end{array}$ & IB & Ciências Naturais & 1934 & $\begin{array}{c}\text { Rua do Matão, } 277 \text { Cidade Universitária } \\
\text { 05508-900 São Paulo, SP } \\
\text { e-mail: amsouza@eb.usp.br } \\
\end{array}$ \\
\hline 18 & Herbário & IB & Ciências Naturais & 1932 & $\begin{array}{c}\text { Herbário do Departamento de Botânica } \\
\text { Rua do Matão, } 277 \text { - Edifício Aylthon B. Joly, } \\
\text { Cidade Universitária 05508-900 São Paulo, SP } \\
\text { e-mail: jrpirani@ib.usp.br }\end{array}$ \\
\hline 19 & $\begin{array}{l}\text { Acervo Didático da Disciplina de } \\
\text { Invertebrados I e II }\end{array}$ & IB & Ciências Naturais & 1934 & $\begin{array}{c}\text { Rua do Matão, } 277 \text { Cidade Universitária } \\
\text { 05508-900 São Paulo, SP }\end{array}$ \\
\hline 20 & $\begin{array}{l}\text { Museu de Anatomia Humana da USP } \\
\text { Prof. Alfonso Bovero }\end{array}$ & ICB & Ciências Naturais & 1920 & $\begin{array}{l}\text { Av. Prof. Lineu Prestes, 2415, Cidade } \\
\text { Universitária 05508-900 São Paulo, SP }\end{array}$ \\
\hline 21 & $\begin{array}{l}\text { Museu de Instrumentos e Cálculo } \\
\text { Numérico }\end{array}$ & ICMSC & Ciências Exatas & 1978 & $\begin{array}{c}\text { Avenida Doutor Carlos Botelho, 1465 Caixa } \\
\text { Postal 668, Vila Pureza 13560-250 } \\
\text { São Carlos, SP } \\
\text { e-mail: biblio@icmc.sc.usp.br }\end{array}$ \\
\hline 22 & $\begin{array}{l}\text { Coleção de Artes Visuais do Instituto de } \\
\text { Estudos Brasileiros }\end{array}$ & IEB & Arte & 1962 & $\begin{array}{l}\text { Av. Prof. Mello Moraes, Trav. 8, 140, Cid. } \\
\text { Universitária 05508-900 São Paulo, SP } \\
\text { Site: http://www.ieb.usp.br/ } \\
\text { e-mail: colecao@ieb.usp.br }\end{array}$ \\
\hline 23 & Centro de Divulgação Científica - CDCC & IFSC e IQSC & Centro de Ciência & 1980 & $\begin{array}{c}\text { Rua Nove de Julho, } 122713560-590 \\
\text { São Carlos, SP } \\
\end{array}$ \\
\hline 24 & Laboratório de Demonstrações Físicas & IFUSP & Ciências Exatas & $?$ & $\begin{array}{c}\text { Instituto de Física } \\
\text { Rua do Matão s/n Cidade Universitária } \\
\text { 05508-900 São Paulo, SP }\end{array}$ \\
\hline 25 & Museu de Geociências & IG & Ciências Naturais & 1934 & $\begin{array}{c}\text { Rua do Lago, 562, Cidade Universitária 05508- } \\
900 \text { São Paulo, SP } \\
\text { Site: http://www.usp.br/ig/museu.htm } \\
\text { e-mail: mugeo@edu.usp.br }\end{array}$ \\
\hline 26 & Serviço de Museu Oceanográfico & 10 & Ciências Naturais & 1988 & $\begin{array}{c}\text { Praça do Oceanográfico, 191, Butantã 05508- } \\
900 \text { São Paulo, SP } \\
\text { Site: http://www.io.usp.br/museu.html }\end{array}$ \\
\hline
\end{tabular}




\begin{tabular}{|c|c|c|c|c|c|}
\hline 27 & Museu de Arte Contemporânea - MAC & MAC & $\begin{array}{c}\text { Arte } \\
\text { Contemporânea }\end{array}$ & 1963 & $\begin{array}{c}\text { Rua da Reitoria, 160, Cidade Universitária } \\
\text { 05508-900 São Paulo, SP } \\
\text { Site: http://www.usp.br/mac } \\
\text { e-mail: infomac@edu.usp.br }\end{array}$ \\
\hline 28 & $\begin{array}{l}\text { Museu de Arqueologia e Etnologia - } \\
\text { MAE }\end{array}$ & MAE & Antropologia & 1989 & $\begin{array}{l}\text { Avenida Professor Almeida Prado, 1466, Cid. } \\
\text { Universitária 05508-900 São Paulo, SP } \\
\text { Site: http://www.mae.usp.br/ } \\
\text { e-mail: mae@edu.usp.br }\end{array}$ \\
\hline 29 & $\begin{array}{l}\text { Centro Regional de Arqueologia } \\
\text { Ambiental }\end{array}$ & MAE & Arqueologia & 1972 & $\begin{array}{c}\text { Rua Washington Osório de Oliveira, 640, Centro } \\
18800-000 \text { Piraju, SP } \\
\text { Site: www.mae.usp.br/projpar } \\
\text { e-mail: jlmorais@uol.com.br } \\
\end{array}$ \\
\hline 30 & Museu Paulista & MP & História & 1893 & $\begin{array}{c}\text { Parque da Independência, s/no }{ }^{\circ} \text {, Ipiranga 04299- } \\
970 \text { São Paulo, SP } \\
\text { Site: http://www.mp.usp.br/ }\end{array}$ \\
\hline 31 & Museu Republicano Convenção de Itu & MP & História & 1923 & $\begin{array}{l}\text { Rua Barão do Itaim, 67, Centro 13300-000 Itu, } \\
\text { SP Site: http://www.mp.usp.br/mr.htm } \\
\text { e-mail: jonasouz@usp.br }\end{array}$ \\
\hline 32 & Museu de Zoologia & MZ & Ciências Naturais & 1894 & $\begin{array}{c}\text { Av. Nazaré, 481, Ipiranga 04263-000 São Paulo, } \\
\text { SP Site: http://www.mz.usp.br/ } \\
\text { e-mail: mimarque@usp.br }\end{array}$ \\
\hline 33 & Museu de Rochas, Minerais e Minérios & POLI & Ciências Naturais & década 40 & $\begin{array}{l}\text { Av. Professor Mello Moraes, } 2373 \text { Cidade } \\
\text { Universitária 05508-900 São Paulo, SP }\end{array}$ \\
\hline 34 & Museu Luiz de Queiroz & $\begin{array}{l}\text { Prefeitura Campus } \\
\text { Piracicaba }\end{array}$ & Ciências Naturais & 1984 & $\begin{array}{l}\text { Av. Pádua Dias, 11, Agronomia } \\
\text { 13400-000 Piracicaba, SP }\end{array}$ \\
\hline 35 & Estação Ciência & $\begin{array}{l}\text { Pró Reitoria } \\
\text { Cultura e } \\
\text { Extensão }\end{array}$ & Centro de Ciência & 1987 & $\begin{array}{l}\text { Rua Guaicurus, 1274, Lapa 05033-002 São } \\
\text { Paulo, SP Site: http://www.eciencia.usp.br/ } \\
\text { e-mail: info@eciencia.usp.br }\end{array}$ \\
\hline
\end{tabular}

Obs: O Centro de Recursos Hídricos e Ecologia Aplicada da EESC informou à CPC/USP, em 1999, que não se enquadrava na categoria "museu". O mesmo ocorreu com a Coleção de Imagens de Radar do Laboratório de Geomorfologia da FFLCH e do Acervo Didático de Vertebrados do IB.

Fontes: Cadastros da CPC - USP; VITAE; Guia de Museus Brasileiros / CPC-USP, 1996; Boletins da CPC-USP; questionários elaborados pela pesquisadora; folhetos; palestras; Revista Ciência em Museus, vol.4, 1992 e Textos apresentados no I Fórum de Museus Universitários (Goiânia, 1992), comunicações realizadas no I Encontro de Museologia da UFMG, em 1997. Diagnóstico das potencialidades museológicas da USP, 2000. Endereços eletrônicos das universidades na internet. 


\begin{abstract}
ANEXO 3
PESQUISAS,

CURSOS, EXPOSIÇÕES E PUBLICAÇÕES DO MAC/USP

1997 A 1999
\end{abstract}


As informações foram obtidas nos Relatórios Anuais do Museu de Arte Contemporânea da USP, de 1997, 1998 e 1999.

Pesquisas

Diretoria

Lisbeth Ruth Rebollo Gonçalves

1. Recepção Estética em Museu de Arte Contemporânea

Situação: Em andamento - 1997

Objetivo: Discutir questões cruciais da arte contemporânea, seus princípios, valores, linguagens, público, entre outras, o presente projeto pretende estimular a reflexão e o debate sobre o tema da recepção estética em museu de arte contemporânea, tendo como beneficiários diretos os pesquisadores das diferentes especialidades envolvidas e suas respectivas instituições.

\section{Divisão de Curadoria}

Daisy Peccinini de Alvarado

1."Criação de Bases de Dados e Banco de Imagens no Museu de Arte Contemporânea da USP: Pesquisa Histórico-Crítica e Difusão Cultural/MAC on-line"

Situação: em andamento $(1997,1998)$

Objetivo: O projeto se define como uma contribuição na área da informatização de museus de arte no país, ainda em fase embrionária. Constitui-se, também, como elemento de estímulo às pesquisas sobre documentação e informática aplicada à arte e história da arte e ainda a utiliza como uma ferramenta-mídia de divulgação e difusão cultural, com integração à Internet. Sendo o MAC-USP o principal museu de arte moderna e contemporânea no Brasil, a pesquisa em pauta servirá de protótipo para outras pesquisas, visando implantar sistemas de bases de dados nos museus de arte do país, abrindo uma via para integração nacional e internacional.

Apoio CNPq e FAPESP, início agosto 1995.

2. "Arte Brasileira dos 20 aos 70 : Pesquisa da Coleção do MAC"

Situação: concluída (1998)

Objetivo: Pesquisa de ordem histórico-crítica e museológica com a finalidade de realizar a exposição "Brasil dos 20 a 70" enfocando através das obras, dispostas em cinco espaços ambientais modernismo/modernidade, Anos 50,60 e Anos 70, as tendências que prevalecem nestas Décadas.

3. "Pesquisa da Tela à instalação"

Situação: concluída (1998)

Objetivo: Pesquisa de ordem histórico-crítica da arte moderna e contemporânea, das obras da coleção. Estabelece uma estrutura narrativa do período de 1912 -1972.

Cristina Freire

1. "A Estética do Processo - Arte Conceitual no Acervo do MAC"

Situação: em andamento $(1997,1998)$

Objetivo: A partir da realização de um levantamento exaustivo e sistemático da coleção de obras de arte conceitual do MAC-USP que se desenvolve o presente projeto que envolve um estudo em profundidade dos artistas e das condições sócio-políticas e culturais da realização de tais obras, além da análise do contexto de suas eventuais 
exposições. Este projeto desenvolve, a partir dos resultados da pesquisa, metodologias específicas para a análise e interpretação de tal produção, assim como procedimentos próprios referentes à catalogação, conservação, e exposição destes trabalhos pertencentes a uma parcela muito pouco conhecida do acervo do MAC-USP.

Apoio: CPNq; FAPESP, Pró-Reitoria de Cultura e Extensão Universitária da USP, LINC - Lei de Incentivo à Cultura do Estado de São Paulo.

Kátia Canton

1. "Arte Conta História"

Responsável: Kátia Canton

Situação: 1997 - finalizado

Objetivo: Projeto de livro voltado ao público infantil que estabelece uma relação entre a narrativa de várias culturas e o trabalho artístico de artistas contemporâneos brasileiros. A pesquisa envolve exposição com as obras originais, trabalho com escolas, livros.

2.Tendências Contemporâneas /Heranças Contemporâneas

Situação: A pesquisa está em fase de conclusão e edição de um livro, projeto FAPESP. (1997-1999)

Objetivo: O objetivo é mapear a produção de um grupo de artistas contemporâneos da geração 90 em relação às influências de seu trabalho dentro do universo da arte contemporânea brasileira e discutir uma nova conceituação da arte.

Helouise Costa ${ }^{1}$

1. "Obra em Contexto"

Situação: projeto de exposição Jean Arp, Scwitters, Domela e Fontana.

Objetivo: estudar o acervo do MAC-USP

Silvia Meira ${ }^{2}$

1. "As diferentes representações da paisagem na Imagem Moderna do início do século $X X "$

Situação: apresentação de trabalho no CBHA (1998)

Objetivo: analisar os diferentes tratamentos da paisagem, na imagem moderna do início do século $\mathrm{XX}$

2. "Biografias e Análises Críticas dos Artistas do acervo do MAC-USP"

Situação: textos para o Banco de Dados do Centro

Objetivo: resumir os principais dados do percurso artístico dos artistas do acervo, e, analisar criticamente suas obras

3. "Os movimentos de Vanguarda no início do século XX e suas repercussões"

Situação: textos para o Banco de Dados

Objetivo: fornecer referenciais históricos para o entendimento de determinados artistas do acervo do MAC-USP

\footnotetext{
${ }^{1}$ A pesquisadora passou para a ECA/USP em 2000 mas voltou para o MAC no início de 2001.

${ }^{2}$ A pesquisadora saiu do MAC em 1999.
} 


\section{Divisão de Ensino e Ação Cultural}

Dilma de Melo Silva ${ }^{3}$

1. "O Museu de Arte e a Escola Pública: Trocas que enriquecem"

Situação: em andamento (1997)

Objetivo: Levar o professor a compreender a Educação Artística como um conjunto de exercícios de conteúdos que desvelam novas formas de conhecimento, possibilitandoo a considerar o conhecimento artístico como um ato de criação estético da consciência que, uma vez projetado em formas artísticas, reflete a cultura particular do aluno. Levá-lo, ainda, a utilizar o museu de arte como estratégia de estimulação para o acesso à produção cultural e ao aprendizado. Propor, conhecendo as necessidades da EMPG Theodomiro Dias, uma experiência de trabalho que possa vir a ser utilizada em outras escolas da rede pública, através da otimização dos trabalhos em andamento na Divisão de Educação do MAC-USP.

\section{Carmen Aranha} Artística"

1. "Percursos Visuais no Acervo do MAC: Uma Fenomenologia da Educação

Situação: 1997, 1998, itens finalizados 1 e 2. (1999)

Objetivo: 1. Criação de materiais visuais a partir do acervo do MAC para subsidiar a prática do professor 10 e 20 graus. 2. Reflexão sobre a compreensão visual através de referenciais da Fenomenologia da Percepção. 3. Produção de vídeos correspondentes. 4. Produção de texto teórico (LD).

Apoio: Pró-Reitoria de Pós-Graduação/FAPESP

2. "Pesquisa Teórica sobre a leitura da obra de arte com desdobramento prático para construção de material visual."

Situação: em andamento (1998)

Objetivo: Pesquisa teórica sobre a leitura da obra de arte com desdobramento prática para construção de material visual.

Gabriela Wilder

1. Exposição de Arte Contemporânea e a educação infantil: um Exercício para a percepção de diversidade cultural.

Situação: em andamento. (1997-1999)

Objetivo: alargar os limites dos cerceamentos naturais do ambiente e da cultura em que a criança cresce, particularmente a criança de famílias de baixa renda.

Avaliar se o contato constante com o conhecer artístico desperta a criança para o reconhecimento de si, do outro, do mundo em que vive, bem como o reconhecimento e respeito pelo outro: Determinar se a criança, por meio de visitas constantes a museus, consegue transformar esse espaço em um local de prazer e descobertas:

Determinar se o uso dos estímulos visuais presentes nas artes plásticas, favorecidos pelo contato direto com obras de arte, possibilita um desenvolvimento mais acentuado da percepção infantil, estimulando o desenvolvimento de diferentes inteligências.

\footnotetext{
${ }^{3}$ A professora da ECA/USP, Dilma de Melo e Silva, foi diretora da Divisão durante a gestão de Lisbeth Rebollo (1993-97).
} 
Maria Helena Pires Martins ${ }^{4}$

1. Ética em Ação Cultural

Situação: em andamento (1999)

Objetivo: estudar a ética dialógica de Habermas, como recurso de interferência do agente cultural em grupos sob sua coordenação, elaboração de material didático sobre tema transversal ética para o ensino fundamental.

Maria Ângela Serri Francoio

1. "Museu, Educação e o Lúdico"

Situação: Continuidade ao atendimento das crianças no espaço expositivo Retratos e Auto-Retratos: Jogos, Brinquedos e planejamento e construindo os materiais. Dinâmicas lúdicas e catálogo da próxima exposição: Ciranda de Formas: Bichos.

Início: 1994

Objetivo: Projeto de pesquisa que desenvolve uma metodologia lúdica para o ensino da arte em museu, com derivação para a criação e construção de materiais e dinâmicas lúdico pedagógicas e seu uso no atendimento dos alunos e professores da rede de ensino. O projeto vem organizando exposições para crianças cuja museografia apresenta um espaço Lúdico que favorece a interação das crianças com os jogos construídos.

Apoio: MAC-USP; COSEAS - USP; CNPq - Pibic; FAU - USP, FAPESP e Bolsa Trabalho COSEAS

Participação: Escolas públicas e particulares; Parceria com a EMEI Desembargador Dalmo do Valle Nogueira dentro do Programa de Melhoria do Ensino Público, apoio FAPESP.

Amanda Pinto da Fonseca Tojal

1. "Projeto Museu e o Público Especial"

Situação: Programa Permanente desde o ano de 1991.

Objetivo: O Projeto "Museu e Público Especial", da Divisão de Ação e Extensão Cultural do MAC/USP, é um programa permanente de atendimento ao público portador de deficiências sensoriais, motoras e mentais e portadores de distúrbios emocionais em exposições especialmente concebidas e adaptadas para receber este público, que de forma não somente visual mas também sensorial poderá apreciar e explorar as obras de arte através do tato.

Estas exposições, denominadas "O Toque Revelador" são compostas por uma seleção de obras de arte pertencentes ao acervo do museu, organizadas segundo um "percurso tátil" que permite tanto a exploração sensorial das obras tridimensionais originais como também das reproduções visuais-táteis em relevo, elaboradas a partir das obras bidimensionais originais.

Apoio: FAPESP e Pró-Reitoria de Pesquisa da USP.

Participação: Apoio na montagem da exposição $O$ Toque Revelador: a poética das formas incluindo material didático multisensorial e cadernos em tinta e braile. Concepção de uma bolsista estudante da USP para o desenvolvimento das pesquisas e elaboração de material didático.

\footnotetext{
${ }^{4}$ A professora da ECA/USP, é diretora da Divisão na gestão de Teixeira Coelho (1998-2002).
} 
Renata Sant'Anna e Silva

1. "Imaginário: formando um dicionário de imagens"

Situação: em andamento (1998)

Objetivo: Realização de um livro para crianças em processo de alfabetização com as obras do acervo do Museu escolhidas e nomeadas pelas próprias crianças.

2. "Coleção Olharte"

Situação: 4 volumes publicados: Picasso (92); Tarsila e Goeldi (95) e Maria Martins (97), outros volumes em andamento.(Mira Schendel e Guignard)

Início: outubro de 1992

Objetivo: publicação de livros de arte para crianças com obras do acervo do MAC. Instituições: MAC e Paulinas Editora

Participação: Autores dos livros e diretor editorial Prof. Dr. Edmir Perrotti.

3. "Meia Volta Vou Ver"

Situação: em andamento (1999)

Início: junho de 1999

Objetivo: Oferecer o contato com as obras do acervo do Museu em visitas múltiplas.

Apoio: CNPq (bolsa)

Participação: MAC e EMEF General Liberato Bittencourt

\section{Divisão de Preservação e Documentação}

Magali Melleu Sehn

1. "Estudo da Tecnologia da obra "Soma de Nossos Dias " de Maria Martins

Situação: em andamento (1998)

Objetivo: $O$ projeto visa a investigação dos materiais e técnicas da obra para conhecer o comportamento mecânico e elaborar métodos para o controle dos agentes de deterioração.

Início: março de 97

2. "Acondicionamento e técnicas expositivas para objetos tridimensionais"

Situação: em andamento (1998)

Objetivo: elaborar métodos para acondicionamento e exibição de objetos tridimensionais que apresentam características técnicas pouco convencionais.

Início: março de 98 


\section{Cursos}

Pós-Graduação/Especialização

1. "Estudos de Museus de Arte"

Coordenação:Profa Dra Lisbeth Rebollo Gonçalves

Vice-Coordenação: Profa Dra Dilma de Melo Silva

Assessoria de Coordenação: Profa Dra Carmen S.G. Aranha

Coordenação de Estágios: Maria Antonieta Z.P. Villela

Professores: Amanda Pinto Tojal; Carmen S.G. Aranha; Daisy V.M.

Peccinini de Alvarado; Dilma de Melo Silva; Gabriela S.Wilder; Helouise Lima

Costa; José Luiz Hernandez; Kátia Canton Monteiro; Marcelo Mattos Araújo; Maria Cristina Machado Freire; Maria Cristina de Oliveira Bruno; Silvia Miranda Meira; Vera Lúcia de Oliveira Filinto; Maria Cristina Castilho Costa; Maria Antonieta Z.P.Villela.

Período: março de 1997 a junho de 1998

Local: MAC - Sede

Natureza: Especialização, Pós-Graduação Lato-Sensu.

Carga Horária: 774 h/a

Inscritos: 76 Selecionados: 40 Desistentes: 17

Objetivo: O curso pretende preparar especialistas para atividades profissionais em Museus de Arte, galerias e centros culturais de documentação. Este preparo envolve reflexão teórica, além de vivência prática nos diferentes setores e atividades do Museu.

\section{Extensão Universitária: atualização e difusão cultural}

1. "Desenho e Pintura"

Coordenação:Profa Dra Lisbeth Rebollo Gonçalves

Professor: Maria Isabel Azevedo da Silva

Período:18 de agosto a 17 de novembro de 1997

Local: MAC Anexo

Carga Horária: 42 horas/aula

Objetivo: Promover um debate em torno do desenho, do claro/escuro e da cor. Serão discutidas as diferentes soluções plásticas que resultam do uso de diversos materiais. A orientação individual objetiva favorecer o desenvolvimento do trabalho pessoal do aluno.

2. "A Aventura do teatro da Bauhaus"

Coordenação:Profa Dra Lisbeth Rebollo Gonçalves

Professor: Maria Victoria Granero

Período: 07 de outubro de 04 de novembro de 1997

Local: MAC Sede

Carga Horária: 7 h30 horas/aula

Objetivo: Levar ao conhecimento dos alunos, o papel cultural e artístico que o Teatro da Bauhaus desempenhou na História do Teatro e nas Artes em geral, bem como a sua influência que exerceu nas artes até nossos dias. Estabelecer relações entre este Teatro com algumas obras do acervo do MAC. 
3. "Arte e Natureza : Paisagem como representação na Obra de Burle Marx"

Coordenação: Elly Ap. Rozo V. Perez Ferrari Professora : Elly Ferrari

Período : 10 de Abril a 22 de Maio de 1997

Local : MAC Ibirapuera

Carga horária : 18 horas/ aula

Objetivo : A partir das discussões das representações da natureza, em arte, levar o aluno a ler e refletir sobre a obra de Burle Marx através de exercícios práticos no Parque Ibirapuera e na exposição "Arte e Paisagem: a estética de Roberto Burle Marx".

4. "Arte Pública: Interação entre Arte, Design e Educação Ambiental"

Coordenação: Prof. Dr. José Teixeira Coelho Netto

Professor: $\quad$ Eileen Adams

Período: $\quad 25$ a 29 de maio de 1998

Local: MAC - Ibirapuera

Objetivo: Explorar as conexões entre arte, design e educação ambiental analisando as funções da Arte Pública, seus desdobramentos através do papel do artista e das questões de integração com o público.

5. "Arte Moderna e Contemporânea: Recortes"

Coordenação: Prof Dr José Teixeira Coelho Netto

Professores: Tadeu Chiarelli; Helouise Costa; Daisy Peccinini; Carmen Aranha; Kátia Canton; Aracy Amaral; Ana Maria Belluzzo; Cristina Freire; Júlio Plaza e Ivo Mesquita.

Período: 08/04 a 1\% de 1999

Local: Auditório das Colméias da USP e Galeria de Arte do SESI

Carga Horária:33 horas/aulas

Objetivo: oferecer um recorte da história da arte dos séculos XIX e XX que contribua para a compreensão da arte contemporânea.

6. "Práxis Artística para Terapeutas"

Coordenação: Prof Dr José Teixeira Coelho Netto

Professor: Sylvio Coutinho

Período: 07/04 a 08/12/1999

Local: MAC - Anexo

Carga Horária: 93 horas/aula

Objetivo: complementar conhecimentos de história/teoria da arte e da prática artística complementar (teoria e prática das artes plásticas), em benefício da práxis terapêutica.

7. "História da Arte para Professores e Educadores"

Coordenação: Prof. Dr. José Teixeira Coelho Netto

Professor: Gabriela Suzana Wilder

Período: 03/05 a 28/06/1999

Local: MAC - Sede

Carga Horária: 27horas/aula

Objetivo: instrumentalizar os professores a se valerem da História da Arte como fio condutor no desenvolvimento de um programa de ensino das artes para crianças.

8. "Preservação e Conservação de Obras de Arte sobre Papel".

Coordenação: Prof Dr José Teixeira Coelho Netto

Professor: Isis Baldini Elias

Período: 16/08 a 08/11/1999 
Local: MAC - Sede

Carga Horária:30 horas/aula

Objetivo: O curso visa oferecer noções básicas de conservação de obras de arte sobre papel, envolvendo o diagnóstico de problemas; a discussão de soluções específicas para cada caso; os modos de acondicionamento; transporte e exposição adequados e o preenchimento de laudos técnicos.

9. "Monitoria em Artes"

Coordenação: Prof Dr José Teixeira Coelho Netto

Professores: José Teixeira Coelho Netto; Martin Grossman; Maria Helena Pires Martins; Carmen Aranha; Maria Angela S.Francoio; Amanda Tojal; Sylvio Coutinho; Renata Sant'Anna; Gabriela Wilder.

Período:20/08 a 19/11/1999

Local: MAC - Sede

Objetivo: preparar monitores da diferentes áreas de conhecimento para criar roteiros e visitas guiadas em variados espaços de arte.

10. "Ensino da Arte na Educação Especial"

Coordenação: Prof Dr José Teixeira Coelho Netto

Professor: Amanda Tojal

Período: 22/10 a 19/11/1999.

Local: MAC Sede

Objetivo: Instrumentalizar profissionais e estudantes no planejamento de aulas e cursos de artes tendo como enfoque a experiência tanto visual como sensorial do objeto artístico.

\section{$\underline{\text { Graduação (disciplinas optativas) }^{5}}$}

1. "Interdisciplinaridade nas Artes Contemporâneas: Arte / Dança / Perfomance / Instalação"

Professor Responsável: Kátia Canton

Período: $1^{\circ}$ semestre de 1998 e $2^{\circ}$ semestre de 1999

Local: MAC Anexo

Carga Horária: 45 horas/aula

Objetivo: proporcionar aos alunos subsídios para refletir sobre conceitos como interdisciplinaridade, vanguarda, modernismo, pós-modernismo, perfomance, instalação. As discussões conceituais serão pontuadas com exemplos retirados da história da arte e cultura ocidental do século XX.

2. "Arte Moderna e Contemporânea no Século XX no Acervo do MAC e na XIV Bienal de São Paulo"

Professor Responsável: Daisy V.M. Peccinini de Alvarado

Período: $2^{\circ}$ semestre de 1998

Local: MAC Anexo

Carga Horária: 45 horas/aula

Objetivo: Oferecer aos alunos subsídios para reflexão e informação das diferentes etapas históricas da Arte Ocidental no Século XX.

\footnotetext{
${ }^{5}$ Além dessas disciplinas, Maria Helena Pires Martins (2000) enumerou outras que podem ser oferecidas: Monitoria em Arte Visual, História das Artes Plásticas e da Literatura no Século XX, História das Artes Plásticas e do Teatro no Século XX. Apreciação da Obras de Arte, Produção Artística a partir de 1950 e Introdução a Crítica de Artes.
} 
3. "Exercícios do Olhar : Uma Fenomenologia da Arte"

Professor Responsável: Carmen S G Aranha

Período: $1^{\circ}$ semestre de $1997,2^{\circ}$ semestre de $1998,1^{\circ}$ e $2^{\circ}$ semestres de 1999

Local: MAC - Sede

Carga Horária: $45 \mathrm{~h} / \mathrm{a}$

Objetivo: O curso pretende oferecer aos alunos de graduação uma reflexão sobre a apreensão da obra de arte e uma derivação prática sobre a criação plástica, através de discussões sobre a História da Arte e a Fenomenologia da Percepção de Merleau-Ponty, em sala de aula, em ateliê e nos acervos do MASP e do MAC.

4. "Arte e Imaginário Contemporâneo"

Professor Responsável: Maria Cristina Freire

Período: $2^{\circ}$ semestre de 1997, 1998 e 1999

Local: MAC - Sede

Carga Horária: $45 \mathrm{~h} / \mathrm{a}$

Objetivo: O curso visa estudar, através de uma abordagem interdisciplinar, inerente à crítica da cultura, as características dos mecanismos de exposição de arte juntamente com os processos de recepção estética, imaginário e memória peculiares à contemporaneidade.

5. "Arte Moderna e Contemporânea no Século XX no Acervo do MAC"

Professor Responsável: Daisy V.M. Peccinini de Alvarado

Professor: Daisy V.M. Peccinini de Alvarado

Período: $1^{\circ}$ semestre de 1999

Local: MAC - Sede

Carga Horária: 45

Objetivo: Oferecer aos alunos subsídios para reflexão e informação das diferentes etapas históricas da Arte Ocidental no Século XX e sua produção em diferentes espaços: na coleção do MAC/USP e outros Museus de Arte de São Paulo.

\section{Workshop}

1. "A Argila como Veículo de Auto-Conhecimento, Criatividade e Expressão" Coordenação: Profa Dra Lisbeth Rebollo Gonçalves

Professor: Silvia Farina

Período: 03 de setembro a 05 de novembro de 1997

Local: MAC Anexo

2. "O Museu de Arte e a Educação Infantil"

Coordenação:Prof Dr José Teixeira Coelho Netto

Professor: Gabriela Suzana Wilder

Período: 08 e 15/04/99

Local: MAC - Sede

3. Internacional - "Museu e Comunidade"

Coordenação:Prof. Dr. José Teixeira Coelho Netto

Professora: Claudia Hernandes

Período: 08/11/99

Local: MAC - Sede 


\section{Exposições}

Acervo

1. "Destaques Internacionais do Acervo MAC/USP" - $2^{a}$ edição

Obras do acervo: 53

Período:junho a dezembro/1997

Local: MAC-Sede

Descrição: Recorte da coleção internacional, reunindo as obras primas da coleção.

2. "A Cidade dos Artistas"

Obras do acervo: 99

Período: 14/agosto a 21/setembro/1997

Local: MAC-Ibirapuera

Descrição: Exposição temática dividida em 3 núcleos: Espaço e Lugar; Dos Labirintos e Das Constelações; Passantes e Passagens, reúne obras que, das mais variadas maneiras, programaticamente ou não, tem referências no universo urbano contemporâneo. Sul"

3. "PHASES - Surrealismo e Contemporaneidade: Grupo Austral do Brasil e Cone

Obras do acervo: 38 obras

Obras comodato: 27 - emprestadas

Período: outubro a novembro/1997 e 1998

Local: MAC-Ibirapuera

Descrição: Exposição de trabalhos de artistas que, desde o final dos anos 50, participaram e participam ainda do movimento neo-surrealista PHASES. Este espalhou-se pelos três continentes: Eurásia, África e Américas. Nesta comunidade internacional de artistas o Brasil teve participação relevante. Precisamente o MAC-USP articulou o Grupo Austral do Movimento PHASES, em 1967.

4. "Arte Brasileira, 50 Anos de História no Acervo do MAC USP (1920-1970)"

Obras do acervo: 161

Período: 26/09/96 a 05/1998

Local: MAC-Sede

Descrição: Panorama das artes plásticas brasileiras iniciando em 1920 até os anos 70. Abrangendo o Modernismo, O Grupo Santa Helena - Família Artística Paulista, o Abstracionismo, o Concretismo, a Nova Figuração e a Jovem Arte Contemporânea.

5. "Arte Brasileira Anos 80-90: Destaques do Acervo do MAC"

Obras do acervo: 14

Obras emprestadas: 01

Período: 08/03 a 22/09/1997

Local: MAC-Ibirapuera

Descrição: Recorte da coleção nacional reunindo as obras mais destacadas das duas últimas décadas.

6. "O Traçado Modernista: Di Cavalcanti no Acervo do MAC"

Obras do acervo: 120

Período: 08/04 a 03/08/1997

Local: MAC-Ibirapuera 
Descrição: A seleção de desenhos dessa exposição buscou justamente apresentar um panorama da diversidade do trabalho de Di Cavalcanti. Os desenhos foram distribuídos em sete módulos. Outro fator que norteou a escolha foi, sempre que possível, privilegiar obras nunca antes expostas. Não houve, também, nenhuma preocupação em estabelecer cronologias.

7. "Rafael França Obra Gráfica"

Obras do acervo: 18

Período: outubro a dezembro/97

Local: MAC-Sede

Descrição: As obras pioneiras e cheias de talento que começam a ser reavaliadas e estudadas a partir de acervo legado pelo artista ao MAC/USP.

8. "Mostra de Cartazes da Staaliche Kunsthalle Berlin"

Organização:Biblioteca

Obras : Cartazes do acervo da Biblioteca Lourival Gomes Machado

Período: 02 a 08/1998

Local: Biblioteca do MAC-Sede

9. "Da Tela à Instalação"

Período: 1998 a dezembro de 1999

Local: MAC-Sede

Descrição: Vanguardas, os abstracionistas dos anos 50 , novas figurações, arte política de 60, nova figurações, instalação, arte eletrônica, estrutura dos anos 80 e 90.

10. "Brasil Anos 20 a 70"

Período: 19.08.1998 a 12.1998

Local: MAC-Sede

Descrição: Exposição relativa à Arte no Brasil dispondo-se em 5 ambientes: Modernismo (20-30); Modernidade (30-50); Anos 50, Anos 60, Anos 70, obras de artistas reveladoras arte das principais tendências brasileiras, nestas cinco décadas.

11. "Anos 80 e 90 no MAC"

Obras: 40

Período: 09/04 a 31/05/1998

Local: MAC-Sede

Descrição: Mostra que reúne 40 obras do acervo do Museu que representam a diversidade de opções de suporte, materiais e propostas utilizadas pelos artistas nesse período. São trabalhos de Renata Barros, Leda Catunda, Macaparana, Nuno Ramos, Paulo Pasta, Ubirajara Ribeiro, Paulo Whitaker, Regina Silveira, Tomie Ohtake e Amélia Toledo.

12. "O Brasil no Século da Arte"

Produção: Centro Cultural FIESP/Galeria de Arte do SESI/MAC

Obras do acervo: 222

Período: 27/04 a 25/08/1999

Local: Galeria do Sesi / Av. Paulista

Descrição: Mostra que integra o programa da Universidade de São Paulo comemorativo dos 500 anos do Brasil, e apresenta uma parte significativa, mas ainda restrita, de um dos mais importantes acervos de arte moderna e contemporânea. 


\section{$\underline{\text { Temporárias }}$}

1. "Arte e Paisagem: A Estética de Roberto Burle Marx"

Obras emprestadas: 100

Período: 08/04 a 25/05/97

Local: MAC-Ibirapuera

Burle Marx.

Descrição: Mostra que pretende revelar o artista plástico que existe no paisagista

2. "Heranças Contemporâneas"

Obras emprestadas: 45

Período: 08/04 a 25/05/97

Local: MAC - Ibirapuera

Descrição: Mostra que apresenta uma produção atual, mas sobretudo, debate suas raízes, articula sua história, dialoga com o seu contexto.

3. "Painel da Crítica ABCA"

Obras emprestadas: 10

Período:08/04 a 25/05/97

Local: MAC - Ibirapuera

Descrição: Exposição de artistas emergentes: Selma Andrade, Gilberto Lustosa, Ana Gastelois, Leandro Gabriel, Gustavo Kai, Eloise Frota, Katia Plotz, Franz Manata, Marlene de Andrade, Maria do Carmo Yunes.

4. "Gerda Brentani"

Obras emprestadas: 48

Período: 27/02 a 30/03/97

Local: MAC-Sede

Descrição: Aos 91 anos de idade, comemorados na data de abertura da exposição, a artista inaugura, uma mostra de sua obra, que demonstra a força expressiva de sua trajetória de quase 50 anos de produção.

5. "Mudança na Paisagem" - EVA SARO

Período: 27/02 A 30/03/97

Local: MAC-Sede

Descrição: Ponto de informação montado no MAC Sede, onde a artista mostra em vídeo, trabalhos que desenvolveu no final do ano passado - 50 imagens. Concomitantemente, são apresentados out-doors transformados na Av. Água Espraiada.

6. "Arte Conta Histórias"

Obras emprestadas: 60

Período: 20/06 a /07/97

Local: MAC-Ibirapuera

Descrição: tem como base a narrativa de contos de fada multiculturais, transformados em projetos artísticos. Participaram da exposição, os artistas: Dudi Maia Rosa, Pinky Wainer, Siron Franco, L.P.Baravelli, Beatriz Milhazes, e outros.

7. "Arte Mexicana- Museo de Monterrey - uma Seleção do Acervo"

Obras Emprestadas: 40

Período: 20/06 a 03/08/97

Local: MAC-Ibirapuera 
Descrição: O museu mexicano traz ao Brasil uma seleção de seu acervo, que põe foco sobre a arte mexicana do século XX naquele país. Obras de Dr. Alt, Rivera, Orozco, Siqueiros, Montenegro, Tamayo, Mérida, Gunther Gerzo, Gironella, Cuevas, Toledo, Tamaríz, Hernandez.

8. "Arte Gráfica Polonesa"

Obras Emprestadas: 24

Período: 15/08/ a 21/09/97

Local: MAC- Ibirapuera

Descrição: Mostra de artistas da Polônia apresentando um recorte da arte gráfica contemporânea naquele país. Integram a exposição oito artistas - Ryszard Hunger, Jacek Bigoszewski, Andrej Gieraga, Leslaw Misckiewicz, Grzegorz Sztabinski, Andrzej Maria Bartczak, Jerzy Trelink e Tomasz Chojnacki - trabalhos de 1979 a 1995.

9. "Arte Gráfica da Hungria"

Obras Emprestadas: 20

Período: 08/10 a 09/11 de 1997

Local: MAC-Ibirapuera

Descrição: Mostra de 19 artistas da Hungria onde apresentam um recorte da arte gráfica contemporânea naquele país.

10. "Visualidade Nascente VII"

Obras Emprestadas: 22

Período: $15 / 08$ a 21/09/97

Local: MAC-Ibirapuera

Descrição: Mostra que revela a capacidade criativa, a vocação e a potencialidade artística dos alunos da USP, prontos para forjar um futuro de sucesso no campo das artes.

11. "Dimensões da Arte Contemporânea Brasileira"

Obras Emprestadas:75

Período: 11/11 a 10/01/98

Local: MAC-Ibirapuera

Descrição: Com obras dos artistas Siron Franco, Humberto Espíndola, Hélio Rôla, Maria Tomaselli, Renato Garcia, Alcindo Moreira Filho, Janaína Tschape, Roberto Mícoli, Macaparana, Ayao Okamoto e Luiz Hermano, com curadoria de Lisbeth Rebollo Gonçalves

12. "Jesus Raphael Soto - Retrospectiva"

Obras Emprestadas: 80

Período: $15 / 08$ a 21/09/97 e 27/11/1997 a 10/01/1998

Local: MAC-Ibirapuera

Descrição: Mostra restrospectiva reunindo obras do período de 1951 a 1996 em colaboração com a Galerie Nationale du Jeu de Paume.

13. "Nova Arte da Croácia"

Obras emprestadas: 49

Período: 26/06/1998 a 15/08/1998

Local: MAC-Sede

Descrição: Dezessete artistas mostram 49 obras entre pinturas, esculturas, desenhos, objetos e instalações. Nos trabalhos de cada artista, no conjunto da exposição, 
a busca de uma identidade croata incorporando idéias universais e destacando a presença do país na nova disposição do continente europeu. Nullius)"

14. "Subtextos Eva Saro (Mudança na paisagem) e Bruno Giovannetti (Res

Período: 07/08/1998 a 13/09/1998

Local: MAC-Ibirapuera

Descrição: Mudança na Paisagem é resultado do trabalho baseado em cartazes urbanos desenvolvidos por Eva Saro, artista plástica suiça, que pesquisa e questiona a iconografia comercial e nossas percepções em geral. Res Nullius foi o nome encontrado pelo fotógrafo e jornalista Bruno Giovannetti para definir seu trabalho: a captura de imagens fugazes que propõe um olhar mais atento sobre o cotidiano.

15. "Moto Migratório - quatro artistas brasileiros na Alemanha"

Obras emprestadas: $\quad 50$

Período: 07/08/1998 a 13/09/1998

Local: MAC-Ibirapuera

Descrição: A exposição sob a curadoria da historiadora da arte Eliana de Simone, discute a relação sujeito/lugar mostrando, como a partir de um deslocamento, o equilíbrio desse binômio vem a ser abalado, relativizado e rearticulado. Participam da exposição, os artistas: Cristina Canale, Luiz Pizarro, Alex Flemming e Cristina Barroso.

16. "Figurações 30 anos na Arte Brasileira"

Obras: 98

Período: 24/09/1998 a 12/11/1998

Local: MAC-Ibirapuera (Pinacoteca)

Descrição: Para compor esta exposição escolheu-se, de um lado, obras com figuras elaboradas por artistas brasileiros em um momento anterior de sua produção, há dez, vinte ou trinta anos atrás, e obras no mesmo gênero, mais recentes. A exposição reúne os artistas: Luiz Paulo Baravelli, José Roberto Aguillar, Wesley Duke Lee, João Câmara, Regina Silveira, Nelson Leirner, Ivald Granato, Ubirajara Ribeiro, Cláudio Tozzi, Siron Franco e Antonio Henrique Amaral.

17. "Heranças Contemporâneas II"

Obras: 50

Período: 24/09/1998 a 12/11/1998

Local: MAC-Ibirapuera (Pinacoteca)

Descrição: A exposição conta com a participação de 13 artistas brasileiros, é o segundo resultado do mapeamento crítico do projeto Tendências Contemporâneas.

18. "Obra em contexto" Jean Rustin

Obras: 01

Período: 09/04 a 31/05/1998

Local: MAC-Ibirapuera

Descrição: Trata-se de um nicho, onde o MAC propõe ao visitante um momento singular de apreciação de uma obra de arte. Na ocasião, apresentando obra do artista Jean Rustin.

19. "Obra em contexto" Ivan Serpa

Obras: 01

Período: 03/1998

Local: MAC-Sede 
Descrição: Trata-se de um nicho, onde o MAC propõe ao visitante, um momento singular de apreciação de uma obra de arte. Na ocasião, apresentando obra do artista Ivan Serpa.

20. "Obra em contexto" Arte Degenerada de Paul Klee

Período: 18/08/1998 a 17/04/1999

Local: MAC-Sede

21. "Deslocamento - displaced"

Produção: UCE/University of Central England in Birmigham /MAC

Obras emprestadas: 75

Período: 01/6 a 25/07/1999

Local: MAC-Ibirapuera

Descrição: Um painel da vida urbana do final do século $X X$ visto pela arte contemporânea britânica, que tem se destacado a partir do início dos anos 90 por um impulso radical de ousadia.

22. " Múltiplas Escolhas"

Produção: The British Council

Obras emprestadas: 29

Período:01/6 a 25/07/1999

Local: MAC-Ibirapuera

Descrição: Organizada pelo British Council com obras de sua coleção, apresenta a arte britânica por meio das gravuras de 16 artistas que experimentam a diversidade nas opções oferecidas pelo mundo da arte.

23. "Heranças Contemporâneas III"

Obras emprestadas: 75

Período:01/6 a 05/12/1999

Local: MAC-Ibirapuera

Descrição: A exposição relaciona a obra de Lygia Clark, Tunga e Carlos Fajardo a dos artistas: Solange Pessoa, Tonico Lemos, Lourdes Colombo, Christiana Moraes, Alexandre da Cunha, Renata Pedrosa, Carlos Arouca, Theresa Amaral, Sonia Guggisberg e Marcus Vinicius, e é o terceiro e mais recente resultado do mapeamento crítico do projeto Tendências Contemporâneas, realizado pela Prof ${ }^{\mathrm{a}} \mathrm{Dr}^{\mathrm{a}}$ Kátia Canton.

\section{Educativas}

1. "O Toque Revelador: Retratos e Auto-retratos"

Obras do acervo: 09

Obras comodato: 01

Período:18.03.97 a 31.07.97 e 03 a 11 de 1998

Local: MAC - Anexo

Descrição: Exposição concebida e adaptada ao público portador de deficiências sensoriais, motoras e mentais incluindo programação educativa especializada.

2. "O Mistério das Formas" - Maria Martins

Organização: Divisão de Educação

Obras do acervo: 02

Período: 1997 
Local: MAC- Ibirapuera

Descrição:Exposição concebida e adaptada ao público infantil com programação educativa especializada.

3. "Retratos e Auto-retratos - Jogos, brinquedos e brincadeiras"

Obras do acervo: 16

Período: 18.03 .97 a 11 de 1998

Local: MAC - Anexo

Descrição: Exposição organizada a partir de seleção de obras cujo critério foi a diversidade no tratamento plástico para este gênero de representação artística. Compondo a museografia da exposição foi organizado um espaço lúdico-interativo para as crianças. Neste espaço elas brincam com jogos especialmente construídos a partir da temática proposta, além de vestir-se com acessórios para auto-retratar-se ou retratar o amigo.

\section{4. "Cachorros"}

Obras do acervo: 11

Período: 04.97 a 09.97

Local: MAC - Ibirapuera

5. "O Toque Revelador a poética das formas"

Período: 17/06/99 a 2001

Local: MAC - Anexo

Descrição: Exposição de caráter permanente visando o atendimento do público portador de deficiências sensoriais (auditivas, visuais) físicas e mentais concebidas e adaptadas para receber tanto estes visitantes como o público em geral incluindo uma programação educativa complementada por material didático multisensorial e publicações em tinta e braile.

6. "Ciranda de formas: bichos, jogos, brinquedos e brincadeiras"

Período: 17/06/99 a 2001

Local: MAC-Anexo

Descrição: Exposição lúdica, dedicada especialmente às crianças e seus professores. Organizada pela Divisão de Ensino e Ação Cultural do MAC, a mostra faz parte do projeto "Museu, Educação e o Lúdico", coordenado pela arte-educardora Maria Angela Serri Francoio. Ciranda de Formas é apresentada a partir de uma seleção de obras do acervo cujo critério, entre outros, foi a diversidade no tratamento plástico na temática dos bichos. A museografia da exposição apresenta em um Espaço Lúdico com jogos tridimensionais e fantoches criados a partir das obras expostas. Estes materiais favorecem o processo de ensino e aprendizagem da arte no Museu.

\section{$\underline{\text { Instalações }}$}

1. "Hetz, Nowak, Rehberger" (artistas alemães)

Período: 25/04 a 31/05/97

Local: MAC-Sede

Descrição: instalação constituída por obras de três representantes da nova arte alemã: Cosima von Bonin, Kai Althoff e Tobias Rehberger. 
2. "Diálogos, Idéias, Papéis"

Período: $14 / 08$ a 21/09/97

Local: MAC-Ibirapuera

Descrição: Instalações conjuntas de Bernardita Vattier (Chile), Coca Rodrigues (Brasil), e Matilde Marín (Argentina), que põe em evidência um diálogo estético, a partir do suporte que utilizam, o "papel".

3. "Receptáculos"

Período: 01/06/99 A 25/07/1999

Local: MAC-Ibirapuera

Descrição: A Instalação reuniu trabalhos em metal, cetim ou cristal das artistas Shirley Paes Leme, Sandra Tucci e Beth Moysés que por meio de seus discursos afetivos procuram organizar o universo emocional.

Curadoria: Katia Canton

4. "Testemunhos"

Período: 26/08/99 a 05/12/1999

Local: MAC-Ibirapuera

Descrição: A Instalação reúne trabalhos das artistas Eide Feldon e Marina Godoy onde o tempo, a memória e o imaginário interpretam de forma crítica - sob a óptica feminina - a comunicação de massa, a velocidade da mídia, a sociedade pós-moderna.

Curadoria: Silvia Meira 


\section{Publicações}

1997 / 1998 / 1999

\section{Diretoria}

- Lisbeth R. Rebollo Gonçalves

Parte de livro: $1 / 0$ / 0

Texto de catálogo: $10 / 0 / 0$

Texto de folder: 7 / 0 / 0

- José Teixeira Coelho Netto

Artigo em revista científica / especializada: 0 / 2 / 2

Artigos em jornais e revistas de divulgação: 0 / 8 / 11

Livro: 0 / 1 / 2 (reimpressões)

Parte de livro: $0 / 0 / 5$

Texto de catálogo: 0 / 2 / 2

- Martin Grossmann 6

Catálogo: $0 / 0 / 3$

Parte de livro: 0 / 0 / 1

\section{Divisão de Curadoria}

- Daisy Valle Machado Peccinini de Alvarado

Artigo em jornais e revistas de divulgação: 0 / 0 / 1

Artigo em revista científica / especializada: 0 / $1 / 1$

Livros: 0 / 0 / 1

Parte de livro: $1 / 0$ / 0

Resenha: 0 / 0 / 1

Texto em catálogos: 2 / 3 / 1

Texto em convite: $1 / 0$ / 0

- Maria Cristina Machado Freire

Artigo em Anais: 0 / 0 / 1

Artigo em jornais ou revistas de divulgação: 0 / 0 / 1

Artigo em revista científica / especializada: 1 / 0 / 0

Livro: 1 / 0 / 1

Texto de catálogo: 0 / 1 / 0

- Elvira Vernaschi

Texto em catálogo: 3 / 2 / 0

Verbetes para CD Rom: 22 / 0 / 0

- Helouise Costa

Texto de catálogo: 1 / 1 / 2

\footnotetext{
${ }^{6}$ A produção de Martin Grossmann só foi contada pelo MAC em 1999.
} 
- Katia Canton Monteiro

Livro: 1 / 0 / 0

Texto de catálogo: $0 / 1 / 4$

Texto de folder: 0 / 0 / 3

- Elly Ferrari ${ }^{7}$

Texto de catálogo: 0 / $1 / 0$

- Silvia Miranda Meira

Artigo em revista científica / especializada: 0 / 3 / 0

Texto de catálogo: 2 / 2 / 0

\section{Divisão de Ação e Extensão Cultural}

- Carmen S. G. Aranha

Artigo em anais: $0 / 0 / 2$

Material didático: 2 / 2 / 1 (em folder e página internet)

Parte de livro: $1 / 0$ / 1

Texto de catálogo: 0 / $1 / 0$

- Gabriela Suzana Wilder

Artigo em anais: 2 / 1 / 2

Artigo em revista especializada: 2 / 0 / 0

Texto em catálogo: $0 / 1 / 0$

Texto página internet: $0 / 1 / 0$

- Maria Angela Serri Francoio

Texto de catálogo: 0 / 1 / 0

- Amanda Pinto Tojal

Artigo em anais:0 / 0 / 1

Dissertação de mestrado: 0 / 0 / 1

- Renata Sant'Anna e Silva

Artigos em jornais e revistas de divulgação: 0 / 0 / 6

\section{Biblioteca}

- Vera Lucia de Oliveira Filinto ${ }^{8}$

Parte de livro: $1 / 1 / 0$

${ }^{7}$ Elly Ferrari foi da Divisão de Ensino e Ação Cultural até 10/1998.

${ }^{8}$ Em 1997 Vera Filinto era diretora da Divisão de Comunicação Visual, Publicações e Produção e em 1998 passou para a Biblioteca. 


\section{Livros, Catálogos e folders do MAC/USP}

Em 1997, o MAC publicou os seguintes livros:

1. "Mistério das formas " - Coleção Olharte *

Autora: Kátia Canton

Projeto Gráfico: Maria Tereza Louro

MAC / Paulinas Editora

Coordenadora da Coleção : Renata Sant'Anna

*Prêmio JABUTI - 1997

2. "Arte e Paisagem: a estética de Roberto Burle Marx"

Tipo de material: livro

Coordenação: Lisbeth Rebollo Gonçalves

Data: abril/97

Quantidade: 1.000

Responsável:Divisão de Publicações, Com. Visual e Produção

Os catálogos publicados pelo MAC em 1997 foram:

1. "O Toque Revelador: Retratos e Auto-Retratos"

Co-Editor: Div. de Com. Visual e Divisão de Educação (versões: tinta e Braile)

Autor: Amanda Tojal ( org) / Patrícia Rodrigues ( textos )

Quantidade: 1.300 (1000 em tinta e 300 em Braile )

Responsável: Projeto Museu e a Pessoa Deficiente

Coordenação : Amanda Tojal

2. "O Toque Revelador: Retratos e Auto-Retratos"

Co-Editor: MAC USP/VITAE

Autor: Amanda Pinto da Fonseca Tojal

Quantidade: 1.000

Responsável: Divisão de Publicações, Com.Visual e Produção/ Elaine Christina Maziero

3. "Arte e Paisagem: a estética de Roberto Burle Marx"

Co-Editor: MAC USP

Autor: Lisbeth Rebollo Gonçalves

Quantidade: 1.000

Responsável: Divisão de Publicações, Com. Visual e Produção

4. "Di Cavalcanti"

Co-Editor: MAC USP

Autor: Lisbeth Rebollo Gonçalves/Helouise Costa

Quantidade: 4.000

Responsável: Divisão de Publicações, Com, Visual e Produção

5. "Arte Brasileira - 50 Anos de História no Acervo do MAC USP"

Co-Editor: MAC USP

Autor: Lisbeth Rebollo Gonçalves

Quantidade: 4.000

Responsável: Divisão de Publicações, Com, Visual e Produção

Apoio: Fundo Nacional de Cultura/ MinC / AAMAC 
6. "Dimensões da Arte Contemporânea Brasileira" Co-Editor: MAC USP

Autor: Lisbeth Rebollo Gonçalves/Helouise Costa

Quantidade: 4.000

Responsável: Divisão de Publicações, Com, Visual e Produção

Apoio: Fundo Nacional de Cultura / MinC / AAMAC

7. "PHASES - Surrealismo e Contemporaneidade: Grupo Austral do Brasil e Cone-Sul"

Co-Editor: MAC USP/ Faculdade de Belas Artes

Autor: Daisy V.M.P. de Alvarado

Quantidade: 2.000

Responsável: Daisy V.M.P. de Alvarado

Os catálogos editados pelo MAC em 1998 foram:

1. "Figurações - 30 anos na Arte Brasileira"

Co-Editor: MAC USP

Autor: José Teixeira Coelho Netto (org.)

Quantidade: 1000

2. "Heranças Contemporâneas II"

Editor MAC USP

Autor: Katia Canton

Quantidade: 1000

Responsável: Divisão de Comunicação Visual e Publicações

3. "Catálogo da Exposição de Avaliação de 1997"

Autor: Programa Lazer com Arte para Terceira Idade

Quantidade: 73 exemplares

Responsável: Sylvio Coutinho

Os catálogos publicados pelo MAC em 1999 foram:

1. "Heranças Contemporâneas III"

Editor:MAC

Autor: Katia Canton

Quantidade: 1000

2. "O Toque Revelador: a poética das formas" (tinta)

Editor:MAC

Autor: Amanda Tojal

Quantidade: 1000

3. "O Toque Revelador: a poética das formas" (braile)

Editor:MAC

Autor: Amanda Tojal

Quantidade: 1000 
Os folders produzidos em 1997 foram:

1. "Exposição: Diálogos, Idéias, Papéis"

Data: agosto/97

Quantidade: 3.500

2. "Curso de Especialização: Estudos de Museus de Arte"

Data: outubro/97

Quantidade: 1.000

3. "Simpósio Internacional: Arte Contemporânea no Museu"

Data: outubro/97

Quantidade: 500

4. "PHASES - Surrealismo e Contemporaneidade: Grupo Austral do Brasil e ConeSul"

Data: nov/97

Quantidade: 2.000

Responsável: Daisy V.M.P. de Alvarado

5. "Simpósio Internacional - PHASES - Surrealismo e Contemporaneidade: Grupo Austral do Brasil e Cone-Sul"

Data: nov/97

Quantidade: 2.000

Responsável: Daisy V.M.P. de Alvarado

Os folders produzidos em 1998 foram:

1. "Projeto Museu e Público Especial"

Data: $2^{\circ}$ semestre de 1998

Quantidade: 1000

Responsável: Amanda Pinto da Fonseca Tojal

2. "MAC: Anos 80 e 90"

Data: abril/98

Quantidade: 1000

3. "Moto Migratório"

Data: agosto/98

Quantidade: 1000

4. "Folder Primavera"

Data: novembro/98

Quantidade: 3000 
Os folders produzidos em 1999 foram:

1. "O Brasil no Século da Arte - A Coleção MAC USP"

Quantidade: 5000

Data: abril/1999

2. "Deslocamento"

Quantidade: 1000

Data: junho/1999

3. "Agenda Inverno"

Quantidade: 5000

Data: julho/1999

4. "Museu e Público Especial"

Quantidade: 3000

Data: setembro/1999 